Ordinary Jerusalem 1840-1940 


\title{
Open Jerusalem
}

\author{
Edited by \\ Vincent Lemire (Paris-Est Marne-la-Vallée University) and \\ Angelos Dalachanis (French School at Athens)
}

VOLUME 1

The titles published in this series are listed at brill.com/opje 


\title{
Ordinary Jerusalem 1840-1940
}

\author{
Opening New Archives, Revisiting a Global City
}

\author{
Edited by
}

Angelos Dalachanis and Vincent Lemire

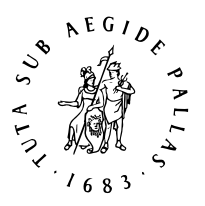

\section{B R I L L}

LEIDEN | BOSTON 
This is an open access title distributed under the terms of the prevailing CC-BY-NC-ND reproduction in any medium, provided no alterations are made and the original author(s) and source are credited.

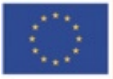

The Open Jerusalem project has received funding from the European Research Council (ERC) under the European Union's Seventh Framework Programme (FP $7 / 2007-2013)$ (starting grant No 337895)

Note for the cover image: Photograph of two women making Palestinian point lace seated outdoors on a balcony, with the Old City of Jerusalem in the background. American Colony School of Handicrafts, Jerusalem, Palestine, ca. 1930. G. Eric and Edith Matson Photograph Collection, Library of Congress. https://www.loc.gov/item/mamcol.o54/

Library of Congress Cataloging-in-Publication Data

Names: Dalachanis, Angelos, editor. | Lemire, Vincent, 1973- editor.

Title: Ordinary Jerusalem, 1840-1940 : opening new archives, revisiting a global city / edited by Angelos Dalachanis and Vincent Lemire.

Description: Leiden ; Boston : Brill, [2018] | Series: Open Jerusalem ;

Volume 1 | Includes bibliographical references.

Identifiers: LCCN 2018019559 (print) | LCCN 2018019932 (ebook) | ISBN 9789004375741 (E-book) | ISBN 9789004375734 (hardback : alk. paper)

Subjects: LCSH: Jerusalem — History—19th century. | Jerusalem—History—2oth century. | Urban anthropology_Jerusalem. | Municipal government-Jerusalem.

Classification: LCC DS109.925 (ebook) | LCC DS109.925 .073 2018 (print) | DDC 956.94/42034-dc23

LC record available at https://lccn.loc.gov/2018019559

Typeface for the Latin, Greek, and Cyrillic scripts: “Brill”. See and download: brill.com/brill-typeface.

ISSN 2543-0211

ISBN 978-90-04-37573-4 (hardback)

ISBN 978-90-04-37574-1 (e-book)

Copyright 2018 by the Authors. Published by Koninklijke Brill NV, Leiden, The Netherlands. Koninklijke Brill NV incorporates the imprints Brill, Brill Hes \& De Graaf, Brill Nijhoff, Brill Rodopi, Brill Sense and Hotei Publishing.

Koninklijke Brill NV reserves the right to protect the publication against unauthorized use and to authorize dissemination by means of offprints, legitimate photocopies, microform editions, reprints, translations, and secondary information sources, such as abstracting and indexing services including databases. Requests for commercial re-use, use of parts of the publication, and/or translations must be addressed to Koninklijke Brill NV.

This book is printed on acid-free paper and produced in a sustainable manner. 


\section{Contents}

List of Figures and Tables IX

Abbreviations XIII

List of Contributors XV

Note on Transliteration XXIV

Introduction: Opening Ordinary Jerusalem $\quad 1$

Angelos Dalachanis and Vincent Lemire

PART 1

Opening the Archives, Revealing the City

Introduction 13

Gudrun Krämer

1 Placing Jerusalemites in the History of Jerusalem: The Ottoman Census (sicil-i nüfüs) as a Historical Source 15

Michelle U. Campos

2 Introducing Jerusalem: Visiting Cards, Advertisements and Urban

Identities at the Turn of the 2oth Century 29

Maria Chiara Rioli

3 The Ethiopian Orthodox Community in Jerusalem: New Archives and Perspectives on Daily Life and Social Networks, 1840-1940 50

Stéphane Ancel

4 Between Ottomanization and Local Networks: Appointment Registers as Archival Sources for Waqf Studies. The Case of Jerusalem's Maghariba Neighborhood 75

Şerife Eroğlu Memiş

5 Foreign Affairs through Private Papers: Bishop Porfirii Uspenskii and His Jerusalem Archives, 1842-186o 100

Lora Gerd and Yann Potin 
6 The Brotherhood, the City and the Land: Patriarchal Archives and Scales of Analysis of Greek Orthodox Jerusalem in the Late Ottoman and Mandate Periods 118

Angelos Dalachanis and Agamemnon Tselikas

PART 2

Imperial Allegiances and Local Authorities

Introduction 139

Beshara Doumani

7 The State and the City, the State in the City: Another Look at

Citadinité 143

Noémi Léry-Aksu

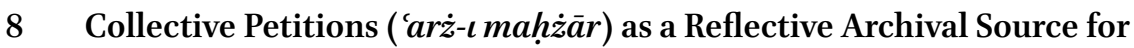
Jerusalem's Networks of Citadinité in the late 19th Century 161 Yasemin Avcı, Vincent Lemire, and Ömür Yazıcı Özdemir

9 Back into the Imperial Fold: The End of Egyptian Rule through the Court Records of Jerusalem, 1839-1840 186

Abla Muhtadi and Falestin Naïli

10 An Institution, Its People and Its Documents: The Russian Consulate in Jerusalem through the Foreign Policy Archive of the Russian Empire, 1858-1914 200 Irina Mironenko-Marenkova and Kirill Vakh

11 Diplomacy, Communal Politics, and Religious Property Management: The Case of the Greek Orthodox Patriarchate of Jerusalem in the Early Mandate Period 223

Konstantinos Papastathis

12 Comparing Ottoman Municipalities in Palestine: The Cases of Nablus, Haifa, and Nazareth, 1864-1914 240

Mahmoud Yazbak 
13 Municipal Jerusalem in the Age of Urban Democracy: On the Difference between What Happened and What Is Said to Have Happened 262

Jens Hanssen

\title{
PART 3
}

\section{Cultural Networks, Public Knowledge}

\author{
Introduction 283
}

Edhem Eldem

14 Reading the City, Writing the Self: Arabic and Hebrew Urban Texts in Jerusalem, $1840-1940 \quad 287$

Yair Wallach

15 Arab-Zionist Conversations in Late Ottoman Jerusalem: Sacid al-Husayni, Ruhi al-Khalidi and Eliezer Ben-Yehuda 305 Jonathan Marc Gribetz

16 Ben-Yehuda in his Ottoman Milieu:Jerusalem's Public Sphere as Reflected in the Hebrew Newspaper Ha-Tsevi, 1884-1915 330 Hassan Ahmad Hassan and Abdul-Hameed al-Kayyali

17 Men at Work: The Tipografia di Terra Santa, $1847-1930 \quad 35^{2}$ Leyla Dakhli

18 The St. James Armenian Printing House in Jerusalem: Scientific and Educational Activities, 1833-1933 366 Arman Khachatryan

19 The Wasif Jawharriyeh Collection: Illustrating Jerusalem during the First Half of the 2oth Century 384 Issam Nassar 
PART 4

Sharing the City: Contacts, Claims and Conflicts

\author{
Introduction 401 \\ Gadi Algazi
}

20 "The Preservation and Safeguarding of the Amenities of the Holy City without Favour or Prejudice to Race or Creed": The Pro-Jerusalem Society and Ronald Storrs, 1917-1926 403

Roberto Mazza

21 Governing Jerusalem's Children, Revealing Invisible Inhabitants: The American Colony Aid Association, 1920s-1950s 423

Julia R. Shatz

22 Epidemiology and the City: Communal vs. Intercommunal Health Policy-Making in Jerusalem from the Ottomans to the Mandate, 1908-1925 440

Philippe Bourmaud

23 Being on a List: Class and Gender in the Registries of Jewish Life in Jerusalem, 1840-1900 457

Yali Hashash

24 The Tramway Concession of Jerusalem, 1908-1914: Elite Citizenship, Urban Infrastructure, and the Abortive Modernization of a Late Ottoman City 475

Sotirios Dimitriadis

25 Waqf Endowments in the Old City of Jerusalem: Changing Status and Archival Sources 490

Salim Tamari

26 The Limitations of Citadinité in Late Ottoman Jerusalem 510 Louis Fishman

Bibliography 531

Index of Persons 580

Index of Places 586 


\section{List of Figures and Tables}

Figures

1.1 Ottoman census header, $1299[1883-84] \quad 18$

1.2 Ottoman census header, $1321\left[1905^{-6}\right] 20$

2.1 Cover of the catalogue "Carte di visita avvisi ec. 1880" 32

2.2 Visiting card of P. Léon Pourrière, of M, ca. 189834

2.3 Visiting card of E. Bertoli, dentist, ca. 1894-95 35

2.4 Visiting card of Salim al-Husayni, ca. 1889-90 37

2.5 Bill of exchange of the Société du Chemin de Fer Ottoman de Jaffa à Jérusalem et prolongements, $1891 \quad 39$

2.6 Visiting card of Albert Antébi, ca. $1898 \quad 44$

2.7 Visiting card of midwife F. Lapidus, ca. 1892-93 47

2.8 Visiting card of Yassin al-Khalidi, ca. $1898 \quad 48$

3.1 Letter of Emperor Yohannes IV to the sultan, dated Yäkkatit 24, 1874 (Ethiopian Calendar)/March 2, $1882 \quad 60$

3.2 Ottoman report concerning the increasing number of Ethiopians in Jerusalem bearing Italian passports, $1893 \quad 61$

3.3 Letter from Abd Mariam to Antonin Kapustin, archimandrite in the Russian Ecclesiastical Mission in Jerusalem, December 6, 1875, Jerusalem 63

3.4 Receipt for the payment of wine, signed by Nicolai Schmidt, January 4, 191666

3.5 Receipt for payment for work done on Empress Taytu's house, April 14, 191568

3.6 Receipt for the payment of tax (recto), Muharram 1314 (June 1896) 69

3.7 Receipt for the payment of tax (verso), Muharram 1314 (June 1896) 70

3.8 Short note signed by Pascal Seraphin, August 1, $1913 \quad 71$

3.9 Receipt for payment for work done on Empress Taytu's house, signed by Pascal Seraphin, November 20, $1902 \quad 72$

3.10 Short letter from Seraphin's wife, n.d 73

4.1 'Atì (Old) record of the "Waqf of the Tombs of Abu Madyan al-Ghawth and "Umar al-Mujarrad" 80

4.2 Cedīd (New) record 80

6.1 Plan of site for YMCA building and soccer field in Jerusalem 128

6.2 Petition, received on June 17, 1910, with the mention of "Jerusalemite" after the petitioner's signature 133 
6.3 Testament dated December 20, 1923, in Arabic and Greek 135

8.1 Classification codes, $1839-1915 \quad 172$

8.2 Original language of petitions, $1840-1915$ (in percentages) $\quad 172$

8.3 Addressee of collective petitions, $1840-76 \quad 174$

8.4 Addressee of collective petitions, 1876-1908 174

8.5 Addressee of collective petitions, 1908-15 175

8.6 Date sequence of 200 collective petitions, 1839-1915 175

8.7 Form of collective petitions, 1839-1915 177

8.8 Collective petition signed by 55 people and submitted to the Grand Vezierate to thank the government for taking precautions to prevent cholera from spreading in the province of Jerusalem, $1865 \quad 178$

8.9 Collective petition signed by 30 people and submitted to the Grand Vizierate to complain about the process of nominating the Greek Patriarch of Jerusalem, $1897 \quad 179$

8.10 Subject matter of collective petitions, $1840-76 \quad 180$

8.11 Collective petition signed by 419 people from the Syriac community and submitted to the Ministry of Justice to complain about Armenian infringement on their rights in the holy sites of Jerusalem, $1893 \quad 183$

12.1 Municipal Archives of Nablus, expenditures document, first collection, vol. 1, $106 \quad 243$

12.2 Municipal Archives of Nablus, document of printed headers, first collection, vol. 3, $3 \quad 244$

12.3 Municipal Archives of Nablus, first collection, vol. 1, $3 \quad 245$

14.1 Khalil Sakakini 292

14.2 Dedication inscription of the Mishkenot Sha'ananim alms houses outside Jaffa Gate, built in 186o 299

14.3 Dedication inscription of the Jewish religious seminary (yeshiva) in the Bukharan Quarter, built in $1927 \quad 302$

17.1 Lithography and printing press of St. Saviour's Convent, Jerusalem 355

18.1 Cover of the SJAPH's first publication, Tetrak Aghót'amatoyts' vasn Jermer'and Aghót'asirats', Vork' ka'm Andzamb ew ka'm Mtók'Nerkayanan $i$ S. Tnórinakan Teghisn K'ristosi Astutsoy Meróy [A booklet for those who pray fervently and visit the places of the Christ either physically or mentally], $1833 \quad 375$

18.2 First page of the January 1870 issue of the SJAPH journal Sion, with the image of St. James Armenian Cathedral 381

18.3 Page from Zhamagirk' Hayastaneats'S. Ekeghets'wots' [Prayer book of the Holy Armenian Church], published by the SJAPH in $1881 \quad 383$

19.1 The page in the notebook where Wasif Jawharriyeh announces the inclusion of the photographs of the sultan 389 
19.2 Ra'uf Pasha, the mutessarif of Jerusalem, as he appeared in the first album 391

19.3 Ottoman troops in Palestine 392

19.4 The mayor's entourage upon the surrender of Jerusalem, December $1917 \quad 394$

19.5 The procession of the patriarch leaving the Church of the Holy Sepulchre 395

19.6 Page from the album showing the destruction of Jewish homes in Hebron and Jerusalem in $1929 \quad 397$

19.7 Visit of Ali al-Kassar to Jerusalem 398

20.1 Newer Jerusalem and suburbs. St. Paul's Hospice, a government office near Damascus Gate 412

20.2 The emblem of the Pro-Jerusalem Society, as depicted on the cover of Charles Robert Ashbee, Jerusalem, 1920-1922 416

23.1 A page from the Sephardic Kolel account book, 1851-80, income, Adar 5613 (January-February 1853) 466

24.1 Tramway project for the suburbs of Jerusalem: outline of the network 478

24.2 Plan of the tramline to be constructed in the city of Jaffa 478

\section{Tables}

4.1 List of the waqfyyāt of Maghariba neighborhood 96

11.1 Land sold to the PLDC 233

12.1 Inventory of the daftars of the budget: Income and expenditure of the Municipality of Nablus (first and second collections) $\quad 246$

12.2 Draft daftars (shatib) of expenditure of Nablus municipality (third collection) 248

12.3 Daftars of minutes, decisions, and correspondence (Madabit, Qararāt and Murāsalat) (fourth and fifth collections) $\quad 249$

12.4 Daftars (sixth, seventh, eighth and ninth collections) $\quad 25^{\circ}$

16.1 Hebrew newspapers in Jerusalem, 1863-1914 334

23.1 Average clinic visits to the English Mission Hospital, 1862-80, by gender 468

23.2 Hospitalization at the Rothschild Hospital, $1870-76$, by gender 469

25.1 Distribution of plots and percentage: total area and percentage, according to kind of property, $1967 \quad 499$

25.2 Distribution of private and endowed properties in the expanded Jewish Quarter, $2013 \quad 503$ 
25.3 Ratio of Jewish and Arab properties in the expanded Jewish Quarter, $1968 \quad 504$

25.4 All categories of property in Jerusalem's Old City, including waqf categories, mid-twentieth century $\quad 507$ 


\section{Abbreviations}

AAPJ Archive of the Armenian Patriarchate of Jerusalem (Yerusaghémi Hayots Patriark'ut'yan Arkhiv)

ACA American Colony Archive

ACAA American Colony Aid Association

ACPF Archives of the Congregation for the Propagation of the Faith (Archivio della Congregazione di Propaganda Fide)

ACRI Association for Civil Rights in Israel

AEPI Archive of the Greek (Rum) Orthodox Patriarchate of Jerusalem (Archeio Ellinorthodoxou Patriarcheiou Ierosolymon)

AIU Alliance Israélite Universelle

AJDC American Jewish Joint Distribution Committee

ALT Armenian-lettered Turkish

ASCTS Historical Archives of the Custody of the Holy Land (Archivio storico della Custodia di Terra Santa)

ASD Italian Ministry of Foreign Office archives (Archivio storico degli Affari Esteri)

Ass Arab Studies Society

AYE Historical and Diplomatic Archive of the Greek Ministry of Foreign Affairs (Istoriko kai diplomatiko archeio tou Ypourgeiou ton Exoterikon) AVPRI Archive of Foreign Policy of the Russian Empire, Moscow (Arkhiv Vneshnei politiki Rossiiskoi Imperii)

AZMU American Zionist Medical Unit

BOA Ottoman State Archives (Başbakanlık Osmanlı Arşivi)

CADN Nantes Diplomatic Archives Centre (Centre d'archives diplomatiques à Nantes)

CJH Center for Jewish History

co Colonial Office

CUP Committee for Union and Progress

CZA Central Zionist Archives

DOH Department of Health

EARJ Ethiopian Archbishop Residence in Jerusalem

EGM Directorate of General Security, Ankara (Emniyet Genel Mudurluğu)

EIE Greek National Foundation for Research (Ethniko Idryma Erevnon)

EMH English Mission Hospital, Jerusalem

ERC European Research Council

Fo Foreign Office

FPP Franciscan Printing Press 


\begin{tabular}{|c|c|}
\hline JMA & Jerusalem Municipal Archives \\
\hline HJP & Historical Jewish Press \\
\hline HMO & Hadassah Medical Organization \\
\hline JNF & Jewish National Fund \\
\hline IHB & International Health Board \\
\hline IJMES & International Journal of Middle East Studies \\
\hline ISA & Israel State Archives \\
\hline LE & Egyptian pound \\
\hline LJS & $\begin{array}{l}\text { London Society for Promoting Christianity among the Jews (or } \\
\text { London Jewish Society) }\end{array}$ \\
\hline MAE & $\begin{array}{l}\text { Diplomatic Archive Center of the Ministry of Foreign and European } \\
\text { Affairs, located in La Courneuve (Archives diplomatiques du Ministère } \\
\text { des Affaires Etrangères, La Courneuve) }\end{array}$ \\
\hline MAN & Municipal Archives of Nablus \\
\hline MESA & Middle East Studies Association \\
\hline NLI & National Library of Israel \\
\hline OJP & Open Jerusalem project \\
\hline IPA & $\begin{array}{l}\text { Historical and Paleographic Archive of the National Bank of Greece } \\
\text { Cultural Foundation (Istoriko kai Paleografiko Archeio tou Morfotikou } \\
\text { Idrymatos tis Ethnikis Trapezas tis Ellados) }\end{array}$ \\
\hline PLDC & Palestinian Land Development Company \\
\hline RAC & Rockefeller Archives Center, Tarrytown, New York \\
\hline REM & Russian Ecclesiastical Mission \\
\hline $\mathrm{RF}$ & Rockefeller Foundation Records \\
\hline RG & Record Group \\
\hline RGADA & $\begin{array}{l}\text { Russian State Archive of Ancient Acts (Rossiiskii Gosudarstvennyi } \\
\text { Arkhiv Drevnykh Aktov) }\end{array}$ \\
\hline RGIA & $\begin{array}{l}\text { Russian State Historical Archives, St. Petersburg (Rossiiskii } \\
\text { Gosudarstvennii Istoricheskii Archiv) }\end{array}$ \\
\hline ROPIT & $\begin{array}{l}\text { Russian Steam Navigation and Trading Company [Russkoe Obshhestvo } \\
\text { Parohodstva I Torgovli] }\end{array}$ \\
\hline SJAPH & St. James Armenian Printing House \\
\hline SPBFARAN & $\begin{array}{l}\text { St. Petersburg Department of the Archive of the Academy of Sciences } \\
\text { (Sankt-Peterburgskii Filial Archiva Rossiiskoi Akademii Nauk) }\end{array}$ \\
\hline SPC & Syrian Protestant College \\
\hline TNA & The National Archives of the UK \\
\hline UNRWA & United Nations Refugee Works Agency \\
\hline VGMA & $\begin{array}{l}\text { Archive of the General Directorate of Foundations (Vakıflar Genel } \\
\text { Müdürlüğü Arşivi) }\end{array}$ \\
\hline
\end{tabular}




\section{List of Contributors}

Gadi Algazi is Professor of Medieval History at Tel Aviv University and an associate fellow at the Work and Human Life Cycle in Global History international research center at the Humboldt University Berlin. His research areas include late medieval and early modern social and cultural history, with an emphasis on historical anthropology and gender history; he is particularly interested in the history and theory of the social sciences, settler colonialism and frontier societies.

Stéphane Ancel is a historian specializing in Ethiopia and religious movements in the Horn of Africa during the nineteenth and twentieth centuries. $\mathrm{He}$ is a full-time researcher in the French Center for National Research (CNRS) in Paris (CéSor-EHESs) and a member of the core team of the Open Jerusalem project. He is coauthor, with Vincent Lemire and Magdalena Krzyzanowska, of Le Moine sur le Toit: une histoire des chrétiens éthiopiens à Jérusalem (forthcoming, 2018) regarding the Ethiopian Christian community in Jerusalem at the beginning of the twentieth century.

Yasemin Avcı joined the History Department of Pamukkale University in 2004, where she is professor of Ottoman history. She is a member of the core team of the Open Jerusalem project. Her research focuses on the urban and social history of the Ottoman Empire in the nineteenth century. In 1996-97 she was a visiting PhD student at the Hebrew University in Jerusalem and in 2005 spent a year at soAs as a visiting scholar. She is the author of Değişim Sürecinde Bir Osmanlı Kenti: Kudüs 189o-1914 [An Ottoman town in transition: Jerusalem, 1890-1914] (2004) and Osmanlı Hükümet Konakları: Tanzimat Döneminde Kent Mekanında Devletin Erki ve Temsili [Ottoman governmental houses: representation of state power in Ottoman cities in the Tanzimat era] (2017).

Philippe Bourmaud is Assistant Professor of Modern and Contemporary History at Lyon 3 University and an associate researcher at the French Institute of Anatolian Studies (IFEA) in Istanbul. After an extensive stay in Nablus and Ramallah for his research on late Ottoman medicine in Palestine, he is currently working on the issues of tuberculosis and alcoholism in the Levant.

Michelle U. Campos is Associate Professor of Middle Eastern History at the University of Florida. She received her PhD in history from Stanford University in 2003. Her first book, Ottoman Brothers: Muslims, Christians, and Jews in 
Early Twentieth Century Palestine (2011), was the recipient of the 2010 Yonatan Shapiro Award for Best Book in Israel Studies, awarded by the Association for Israel Studies, as well as the 2011 National Jewish Book Award in Sephardic Culture. She is currently writing a spatial history of intercommunal relations in Jerusalem in the late nineteenth and early twentieth centuries.

Leyla Dakhli is a full-time researcher in the French Center for National Research (CNRS-Marc Bloch Center, Berlin) and member of the core team of the Open Jerusalem project. Her work focuses particularly on the study of Arab intellectuals, the social and cultural history of southern Mediterranean region with a special focus on women, the social uses of languages, social movements and popular politics. She has published Une génération d'intellectuels arabes: Syrie et Liban (1908-1940) (2009) and Histoire du Proche-Orient contemporaine (2015) and edited the collective volume Le Moyen-Orient fin XIX-XX siècle (2016). She now leads the European Research Council-funded project "Drafting and Enacting the Revolutions in the Arab Mediterranean: In Search of Dignity, from the 1950s until today" or DREAM (ERC consolidator grant, 2018-23).

Angelos Dalachanis is a research fellow of the French School at Athens. He is member of the Open Jerusalem project core team and coeditor (with Vincent Lemire) of the Open Jerusalem series at Brill. He holds a PhD in history from the European University Institute, Florence. He was a postdoctoral research fellow at the LabexMed at Aix-Marseille University (2012-14), and at the Seeger Center for Hellenic Studies at Princeton University (2014-15). He has taught at Paris-Est Marne-la-Vallée University. His research interests include the Greek diaspora, migration, labor, and intercultural contacts in the eastern Mediterranean in the modern period. He is the author of The Greek Exodus from Egypt: Diaspora Politics and Emigration, 1937-1962 (2017).

Sotirios Dimitriadis is a historian of the late Ottoman Empire, with a special interest in urban and social history. He holds a PhD from the Department of History of soAs (University of London) and is a postdoctoral researcher at the University of Macedonia in Thessaloniki.

Beshara Doumani is Professor of History and Director of Middle East Studies at Brown University. His research focuses on groups, places, and time periods marginalized by mainstream scholarship on the early modern and modern Middle East. His books include Family Life in the Ottoman Mediterranean: A Social History (2017) and Rediscovering Palestine: Merchants and Peasants in Jabal Nablus, 1700-190o (1995). He has edited Academic Freedom After 
September 11 (2006) and Family History in the Middle East: Household, Property and Gender (2003). He is also the editor of a book series, New Directions in Palestinian Studies, with the University of California Press.

Edhem Eldem is Professor of History at the Department of History of Boğaziçi University and holds the International Chair of Turkish and Ottoman History at the Collège de France. He has also taught at Berkeley, Harvard, Columbia, EHESS, EPHE, ENS, and was a fellow at the Wissenschaftskolleg zu Berlin. He has worked and published extensively on Levant trade, funerary epigraphy, Istanbul, the Imperial Ottoman Bank, the history of Ottoman archaeology and collections, Ottoman first-person narratives and photography in the Ottoman Empire.

Şerife Eroğlu Memiş is a historian and expert on foundations in the Archive of the General Directorate of Foundations in Ankara, Turkey. She graduated from the Department of History of the Middle East Technical University and pursued her studies with a masters on minorities in the Ottoman Empire at the Middle East Studies program of the same university. She received a PhD from Hacettepe University (2016) for a thesis entitled "Ottoman Provincial Society and the Waqf: Jerusalem, 1703-1831," in which she examined the role of Jerusalem's waqf network on urban space, social relations, and relations with the central government during the period under scrutiny. She is continuing her research on urban history, the Ottoman waqf system and political culture.

Louis Fishman is Assistant Professor at Brooklyn College, City University of New York. His work focuses on late Ottoman history, in addition to modern Turkish, Palestinian, and Israeli history. He currently is on the last stages of his book, with the tentative title Claiming the Homeland:Jews and Arabs in late Ottoman Palestine (1908-1914).

Lora Gerd is Lecturer at St. Petersburg State University and researcher at the Russian Academy of Science (St. Petersburg Institute of History). She is the author of numerous books and articles on Greek-Russian relations (church policy and cultural relations) and on Greek manuscripts. She has edited several primary archival sources including the correspondence of George Begleri $(1878-98)$ and the journals of Antonin Kapustin, 1850-60. She collaborates with the Open Jerusalem project for Russian-language archives and she is also working on projects on the history of Mt. Athos, the Patriarchate of Alexandria and the history of Byzantine studies in Russia and the Greek world. 
Jonathan Marc Gribetz is Assistant Professor of Near Eastern Studies and Judaic Studies at Princeton University. He is the author of Defining Neighbors: Religion, Race, and the Early Zionist-Arab Encounter (2014). He is currently writing a book on the Palestine Liberation Organization's Research Center in Beirut, for which he received a Fulbright Scholarship and a grant from the National Endowment for the Humanities.

Jens Hanssen is Associate Professor of Arab Civilization, Middle Eastern and Mediterranean history at the University of Toronto, where he teaches Arab intellectual history; the late Ottoman Empire; settler colonialism in Palestine; counter-insurgency and decolonization in the Middle East; and urban colonialism in the modern Mediterranean. His book publications include Arab Provincial Capitals in the Late Ottoman Empire (2002), Zokak al-Blat: History, Space and Social Conflict in Beirut (2005), Fin de Siècle Beirut (2005), The Oxford Handbook of Contemporary Middle Eastern and North African History (with Amal Ghazal); Arabic Thought Beyond the Liberal Age and Arabic Thought Against the Authoritarian Age (both with Max Weiss).

Yali Hashash heads the Gender Studies department in Beit Berl College. She holds a PhD in Jewish History (Haifa University, 2011) and was a postdoctoral fellow of Tel Aviv University (2011) and of the Taub Center for Israeli Studies, New York University (2012). She is a founding member of the Women Historians Forum of the Isha Lisha Feminist Research Center, and coheads the Oral History Laboratory of Tel Aviv University. Her research interests include the social history of the nineteenth- and twentieth-century Palestine and the Middle East, poverty, gender, nationalism, ethnicity and reproduction. Her work has appeared in several peer-reviewed journals and she is currently working on a book on Mizrahi feminism.

Hassan Ahmad Hassan is a historian and linguist at the Faculty of Foreign Languages of the University of Jordan. He holds a master's degree in Jewish studies from the University of Jordan. His research focuses on the Hebrew press in late Ottoman and Mandatory Palestine.

Abdul-Hameed al-Kayyali is a historian and member of the core team of the Open Jerusalem project. He is an associated researcher at the Institut français du Proche-Orient (Ifpo) in the Department of Medieval and Modern Arabic Studies (DEAM). He holds a PhD from the University of Aix-Marseille in the "Studies of Arab and Muslim World". His research focuses on the cultural and religious contacts of Arab Jews in general and Jerusalemite Jews in particular during late Ottoman and Mandatory Palestine. 
Arman Khachatryan is a $\mathrm{PhD}$ candidate in interdisciplinary studies at BenGurion University of the Negev, Israel. He holds a BA and an MA in cultural studies from Yerevan State University and a master's degree in Israel studies from Ben-Gurion University. Since 2014, he has been a collaborating researcher with the Open Jerusalem project. He is currently working on his dissertation, which focuses on the activities of the Armenian Patriarchate of Jerusalem from 1909 to 1949. His research interests include Israel studies, Armenian studies, nationalism, and ethnic and religious studies.

Gudrun Krämer is Professor of Islamic Studies and Director of the Berlin Graduate School Muslim Cultures and Societies at Freie Universität Berlin; a member of the Berlin-Brandenburg Academy of Sciences and the Tunisian Academy of Sciences (Bayt al-Hikma), and an executive editor of The Encyclopaedia of Islam Three. She has been a visiting scholar in Beijing, Beirut, Bologna, Cairo, Erfurt, Jakarta, and Paris and has published widely on Middle Eastern history, Islamic movements, and Islamic political thought.

Vincent Lemire is Associate Professor at Paris-Est Marne-la-Vallée University and director of the ERC project "Opening Jerusalem's archives: for a connected history of "Citadinité' in the Holy City (1840-1940)" (ERC starting grant, 2014-19). He holds a PhD from the University of Provence and his work focuses mainly on Jerusalem and the modern Middle East, environmental history and the history of cultural heritage. He is the author of La soif de Jérusalem: essai d'hydrohistoire 1840-1948) (2010), Jérusalem 19oo: la ville-sainte à l'âge des possibles (2012) and edited the volumes Jérusalem: Histoire d'une ville-monde (2016) and Le Moyen-Orient de 1876 à 1980 (2016).

Noémi Lévy-Aksu is a British Academy Newton International Fellow at the School of Law of Birkbeck College, University of London. After completing a $\mathrm{PhD}$ in Ottoman history at the EHEss-Paris in 2010, she worked as an assistant professor in the Department of History of Boğaziçi University until 2017. Besides her book Ordre et désordres dans l'Istanbul ottomane (2013), she has published several articles and book chapters on late Ottoman urban, political and legal history.

Roberto Mazza is Lecturer at the University of Limerick and research associate at SOAS. He is the author of Jerusalem from the Ottomans to the British (2009) and editor (with Eduardo Manzano Moreno) of Jerusalem in World War I: The Palestine Diary of a European Consul (2011). He is a member of the editorial board of Jerusalem Quarterly and a contributor to the same publication. He has published several articles discussing World War I in Jerusalem and in Palestine, 
including a recent chapter on the evacuation of Jaffa in 1917. He is currently working on a large project discussing the urban planning of Jerusalem from 1918 to 1926 .

Irina Mironenko-Marenkova is a historian, teacher and translator. She studied in Moscow (Russian State University for the Humanities) and in Paris (EHESS). Her research interests concern the history of religious beliefs and the diplomatic relationship between France and Russia. She has translated numerous works in the humanities from French to Russian.

Abla Muhtadi is an award-winning independent researcher and author with a focus on Jerusalem. She worked as a researcher at the Centre for Documents, Manuscripts and Bilad al-Sham Studies of the University of Jordan from 2005 to 2016 and is the author of five books in Arabic, including AlQuds, tarikh wa hadara [Jerusalem, history and civilization] (2000), Al-Quds wa-l hukm al-'askari al-britani, 1917-1920 [Jerusalem and British military rule, 19171920] (2003) and Awqaf al-Quds fi zaman al-Intidab al-britani [Endowments in Jerusalem at the time of the British Mandate] (2005).

Falestin Naïli is a social historian and researcher at the Institut Français du Proche-Orient (Ifpo) in Amman. She is a member of the core team of the Open Jerusalem project. Her publications deal with urban governance in the Ottoman and Mandate period, millenarist settlement and missionary projects in Palestine, forced migration in the contemporary Middle East, early ethnographies of Palestine, and collective memory and heritage issues in these contexts.

Issam Nassar is Professor of History at Illinois State University and coeditor of Jerusalem Quarterly. He is author of a number of books on photography and Jerusalem, including Laqatat Mughayira: Al-Taswir Al-Mahalli Al-Mubakkir Fi Filastin, 1850-1948 [Alternative shots: early local photography in Palestine, 1850-1958] (2006). He has edited a number of books, including, with Salim Tamari, The Storyteller of Jerusalem: The Life and Times of Wasif Jawhariyyeh, 1904-1948 (2013).

Ömür Yazıcı Özdemir graduated from the History Department of Ege University in 2012. She received an MA from the History Department of Celal Bayar University in 2015. Her master's thesis was published as Aydın Vilayetinde Suçve Ceza (1866-1877) [Crime and punishment in Aydın province] 
(2016). She is currently working on her PhD thesis entitled "Urban Politics and Collective Petitions in Ottoman Jerusalem (1840-1917)" at the History Department of Pamukkale University under the supervision of Yasemin Avcı.

Konstantinos Papastathis is a research associate at the University of Luxembourg. He has worked as a research fellow at the Hebrew University of Jerusalem (2011-13) and was adjunct lecturer at Aristotle University of Thessaloniki (2008-12). He has published in several peer-reviewed journals (including Middle Eastern Studies, British Journal of Middle Eastern Studies, Jerusalem Quarterly, Journal of Eastern Christian Studies, Religion, State and Society) as well as in collected volumes.

Yann Potin is a historian and an archivist. He works at the National Archives in Paris and is an Associate Professor at Paris-Nord University. He is a member of the core team of the Open Jerusalem project. His research is devoted to the comparative history of archival practices and policies. He is the author of numerous articles and has contributed to many collective works. He is coordinator of the Histoire mondiale de la France, edited by Patrick Boucheron (2017), collaborator of Jerusalem: Histoire d'une ville-monde des origines à nos jours (2016), edited by Vincent Lemire, and coeditor of Les Archives et la genèse des lois (2016).

Maria Chiara Rioli is a historian of modern Christianity. She received her $\mathrm{PhD}$ in contemporary history at the Scuola Normale Superiore. She is a postdoctoral fellow at the University of Paris-Est Marne-la-Vallée as well as project manager, digital humanist and member of the core team of the Open Jerusalem project. Her research focuses on the history of the Roman Catholic community in Palestine, Israel and Jordan, Jewish converts to Christianity within the Latin Patriarchate of Jerusalem, and the history of Mediterranean Christian thought. Her forthcoming book Tribulationis Tempore: The Latin Church of Jerusalem, the First Arab-Israeli War and its Aftermath, 1946-1956 is under contract with Brill.

Julia R. Shatz is Assistant Professor of History at California State University, Fresno. She received her PhD in history from the University of California, Berkeley. Her work examines the intersection of social and political histories of the Middle East with global and transnational movements in the twentieth century. She has written and presented on multiple aspects of social welfare in Palestinian history, including public health, juvenile delinquency, and 
child-saving initiatives. Her current project, Governing Global Children: Child Welfare in Palestine, 1917-1950, explores the local and global origins of a regime of child welfare governance during the years of the Mandate for Palestine.

Salim Tamari is Emeritus Professor of Sociology at Birzeit University, a research associate at the Institute for Palestine Studies and editor of Jerusalem Quarterly. His recent publications include Mountain Against the Sea: Essays on Palestinian Society and Culture (2009); Year of the Locust: A Soldier's Diary and the Erasure of Palestine's Ottoman Past (2011); (with Issam Nassar) The Storyteller of Jerusalem: The Life and Times of Wasif Jawhariyyeh (2014); The Great War and the Remaking of Palestine (2017); Jerusalem properties and endowments in the 2oth century (with Munir Fakhr ed-Din, forthcoming 2018 in Arabic). He holds a $\mathrm{PhD}$ in sociology from Manchester University and was a visiting professor at Ca Foscari University, Georgetown University, New York University, Cornell University, University of Chicago, Harvard University and Columbia University.

Agamemnon Tselikas is a graduate of classical philology of the University of Athens and a specialist in Greek paleography. He completed his postgraduate studies in Venice and Paris. Since 1980 he has been the director of the Center for History and Paleography (IPA) of the National Bank of Greece Cultural Foundation. He has carried out more than two hundred missions throughout Greece and the Middle East for the digitization of manuscripts. He has also taught courses on Greek paleography at the universities of Patras, Corfu and Ravenna and has conducted a seminar on Greek paleography at the IPA for the last 35 years.

Kirill Vakh is a historian and an archivist. Since 1999 he has been the director of Indrik publishing house, which specializes in the humanities. He is also the editor of the web platform Ierusalimsky Pravoslavny Seminar for scholars working on the history of the Holy Land. He has participated in numerous different archival and publishing projects as well as in exhibitions concerning the history of the Russian presence in the Holy Land.

Yair Wallach is Lecturer in Israeli Studies in soAs, University of London, where he is also the head of the soAs Centre for Jewish Studies. He specializes in the cultural, material and social history of modern Palestine/Israel. He has written on topics such as maps as symbols in Zionism and Palestinian nationalism, and "shared space" in modern Jerusalem. He is currently working on a book on Arabic and Hebrew street texts in Jerusalem under late Ottoman and British rule. 
Mahmoud Yazbak is Senior Lecturer in Palestinian History at the Department of Middle Eastern History of the University of Haifa. He studied at the University of Haifa, the Hebrew University in Western Jerusalem and Oxford. He is the author of numerous articles and of Haifa in the Late Ottoman Period, 1864-1914: A Muslim Town in Transition (1998). He is also the coeditor (with Yfaat Weiss) of Haifa Before and After 1948: Narratives of a Mixed City (2011). 


\section{Note on Transliteration}

One of the main challenges faced by the Open Jerusalem project is the multilingual nature of the city of Jerusalem and, subsequently, the variety of languages in its archives. This volume contains words from twelve different languages, five of which are in the Latin alphabet (English, French, German, Italian, Turkish) and seven in non-Latin characters (Amharic, Arabic, Armenian, Greek, Hebrew, Ottoman Turkish, Russian). Our effort was to standardize these several languages through romanization, with the assistance of Lilach Assaf, Lora Gerd, Hassan Ahmad Hassan, and Elias Kolovos, by members of the core team of the project and, of course, volume contributors. For Arabic, Hebrew and Ottoman Turkish, we generally follow the transliteration guidelines of the International Journal of Middle East Studies and for Armenian the Library of Congress system. Greek has been rendered using the ELOT 743 standard. For Amharic a simplified version of the transliteration system of Encyclopedia Aethiopica (edited by Siegbert Uhlig) has been adopted, whereas for Russian the us transliteration system is followed. 


\title{
Introduction: Opening Ordinary Jerusalem
}

\author{
Angelos Dalachanis and Vincent Lemire
}

Is Jerusalem an ordinary city? To understand its history, should we favor a local or global approach? The goal of this collective volume is to take a head-on approach to these two persistent questions, which have long stood as a hindrance to writing the city's history. Taking as a departure point the conceptual framework of Open Jerusalem, a project funded by the European Research Council (ERC), ${ }^{1}$ each contribution works in its own way to confront, and transcend, a double uncertainty. First, Jerusalem is an extraordinary city that can be understood only with the greatest possible use of the most ordinary tools of social, political and cultural historical research. Second, Jerusalem's local history can only be reconstructed by reference to archives often located in faraway places, including, among others, Addis Ababa, Amman, Athens, Berlin, Erevan, Istanbul, London, Madrid, Moscow, Rome, St. Petersburg, Sofia and Washington. In transforming this double contradiction into a creative analytical tension, the thirty-seven authors of this volume revisit the ordinary history of a "global city" from 1840 to 1940, a century that covers the later period of Ottoman rule and most of the Mandate years.

\section{New Objects}

This new approach has thematic consequences. The new history of Jerusalem, to which this volume aims to contribute, goes beyond a study of geopolitics and religion. Western historians have long concentrated on these dimensions: from the top of the Mount of Olives they observed what they had come to find, that is, a constellation of controversial holy places clustered together on an

1 The Open Jerusalem project (full title: "Opening Jerusalem Archives: For a Connected History of Citadinité in the Holy City, 1840-1940") is funded by the European Research Council (starting grant) from 2014 to 2019 and is based at the Paris-Est Marne-la-Vallée University in France. The project is directed by Vincent Lemire and run jointly with the researchers of the core team: Stéphane Ancel, Yasemin Avcı, Louise Corvasier, Leyla Dakhli, Angelos Dalachanis, Abdul-Hameed al-Kayyali, Falestin Naili, Yann Potin, Maria Chiara Rioli and Katerina Stathi. In addition, more than 50 other scholars from Europe, the Middle East, the United States and Canada have been involved in the project so far. For more information see: http://www .openjerusalem.org.

(C) ANGELOS DALACHANIS AND VINCENT LEMIRE, 2018 | DOI:10.1163/9789004375741_002

This is an open access chapter distributed under the terms of the prevailing CC-BY-NC-ND License at the time of publication. 
eternal battlefield. Here we choose to shed light on unexpected actors hidden in the blind spots of the city's history, too long ignored by an expanding historiography, which sometimes is unperceptive and preconceived. These actors include the printers of visiting cards, Ottoman officers in charge of fiscal censuses, angry city dwellers signing petitions in favor of modernizing the water supply system, epidemiologists fighting malaria, municipal civil servants looking to Beirut, Haifa and Nablus for inspiration, an Islamic court judge deciding a case pitting a Russian plaintiff against an Armenian defendant, an Arab parliamentarian in conversation with the creator of modern Hebrew, an orphanage built on and run along American standards, a musicianphotographer, and the engineers and investors behind an aborted tramway project. These ordinary episodes are brought to life by ordinary actors who were part of Jerusalem's extraordinary destiny. It is through a history told from below, through small, everyday stories, that the grand history of the city emerges with new colors.

\section{New Timeline}

Chronologically speaking, this new approach also has consequences. Though the transition from Ottoman rule (1516-1917) to the British Mandate (1917-48) has traditionally been considered a key turning point in the history of Palestine and Jerusalem, the majority of the volume's contributors do not consider the year 1917 to be useful in their analyses. ${ }^{2}$ Nor do the historians represented here take a strictly geopolitical approach. Making use of the chronological framework offered by the Open Jerusalem project, they chose to consider the period from 1840 to 1940 as a coherent historical sequence that is well-suited to the study of Jerusalem's history. The commitment to studying these hundred years is in itself a historiographical novelty. Indeed, seeing past the 1917 mark makes it possible to analyze long-term historical factors otherwise overlooked by the geopolitical watershed associated with that year. Between the vigorous demographic renewal and the arrival of the first European consulates in the 1840 s, on the one hand, and the rise of intercommunity conflict in the late 1930s, on the other, the 1840-1940 span becomes a seamless historical sequence. This hundred-year period saw the birth, maturity and ruin of a certain model of citadinité, understood here as the way in which city dwellers share urban space, in varying degrees of harmony or conflict.

2 Abigail Jacobson recently attempted to rethink the breaks and continuities between the Ottoman period and the British Mandate in From Empire to Empire: Jerusalem between Ottoman and British Rule (Syracuse: Syracuse University Press, 2011). 
This relative continuity is particularly evident when one examines the specific institutional structures that largely persisted even after the fall of the Ottoman Empire, and on which many of the authors chose to concentrate, such as the municipalities, the patriarchates (Greek Orthodox, Armenian, Latin), the Muslim awqāf, the Sephardic kolels, the Islamic courts and the Franciscan Custody. These entities - religious, political, cultural and economic - are proof of an institutional resilience that, through this day, have rendered the "key years" of Jerusalem's history $(1917,1947,1967)$ partly meaningless. Certain local political actors, and some of the important Jerusalem families, also contributed to creating continuity between the Ottoman period and the British Mandate. Finally, administrative practices and daily urban problems such as public health and hygiene, public order, patrimony and public spaces reinforce this chronological continuity and reduce the importance of the geopolitical marker of 1917.

\section{New Archives}

This new approach has its most significant consequences in the realm of methodology. The history that we set out to tell here is informed by unpublished archival materials and is, as a result, a collective history founded on collaboration as well as the confidence in the utility of a collective endeavor. It would be impossible for a single researcher to access and analyze documents in Amharic, Arabic, Armenian, English, French, German, Greek, Hebrew, Italian, Ottoman Turkish, Russian, Syriac, to name but a few. Indeed, almost every language connected to the three Abrahamic religions was spoken, written and archived in the "global city" of Jerusalem. In addition to linguistic obstacles, there are, in many cases, geopolitical challenges. These archives are not always public and immediately accessible. They are dispersed throughout the world and can often be consulted only after passing checkpoints and borders that not all researchers can cross. The trust of archival institutions was secured thanks to the Open Jerusalem project's founding ideas: focusing on the description of archives rather than on their digitization. This approach stands out from most digital humanities history projects, which have often confused accessibility and mass digitization. Open Jerusalem privileges the description, indexing and translation of archives, in the conviction that the mere uploading of tens of thousands of digitized pages with no accompanying description does not necessarily make information accessible. With this approach, information is not merely made visible, but searchable and findable. This new strategy is perhaps the only way to break down the barriers that still limit and challenge community historiographies. 
The contributions assembled here illustrate another methodological ambition of the Open Jerusalem project: archival release must not be understood only in quantitative terms, but also, and perhaps especially, in qualitative ones. Renewing the history of Jerusalem requires more than gaining access to a mass of documents. Our aim also is to renew the type of documentation mobilized and fashion the theoretical and practical tools needed to establish links between documents. The articles in the present volume embody this renewal of documentary typology, voluntarily putting aside the most accessible exogenous narrative sources (such as travel narratives), and focusing instead on internal administrative sources. Repetitive as they may be, and requiring extra analytical efforts, these are the only sources that allow for a thorough reexamination of the historical stereotypes of the city. Such documents include baptismal registers, tax registers, meeting minutes, technical reports, collective petitions, accounting documents, payroll records, quotes, invoices, engineering plans, personnel directories, municipal deliberations, lists of indigents who received assistance, judicial reports, offers of concessions, signs and posters. These archives of quotidian lives and daily administrative practices often tell us more about the urban history experienced by Jerusalem residents than external narratives, which are so often interspersed with religious discourse and ideological projections.

\section{Connected History}

In addition to unlocking previously inaccessible archives and revising the typology of the documents studied, the Open Jerusalem historians also attempt to establish links between the various documentary collections. This effort is intended to refine analyses by encouraging comparisons between the city's communities. From a practical perspective, it also means that more information is made available about each community. In Jerusalem more than anywhere else, interactions between communities - whether they be peaceful or conflictual - are strong and frequent. They are documented through correspondence, complaints and petitions, and more. Essential information about a specific community may thus be scattered across many diverse archival holdings, sometimes in multiple languages and in many countries. It is in this way that descriptions and indexes, translations and collaboration, take on primary importance.

For example, in order to document the history of the city's small Ethiopian community, for example, it is not enough to consult Amharic records in the Ethiopian Archbishop's Palace in Jerusalem or in Addis Ababa. Given the 
relationship of subordination and protection that the Ethiopians of Jerusalem established with the Great Powers in the Holy City, one must also visit the Italian archives in Rome, and the Russian and Ottoman archives, respectively, in St. Petersburg and Istanbul. The history of the Armenian community is also documented in the archives of the Greek Orthodox Patriarchate, but these archives are largely connected to the Russian archives because of the links between these two major Orthodox churches. The history of Jerusalem's Jewish communities is contained in the British consular archives in London, but also in the American archives in Washington. The examples go on, but all of them show that Jerusalem has always been an open city, open to all influences, interferences and appropriations, be they symbolic, textual, military or territorial. For the historians of the Open Jerusalem project and those participating in this volume, the question is not so much how to open a city that is closed to the outside as it is to deal with a city that is compartmentalized and burdened by internal fractures. In order to begin this process, we must first open pathways that can be used to allow researchers to proceed to make connections between separate documentary collections. This opening process is one of the essential objectives of this collective work. ${ }^{3}$

\section{From New Archives to New Narratives}

For the Open Jerusalem project, this volume marks a shift from the identification and collection of archives to their assembly and the synthesis of original narratives. This is not to suggest that the archival work has come to an end. On the contrary, the Open Jerusalem web platform (www.openjerusalem.org) already makes documentation accessible to interested researchers and will keep the project alive, even after the end of ERC funding in 2019. Our ambition, though, is to begin putting concrete meaning on the extensive and unique raw empirical material that exists; to do so, we needed to approach these archives with methodology and theory, with content and structure. Our ambition is to offer a pivotal contribution to the history of Jerusalem of the late Ottoman and Mandate periods, not only by being methodologically and theoretically innovative, but also by challenging well-established ideological narratives regarding the city.

Many of the volume's chapters were initially presented as original papers at a symposium at the Institute for Mediterranean Studies in Rethymno,

3 Vincent Lemire (ed.), Jérusalem: Histoire d'une ville-monde des origines à nos jours (Paris: Flammarion, 2016), available in Italian and forthcoming in Arabic and English. 
Greece, in May 2016. Amounting to much more than a simple symposium, this research meeting, held halfway through the Open Jerusalem project, sought to be a forum for the deepening of discussions and the opening of scholarly debates, based on contributions by academics specializing in Jerusalem and Palestine as well as urban historians specialized in other Ottoman cities and related topics. Our subsequent objective was not to publish the symposium proceedings, but to combine the papers with a number of new contributions to produce a coherent volume that privileges interconnectedness. Our effort to link dissimilar approaches is somewhat reflected in the various origins of the volume's thirty-seven contributors. The scholars represented here are mostly young academics, of diverse national, ethnic and religious backgrounds, who in a way mirror the global character of the city that was and still is Jerusalem.

From the very start, our intention was to underline the city's global quality through a comparative perspective and, wherever possible, by adopting a gaze from below. To this end, the archival dimension of the authors' methodological work and analysis has been crucial. Each contributor was asked to include in their chapters a presentation and description of the sources and archives that they used for their contribution. More generally, they were also asked to discuss the available sources and archives relating to their topic. Seeking a "chronological" history, we asked the scholars to extend time limits when necessary, to include and analyze turning points, changes, shifts and gaps along with various experiences or perceptions of time. We also suggested that they look for connections with other studies, research fields and communities in order to create links between the city's usually fragmented historical narratives. To privilege connection over fragmentation, we encouraged the authors to seek contact points within their complex documentary archipelago and to show the exchanges, interactions and, where evident, hybridization between different populations and traditions. Finally, we asked them to try to bridge their contributions with the other papers that were presented at the symposium. We challenged them to cross-reference their fellow scholars, both in terms of content or methodology, and in terms of comparison or contrast. Our ambition is to open new paths for interconnected historical work.

\section{Looking for Citadinité}

In devising a novel historical approach to Jerusalem, our aim has been to publish a collective work structured around topics and questions already raised by the Open Jerusalem project. First, there is the central concept of citadinité, which the authors were invited to discuss critically whenever possible in light 
of their own research. As most historical studies do for the period under scrutiny, this volume attempts to deconstruct nationalism, colonialism and imperialism as well as to propose a different analytical framework for the study of the city. The concept of citadinité offers such a novel framework since it overcomes the binary scheme of domination/subjugation and regards Jerusalem as an inclusive city.

The notion of citadinité, borrowed from the French vocabulary of geography and urban sociology, describes the dynamic identity relationship city dwellers have with each other and their urban environment. ${ }^{4}$ It is also close to the notion of "cityness" forged by Saskia Sassen to reflect on the ability of residents of global cities to "make a city" together. ${ }^{5}$ While the Open Jerusalem project borrows from historical geography, it also avails of the tools of urban anthropology. ${ }^{6}$ Here, a connected history of citadinité embraces the key notion of "urban citizenship," meaning the identity-forming ties which (individually or collectively) link residents to their city, its history, patrimony, monuments, landscapes and eminent historical figures. Such ties are imagined, manufactured, appropriated and maintained, just like the ties that national citizenship produces. ${ }^{7}$ The notion of citadinité is, therefore, crucial to the study of the history of mixed, imperial and divided cities, as it asks a fundamental question: in the face of religious barriers and projections of national identities, how do residents proceed to "make a city" anyway?

Citadinité is not a vague, abstract notion that hovers above the city; nor is it only a discursive category. It is to a city what nationality is to a country, and it is materialized in institutions, actors and practices. Revisiting Jerusalem through citadinité also means revisiting practices related to it such as urban policies and institutions (municipality, waqf, consulates, patriarchates, associations). Contrary to what historiographic tradition has long maintained, ${ }^{8}$ the notion of public space is not absent from Muslim cities, where it must be studied

4 Michel Lussault and Pierre Signoles, eds, La citadinité en questions (Tours: Urbama; University of Tours, 1996).

5 Saskia Sassen, "Cityness," in Urban Transformation, ed. Andreas Ruby and Ilka Ruby (Berlin: Ruby Press; Zurich: Holcim Foundation for Sustainable Construction, 2008).

6 Jeff Halper, "On the Way: The Transition of Jerusalem from a Ritual City to Colonial City (1800-1917)," Urban Anthropology 13, no. 1 (1984).

7 Benedict Anderson, Imagined Communities: Reflections on the Origins and Spread of Nationalism (New York: Verso, 1983).

8 Xavier de Planhol, Les fondements géographiques de l'histoire de l'Islam (Paris: Flamarrion, 1968). 
simultaneously on the municipal, judicial and imperial levels. ${ }^{9}$ The Ottoman administrative reforms (Tanzimat) of the 1840 os favored the emergence of institutions such as the municipality, which furthered a shared city identity transcending communitarian barriers. ${ }^{10}$ Work on citadinité needs to prioritize such institutions, to which other institutions, notions and concepts are strongly linked, such as public services (transport, hygiene, etc.), public order (police), public knowledge (printing houses, multilingualism), public charity (the poor and orphans) and public opinion (newspapers, petitions, press interviews and debates). These are but a few examples of the investigations, made possible by connections between documentary collections, undertaken in the volume. The contributors revisit these approaches to citadinité along with other notions and analytical categories that have been rarely linked to Jerusalem, such as gender relations and children's lives. Jerusalem offers an impressive potential for a connected history of citadinité. We hope that this effort to uncover further opportunities will continue even after the ERC funding of the Open Jerusalem project ends.

\section{Four Parts, Four Paths}

Apart from primary sources, the authors of the volume put to use local and national historiographies in many different languages and adopted a variety of angles to revisit the aforementioned objects and approaches in the twenty-six chapters of the volume, which are divided into four thematic parts. We invited four prominent colleagues (Gadi Algazi, Beshara Doumani, Edhem Eldem and Gudrun Krämer) to preface these four parts using their sometimes distant but also highly qualified and sensitive perspectives. We asked them to provide a global reflection on their respective part with a short preface and we appreciate their eagerness to do so.

The first part, "Opening the Archives, Revealing the City," is prefaced by Krämer. This part is mostly structured around the archival material recently discovered by the core team and other researchers associated with the project. The opening of these archives provides material proof of the Open Jerusalem project's aim to create new perspectives on citadinité and global entanglements. Doumani prefaces the second part, "Imperial Allegiances and Local recherche sur le Maghreb contemporain, 2002).

10 Vincent Lemire, Jerusalem 19oo: The Holy City in the Age of Possibilities, trans. Catherine Tihayni and Lys Ann Weiss (Chicago: University of Chicago Press, 2017). 
Authorities," which brings the city into the logics of imperial and local legitimacy through the analysis of agency and various institutions: municipalities, patriarchates, consulates and court records. Jerusalem has always been a city of schools, teaching and libraries. During the second half of the nineteenth century, there was an increase in the flow and exchange of knowledge in a process of hybridization that helped bring about a shared urbanity. ${ }^{11}$ In this respect, the third part, entitled "Cultural Networks, Public Knowledge," is devoted to this reality. With his preface, Eldem offers the perspective of an Ottoman historian. The entire volume proposes a relational ordinary history of the city through links and contacts among people whose narratives of exceptionality and exclusivity are widespread. This is true not only among Jews and Palestinians, but also among Greeks, Armenians and other communities. The fourth and final part, "Sharing the City: Contacts, Claims and Conflicts," is prefaced by Algazi. It shows that the relational history of Jerusalem has never been harmonious, nor has it been a constant battlefield. Our goal is not to deny the existence of antagonisms between communities or to paint an idyllic picture of a city at peace. However, current communitarian, religious and ethnic divisions may obscure or disorient our gaze to the past, either by overemphasizing conflicts between specific ethnic or religious groups or by downplaying differences between others. Here, we seek to go far beyond partisan politics to shed light on a complex and stunning city.

Finally, we would like to express our gratitude to all the authors of the volume for their collaboration. We heartily thank the Institute for Mediterranean Studies of the University of Crete for hosting the symposium, its then-director Christos Hadziiossif, and Katerina Stathi, who coorganized it with us. The support of the University Paris-Est Marne-la-Vallée, and especially of Gilles Roussel, Damien Lamberton, Caroline Trotot, Loïc Vaderloge, Geneviève BührerThierry, Frédéric Moret, Valérie Theis, Bertrand Alliot, Bastien Pincanon, Virginie Leroy and Virginie Dubos-Jan, has been continuous and salient since the beginning of the Open Jerusalem project. The English-language editors of the volume, Jill A. McCoy, Niamh Keady-Tabbal and Damian Mac Con Uladh, did a great job and collaborated firmly and smoothly with us and the contributors. Katelyn Chin, the acquisition editor of the Open Jerusalem series at Brill, has been helpful and always available to discuss issues regarding the series and this volume in particular. Last but not least, we would like to thank

11 Jürgen Habermas, The Structural Transformation of the Public Sphere: An Inquiry into a Category of Bourgeois Society, trans. Thomas Burger and Frederick Lawrence (Cambridge: MIT Press, 1989). 
the rest of the core team of the project, namely Stéphane Ancel, Yasemin Avcl, Louise Corvasier, Leyla Dakhli, Abdul-Hameed al-Kayyali, Falestin Naïli, Yann Potin, Maria Chiara Rioli and Katerina Stathi. Since 2014, we have shared this long Jerusalem adventure together, and all of you have been available to read the chapters of the volume and provide excellent feedback. 


\section{PART 1}

\section{Opening the Archives, Revealing the City}


Angelos Dalachanis and Vincent Lemire - 978-90-04-37574-1 Downloaded from Brill.com04/26/2023 02:29:03PM via free access 


\title{
Introduction
}

\author{
Gudrun Krämer
}

Jerusalem was never an ordinary city. From an early date, it was charged with religious meaning as a site of yearning and learning, of pilgrimage and travel. For this reason, it was both attractive and contested, even during the long periods when it was quite peripheral in terms of its economic, political, and strategic importance to the larger units to which it belonged. Yet the majority of the city's inhabitants were ordinary people. They were not part of the local sociopolitical elite, and they led normal daily lives. We are still struggling to understand how the lives of ordinary people were actually lived at various points in time, and to what extent they were defined by communal affiliation, be it religious, ethnic, or both.

What kind of boundaries did communal affiliation create between the groups and individuals that made up the local population? Was there a sense of belonging that transcended the smaller units of family and community to include the city's population as a whole - a citadinité that preceded the modern concept of citizenship, or coexisted with it? And if it existed, how did it manifest itself? Answers can be found by delving deeper into Jerusalem's rich and often untapped archives, but this requires persistence on the part of the researcher. These archives range from Ottoman and other state archives to the archives of various religious communities and their pious foundations, and from public to private collections. The materials they contain range from official to "ephemeral" documents, some of which seem to equal the egodocuments that have enriched the study of European history in the early modern period.

The chapters in this volume show that, during the period under study, Ottoman authorities, foreign powers, and observers used religious affiliation, or millet, rather than property, status, class, language and locality, as the chief identifier for the groups and individuals living within the empire. What has been called the "tunnel vision" separating not just Arabs and Jews, but also Muslims, Christians, and Jews of various origins and denominations is therefore not merely the product, and indeed the fabrication, of Western orientalism. It is literally inscribed in the local and imperial archives. The Ottoman census of the early 188 os and early 1900 is so strictly organized along millet lines that it obscures, as Michelle Campos shows in her chapter, a "connected" vision of the city's population, forcing the researcher to compare a

(C) GUDRUN KRÄMER, 2018 | DOI:10.1163/9789004375741_003

This is an open access chapter distributed under the terms of the prevailing CC-BY-NC-ND License at the time of publication. 
whole number of files, or defters, in order to reconstruct the demographic and social setup of any given neighborhood.

The religious bias was not just imposed from above but actively sustained from below by the leaderships of the religious communities that tended to defend their respective territories, reinforcing the notion that Jerusalem's population was indeed a mosaic, made up of sharply delineated if not segregated religious groups. The Ethiopian community studied by Stéphane Ancel is a case in point. Another example is the Russian mission in Jerusalem, for which Lora Gerd and Yann Potin introduce an important private archive. Both chapters focus on church and diplomatic affairs but also provide information on the level of competition and cooperation among the Christian communities living in the city and the empire at large.

Communal competition was reflected in communal archives. In their chapter on the patriarchal archives of the Greek Orthodox community, one of the most important in the city, Angelos Dalachanis and Agamemnon Tselikas highlight the spirit of distrust and rivalry among the various religious communities that caused them to protect their archives, limit access to outsiders, and prevent sharing their materials with others. Still, there are written materials that, despite being tied to individual communal entities, allow us to catch a glimpse of the very connectedness the state and communal archives tend to hide. The visiting cards printed by the Franciscan Printing Press and found in the Franciscan Library are a fascinating example discussed by Maria Chiara Rioli in her contribution to this volume. To be sure, visiting cards and advertisements are a heterogeneous lot that may be more difficult to explore in a systematic way than an official census. But seen as ego-documents they illustrate connections that might be difficult to document otherwise.

In studying the appointment, promotion, and dismissal registers for the pious foundations of Jerusalem's Maghariba neighborhood, Şerife Eroğlu Memiş deals with a different type of connection that existed between local and wider Ottoman networks of scholars and officials. The archival materials presented in this volume, often for the first time, are full of promise. Carefully analyzed and systematically connected and put "in dialogue," as Dalachanis and Tselikas note in their chapter, with other materials, they make it possible to write a social history of the city that is worthy of the name. 


\title{
Placing Jerusalemites in the History of Jerusalem: The Ottoman Census (sicil-i nüfüs) as a Historical Source
}

\author{
Michelle U. Campos
}

Over a decade ago, the distinguished Palestinian historian Rashid Khalidi published "A Research Agenda for Writing the History of Jerusalem," in which he identified a number of notable problems in the then-extant historiography of the city: historical unevenness, an imbalanced emphasis on some subjects and communities, and significant thematic gaps in intellectual, religious, legal, urban, and demographic history. ${ }^{1}$ Since then, there has been a wave of important works on Ottoman Jerusalem addressing some of Khalidi's desiderata. However, there is still much work that can and should be done. ${ }^{2}$ One of the

1 Rashid I. Khalidi, "A Research Agenda for Writing the History of Jerusalem," in Pilgrims, Lepers, and Stuffed Cabbage: Essays on Jerusalem's Cultural History, ed. Issam Nassar and Salim Tamari (Jerusalem: Institute of Jerusalem Studies, 2005).

2 For recent works on the Ottoman period alone, see Bedross Der Matossian, Shattered Dreams of Revolution: From Liberty to Violence in the Late Ottoman Empire (Stanford: Stanford University Press, 2014); Vincent Lemire, Jérusalem 19oo: La ville sainte à l'âge des possibles (Paris: Armand Colin, 2013); Abigail Jacobson, From Empire to Empire: Jerusalem between Ottoman and British Rule (Syracuse: Syracuse University Press, 2011); Michelle U. Campos, Ottoman Brothers: Muslims, Christians, and Jews in Early Twentieth Century Palestine (Stanford: Stanford University Press, 2011); Johann Büssow, Hamidian Palestine: Politics and Society in the District of Jerusalem, 1872-1908 (Leiden: Brill, 2011); Salim Tamari, Year of the Locust: A Soldier's Diary and the Erasure of Palestine's Ottoman Past (Berkeley: University of California Press, 2011); Musa Sroor, Fondations pieuses en mouvement de la transformation du statut de propriété des biens waqfs à Jérusalem (1858-1917) (Beirut; Damascus: Institut français du Proche-Orient (Ifpo); Aix-en-Provence: Institut de recherches et d'études sur le monde arabe et musulman (IRемAм), 2010); Vincent Lemire, La soif de Jérusalem: essai d'hydrohistoire (1840-1948) (Paris: Publications de la Sorbonne, 2010); Roberto Mazza, Jerusalem from the Ottomans to the British (London: I. B. Tauris, 2009); Yair Wallach, "Readings in Conflict: Public Texts in Modern Jerusalem, 1858-1958" (PhD diss., Birkbeck College, University of London, 2008); Yasemin Avcı, Değişim sürecinde bir Osmanlı Kenti: Kudüs (1890-1914) [An Ottoman city in the period of transformation: Jerusalem, 1890-1914] (Ankara: Phoenix, 2004); Salim Tamari and Issam Nassar, eds., Al-Quds al-Uthmaniyya fi alMudhakkirat al-Jawhariyya: al-Kitab al-Awwal min Mudhakkirat al-Musiqi Wasif Jawhariyya,

(C) MICHELlE U. CAMPOS, 2018 | DOI:10.1163/9789004375741_004

This is an open access chapter distributed under the terms of the prevailing CC-BY-NC-ND License at the time of publication. 
weakest spots in the enormous literature on Jerusalem is the field of social history, demonstrated by the general absence of ordinary Jerusalemites in many of the city's written histories.

Due to the kinds of sources preserved and typically accessed, as well as the past focus of scholarly and public interest, a great deal is known about certain elites and segments of the Jewish communities in Jerusalem, while very little is known about the rest of the urban population. In an effort to reinsert Jerusalemites onto their urban landscape (in their houses, in the markets, and on the streets), my current project turns to the Ottoman-era census (nüfüs) records from Jerusalem. This incomparable historical source offers startling insights into Jerusalem's history on its own, but will also undoubtedly serve as a necessary building block for future social historical work. Most importantly, the Jerusalem census records allow us to painstakingly reconstitute snapshots of Jerusalem's permanent population at two particular moments in time. We gain unparalleled (though partial) insights onto social structure, economic history, family life, and urban morphology. Furthermore, the census illuminates not only the rich tapestry of urban residents, but also sheds light on relations between the city and surrounding countryside, and between Jerusalem and other Palestinian and Ottoman towns and cities, presenting Jerusalem as a part of a global migration network. Moreover, as the most comprehensive census records currently available from any Ottoman city, the Jerusalem census holds great value for comparative Ottoman urban and social history.

Importantly, the census also allows us to write a "connected" social history of the city; helping to bridge the religious, ethnic, class, and nationalist chasms which have characterized too much of the historiography until recent years. ${ }^{3}$ Many of these newer works referenced earlier offer their own distinct

1904-1917 [Ottoman Jerusalem in the Jawhariyyeh memoirs: the first book from the memoirs of the musician Wasif Jawhariyya, 1904-1917] vol. 1 (Beirut: Institute for Palestine Studies, 2003); Akram Musallam, ed., Yawmiyat Khalil al-Sakakini [Diaries of Khalil Sakakini], vol. 1 (Ramallah: Khalil Sakakini Culture Centre; Institute of Jerusalem Studies, 2003).

3 Such a connected history would not only expand on the postcolonial notion of "relational history" that emerged in the 1990s in the Israeli-Palestinian context among "critical sociologists" and "revisionist historians" such as Baruch Kimmerling, Zachary Lockman and Gershon Shafir, but would also take up the broader theoretical challenge to static visions of communalism, "groupism," and ethnic identities. On relational history in the Israeli-Palestinian context, see especially Baruch Kimmerling, "Be'ayot Konseptu’aliyot ba-Historyografya shel 'Erets 'Ahat u-Shne 'Amim" [Conceptual problems in the historiography of one land with two peoples], in Eretz ahat u-shne 'amim [One land, two peoples], ed. Danny Ya'akobi (Jerusalem: Magnes Press, 1999); Zachary Lockman, "Railway Workers and Relational History: Arabs and Jews in British-Ruled Palestine," Comparative Studies in Society and History 35, no. 3 (1993); 
visions of Jerusalem as a connected city, visions theorized to varying degrees and bridging languages, communities, and historiographies in their coverage of different thematic issues. Furthermore, some of these works have even explored Jerusalemites' visions and practices of a shared urban citizenship as a common thread that bound them. ${ }^{4}$ What is needed still, however, is a better understanding of the demographic contours of that urban citizenry. In this chapter I discuss the nüfüs as a source, as well as some of the methodological challenges and opportunities involved in working with it.

\section{The Census: Background, Context and Historiography}

First, a few historical comments about the emergence of the Ottoman census and historiographic observations about the state of Ottoman and Palestinian nüfüs studies are in order. Although the Ottomans kept extensive tax registers (tahrir defterleri) in various parts of the empire from the fifteenth through seventeenth centuries, the first major empire-wide modern population censuses did not take place until the middle of the nineteenth century. ${ }^{5}$ After a series

Gershon Shafir, Land, Labor and the Origins of the Israeli-Palestinian Conflict, 1882-1914 (Berkeley: University of California Press, 1996); Zachary Lockman, Comrades and Enemies: Arab and Jewish Workers in Palestine, 1906-1948 (Berkeley: University of California Press, 1996). For conceptual critiques of groupism and static views of ethnicity, see Rogers Brubaker, "Ethnicity without Groups," Archives européennes de sociologie 43, no. 2 (2002); Jimy M. Sanders, "Ethnic Boundaries and Identity in Plural Societies," Annual Review of Sociology 28 (2002); Fredrik Barth, "Enduring and Emerging Issues in the Analysis of Ethnicity," in The Anthropology of Ethnicity: Beyond "Ethnic Groups and Boundaries," ed. Hans Vermeulen and Cora Govers (The Hague: Het Spinhuis, 1994).

4 See especially Yasemin Avcı, Vincent Lemire and Falestin Nä̈li, "Publishing Jerusalem's Ottoman Municipal Archives (1892-1917): A Turning Point for the City's Historiography," Jerusalem Quarterly, no. 60 (2015); Campos, Ottoman Brothers; Jacobson, From Empire to Empire; Avcı, Değişim sürecinde bir Osmanlı Kenti.

5 For a historical geography of rural Palestine based on the sixteenth-century tax registers, see Wolf-Dieter Hütteroth and Kamal Abdulfattah, Historical Geography of Palestine, Transjordan and Southern Syria in the Late 16th Century (Erlangen: Erlanger Geographische Arbeiten, 1977). For a methodological discussion of the tahrïr defterleri, see Metin M. Coşgel, "Ottoman Tax Registers (Tahrir Defterleri)," Historical Methods 37, no. 2 (2004). Although there is record of a series of population recordings taking place from the 1830s-1870s, these served conscription purposes and as a result recorded men only. For a study drawing on these yoklama defterleri in the Black Sea region, see Justin McCarthy, "Age, Family, and Migration in Nineteenth-Century Black Sea Provinces of the Ottoman Empire," International Journal of Middle East Studies 10, no. 3 (1979). Schölch analyzed Ottoman records from 1849 and 1871 
of preliminary starts (chiefly consisting of conscription and male population registers) and new imperatives due to a variety of concerns relating to taxation, conscription, non-Muslim communities, and bureaucratic reforms, the first sicil-i nüfūs nizāmnāmesi (population registry ordinance) was issued in 1881, and over the following decade a comprehensive census was conducted throughout the empire. ${ }^{6}$

The census was based on a household-level survey, aimed at documenting all men, women and children in residence. Ottoman subjects were recorded in separate notebooks divided according to millet (Ott. Turk. millet; Ar. milla/ millat); Muslims also were registered according to their urban neighborhood. Attempts were made to register foreign citizens and foreign institutions in separate notebooks as well, although in most of these cases, "foreigner" is taken to mean "nonlocal," as many of the individuals registered here hail from other towns in Palestine or the Ottoman Empire. In this first census, which I will refer to as the 1299 census $(1883-84),{ }^{7}$ the following fields were recorded on one page (from right to left) (fig. 1.1):

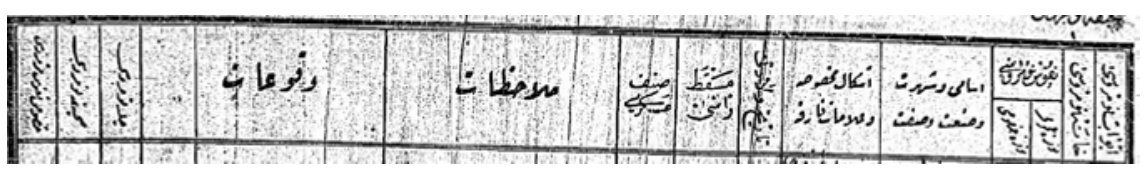

1-3 Ordinal fields (for household number, numbers of male members and female members)

4 Name/patronym/trade

$5 \quad$ Personal traits and distinguishing information

6 Date of birth

7 Place of residence

8 Army status

9 Notes

10 Events (life cycle)

FIGURE 1.1 Ottoman census header, 1299 [1883-84].

ISRAEL STATE ARCHIVES.

in Palestine. Alexander Schölch, "The Demographic Development of Palestine, 1850-1882," International Journal of Middle East Studies 17, no. 4 (1985).

6 For vital background, see Kemal Karpat, "Ottoman Population Records and the Census of 1881/82-1893," International Journal of Middle East Studies 9, no. 3 (1978); Stanford J. Shaw, "The Ottoman Census System and Population, 1831-1914," International Journal of Middle East Studies 9, no. 3 (1978).

7 This refers to the Ottoman administrative (fiscal $/ m \bar{a} / \bar{\imath}$ ) year when recording began. Since the $m a \bar{l} \bar{\iota}$ year begins in March and continues through the following February, this corresponds to $1883-84$. 
Newspapers, village, and neighborhood mukhtars, as well as millet leaders were charged with informing Ottoman subjects about the new regulations, procedures, and updates. In general, subjects were required to report to the local government offices (sarāy), where the nüfüs clerks held regular office hours, with identifying papers or witnesses and the requisite registration fee. In order to ensure compliance, the Ottoman government both incentivized participation and punished shirkers: census registration was a prerequisite for receiving the nüfüs tezkeresi, a vital government document necessary for land purchase, court appearances and travel documents, among other things. At the same time, subjects who failed to register were threatened with fines and imprisonment.

Compilation of the census stretched out over almost a decade and results were published in the local press as well as in imperial yearbooks (salnames). At its conclusion, however, serious criticisms were raised about census methodology and uneven compliance, prompting a revision of the census regulations in 1901, and a new empire-wide census launched shortly thereafter. ${ }^{8}$ Among the main changes between the first (1299/1883-84) and second (1321/1905-6) censuses were new procedures for ongoing registration of vital statistics in separate registers as well as updates in the original census books, the addition of new biographical data categories, and a more comprehensive attempt to record locational data. In these ways, the registration of Ottoman subjects became more thorough while, at the same time, the registration of "foreigners" seems to have dropped off, as many more non-Jerusalemites were incorporated into the regular notebooks.

The changes to the 1321 census included the addition of more data fields to create a standard two-page form (fig. 1.2):

8 I will refer to this as the $13^{21}\left(1905^{-6}\right)$ census, again referring to the māli year in which recording began. 


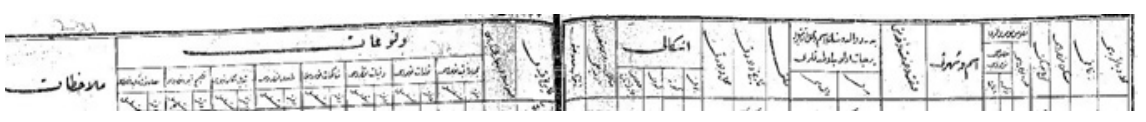

1-2 Locational data (maḥalle, zukāạ, house number)

3, 5 Ordinal fields

4 Building type

6 Name (including honorifics; other household members were prefaced by their relationship to the head of household)

7 Occupation/trade (languages known occasionally included)

8 Parents (father/mother fields separated; deceased parents marked as such)

$9 \quad$ Millet

10-11 Birth (year and city/village)

12 Physical traits (filled for men only)

13 Marital status (inconsistently filled)

14 Election status (rarely filled)

15 Date of registration

16 Military status (rarely filled)

17 Life cycle events (vuku'ät - inconsistently entered)

18 Notes (inconsistently entered, but could include information about life cycle events registered; subsequent relocations; at times court cases, army service or deferrals, elections status, etc.)

FIGURE 1.2 Ottoman census header, 1321 [1905-6].

ISRAEL STATE ARCHIVES.

Together, the two Ottoman censuses gathered a remarkable and unprecedented amount of information about millions of imperial subjects. Despite their unique and undeniable historical significance, however, there is relatively little scholarship based on Ottoman census records, perhaps due to the inaccessibility of most of the records themselves, the tedious nature of working with them, and the declining interest in quantitative social history since the $1970{ }^{9}{ }^{9}$ That said, there are several distinct trends and changes in the tiny field worthy of mention.

Much of the first generation of nüfüs scholarship dealt with calculating aggregates at the imperial and provincial levels. ${ }^{10}$ For these scholars, the emphasis was on measuring the accuracy of the census for the purpose of

9 For an albeit outdated introduction, see Daniel Panzac, La population de l'empire ottoman: cinquante ans (1941-1990) de publications et de recherches (Aix-en-Provence: Institut de recherches et d'études sur le monde arabe et musulman (IREMAM), 1993).

10 Kemal H. Karpat, Ottoman Population, 1830-1914: Demographic and Social Characteristics (Madison: University of Wisconsin Press, 1985); Justin McCarthy, Population History of the Middle East and the Balkans (Istanbul: Isis Press, 2002); McCarthy, The Population of Palestine: Population History and Statistics of the Late Ottoman Period and the Mandate (New York: Columbia University Press, 1990). 
providing a "scientific" demographic history of the empire or for combatting the demographic claims of former Ottoman minorities, or both. ${ }^{11}$ Among these scholars a consensus emerged that the 1321 census was far more comprehensive and reliable than the 1299 census, although in both cases there was an acknowledged slight-to-significant undercounting of nomads, rural residents, women and children, some ethno-religious groups in certain locales, and certain urban social classes. ${ }^{12}$

A second wave of nüfüs scholarship utilized the census on smaller provincial, city, or neighborhood scales, either in aggregate or through sampling, in order to discuss broader patterns of family, household, migration, demographics and urban history. The most prominent works in this vein have focused on Istanbul, but there are a few studies from other cities or provinces from which to draw comparisons. ${ }^{13}$ The extant scholarship on Palestine fits into this model

11 Servet Mutlu, "Late Ottoman Population and Its Ethnic Distribution," Turkish Journal of Population Studies 25 (2003). The Ottomans were not the only ones interested in their population figures; for their own reasons, European powers closely monitored Ottoman population results, and many additional and competing population estimates were given by European diplomats, travelers, missionaries, church officials, and in the specific case of Palestine, Zionist officials and settlers. However, for the most part, none of these other population counts were based on any discernible methodology close to the Ottoman census, and seem to be little more than the "guesstimate" impressions of one observer that were repeatedly cited until they assumed the status of consensus. This is clearest in the case of Palestine, where the population estimates of Arthur Ruppin, the World Zionist Organization official in Jaffa from 1908 onward, were adopted by the British Mandatory regime despite any method or justification. John Bernard Barron, Palestine: Report and General Abstracts of the Census of 1922 (Jerusalem: Greek Convent Press, 1923), 3. Karpat, Ottoman Population; McCarthy, Population History. Duben estimates that reporting in Istanbul was less complete for the petit bourgeois, artisanal and working classes. Alan Duben, "Household Formation in Late Ottoman Istanbul," International Journal of Middle East Studies 22, no. 4 (1990). Mutlu discusses the issue of Armenian undercounting in certain provinces. Mutlu, "Late Ottoman Population and Its Ethnic Distribution." In a later work McCarthy argued that undercounting in Jerusalem due to age and sex was 7.5 percent, the lowest in all the Arab provinces. McCarthy, Population History, 193.

13 Stanford Shaw, "The Population of Istanbul in the 19th Century," International Journal of Middle East Studies 10, no. 2 (1979). Duben and Behar's monumental work was based on a 5 percent sampling of five central neighborhoods in Istanbul with Muslim populations only. Alan Duben, "Household Formation"; Cem Behar and Alan Duben, Istanbul Households: Marriage, Family, and Fertility, 1880-1940 (Cambridge: Cambridge University Press, 1991). In 2014 Duben and Behar's samples were uploaded to the Mosaic Census project on European demographic history, and are currently available for scholars to download: http://www.censusmosaic.org/data/mosaic-data-files. In addition, the original defter pages, transcription sheets, methodological notes, and related documents have been uploaded to SALT Istanbul's website and are accessible for comparison: "Istanbul 
of local demographic history and historical geography. Alexander Schölch's pioneering work linked the demographic, economic and political history of Palestine based on earlier censuses and diplomatic records. ${ }^{14}$ Adar Arnon has been the only scholar to publish on the 1299 Jerusalem census, which he did from a more geographic perspective. ${ }^{15}$

The most comprehensive research utilizing the Palestinian census materials, this time on the 1321 census, was carried out by the late Uziel Schmelz, a demographer aided by a research team of transcribers and computer specialists. His research is based on more rigorous demographic method and makes arguments about aggregate and average population characteristics. ${ }^{16}$ Among the more suggestive revelations of Schmelz's work was that many Jerusalem neighborhoods were mixed and heterogeneous, rather than ethno-religiously homogeneous, as had been assumed by much of the scholarship on Jerusalem until that point. However, certain issues elude us even at the city level and

Households," Salt Research, accessed January 16, 2018, https://www.archives.saltresearch .org/R/1 ${ }_{93}$ PGILMGKFP6XLXVB4FAIML5XK4KGBLYKFH7 ${ }_{7}$ LLHCPY188JH-o1210?func= collections\&collection_id $=3241$.

14 Schölch, "The Demographic Development of Palestine."

15 Adar Arnon, "Mifkede ha-'Ukhlusiya bi-Rushalayim bi-Shalhe ha-Tekufa ha-'Otomanit" [Censuses of the population in Jerusalem at the end of the Ottoman period], Cathedra, no. 6 (1977); Arnon, "The Quarters of Jerusalem in the Ottoman Period," Middle Eastern Studies 28, no. 1 (1992). Although the historicized discussion of quarter names and boundaries is of value, Arnon makes geographic mistakes about certain places. For a back and forth discussion on some of these points, see Menachem Levin, "Be'ayot Zihuyan shel Shekhunot Yerushalayim lefi Sheman ha-'Aravi-ha-'Otomani be-Sifre ha-Nufus" [Problems of identification of Jerusalem neighborhoods according to their Arabic-Ottoman names in the census books], Cathedra, no. 15 (1980); Adar Arnon, "Teguva le-He'arot M. Levin 'al Zihuy Shemot Rov'e Yerushalayim ba-Tekufa ha-'Otomanit" [Response to the comments of M. Levin on the identification of the names of Jerusalem quarters in the Ottoman period], Cathedra, no. 15 (1980). In addition, Arnon's numbers seem to be drawn simply from the total counts offered in the archive table of contents for each defter, and represent a significant undercount in some areas.

16 Uziel O. Schmelz, "Population Characteristics of Jerusalem and Hebron Regions According to Ottoman Census of 1905," in Ottoman Palestine, 1800-1914: Studies in Economic and Social History, ed. Gad Gilbar (Leiden: Brill, 199o); Uziel O. Schmelz, "Ha-'Ukhlusiya haKelalit be-'Erets Yisrảel: Godel ha-'Ukhlusiya ha-Kelalit ba-'Arets 'Erev ha-Milhama” [The general population in the land of Israel: the size of the general population in the country on the eve of the war], in Be-Matsor u-Vematsok: -'Erets Yisrảel be-Milhemet ha'Olam ha-Rishona [Siege and distress: the land of Israel during the First World War], ed. Mordechai Eliav (Jerusalem: Yad Ben Zvi, 1991); Schmelz, "The Population of Jerusalem's Urban Neighborhoods according to the Ottoman Census of 1905," Scripta Hierosolymitana 35 (1994). However, Schmelz's data, too, shows some incompatibility with mahalle-level studies by Büssow and myself. 
necessitate a closer look at the household, neighborhood, and millet levels. For example, questions such as urban segregation look very different once we scale down within the city. Focusing on the neighborhood level can reveal smallerscale patterns of integration or segregation and can also reveal other neighborhood characteristics. ${ }^{17}$

While Schölch's, Arnon's, and Schmelz's works were important contributions to the demographic history of southern Palestine, for social historians, aggregate city-, province-, or empire-wide studies of the nüfüs are of limited value on their own and require a careful incorporation of qualitative sources and questions. Duben and Behar's work on Istanbul provided one model for how this could be done; they brought extensive court records, newspaper accounts, autobiographies, oral, and other primary sources to give broader social context to their quantitative data on household formation and family life. In a second related study, Behar later fleshed out the neighborhood of the census samples, Kasap İlyas, on a broader social and economic basis. ${ }^{18}$ Likewise, although on a much smaller scale, Johann Büssow studied samples of several Jerusalem neighborhoods in order to provide broader context for the biographies and historical trends discussed in his larger work. ${ }^{19}$ More localized and multimethodological works along these lines will add to the value of census records as a historical source.

Very recently, a third approach to the nüfüs has focused on aspects of governmentality and intercommunal politics rather than on the empirical data it collected. The most outstanding example of this kind of approach to the census has been the work of İpek Yosmaoğlu, who examined the contested ethno-national-religious categories and categorization surrounding the 1321 census in the Balkans. ${ }^{20}$ Yosmaoğlu's work turns our attention to the ways in which the census categories themselves were constructed, debated and challenged, as well as to how population figured into nationalist and international struggles in the late Ottoman period. This is a valuable contribution to better understanding Ottoman governmentality and state-society relations in the various corners of the empire.

17 See my forthcoming article "Mapping Urban Communities in Late Ottoman Jerusalem: A Digital Neighborhood Study."

18 Cem Behar, A Neighborhood in Ottoman Istanbul: Fruit Vendors and Civil Servants in the Kasap Ilyas Mahalle (Albany: State University of New York Press, 2003).

19 Büssow, Hamidian Palestine, 140-65.

20 İpek K. Yosmaoğlu, "Counting Bodies, Shaping Souls: The 1903 Census and National Identity in Ottoman Macedonia," International Journal of Middle East Studies 38, no. 1 (2006). 


\section{Reading the Jerusalem Census Despite Lacks and Gaps}

Given this snapshot of the changing Ottoman census system as well as its historiography, it is now time to turn to look at the census in Jerusalem. In my view, a return to the primary source itself opens the doors for a more finegrained analysis of both microhistorical and macrohistorical questions.

Over $45^{\circ}$ original notebooks of the Palestine census (nüfüs defterleri) from three periods are housed in the Israel State Archives (ISA): the 1299 census (1880s), the 1321 census (early 190os), and a third update to the census in 1914${ }_{15}$, apparently conducted in Jerusalem only among newly Ottomanized Jews. ${ }^{21}$ An important book published by Yonatan Pagis in 1997 to aid the use of the nüfüs records includes a brief historical introduction to the nüfüs based on English and Hebrew secondary sources as well as some details about the nüfüs collection, including methodological matters and detailed descriptions of the categories of records. The notebooks are of various types of official census registrations: 147 draft registers (mesvedde defterleri) and 231 basic registers (esās defterleri), an additional 10 "foreign registers" (including nonlocal Ottoman officials as well as foreign residents), 47 life cycle events registers (vukúät defterleri - which includes birth, death, marriage, and divorce registers), and 17 army registers. In addition, there are eight mukhtar notebooks from the Ashkenazi Jewish populations in Jerusalem, as well as one mukhtar notebook from the Muslim population near al-Majdal 'Asqalan (today's Ashkelon). ${ }^{22}$

The bulk of Pagis' book is made up of an index categorized by location. Although not immediately apparent due to the format of the index, it turns out that the first sixty-five notebooks (defters) deal with the city of Jerusalem and include draft and basic notebooks from the three census periods. Another large percentage of notebooks deals with 130 villages, towns, encampments, and colonies in the districts surrounding Jerusalem; these villages to the west and south of Jerusalem were forcibly depopulated during and after

21 Pagis tells a very partial history of the notebooks; he writes that no books from Tulkaram or Jenin districts have been located. In addition, the records for the north of Palestine are spotty, given that those districts were in the vilayet of Beirut in the Ottoman period, and apparently not all of the administrative records were transferred between the French and British mandatory authorities. Yonatan Pagis, Mifkede ha-'Ukhlusin ha-'Otomaniyim be-'Erets Yisrảel 1875-1918 [Ottoman population censuses in the land of Israel, 1875-1918] (Jerusalem: Achva Press, 1997), 29-32.

22 Ibid., 19-25. Both Pagis and Karpat mention "summary registers" (icmäl defterleri) as having been compiled by census officials, but they do not appear to have survived for the Jerusalem district. 
the 1948 war, whereas many of the villages to the north and east of Jerusalem, which were under Jordanian control until the 1967 war, have been incorporated into Jerusalem's contemporary municipal boundaries since then. In an appendix at the back of the book, Pagis includes a neighborhood-level listing of the Jerusalem census records, including helpful (though not comprehensive) information on neighborhood boundaries and landmarks. In addition, there are eight separate life cycle defters from Jerusalem between 1905 and 1917, including birth, death, marriage, and divorce registers. Unfortunately, none of the extant army registers are from Jerusalem.

Until the last archival reorganization of winter $2015^{-16}$, when the reading room of the ISA was declared permanently closed, microfilm copies of the nüfüs defterleri were available for public viewing. ${ }^{23}$ As of late 2017, digitized copies of the microfilms have been made available on the archive's website. In addition, all eighty-three microfilms of the entire Ottoman Palestine census were purchased by the Church of Jesus Christ of Latter-Day Saints decades ago, and are available through their regional Family History Centers for on-site consultation. ${ }^{24}$

As it turns out, though, accessing the census records is the rather straightforward part of the process. Putting them to use is significantly more complicated. First, neither the Pagis book nor the archive catalog provides a simple listing of each defter and its contents. Even more problematic is that the desired defter must be matched with the correct microfilm reel by referencing a paper folder available only in the reading room. This step is necessary in order to make use of the LDS microfilms as well. Furthermore, the Pagis index is organized rather

23 For the archive's account of its transition to digital format, see "A New Website with Free Birth-pangs," Israel's Documented Story, April 12, 2016, accessed January 16, 2018, http:// israelsdocuments.blogspot.co.il/2016/04/a-new-website-with-free-birth-pangs.html. The Middle East Studies Association (MESA), the Association for Civil Rights in Israel (ACRI), and numerous Israeli and foreign scholars have protested the decision to close the reading room and render actual documents off-limits. For more on this, see "Israel State Archives End Access to Paper Records; Archive Users Protest the Move," Akevot Institute for Israeli-Palestinian Conflict Research, n.d., accessed January 16, 2018, http:// akevot.org.il/en/news-item/state-archive-ends-access-to-paper. For a discussion of some of the implications for research, see "Past as Probate: An Interview With Historians About Israel's Archives," The Nakba Files, June 6, 2016, http://nakbafiles.org/2016/o6/o6/ past-as-probate-an-interview-with-historians-about-israels-archives, and "Archives Week on The Nakba Files," The Nakba Files, May 26, 2016, http://nakbafiles.org/2016/05/26/ archives-week-on-the-nakba-files.

24 The Family History Centers, however, are staffed by church volunteers, and typically have very limited hours and older microfilm reader technology. 
haphazardly within each geographic location. This becomes particularly difficult for large cities such as Jerusalem, which contain dozens of original defters. In the end, I simply created an Excel spreadsheet to keep track of and rearrange the information on the microfilms and defters.

After doing this, it became apparent that the Pagis index contains some errors and omissions in the neighborhood-level appendix; more importantly, both it and the census archive itself are structured in a way that obscures a "connected" vision of Jerusalem's population. In other words, because the defters are grouped together by millet rather than by census year or neighborhood, in order to get even a neighborhood snapshot during one census, for example, one must consult up to eight separate defters for a comprehensive population account.

A second difficulty with the census records is the actual legibility of the records. Some of the microfilm copies are dark, blurry, and scratched, and parts of them are difficult to read; in these cases, not having access to the original notebooks is an additional problem. The census records were written in what might be considered a sliding scale of Ottoman Turkish to Ottomanized Arabic, depending on the scribe. Some scribes used exclusively Turkish words and terminology, whereas others used Arabic, and others used a mixture. Some crafts and trades were labeled with different terms, and it is reasonable to wonder whether we can assume a total equivalence between the Turkish and Arabic terms, or whether there might have been meaningful or even subtle distinctions between the two. The dual language issue also presents a minor problem when encountering scribal errors in language or transcription where it is unclear what the intended word was. However, it can be a more significant problem to understand some of the transcriptions of non-Arabic names, which were transliterated into Arabic letters in an inconsistent or incorrect manner.

A third difficulty of the materials is the inconsistency of the submitted information, which makes quantitative aggregates and geospatial uses of the census somewhat-to-quite problematic. First, there is a high percentage of gaps in several specific data fields: occupation, languages known (while not a separate data field, this was occasionally included under occupation), but also most of the data on the second page of the census form. In the case of occupations, not infrequently the item is left blank; at other times "bilā șan'at" (without a trade) is explicitly written. Is there a substantive difference between the social and economic status of the two manners of entry or lack of entry, or are these simply the vagaries of reporting or recording? Similarly, when they are listed, languages are distinguished by reading, writing, and spoken knowledge; how accurate can we assume this information was at least among those 
who offered the data? Alternatively, drawing on evidence from biographical records that reveals the inconsistent reporting of language skills in the census, why might they have concealed or failed to mention their language abilities?

More serious for spatial purposes is the absence of locational information in large numbers of records - for all non-Muslims in the 1299 census, and for variable percentages of households in the 1321 census. In the 1321 census, some households have explicit locational information, including street, building number, and apartment number, while others have no identifying information other than neighborhood; the degree of completeness varies by neighborhood, millet, and class. In one neighborhood, al-Wad, the locational data in the 1321 census varies wildly by millet: 22 percent of Muslims and Greek Orthodox Christians do not have any locational data, but fully 49 percent of Maghrebi Jews and $5^{2}$ percent of Sephardi Jews have none. ${ }^{25}$ This means that while many households can be located quite specifically in the urban landscape, others can only be located more loosely within a neighborhood, a shortcoming which affects our understanding of the urban topography significantly.

Related to this, the census records provide no information about the census tracts, the geographic boundaries of mahalle and zuka $a$, or the numbering system used for houses. Unfortunately, there is no map, table, or descriptive information to accompany the notebooks. Together this poses a direct problem when one tries to utilize Gis to map out the census, a problem I write about elsewhere. ${ }^{26}$ It is certainly possible to gather some of this geographic and locational information through other means, as I am attempting to do, but it is necessarily laborious and incomplete. The importance of these methodological issues will vary according to the kind of study being conducted; for some studies, conceivably, space will not matter at all.

At the same time, it is worth remembering that the kind of geographic data necessary for plotting a household on GIS might be very far from the historical understanding of that space itself. Street names, for example, had several variants, and street segments were often conceptualized and referred to by a landmark rather than in continuous linear terms. Furthermore, while we know that house numbers existed starting already in the mid-nineteenth century in Jerusalem, when the Ottoman governor required their issuance, ${ }^{27}$ these numbers were not used on a daily basis. Instead, popular and legal geographic

25 Data taken from my research.

26 See Campos, "Mapping Urban Communities in Late Ottoman Jerusalem."

27 On this see Wallach, "Readings in Conflict," 140. 
markers were related to property description, ownership, rentership and adjacency to other properties. ${ }^{28}$

\section{Conclusion: To be Continued}

Despite its limitations and challenges, at its best, there is no question that the census can flesh out our understanding of Jerusalemite households in an intimate way. More so than in any other existing source, we meet families, learn about the professional profile of government clerks, bakers, shoemakers, teachers, greengrocers and businessmen, learn the names of wives and daughters and mothers and sisters. We also get a fascinating portrait of rural, regional, and international migration to Jerusalem. We are alerted to the presence of groups in the city who have eluded historical study - African migrants, heterodox Muslim gypsy sects, Protestant converts, and many kinds of "marginal" women (concubines, servants, those who married out of their religious communities, those forced to head up a household on their own due to widowhood or divorce).

We can also begin to illustrate the urban landscape with people in their homes and shops and markets, side by side with the more and less prominent religious institutions that have dotted the Jerusalem landscape. Combining the two censuses, we can track the changing urban landscape over a thirty-year period (between 1299 and 1321) as families moved from intra to extra muros neighborhoods, as households began to shrink and reconstitute themselves, as sons received modern educations or took apprenticeships that paved paths for them different from those of their fathers. We can carefully construct kinship ties within the city, tracing the strategies behind marriages.

Beyond this critical "thickening" of Jerusalem from the bottom up, the real promise of the census perhaps lies in its power as a database to be used in conjunction with other primary sources. Family archives, newspaper reports, court records and contracts, and myriad other primary sources can shed further light on the life cycles of ordinary and elite Jerusalemites alike. Furthermore, in the age of the digital humanities, a digitized, mapped and linked Ottoman census could provide us with a rich visual and textual record of Jerusalem and Jerusalemites in its earlier, truly connected moments. ${ }^{29}$

28 See some of the legal descriptions of properties in Eliezer Rivlin, "Hazakot shel Hatserot u-Vatim bi-Rushalayim" [Subleases of courtyards and houses in Jerusalem], in Festschrift Dr. Jakob Freiman zum 70 Geburtstag (Berlin: Viktoria, 1937).

29 This kind of project is the subject of my current grant proposal under consideration, "Jerusalem 1905." 


\title{
Introducing Jerusalem: Visiting Cards, Advertisements and Urban Identities at the Turn of the 2oth Century
}

\author{
Maria Chiara Rioli
}

Sources are neither open windows, as the positivists believe, nor fences obstructing vision, as the skeptics hold: if anything, we could compare them to distorting mirrors. ... [T] he projection of desire, without which there is no research, is not incompatible with the refutations inflicted by the principle of reality. ${ }^{1}$

In August 2013, during the renovation of the Franciscan Custody library, an Italian collector found an album containing around 1,500 visiting cards in a deposit of books that were to be thrown away. ${ }^{2}$ The carte da visita in this catalogue were issued by the Stamperia di Terra Santa ${ }^{3}$ and were printed from 1880 to the beginning of the twentieth century, although their production was continued by the Franciscan Printing Press (FPP) over the following decades. As this anecdote shows, Jerusalem's archives are everywhere: not only in the hands of institutions and archivists, but also in basements, attics, or stacks of volumes ready to be discarded.

The organization of labor inside the FPP sets the Franciscan Custody of the Holy Land ${ }^{4}$ within the larger context of political and economic connections, governed by systems of favors among families and religious groups, and an unstable balance of interests. We don't know how, or if, the clients of the press

1 Carlo Ginzburg, History, Rhetoric, and Proof (Hanover: University Press of New England, 1999), 25 .

2 The research for this chapter was conducted in close collaboration with Leyla Dakhli. I express my deep gratitude to this collector for allowing us to consult this album.

3 The Franciscan Printing Press (FPP) was referred to as the Stamperia and Tipografia due to the Italian prominence in the history of the Custody of the Holy Land.

4 For a bibliography of the history of the Franciscan presence in the Palestinian area and the FPP, see the contribution of Leyla Dakhli, "Men at Work: The Tipografia di Terra Santa, 18471930," in this volume, especially notes 1 and 3 .

(C) MARIA CHIARA RIOLI, 2018 | DOI:10.1163/9789004375741_005

This is an open access chapter distributed under the terms of the prevailing CC-BY-NC-ND License at the time of publication. 
perceived the rigid internal system of rules. What is evident from the registries is that the press had a wide range of buyers and clients.

In attempting to understand the external dimension of the FPP's activities, the collection of visiting cards, advertisements, and announcements issued by the friars' atelier is an extremely rich and prismatic source. Shortly after its opening in 1847, the publishing enterprise of Custody friars had expanded beyond the ecclesiastical community. It was attended by Ottoman officials from the most important institutions of the government and later by authorities of the British Mandate as well as by a constellation of private clients of different languages, religions, genders, and social and political status. ${ }^{5}$ The FPP established itself as a center of production of all kinds of printed signs for the city: posters, signs, billboards, visiting cards, programs, menus, directions for use, guides for travelers, etc. In its capacity as the source of much of the city's media, the Custody is a key resource for the study and understanding of Jerusalem's citadinité. It reveals the history of the city across many levels varying in scope and detail. From the operations itself, through the printing house and its network of clients and users, we ultimately see the extent of Custody's influence as evidenced by the papers themselves. Produced and printed in the Custody, they circulated throughout the streets, libraries, boutiques, hotels, and administrative centers of the city and beyond, thanks to the international network of the Franciscan order.

Printed materials other than books made up a large part of the friars' production. Paper sheets, envelopes, flower cards, postcards, sheet music, medical prescriptions, labels, announcements, programs for lotteries, plays or other performances, school reports, nationality certificates, travel plans, lodging tickets, railway timetables, and restaurant menus were issued daily, testifying to an intense flow of work. This list demonstrates how the FPP was not a traditional religious and confessional publisher: its many clients included secular people and institutions. Furthermore, the Franciscans worked for the Jerusalem government; the press produced for the municipality of Jerusalem printed statistics and registries, announcements, licenses, and regulations for the election of its members.

5 In 1865 the FPP printed the city's first hydraulic project, Relazione e progetto di condurre l'acqua del fonte-segnato all'altezza della porta Bab-el-Kalil, by Fra Remigio Buselli for Jerusalem governor Izzet Pasha. See Vincent Lemire, La soif de Jérusalem: essai d'hydrohistoire (1840-1948) (Paris: Publications de la Sorbonne, 2011), 240-47. 
As revealed by the registries collected by the Custody of the Holy Land's archives at St. Saviour's convent, ${ }^{6}$ during the last decades of the nineteenth and the first half of the twentieth centuries, some of the products most commonly ordered from the Franciscans were calling cards, trade cards, advertisements, greetings cards, and cards for announcements and invitations. A repertory of 1,485 pieces was collected in a catalogue named "Carte di visita avvisi ec. 1880," covering the period from 1880 to the first years of the new century, probably 1906 (fig. 2.1). ${ }^{7}$ No similar albums seem to be currently held in the Franciscan archives or in any other archive of the city. The precise use of this volume is unclear. Maybe it was a way to register the cards printed, to keep an exemplar that could be shown to new potential clients. The registries of the objects issued reveal that the album contains a large percentage of the cards printed at that time.

Calling cards, business cards, and trade cards accompanied social and economic relations from the eighteenth century onwards, reaching the peak of their popularity in the nineteenth century in Europe and in the United States, ${ }^{8}$ as well as in the Ottoman Empire, where they were called kart fizit. ${ }^{9}$ Calling

6 Historical Archive of the Custody of the Holy Land (ASCTS), Jerusalem, "Introito attivo" generale, 1: January 2-December 31, 1923; 2: January 2, 1924-September 30, 1931; 3: October 3 1931-December 1938; 4: January 1939-January 1945; "Introito attivo" oggetti stampati, 1:January 2, 1888-December 22, 1894; 2:January 12, 1895-February 6, 1909; "Introito passivo," 1: January 1900-December 1908; January 1919-December 1919; "Libri ed oggetti dati o stampati gratuitamente 1900-1908 coll'aggiunta solo l'anno 1919;" 2: January 4, 1909-December 30, 1918; January 1, 1920-December 26, 1931; 3: January 2, 1922-October 31, 1931; 4: November 2, 1931-January 4, 1938.

7 This catalogue, whose dimension is $26 \times 39 \mathrm{~cm}$, contains 112 pages. Cards are thickly attached horizontally and vertically in order to fill all the available space. They are numbered by hand until number 411. Some cards contain dates, as in the case of wedding cards and other announcements. As they were placed in chronological order, although not completely precise, the contemporary reader can retrace the periodization.

8 In the extensive bibliography, see at least William C. Darrah, Cartes de Visite in Nineteenth Century Photography (Gettysburg: W. C. Darrah, 1981); Robert Jay, The Trade Card in Nineteenth-Century America (Columbia: University of Missouri Press, 1987); Margaret E. Hale, "The Nineteenth-Century American Trade Card," Business History Review 74, no. 4 (2000); Geoffrey Batchen, "Dreams of Ordinary Life: Cartes-de-Visite and the Bourgeois Imagination," in Photography: Theoretical Snapshots, ed. Jonathan J. Long, Andrea Noble and Edward Welch (Abingdon: Routledge, 2009); Andrea L. Volpe, "Cartes de Visite Portrait Photographs and the Culture of Class Formation," in The Middling Sorts: Explorations in the History of the American Middle Class, ed. Burton J. Bledstein and Robert D. Johnston (London: Routledge, 2001).

9 As mentioned by Ami Ayalon about Haifa in Reading Palestine: Printing and Literacy, 19oo1948 (Austin: University of Texas Press, 2004), 59. 


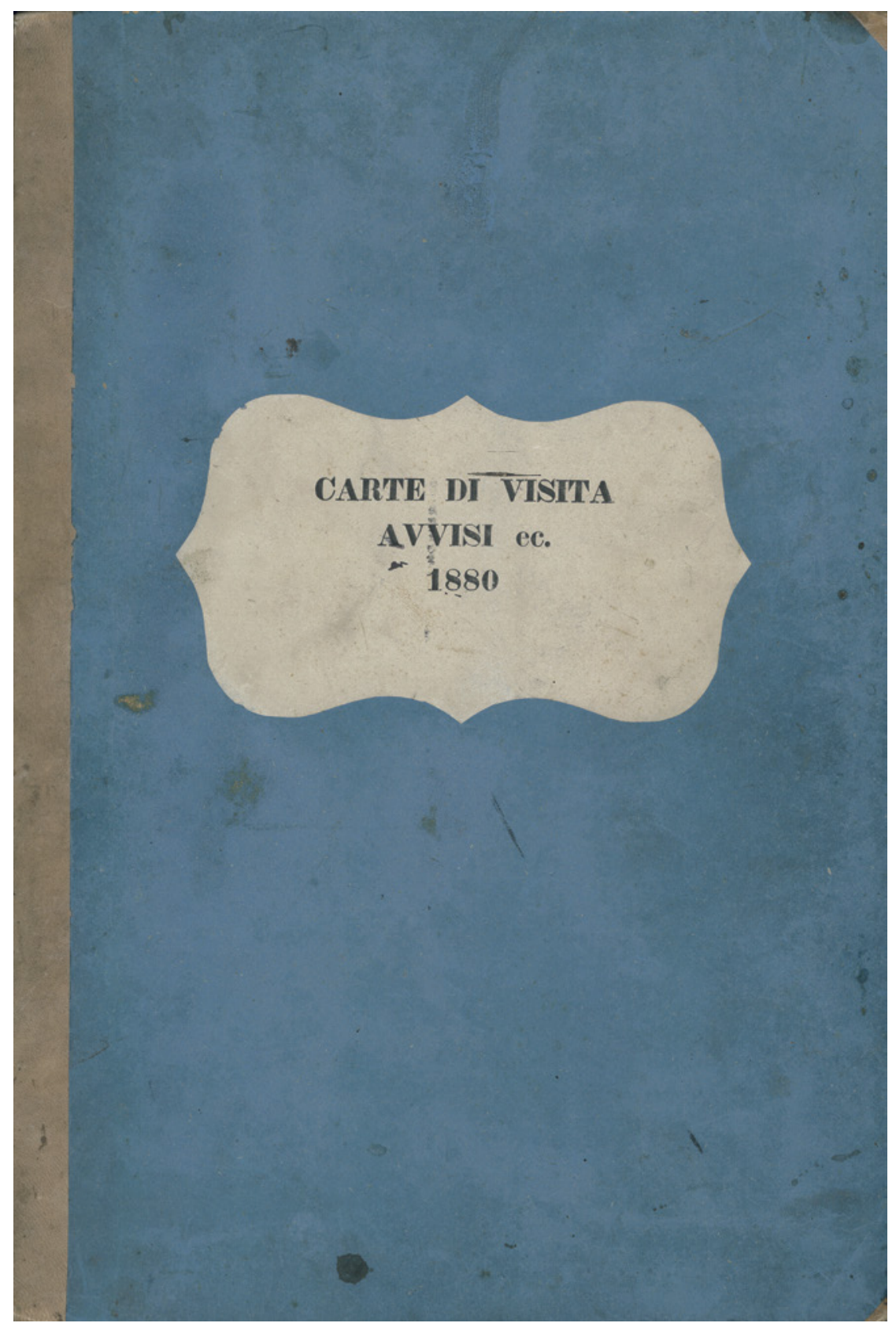

FIGURE 2.1 Cover of the catalogue "Carte di visita avvisi ec. 1880". 
cards had different purposes: to announce a visit, to inform others of a change of address, to invite people for a special occasion, or to make what was considered a polite gesture. They were tools in the hands of notabilities and the middle classes to create or strengthen networks of acquaintance. Cards were also used to convey the sender's regards on occasions such as weddings, births, and funerals. Trade cards were used to advertise shops and products, and they came in a variety of shapes and sizes.

The items listed above can be said to fall under the definition of "egodocuments" that testify to varied constructions of the self and its narratives, although visiting cards have not yet been studied as part of this category. ${ }^{10}$ These "printed ephemera" have traditionally been neglected by historiography. ${ }^{11}$ However, renewed attention to social, cultural, economic, and art history has contributed to the rediscovery of this material; a precious source for the study of material culture and consumption, ${ }^{12}$ design, etiquette between senders and recipients, social connections, and emotions. ${ }^{13}$ Nevertheless, the majority of case studies remains confined to Europe and the United States.

Linking the history of the FPP to the cards allows us to investigate a further aspect: the relevance of these materials to urban life and the connections between the city's inhabitants and the custodian publisher. The cards depict Jerusalemites crossing the gates of St. Saviour's convent to enter the FPP. This "history through names and surnames" provides a glimpse of the people living in the city and how they intended to present themselves. Comparing the cards reported in the album with the registries helps to describe the various landscapes of men and women, and the institutions and associations, that circulated around the FPP. The registries give further details about the characteristics of the cards themselves, their format, and their price. They report the name of the client, the type of object printed, their dimension expressed in

$10 \quad$ Ralf Elger and Yavuz Köse, eds., Many Ways of Speaking About the Self: Middle Eastern EgoDocuments in Arabic, Persian, and Turkish (14th-2oth Century) (Wiesbaden: Harrassowitz, 2010); Winfried Schulze, ed., Ego-Dokumente: Annäherung an den Menschen in der Geschichte (Berlin: Akademie, 1996).

11 For useful considerations on ephemera and historical narration, Mary-Elise Haug, "The Life Cycle of Printed Ephemera: A Case Study of the Maxine Waldron and Thelma Mendsen Collections," Winterthur Portfolio 30, no. 1 (1995).

12 See, for example, Maxine Berg and Helen Clifford, "Selling Consumption in the Eighteenth Century: Advertising and the Trade Card in Britain and France," Cultural and Social History 4, no. 2 (2007); Troy Bickham, "Eating the Empire: Intersections of Food, Cookery and Imperialism in Eighteenth-Century," Past \& Present, no. 198 (2008).

13 Barry Shank, A Token of My Affection: Greeting Cards and American Business Culture (New York: Columbia University Press, 2004). 


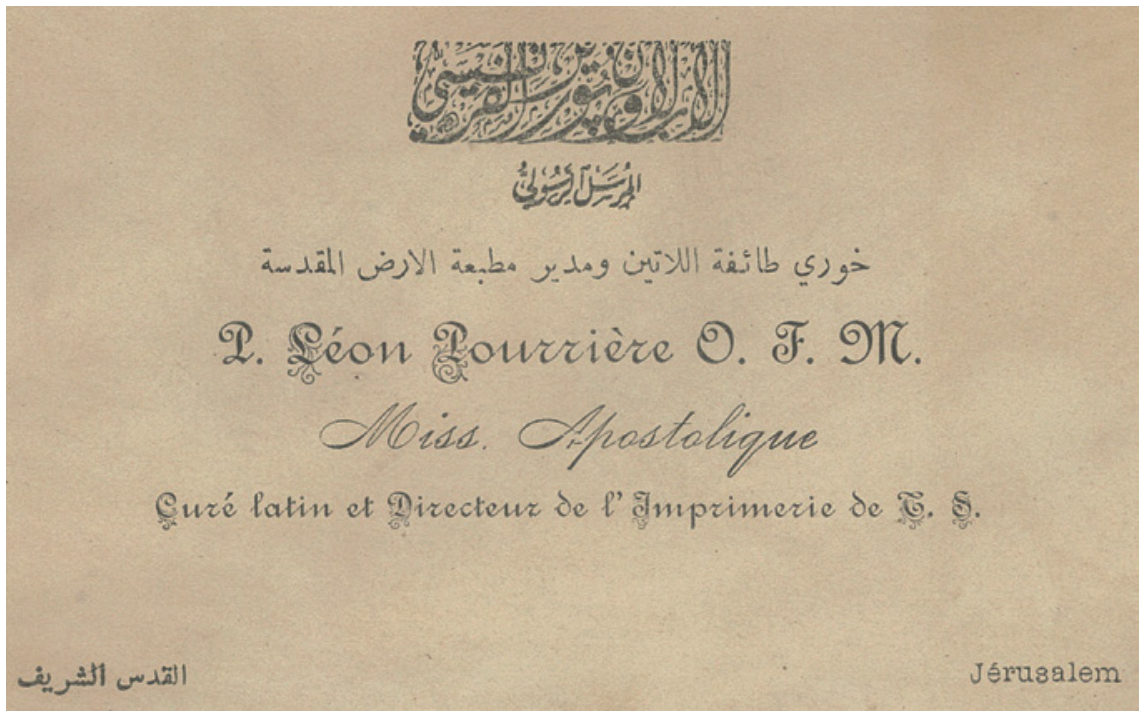

FIGURE 2.2 Visiting card of P. Léon Pourrière, OFM, ca. 1898.

"CARTE Di VISITA AVVISI EC. 1880," UNNUMBERED, 94.

sest $i$ - for visiting cards, usually 4, 8 and 16 sesti -14 their number, the binding (not included for cards), and finally, the price and date of delivery, sending and payment. The price, expressed in francs or local piastre, was affordable and permitted a wide circulation of these printed materials..$^{15}$

Jerusalem business and calling cards generally reported the name, the title, and often (although not always) the profession of the person engraved in black ink at the center of the card (fig. 2.2). Decorative motifs, often with art nouveau influences, were sometimes added while blessings or holy images appeared on the cards of representatives of the Christian communities. Compared to coeval trade cards, the cards printed at the FPP still predominantly used words rather than images, though images appear in a few examples (fig. 2.3). Visual advertising culture was purveyed later and through different channels.

The album does not present the kind of photographic business and calling cards that circulated elsewhere in these decades showing the engraved name and a professional studio photograph of the person. However, studio

14 It was impossible to find out the exact dimension of sesto but generally the cards were $7.5 / 8 / 8.5 / 9.5 \mathrm{~cm} \times 4 / 5 / 5.5 / 6.5 \mathrm{~cm}$.

15 In 1900 the price of one hundred visiting cards was two francs. 


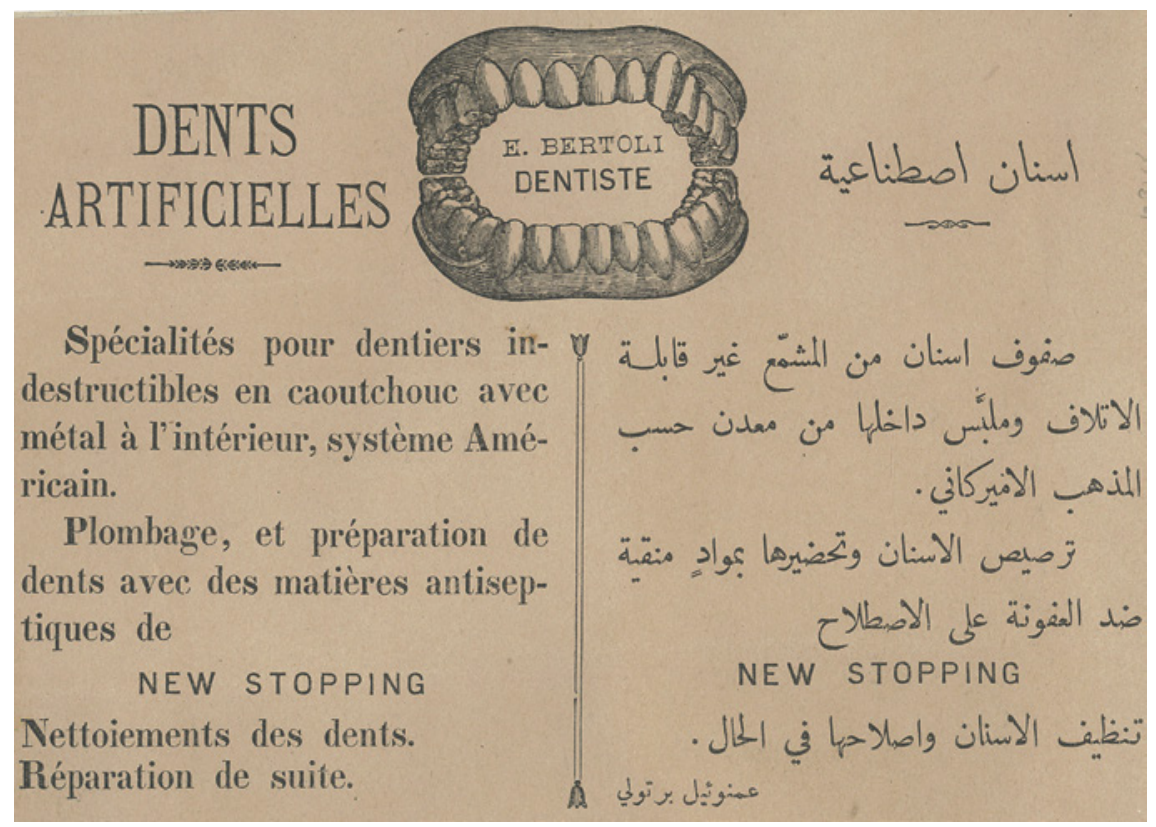

FIGURE 2.3 Visiting card of E. Bertoli, dentist, ca. 1894-95.

“CARTE Di Visita AVVISI EC. 1880," UNNUMBERED, P. 85.

photography was widely used in Jerusalem and the wider region at the time. ${ }^{16}$ Traditional nonphotographic cards remain unexplored. Therefore, the FPP objects can provide new insight into the construction, representation, and communication of Jerusalemites senses of the self in a phase of deep change.

The richness of this source relies on the number of the pieces, which is enough to give a relevant account of Jerusalem's bourgeoisie during a period in which the population of the city grew from 20,000 inhabitants in 1870 to 70,000 on the eve of World War I. The cards, which number around 1,500, are enough to test and even to validate research hypotheses. Moreover, these documents show that the Custody's publishing house was the city's de facto printing press.

16 Stephen Sheehi, "Portrait Paths: Studio Photography in Ottoman Palestine," Jerusalem Quarterly, no. 61 (2015), and Yair Wallach's chapter, "Reading the City, Writing the Self: Arabic and Hebrew Urban Texts in Jerusalem, 1840-1940," in this volume. 


\section{Urban Selves}

The governor of Jerusalem, the president of the municipality and its sitting members, the dragoman, the middleman, the banker, the shopper, the teacher, the shaykh of the mosque, the Jewish bookbinder, the Greek monk, the Druze chief, the young lady and her fiancé, the actress, the midwife, the artist, the engineer working on the Jaffa-Jerusalem railway, the pilgrim, the tourist ... all of these individuals flow through the pages of the catalogue in a "human comedy," testifying to the complexity and the vitality of the global city of Jerusalem. ${ }^{17}$ This gallery of inhabitants of and visitors to the city reveals their various social milieus, languages, civil statuses, occupations, religions, gender, and age, all reflecting a multifaceted and fascinating prism of citadinité. Each item adds a detail on the map of historical biographies, tracing new links between men, women, places, and spaces in the city and beyond.

Most of the cards are written in Latin characters, even Arab and Ottoman names. Around 15 percent of the cards use characters in the Arabic and/or Ottoman alphabets. Many cards are in French and English, while some are in Italian, German, Armenian, Spanish, Greek, Russian, Portuguese, Polish, Dutch, and even in Latin. Many pieces, especially business cards, combine two or three languages (often including errors), attesting to the linguistic diversity of the city at that time. Languages are sometimes linked to fonts: for example, German cards were habitually printed in Gothic fonts.

It doesn't come as a surprise to find, with certain titles of his transliterated according to French, the card of Sharif Mehmed Ra'uf Pasha [or Ch. M. Raouf Pacha on the card], ${ }^{18}$ governor of Jerusalem from 1877 to 1889; a key person in the history of the city as an Ottoman reformer, as well as that of Ibrahim Pasha [Ibrahim Pacha], mutessarif from 1890 to $1897 \cdot{ }^{19}$ The world of the Jerusalem municipality (baladīyya) appears in Salim al-Husayni's [Sélim el-Houseini and Sélim el-Husseini] calling cards as president of the municipality of Jerusalem (1882-97) (fig. 2.4), his successor Yassin al-Khalidi's [Yassine el-Khalidi] (18901901), as well as some municipal council members and secretaries of the city's government. $^{20}$

17 Vincent Lemire, Jérusalem: Histoire d'une ville-monde des origines à nos jours (Paris: Flammarion, 2016).

18 The names on the cards are transliterated (according to IJMES) and are followed in brackets by the name as it appears on the card where a difference exists.

19 Vincent Lemire, Jerusalem 19oo: The Holy City in the Age of Possibilities, trans. Catherine Tihanyi and Lys Ann Weiss (Chicago: University of Chicago Press, 2017), 86-87.

20 At the turn of the century, among the members of the Jerusalem government whose cards were printed by the Franciscans was Negib Azoury [M. Azoury], a young Ottoman 


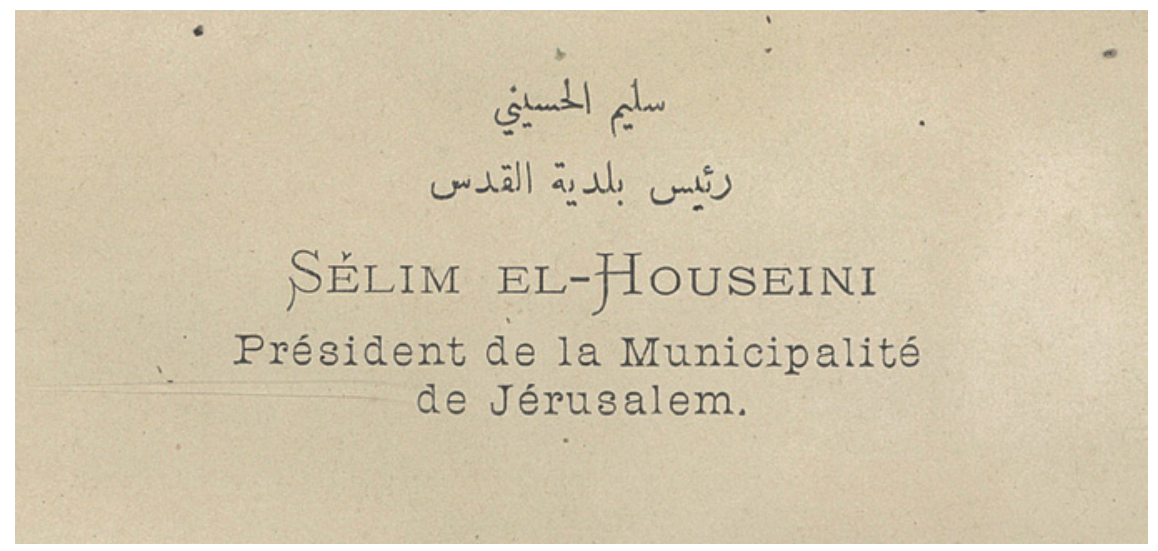

FIGURE 2.4 Visiting card of Salim al-Husayni, ca. 1889-9o.

“CARTE Di VISITA AVVISI EC. 1880, UNNUMBERED, P. 58.

Other representatives of the Ottoman administration had their cards issued by the FPP and these pieces attest to the introduction of new offices such as the Public Debt Administration, established in 1881, and the tobacco Régie after the establishment of the state monopoly on tobacco in 1874. Political modernization and technological innovations created brand-new roles and transformed already existing occupations: the electric telegraph reached Palestine in the middle of the 1860 s, and the calling cards of the telegraph and mail station chief in Bethlehem and Jaffa testify to their introduction. The governor's power is also symbolized by the gendarmerie, introduced during the Tanzimat period: 'Ali Bey [Aly Bey], major of the gendarmerie; Rustum Pasha [Rustem Pacha], general brigadier, and Rashid Bey [Rached bey], colonel of the infantry, used the FPP's services for their cards.

In this context of transformation, Jerusalem saw the birth of its Museum of Antiquities (1901), the first of four imperial museums conceived during the reign of Abdülhamid II to reinforce Ottoman power by linking it to the past (though not without reshaping it). ${ }^{21}$ Mahmud Şevket al-Khalidi [Mahmoud Chevket al-Khalidi] and Ibrahim Adham al-Khalidi feature among the inspectors of the museum. The construction of the imperial museum and new schools such as

official who, after leaving the city, would publish Le réveil de la nation arabe dans l'Asie turque (Paris: Librairie Plon, 1905), one of the first theorizations of Arab nationalism and anti-Zionism.

21 Beatrice St. Laurent and Himmet Taskömür, "The Imperial Museum of Antiquities in Jerusalem, 1890-1930: An Alternate Narrative," Jerusalem Quarterly, no. 55 (2013). 
the Ottoman lycée, whose teachers were clients of the FFP, are but examples of the rapid development of the city in the late nineteenth century.

The cards of Georgios Frangkias [Georges Franghia] and Olivero de Roccabigliera use the title of "Ingénieur en Chef de Palestine." The need to regulate and supervise urban growth pushed the municipality to create the position of chief engineer, a member of the municipal council. Georgios Frangkias, an Ottoman of Greek origin, contributed significantly to the city's transformation. ${ }^{22}$

The FPP recorded another crucial moment in the history of Jerusalem: the construction of the railway between Jaffa and the Holy City, completed in 1892. From 1890 on, the names of work superintendents, station chiefs, employees, accountants, technicians of the French company Société du Chemin de Fer Ottoman de Jaffa à Jérusalem et Prolongements, and the secretary of the imperial commissioner for the railroad, ordered their visiting cards in St. Saviour's convent. Bills of exchange (1891) (fig. 2.5) and the governor's invitation to the banquet celebrating the inauguration of the line, "le lundi, 26 septembre [1892], à 6 heures du soir," can be found among the cards. The Jaffa-Jerusalem railway construction had multiple and less obvious consequences, for example it permitted the opening, under the supervision of Dr. Fotios Efklidis [Photius Euclidès and Le Docteur Photios], of the municipal hospital (1891), ${ }^{23}$ access to which was free to all Jerusalemites. ${ }^{24}$ Efklidis' name appears among the FPP cards along with many other representatives of the medical milieu of the time. ${ }^{25}$

Glimpses into the world of entertainment can be caught as well. Examples include a ticket for a show by the illusionist Charles Reinhardt in the 1880 , performances in August 1889 "in favor of the Municipal pharmacy," and a lottery for a sewing machine.

\footnotetext{
22 Lemire, La soif de Jérusalem, 306-7.

23 Johann Büssow, Hamidian Palestine: Politics and Society in the District of Jerusalem, 18721908 (Leiden: Brill, 2011), 529 .

24 Zalman Greenberg, "The Turkish Municipal Hospital in Jerusalem and its Director Dr. Photios Efklides," in 38. Uluslararası Tip Tarihi Kongresi Bildiri Kitabı. Proceedings of the 38 th International Congress on the History of Medicine. Actes du 38. International d'Histoire de la Médécine, ed. Nil Sarı, Ali Haydar Bayat, Yeşim Ülman and Mary Işin (Ankara: Turk Tarih Kurumu, 2005).

25 Yaron Perry and Efraim Lev, Modern Medicine in the Holy Land: Pioneering British Medical Services (London: I. B. Tauris, 2007).
} 


\section{TRAVAUX DU CHEMIN DE FER DE JAFFA A JÉRUSALEM ET Pts}

Entreprise: FRANGHIA

Maconneries

(du Kil. 26 au Kil. 55)



Bon pour

Veuillez payer au porteur nommé:

la somme de:

pour

Wady-Sarar le 1891

pour G. Franghia

\section{à $\mathbf{M}^{\mathrm{r}}$ Housseïn eff. el Housseёni}

FIGURE 2.5 Bill of exchange of the Société du Chemin de Fer Ottoman de Jaffa à Jérusalem et prolongements, 1891.

“CARTE Di VISITA AVVISI EC. 1880," UNNUMBERED, P. 70.

\section{Advertising the City}

Merchants, middlemen, and commercial entrepreneurs in Jerusalem widely patronized the FPP. Among them were Hayim 'Aharon Valero [H. A. Valero], representative of one of the most notable coalitions of Sephardi entrepreneurs in the city, ${ }^{26}$ consisting of Joseph Navon Bey, ${ }^{27}$ As'ad Kayat [Assad Kayat] (whose store's sign was inside Jaffa Gate), ${ }^{28}$ and 'Isa D. Katas [Eissa D. Gattas]. There were also representatives of foreign companies, such as Rafa'el Z. Kohen [Raphael Z. Cohen], who worked for Singer at a time when the sewing machine factory was expanding in the Middle East.

26 Joseph B. Glass and Ruth Kark, Sephardi Entrepreneurs in Jerusalem: The Valero Family, 1800-1948 (Jerusalem: Magnes Press, 2007).

27 Joseph B. Glass, "Biography in Historical-Geography Research: Joseph Navon Bey. A Case Study," in The Land that Became Israel: Studies in Historical Geography, ed. Ruth Kark (New Haven: Yale University Press; Jerusalem: Magnes Press, 1990).

28 Ayalon, Reading Palestine, 70. 
Among the main categories of people who used business cards extensively in Jerusalem and in the Ottoman Empire as a whole were the dragomans. ${ }^{29}$ Several dragomans were active in the city and had different functions and responsibilities. The registries and the cards reported their frequent visits to the FPP. Of these, dragomans serving as diplomatic interpreters between the European consuls, the Jerusalem government, and the Sublime Porte were the most important. The registries and the number of the ordered cards testify to their frequent visits to the FPP. Another class of client were tourist guides, who would sometimes also provide transport and accommodation. For example, the FPP printed business cards for the agents of Thomas Cook, pioneer of mass tourism in the nineteenth century, who had a branch in Palestine, as well as the tickets for their tours and many handbooks for Palestine and Syria, such as the famous Cook's and Baedeker's guides. Independent dragomans flourished in the city in these years. In their business cards, they highlighted their multilingualism and boasted, in a mix of French and English, that they were "natif of Jerusalem." They advertised their ability to "take private parties \& families on first class tours at a moderate price" and, in so doing, testified to the creation of a "language of success." 30

In the rising tourism industry, hotel owners also resorted to the use of business cards. In the 1880s, Jerusalem opened its first hotels following European standards and the Feil Hotel was the first to be erected outside the city walls. ${ }^{31}$ Its business cards signal that the hotel was furnished with "all the conveniences usually found in a first class hotel" and mention that the

29 On dragomans, guidebooks, tourists and pilgrims at this time, see Sarga Moussa, "Le sabir du drogman," Arabica 54, no. 4 (2007); Mark Mazower, "Travellers and the Oriental City, c. 1840-1920," Transactions of the Royal Historical Society 12 (2002); Bernard Heyberger, "Les nouveaux horizons méditerranéens des chrétiens du Bilād al-Šām (XVII ${ }^{\mathbf{e}}-$ XVIIII $^{\mathbf{e}}$ siècle)," Arabica 51, no. 4 (2004); Doron Bar and Kobi Cohen-Hattab, "A New Kind of Pilgrimage: The Modern Tourist Pilgrim of Nineteenth-Century and Early TwentiethCentury Palestine," Middle Eastern Studies 39, no. 2 (2003); Edmund Bosworth, "The Land of Palestine in the Late Ottoman Period as Mirrored in Western Guide Books," Bulletin (British Society for Middle Eastern Studies) 13, no. 1 (1986); Madiha Doss, "The Dragoman's Journey through Time and Space," Alif:Journal of Comparative Poetics, no. 26 (2006).

$30 \quad$ Natacha Coquery, "Language of Success: Marketing and Distributing Semi-Luxury Goods in Eighteenth-Century Paris," Journal of Design History 17, no. 1 (2004).

31 On the Feil Hotel and the dragomans in Jerusalem Rachel Mairs, From Khartoum to Jerusalem: The Dragoman Solomon Negima and His Clients, 1885-1933 (London: Bloomsbury, 2016), 192-93. 
hotel is "most conveniently situated for health and scenery."32 The cleanliness and the safety of these buildings were among the most common features boasted of on the cards, for example, the Damascus Hotel's owners, Alexander Howard and Morcos, ordered a bold-printed note saying "no pools or stagnant water around it," while Howard's Hotel opposite the Jaffa Gate (whose owner was the same Howard) asserted that "this Hotel has been constructed on the best Sanitary principles." Their insistence on cleanliness is consistent with the concern for the spread of diseases through water stagnation, which was frequently expressed in these decades by Jerusalem's inhabitants and authorities. The ambition to emulate European standards in order to attract Western clients is clearly reflected in the cards. The Damascus Hotel was equipped with a reading room with European and American newspapers, while the Howard's claimed to combine "the comforts of home with the luxury of the finest Hotels in Europe." The geography of tourism was another element and every card pointed out the major sites of interest near the hotels. Sites included the Damascus Gate, the Holy Sepulchre, the Mosque of Omar, as well as various consulates, and banks, thereby drawing a sort of religious, political, and economic sketch of the city.

The hotel cards printed by the FPP were mostly designed to serve the Western middle classes and haute-bourgeoisie. Other cards targeting tourists and pilgrims were those ordered by Jerusalemite shop owners. Through these cards, we can reconstruct a walk along the streets of the center city and its immediate surroundings, hearing the voices of the vendors quickly listing their products "at a moderate cost" to catch the attention of the foreign passersby. Objects of piety were the most common articles depicted on the cards, together with embroideries, photographs and lantern slides, mother-of-pearl, gold and silver, Dead Sea stone, old glass, pottery, coins, and other "Oriental articles illustrating Bible life \& history." Additional objects sold included flower cards, Bibles, manuscripts, and guidebooks. Most of the shop cards use varying typeface styles and sizes to highlight certain words. Some advertisements directly referred to the clients. ${ }^{33}$ In the pages of shop cards, we encounter Mitri Habib Kurt [Mitre Habib Kurt] in the Via Dolorosa and Y'aqub Marum [Jacob Marroum], Mantura Salah [Mantoura Salah] and Gabriel and Ibrahim Dabdub [Gabriel \& Abraham Dabdoub] near the Casa Nova. The renowned shop of

32 Shimon Gibson, Yoni Shapira and Rupert L. Chapman, eds., Tourists, Travellers and Hotels in 19th-Century Jerusalem (Leeds: Maney, 2013); Kobi Cohen-Hattab and Noam Shoval, Tourism, Religion and Pilgrimage in Jerusalem (New York: Routledge, 2015).

33 For example, A. Morcos and A. Abd-el-Messihi "Beg the travellers to the Holy Land to inspect their shop situated near the Jaffa Gate and the Greek Bazaar." 
Boulos Meo, situated very close to Jaffa Gate, was a distinctive part of the city landscape. Just beside Boulos Meo, under the Grand New Hotel, lay another important shop, the American Colony store, owned by Ferdinand Vester in what was then called "new Greek building." The various cards commissioned by Mr. Vester advertised that his collections had won "medals of merit" in recent universal exhibitions. Immanuel Berner, whose shop was beside the Hotel Fast near the Jaffa Gate, sold water from Jordon that he bottled himself as well as wines from the German settlements in Palestine. ${ }^{34}$ A few meters away, Ferdinando Nicodemo had his own shop. Nicodemo is an example of the "multiple selves" traceable through the FPP cards. The Franciscans printed several cards for him, each for a different profession and responsibility: he sold handicrafts and photographs, was a member of religious associations, and worked as dragoman for the Italian consulate in Jerusalem, which was very well-connected with the Catholic and Ethiopian Orthodox communities..$^{35}$ Nicodemo was one of the lay people living and working in the city who also belonged to religious congregations or groups (as in the case of the German Catholic workers' association, whose presence was revealed through pieces in the album), at the crossroad of economic, social, political, and religious worlds.

Tourists and pilgrims were not only recipients of business cards; they often had them commissioned for themselves. In the collection of the FPP, we find cards printed for travelers from France, Canada, and the United States. The predominance of French cards can be easily explained by the revival of pilgrimage in French culture after the war of $1870-71$ and the experience of the Paris Commune. ${ }^{36}$ Pilgrims' cards frequently presented the Jerusalem cross, then the name of the person and the year in which he/she visited the Holy Places, followed by their address in their country of origin. ${ }^{37}$ That a pilgrim

34 The Franciscan Custody complained that water from the Jordan river was being sold in bottles labeled "baptism water" and depicting an image of the Cross of the Holy Land. Archives of the Congregation for the Propagation of the Faith (ACPF), sC, Terra Santa e Cipro, vol. 24, ff. 650-51, Fra Serafino Milani to Card. Alessandro Barnabò, September 22, 1870.

The fonds of the Italian consulate of Jerusalem in the historical archives of the Ministry of Foreign Affairs in Rome has been recently inventoried by Costanza Lisi within the framework of Open Jerusalem project. See Roberto Mazza, Maria Chiara Rioli, and Stéphane Ancel, "The Italian Consulate in Jerusalem: The History of a Forgotten Diplomatic Mission, 1846-1940," Jerusalem Quarterly, no. 71 (2017).

36 Bertrand Lamure, "Le premier pèlerinage populaire de pénitence en Terre Sainte: L'ultime croisade," Bulletin du Centre de recherche français à Jérusalem, no. 14 (2004).

37 In 1901 Pope Leo XIII announced that every pilgrim to the Holy Land would be awarded a medal in bronze, silver or gold, depicting the Jerusalem cross, as a "signum sacri itineri 
could obtain a calling card during the pilgrimage to be shown and distributed upon arriving home shows how this tool was a way to state a sort of "pilgrim citadinite" in recognition of their voyage to the Holy City. Calling cards contributed to making the pilgrims inhabitants of Jerusalem in a way, although physically they were present for just a few weeks or months. The cards acted as symbols of this status.

Trade cards printed by the FPP were also in high demand outside of the tourist industry. Photographers often called on the services of the Franciscans to advertise their activities, and the cards bear witness to the new market which appeared at the end of the 1830 s. $^{38}$ Tancrède R. Dumas was an important artist who, like Felix Bonfils, had his studio in Beirut. Through his business card, we learn that during his stay in Jerusalem he worked for the German consulate, the American Palestine Exploration Society, and was a correspondent for L'Illustration. Luigi Fiorillo was an internationally known artist who mainly worked in Alexandria. He visited Jerusalem and the Holy Land between 1885 and 1887, documenting the work of the Franciscan friars who today preserve about 150 of Fiorillo's images in the Archivio Provinciale Aracoeli in Rome. Another well-known photographer at that time was Alexandre Gherardi, who had his studio just out of the Jaffa Gate. His business card relates his Catholic confession and his work photographing French pilgrims. The cards document other types of workers: sculptors, mercers, cabinetmakers, organ builders, potters, plasterers, saddlers, and upholsterers enrich the "census" of Jerusalemite craftsmen and artists of the period. The cards are mostly written in Italian and German, showing the origins of these workers and their client base.

\section{An Interfaith Printing Press?}

Predictably, a significant corpus of business cards belonged to teachers and theology professors of Christian schools and seminaries (Frères des écoles chrétiennes, Notre-Dame de Sion, St. Anne and others), and priests used their cards to solicit donations. In addition to this, it would seem that the FPP

hierosolymitani" (sign of the holy journey to Jerusalem). ACPF, NS, vol. 235, rubrica 126, ff. 387-403, Propaganda Fide to Patriarch Ludovico Piavi, 1902.

38 Walid Khalidi, Before Their Diaspora: A Photographic History of the Palestinians, 18761948 (Washington, DC: Institute for Palestine Studies, 1984); Badr al-Hajj, "Khalil Raad Jerusalem Photographer," Jerusalem Quarterly, nos. 11/12 (2001); Abigail Solomon-Godeau, "A Photographer in Jerusalem, 1855: Auguste Salzmann and His Times," October, no. 18 (1981). 


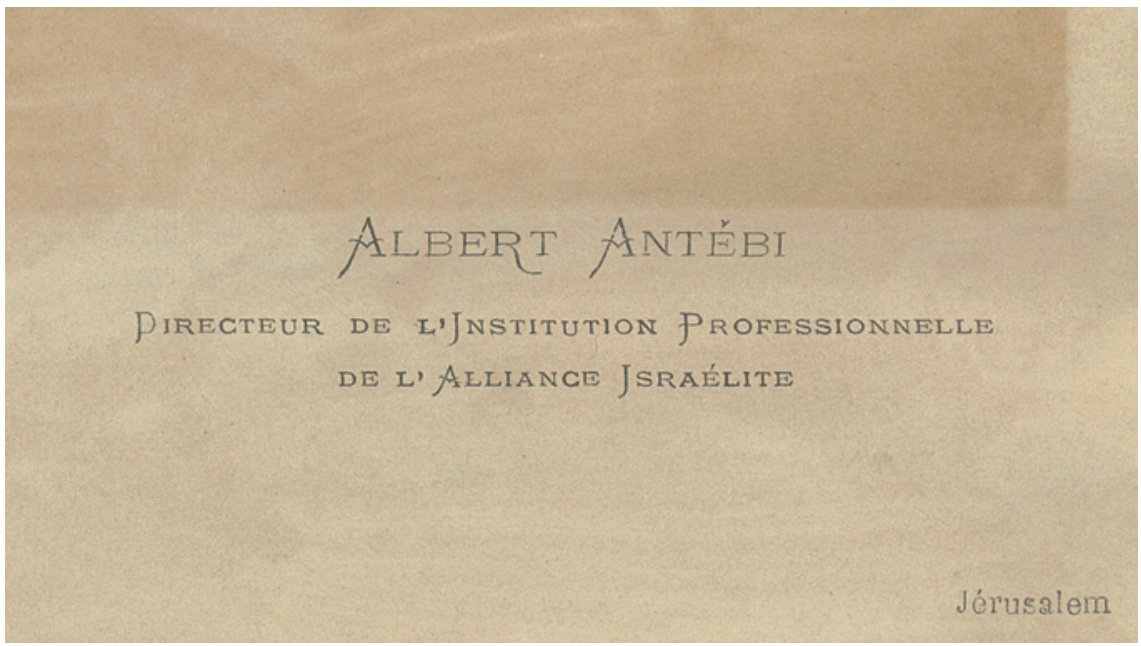

FIGURE 2.6 Visiting card of Albert Antébi, ca. 1898 .

“CARTE Di VISITA AVVISI EC. 1880," UNNUMBERED, P. 93.

functioned as an interfaith printing press patronized by Jewish intellectuals and Muslim chiefs. One finds the cards of prominent Sephardi Jewish Ottoman educators such as Nisim Bekhar [Nissim Behar] (1848-1931), and Albert Antébi (1873-1919) (fig. 2.6), the first two principles of the school of the Alliance Israélite Universelle (AIU) on Jaffa Road. ${ }^{39}$

Although visiting cards printed in Hebrew are scarce, the friars had close links with Jewish publishers. For example, the Franciscans sold machines and letter cases to Jewish bookbinders whose names recur several times in the registries. The same can be said for the AIU, which was a frequent client of the FPP at the turn of the century, as evidenced by the many books that the Franciscans printed and bound for them.

The interconfessional work by the FPP was attested in other publications. Jerusalem Rabbi Panigil's card (in French and Hebrew) and the invitation

39 On these two figures, see Alisa M. Ginio, Between Sepharad and Jerusalem: History, Identity and Memory of the Sephardim (Leiden: Brill, 2014), 138. On Antébi, see Elizabeth Antébi, L'homme du Sérail (Paris: Nil, 1996). On Bekhar and Ottoman citizenship, see Michelle U. Campos, Ottoman Brothers: Muslims, Christians, and Jews in Early Twentieth-Century Palestine (Stanford: Stanford University Press, 2011), 154, while on Antébi's anti-Zionism, see ibid., 218-20. Another important teacher of AIU Jerusalem school, Elie Astruc, printed his card at the FPP; Georges Weill, "Élie-Aristide Astruc, rabbin, écrivain et publiciste (Bordeaux, 12 décembre 1831-Bruxelles, 23 février 1905)," Archives Juives 35, no. 1 (2002). 
(only in French) to a circumcision ceremony hosted by the Amiel family on February $17,1889^{40}$ were among the papers issued by St. Saviour's convent. Printed materials, visiting cards in particular, were also a sort of "currency of exchange" for mutual respect and peace among religions. The FPP printed several books and other objects for free. Generally, these clients were Franciscan people or institutions, but in the registries we discover that the friars also issued visiting cards free of charge, as well as copies of the Qur'an and timetables of the Ramadan hours for the sheikhs of certain Jerusalem mosques. ${ }^{41}$ The cards seem to have been embedded within a system of favors to ensure stable relations between the custody and Islamic leaders in the city, particularly before the outbreak of World War I. ${ }^{42}$

Apart from Jewish Ottomanism and Muslim-Catholic relations, the FPP business cards and announcements are fascinating sources for the history of Christian millenarianism in nineteenth-century Palestine. Information on the Templers is particularly forthcoming. A vast catalogue of engagement and wedding announcements was printed by the machines at St. Saviour's. The names Hoffmann, Blankertz, Rockenbauch, Münzinger and Blenk are among the many Templer families in Jerusalem, Jaffa, and Sarona mentioned in the cards. ${ }^{43}$ The Templers' commercial activities are also documented. An example is Christian Fr. Eppinger (1833-1918), who made his living selling "Jerusalem's Wein." The Templer cross he chose to put on his card clearly attests to his identity and where he belonged within the city's mosaic of communities. ${ }^{44}$ The presence in Jerusalem - documented by his card, probably printed in 1883 - of François Vercruysse (1822-90), one of the forerunners of Christian Zionism, invites new paths of investigation: with whom was the author of Rénovation du monde in contact in the city? Did he come to promote and circulate his and his father's ideas on the return and conversion of Jews? ${ }^{45}$

\footnotetext{
40 ASCTs, "Introito attivo," oggetti stampati 1, January 2, 1888-December 22, 1894.

41 ASCTS, "Introito passivo," 1, January 1900-December 1908; January 1919-December 1919 "Libri ed oggetti dati o stampati gratuitamente 1900-1908 coll'aggiunta solo l'anno 1919." As far as I can tell from the registries, these public relations activities did not continue after 1918 .

43 On the Templers in Palestine, see Alex Carmel, Die Siedlungen der württembergischen Templer in Palästina, 1868-1918 (Stuttgart: Kohlhammer, 1973).

On Eppinger, see Helmut Glenk, From Desert Sands to Golden Oranges: The History of the German Templer Settlement of Sarona in Palestine, 1871-1947 (Victoria: Trafford, 2005).

François was the son of Dominique Joseph Vercruysse-Bruneel (1797-1880), Belgian author of La régénération du monde: opuscule dédié aux douze tribus d'Israël (Paris: Eugène Beyaert, 1860) and La résurrection dans le système de la régénération du monde: opuscule dédié aux douze tribus d'Israël (Brussels: Terneu, 1869). On these figures, see Yves
} 


\section{Portraits of Ladies}

The sketches of the population of Jerusalem that emerge from a study of business cards and announcements is at first sight a mostly male history. However, women do appear in different roles. Predictably, they are often recorded as wives and daughters of the diplomatic corps or other professionals (especially doctors or bankers, as in the case of Martha Frutiger of the Frutiger Swiss bankers), ${ }^{46}$ but there are also "couple's cards" in which the woman's name was more familiar in Jerusalem than the man's. This is the case for Mr. and Mrs. Sodar de Vaulx, from Belgium. Marie Sodar de Vaulx was the author of travel accounts ${ }^{47}$ and a book on the Holy Land ${ }^{48}$ which were widely circulated.

On occasion, women's names appear alone. They are mostly European superiors of female congregations running schools, hospitals or similar institutions. Less evident but more interesting is the small galaxy of women married, widowed, but more often single - whose names are linked to the launch of enterprises and who therefore ordered calling cards to publicize their activities. One such woman is "Mademoiselle de St. Cricq Dartigaux," who helped rebuild the Emmaus church after founding a Carmelite monastery in Bethlehem.

The registries report orders coming from many young French and Spanish women, especially in May, the Marian month which, according to Catholic tradition, marks the season of pilgrimage. Female pilgrims would therefore request their cards from the FPP in May, to mark the season. The most intriguing discovery in the Jerusalem's female universe as gleaned from these cards is the name of Ms. L. M. von Finkelstein (1855-1917). Born in Jerusalem, Finkelstein is still of uncertain origins. She may have been a Russian Jew who converted to Christianity or a Pentecostal religion. She was an eclectic actress and writer who became famous for her representations of the Bible all over the world, especially in the United States, where she spent many years. ${ }^{49}$ The FPP printed

Chevalier, "Quelques précurseurs chrétiens du Sionisme," in Aspects du Sionisme: théorie, utopie, histoire. Actes de l'atelier international INALCO tenu au Collège de France (Paris: INALCO, 1982).

46 Hans H. Frutiger and Jakob Eisler, Johannes Frutiger (1836-1899): Ein Schweizer Bankier in Jerusalem (Cologne: Böhlau, 2008).

47 Marie Sodar de Vaulx, Les splendeurs de la Terre Sainte, ses sanctuaires et leurs gardiens (Paris: Bloud et Barral, 1899).

48 Marie Sodar de Vaulx, Les gloires de Terre sainte, histoire de ses héros, de ses martyrs, de ses pèlerins (Paris: Bloud et Barral, 1899).

49 Burke O. Long, Imagining the Holy Land:Maps, Models, and Fantasy Travels (Bloomington: Indiana University Press, 2003), 22-25. 


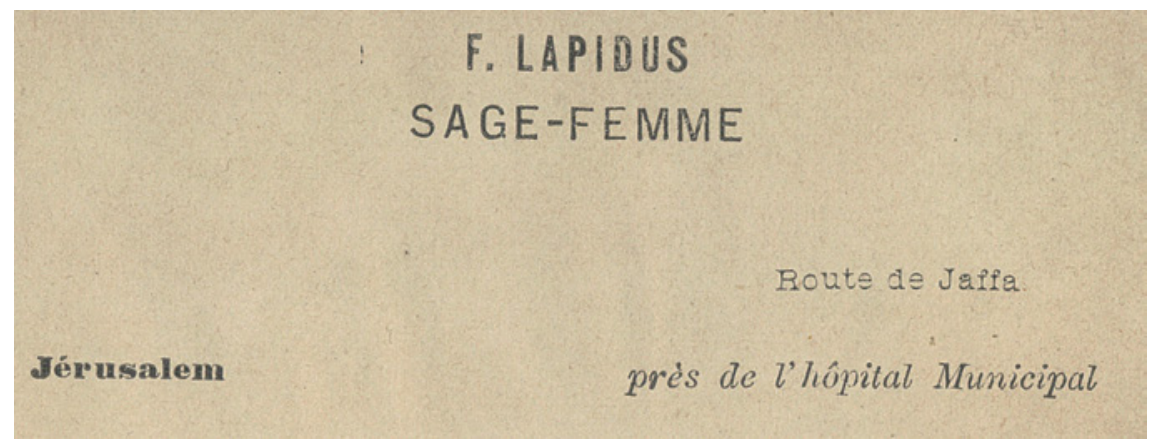

FIGURE 2.7 Visiting card of midwife F. Lapidus, ca. 1892-93.

“CARTE Di Visita AVVISI EC. 1880," UNNUMBERED, P. 75.

at least two versions of her card, with two different names. Printing the card of a nonauthorized performer of biblical interpretations, and a non-Catholic woman, shows the variety of city inhabitants and travelers who patronized the printing press at St. Saviour's. It also bears witness to the extent that women's freedom and self-initiative existed in Jerusalem at the time.

At least two midwives had their visiting cards printed at the FPP (fig. 2.7) ${ }^{50}$ For women, cards were not only a way to access various social circles, but were also used as tools to affirm their professional status and working capabilities. The desire to advertise their skills also indicates certain transformations in the job market. This stands in stark contrast to the harsh campaign pursued by Mandate authorities by which they attempted to control and restrict the activity of midwives in favor of the male British medical establishment, especially after the Midwives Ordinance of 1929 regulated the practice of midwifery. ${ }^{51}$ Concurrently, these decades saw a progressive professionalization of the medical field, with new regulations on hygiene and public sanitation implemented by Jerusalem's authorities. In a more competitive job market, where gender boundaries tended to grow more defined, midwives needed to make their job more visible in order to compete, rather than to confine their activity to the private sphere. This may suggest that other female service providers at the time did not need to declare their competences; they were acknowledged and

$5^{0}$ "F. Lapidus Sage-femme Route de Jaffa Jérusalem près de l'Hopital Municipal" and "Frumze Kestelmann Sage-femme Jérusalem."

$5^{1}$ Ellen L. Fleischmann, The Nation and Its "New" Women: The Palestinian Women's Movement, 1920-1948 (Berkeley: University of California Press, 2003), 243. 
circumscribed as performing exclusively female tasks, with no competition from male-dominated activities, especially in the countryside.

\section{Printed Voices of the City}

Life, time and space flow through the pages of the album. Reading the card for the Italian-Arab wedding of Martino Bertoli and Giulia Haddad, one may begin to imagine the relations connecting the families and communities of the bride and groom. Mourning times are also recorded. Many clients came to the friars to commission messages of condolence. The cards reflect birth and death, reveal the conjunction of public and private spheres, and the intersection of different professions, religions, and genders. The polyphony of these visiting cards attests to the richness of sources such as these, traditionally considered "ephemeral." Reconstructing the itineraries of the card owners is work that, in most cases, remains to be done.

What can already be clearly ascertained is that, together with other printed materials issued by the FPP, the proliferation of the visiting cards throughout Jerusalem allowed the friars to mark their presence in the city across different contexts. In light of this, these multilingual visiting cards must have been a powerful vehicle for social influence. The same card was often designed to be addressed to different recipients, as shown by Yassin al-Khalidi's card, where the languages bear witness to a varied set of targets (fig. 2.8): al-Khalidi's name



FIGURE 2.8 Visiting card of Yassin al-Khalidi, ca. 1898.

“CARTE Di VISiTA AVVISI EC. 1880," UNNUMBERED, P. 91. 
is written in Arabic while his charge appears in Ottoman and in French, aiming at reaching, simultaneously but separately, Arab notables and people, Ottoman officials, and European diplomats and professionals. In a way, cards appear as both sectarian and nonsectarian tools, expressing relations within the communities (as in the case of the wedding cards), and to an even larger extent between them, retracing connections influenced by economic interests, social hierarchies, and religious messages.

Moreover, various other boundaries are redefined by these sources. A system of archival division wherein each section supposedly corresponds to a specific historical narrative now appears contradictory and limiting. Ecclesiastical archives reveal their nonconfessional patrimony, showing how religious sources and studies can contribute to general history, and, particularly, to urban history. Rescuing these books destined for the trash shows how the reclamation of abandoned sources can recast the definition of archives. Indeed, archives must sometimes leave the walls of institutions in order to expand the vast and unpredictable horizon of research possibilities open to historians.

This corpus of sources offers an exercise in microhistory. It is worth studying details such as the languages used and how they mixed, the order of the words, and the dimensions of the font on the cards. Furthermore, it is important to consider that in the same catalogue, at the same level, the card of the president of Jerusalem municipality and the card of an unknown midwife lay beside one another. Such observations provide opportunities to cross biographies, memories of the public self, codes of manner, ambitions and desires of social affirmation. In the end, the vast catalogue of objects printed by the FPP provides, as in a distorting mirror, ${ }^{52}$ an extremely vivid representation of daily life in Jerusalem; a nuanced and prismatic portrait made of "unconsidered or unnoticed details, from the rubbish heap." ${ }^{53}$

\footnotetext{
52 Ginzburg, History, Rhetoric, and Proof, 25.

53 This phrase by Sigmund Freud was quoted and adapted by Carlo Ginzburg in Myths, Emblems, Clues, trans. John and Anne C. Tedeschi (London: Hutchinson Radius, 1990), 99.
} 


\title{
The Ethiopian Orthodox Community in Jerusalem: New Archives and Perspectives on Daily Life and Social Networks, 1840-1940
}

\author{
Stéphane Ancel
}

According to Ethiopian accounts, a plague in 1838 killed every Ethiopian monk in Jerusalem. Dayr al-Sultan, the monastery on the roof of the Chapel of St. Helena, where Ethiopian and Coptic monks had lived together, was from then on occupied only by the Copts, with permission from the Armenian Patriarchate, the traditional protector of both Ethiopians and Egyptians in Jerusalem. Three years later, a new group of Ethiopian monks arrived in town and immediately accused the Copts of unfairly appropriating the site. This event marked the beginning of a long-term conflict in which Ethiopians fought with Copts and Armenians over ownership of Dayr al-Sultan. Indeed, between 1840 and 1940, Dayr al-Sultan was the site of disturbances, demonstrations, and fights. However, in addition to conflict, this period also witnessed the development of the Ethiopian Orthodox community in Jerusalem. From the second half of the nineteenth century, Ethiopians could acquire houses and lands in Jerusalem, their population grew and finally, in 1905, the Ottoman authorities designated a part of the town as Haret al-Habash, known today as the Ethiopian compound. Despite numerous obstacles, the small Ethiopian community thus managed to leave an indelible mark on Jerusalem.

The history of the Ethiopian community in Jerusalem during the nineteenth and twentieth centuries has attracted but a few scholars, mainly specialized in Ethiopian studies, and the majority of research has focused on the controversial ownership of Dayr al-Sultan. In collecting and analyzing documents on the Ethiopian presence, scholars have contributed, either consciously or unconsciously, to the Dayr al-Sultan debate. Among them are Enrico Cerulli, ${ }^{1}$ Otto Meinardus, ${ }^{2}$ and Archbishop Philippos. ${ }^{3}$ Our knowledge of the nineteenth- and

1 Enrico Cerulli, Etiopi in Palestina, 2 vols. (Rome: Libreria dello Stato, 1943-47).

2 Otto Meinardus, "The Ethiopians in Jerusalem," Zeitschrift für Kirchengeschichte 76, nos. 1/2 (1965), 3/4 (1965).

3 Abba Philippos, Know Jerusalem (Addis Ababa: Berhannena Selam Haile Selassie I Printing Press, 1972); Abba Philippos, The Rights of the Abyssinian Orthodox Church in the Holy

(C) STÉPHANE ANCEL, 2018 | DOI:10.1163/9789004375741_006

This is an open access chapter distributed under the terms of the prevailing CC-BY-NC-ND License at the time of publication. 
twentieth-century situation of Ethiopians owes much to Kirsten Pedersen and her pivotal work in $1983,{ }^{4}$ the first study devoted more to the development of the community as a whole than to Dayr al-Sultan. The principal aim of her study was to create a chronology of events related to the Ethiopian community in Jerusalem without a focus on the political, economic, or social context of the city. It appears, based on a small number of Ethiopian texts and European sources (travelers' narratives and British consular archives), that all previous studies neglected Ottoman and Arabic sources. In a similar way, a large part of French and Italian consular archives remained unstudied despite the later valuable works of Henrich Scholler and Alain Rouaud. ${ }^{5}$ More recent studies focus on the current situation of the community starting from the end of World War II. ${ }^{6}$

The Ethiopian Orthodox community appeared in early studies as a community unconnected to Jerusalem, with no role in local daily life. This probably explains why the Ethiopian community seldom appears in historical works about Jerusalem. Still today, the presence of Orthodox Ethiopians in Jerusalem is often considered as an exotic phenomenon; far removed from local historical processes.

The relatively overlooked story of Jerusalem's Ethiopians assuredly warrants new historical research. My research on the subject has been driven by a simple idea: the Ethiopian Orthodox community archives of 1840-1940 most certainly contain information about community members' interaction

Places: Documentary Authorities (Addis Ababa: Documentary Authorities, 1962). In 1959, the Ethiopian government, under the supervision of Philippos, published documents and their translation into Amharic through a publication called Zena Ityopya bä-Hagär Qeddest Iyärusalem [Story of Ethiopia in Holy Jerusalem]. Correspondence Respecting Abyssinians at Jerusalem, 1850-1867 (Addis Ababa, 1959).

4 Kirsten Pedersen, The History of the Ethiopian Community in the Holy Land from the Time of Emperor Tewodros II till 1974 (Jerusalem: Ecumenical Institute for Theological Research, 1983). See also Kirsten Pedersen, "The Historiography of the Ethiopian Monastery in Jerusalem," in Ethiopian Studies: Proceedings of the Sixth International Conference of Ethiopian Studies, ed. Gideon Goldenberg and Baruch Podolsky (Rotterdam: Balkema, 1986).

5 Heinrich Scholler, "The Ethiopian Community in Jerusalem from $185^{\circ}$ to the Conference of Dar-el-Sultan 1902, the political struggle for independence," in Ethiopian Studies, Proceedings of the Sixth International Conference of Ethiopian Studies, ed. Gideon Goldenberg and Baruch Podolsky (Rotterdam: Balkema, 1986); Alain Rouaud, "La protection française des Abyssins de Jérusalem (1843-1898). Aperçu," Transversalités 85 (2003).

6 See Steven Kaplan, "The Transnationalism of the Ethiopian Orthodox Tewahedo Church in the Holy Land," Journal of Levantine Studies 3, no. 1 (2013); Makonnen Zäwde, Ityopya enna Eyärusalem (Addis Ababa, 1991; Ethiopian calendar: 1998-99). 
with the surrounding population and institutions. Archival documents thus should not only be read as a series of events and dates, as they have been until now, but also as vectors of discourse, claims, and ideas of the people who produced them. Additionally, new archival material, previously neglected, must be collected.

This challenging research would be difficult for a scholar without the multidimensional support of the Open Jerusalem project (OJP) which has made it possible to gather sources produced in different religious, sociological, and institutional contexts in Jerusalem and elsewhere. Until now, OJP researchers and I have visited archives in Jerusalem, Addis Ababa, Istanbul, La Courneuve, Nantes, Rome and St. Petersburg, and the analysis of hundreds of documents is still in progress. ${ }^{7}$ The objective of this chapter is therefore not to present final results, but rather to present our methodological approach and suggest some research perspectives.

\section{Opening and Reopening Archives}

To my knowledge, until our project, Pedersen was the only scholar to have accessed the archives of the Ethiopian bishopric in Jerusalem. However, she was not able to examine and study the entire set of records, and the archives remained inaccessible to scholars up until recently. ${ }^{8}$ Thanks to the authorization of His Holiness Matthias, Patriarch of the Ethiopian Orthodox Church, and of His Grace Enbakom, ${ }^{9}$ Ethiopian Orthodox Archbishop of Jerusalem, I obtained access to unpublished material from the Ethiopian Archbishopric archives in Jerusalem. These records are preserved in the building of the Ethiopian bishopric in the old city on Ethiopian Monastery Street and are divided into two sections: the current administrative archives and the manuscript section.

The current administrative archival office preserves a heterogeneous set of documents dating from the end of the nineteenth century to the present. These

7 I would like to express my gratitude to my colleagues from the Open Jerusalem project for helping me during my research and sharing with me their knowledge concerning sources: Vincent Lemire, Yasemin Avcı, Falestin Naïli and Abdul-Hameed al-Kayyali, Maria Chiara Rioli, Angelos Dalachanis, Yann Potin and Leyla Dakhli.

8 Pedersen, History of the Ethiopian Community, 41, n. 90.

9 The transliteration system used in this chapter is an adaptation of the Aethiopica Encyclopedia one, simplified for easy reading. The names are also transliterated according to this system, except when it exists in another form in an official publication (for example, here Matthias and Enbakom for the Ethiopic Matyas and Enbaqom). 
do not constitute historical archives strictly speaking. Among the folders, seven contain documents produced during the period under scrutiny: Folders 6, 154, $356,358,359,360$ and a final folder with the Amharic title "yä-leyu leyu guday däräseññoč käzih yegäññalu" (receipts concerning diverse issues found here) contains different types of unclassified documents. The documents of the "administrative" archives, which comprise approximately $15^{\circ}$ pieces, date from the end of the nineteenth to the middle of the twentieth centuries. They are administrative and financial documents such as payment receipts, tickets, bank checks and documents, short letters, and notes. These documents are written in Arabic, English, French, German, Greek, and Armenian. Amharic marginalia are often added to documents in order to provide context. In addition to these folders, a report on Dayr al-Sultan written in 1925 by the lawyer Boris Nolde is classified as Folder $216 .{ }^{10}$ Also, a 122-page manuscript written in Amharic between 1903 and 1906 by an Ethiopian monk called Wäldä Mädhen was inventoried as Folder $172 .{ }^{11}$ Numerous precious parchment and paper manuscripts are carefully stored in a different room of the same building, the so-called "manuscript section." To date, no previously unknown document has been found. ${ }^{12}$ The Amharic text entitled "History of Dayr al-Sultan" [yä-Der Sultan tarik], written during the 1920 and still unpublished, is preserved in the Jerusalem archives as a large paper manuscript (code Ms. JE692E). ${ }^{13}$

I also launched an investigation in Ethiopia to discover archives about the Ethiopian Orthodox community in Jerusalem. The National Archives in Addis Ababa have recently received and inventoried the records of the Jerusalem Memorial of Ethiopian Believers association. Since its creation in 1963, this association has organized Ethiopian pilgrimages to the Holy Land. Inventoried in 2013 under the archival code 6.1, these archives comprise seven boxes (from 6.1.1 to 6.1.7), some containing more than ten folders, making a total of 71 folders. Documents preserved inside are mainly dated from the 1960s to the $1990 \mathrm{~s}$

$10 \quad$ In French and entitled "Consultation concernant les droits de la communauté religieuse abyssine en Palestine," it was translated into Amharic and English in Zena Ityopya, 45-50 (Amharic), 38-46 (English). See also Pedersen, History of the Ethiopian Community, 75.

11 Pedersen, History of the Ethiopian Community, 13, n. 35; see also Pedersen, "Historiography of the Ethiopian Monastery," 419-26.

12 The manuscript collection was shortly inventoried by Ephraim Isaac during the 1980s; See Ephraim Isaac, "Shelf List of Ethiopian Manuscripts in the Ethiopian Patriarchate of Jerusalem," Rassegna di Studi Etiopici 30-31 (1984).

13 About this text, see Pedersen, "Historiography of the Ethiopian Monastery," 419-26; Getatchew Haile, "Empress Tayitu and the Ethiopian Property in Jerusalem," Paideuma 35 (1989). 
and deal with the association's administrative life. However, the association also held some unpublished documents from the Ethiopian community in Jerusalem during the 1920 s.

Several events relating to the Ethiopian community during the second half of the nineteenth and the beginning of the twentieth centuries are documented in the British, French and Italian consular archives. The correspondence of the British consuls in Jerusalem, James Finn and Noel Temple Moore, provides information for the period from 1850 to 1868 and has been quoted regularly in previous studies. On the contrary, the French and Italian archives have not been studied exhaustively.

The French consular archives span from 1846 to 1913, years during which the French administration claimed to protect unofficially the Ethiopian community. A large volume of documents concerning Ethiopians is still preserved in Nantes and La Courneuve. Approximately 700 folios make up these archives. The Nantes archives (CADN) contain the records of the French consulate in Jerusalem (code $294 \mathrm{PO}$ ). Two boxes contain documents about the Ethiopian community in Jerusalem: 294/PO/A/134 (1846-1912, 322 folios) and 294/PO/A/135 (1881-1913, 155 folios). The French Ministry of Foreign Affairs in La Courneuve holds a large folder containing documents about the Ethiopian community in Jerusalem (1898-1907, 325 folios). These documents are part of a file entitled "correspondances politiques et commerciales, nouvelle série-cPc" and are contained in the subfile dedicated to the Vatican ("Saint-Siège/89").

The Italian consulate in Jerusalem also claimed to protect Ethiopians during the same period until the official recognition of this protection in 1902. At the Italian Ministry of Foreign Office archives (Archivio storico degli affari esteri, ASD), the subfile dedicated to Ministry of Italian Africa (Ministero dell'Africa Italiana) preserves five boxes totally dedicated to the Ethiopian community in Jerusalem, containing more than 200 folios each: boxes $42^{-1}$ (1885-90), 42-2 (1897-1902), 42-3 (1902-3), 42-4 (1904-5) and 42-5 (1906-12).

The OJP is currently carrying out a colossal collection of documents in the Ottoman State Archives (Başbakanlı Osmanlı Arşivi, BOA) in Istanbul. Among the files dealing with the Ottoman administration of Jerusalem (petitions, justice, public works) dated from 1840 to 1917 , one also finds many documents from the Orthodox Ethiopian community. More than 185 files (more than 600 documents) have been discovered and are currently under analysis. These documents include letters, reports and decrees produced by Ottoman officials as well as letters written by Ethiopian authorities.

Other documents located at other archives will be also collected. Letters from the Ethiopian community to Antonin Kapustin at the archives of the Russian Academy of Sciences in St. Petersburg (fond 214) will be collected and 
analyzed. Finally, Georges Hintlian of the Gulbenkian Library has sent me the translation of the $1875^{-76}$ diary of the dragoman of the Armenian Patriarchate, which is preserved in the Archives of the Armenian patriarchate of Jerusalem.

\section{Is Ethiopian Isolation in Jerusalem Overestimated?}

Previous studies on the Ethiopian community in Jerusalem refer to two types of institutions that played a role in the development of the Ethiopian Orthodox community: the Ethiopian monarchy and the Western consular authorities. Other institutions or authorities in Jerusalem, such as Coptic, Armenian or Ottoman entities, though appearing rarely, are invariably represented in a very negative way.Jerusalem is depicted as a dangerous land in which Ethiopians are surrounded by various enemy groups and only their motherland, or European countries, could assist them. The Ethiopian community is presented as lonely and lacking local connections.

Enrico Cerulli, Otto Meinardus and Kirsten Pedersen have used British sources to explore the condition of Ethiopians in Jerusalem during the nineteenth century. ${ }^{14}$ According to these sources, Ethiopians were completely isolated. James Finn, the British consul in the city, wrote on August 17, 1852, that

I shall very willingly attend to those instructions in favour of the poor and oppressed [Ethiopian] people, but I fear it will often require delicate management in using those friendly offices, since they have powerful enemies in the rich Armenian community and the vindictive Copts, and are themselves of very hot temperament. ${ }^{15}$

Such statements must have discouraged scholars from examining the relationship of the Ethiopians with local institutions. Western consular authorities are an exception to this, however. For example, to study the end of the nineteenth and the beginning of the twentieth centuries, Pedersen focused on Russian and Italian endeavors to protect Ethiopians and to help Ethiopian monarchs to

14 Cerulli, Etiopi, vol. 2, 274-327; Meinardus, “The Ethiopians," 131-37; Pedersen, History of the Ethiopian Community, 17-29.

15 British consul to the Earl of Malmesbury (August 17, 1852), Jerusalem. Quoted by Cerulli, Etiopi, vol. 2, 290; Meinardus, "The Ethiopians," 133; Pedersen, History of the Ethiopian Community, 21. 
improve their position in the town. ${ }^{16}$ Following her work, other studies of the Ethiopian community in Jerusalem focused on the characteristics of French and Italian protection ${ }^{17}$ and contributed, probably unconsciously, to the presentation of Ethiopians as alienated from local social networks.

Another factor that played a role in overestimating the isolation of Ethiopians is related to the texts produced by the official Ethiopian historiography, chiefly made up of two texts: the "History of Dayr al-Sultan," composed of several different documents among which are copies of the emperor's letters ${ }^{18}$ and a history of Empress Taytu Betul (ca. 1853-1918) composed after $1930 .{ }^{19}$ Both texts depict the Ethiopian community during the nineteenth century as an isolated entity, surrounded by enemies and finally saved by the devotion and ability of Emperor Menilek II (r. 1889-1913), his wife, Taytu Betul, and his granddaughter Empress Zäwditu (r. 1916-30).

Nonetheless, it would be useful to carefully analyze the context and the aim behind the production of these sources before drawing any conclusions. Ethiopian monarchs used official texts as panegyrics and therefore such texts should be evaluated carefully. These texts aimed at explaining why the Ethiopian community encountered great difficulties during the nineteenth century and tried to justify the late involvement of monarchs and the aristocracy in an attempt to conserve the reputation of the Ethiopian monarchy and aristocratic ideology.

Concerning the British sources, one should interrogate the political and religious objectives of James Finn. ${ }^{20}$ In favor of British involvement in Ethiopian affairs in Jerusalem, Finn supported British actions that exaggerated the isolation of the Ethiopians. It is crucial to meticulously examine the European perception and discourse on Ethiopia and Jerusalem's Ethiopians with regards to European discourse on Jerusalem and Africa more generally at that time. The partial analysis of a few European sources, and their connection to some Ethiopian ones, persuaded scholars that between $185^{\circ}$ and 1920 , Ethiopians were isolated and placed themselves under the protection of the European consulates that, in turn, helped Ethiopian monarchs.

16 Pedersen, History of the Ethiopian Community, 49-52, 62-77.

17 Scholler, "The Ethiopian Community," 487-500; Rouaud, "La protection française," 63-74.

18 Ethiopian Archbishop Residence in Jerusalem (EARJ), Manuscript section, MS JE692E. About this text, see Pedersen, "Historiography of the Ethiopian Monastery," 421.

19 About this text, see Getatchew Haile, "Empress Tayitu," 67-81.

20 Concerning James Finn and British policy in Jerusalem, see Mordechai Eliav, Britain and the Holy Land, 1838-1914: Selected Documents from British Consulate in Jerusalem (Jerusalem: Yad Izhak Ben-Zvi, 1997); Falestin Naili, "La mémoire et l'oubli à Artas: un élément de l'histoire rurale de la Palestine, $1848-1948$ " (PhD diss., University of ProvenceAix-Marseille I, 2007), 65-79. 


\section{Behind the "Veil" of the European Sources}

In a letter dated to 1898, the French consul Auzépy justified the French involvement in an 1893 conflict between Copts and Ethiopians:

It was difficult for me not to take into consideration these complaints [of Ethiopians] and, like my [Russian] colleague M. Yacolew, I did not miss the chance, in the name of humanity and of public hygiene, to intercede informally on behalf of Tewfick Bey [Turkish governor].21

The arguments of Auzépy are similar to these of Finn from 1852; compassion seems to have guided European intervention in favor of Ethiopians, who were "poor and oppressed people," according to Finn. ${ }^{22}$ Commentators and historians contributed to the spreading of this idea, ${ }^{23}$ sometimes forgetting that European governments saw many advantages in supporting Ethiopians in Jerusalem. European countries' influence in the Horn of Africa and the consequent competition among them became an issue from the mid-nineteenth century onwards. By protecting Ethiopians in Jerusalem, Europeans must have expected a gesture of goodwill from the Ethiopian government that would improve their position and reputation there. ${ }^{24}$ In Jerusalem, the protection of the Ethiopian community could be seen as a strategy for preventing other countries or communities from enlarging their sphere of influence too. ${ }^{25}$

European sources have created a "veil" that not only prevents a thorough examination of the relationships between Ethiopians and local institutions, but also hides Ethiopian involvement in the Jerusalemite social networks. Even if the documents describe facts and sometimes events related to the Ethiopian community, we need to keep in mind that they are produced by Europeans and thus they represent their point of view. Such documents describe, explain and justify British, French and Italian consular policies to the metropolitan authorities. They emphasize the role of the European consular administrations while they downplay the role of other institutions, which

21 Nantes Diplomatic Archives Centre (CADN), French consul in Jerusalem to French Ministry of Foreign Affairs (July 1, 1898), Jerusalem, 294/PO/A/135, fol. 39 .

22 See note 15.

23 Meinardus, "The Ethiopians," 131.

24 CADN, French consul in Cairo to French consul in Jerusalem (January 25, 1882), Cairo, 294/PO/A/134, fol. 53-56.

25 CADN, French consul in Jerusalem to French Ministry of Foreign Affairs (December 15, 1880), Jerusalem, 294PO/A/134, fols. 21-25. 
are depicted as unfair, authoritarian and useless. The isolation and poverty of Ethiopians in Jerusalem was a topos serving as a pretext for their intervention. The discourse of some Europeans concerning Jerusalem ${ }^{26}$ is reminiscent of other discourse on African countries at the same time. Africa was portrayed as a continent of empty lands, devoid of effective governments, whose inhabitants were poor and isolated from the rich, prosperous and civilized Europe. ${ }^{27}$ One may wonder whether Ethiopians in Jerusalem did not hold the concurrent disadvantages, in European eyes, of both being Africans and living in Jerusalem.

The fact that these documents probably overemphasize the role of the European consular authorities in Ethiopian affairs does not mean that they do not contain information about the daily lives of Jerusalem Ethiopians. Careful analysis and cross-checking with other sources shows that Ethiopians in Jerusalem organized their life mostly away from European influence. The same documents illustrate that Ethiopians always solicited European help after they had negotiated first with local authorities and local communities, not before. For example, in 1850, Ethiopians met the British consul, Finn, in order to seek his help with Dayr al-Sultan, a problem that had arisen several years before. The Islamic court of Jerusalem had already issued three decisions on the matter, in 1845,1846 and $1848 .{ }^{28}$ When problems in Dayr al-Sultan between Ethiopians and Copts reappeared in 1862-63, 1880-83, 1890-93 and in 1898, Ethiopians systematically solicited European support (Russian, French or Italian) but only after the breaking off of negotiations with the local authorities. For example, on October 21, 1890, Ethiopians asked for help from the French consul because the negotiations with local authorities had stalled. ${ }^{29}$ Each consul considered that his own action was the only solution for the Ethiopians. The Ethiopians, though, had several other options, and sometimes solicited help from the British, Russian, French and Italian consulates for the very same problem. On

26 Vincent Lemire, Jérusalem 19oo: La ville sainte à l'âge des possibles (Paris: Armand Colin, 2013), 105-8.

27 William B. Cohen, Français et Africains. Les Noirs dans le regard des Blancs, 1530-1880 (Paris: Gallimard, 1981).

28 Documents of the Islamic court decisions were copied by Italians in 1905 and preserved. See Historical Archive of the Italian Foreign Ministry (ASD), Ministero dell'Africa Italiana, posizione $42-4$.

29 CADN, French consul in Jerusalem to French Ministry of Foreign Affairs, October 21, 1890, Jerusalem, $294 \mathrm{PO} / \mathrm{A} / 135$, fol. 31 . 
April 15, 1891, the Italian consul said that he had contributed to the liberation of an Ethiopian who had been arrested during the 1890 confrontation. ${ }^{30}$

These European documents also remind us that Ethiopians were strongly linked to the Armenian and Greek Orthodox patriarchates in Jerusalem whose members were mostly local Ottoman subjects. The Armenian authorities were considered to be the protectors of Ethiopians and Copts, while at the same time some Ethiopians were accommodated in Jerusalem by the Greek Orthodox patriarchate. It seems that Ethiopians were involved in a local network even before Ethiopian contact with European entities. The problem was that from the 1850 s onwards, such a local network did not satisfy the Ethiopian expectations concerning Dayr al-Sultan. European support was seen as a complement to the intercession of Armenian and Greek efforts in the attempts to make headway on the Dayr al-Sultan conflict. But the appeal to European support did not mean that Europeans replaced local authorities as the main interlocutors of Ethiopians in Jerusalem. The Ethiopian government could still enter into contact with Istanbul in order to defend its community. For example, in 1882, Ethiopian Emperor Yohannes IV (1872-89) officially complained about the behavior of the Coptic Bishop Baselios in Jerusalem (fig. 3.1). ${ }^{31}$

An important constraint prevented the replacement of a "local" Ethiopian network by a "European" one. Until 1902, the Ottoman state regularly refused foreign protection to Ethiopians. In the eyes of the Ottoman state, Ethiopians were local people and not foreigners and thus the state protested against all attempts to present Ethiopians as citizens of a foreign country. In 1862, the Ottomans rejected the idea of British protection of Ethiopians. ${ }^{32}$ In 1881, they complained against French policy and expressed themselves in favor of Ethiopians while in 1882, they rejected Russian and Greek protection. ${ }^{33}$ In 1893 , the Ottoman authorities in Istanbul expressed concern about the increasing number of Ethiopians in Jerusalem bearing Italian passports (fig. 3.2). ${ }^{34}$ When in 1902, the Sublime Porte finally accepted the Italian protection of Ethiopians,

30 ASD, Ministero dell'Africa Italiana, Italian consul in Jerusalem to Italian Ministry of Foreign Affairs, April 15, 1891, Jerusalem, posizione 42-1.

32 Consul Finn to Sir H. Bulwer (March 11, 1862), Jerusalem. Quoted by Cerulli, Etiopi, vol. 2, 312-13.

CADN, French consul in Istanbul to French consul in Jerusalem (December 9, 1881), Istanbul, 294/PO/A/135, fol. 25; CADN, French consul in Jerusalem to French Ministry of Foreign Affairs (September 6, 1882), Jerusalem, 294/PO/A/134, fols. 48-49. BOA, Hariciye Nezareti fon (Ministry of Foreign Affairs fond), HR.HMS.ISO.179.19. 


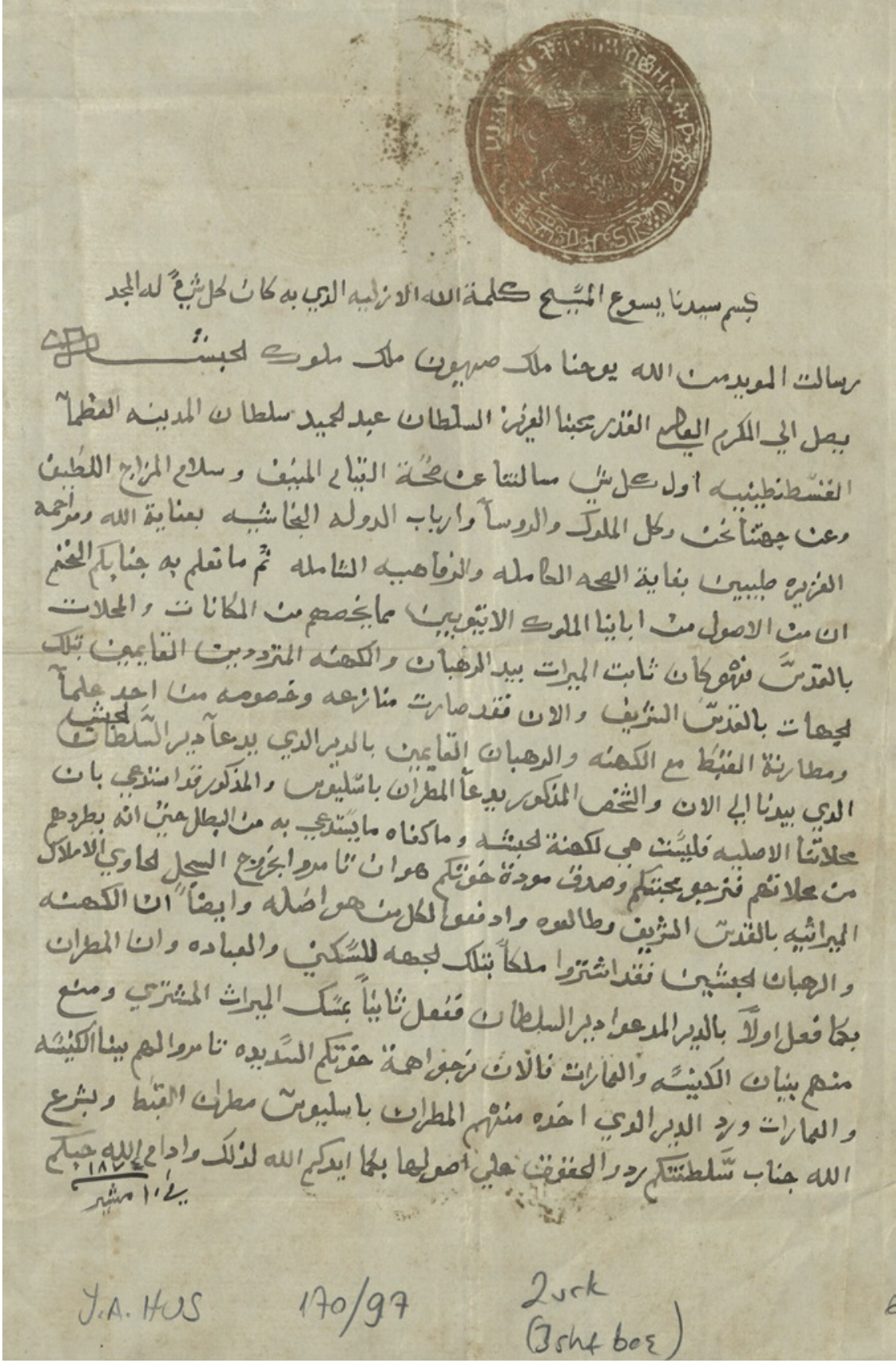

FIGURE 3.1 Letter of Emperor Yohannes IV to the sultan, dated Yäkkatit 24, 1874 (Ethiopian Calendar)/March 2, 1882.

BOA, YILDIZ FON, Y.A.HUS.170-97. 


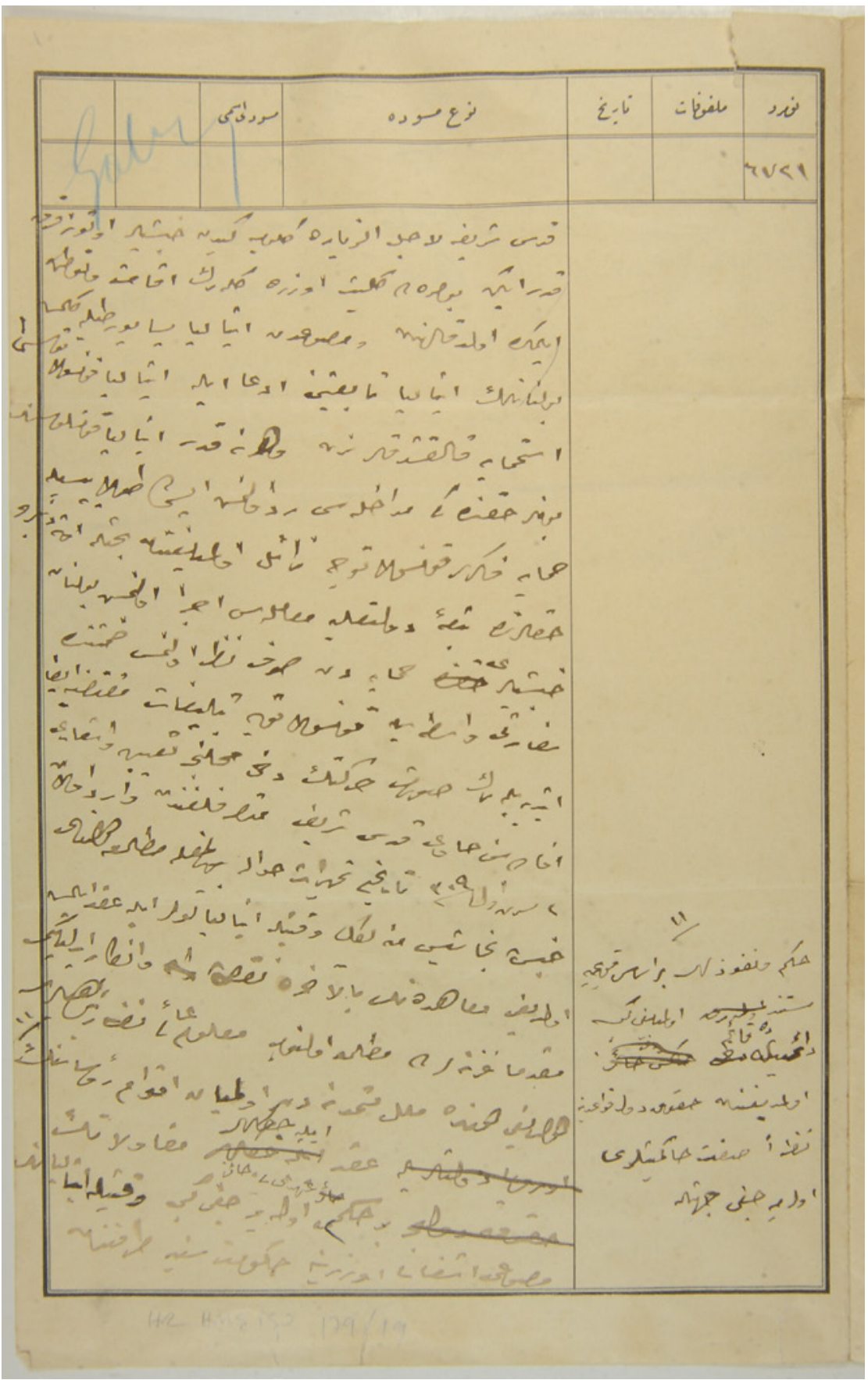

FIGURE 3.2 Ottoman report concerning the increasing number of Ethiopians in Jerusalem bearing Italian passports, 1893 . BOA, HARICIYE NEZARETI FON, HR.HMS.IŞO.179.19. 
it imposed important constraints and specified that Ethiopians were to stay under Ottoman jurisdiction. ${ }^{35}$

\section{Behind the "Veil" of the Ethiopian Sources}

Documents produced by Ethiopians and preserved in Ethiopian or European archives are much more scarce, but should also be analyzed carefully. These documents proposed a discourse that tends to hide the complex Ethiopian network operating in Jerusalem. A letter dated December 6, 1880 arrived at the French consulate in Jerusalem signed by the Ethiopian community assembly. The letter began:

Monsieur le Consul, we members of the Abyssinian community in the Holy Lands, have the honor to say to you that we are poor pilgrims who remain at home in the Convent of the Sultan, in the accommodation of indigent Abyssians. ${ }^{36}$

Thanks to such Ethiopian letters received by Europeans, it is possible to detect an extremely stereotyped Ethiopian discourse regarding their own situation in Jerusalem. These texts emphasize the poverty and isolation of the community, denounce oppression and systematically depict the European consul as the community's last resort. Without denying the difficulties the Ethiopian community faced at the time, the historian should nevertheless question the elements of this discourse.

Documents concerning an Ethiopian monk called Abd Mariam (Gäbrä Maryam for Ethiopians) illustrate the problem posed by Ethiopian sources. Abd Mariam was an Ethiopian monk living in Dayr al-Sultan during the second half of the nineteenth century. His name was associated with different cases involving the Ethiopian community and reported in documents preserved in French, Russian and Armenian archives. In 1875, Abd Mariam signed two letters addressed to Antonin Kapustin, archimandrite in the Russian Ecclesiastical Mission in Jerusalem. In these two letters, the Ethiopian monk requested Russian protection and intervention for the Ethiopian community.

35 CADN, Translation of the Irade dated AH 1320, concerning Italian protection over the Ethiopians, 294/PO/134, fols. 271.

36 CADN, Ethiopian letter translated into French (December 6, 1880), Jerusalem, $294 \mathrm{PO} / \mathrm{A} / 134$, fol. 19 . 


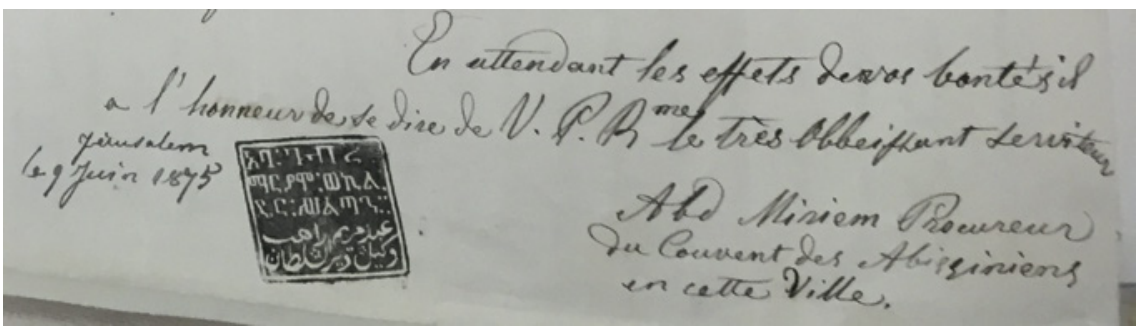

FIGURE 3.3 Letter from Abd Mariam to Antonin Kapustin, archimandrite in the Russian Ecclesiastical Mission in Jerusalem, December 6, 1875, Jerusalem.

ST. PETERSBURG DEPARTMENT OF THE ARCHIVE OF THE ACADEMY OF SCIENCES (SPBFARAN), FOND 214.

The first one, dated June $9,1875,{ }^{37}$ contains an explanation by Abd Mariam that Ethiopian monks, led by the Coptic Bishop Baselios, had complained about him because, in their eyes, he did not give them a part of the money sent by Ethiopian Emperor Yohannes IV. A trial was therefore organized, and Abd Mariam asked for Russian support. At the end of the letter, he signed himself as "Abd Miriam, procurator of Ethiopian convent in this town" and added his seal (fig. 3.3).

During the second half of the nineteenth century, the Ethiopian community regularly received money from Ethiopia. ${ }^{38}$ In 1867 , the Armenian patriarchate informed the French consul in Jerusalem that Abd Mariam had to go to Saïda (Sidon) in order to receive money from Ethiopia. This money was entrusted to the French administration and was supposed to help the community in Jerusalem. ${ }^{39}$ Of course, we cannot say for certain that the money received in 1867 created a problem in 1875 . But it is interesting to observe that in 1867 Abd Mariam was in charge of receiving money from Ethiopia.

In June 1875, Abd Mariam describes the situation in an ambiguous way. Did the Coptic bishop complain about him directly, or in a more general fashion, about members of the community? The reader does not know. Abd Mariam signed the letter with his seal as procurator of the community, thus presenting

37 St. Petersburg Department of the Archive of the Academy of Sciences (spbFaran), Abd Mariam to the archimandrite of Russian Mission (December 6, 1875), Jerusalem, fond 214.

38 Bairu Tafla, A Chronicle of Emperor Yohannes IV (1872-1889) (Wiesbaden: Harrassowitz, 1977), 162-89; See also Pedersen, History of the Ethiopian Community, 45.

39 CADN, French consul in Jerusalem to French vice-consul in Saïda (March 9, 1867), Jerusalem, 294PO/A/134, fol. 9 . 
himself as the representative of Ethiopians. Did this case represent a new step in the conflict between Ethiopians and Copts?

A few months after the first letter to Kapustin, the situation became more complicated. Abd Mariam sent a second letter to Kapustin dated November 12, $1875{ }^{40}$ In that letter, he complained about the Armenian authorities' lack of resource provision. Because of previous problems between Ethiopians and Armenians not specified in the letter, the latter decided to give food only to a few Ethiopian monks in Dayr al-Sultan. Abd Mariam presented himself as the representative of Ethiopian members who were deprived of provisions, asking the Russian Mission for help. Like the first one, this second letter is also very ambiguous. Abd Mariam depicted himself again as the representative of the whole Ethiopian community, but he wrote that some Ethiopians did continue to receive food from the Armenians. Had a new conflict between the Armenians and Ethiopians arisen or not?

An Armenian source confirms the delicate situation inside the Ethiopian community. The Armenian patriarchate dragoman's diary from $1875^{-76}$ provides valuable information. The author describes a major problem with regards to the food supply to Ethiopians. One day, an Ethiopian called Mika'el requested the food that the Armenians traditionally provided to the Ethiopians. The Armenian patriarch agreed to this and the day after, the provisions were ready to be collected by the Ethiopians. However, nobody came. As a result, the Armenians decided to send the supplies to the Ethiopians. Ethiopian monks led by Abd Mariam forbade the food from entering Dayr al-Sultan. Someone from the Armenian patriarchate called the local authorities. Police arrived and finally the food found its way to the monastery. Some days later, an Ethiopian representative went to the dragoman's office and explained that the community was ready to petition against Abd Mariam.

The Armenian source refers most probably to the problem that was reported by Abd Mariam in his letters to Kapustin. It shows that the Ethiopian community was divided and Abd Mariam represented only a part of it, for he was accused by the other part. This case highlights the need for careful analysis and cross-checking of sources: because an Ethiopian presented himself as a representative of the Ethiopian community does not mean that the entire community was involved in his demand. Likewise, just because these documents highlighted the community's poverty and isolation does not mean this was always the case. Documents produced by Ethiopians proposed an oriented 
view which often hid the great complexity of the facts. The same is true of European documents.

Cases involving the name of Abd Mariam do not end here. In 1880, the French consul received a letter signed by the "assembly of Ethiopian community" complaining about the Armenian authorities. ${ }^{41}$ I quote the letter's introduction at the beginning of this section. The letter states that Abd Mariam had left Jerusalem after going insane. Thus, his cell in the monastery became free. The letter is not clear about what happened after that but it says clearly that the Ethiopians and Armenians argued over this cell and wanted to organize a trial in order to determine what to do with it. The Ethiopians asked for the protection of the French government in the matter. This letter recalls the letters Abd Mariam addressed to the Russian Mission some years earlier in which he depicted himself as the representative of all members of the community and asked for protection against a vague Armenian/ Copt oppression. The French consul did not question the Ethiopian motives. It is reasonable to assume that the words "protection of France" sounded very good to him and covered all other considerations. Immediately, he reported the official demand to his administration. ${ }^{42}$

The above example demonstrates that the conflict involving Armenians/ Copts and Ethiopians over Dayr al-Sultan did not always pit Armenians (or Copts) on one side and Ethiopians on the other. The appeal for European help could be solicited by a part of the community while the other part was looking for support elsewhere. In such documents, the confrontation between Armenians or Copts and Ethiopians, as well as the community's poverty or its isolation, could be topoi that belie the complexity of relationships between Ethiopians and local institutions.

\section{Receipts, Bank Checks and Bills: Signs of Ethiopian Daily Life}

Ethiopian archbishopric archives in Jerusalem preserve documents bearing witness to the involvement of the Ethiopian community in the daily life of Jerusalem. These documents are dated from 1896 to the middle of the twentieth century. They do not concern official relationships with European consulates but rather involve local merchants, local workers, lodgers and civil servants.

41 CADN, Ethiopian letter translated into French (December 6, 1880), Jerusalem, 294PO/ A/134, fol. 19 .

42 CADN, French consul in Jerusalem to French Ministry of Foreign Affairs (December 15, 1880), Jerusalem, 294PO/A/134, fols. 21-25. 


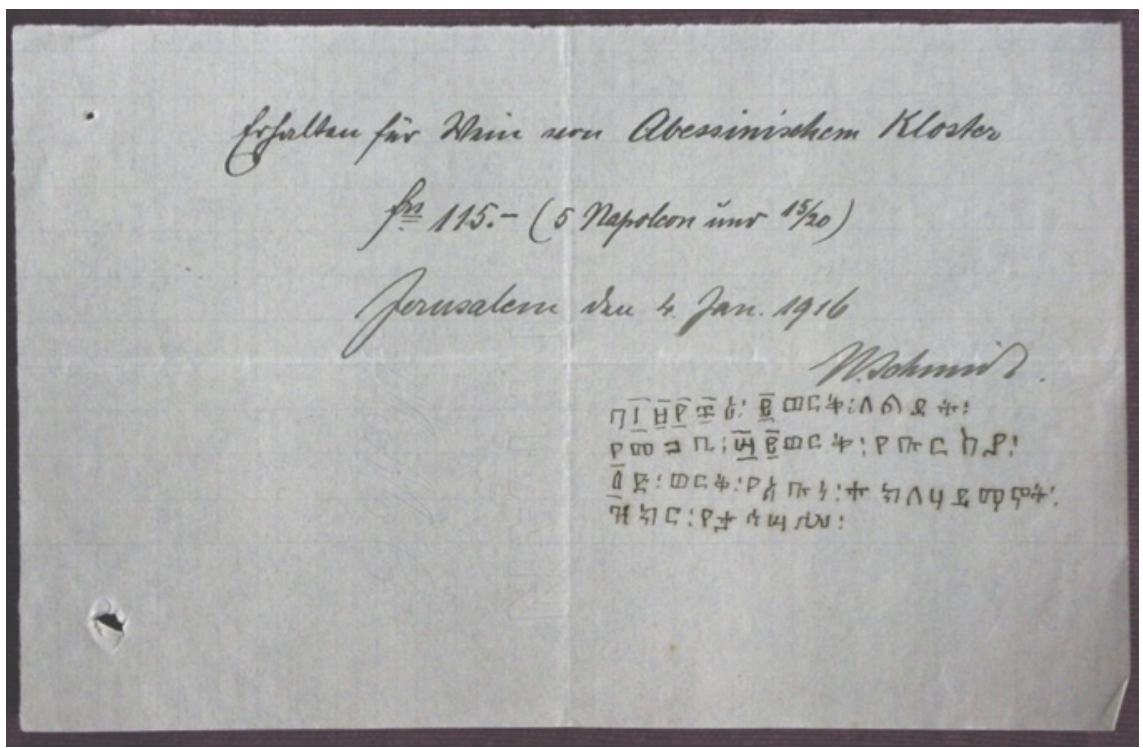

FIGURE 3.4 Receipt for the payment of wine, signed by Nicolai Schmidt, January 4, 1916. EARJ, ARCHIVES SECTION, FOLDER "YÄLEYU LEYU".

They are administrative and financial documents such as payment receipts, tickets, bank checks, bank documents and short letters. ${ }^{43}$ Such documents bear witness to the role of Ethiopians as consumers of goods, users of public services, property owners and employers of Jerusalemite people for works or of middlemen for services. They give also clues to the great flexibility needed for establishing and managing places of worship in Jerusalem. Ethiopians had different interlocutors according to their needs and opportunities. Each interlocutor implied the use of a different language: Arabic, English, French, German, Greek, and/or Armenian. Amharic marginalia were often added to documents in order to provide context or extra information.

Payment receipts were provided by merchants in exchange for goods bought by the community. Among them, receipts for the purchase of wine are particularly interesting. In 1915-16, fifteen receipts are preserved and all of them come from a same shop run by Nicolai Schmidt. All are written in German and signed by him. For example, on January 4, 1916 (fig. 3.4), the community paid for wine that had been used for the celebration (zeker) of the birth of Saint Täklä Haymanot, which takes place annually on Tahasas 24 according to the Ethiopian calendar. The date of the receipt in question corresponds 
to January 3, 1916. The Ethiopian convent also paid for local services such as grinding wheat, as shown by a receipt dated February 24, 1905 (Yäkkatit 17, 1897 according to the Ethiopian calendar) and written in English. The community also rented devices from other communities in Jerusalem. A receipt dated October 17, 1914 (October 4, 1914 according to the Russian calendar) tells us in French that the community rented a water pump from the Russian Orthodox community. Here again, the language of the receipts depended probably on the origin of the worker. For example, an Arabic speaker received money in 1913 for work on the Ethiopian monastery Däbrä Gännät. On April 14, 1915, an English-speaking worker received money for work on Empress Taytu's house (fig. 3.5).

Among these documents, one finds a receipt in Arabic and dated to Muharram 1314 (June 1896). It records payment by Ethiopians living in the old city of a tax for the use of an oven and of a garden (fig. 3.6). ${ }^{44}$ On the document verso, there is a note written in Amharic: "receipt for 6o qirsh (here girsh) for Hanna Karno house" (fig. 3.7). The "History of Dayr al-Sultan" informs us that "five minutes' walk from Dayr al-Sultan monastery," the abbot could stay in a house called "Hanna Karno." For this house, the text says that 60 qirsh was paid per year and one coin of gold for cleaning and lighting. ${ }^{45}$ The name "Hanna Karno" thus referred to the only place where Ethiopians could settle in the old city, the current residence of the Ethiopian archbishop in the old city (Ethiopian Monastery Street). Even if there is little information about the acquisition of this house, it still remains unclear how Ethiopians managed to acquire it. ${ }^{46}$ Italian archives provide some hints, however. Documents refer to a house called "Hanna Carlo," occupied by the Ethiopian abbot Fäqädä Egzi'e in $1903 .{ }^{47}$ This was most probably the same house, "Carlo" being "Karno" in Ethiopian documents. In fact, the Ethiopians received it as a waqf or endowment in 1890 from Johannes Frutiger, a banker in Jerusalem at that time. ${ }^{48}$

Frutiger appeared under other circumstances in sources regarding the Ethiopian community, which raises questions about the role of middlemen in Ethiopian networking in Jerusalem. Ethiopian Empress Taytu entrusted

\footnotetext{
44 Ibid.

45 EARJ, Manuscript section, MS JE692E, 289.

46 Pedersen, History of the Ethiopian Community, 47-48.

47 ASD, Ministero dell'Africa Italiana, Italian consul in Jerusalem to Italian Ministry of Foreign Affairs (May 4, 1903), Jerusalem, posizione 42-3.

48 ASD, Ministero dell'Africa Italiana, Italian consul in Jerusalem to Italian Ministry of Foreign Affairs (July 3, 1903), Jerusalem, posizione 42-3.
} 




FIGURE 3.5 Receipt for payment for work done on Empress Taytu's house, April 14, 1915. EARJ, ARCHIVES SECTION, FOLDER "YÄLEYU LEYU".

an Ethiopian prince, ras Makonnen, with money to buy a house for her in Jerusalem. But Makonnen could not buy himself a house without being a Jerusalem resident. Thus, the Italian consulate was contacted and finally it was given the responsibility of purchasing the house with the money given by Makonnen. A house was found and the owners, Mathilde and Giulia Ungar, signed a deed of sale with Italian consul Solanelli, who acted on behalf of 


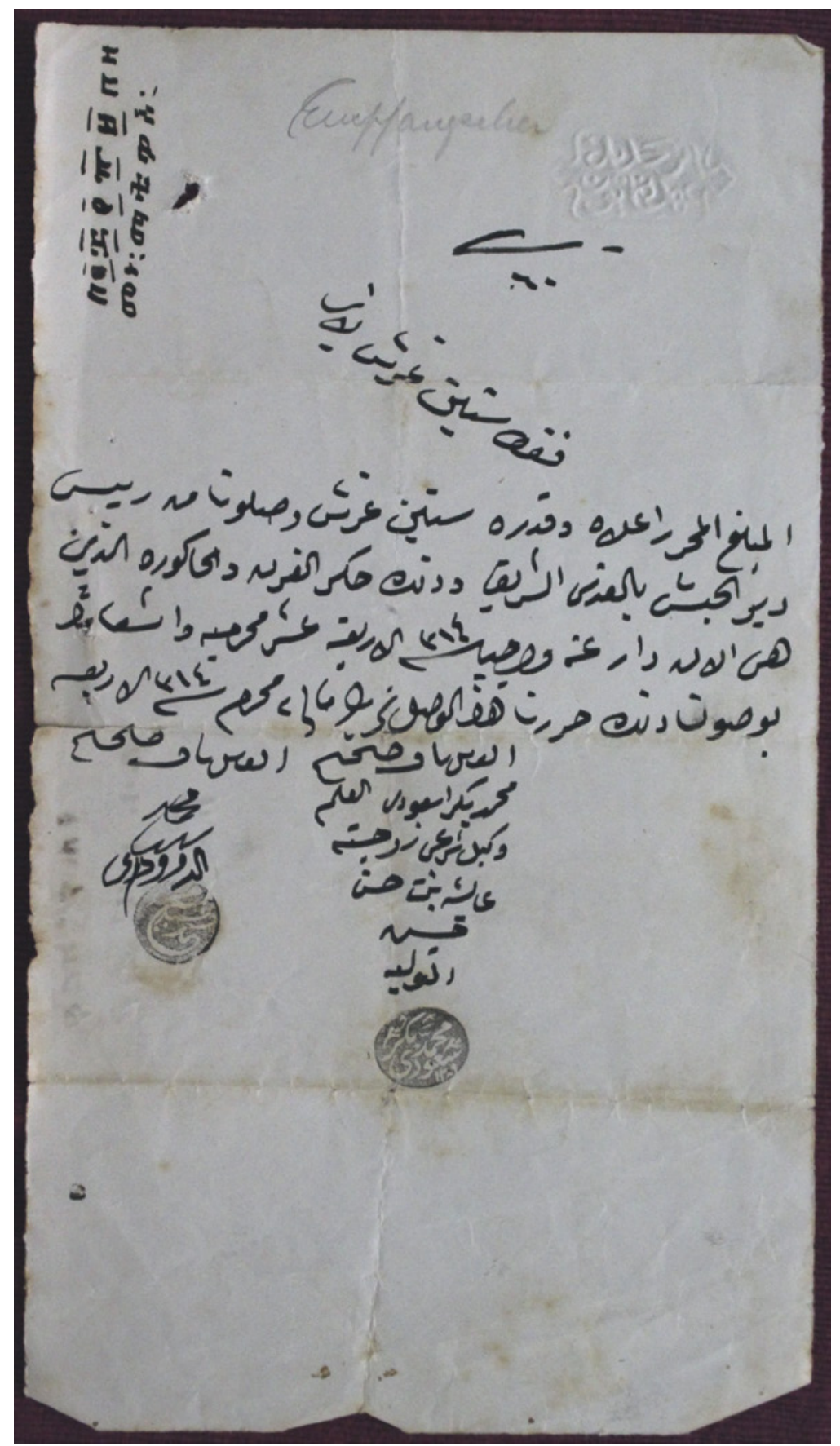

FIGURE 3.6 Receipt for the payment of tax (recto), Muharram 1314 (June 1896). EARJ, ARCHIVES SECTION, FOLDER "YÄLEYU LEYU". 


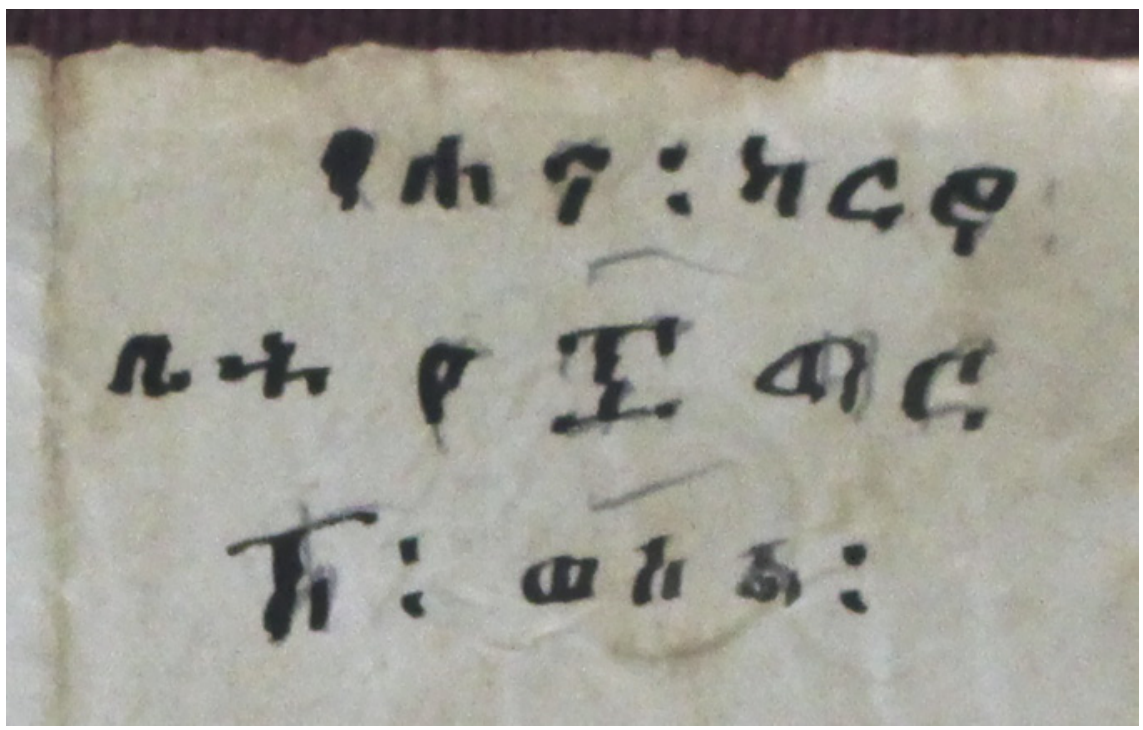

FIGURE 3.7 Receipt for the payment of tax (verso), Muharram 1314 (June 1896). EARJ, ARCHIVES SECTION, FOLDER "YÄLEYU LEYU".

Makonnen on January $7,189 .^{49}$ During the procedure, Frutiger acted on behalf of the former owners of the house, serving as a guarantor and intermediary with the Italian consulate. ${ }^{50}$

The Ethiopian archives hold two small documents highlighting the role of another middleman. ${ }^{51}$ A short document written in August 1913 in French testifies the role of Pascal Seraphin in collecting information about houses for sale or rent in Palestine on behalf of the Ethiopian community (fig. 3.8). A similar document is preserved in the Italian archives. In a short letter to the Italian consul dated to 1903, Seraphin gave precise information concerning a house next to Empress Taytu's residence. ${ }^{52}$ An architect in Jerusalem, Seraphin was

49 ASD, Ministero dell'Africa Italiana, document in Italian and attached to Italian consul's letter to Italian Ministry of Foreign Affairs (January 7, 1890), Jerusalem, posizione 42-1.

50 ASD, Ministero dell'Africa Italiana, Copy of declaration of Johannes Frutiger as guarantor (May 5, 1890), in French, attached to Italian consul's letter to Italian Ministry of Foreign Affairs (May 6, 189o), Jerusalem, posizione 42-1; ASD, Ministero dell'Africa Italiana, Receipt signed by Johannes Frutiger (May, 1890), Jerusalem, posizione 42-1.

$5^{1} \quad$ EARJ, Archives section, folder "Yäleyu leyu."

$5^{2}$ ASD, Ministero dell'Africa Italiana, Pascal Seraphin to Italian consul in Jerusalem (December 15, 1903), Jerusalem, posizione 42-3. 


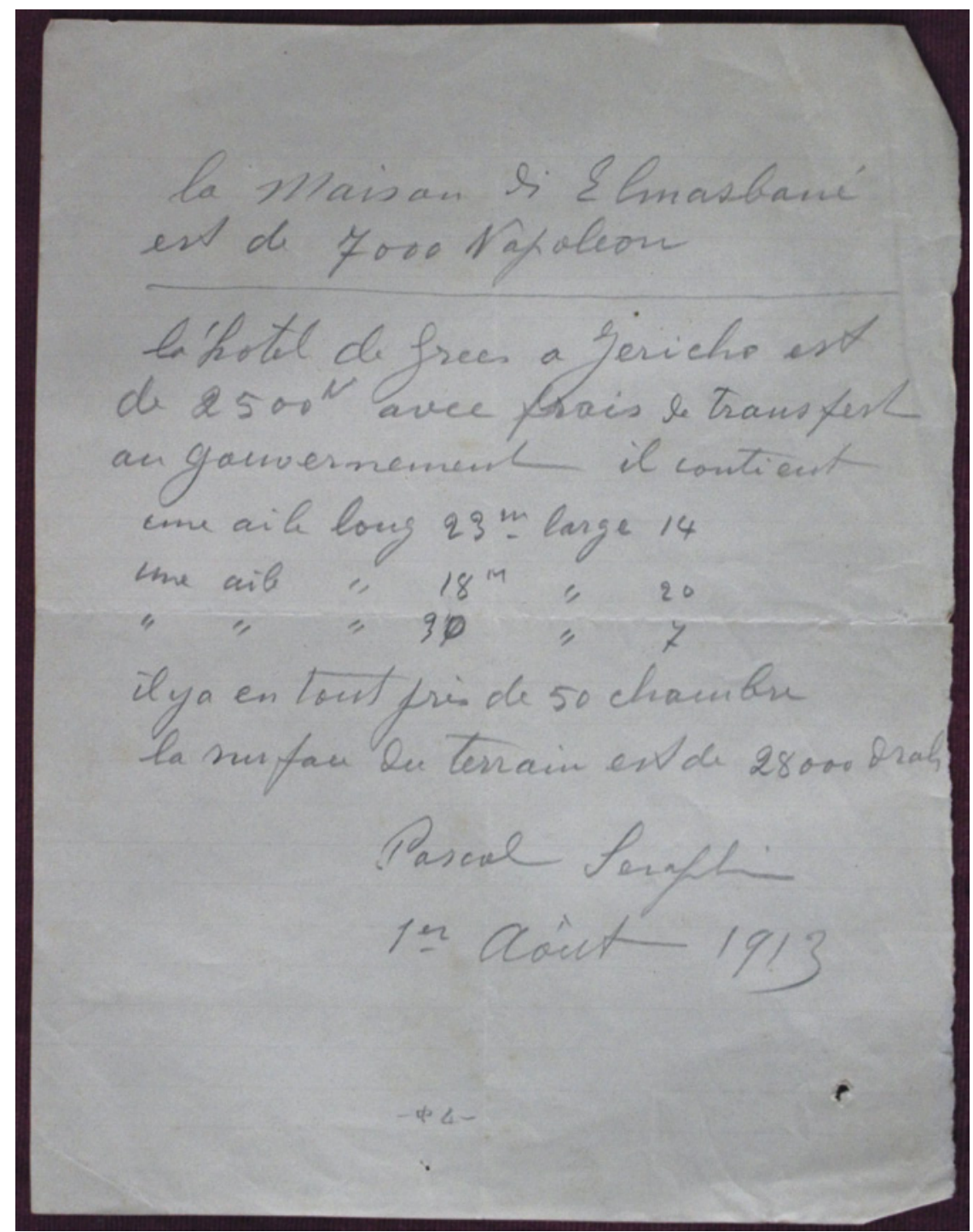

FI IGURE 3.8 Short note signed by Pascal Seraphin, August 1 , 1913. EARJ, ARCHIVES SECTION, FOLDER "YÄLEYU LEYU".

hired in 1902 by the Italian consulate in order to carry out works on Empress Taytu's house. Known as "Ungar House" after the name of its previous owners, the house needed major construction work. At first, the Ethiopians contacted the French consulate in Jerusalem in 190o. The French consul proposed that an Augustine monk living in Jerusalem, Father Etienne, perform the 


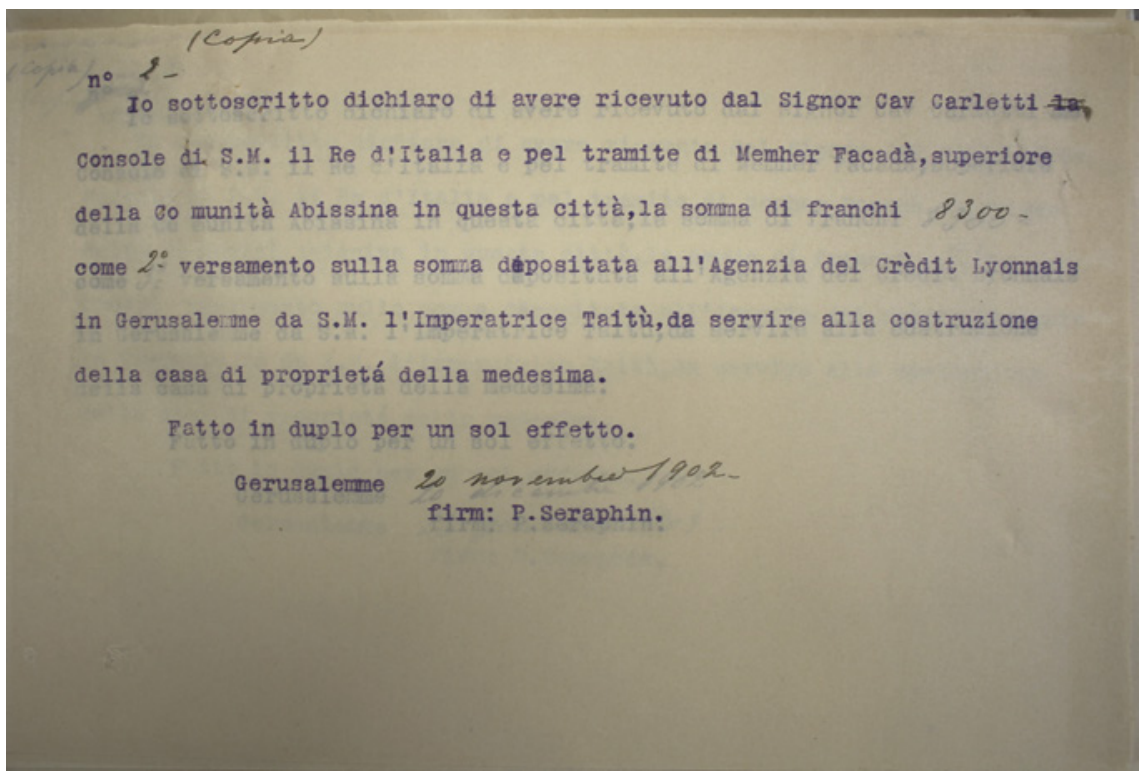

FIGURE 3.9 Receipt for payment for work done on Empress Taytu's house, signed by Pascal Seraphin, November 20, 1902.

ASD, MiNisTERO DELL'AFRICA ITALIANA, POSIZIONE 42-3.

work, ${ }^{53}$ but the Ethiopians changed their plans and entrusted the job to the Italian consulate, which ended up supervising the reconstruction in $1902 .{ }^{54}$ The Italian consulate chose Seraphin at that point. Receipts signed by him for the payment of his labor are preserved in the Italian archives (fig. 3.9) and bear witness to his activities. ${ }^{55}$ Apparently, he continued to provide services at least until 1913. After his death, his family in Jerusalem remained somewhat dependent on the Ethiopian community. His wife sent a letter, unfortunately undated, to the Ethiopian abbot (fig. 3.10), ${ }^{56}$ requesting help from the community in exchange for the "numerous services done by [her] husband." The Ethiopian abbot at the time was Mahtsantä Sellase, who was in

53 CADN, French consul in Jerusalem to French Ministry of Foreign Affairs (October 13, 1900), 294PO/A/134, fol. 211-12.

54 CADN, French consul in Jerusalem to French Ministry of Foreign Affairs (September 28, 1903), 294PO/A/134, fols. 279-80.

55 ASD, Ministero dell'Africa Italiana, Receipts signed by Pascal Seraphin (November 20, 1902), posizione $42-3$.

$5^{6}$ EARJ, Archives section, folder “Yäleyu leyu." 


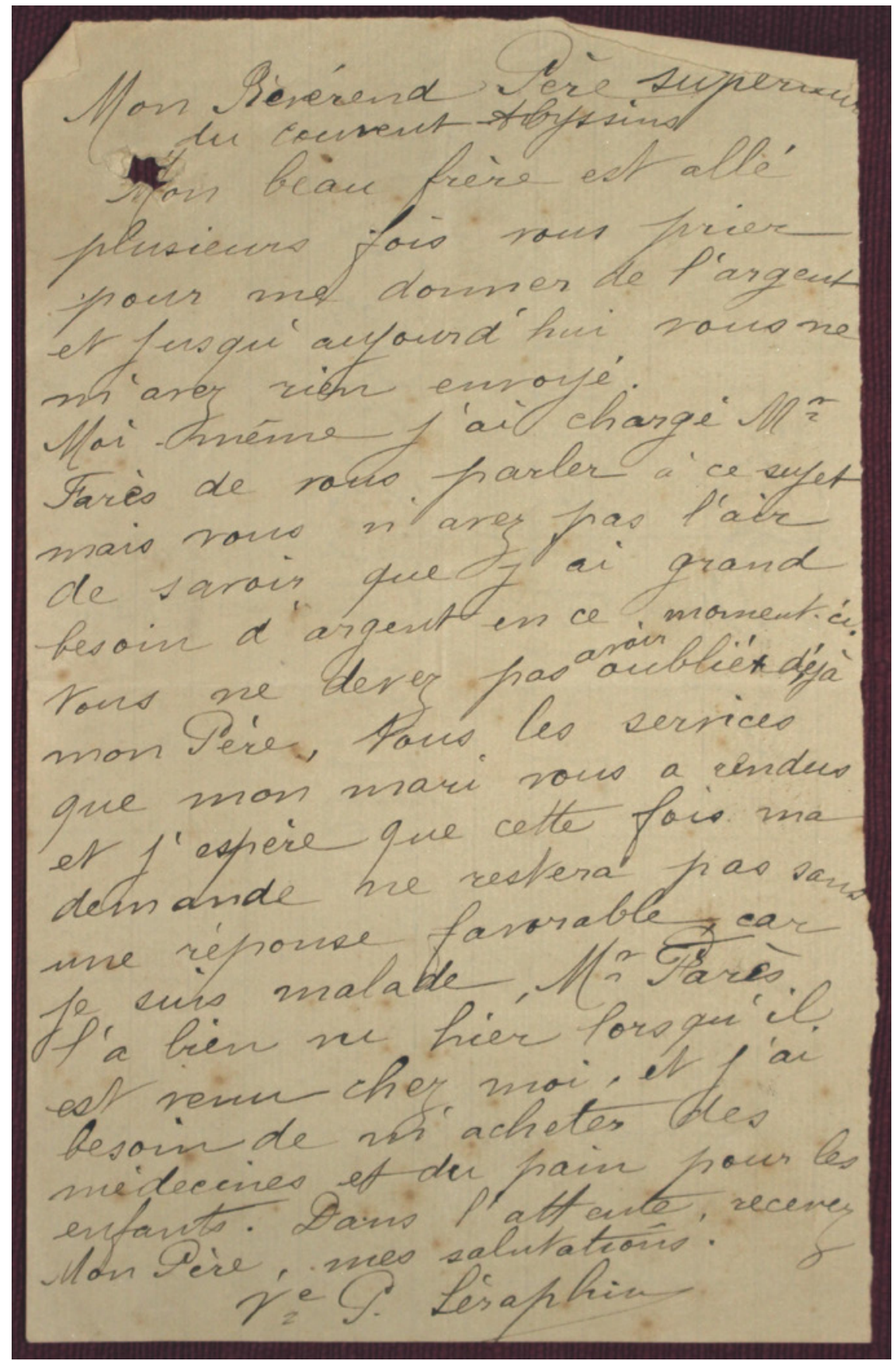

FIGURE 3.10 Short letter from Seraphin's wife, n.d. EARJ, ARCHIVES SECTION, FOLDER "YÄLEYU LEYU". 
charge of the community from 1906 to 1923 and the only abbot to have been aware of Seraphin's activities after 1913.

\section{Conclusion}

Information about the daily life of the Ethiopian Orthodox community from 1840 to 1940 is not easy to find: no substantial efforts have been made so far to characterize or understand it. However, a new approach and new archival material can reveal perspectives and can alert scholars to some methodological traps. This study is still very much in progress. The analysis of the documents discussed in this chapter is under way and new archival material from other institutions in Jerusalem will be added to them shortly. Nonetheless, we already have new insights into the daily lives of Ethiopians in Jerusalem. This chapter shows that European and Ethiopian sources themselves have so far prevented scholars from gaining a deep understanding of the Ethiopian conditions in Jerusalem during the period under scrutiny. Provided they are carefully analyzed and connections are established among them, these sources can provide valuable information concerning the social networks of members of the community. Members of the Ethiopian community did not passively wait for other communities to decide on their behalf whether to help them. On the contrary, they established contacts with all segments of Jerusalem social life and, therefore, played an active role in the daily life of the city. 


\title{
Between Ottomanization and Local Networks: Appointment Registers as Archival Sources for Waqf Studies. The Case of Jerusalem's Maghariba Neighborhood
}

\author{
Şerife Eroğlu Memiş
}

This study presents the 'atīk (old) and cedid (new) appointment registers located in Ankara in the Archive of the General Directorate of Foundations in Turkey, and discusses their importance for the social and economic history of Jerusalem after 1840. They are composed mainly of records of appointments, promotions, and dismissals of waqf employees, and were continually updated. This article focuses on the registers of the Maghariba neighborhood, a unique example of an area founded as a waqf quarter; an unprecedented event in Islamic history. Although a number of studies have explored the establishment of the quarter and its $a w q \bar{a} f$ (Ar. s. waqf; Ott. vakf, pl. evkaf), ${ }^{1}$ the changing nature of these institutions over time merits more attention.

The word waqf and its plural form $a w q \bar{a} f$ are derived from the Arabic root verb waqafa, which means to cause something to stop and stand still. In the Ottoman Empire, the word waqf was also used to describe a sophisticated philanthropic foundation; a revenue-generating property in which a part of the

1 See for example Mujir al-Din al-'Ulaymi al-Hanbali, Al-Uns al-Jalil bi-Tarikh al-Quds wa-lKhalil [The glorious history of Jerusalem and Hebron], 2 vols. (Amman, 1973); Abdul Latif Tibawi, The Islamic Pious Foundations in Jerusalem (London: Islamic Cultural Centre, 1978); Ador Arnon, "The Quarters of Jerusalem in the Ottoman Period," Middle Eastern Studies 28, no. 1 (1992); Tom Abowd, "The Moroccan Quarter: A History of the Present," Jerusalem Quarterly, no. 7 (200o); Kamil Jamil Asali, "Haratu'l-Maghariba fi al-Quds wa Ahammiyyatuha at-Tarihiyya" [Maghariba quarter in Jerusalem and its importance in history], in Al-Buhus ve al-Dirasatve al-Makalat [Matters, studies and the articles], 2 vols. (Amman:Vezaretu's-Sakafe, 2009), 19; Muhammad Hashim Musa Dawud Ghushah, Al-Awqāf al-Islamiyah fi-l-Quds alsharif: dirasa tarikhiyya muwathaqa [Islamic awqāfin Jerusalem: a historical documentation] (Istanbul: IRCICA, 2009); Hasan H. Güneş, "Kudüs'te Bir Mahalle: Sekiz Yüz Ylllık Meğāribe Mahallesi ve Serencamı" [A Waqf neighborhood in Jerusalem: The Magarebeh neighborhood of eight hundred years and its adventure], Vakıflar Dergisi 44 (2015).

(C) ŞERIFE EROĞLU MEMIŞ, 2018 | DOI:10.1163/9789004375741_007

This is an open access chapter distributed under the terms of the prevailing CC-BY-NC-ND License at the time of publication. 
revenue is disbursed for a pious purpose in order to seek God's favor. ${ }^{2}$ More than five decades of empirically-based research in the Ottoman archives have contributed to a clear understanding of the depth of influence awqāf had on the societies in which they operated. Awqā $f$ oversaw a number of public, charitable, and religious activities, and their reach extended to all socioeconomic levels of society. As uniquely autonomous institutions in terms of administration, fiscal management, and the provision of public order and security, awqā $f$ constitute an interesting topic of historical study, particularly from the standpoint of the history of settlement and citadinité.

Awq $\bar{a} f$ were one of the major institutions in Jerusalem from the Muslim conquest of the city until the end of the nineteenth century. During this time, the area of Haram al-Sharif, which included al-Aqsā mosque and the Dome of the Rock, became the nucleus of the Muslim waqf network ${ }^{3}$ in the city. Awqa $f$ carried out various charitable and religious activities in the city such as feeding the poor and students at the Hasseki Sultan Soup Kitchen. The revenue generated by awqāf also went toward the financing of a number of public services including the construction and maintenance of irrigation systems and aqueducts, and some of the municipal services run jointly by the guilds and the awqāf. Revenue from the waqf endowed by Saladin funded the maintenance and operation of the biggest hospital in the city. In addition, the awqāf built and ran schools (madrasa), and provided religious services such as the building of mosques in Jerusalem. In contrast to the Ayyubids and the Mamluks, who gave priority to religious and educational $a w q \bar{a} f$ in the city, the Ottomans invested in the city's infrastructure. ${ }^{4}$ They preferred to spend the appropriations and donations given to the city on projects such as improving security and the water supply, and on building a new open-air market. These initiatives aimed to show that the Ottomans were increasing the prosperity of Jerusalem. ${ }^{5}$

2 Ömer Hilmi Efendi, İthaf-Ül-Ahlaf Fi Ahkam-İl-Evkaf [Laws relating to foundations] (Ankara: Vakıflar Genel Müdürlüğü Yayınları, 1977), 13; For more detailed information, see David Stephan Powers, "Waqf," Encyclopedia of Islam, 2nd ed., vol. 40 (2002).

3 Şerife Eroğlu Memiş, "Osmanlı Taşra Toplumu ve Vakıf Kurumu: Kudüs, 1703-1831" [Ottoman provincial society and the waqf: Jerusalem, 1703-1831] (PhD diss., Hacettepe University, 2016), 12-16.

4 Dror Ze'evi, An Ottoman Century: The District of Jerusalem in the 16oos (Albany: Syracuse University Press, 1996), 31; Yasemin Avcı, Değişim Sürecinde Bir Osmanlı Kenti, Kudüs (18901914) [An Ottoman city in the period of transformation: Jerusalem, 1890-1914] (Ankara: Phoenix, 2004), 36.

5 André Raymond, "The Ottoman Conquest and the Development of the Great Arab Towns," International Journal of Turkish Studies 1 (1979-80). 
The present study focuses on the role of awqā in the Maghariba neighborhood of Jerusalem. While endowment deeds (waqfiyya $t)^{6}$ are the most valuable and rich resources for waqf studies, they do not provide us with adequate information on the actual nature of the social and economic activities of a waqf, or on the changes in these activities over time. The waqfiyyāt must be supported by other primary sources such as the appointment registers (esāa) şąsiyāt).

The first part of this article presents general information about the registers from the records of the awqāf of the Maghariba neighborhood. The second part touches briefly on the founding of the neighborhood and its awqāf, and on the significance of the Maghariba neighborhood for Jerusalem. Part three analyzes the appointment records for waqf endowments in detail in order to shed light on the employment policies of the Ottoman state in a provincial town, in which it maintained control through postings and entitlements to waqf stipends.

\section{The Old and New Registers of the Maghariba Neighborhood: before and after 1882}

The Archive of the General Directorate of Foundations (VGMA), located in Ankara, specializes in waqf registers and documents. It houses 610 old appointment and 136 new registers. ${ }^{7}$ The 'atīk registers were also called treasury registers and covered the appointment records of waqf staff before 1300/1882. These are mainly composed of the Istanbul, Anatolian, Rumelian, and Haramayn (Mecca and Medina) series. Although these registers have been

6 For more on the importance of waqf documents, see Fuad Köprülü, "Vakıf Müessesesinin Hukuki Mahiyeti ve Tarihi Tekamülü” [Legal status and evolution of waqf institution], Vakıflar Dergisi 2 (1942); Ömer Lütfi Barkan, "Edirne ve Civarındaki Bazı İmaret Tesislerinin Yllık Muhasebe Bilançoları" [Annual accountancy balances of some Imārah facilities in and around Edirne], Türk Tarih Belgeleri Dergisi 1, no. 2 (1964): 237-39.

7 The Archive of the General Directorate of Foundations (VGMA) houses the records related to $a w q \bar{a} f$ in the Ottoman Empire. For the history of this institution, the number of records stored there and its present situation, as well as the stages in the official founding of the VGMA, see Kani Özyer, "Vakıflar Genel Müdürlüğü Arşivi” [Archive of the General Directorate of Foundations], in Uluslar arası Türk Arşivleri Sempozyumu [Turkish Archive Symposium], 17-19 November 2005 (Istanbul: вОА Publications, 2006); Mustafa Alkan, "Türk Tarihi Araştırmaları Açısından Vakıf Kayıtlar Arşivi” [Waqf records archive from the perspective of Turkish historical studies], Vakıflar Dergisi 30 (2007). 
mentioned in some studies on the VGMA collections, no study has yet assessed the two collections together.

The registers are bound in leather, cloth, or marbled paper, and are written in the inaccessible siyakat writing style, which may explain why studies have not dealt with them. Siyakat refers to letters and numbers expressed in the "stairs" style of writing, used in Ottoman accounting documents to establish a powerful regime of surveillance, inspection, and communication. ${ }^{8}$ Each register starts with an index page. In the index, the records are organized under the headings of the district names and the records were entered on this basis. Records are usually written vertically. The contents provide detailed information about the administrative structure of the area, the names of the district, names of the awqā $f$ and their founders, types of work, previous and current names of office holders, reasons for new postings, fees, names of administrators who can request different postings, and the dates of documents recorded in a specific order and sequence.

Another important detail that appeared in the records was the reason for the appointment. Possibilities were renewal (mujaddid), vacancy (makhlül), removal or suspension (kasr al-yad, kaff al-yad), quitting, or resignation in favor of another person (färigh). The waqf staff was considered to be part of the ruling class ('asker $\iota^{-9}$ ) in the social structure of the Ottoman state, and was therefore exempted from taxes..$^{10}$ All staff salaries were paid by the waqf

8 For detailed information on the șiyakat writing style, see Mübahat S. Kütükoğlu, Osmanlı Belgelerinin Dili: diplomatik [The language of Ottoman documents: diplomatic] (Istanbul: Kubbealtı Akademisi Kültür ve San’at Vakfı, 1994), 64-67; Hilmi Erdoğan Yayla, "Accounting and the Art of Writing" (paper presented at the 19th Accounting, Business and Financial History Conference, Cardiff Business School, September 2007, and the 31st annual congress of the European Accounting Association, Erasmus University, April 2008).

9 Studies on Ottoman social structure and Ottoman society fall into two main classes. Usually, the ruling elite or ruling class, which was differentiated from ordinary taxpayers ( re $\bar{a} y \bar{a})$, was composed of people who had religious or administrative power as granted by a sultan's charter. This was a service-based nobility, which was composed of the officials who were affiliated with the palace and the military, civil servants and "scholars." Halil İnalcık, "The Nature of Traditional Society: Turkey," in Political Modernization in Japan and Turkey, ed. Robert E. Ward and Dankwart A. Rustow (Princeton: Princeton University Press 1964), 44. See also Abdul-Karim Rafeq, "Political Power and Social Networks: Popular Coexistence and State Oppression in Ottoman Syria," in Islamic Urbanism in Human History: Political Power and Social Networks, ed. Tsugitaka Sato (London: Kegan Paul International 1997), 22.

10 Some of the registers in the series are labeled Aleppo Ruling Class (Halep Askerī), Province of Yemen Ruling Class (Vilayet-i Yemen 'Askerī), with a specific reference to the status of waqf staff among the ruling class. See VGMA $529,5^{26}$. 
administrations as designated and included in the waqfyya.${ }^{11}$ Requests for appointments within the Ottoman bureaucracy were submitted by the chief judge (każasker). ${ }^{12}$

While the records in the 'atik registers are arranged according to their administrative units, the cedid structure is identical to the waqf registers. These registers began to be kept after 1300/1882, with a specific reference to the 'atik. series. These are also hardcover volumes bound in leather, cloth, or marbled paper, written in rik'a, rik'a crumble, dìvanī or $t \bar{a} \bar{l}^{\prime} \bar{k} k$ style. The records are usually written horizontally. Four series of registers make up this collection. ${ }^{13}$ The cedìd registers are also organized differently than the 'atikk registers and are written in a systematic way in a chart called the "Register of Professions" (Defter Esās Cihāt). All new appointments and other additions are written in the events section of the chart. Thus, this chart acts as a summary of the activities of the waqfiyya.

The records of the Maghariba neighborhood are located in number 515 of the 'atīk registers (Kudüs 'atīk) (fig. 4.1) and in number 160 of the cedìd (Kudüs cedīd) registers (fig. 4.2). There is also an index register numbered 163 called the Index of Benghazi and Jerusalem, which includes the index of the 'atīk and cedīd registers. ${ }^{14}$ In the 515 Jerusalem 'atīk register, there are 594 records written according to the district names, 137 of which are written under the heading "Awqā $f$ of the District of Jerusalem."

11 Bahaeddin Yediyıldız, "Müessese-Toplum Münasebetleri Çerçevesinde XvıII. Asır Türk Toplumu ve Vakıf Müessesesi” [On the framework of institution-society relations in 18thcentury Turkish society and waqf institutions], Vakıflar Dergisi 15 (1982).

The appointee received a certificate called an appointment deed (berāt) issued by the chief judge. The District of Jerusalem was under the jurisdiction of the Anatolian chief judge. In the Ottoman state there were two offices of the chief judge: the Anatolian and Rumelian chief justices. One dealt with affairs related to the districts of Rumelia and the Aegean Islands and the other dealt with Anatolia, Egypt, Syria and other districts in the Arabian Peninsula. See Mehmet İpşirli, "Osmanlı Devleti'nde Kazāskerlik (xvir. Yüzylla kadar)" [The office of chief judge in the Ottoman state (up to the 17 th century)], Belleten 61, no. 232 (1997): 640-41.

13 For detailed information on the series, see Alkan, "Türk Tarihi Araştırmaları," 8-9.

14 In the archive, there are many index registers providing details on the registers. See for example the Index of Baghdad, Aleppo, Mosul: vGMA 165; Index of Monastir and Kosovo: VGMA 172; Index of Adrianople: vgma 173; Index of Thessaloniki: vgma 178; Index of Ioannina, Shkodër, Crete, Mediterranean islands, Cyprus: VGMA 181; Index of Ḥaramayn: VGMA 753; Index of Rumelia: VGMA 755. 


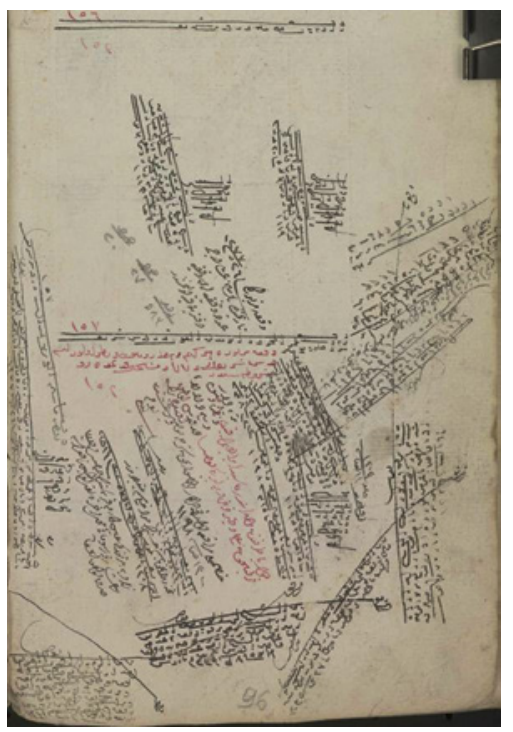

FIGURE 4.1

Atik (Old) record of the "Waqf of the Tombs of Abu Madyan al-Ghawth and Umar al-Mujarrad." VGMA, 515: 97/157.

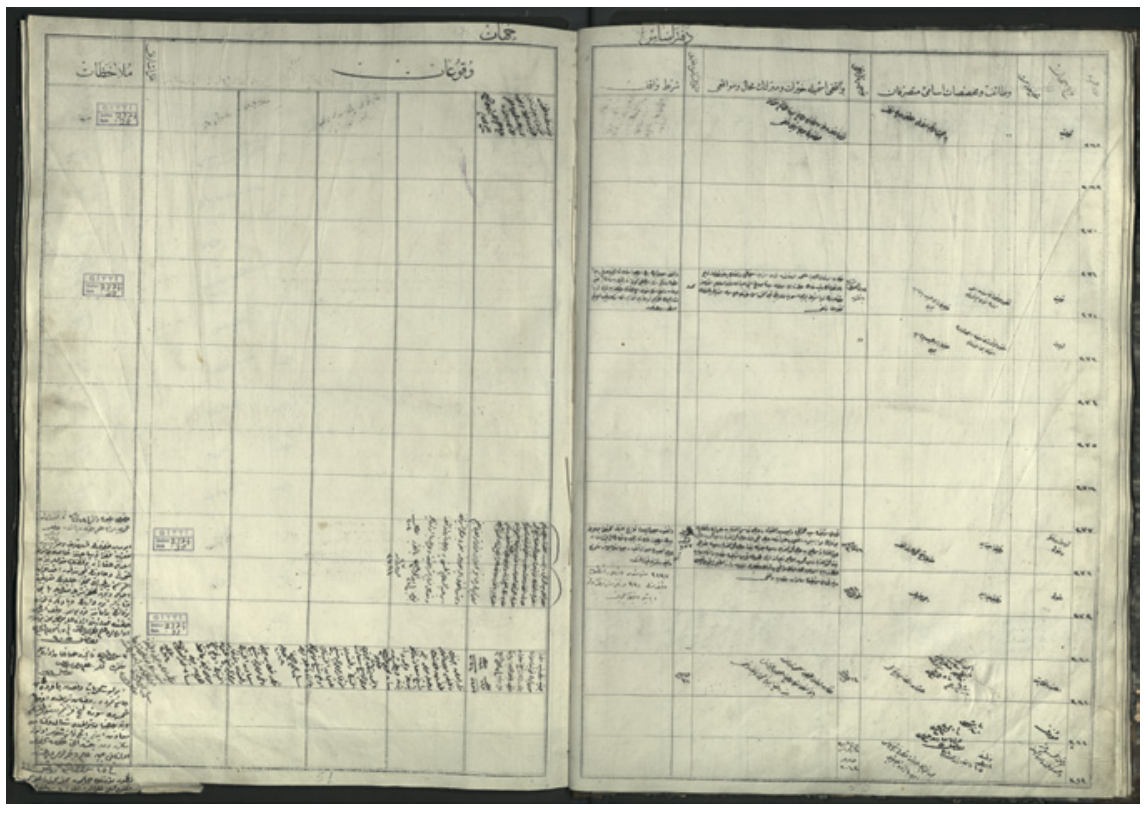

FIGURE 4.2 Cedid (New) record.

VGMA, 160: 50/378-79. 
The records of the awqā $f$ of the Maghariba neighborhood before 1882 are also recorded on different pages. ${ }^{15}$ Each record starts with a heading that indicates the name of the waqf. For example, "Waqf of Zawiya Maghariba in Jerusalem" or "Waqf of the Tombs of Sayyid "Umar al-Mujarrad and Abu Madyan alGhawth in Jerusalem." Each member of the staff is recorded in a triangleshaped space filled with five pieces of information: name of the staff member, ${ }^{16}$ title of the office, share, salary and the periodicity of payment (daily, monthly or yearly). For example, Sheikh Osman, son of Sheikh Muhammad al-Maghribi, was appointed as mutawalli and sheikh with a half share and $1.5 \mathrm{kirsh}$ salary per day. ${ }^{17}$

In 160 Jerusalem Cedīd Esās, there are 142 pages; however, only 46 pages include records. Out of the total of 760 records, between 1 and 137 are

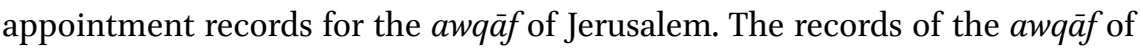
the Maghariba neighborhood after 1882 are written on different pages. ${ }^{18}$ The 'atïk and cedìd appointment registers are therefore highly consistent, and should be examined with an integrated approach. While the Cedid registers start with the last record in the 'atïk registers, references to 'atīk registers are also indicated. The appointment records are brief, but further detail can be found in the notes. If more explanation is needed, the notes indicate that other registers, particularly the tafșil registers, should be consulted for a detailed description of the appointment process.

\section{The Neighborhood and the awqā $f$ of Maghariba}

The presence of North Africans from Morocco, Tunisia and Algeria in Jerusalem dates back to the earliest periods of Islam. Known as the Maghribis,

15 Madrasa al-Afdaliyya (VGMA, 515: 78/88); Zāwiyat al-Maghariba (vgmA, 515: 79/89); Zäwiyat al-Fahriyya (VGMA, 515: 92/139); Waqf of Abu Madyan al-Ghawth and Sayyid 'Umar al-Mujarrad (VGMA, 515: 97/157); Tomb of the Buraq (VGMA, 515: 98/159).

16 Sometimes the name of the employee is recorded with his social status. For example, in the record of the Zawiya al-Fahriyya, the professor (mudarris) Sheikh Abdurrahman is recorded as a member of the ulema.

17 VGMA, 515: 79/89.

18 "Awqā $f$ of Sayyid 'Umar al-Mujarrad and Abu Madyan al-Ghawth and al-Hajj Kasım al-Maghribi ibn Abdullah and the Awqā $f$ of Hajj Necme bint Hajj Muhammed alMaghribi and Sayyid Muhammed ibn Hajj Abdullah al-Maghribi and Ismail ibn Hajj Muhammed al-Maghribi and Sayyide Cennet bint Hajj Muhammed al-Maghribi and Sayyide Hatice bint Muhammed al-Maghribi and Sayyid Muhammed ibn Ismail" (160: 50/378-79); "Hangah-1 Fahriyye" (160: 56/420-25); "Cāmi' al-Maghariba” (16o: 96/735-37). 
they travelled to Mecca for the Hajj pilgrimage and also visited Medina, where the tomb of Muhammad is located. At that time, they also visited Jerusalem, considered the third holiest city of Islam. ${ }^{19}$ Those who visited the Holy City typically stayed near the Masjid al-Aqsā. ${ }^{20}$ The Maghribis were also aware of the presence of Maghribi scholars in the city, which might explain why they travelled there.

Of these Maghribi scholars, Shu'aib Ibn al-Husain al-Andalusi, known as Abu Madyan al-Ghawth, was a celebrated traditionalist and mystic (d. AH 594/ $\mathrm{AD}$ 1197). He was the leading member of the Andalusian-Maghribi family of great learning and wealth. Tradition relays that his piety, learning, and munificence benefitted the holy city of Jerusalem. The head of the family, Shu'aib, along with other members, moved from Andalusia to Fez, which was then regarded as the chief city in the Maghreb. Later on, his brother 'Ali and his son Madyan immigrated to Egypt. Other members of the family moved later from Egypt to Jerusalem, where the Maghribi community was already well established. $^{21}$

A number of historians of Jerusalem date the establishment of the Maghariba neighborhood to the time of the Ayyubids. In 583/1193, after Saladin defeated the Crusaders, one of the most important foundations was established around the Haram al-Sharif area in Jerusalem by the governor of Damascus (582-592), 'Afdal Malik Nur al-Din 'Ali, son of Saladin.. ${ }^{22}$ Mujir al-Din relates that 'Afdal al-Din "endowed as waqf the entire neighborhood of the Maghribis in favor of the Maghribi community, without distinction of origin," and that the "donation took place at the time when the prince ruled over Damascus [AD 1186-1196], to which Jerusalem was joined."23 He simultaneously authorized the building of the Harat al-Sharaf neighborhood contiguous to the Maghariba neighborhood in what today is referred to as the Jewish Neighborhood. ${ }^{24}$ As a waqf endowment, the area was to serve as a destination for new arrivals from the Maghreb. From the thirteenth century until the final days of the Jordanian regime in 1967 , immigrants from the Islamic world visited and made this neighborhood their home. ${ }^{25}$

\footnotetext{
19 Güneş, "Kudüs'te Bir Mahalle," 10.

20 al-Asali, "Haratu'l-Maghariba fi al-Quds," 19.

21 Tibawi, Islamic Pious, 10.

22 Güneş, "Kudüs'te Bir Mahalle," 10-12.

23 See al-Hanbali, al-Uns al-Jalil, vol. 2, 397.

24 Ibid. See also Tibawi, Islamic Pious.

25 Abowd, "Moroccan Quarter," 6-16.
} 
The neighborhood is located in the extreme south of the Old City, and measures roughly 10,000 square meters. It became the site of a number of historically and culturally significant structures erected during the Ayyubid and Mamluk eras. These included Waqf al-Maghariba and Madrasa al-Afdaliyya, endowed by 'Afdal in this neighborhood during the latter part of the twelfth century for the use of Maliki jurists (fuqahā).${ }^{26}$ Zāwiyat al-Maghariba, Mosque (cāmic) al-Maghariba, and zāwiya al-Fahriyya were other notable structures in the neighborhood at that time. ${ }^{27}$ Although during the seventeenth, eighteenth, and twentieth centuries, there were six, twelve, and three new awqāf established respectively, no new structures were built. All the founders of the awqā $f$ were Maghribi residents of Jerusalem. Three of them were founded for the benefit of the public, one was a cash (nuküd) waqf, and the remaining twenty were modest and locally founded family awqā (see table 4.1). The concentration of these religious, charitable and educational foundations in this particular area was undoubtedly due to its association in the Qur'an and Islamic tradition with Muhammad's miraculous nocturnal journey to Jerusalem. It is believed that the two stages of Muhammad's journey: al-Isrä (the nocturnal journey) and al-Miraj (ascension) took place around the western wall of Haram al-Sharif and the Dome of the Rock. These miraculous events in Islamic tradition have endowed the area with a special importance for Muslims. For centuries, scholars and other travelers from all over the Muslim world have come to pray at the Haram and lodge in the sacred places mentioned in the verse: "Glory be to Him, who carried His Servant by night from the Holy Mosque [in Mecca] to the Farther Mosque [al-Masjid al-Aqsā], the precincts of which We have blessed ..."28

\section{a Waqfal-Maghariba}

The Maghribi waqf was founded by al-Malik al-Afdal Nurud-Din Ali, soon after the recapture of Jerusalem from the Crusaders. Al-Afdal was king (malik) in Damascus from $\mathrm{AH} 582$ to 592. Malik al-Afdal dedicated the whole area outside the western walls of Haram al-Sharif, known as Hārat al-Maghāriba, as a waqf for the benefit of all Maghribis, male and female. In a series of

26 According to Donald Little, "The location of this school in the Maghariba Quarter was appropriate, since most of the Mālikīs traced their origins from North Africa." See his "Jerusalem under the Ayyubids and Mamluks, 1187-1516 AD," in Jerusalem in History, ed. Kamil Jamil al-Asali (Buckhurst Hill: Scorpion, 1989), 180.

27 See Michael Hamilton Burgoyne, Mamluk Jerusalem: An Architectural Study (London: British School of Archaeology for the World of Islam Festival Trust, 1987).

28 Kur'an-ı Kerim, Surah XvII, verse 1. 
documents, immigrants from the Maghreb and residents of Jerusalem were defined as "Western Tunisians, Algiers and Moroccans."29 The area was consequently turned into a neighborhood for Maghribi Muslims. ${ }^{30}$ As the name sharaf (honor) indicates, and as the occupations of the three prominent types of residents confirm, religious dignitaries and high government officials inhabited the area. ${ }^{31}$

This waqf had several forms of income. According to the Jerusalem sijillāt (Js), income was controlled by the sheikh of the neighborhood and disbursed among the community's population. To these incomes, Shu'aib Ibn Muhammad Ibn Shu'aib, generally known simply as Abu Madyan, grandson of Abu Madyan al-Ghawth, added his lands of the village of 'Ayn Karim near Jerusalem, the income of which was to benefit the Maghribis. ${ }^{32}$ However, in the Esās registers, there is no record specifically entitled "Waqf of Maghariba," but rather "Waqf of the Tombs of Abu Madyan al-Ghawth and "Umar al-Mujarrad."

\section{b Madrasa al-Afdaliyya}

Apart from being religious and charitable, al-Afdal's waqf was also educational in that he established a madrasa called al-Afdaliyya after him. According to the waqfiyya of the Afdaliyya madrasa, it was stipulated that the madrasa was created to train jurists in line with the Maliki school of jurisprudence, the dominant school in the Maghreb and the most prominent among the Maghrebi diaspora in Jerusalem. ${ }^{33}$ This madrasa was also called the "Dome" or "Dome of Afdaliyya," or sometimes "Madrasa al-Malikiyya" and was founded in the year $590 / 1193 \cdot{ }^{34}$

29 See for example воA, ŞD.2296.40.49, 22 Haziran 1319 [5 July 1903]/SD.2296.40.44, 21 Ağustos 1319 [3 September 1903]/SD.2296.40.36, 23 Ağustos 1319 [5 December 1319].

Mujir al-Din, al-Uns al-Jalil, vol. 2, 397. As Mujir al-Din states, the waqfiyya document seems to have been lost, but the waqf was recorded and legalized after the death of al-Afdal. This was done twice, once before Mujir al-Din wrote his history and once afterwards: in AH 666 and 1004 (AD 1267 and 1595), shortly after the beginning of the Mamluk period and some eighty years after the beginning of the Ottoman period, respectively. The following translation is a certified copy of the valid document (and a prefatory note confirming Mujir al-Din's statement), preserved at the shari'a Court in Jerusalem (Js 77: 588).

31 Tibawi, Islamic Pious, 10-13.

32 Ibid.

33 Mujir al-Din, al-Uns al-Jalil, vol. 2, 397.

34 VGMA, 1107:2/78. 
In the eighteenth-century registers, the appointment records of the madrasa appear along with the waqf of Abu Madyan al-Ghawth. ${ }^{35}$ Some of the other staff members such as the doorkeeper and the sweep were appointed and recorded separately. ${ }^{36}$ On the other hand, in the appointment registers, six employees were registered under the heading of "Madrasa al-Afdaliyya" between AD 1670 and 1825 (AH 1081-1241). The first employee was the mudarris, followed by his assistant (muid). ${ }^{37}$ While the fee of the mudarris was recorded as a certain unspecified amount (mu'ayyen), the assistant's fee was recorded as one kirsh daily. In the third and fourth registers, the collection clerks $\left(c \bar{a} b i{ }^{i}\right)$ were registered as receiving a half share. The fifth employee was a doorkeeper and sweep who was paid one kirsh daily. The last employee was the supervisor and inspector. However, there were no references to the waqf of the madrasa in the cedìd record.

\section{c Zāwiyat al-Maghariba}

By the middle of the fourteenth century, the considerable Maghribi community in Jerusalem, residing just outside the western wall of Haram al-Sharif between the two gates of Bab al-Silsala and Bab al-Maghariba, could benefit from two Maghribi waqf charitable foundations or zāwiya. The first zāwiya was established by an immigrant, 'Umar Ibn 'Abdullah Ibn 'Abdun-Nabi

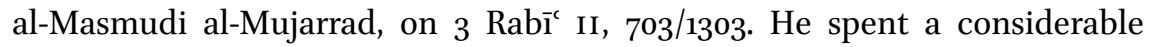
amount of his money on the endowment of a zawiy ${ }^{38}$ for the benefit of Maghribis living near Haram al-Sharif in a neighborhood named after them. ${ }^{39}$ This was the first waqf instituted by a Maghribi for the benefit of al-Maghariba in Jerusalem. There is a prayer lodge in the upper part of the zāwiya which had two floors. In the lodge, the poor of the Maghribis were received and their needs were met. ${ }^{40}$

The second $z \bar{a} w i y a$ was endowed in the same Maghariba neighborhood close to Bab as-Silsila, one of the gates of Haram al-Sharif, by Shu'aib Ibn Muhammad Ibn Shu'aib. ${ }^{41} \mathrm{He}$ was renowned for his scholarship and generosity

\footnotetext{
35 VGMA, 1107: 2/78; 1160: 116/42.

36 VGMA, 1109: 6/37; 1128: 68/28.

37 VGMA, 515: 78/88.

38 Literally a "retreat" for meditation and prayer, but also a hostel for dervishes and an educational establishment.

39 Mujir al-Din, al-Uns al-Jalil, vol. 2, 397, 580.

40 Tibawi, Islamic Pious, 10.

41 According to Tibawi, the attachment to Shu'aib as a first name and Madyan as a last name was probably inspired by the Qur'an. In the holy book, Shu'aib figures as one of God's prophets sent to Madyan (for example, Surah 7:85: "And unto Madyan did we send their
} 
among Maghribis who had settled in Jerusalem. As mentioned, he assigned the lands of the village of 'Ayn Karim near Jerusalem, his own property, as a waqf whose income was intended for the zāwiya and the Maghribis. ${ }^{42}$

During the eighteenth century, only the sheikh's appointment records were recorded. ${ }^{43}$ The records of the 515 appointment registers show that the duties of the sheikh and supervisor were shared by two members of the Maghribi family; Sheikh Osman Ibn Sheikh Muhammad al-Maghribi and Sheikh Abu Bakr Ibn of Sheikh Ahmed al-Maghribi. Each employee had a half share of the position and were paid 1.5 kirsh daily. In the register, at the end of the record, a short statement indicates that the confiscation of the administration of these two awqa $f$ was ordered in $1208 / 1794$. After that time, although the appointment of the sheikh to the zāwiya continued, ${ }^{44}$ the administration and control of the waqf were placed under the heading of "Waqf of the Tombs of Sayyid 'Umar al-Mujarrad and Abu Madyan al-Ghawth in Jerusalem."

Summaries of twenty-one appointment deeds (berāt) appear in the records under the heading of this waqf. Two records refer to the renewal of the appointment deeds after the coronation of a new sultan. ${ }^{45}$ There is a note dated 15 Șafar 1195 [February 10, 1781] under the heading of the waqf, stating that the people who had been appointed supervisor, instructor, and keeper of the tomb of the waqf were also appointed as the sheikh of the town criers. In a record dated 13 Safar 1198 [December 10, 1783], it is claimed that this was a long-standing tradition. ${ }^{46}$ The initial meaning of the verb dalla is "to

brethren Shu'aib." He is supposed to be Jethro of the Bible, the father-in-law of Moses. See Exod. 3:1, where the name is written Midian.)

Tibawi, Islamic Pious, 13. This copy of the Qur'an is preserved in the Islamic Museum in Haram al-Sharif.

43 VGMA, 1160: 116/18; 1109: 6/105; 1112: 1/36; 1112: 1/148; 1111: 54/55; 557: 43/3.

44 VGMA, 1111: 54/55; $557: 43 / 3$.

45 The first renewal was written on 11 Receb 1203 [07 April 1789]. (Cutūs berātı sitāde). The second renewal was dated 4 Cemāziyelahir 1223 [28 July 1808]. (Culūs-ı emr-i sherīf sitāde.) VGMA, 515: 97/157.

46 Because of the vacancy in the position, Sayyid Ahmed Effendi was appointed as supervisor, inspector, keeper of the tomb and the sheikh of the town criers in exchange for 7 kirsh ( $\dot{g} u r u ̄ s ̧)$ daily. In the first record, it was stated that the appointment deed (berāt) was received on 15 Safar 1195 [10 February 1781] along with his own petition and the appointment decree (ru'ūs). In the second record about the same appointment, it is stated that the order (emr-i sheriff) was received on 15 Muharram 1198 [10 December 1783] with his own petition and the imperial edict (fermān). In the last record, it is stated that a detailed remark was written on 13 Safar 1198 [ 7 January 1784]. Furthermore, in a hurūfāt record dated Shawwāl 111 [March/April 1700], Sayyid Yakub al-Mansur al-Maghribi was appointed supervisor, inspector and keeper of the tomb as well as the sheikh of the 
indicate, to demonstrate and to show publicly." As a noun, dallāl becomes "a broker," "a middleman," in short, a dealer, but the guild kept exercising its original public-crying function as well. The members of this guild pledged to consult their head on every transaction and to obey his orders: "As long as he did nothing to antagonize the guild members and committed no offense (junha), he could proceed with his responsibilities. If, on the other hand, he could not properly conduct the guild's affairs, either because of health problems or due to his absence from town, the judge (qadi) replaced him immediately." In the seventeenth and eighteenth centuries, the head of the Maghariba neighborhood was granted the right to this position by official decrees from Istanbul. ${ }^{47}$ For Amnon Cohen, this was one of the most active guilds during the seventeenth century in Jerusalem.

This position was sought after by many, and created fierce competition that often ended in opponents sharing the leadership. People in these positions were also granted a daily stipend of eight $k \iota t t^{t} a$. The combination of a steady salary and a certain percentage of every guild was exceptional and made this position more lucrative and desirable than others. ${ }^{48}$

Regarding the first appointment, it is also noted that this was a precaution designed to prevent the intervention of the head of the palanquin artisans in matters concerning the town criers guild. ${ }^{49}$ However, the precaution was also related to the tax revenues ( $a$ ş̧är u rusūmāt $)$ of the village of 'Ayn Karim. According to this record, the tax revenues of the village would only be delivered to the poor of the zāwiya al-Maghariba. ${ }^{50}$ The last record, dated 26 Rabī II

town criers to the Waqf of Abu Madyan al-Ghawth. Then, in Shawwāl 1138 [June 1726], Sayyid Abdussalam al-Maghribi was appointed as the head of the town criers in the sūq of Jerusalem (VGMA 1091: 77/11).

47 VGMA, 515: 97/157; BOA, C.EV.566.28553 and C.EV.552.27881.

48 Amnon Cohen, The Guilds of Ottoman Jerusalem (Leiden: Brill, 2001), 178-79.

49 In a variety of documents recorded during different years of that century, there are recurrent attempts to wrest these lucrative positions from the head of the North Africans and invest the honor, and more importantly, the accompanying income, in other candidates. In this case, for example, the head of the palanquins' guild (tahteravanci bashi) claimed that he had been granted this position by a sultanic decree from Istanbul, although the head of the North African descendants of the Prophet in town insisted that, upon the death of his predecessor, he had been put in charge of both functions. As it turned out, the outside contender had been appointed under false pretenses, in violation of the incontestable link established for generations among all these functions. Thereupon the qadi confirmed the status quo, to the disadvantage of "the foreigner," who had tried to usurp it. VGMA, 515: 97/157; for other examples see Cohen, Guilds, 178-83. 
1277 [December 11, 186o], references Jerusalem Cedìd register number 16o. This illustrates the consistency between the old and new series. After this date, three more appointments were recorded. In the first record, dated Dhū al-Qa'dah 1301 [September 1884], it is stated that after Mehmed Arif Effendi's passing away, al-Hajj 'Umar al-Maghribi, the oldest, most mature and most suitable candidate in the Maghariba neighborhood, was appointed to the waqf as its supervisor (mutawalli), inspector (näzır), and keeper of the tomb (türbedār) by a petition and an imperial edict. ${ }^{51} \mathrm{After}$ this date, there are no references to the sheikh of the town criers. We do not know whether the post continued to be held by the head of the neighborhood.

The second record, dated 15 Muharram 1321 [April 13, 1903], states that there was a trial concerning the administration of the awqāf. During the trial, waqf lands and properties could not be rented to any tax farmers. The record states that the keeper of the Tomb of the Prophet David or any other trustworthy man would be appointed as temporary deputy supervisor by the waqf governorship. ${ }^{52}$ The correspondence concerning these issues was reported to all the related departments as ordered in the imperial edict. In the third and last record, it is stated that after the death of Maghribi Sheikh Mehmed Arif Effendi, according to the conditions stipulated in the waqfiyya and procedures applied as usual, Maghribi al-Hajj Bashir Effendi, son of Abdussalam al-Hasani, was appointed as the supervisor, inspector, and keeper of tomb of the waqf on 28 Dhū al-Hijjah 1329 [December 20, 1911].53 The records of the "Waqf of the Tombs of Sayyid 'Umar al-Mujarrad and Abu Madyan al-Ghawth in Jerusalem" end with this record.

The 'atīk and cedīd appointment registers that started with zāwiyat alMaghariba on 18 Dhū al-Qa'dah 1134 [August 30, 1722] are grouped under the heading of the waqf of the Tombs of Sayyid 'Umar al-Mujarrad and Abu Madyan al-Ghawth on 15 Ṣafar 1195 [February 10, 1781]. All the public awqā $f$ of the neighborhood are grouped thereafter under the heading "Awqâf of Sayyid 'Umar al-Mujarrad and Abu Madyan al-Ghawth and al-Hajj Kasım al-Maghribi ibn Abdullah and the awqāf of Hajj Necme bint Hajj Muhammad al-Maghribi and Sayyid Muhammad ibn Hajj Abdullah al-Maghribi and Ismail ibn Hajj Muhammad al-Maghribi and Sayyide Cennet bint Hajj Muhammad al-Maghribi and Sayyide Hatice bint Muhammad al-Maghribi and Sayyid Muhammad

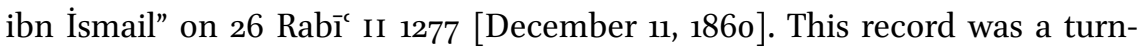
ing point for the awqā of the neighborhood since both the public and family $a w q \bar{a} f$ were combined and administered together. It was not a confiscation,

\footnotetext{
$51 \quad$ VGMA, $160: 378$.

52 VGMA, Tafsïl 405 .

53 VGMA, Tafsül 202.
} 
awqā $f$ were still run by families, but their administration was united by the central authority. In the registers, corruption and mismanagement of the awqā $f$ were listed as the main reasons for the changes in the waqf administrative staff. ${ }^{44}$ The last waqf added to this administratively united structure was the Waqf of the Descendants of the Prophet (sādāt) of Maghariba, which will be discussed further on.

\section{d Cāmi al-Maghariba}

Al-Maghariba Mosque, near the Bab al-Maghariba, ${ }^{55}$ was constructed northsouth to the Haram al-Sharif area and it was considered an integral part of the Haram. ${ }^{56}$ There are no records of the mosque in Jerusalem's 'atîk register, but in the cedid register of the waqf, there is a note stating that the 'atīk registers of the waqf were recorded in the Mecca and Medina 'atīk register numbered 92. ${ }^{57}$ In the cedid, three employees were appointed, but the Treasury later decided that one employee should be appointed at 50 kirsh monthly for all these duties. The name of the waqf was also recorded as "Evkāff-ı mażbütadan Kudüs-i Şerīfde kāin Meḡāribe Cämi'-i Şerîfi Vakfi," meaning that this waqf had already been administered by the representatives of the central authority.

\section{e Madrasa and zāwiyat al-Fahriyya}

Madrasa al-Fahriyya is also known as the zäwiyat al-Fahriyya in the Jerusalem court registers, and was founded by Qadi Fahreddin Muhammad ibn Fadlullah in 732/1331. The madrasa was situated to the west of al-Maghariba Mosque and remained within the walls around the mosque. The library of the madrasa played an important role among Jerusalem's public libraries. Founded by Qadi Fahreddin in 732/1339, this library is said to have housed approximately 10,000 volumes. Its collection of manuscripts on astronomy and religious sciences has

54 For the details of the records, see zāwiya of Maghariba (VGMA, 515: 79/89); Waqf of Abu Madyan al-Ghawth and Sayyid 'Umar al-Mujarrad (vgma, 515: 97/157); Awqāf of Sayyid 'Umar al-Mujarrad and Abu Madyan al-Ghawth and al-Hajj Kasım al-Maghribi ibn Abdullah and the Awqā $f$ of Hajj Necme bint Hajj Muhammed al-Maghribi and Sayyid Muhammed ibn Hajj Abdullah al-Maghribi and İsmail ibn Hajj Muhammed al-Maghribi and Sayyide Cennet bint Hajj Muhammed al-Maghribi and Sayyide Hatice bint Muhammed al-Maghribi and Sayyid Muhammed ibn İsmail (160: 50/378-79).

55 Burgoyne, MamlukJerusalem.

$5^{6}$ Although Mujir al-Din says the mosque was built during the second caliph's visit to Jerusalem, this is a very remote possibility. The general consensus is that this mosque was built during the Umayyad period, based on the inscription on the eastern entrance to the mosque, which states Sultan Abdülaziz repaired it in the year 1288/1871. Güneş, "Kudüs'te Bir Mahalle," 10-12.

'Atīk Mecca and Medina, 92. 
been lost. ${ }^{58}$ The Fahriyya Bazaar was among the most important sources of joint income of the madrasa and the zäwiya. The revenue from the shops in the bazaar was spent on each waqf's expenses. In 978/1570, repair and maintenance of the lodge was carried out by the Ottomans and cost 25 gold coins. ${ }^{59}$

In Jerusalem's 'atîk appointment register, four employees were appointed as mudarris, ${ }^{60}$ two sheikhs of the lodge with half salaries and an inspector. The last appointment was dated 16 Rabī 'iI 1294 [April 30, 1877]; subsequently the record was transferred to the 160 Jerusalem Cedid appointment register. These Cedid records show that two new employees whose shares were onethird of a neighborhood were appointed after of the death of the former staff. The last record is dated 20 Muharram 1318 [May 20, 1900].

What is striking about this record is that the duties and the salary of the sheikh in the lodge were divided among seven employees. Two of the employees were allocated half of one neighborhood, and the remaining five received one third of a neighborhood as daily income. Furthermore, all of the employees were relatives of the former employees. This was maintained by the imperial edicts and orders sent by the central authority. ${ }^{61}$ During the eighteenth and the first half of the nineteenth centuries, shared waqf duties were very common because of the privileges linked to the 'akseri appointment deeds (berāt) and the economic conditions of the period. ${ }^{62}$ These duties conferred social status, economic power, and exemption from taxes, which made them attractive to the common people $\left(r e^{\top} \bar{a} y \bar{a}\right) .{ }^{63}$

Another public waqf structure recorded in the registers is the Tomb of al-Buraq (Makām al-Buraq al-Arbainn). In the 'atīk register of the neighborhood, four records describe the appointment of the sheikh for the tomb. ${ }^{64}$ However, we do not know whether this tomb was a different structure in that spot or whether it was the masjid discussed earlier. The "Waqf of al-Hajj

58 'Arif al-Arif, al-Mufassal fi tarikh al-Quds [A detailed history of Jerusalem] (Jerusalem, 1961), 451.

59 Güneş, "Kudüs'te Bir Mahalle," 12.

6o Holding the title of mudarris meant that one had completed the course of study at one of the recognized teacher-training madrasas of Istanbul, Edirne or Bursa, and that one was qualified to teach. See Madeline C. Zilfi, The Politics of Piety: The Ottoman Ulema in the Postclassical Age, 1600-180o (Minneapolis: Bibliotheca Islamica, 1988).

61 See for example VGMA, 814: 11.

62 Mohammad Ali al-Alami, "The Waqfs of the Traditional Families of Jerusalem during the Ottoman Period," in Ottoman Jerusalem: The Living City, 1517-1917, ed. Sylvia Auld and Robert Hillenbrand (London: Altajir World of Islam Trust, 2000).

63 Hülya Canbakal, Society and Politics in an Ottoman Town: Ayntäb in the 17th Century (Leiden: Brill, 2007), 83-84.

64 VGMA, $515: 98 / 159$. 
Kasım al-Maghribi ibn Abdullah" is recorded under the heading of "Waqf of the Tombs of Sayyid "Umar al-Mujarrad and Abu Madyan al-Ghawth" in 1860. Lastly, "the waqf of the descendants of the Prophet in the neighborhood" (Waqf of Sādāt-ı Maghariba) appears in the Cedìd appointment register of the Maghariba. Ahmed al-Maghribi was appointed supervisor of the waqf on 15 Safar 1194 [February 21, 1790]. This is the only record in the register. A reference to the 'atīk appointment register indicates that the administration of the waqf was handled jointly by 'Umar al-Mujarrad and Abu Madyan al-Ghawth. Like other family awqāf, the status of this waqf did not change. In 1860, it was grouped with the public awqāf..$^{65}$

\section{Appointment Registers as Archival Sources for Waqf Studies: Ottomanization and Integration of the Local Elites}

All of the public awqā $f$ in the neighborhood are recorded in the registers. Updated details including changes in the administration of the $a w q \bar{a} f$, and the reasons for these changes, can also be traced. Some of the centralization measures implemented by the central authority from the very beginning of the establishment of the Ministry of Awqā $f$ in 1826 can also be observed in the records. In the Maghariba neighborhood, thanks to the measures taken in 1860, all the awqā $f$ in the neighborhood were combined and administered together. As a result, the duties of the public and family awqā $f$ in the neighborhood were recorded. The records also detail the mismanagement of the awqa $f$ in the neighborhood and show that some of the revenue of the newlyestablished family awqā $f$ was added to public awqāf. However, the residents of the neighborhood continued to administer these institutions under greater supervision of the central authorities during the nineteenth century.

This analysis of the waqf records of the Maghariba neighborhood shows that these institutions were managed by the residents for centuries, creating a local network within the neighborhood. The records also show that during the eighteenth and nineteenth centuries, corruption and the mismanagement of waqf properties were rampant. In an attempt to control the situation, the waqf structure was united administratively and control was centralized. Both public and family awqāf in the neighborhood were administratively combined in 1860 , yet certain records show that some employees continued to be appointed separately. These registers were part of a bureaucratic mechanism that allowed the central authority to exercise strict control over the administration 
of $a w q \bar{a} f$ through appointments to waqf posts. The organization of the $a w q \bar{a} f$ in Jerusalem through the local Ottoman bureaucracy facilitated this strict control. Ottoman bureaucracy thus included waqf administration, and incorporated a network of scholars (ulema; Ar. 'ulamả) into the state's bureaucratic, economic and administrative structure. ${ }^{66}$

The registers also reveal the changes in the number of waqf staff and show how these numbers differentiated from the original waqfiyya over time as a result of these new appointments. Ottoman bureaucracy was able to establish itself locally through these new appointments. ${ }^{67}$ This meant that local people became involved in the administrative and distributive networks of the imperial center. A newly formed elite class was integrated into the system as Ottoman bureaucracy was introduced to local affairs.

The decentralization expressed in the concept of Ottomanization ${ }^{68}$ also meant a "restructuring" of Ottoman administrative mechanisms and the

66 Gabriel Baer, "Jerusalem's Families of Notables and Waqf in the Early 19th Century," in Palestine in the Late Ottoman Period, ed. David Kushner (Leiden: Brill, 1986), 109-23; al'Alami, "Waqfs"; Şerife Eroğlu Memiş, "Waqfs as a Tool for the Rise of Local Notables in Jerusalem During the 18th Century" (paper presented at the 46th annual meeting of the Middle East Studies Association, New Orleans, 2016). For a detailed analysis on the case of Damascus, see Richard van Leeuwen, Waqfs and Urban Structures: The Case of Ottoman Damascus, (Leiden: Brill, 1999), 133-63.

67 Canbakal, Society and Politics, 82; Ali Yaycıoğlu, "Sened-i İttifak (1808): Osmanlı İmparatorluğu'nda Bir Ortaklık ve Entegrasyon Denemesi” [Charter of alliance (1808): a partnership and integration experiment in the Ottoman Empire], in Nizam-ı Kadimden Nizam-ı Cedide: III. Selim ve Dönemi [Selim III and his era from ancien régime to new order], ed. Seyfi Kenan (Istanbul: ISAM, 2010).

68 Fundamental changes occurred in the relationship between the Ottoman state and the elites in the provinces during the eighteenth century. Moreover, these changes differed from province to province. Some historians have argued that a large part of the local elites were Ottomanized in the eighteenth century. According to them, this Ottomanization functioned as an antidote to the disintegration of the central control that had developed considerably in the late 170os. While Jane Hathaway, in The Politics of Households in Ottoman Egypt: The Rise of the Qazdağlis (Cambridge: Cambridge University Press, 1998), does not use the term Ottomanization in her study, in which she argues that a distinctly Ottoman elite political culture was transferred to Egypt. She does indicate that the secondary management environment spread to the Ottoman provinces. By contrast, Bruce Alan Masters, in The Origins of Western Economic Dominance in the Middle East: Mercantilism and the Islamic Economy in Aleppo, 1600-1750 (New York: New York University Press, 1988), appraises these groups as part of the emergent Ottoman upper class, and Dina Rizk Khoury, in State and Provincial Society in the Ottoman Empire: Mosul, 1540-1834 (Cambridge: Cambridge University Press, 1997), defines the process as Ottomanization. 
relations between center and periphery. ${ }^{69}$ By integrating provincials into the imperial institutional framework, Ottoman power in the provinces was increased, on the one hand, while the empire's traditional administrative structure was transformed, on the other. The Ottoman center had no other choice than to provide the provinces with resources and to integrate the provincial forces into its own structure to ensure local security and surveillance. However, this integration did not result from a vertical appointment process from the central to the regional, but rather from a horizontal process of ongoing negotiation and consensus. ${ }^{70}$

In terms of the relations between the Ottoman authorities and its provinces, this view is contrary to the claim that central control was gradually relaxed and local powers became more independent during the eighteenth century. Rather, central authority was strengthened, not only through the enactment of strict bureaucratic centralization measures, but also by monitoring events through the appointment of officers with strong local ties and decent stipends. This control was also enforced by careful appointment policies and authorizations to families to build a power base that ensured stability in the local power structures. The awqāf functioned as an important mechanism for central control because they served to form and integrate relationship networks and institutions, and hence to monitor them. At the same time, by including the economic network to state officers in its administration, the state was able to supervise waqf institutions and could implement its own policies. ${ }^{71}$

69 See Karl K. Barbir, Ottoman Rule in Damascus, 1708-1758 (Princeton: Princeton University Press, 1988); Rifa'at Abou-el-Haj, Formation of the Modern State: The Ottoman Empire, Sixteenth to Eighteenth Century (Albany: State University of New York Press, 1991); Ariel Salzmann, 'An Ancien Régime Revisited: 'Privatization' and Political Economy in the Eighteenth-Century Ottoman Empire," Politics and Society 21, no. 4 (1993); Dina Rizk Khoury, State and Provincial Society, Karen Barkey, Bandits and Bureaucrats: The Ottoman Route to State Centralization (Ithaca: Cornell University Press, 1994), and Jane Hathaway, "Rewriting Eighteenth-Century Ottoman History," Mediterranean Historical Review 19, no. 1(2004):37. For critical comments on the issue, see Leslie Peirce, "Changing Perceptions of the Ottoman Empire: The Early Centuries," Mediterranean Historical Review 19, no. 1 (2004).

$70 \quad$ Yaycioğlu, “Sened-i İttifak (1808)," 667-709.

71 Van Leeuwen, Waqfs and Urban Structures, 133-63. 
In the case of the awqā $f$ of the Maghariba neighborhood, the Ottoman state maintained the same policies. Waqf employees were appointed from among the leading scholars of the neighborhood. As seen in the records, nearly all the employees were members of the ulema of the neighborhood. Apart from stipends and tax exemption, the waqf staff enjoyed accrued prestige in society. The Ottoman state also retained the loyalty of these notables through grants provided to them and to the poor of the community during the period under review. Two important devices that were implemented were food allocations from the al-Imara al-Hasekiyya and the surra incomes sent from Istanbul. This included allocations for bread, provided daily by the al-Imara al-Hasekiyya, for the employees of zāwiya Abu Madyan al-Ghawth and $z \bar{a} w i y a$ al-Buraq. ${ }^{72}$ In addition, allocations were distributed through the surra grants. Surra is a general term that refers to all of the money, gifts, and goods sent to the people in Haramayn during hajj season by the Ottoman Empire. ${ }^{73}$ As in previous centuries, these grants were earmarked for Jerusalem, and they continued being distributed during the nineteenth century. ${ }^{74}$ The last surra register found in the records is dated $1318 / 1900$. The prayer recitants, muezzins, and other employees of the al-Maghariba Mosque were recorded among the prayer reciters of Masjid al-Aqsā and the Dome of the Rock. Grants also

72 See for example воА, EV.d.13645; воА, EV.d.18277; воА, EV.d.18617; воА, EV.d.19214.

73 The tradition of sending surra to Haramayn started during the time of al-Muktedir Billah, one of the Abbasi Caliphs (311/923-924). Later states continued this tradition. The Ottoman Empire began to send surra to Haramayn during the reign of Bayezid I (Ylldırım Bayezid). The regular transfer of Surre-i Hümāyūn (dynasty surra) started during the reign of Yavuz Sultan Selim (Selim I). As one of the principal sources of Ottoman political history in the chronicle of Aşıkpaşa-zāde, while talking about Murat II, he also stated that the sultan sent gifts and money to Mecca and Medina as well as to Jerusalem and Hebron. It is not clear if this was sent within the context of surra or not. Beginning with the conquest of the city by Selim II in 1516, there was a great deal of help and assistance provided to the city. However, the oldest surra register associated with Jerusalem is dated 1593. The registers state the amount and the consignee of the gifts and assistance sent to these holy cities regularly on an annual basis. For detailed information, see Sit Tufan Buzpınar; "Surre" [Surra], DIA - Türkiye Diyanet Vakfi İslam Ansiklopedisi [Turkish Religious Foundation Encyclopedia of Islam], vol. 37 (Istanbul: TDV, 2009), 567; Münir Atalar; Osmanlı Devletinde Surre-i Hümayun ve Surre Alayları [Surra-i Humayun and surra regiments in the Ottoman state] (Ankara: Diyanet İşleri Başkanlığı, 1991), 12.

74 For more detailed information about the surra allocations in Jerusalem during the eighteenth and the first decades of the nineteenth centuries, see Eroğlu Memiş, Osmanlı Taşra Toplumu, 266-74. 
supported the poor of the Maghariba neighborhood together with the Risha neighborhood. The latter group was made up of the scholars and the poor of zāwiyat al-Maghariba. The amount of the grants remained constant throughout this time.

\section{The Power of Archives}

There is a historical link between the conservation of documents and the control exerted by a central authority. In the case of Jerusalem, the central authority - the Ottoman state - maintained control through strict appointment policies on questions of waqf administration..$^{75}$ Comprehensive files on the administration of Jerusalem were preserved in Istanbul. This situation was not limited to the imperial awqāf, whose supervisors were called to Istanbul from time to time for the inspection of these files. These appointment registers can be considered part of this bureaucratic process because they also include regularly updated summaries of appointment deeds (berāts) of waqf staff. To monitor the appointment of waqf staff and remain informed about conflicts concerning the execution of duties, Istanbul demanded oversight of these registers. The preservation and continuous indexation and updating of these registers thus enabled the central authority to exert its control.

In this sense, the 'atikk and cedid appointment registers provide valuable insight into the administration of the awqāf and their effects on social and economic life from the start of the seventeenth century until the end of the Ottoman Empire. Like the awqā $f$ of the Maghariba neighborhood, these registers deserve much more historical attention, given that they reveal the changing nature of the awqā $f$ and divergences from the conditions stipulated in the waqfiyyāt over time.

75 Leeuwen, Waqfs and Urban Structures, 163; see also Mosa Sroor, Fondations pieuses en movement: De la transformation du statut de propriété des biens waqfs à Jérusalem (18581917) (Damascus: Institut français du Proche-Orient (Ifpo); Aix-en-Provence: Institut de recherches et d'études sur le monde arabe et musulman (IREMAM), 2010), 461. 
TABLE 4.1 List of the waqfiyyāt of Maghariba neighborhood

\begin{tabular}{llll}
\hline No. & Date & Founder of the waqf & Properties of the waqf \\
\hline 1 & 4 Rajab & 'Afdal Malik Nur al-Din & Maghariba neighborhood \\
& $\begin{array}{l}\text { 666/April 9, 1268 } \\
\text { (26 Sha'bān } 1004 / 1595)\end{array}$ & 'Ali, son of Saladin & \\
& &
\end{tabular}

23 Rabīi I $^{\circ}$

703/October 15, 1303

329 Ramadān

$720 /$ November 2, 1320

$4 \quad 753 / 1352$

$5 \quad 5$ Dhū al-Hijjah 1021/January 27, 1613

$6 \quad 10 \operatorname{Rabīi~}^{\mathrm{c}} 1033$ /

January 1,1624

$7 \quad 1048 / 1631$

$8 \quad 15$ Ramadān 1058/

February 3, 1648

95 Rabī' II 1063/March 5 , 1653

$10 \quad 12$ Jumāda I 1088/

July 13,1677

11 Evāhir-I Shawwāl 1134/

August 12, 1722

1213 Muharram

1137/October 2, 1724

$13 \quad 1137 / 1727$
'Umar al-Mujarrad ibn

Abdullah al-Maghribi

Abu Madyan Shu'aib

al-Maghribi

'Ali ibn 'Uthman ibn Yảqub

ibn 'Abdul-Haqq al-Marini,

King of al-Maghrib

Muhammad ibn Ismail

Beshe al-Lumdani

al-Maghribi

Isa bin Ahmed ibn

ez-Zeim al-Maghribi

Al-Haje Necme bint Hajj

Mehmed al-Maghribi

al-Haje Safiye bint

Abdullah al-Jazairiyya

al-Maghribiyya

Meryem bint Abdülkadir

al-Maghribi

Al-Hajj Kasım ibn al-Attavi

al-Maghribi

Al-Hajj Muhammad ibn

Ebubekir al- Maghribi

Al-Hajj Kasım ibn Abdullah

al-Maghribi al-Marakashi

ibn Ali al-Shaybani

Abdussalam ibn Ibrahim

al-Jalili ibn Muhammad

ibn Ibrahim al-'Uthmani

al- Maghribi
Three houses in Maghariba neighborhood

1. Village of 'Ayn Karim

2. A house situated in Bab al-Silsila

A copy of the Qur'an which he himself wrote

A house with a garden in Maghariba neighborhood and neighbor to the Waqf of Abu Madyan

A house in Hatt-ı Merziban

A house in Maghariba neighborhood

350 Esedī kirsh

A house in Maghariba neighborhood

A house in Maghariba neighborhood

A house in Maghariba neighborhood

A ruined house in

Maghariba neighborhood

A house in Maghariba neighborhood with a share of $1 / 213$ kir 'at 


\section{Conditions Public/Family Sources}

Maghribis Public Jerusalem Court Sijillāt

(Js) 77:588; Abdullatif Tibawī, Awqāf al-Islāmiyya bi-Jiwār al-Masjid al-Aqsā, Vezārat al-Awqāf wa al-Şuūn wa al-Muqaddasāt al-Islāmiyya, Jordan 1404-1981, 13-17

The poor of Maghariba

Public Archive of the General Directorate of neighborhood and visitors of Haram al-Sharif

The Maghribis who live in

Public Foundations of Turkey (VGMA) 583 : $28 / 21$

Maghariba neighborhood and visitors to Haram al-Sharif Al-Aqsā Mosque

Public

Tibawi, 1978: 13

Zāwiya Abu Madyan

Family

al-Alami, Waqfiyyāt al-Maghariba, 167-69

Dome of the Rock and al-Aqsā Family

JS 107: 227 .

Mosques

For the feeding of the poor of

Family

VGMA 589: 119/332

Maghariba neighborhood

For the feeding of the poor of

Maghariba neighborhood

Public (cash)

JS 141: 41; al-Alami, Waqfiyyāt

al-Magharibah, 53-55

The poor of Maghariba

Public

JS 146: 207; al-Alami, Waqfiyyāt

neighborhood al-Maghariba, 1-11

Cihātü'l-bir (ber)

Public

Js 179: 288

Waqf of Abu Madyan

Family

JS 218: 567

The poor of Maghariba

Family

al-'Alami, Waqfiyyāt al-Maghariba, neighborhood 42-45; VGMA 583: 28/22

The poor of Jerusalem

Family

JS 218: 486 
TABLE 4.1 List of the waqfiyyāt of Maghariba neighborhood (cont.)

\begin{tabular}{|c|c|c|c|}
\hline No & Date & Founder of the waqf & Properties of the waqf \\
\hline 14 & $\begin{array}{l}10 \text { Rajab } \\
1141 / \text { February 9, } 1729\end{array}$ & $\begin{array}{l}\text { Abdussalam al-Maghribi } \\
\text { (sheikh al-Maghariba) }\end{array}$ & $\begin{array}{l}\text { A house in Maghariba } \\
\text { neighborhood }\end{array}$ \\
\hline 15 & $\begin{array}{l}\text { 1 Shacbān } \\
1153 / \text { October 22, } 1740\end{array}$ & $\begin{array}{l}\text { Muhammad el-Maghribi, } \\
\text { known as al-Gazzal, and } \\
\text { al-Hajj Muhammad } \\
\text { at-Tawil }\end{array}$ & $\begin{array}{l}\text { A multistory house in the } \\
\text { Damascus Gate } \\
\text { neighborhood, close to } \\
\text { the Dome of Hamra }\end{array}$ \\
\hline 16 & $\begin{array}{l}10 \text { Rabī' II } \\
1158 / \text { May 12, } 1745\end{array}$ & $\begin{array}{l}\text { Abdullah Agha ibn } \\
\text { al-Hajj Muhammad } \\
\text { al- Maghribi }\end{array}$ & $\begin{array}{l}\text { A house in the Sharaf } \\
\text { neighborhood with a } \\
\text { share of } 12 \text { kir'at }\end{array}$ \\
\hline 17 & $\begin{array}{l}13 \text { Rajab } \\
1171 / \text { March 23, } 175^{8}\end{array}$ & $\begin{array}{l}\text { Ismail ibn Hajj Muhammad } \\
\text { Lemedani el-Maghribi }\end{array}$ & $\begin{array}{l}\text { A house in the Hutta Gate } \\
\text { neighborhood }\end{array}$ \\
\hline 18 & $\begin{array}{l}1 \text { Rabī' I } \\
1181 / \text { July } 28,1767\end{array}$ & $\begin{array}{l}\text { Hatice ve Cennat bint } \\
\text { al-Hajj Muhammad } \\
\text { Agha al-Hodja at-Tawil } \\
\text { al-Maghribi }\end{array}$ & $\begin{array}{l}\text { A storey house in the } \\
\text { Damascus Gate } \\
\text { neighborhood }\end{array}$ \\
\hline 19 & $\begin{array}{l}\text { Rabī'c II } \\
1185 / \text { July 14, } 1771\end{array}$ & $\begin{array}{l}\text { Al-Hajj Ali ibn Ahmed } \\
\text { al-Maghribi }\end{array}$ & $\begin{array}{l}\text { A house in the Cotton Gate } \\
\text { neighborhood }\end{array}$ \\
\hline 20 & $\begin{array}{l}\text { 10 Jumāda I } \\
1187 / \text { July 10, } 1774\end{array}$ & $\begin{array}{l}\text { Al-Hajj Ali ibn Ahmed } \\
\text { al-Maghribi }\end{array}$ & $\begin{array}{l}\text { A house in the } \\
\text { Hutta Gate neighborhood }\end{array}$ \\
\hline 21 & $1196 / 1782$ & $\begin{array}{l}\text { as-Sayyid M ibn Hajj } \\
\text { Abdullah al-Maghribi }\end{array}$ & $\begin{array}{l}\text { A house in the Shark } \\
\text { neighborhood }\end{array}$ \\
\hline 22 & 5 Muharram 1205/1791 & $\begin{array}{l}\text { as-Sayyid Muhammad } \\
\text { ibn Ismail Beshe } \\
\text { (al-Lemdānī al-Maghribi) }\end{array}$ & $\begin{array}{l}\text { Vegetable garden (hakūra) } \\
\text { consisting nursery and trees } \\
\text { from Abu Madyan waqf }\end{array}$ \\
\hline 23 & $\begin{array}{l}5 \text { Dhū al-Qa`dah } \\
\text { 1349/1931 }\end{array}$ & $\begin{array}{l}\text { Idris ibn al-Hajj Musa } \\
\text { ibn al-Hajj Hasan } \\
\text { al-Kasri al-Maghribi }\end{array}$ & $\begin{array}{l}\text { A house in the Sa'diyya } \\
\text { neighborhood, close to } \\
\text { the vegetable garden of } \\
\text { Mawlawiyya }\end{array}$ \\
\hline 24 & $\begin{array}{l}25 \text { Dhū al-Hijjah } \\
1349 / 1931\end{array}$ & $\begin{array}{l}\text { Idris ibn al-Hajj Musa } \\
\text { ibn al-Hajj Hasan } \\
\text { al-Ḳasri al-Maghribi }\end{array}$ & $\begin{array}{l}\text { 1. A house in the Damascus } \\
\text { Gate neighborhood } \\
\text { 2. Two shops in the Silsila } \\
\text { Gate neighborhood with } \\
\text { the share of } 17.5 \text { kirat and } \\
\text { 1/2 kirat }\end{array}$ \\
\hline 25 & $\begin{array}{l}7 \text { Jumāda I } \\
1356 / 9,1937\end{array}$ & $\begin{array}{l}\text { al-Hajj Mes'ud ibn } \\
\text { Bilal known as al-Susi } \\
\text { al-Maghribi }\end{array}$ & $\begin{array}{l}\text { Two rooms in Maghariba } \\
\text { neighborhood and } \\
6 \text { o cuneyh cash }\end{array}$ \\
\hline
\end{tabular}




\section{Conditions Public/Family Sources}

Zāwiya Abu Madyan Jamily JS 222: 66

To Haramayn (Mecca and

Family JS 230: 240-41

Medina) and the Dome of

the Rock

Zāwiya Abu Madyan

Family

JS $235: 318$

Zāwiya Abu Madyan

Family

VGMA 589: 195/331

For the Maghribis staying in

Family

JS 250: 17-18. al-'Alamī, Waqfyyāt

the Zāwiya Abu Madyan

al-Maghariba, 25-27; VGMA 589:

$192 / 328$

Waqf of Maghariba

Family

JS 253: 70-71

Rawāk Abu Ferve that belong

Family

JS 255: 47

to the Maghribis

Family

VGMA 589: 192/327

Family

VGMA 589: 194/330; JS 272, 134-35

Division of the incomes

Family

JS 404: 19-21

between the (Dārü'l-Eytāmü'l-

Issāmiyye es-Sınāiyye) and his

family

Muslim Orphanage House

(Dārül-Eytāmül-İslāmiyye)

Family

JS 454: 19-21

Waqf of Maghariba

Family

JS 474: $133-34$ 


\title{
Foreign Affairs through Private Papers: Bishop Porfirii Uspenskii and His Jerusalem Archives, 1842-1860
}

\author{
Lora Gerd and Yann Potin
}

Jerusalem is now become a central point of interest to France and Russia. It is no doubt the object of Russia to subjugate the primitive churches of the countries. ${ }^{1}$

Since the Open Jerusalem project began, the documentation of the Russian presence in Jerusalem from 1840 onwards has posed major challenges for scholars. Access to archives both in and outside of Jerusalem has become increasingly difficult as Russia's strategic presence in the Middle East expands. The question we ask is: where in the Russian archives can scholars find material to explore the intimate relations between the Russian Orthodox Church, Russian imperial patronage, and the city of Jerusalem? The starting point for documentation and archival study in this area is the exploration of a private archive, preserved for more than a century in the collections of the Academy of Sciences of St. Petersburg, on the banks of the river Neva.

\section{The Russian Presence in Jerusalem and Its Official Records: Recent and Century-old Publications}

The pilgrimage to Jerusalem has played a central role in Russian Christianity since the nineteenth century, when messianic movements in the Orthodox church increased their emphasis on pilgrimage. The number of Russian pilgrims to Jerusalem each year during the nineteenth century was at least five times more than that of Catholic or Protestant pilgrims from Western Europe. Historians have highlighted this in order to demonstrate the strategic role it

1 The National Archives of the UK (TNA), Foreign Office (FO) 78/581, Letter from William Tanner Young, British Vice Consul in Jerusalem to Stratford Canning, Ambassador of the United Kingdom in Constantinople, January 8, 1844.

(C) LORA GERD AND YANN POTIN, 2018 | DOI:10.1163/9789004375741_008

This is an open access chapter distributed under the terms of the prevailing CC-BY-NC-ND License at the time of publication. 
played in the Eastern policy of the Tsarist Empire. ${ }^{2}$ By marking its presence in Jerusalem, the Russian Empire managed to penetrate the heart of its biggest rival, the Ottoman Empire. Since the eighteenth century, the Tsars carried out continuous attempts to erode Ottoman boundaries. While, until 1917, the Tsars continued to formally claim their rights to Constantinople, sending missionaries to Jerusalem was another form of diplomatic residence. In parallel, the latent competition between the Greeks and the Russians reflected ancient divisions within Orthodox Christianity. The Russian archives must therefore be examined along with the Greek archives in Jerusalem, Athens, and Istanbul. The Russian presence in Jerusalem grew steadily during the nineteenth century. As a result, from 1860 to 1872 , outside the walls of the Old City near the NotreDame-de-France hospital, a large hospice known as the Russian Compound was established. It could accommodate more than a thousand patients and pilgrims. It quickly became the nucleus of a Russian neighborhood. Today it is integrated in the old part of West Jerusalem, making it not only a part of the history of diplomacy, but also a symbol of urban development, further complicating the question of how the Russian archives were scattered. After 1917, the situation became even more complicated when the Soviet Union seemed to lose interest in the Russian presence in the Holy Land. The situation did not change until the post-1948 concession of the Russian compound to the state of Israel. The actual presence of the archives in the building, as well as their eventual location and preservation, is yet to be verified. A major Russian emigration to Palestine following internal schisms within the Russian Orthodox Church continued during the interwar period. Russian Jews making aliyah to Israel, particularly to Jerusalem, made up a large portion of Russian emigration to the Holy Land.

Since 1882, the Russian presence in Palestine has been inseparable from the activities of the Imperial Society of Palestine. The Society publishes a multiplicity of sources, both historiographical and apologetic. ${ }^{3}$ The revival and renewal of the activities of the Imperial Society in recent years is impressive, and has resulted in numerous reeditions and new collections of published sources. Over the past 20 years, Indrik publishers, run by Kirill Vakh, has edited a unique catalogue of inventories and documents. The last collection

2 See, for example, Lorraine de Meaux's recent La Russie et la tentation de l'Orient (Paris: Fayard, 2010), 278-91.

3 Elena Astafieva, "La Russie en Terre Sainte: le cas de la Société Impériale Orthodoxe de Palestine (1882-1917)," Cristianesimo nella storia 1 (2003). 
was published in 2017. It was prepared by Nikolai Lisovoi in collaboration with the (new) Imperial Society of Palestine. ${ }^{4}$

Until 1917, one of the main cultural and scientific activities of the society consisted of publishing sources and archival documents about the early years of the "Russian presence" in Jerusalem. ${ }^{5}$ Historiography retains 1843 as a founding date. The year corresponds to the secret mission carried out between December 1843 and August 1844 by Archimandrite Porfirii Uspenskii in Jerusalem. This was followed by a second mission between 1847 and 1854 . However, the Russian Ecclesiastical Mission in Jerusalem was only officially recognized in 1858, after the Crimean War. In 1865, the arrival of Antonin Kapustin at the head of this mission began an active period of initiative and sustainable investments that continued until the death of Kapustin in $1894 .{ }^{6}$

\section{The Academy of Sciences of St. Petersburg: An Archival Oasis}

The beginning of the Russian presence in Jerusalem is connected to the Russian mission's first leader, the prominent ecclesiastic Archimandrite (later Bishop) Porfirii Uspenskii (1804-85). ${ }^{7}$ Porfirii, whose secular name was Konstantin Alexandrovich Uspenskii, was born into the family of a church lector in the provincial town of Kostroma. After finishing the local church school $(1813-18)$, he studied in the Kostroma Theological Seminary (1818-24) and the St. Petersburg Theological Academy (1825-29). After graduating from the Academy, he took his monastic vows and was ordained deacon, and later priest. He started his career as a teacher in the Richelieu Lyceum in Odessa. In 1838, he was appointed rector to the Kherson Theological Seminary and in 1840 he was appointed priest to the Russian mission in Vienna. On November 14, 1842, the Russian Holy Synod sent Porfirii to Jerusalem to gather information about the life of the Orthodox Christians in Palestine and Syria. His first stay in Jerusalem lasted from December 20, 1843, to August 7, 1844. On July 31, 1847,

4 Nikolai. N. Lisovoi ed., Rossiia $v$ Sviatoi Zemle. Documenty i materialy [Russia in the Holy Land. Documents and materials] 2 vols. (Moscow: Indrik, 2017).

5 Derek Hopwood, The Russian Presence in Syria and Palestine, 1843-1914: Church and Politics in the Near East (Oxford: Clarendon Press, 1969).

6 Lucien J. Frary, "Russian Missions to the Orthodox East: Antonin Kapustin (1817-1894)," Russian History 40, no. 1 (2013).

7 Theophanis G. Stavrou, "Russian Interest in the Levant, 1843-1848: Porfirii Uspenskii and the Establishment of the First Russian Ecclesiastical Mission in Jerusalem," Middle East Journal 17 , nos. $1 / 2$ (1963). 
he was appointed chief of the first Russian Ecclesiastical Mission to Jerusalem, where he arrived in mid-February 1848 , and stayed until May 3, 1854, when he had to leave due to the outbreak of the Crimean War (1853-56). After the war, Porfirii was no longer head of the mission, but in 1860 , he visited Jerusalem a third and final time. During the years of Porfirii's stay in Jerusalem, he was involved in church and political activities. He was also engaged in intensive research work on the archeology and history of Palestine, Syria and Egypt. From this research, he gathered a substantial collection of manuscripts and books. At that time, his knowledge of the lives of the non-Muslim population of Jerusalem superseded that of any other Russian representative in the Christian East. The archives of Porfirii are now in good condition and are preserved in the St. Petersburg Department of the Archives of the Russian Academy of Sciences (fond 118). The Imperial Academy of Sciences acquired them after his death on April 19, 1885, as was stated in Porfirii's testament.

Porfirii left the Academy an endowment, the interest of which was bound to fund the publication of his scientific works. In 1886, two members of the Russian Imperial Academy, Bychkov and Bühler, reported on their preliminary work with the archives. At the same meeting of the Academy, it was decided that Polikhronii Syrku, a specialist in Byzantine and Old Slavonic studies, would endeavor to further systematize and describe Porfirii's archive. The outcome of this work was impressive. In 1891, a printed catalogue of Porfirii's papers appeared. ${ }^{8}$ Between 1894 and 1901, the Academy of Sciences published eight volumes of Porfirii's journals. ${ }^{9}$ Other important publications of the "Porfirii Commission" are two volumes of documents and official correspondence prepared by the Byzantine historian Pavel Bezobrazov. ${ }^{10}$ Several research studies on Porfirii's activities were carried out using both the published and unpublished archival material.11

8 Polikhronii Agapievich Syrku, ed., Opisanie bumag episkopa Porfiriia Uspenskogo pozhertvovannykh im v Imperatorkuiu Academiiu nauk po zaveshchaniiu [Description of the papers of Bishop Porfirii Uspenskii, left by him to the Imperial Academy of Sciences according to his testament] (St. Petersburg: Imperial Academy of Sciences, 1891). Porfirii Uspenskii, Kniga bytiia moego. Dnevniki i avtobiograficheskie zapiski episkopa Porfiriia Uspenskogo [The book of my being: journals and autobiographical notes of Bishop Porfirii Uspenskii], 8 vols. (St. Petersburg: Imperial Academy of Sciences, 1894-1901).

10 Pavel V. Bezobrazov, ed., Materialy dl'a biographii episkopa Porfiriia Uspenskogo [Materials on the biography of Bishop Porfirii Uspenskii]. Vol. 1, Official Papers; Vol. 2, Correspondence (St. Petersburg: Imperial Academy of Sciences, 1910).

11 Alexei Afanas'evich Dmitrievskii, Ep. Porfirii Uspenskii kak iniciator i organizator pervoi russkoi dukhovnoi missii v Ierusalime [Bishop Porfirii Uspenskii, the initiator and 


\section{Between Inspection and Messianism: An Overlap between Official Documentation and Personal Papers}

The first set of documents, which concern Porfirii's appointment to Jerusalem, are the official papers of the Holy Synod and to the Russian Ministry of Foreign Affairs. ${ }^{12}$ Most of them are preserved in at least two copies - one or more in Porfirii's archive, and the other in the archive of the Holy Synod. A third copy can be found in the Ministry of Foreign Affairs. Among them are Porfirii's letters to the over-prosecutor [Ober-prokuror] of the Holy Synod, Count Nikolai Protasov (sixteen letters), and his letters to the directors of the departments of the synod, Serbinovich (eighty-five letters), Voitsekhovich (two letters) and Karasevskii (eight letters). ${ }^{13}$ The next file (number 45 ) also contains official letters written by Porfirii, which were addressed to the Russian Ambassador at Constantinople Vladimir Titov (seventy-four letters), and to the Asian department of the Ministry of Foreign Affairs. Many of them contain detailed reports on the state of affairs in the Near East. Dossiers 46 and 47 contain 143 letters from 1848 to 1853 written by Porfirii to the Russian Consul General at Beirut, Konstantin Basili. They also include one report about the Holy Sepulchre written for Emperor Nicolas I. The official answers from these individuals form a separate file (49). Another group of interesting letters were addressed to Porfirii by the Russian consuls in Jaffa (G. Mostras) and in Beirut (K. Basili, file 5o). Porfirii also corresponded with Boris Mansurov, the founder of the Palestine

organizer of the First Russian Ecclesiastical Mission in Jerusalem] (St. Petersburg, 1906); Dmitrievskii, Porfirii (Uspenskii). Po povodu stoletija so dnia ego rozhdenija [Porfirii (Uspenskii): on the occasion of the centenary of his birth] (St. Petersburg, 1906); Dmitrievskii, "Uchrezhdenie i pervyi period deiatel'nosti Russkoi Dukhovnoi missii pod nachal'stvom Arkhimandrita Porfiriia (1842-1855)" [Foundation and first period of the activities of the Russian ecclesiastical mission under archimandrite Porfirii (18421855)], in Rossiia v Sviatoi Zemle. Documenty i materialy, vol. II., ed. Nikolai N. Lisovoi, (Moscow, Mezhdunarodnye otnosheniia, 200o). The scholarship on Porfirii's materials has been mainly focused on his scientific research in church history and manuscripts. See Archimandrite Innokentii (Prosvirnin), "Pam'iati Episkopa Porfiriia (Konstantina Alexandrovicha Uspenskogo) 1804-1885" [In memory of Bishop Porfirii (Konstantin Alexandrovich Uspenskii)] Bogoslovskie Trudy 26 (1985); Lora A. Gerd, "Porfirii Uspenskii: iz epistoliarnogo naslediia" [Bishop Porfirii Uspenskii: from his epistolograpy], in Archivy Russkikh vizantinistov v Sankt-Peterburge [Archives of the Russian Byzantinologists in St. Petersburg], ed. Igor P. Medvedev (St. Petersburg: Dmitrii Bulanin, 1995), 8-21. 118, op. 1, d. 44 .

13 Ibid., d. 44. 
Committee. Most of the letters focus on Mount Athos, but one of them concerns the new head of the Russian mission in Jerusalem after the Crimean War, Bishop Kirill Naumov. Porfirii found the appointment of a Russian bishop to Jerusalem to be unfitting because the presence of two bishops in one town was against the church canons. Furthermore, Kirill Naumov's behavior was, in his opinion, "inappropriate." Among the letters written by Porfirii to Russian high ecclesiastics, his correspondence with Metropolitan Filaret (Drozdov) of Moscow is the most noteworthy. ${ }^{14}$

The papers of the Russian mission eo ipso are conserved in two large files (238 and 352ff.) containing official correspondence between Porfirii and different persons in Russia and abroad dating from 1842 to 1854 . Apart from letters written by Basili and Titov, the files also contain the mission's financial papers and an architectural plan for the house of the Russian mission, which was eventually built in 1853 . Porfirii wrote a summary of his activities in Jerusalem. ${ }^{15}$ During his absence from Jerusalem, he was kept informed by his assistant and a member of the mission, Hieromonk Feofan (eight letters dated 1851-52). Information on Jerusalem is dispersed in all his private correspondence during his stay there. Nineteen letters were addressed to Greek high ecclesiastics; eleven of which were sent to Kyrillos II, the Patriarch of Jerusalem (1848-54, 40ff.). ${ }^{16}$

During his stay in Jerusalem, Porfirii wrote detailed notes on the history, geography, ethnography and statistics of Palestine. ${ }^{17}$ In a separate file he collected copies and translations of others' descriptions of the Holy Land as well as journals kept by pilgrims from different countries and centuries. ${ }^{18}$ Among the copies of documents written by others, the most important document is the printed report by Boris Mansurov (the founder of the Palestine Commission, dated 1858), written after his visit to Jerusalem. It was followed by a letter sent by Grand Duke Konstantin Nikolaevich to Porfirii, and Porfirii's response which outlined his opinion on Mansurov's proposals. ${ }^{19}$ Another note, which was also published later, belongs to Consul Basili and contains statistics relative to Syria and Palestine. ${ }^{20}$ Porfirii's collection is rich in illustrative

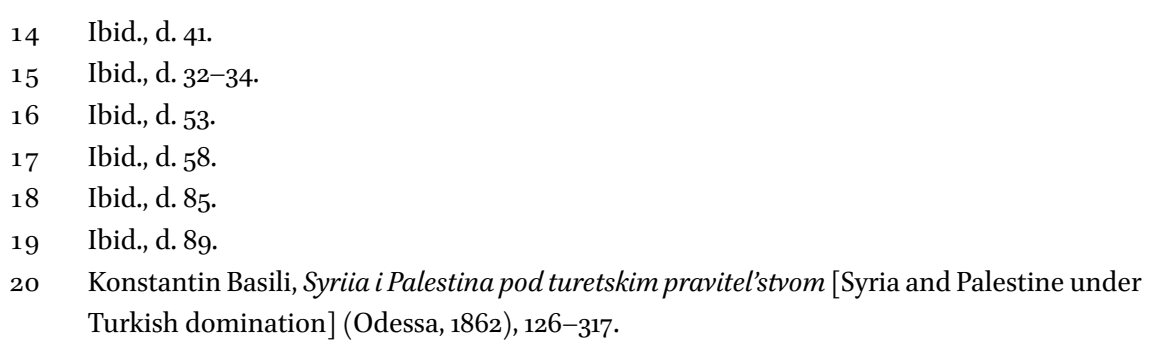


materials including engravings, sketches, drawings, and photos; seventy-six of them are related to the Holy Land and Jerusalem. ${ }^{21}$

The Russian Ecclesiastical Mission to Jerusalem was initially established to address two principal ideas. The first aim of the mission was to support Eastern Orthodoxy (both Greek and Arab) against Catholic and Protestant proselytism. The second aim was to offer aid and efficient organization to Russian pilgrimages to the Holy Land. These two aims are constantly emphasized in the majority of official and unofficial letters and notes, written between 1838 and $1842,{ }^{22}$ about the mission. On March 1, 1841, the over-prosecutor of the synod, Count Protasov, sent Emperor Nicolas I a note in which he highlighted the interests of the Russian pilgrims to the Holy Sepulchre, and the importance of providing a Russian church service for them. ${ }^{23}$ On June 13, 1842, the Minister of Foreign Affairs, Vice-Chancellor Count Nesselrode, wrote an extensive note encouraging a Russian ecclesiastical with wide-ranging functions to be sent to Jerusalem. Such an envoy could assist the Greek Orthodox clergy and the local Orthodox population. An envoy could also act as a link between the Patriarchate of Jerusalem and the Russian church. Moreover, he could gather necessary information for the Russian government. The envoy's mission would be to support Orthodoxy against Roman Catholicism and Protestantism, and to prevent the local Christians from leaving the church of their baptism. At the same time, the chosen person would have to travel independently of any official mission and would have the technical status of a mere pilgrim. ${ }^{24}$ The Vice-Chancellor's requests resulted in the appointment of Archimandrite Porfirii to the Russian mission in Jerusalem. According to the terms of his appointment, Porfirii could not interfere in any political affairs.

21 SPBFARAN, Fond 118, op. 1, d. 171, 174, 175, 191, 195. Most of the photographic views are published in Roman Gultiaev, ed., Ierusalim v 1857 godu v fotografiiakh iz kollektsii episkopa Porfiria (Uspenskogo) [Jerusalem in 1857 based on photos from the collection of Bishop Porfirii (Uspenskii)] (Moscow: Indrik, 2007).

22 See for example the note of Andrei Muraviev on the Monastery of the Cross near Jerusalem (1838) in Lisovoi, Rossiia v Sviatoi Zemle, 8; Konstantin Basili (consul in Beirut) to Andrei Muraviev, October 6/18, 1839 in Lisovoi, Rossiia $v$ Sviatoi Zemle, 9-11 and the report by Karl Nesselrode on the monasteries in Jerusalem where Russian pilgrims can stay (April 30, 1840) in Lisovoi, Rossiia v Sviatoi Zemle, 11-12.

23 Bezobrazov, Materialy dl'a biographii, vol. 1, 3-5.

24 Ibid., 5-8. A copy of this paper is preserved in: Russian State Historical Archives (in St. Petersburg) (Rossiiskii Gosudarstvennyi Istoricheskii Archiv, RGIA), fond 797, op. 11, II otd. 2 st., d. 28809. Most recent edition (following a copy from the Archives of Foreign Policy of the Russian Empire (AVPRI - Arkhiv Vneshnei Politiki Rossiiskoi Imperii), Moscow), Lisovoi, Rossiia v Sviatoi Zemle, 13-14. 
He was to act in coordination with the Russian consul in Beirut. He was responsible for ensuring the proper distribution of donations from Russia. ${ }^{25}$ The religious and political situation in Jerusalem during the 1840 s was complex. Working there as an individual with no official status in an ostensibly diplomatic capacity was challenging. Porfirii himself understood this well and ironically called himself a kataskopos (spy in Greek).

\section{Impressions and Reflections of Jerusalem in the Eye of a Learned Monk}

On December 20, 1843, Porfirii entered Jerusalem. He was greeted by a delegation of local monks who invited him to stay in the Patriarchate. Instead, he decided to live in St. Theodore Monastery, where the Russian pilgrims lived at that time. ${ }^{26}$ "I am spreading my network," he wrote on December 21; "The French consul, and me as if a consul." 27 Despite his incognito status, from his initial appearance in Jerusalem, Porfirii was regarded as a Russian resident, even though Russia had no consulate in Palestine at that time. ${ }^{28}$

After arriving in Jerusalem, he was too preoccupied to meet with the local high clergy, and to gather detailed information about the state of church affairs. During 1844, he traveled extensively in Palestine. He visited Bethlehem, Hebron, Nazareth and the monasteries of the desert. Everywhere he went, he met local ecclesiastics, and engaged in discussions with Catholics, Armenians, Greeks, and Greek Orthodox Arabs. The poverty of the Greek Orthodox Arabs struck him, especially in contrast to the wealth of the bishops of the Brotherhood of the Holy Sepulchre. ${ }^{29}$ He had serious discussions with the Armenian Patriarch in Jerusalem, who expressed his concerns about both Greeks and Catholics. He expressed hope to receive assistance from the future Russian mission. Porfirii became a friend of the Metropolitan of Bethlehem, Dionysios. The pages of his journals contain rich information on

25 Bezobrazov, Materialy dl'a biographii, vol. 1, 20-24.

26 Porfirii Uspenskii, Kniga bytiia moego, vol. 1, 353.

27 Ibid., 354.

28 See Mironenko-Marenkova and Vakh's chapter, "An Institution, Its People and Its Documents: The Russian Consulate in Jerusalem through the Foreign Policy Archive of the Russian Empire, 1858-1914," in this volume.

29 See Dalachanis and Tselikas' chapter, "The Brotherhood, the City and the Land: Patriarchal Archives and Scales of Analysis of Greek Orthodox Jerusalem in the Late Ottoman and Mandate Periods" in this volume. 
the ethnography, local customs, history and archaeology of Jerusalem and Palestine. From July 22 to August 3, 1844, he carried out research on the monasteries of Jerusalem and the library of the Greek Orthodox Patriarchate. ${ }^{30}$ In December 1844, in Constantinople, he attended the funeral of the Patriarch of Jerusalem, Athanasios. During his stay, he gathered additional information concerning the administration of the Orthodox Patriarchal See of Jerusalem, the elections of the Patriarch, and the role of Russian diplomacy. Later he was interviewed on these matters by the Metropolitan of Moscow, Filaret, an integral figure in the foreign policy of the Russian Church in the nineteenth century. According to Porfirii, the Ecumenical Patriarchate of Constantinople pretended to manage the finances of the See of Jerusalem and to appoint the high clergy there. The Russian Embassy interfered immediately, demanding to control the distribution of donations from Russia to the Holy Sepulchre Brotherhood.

The observations Porfirii made during his first stay in Palestine resulted in several extensive reports written in Constantinople during SeptemberDecember 1844, that were sent to Titov, the Russian ambassador. The first report is called "Historical note about the Arab Catholics, or Units, in Syria and Palestine" (September 5-6, 1844, Constantinople). ${ }^{31}$ From as early as 1737, Porfirii reported on Rome's efforts in order to encourage unity among the Arabs from Aleppo, Damascus, and Lebanon. The Jesuits and Armenian Catholics were also included in these efforts. He also gave a brief update on the Armenian Catholics in Palestine in the nineteenth century, reporting on the protection they enjoyed from the French consul. On October 28, 1844, Porfirii presented Ambassador Titov with a detailed note, dated October 12, on the state of the Orthodox church of Jerusalem. ${ }^{32}$

In the note, he addresses the main problems with the Greek Orthodox Patriarchate of Jerusalem. He criticized the Patriarch for living in Istanbul, rather than in Jerusalem. Furthermore, he pointed out that the Greek clergy was poorly educated and neglected the Arab clergy. According to the bishop, the Arab clergy were extremely poor and possessed little education or enlightenment. The second part of Porfirii's note focused on the Catholic mission and its success among the Orthodox population, while the third part discussed the Protestant, mainly Anglican mission. Porfirii then proposed methods of supporting Orthodoxy in Jerusalem and throughout Palestine. The suggested measures concerned the organization of regular school education, 
hospitals, and an old-age home in Jerusalem. Such establishments would not only benefit the Greeks, but also the Arabs. Finally, he presented the ecclesiastical and financial aims of the future Russian mission in Jerusalem. On the same day, Porfirii sent Titov a detailed historical essay and a description of the present state of the holy sites in Jerusalem, including statistical data on the incomes and expenses of the Temple of the Holy Sepulchre, and other important places of veneration. ${ }^{33}$ On December 3, 1844, Titov forwarded Porfirii a note written in French that had been sent to him a few months earlier by Zachariah, the Armenian Patriarch in Jerusalem. The note discussed the properties and rights of the Armenians in Jerusalem. Porfirii responded by expressing his opinion on these matters. ${ }^{34}$ His critical notes concern the historical data presented by the Armenian Patriarch (on the Christianity of the wife of King Abgar, the omission of the period between the Council of Chalcedon and Saladin's time, etc.). Porfirii was uncertain about the legal force of Saladin's firmans, but was inclined to support Zachariah's claim to the property on Mount of Olives, which had been purchased by the Armenians in 1836, and expropriated by the Catholics and Greeks in 1839. Porfirii believed the best solution was to build a church where all Christian groups could hold their own individual liturgical services.

By 1845 , the Russian mission had largely been planned. On January 6, Porfirii sent Titov a detailed plan of the mission's structure along with the aims and functions of each member. In order to avoid political suspicions, the status of the mission was still semiofficial. It was called "a pilgrimage monastery," and its members were appointed for seven years. According to the instruction on his appointment, Porfirii should have begun negotiations with the Greek Orthodox Patriarch of Jerusalem by August 28, 1847. The purpose of the negotiations was to encourage the Greek Orthodox Patriarch to agree to provide an occasional divine liturgy in Slavonic for the Russian pilgrims, as well as to educate Greek and Arab boys. The members of the mission brought official recommendation letters from the Russian Holy Synod, addressed to the Patriarch of Jerusalem. ${ }^{35}$ Before leaving for Jerusalem, Porfirii requested permission from the administration of the Holy Synod for two young Arabs to study icon painting in the St. Petersburg Theological seminary. He also requested that Russian ecclesiastical books be sold in Jerusalem for Bulgarian and Serbian pilgrims. Both requests were approved. On October 14, Porfirii left St. Petersburg

\footnotetext{
33 Ibid., $96-128$.

34 Ibid., $128-37,138-45$.

35 Ibid., 146-6o. The main contest of the report is repeated by Porfirii in his journals.
} 
for the Holy Land. On arriving in Jerusalem, he had a meeting with the new Greek Orthodox Patriarch of Jerusalem, Kyrillos II, who had been elected on March 28, 1845. They discussed the relations between the Orthodox and Armenian clergy and the Latin Catholics. In a few days, Porfirii and his three companions (Hieromonk Feofan Govorov and two students of St. Petersburg Theological Academy, Soloviev and Krylov) settled in the Monastery of the Archangels, and lived there until the beginning of 1854 .

\section{Uspenskii in the Report: Imperial Foundation Disguised?}

On June 6,1847 , Porfirii wrote a note outlining the organization and structure of the mission, addressed to K. Serbinovich, the director of the office of the Holy Synod. ${ }^{36}$ He gave a detailed account on the material life of the members of the mission. He discussed their needs, taking into attention the local peculiarities of Jerusalem. A financial note and an account of the expenses, including the salaries of the members, follow the list of items.

In a document dated January 19, 1848, but obviously finished later, Porfirii wrote an extensive report to Ambassador Titov regarding the state of affairs of the church of Palestine. ${ }^{37}$ He details the position of Patriarch Kyrillos II and the opposition party, which planned to replace him with the Metropolitan of Tabor, Ierotheos. Then he reported in brief on the conflicts between Latins and Orthodox in Bethlehem and discussed the Ottoman government's attempts to pacify the Christian confessions. He then reports on the appointment of Giuseppe Valerga, the Latin Patriarch at Jerusalem, and on the state of Catholicism in Palestine. Finally, he discusses Protestant activities and Bishop Samuel Gobat's attempts to Christianize the Jews. ${ }^{38}$ Porfirii's notes contain details on the contemporary situation, including confidential information about the internal dynamics of the Greek Orthodox Church. Special attention is paid to the missionary activities of Gobat, consecrated in 1846 as the second Anglican bishop in Jerusalem, and to his plans to convert both the Eastern Christians and the Jews to the Anglican church. Porfirii also commented on the problematic relationship between Gobat and the British authorities in the United Kingdom.

$\begin{array}{ll}36 & \text { Ibid., 261-67. } \\ 37 & \text { Ibid., 277-84. } \\ 38 & \text { Ibid., 284-85. }\end{array}$ 
The next report to Titov, dated October 4, 1848, concerns the economic aspects of the mission and the restoration of the monastery where Porfirii and his companions lived. ${ }^{39}$ It also touches upon the Holy Synod report of February $11,1849 .{ }^{40}$ Three months later, Porfirii wrote a note about the Russian pilgrims in Palestine and sent it to Basili, the consul in Beirut. ${ }^{41}$ In it, he described the urgent need to improve the poor living conditions of the pilgrims. This included plans to reorganize a permanent medical service for the pilgrims in the Archangels Monastery. The next step would address their spiritual interests. According to Porfirii, this would be the responsibility of the members of the mission. The report is followed by a list of additional expenses that needed to be covered. On November 15, 1849, Porfirii informed Titov of the needs of the Orthodox population in Palestine, which included church vessels, vestments, icons, Arabic books, and money for the poor. ${ }^{42}$ He requested an annual sum of a thousand rubles to meet these demands.

One of the main topics that were further discussed with Patriarch Kyrillos II concerned the property of the Holy Sepulchre in the Danube Principalities. Since the seventeenth century, about a quarter of the lands in Moldavia and Wallachia had been granted to the Eastern Orthodox churches and to a number of monasteries (including Sinai and Mount Athos). The earnings from these properties made up the main source of income for the Orthodox churches under Ottoman domination. After the Russo-Ottoman War of 182829, the local princes threatened to secularize these wastelands. The Russian government, which considered itself as the official protector of Orthodoxy in the Ottoman Empire, consistently stopped all attempts to reduce the rights of the church owners. Only after the Crimean War of $1853^{-56}$ did secularization become possible. ${ }^{43}$

In January 1851, Blondel, the Belgian minister at Constantinople, visited Jerusalem with the intention of restoring the tombs of the two famous Crusader kings, Baldwin and Gottfried. In a long discussion with Blondel and the Austrian consul, Porfirii tried to explain how complicated this endeavor

\footnotetext{
39 Ibid., $285-86$.

$40 \quad$ Ibid., $286-87$.

41 Ibid., $323-28$.

42 Ibid., $33^{1-36}$. See also the report from November 30 on the printing of Arab church books (ibid., 336-37).

43 See Lora A. Gerd, "Sekuliarizatsiia imenii vostochnykh monastyrei I tserkvei v Valakhii I Moldavii v nachale 1860-kh godov I Rossia" [Secularization of the properties of the eastern monasteries and churches in Walachia and Moldavia in the beginning of 1860 and Russia], Vestnik pravoslavnogo Sviato-Tichonovskogo Gumanitarnogo universiteta 6, no. 61 (2004).
} 
would be. Meanwhile, he conveyed his position on the church and national situation at the holy sites. In Porfirii's view, the holy sites belonged to all Christians, and all Orthodox peoples had equal rights as their keepers. The restoration of these tombs would have provoked jealousy and indignation from the Ottoman authorities and different Christian confessions. ${ }^{44}$

After the publication of the Hatt-l S Serîf of Gülhane in 1839 and the transformation of the administrative system of the Ottoman Empire, church reforms were planned. ${ }^{45}$ One of them was the introduction of a regular salary for the high Orthodox bishops. During his visit to Jerusalem in September 1851, the Patriarch of Alexandria, Ierotheos, discussed these reforms with Porfirii, who stressed that these measures might be harmful for the church. ${ }^{46}$ Metropolitan Filaret later developed the same ideas about the second stage of Tanzimat in the late $185 \mathrm{os}^{47}$ Porfirii was also opposed to reducing the number of the bishoprics of the Orthodox Church in the East. In his opinion, this measure would weaken the church and create opportunities for Western missionaries.

After a short journey to Russia at the end of 1851 , Porfirii focused on the restoration of the dome of the Holy Sepulchre and ensured the participation of Russia and France in the project. ${ }^{48}$ During a series of discussions with Russian diplomats and Greek clergymen, he proposed that, as an initial step, the Russian government should rent the upper floor and the roof of the temple, then inhabited by a family of noble Muslims. ${ }^{49} \mathrm{He}$ continued his mediation in family affairs of the Greek Orthodox Arabs and Greek clergy as well, trying

44 Uspenskii, Kniga bytiia moego, vol. 4, 80-83.

45 See Dimitrios Stamatopoulos, Metarrythmisi kai ekkosmikefsi. Pros mia anasynthesi tis istorias tou Oikomenikou Patriarcheiou [Reforms and secularization: towards a reconstruction of the history of the Ecumenical Patriarchate] (Athens: Alexandria, 2003), 37-45.

46 Uspenskii, Kniga bytiia moego, vol. 4, 132.

47 Sobranie mnenii I otzyvov Filareta, mitropolita Moscovskogo i Kolomenskogo, po delam Pravoslavnoi tserkvi na Vostoke [A collection of the opinions and relations of Filaret, Metropolitan of Moscow and Kolomna, on the affairs of the Eastern Orthodox Church] (St. Petersburg: Synod Print, 1886), especially 1-14.

48 The realization of this project came only after the Crimean War. See Oleg Viktorovich Anisimov, Rossiia i Napoleon III: bor'ba za Sviatye Mesta Palestiny [Russia and Napoleon III: the struggle for the holy sites of Palestine] (Moscow: Indrik, 2014).

49 Besides the journals, very informative on the question of the dome is Porfirii's note from October 31, $185^{0}$ addressed to Consul Konstantin Basili (Bezobrazov, Materialy dl'a biographii, vol. 1, 338-47). Here he expressed his ideas on purchase of the whole house for 50,000 rubles and its reconstruction for the Russian mission for another 50,000. 
to support Arab priests and parishes when possible. ${ }^{50}$ Once more, he proposed to try and pacify relations among Christian confessions in Jerusalem. According to Porfirii's proposal, none of the three (Orthodox, Catholics or Armenians) would perform their liturgy in the temple, but they would go there for prayer.

From $185^{2}$ on, Porfirii was busy with the construction of the building for the Russian mission. On April 16, 1852, he addressed a note to the Russian chargé d'affaires in Constantinople, A. Ozerov, about this project. In it, he provided details about the funding of the construction by Patriarch Kyrillos II and about the Russian obligations in the project. ${ }^{51}$ Porfirii's archives contain several unpublished plans of the area and designs for the future building. ${ }^{2}$ Moreover, it appears that the reorganization of the Patriarchal school at the Holy Cross Monastery in Jerusalem and the foundation of an Arab printing house under Porfirii's direction were significant events in the early 185 os. $^{53}$ According to Porfirii's account, the printing house was organized in St. Nicolas Monastery under the typographer Lazaridis. The machines and the letters (both Greek and Arabic) were acquired in Paris, and the printing house was supposed to produce all liturgical books. Patriarch Kyrillos II appointed Porfirii as supervisor of the schools and the printing house.

After a short stay in Jerusalem in January-May 1854, Porfirii and the members of his mission, followed by some Russian pilgrims, had to leave Jerusalem. The beginning of the year had been marked for Porfirii by the conflict between the Latin Patriarch Valerga and the Orthodox inhabitants of the village of Beit Jala. On the French consul's demand, the Ottoman authorities imprisoned the inhabitants. Porfirii could not defend them openly, and expressed his sympathy only by sending them food at Easter. ${ }^{54}$

On the whole, the activities of the First Russian mission to Jerusalem were rather limited. Almost all of Porfirii's initiatives were paralyzed by the cautiousness of the Russian Ministry of Foreign Affairs and the international context. This institution can hardly be compared to the large-scale Russian activities

\footnotetext{
50 Bezobrazov, Materialy dl'a biographii, vol. 1, 338-47.

$5^{1}$ Ibid., $35^{6-59 .}$

$5^{2}$ SpbFARAN, fol. 118, op. 1, d. 33, fols. 179-83.

53 See Porfirii's report to A. Ozerov, November 15, 1852. Bezobrazov, Materialy dl'a biographii, vol. 1, 361-70.

54 Uspenskii, Kniga bytiia moego, vol. 4, 174-216. Details of the conflict are described by Porfirii in the report to the Asian department of the Ministry of Foreign Affairs, dated January 30, 1854. Bezobrazov, Materialy dl'a biographii, vol. 1, 376-429. This paper is in fact a general observation of Porfirii's activities in Palestine, beginning with his appointment and arrival in Jerusalem.
} 
that took place in the second half of the nineteenth century. Putting aside the major research work carried out by the members of the mission, the only essential result of its work was Porfirii's participation in the educational projects of Jerusalem Patriarch Kyrillos II.

\section{The Legacy of the Archimandrite Scholar and Its Unpublished Part}

After the Crimean War, Porfirii was no longer appointed to Jerusalem. He devoted the rest of his life to his research on the archival material, mainly manuscripts, that he brought to Russia from the Near East and the Balkans. After his time in Jerusalem, he was ordained bishop in Kiev, and later lived in Moscow. Nevertheless, his opinion as an expert on Palestine continued to be solicited. On January 6, 1858, following a request from Grand Duke Konstantin Nikolaevich, Porfirii responded to a proposal by Boris Mansurov, the future chief of the Palestine Committee, on the subject of organizing support for Russian pilgrims. ${ }^{55}$ Porfirii pointed out the necessity of establishing a Russian consulate at Jerusalem so that Russian pilgrims would be protected and helped. His view on the Russian donations to the Greek church in Jerusalem diverged strongly from that of the Foreign ministry. In Porfirii's eyes, Russia had no business concerning itself with the uses made of donations. The increasing number of pilgrims was a far more important concern. On the whole, Porfirii highly appreciated Patriarch Kyrillos' behavior towards the Russians and bitterly accused the Russian government for lack of support during his stay in Jerusalem in 1847-54. According to Porfirii's observations, the activities of the Western missionaries did not prove to be particularly threatening for Orthodoxy in Palestine. Even if Arabs converted to Catholicism or Protestantism, they quickly returned to the Orthodox Church in most cases. Porfirii advised the Russian authorities to use the Palestinian Jews of Russian origin to receive information. Finally, instead of placing a Russian missionary among the Orthodox population of Palestine, he proposed delegating an apokrisiarios (a permanent representative of the Russian church at the Patriarchate of Jerusalem). ${ }^{56}$

55 Bezobrazov, Materialy dl'a biographii, vol. 1, 429-68.

56 The restoration of the ancient church tradition of apokrisiarioi was discussed many times by prominent Russian and Greek ecclesiastics during the nineteenth century (Archimandrite Antonin Kapustin, Patriarch of Constantinople Ioakeim III, etc.). It was also under discussion in the Russian Holy Synod. Nevertheless, the subject always 
Porfirii's last visit to the Holy Land was from February 16, to July 23, 1860. Upon arriving in Jerusalem, after finding that his private belongings were safe, he went to visit old friends from the Greek clergy. Most of his time was spent on his research on the manuscripts, icons, and architecture of the Monastery of St. Sabbas, the basilica in Bethlehem, and the Monastery of the Holy Cross in Jerusalem. A number of sketches of these sites were made and later included by Porfirii in the text of his journals. He met European and Russian diplomats as well, but did not discuss political matters. His comments on the new leader of the Russian ecclesiastical mission bishop, Kirill Naumov, are quite critical. Naumov would, incidentally, soon be called back to Russia. ${ }^{57}$ During this final stay, Porfirii wrote four reports, addressed to the over-prosecutor of the Holy Synod, A. P. Tolstoi. The reports focused on the end of his stay in Jerusalem and his future service in Russia.

Two large files with documents, both published and unpublished, on the first Russian mission to Jerusalem are preserved at the Archives of the Holy Synod in St. Petersburg. ${ }^{58}$ There, one finds official reports from Porfirii to the synod recounting his arrival in Jerusalem, his move into the Archangels Monastery in 1848 , and the restoration of the rooms of the monastery. The Russian Synod rewarded Kyrillos' hospitality to the mission: instead of an annual sum of 300 Russian rubles rent, he received 700 rubles beginning in 1849. ${ }^{59}$ Many of the papers in the files concern financial matters, the appointment of new members, and a translator, Fadlala Saruf. ${ }^{60}$ Other papers include details on Porfirii's research journeys to Egypt and Sinai, his departure to Russia, and return trip to Jerusalem in $185^{1-52}$. A common topic of discussion was the construction of the new Mission building. Subjects on this topic included the Russian government's funding of the construction and budget required by the project. Patriarch Kyrillos II financed the initial construction, but the Russian Synod planned to cover all the expenses (12,00o rubles) over the course of four years. The synod's assumption was that the land and

managed to get buried in the paper routine of the ultraconservative and cautious governmental and church institutions, and the idea never became reality.

57 Uspenskii, Kniga bytiia moego, vol. 7, 225-75.

$5^{8}$ RGIA, fond 797 (Chancellery of the over-prosecutor of the Synod), op. 11, 2nd dept., 2d bureau, files 356 a and $\mathrm{b}$.

59 RGIA, K. Nesselrode to A. Protasov, December 7, 1848. Ibid., fols. 189-89v.

6o RGIA, Correspondence on the expenses of the mission (1850). Ibid., fols. 244-49v. Note by Porfirii on the appointment of new members of the mission, October 31,1851 , fols. $288-89$. 
building would become Russian property. ${ }^{61}$ In a letter, Porfirii informed overprosecutor Protasov about the Patriarch's invitation to become a curator of the Orthodox schools in Palestine. ${ }^{62}$

Porfirii's presence in Jerusalem was highly appreciated by the Ministry of Foreign Affairs, especially in the early 1850 s, when questions arose about the holy sites in Palestine. ${ }^{63}$ Several letters to the officials of the synod deal with the beginning of the war with Turkey in 1853 , the danger of further stay in Jerusalem, and a possible move to Beirut or Greece. ${ }^{64}$ Finally, official documents on the closing of the mission and discontinued funding are preserved in the same dossier. ${ }^{65}$ Many letters and reports from this file are originals, while some copies can be found in the Ministry of Foreign Affairs archives and in Porfirii's personal archives.

\section{Conclusion}

The value of Porfirii's archives was recognized long before the revolution of 1917. This serves to explain why special efforts were undertaken to publish them. The question we ask now is whether these publications cover his entire legacy. The journals published by Polikhronii Syrku contain not only the text of his notebooks, combined and ordered from different files, but his sketches and drawings as well. Nevertheless, a comparison with the archives themselves shows that the occasionally unpublished original letters written by others are filed to his handwritten journals. Even more gaps and additional data can be found in the publication of the correspondence and official papers. For example, all financial reports of the mission, as well as numerous letters on its economics and organization, remain unpublished. Through its systematic inventory work, the Open Jerusalem project is able to deliver a retroactive reconstitution of the Porfirii Uspenskii fonds through published and,

61 RGIA, K. Nesselrode to A. Protasov, January 30, 1850. Ibid., fols. 229-30; further correspondence, fols. 252-59. L. Seniavin to A. Protasov (on an expertise in situ whether the construction of a new house was really needed, October 10, 1859), ibid., fols. 268-69. Extract from the decision of the synod about the building of a new house (August 13, 1852, ibid., fol. 338), etc.

62 RGIA, Porfirii to Protasov, October 9, 1852. Ibid., fols. 349-49v.

63 RGIA, L. Seniavin to A. Protasov, September 10, 1852. Ibid., fol. 342.

64 RGIA, Porfirii to Serbinovich, ibid., fols. $385^{-86 v}$.

65 RGIA, Extract from the decision of the Holy Synod, December 22/31, 1854. Ibid., fols. 389-90. 
in some cases, online documentation. As such, it is now possible to distinguish diplomatic from personal papers without obscuring the close and necessary interweaving between them. Even though he appears as one of the bestdocumented actors in Russian "Oriental" history in the nineteenth century, Porfirii deserves further attention. Previous publications of source texts do not preclude later publications of other texts once considered unimportant or marginal. The initial publication of Porfirii's archives obscured some of the material context of the documents and failed to reveal the variety of the sources from which the documents were derived. In so doing, personal, collective, and state archives were amalgamated and confused, and the result was a monumental publication meant to memorialize rather than to reveal complexity. Instead of calling upon the mutual critical efforts of historians and archivists, this editorial strategy sought to contribute to a political and religious hagiography. The many large-scale publication projects dedicated to Porfirii's "missionary" work reveal how his personal papers have been politically and nationally instrumentalized throughout time. Such projects, essentially trivial, lend particular urgency to the archival work of the Open Jerusalem initiative and justify the systematic revisiting of the contexts and logics that guided past archival and editorial work on the "Russian presence" in Palestine before 1917. 


\title{
The Brotherhood, the City and the Land: Patriarchal Archives and Scales of Analysis of Greek Orthodox Jerusalem in the Late Ottoman and Mandate Periods
}

\author{
Angelos Dalachanis and Agamemnon Tselikas
}

Could opening the archives of the Greek Orthodox patriarchate endanger the peaceful coexistence of communities in Jerusalem? What would be the impact of these largely unexplored records on our understanding of the history and life of Jerusalem? These questions echo the apprehension, which prevails in some of Jerusalem's ecclesiastical and academic circles, both within and outside of the patriarchate. ${ }^{1}$ This apprehension is not without reason. The Greek Orthodox patriarchate is the oldest Christian institution in the Holy Land, the principal custodian of the Christian sacred shrines and one of the most important nonstate landowners in Palestine and Israel today. ${ }^{2}$ It is administered by the Brotherhood of the Holy Sepulchre. Because of the patriarchate's central and multilayered role, its archives, which cover a period of almost a thousand years, are expected to provide information and answers to inquiries regarding the city's Christian population and beyond. These archives record not only the patriarchate's institutional life and its relationship with imperial, religious, and state authorities throughout centuries, but also the life of the Greek Orthodox community, namely of the Greek and Palestinian Arab subcommunities that formed the clergy and the flock. Additionally, these records contribute to our understanding of ordinary Jerusalem life and of the meaning of citadinité in this setting. This chapter is the outcome of the collaboration between an archivist and a historian. We aim to present - for the first time in a language other than Greek - the collections and series of the patriarchate's archives, especially from the late Ottoman and British Mandate periods, and to

1 We are grateful to His Beatitude, the Patriarch of the Holy City of Jerusalem and all Palestine, Syria, Arabia, beyond the Jordan River, Cana of Galilee, and Holy Zion, Theofilos III, who permitted us to consult the records of the patriarchate.

2 Itamar Katz and Ruth Kark, "The Church and Landed Property: The Greek Orthodox Patriarchate of Jerusalem," Middle Eastern Studies 43, no. 3 (2007).

(C) ANGELOS DALACHANIS AND AGAMEMNON TSELIKAS, 2018 | DOI:10.1163/9789004375741_009 This is an open access chapter distributed under the terms of the prevailing CC-BY-NC-ND License at the time of publication. 
understand Jerusalem's citadinité through the comparison of the patriarchate's involvement in the city's affairs on broad and narrow scales. We argue that a deep knowledge of the institutional framework of the Greek Orthodox patriarchate is necessary in order to approach the archival fond itself. In particular, we argue that it is important to consider the material and intellectual organization, classification, and, finally, the history of the patriarchate.

\section{The Patriarchate: A Steadfast Player in an Ever-Changing Context}

The Greek (or Rum) Orthodox patriarchate in Jerusalem, which sees itself as the "mother of the churches," is an independent, self-governed church headed by the patriarch, who is considered to be the successor of St. James, the first bishop and patron saint of the Holy City. ${ }^{3}$ The terms Greek Orthodox and Rum Orthodox are in essence synonyms. The Ottoman Turkish term Rüm signifies the Byzantine roots of the institution when Constantinople was known as the "New Rome" and refers also to the millet-i Rüm, the Orthodox confessional community that was formed during the Tanzimat and administered itself under its own set of rules. To this day, some Palestinian Arab Greek Orthodox use the term Rüm to distinguish themselves from the term "Greek," which they object to because of the ethnic and national affiliation that it signifies.

The Greek Orthodox patriarchate is one of the four ancient Orthodox patriarchates. The other three are the Ecumenical Patriarchate of Constantinople;

3 For the history of the patriarchate until the first decades of the twentieth century, see Chrysostomos A. Papadopoulos, Istoria tis ekklisias ton Ierosolymon [History of the church of Jerusalem] (1910, repr., Thessaloniki: Pournaras, 2010); Konstantinos Papastathis, "To keno exousias sto Patriarcheio Ieorosolymon, 1917-1918" [The power vacuum within the Orthodox patriarchate of Jerusalem, 1917-1918], Historica 51 (2009); Papastathis, "Secularizing the Sacred: The Orthodox Church of Jerusalem as a Representative of Greek Nationalism in the Holy Land," Modern Greek Studies Yearbook 2014-15, 30-31 (2016); Daphne Tsimhoni, "The Greek Orthodox Patriarchate of Jerusalem during the Formative Years of the British Mandate in Palestine," Asian and African Studies 12, no. 1 (1978). For a broader but still Greek-centric perspective, see Sotirios Roussos, "Greece and the Arab Middle East: The Greek Orthodox Communities in Egypt, Palestine and Syria, 1919-1940" (PhD diss., soAs, University of London, 1994). The most detailed study on the matter remains the report of the Bertram and Young Commission: Anton Bertram and John W. A. Young, The Orthodox Patriarchate of Jerusalem: Report of the Commission Appointed by the Government of Palestine to Inquire and Report upon Certain Controversies between the Orthodox Patriarchate of Jerusalem and the Arab Orthodox Community (London: Oxford University Press, 1926). 
the Patriarchate of Antioch and all the East, now based in Damascus; and the Patriarchate of Alexandria and All Africa. The cities hosting the four patriarchal sees may appear odd to a contemporary observer who is not familiar with the history of Christianity in the area, yet they correspond to the centers of the initial expansion of Eastern Christianity in a direction opposite to Rome: namely southwards and eastwards of Constantinople. Unlike in the Catholic Church, there is no supreme governing authority among the four patriarchates. Rather there is an honorary hierarchy within which the Jerusalem institution is ranked fourth (after Constantinople, Alexandria and Antioch) because it was the last of the four to be created after the Council of Chalcedon in 451. From this point on, the Jerusalem bishopric was upgraded to a patriarchate, mostly for symbolic reasons and despite its restrained territory. The patriarchate initially comprised of only Jerusalem and its close environs. ${ }^{4}$

The jurisdiction of the patriarchate of Jerusalem now extends far beyond the Holy City. It stretches from the eastern coast of the Mediterranean to the Arabian Peninsula. Within this broad geographical area, where numerous states now exist, the political, demographic and religious map has been constantly changing over the last 1,566 years, often quite radically. After centuries as a Roman province, the area became part of Byzantium and later of the Arab caliphates. The Ayyubid and Mamluk dynasties, the Ottomans, and later the British came to rule over it, though one must take into account the Crusaders, the Mongols and the Seljuqs. In all cases the imperial and other administrative centers were located far away from Jerusalem, a fact that contributed to the patriarchate's autonomy as well as to the consolidation of its authority over the sacred shrines. Successive scissions in Eastern Christianity from the fourth century onwards split the Christians of the region into various doctrines and churches, with differences stemming from geographical position, language, and sets of symbolisms.

Despite the frequent changes in the region, the patriarchate managed to preserve the same solid yet atypical administrative model throughout the centuries: it has always been run by the Brotherhood of the Holy Sepulchre (Hagiotaphite). ${ }^{5}$ It is worth asking how and why this came about. After the new Christian religion became the official faith of the Roman state and monumental churches were built, a considerable number of clergymen who had

4 Louis Bréhier, Le monde byzantin, vol. 2, Les institutions de l'Empire byzantin (Paris: Mimésis, 2015), 363-65.

5 Memorandum on the Monastic Character of Administration of the Greek Orthodox Church if Jerusalem (Jerusalem: Greek Convent Press, 1923). 
been leading a monastic life created the regiment of spoudaioi (magnificent) in 326. The spoudaioi were lettered monks dedicated to study and devoted to the guardianship and maintenance of the Church of the Resurrection in Jerusalem. This regiment developed over time into the well-known brotherhood of today. Senior bishops were recruited or appointed from their ranks, a practice that continued even after the spoudaioi system became the brotherhood - most probably during the fifth century. ${ }^{6}$

During the Byzantine period, the Jerusalem Church was highly regarded by the Ecumenical Patriarchate of Constantinople. The fact that Jerusalem bishops were invited to the capital to participate in ecumenical synods is a strong indication of this relationship. After the Ottoman conquest of Palestine in $1516-17$, the links of the Jerusalem patriarchate with the Ecumenical Patriarchate became more pronounced and contributed to the Hellenization of the former. This occurred mainly because the selection of the new patriarch in Jerusalem was highly influenced by the Ecumenical Patriarchate, controlled by a Greek-speaking clergy, and the equally Greek-speaking Stambouliote elite of Fanariotes. After his election, the patriarch of Jerusalem resided in Istanbul, whereas the brotherhood supervised the Holy Land in situ. According to the regulations of the brotherhood, which were set in the seventeenth century, the patriarch had to be the head of the brotherhood and was chosen from among its members. ${ }^{7}$ Theoretically, membership in the brotherhood has always been free and independent of any ethnic or national affiliation. However, the choice of the bishops and the patriarch has been customarily made among the Greek-speaking members of the brotherhood and, after the foundation of the Greek state in 1830, among Greek nationals. Thus, the brotherhood's functioning, which resembles that of a "closed corporation," 8 explains how the patriarchate's Greek character has been preserved throughout the years despite pressure from several Slavic churches to gain control of the Christian sacred shrines or the patriarchate itself. As a result of its strong Greek character, all requests from Palestinian Arab Christians to participate more actively in the patriarchate's governance have been rejected. This is in spite of the fact that Palestinians have constituted a large - and often the

6 Panayiotis J. Vatikiotis, "The Greek Orthodox Patriarchate of Jerusalem: Between Hellenism and Arabism," Middle Eastern Studies 30, no. 4 (1994).

7 Sotirios Roussos, "Eastern Orthodox Perspectives on Church-State Relations and Religion and Politics in Modern Jerusalem," International Journal for the Study of the Christian Church 5 , no. 2 (2005).

8 Vatikiotis, "The Greek Orthodox Patriarchate." 
largest - part of the Greek Orthodox congregation. Today they make up the congregation almost exclusively. ${ }^{9}$

The close links between Jerusalem and the Ecumenical Patriarchate of Constantinople, and consequently the Ottoman administration, undoubtedly contributed to the rights and privileges that the Ottoman authorities granted to what was also referred to as the Church of Zion. Due to the strong identification of the patriarchate's senior clergy with the members of the brotherhood, the fraternity and the patriarchate have become almost inseparable entities and maintain the role of custodians of the holy sites, even until today, sometimes jointly with the Roman Catholic and the Oriental churches (Armenian, Coptic and Ethiopian) according to the Status Quo, the set of regulations established during the Ottoman era. ${ }^{10}$ During the nineteenth century, Greekspeaking and Greek-born individuals progressively felt they belonged to a distinct ethnicity. A similar sentiment can be found among many other confessional communities of the Ottoman Empire including Palestinian Arabs, who also gradually developed ethnic or national aspirations. The foundation of the Greek state in 1830 and the impact it had across the eastern Mediterranean consolidated this feeling and the dominant place of the Greek clergy within the patriarchate. Likewise, the patriarchate was placed, to an extent, under the protection of the newborn state and remains so to this day. The Greek clergy still controls this institution, as well as the other two ancient patriarchates in Constantinople and in Alexandria. However, this is no longer the case for the patriarchate of Antioch, whose Arab-speaking priesthood took control after the native Arab Greek Orthodox, Meletios of Latakia, was elected patriarch in 1899, taking advantage of the emerging wave of Arab nationalism in the region. ${ }^{11}$

9 For the issue of the Palestinian Arabs in Jerusalem and Palestine during the Mandate, see Laura Robson, Colonialism and Christianity in Mandate Palestine (Austin: University Press of Texas, 2011); Noah Haiduc-Dale, Arab Christians in British Mandate Palestine: Communalism and Nationalism, 1917-1948 (Edinburgh, Edinburgh University Press, 2013).

10 Konstantinos Papastathis, "To proskynimatiko zitima stin Palestini: Apo tin othomaniki kyriarchia stin vretaniki entoli 1914-1931" [The question of the Holy Places of Palestine: From Ottoman rule to the British Mandate, 1914-1931] (PhD diss., Aristotle University of Thessaloniki, 2008); Papastathis, "Religious Politics and Sacred Space: The Orthodox Strategy on the Status Quo Question, 1917-1922," Journal of Eastern Christian Studies 65, nos. 1/2 (2013).

11 See Paschalis M. Kitromilidis, "The Legacy of the French Revolution: Orthodoxy and Nationalism," in The Cambridge History of Christianity, vol. 5, Eastern Christianity, ed. Michael Angold (Cambridge: Cambridge University Press, 2006); Denis Vovchenko, "Creating Arab Nationalism? Russia and Greece in Ottoman Syria and Palestine (18401909)," Middle Eastern Studies 49, no. 6 (2013). 
The ruling body that elects the patriarch is the Holy Synod. Its members are the senior bishops of the patriarchate and members of the Brotherhood of the Holy Sepulchre. The patriarch himself is the head of the brotherhood and president of the Holy Synod, while the executive authority of patriarchal and synodical decisions has been entrusted since the late sixteenth century to four bishops in charge of different services: the dragoumanos (dragoman) is responsible for the relations with the state and the representatives of the other religions; the kamarasis deals with the internal affairs of the patriarchate; the skevofylax deals with property issues along with the supervision of the Status $q u o$ and the rights of the patriarchate on the holy sites, and the archigrammateas (secretary-general) deals with all secretarial affairs (correspondence, library and archives). In the mid-nineteenth century some other intermediary positions were created, such as the economic and real estate commissioners who are, respectively, the heads of the economic and real estate commissions and the ecclesiastical court supervisor.

\section{The Patriarchal Archives: A Recent Service of an Old Institution}

Despite its long administrative tradition, the Greek Orthodox patriarchate created a distinct archival service only in the early twentieth century and placed it under the authority of the archigrammateas. ${ }^{12}$ Today, most of the material is hosted in a two-story building within the patriarchal complex and contains documents from the tenth to the late twentieth centuries. The pilgrimage series and the real estate series make up the initial nucleus of the records. The former contains mainly caliphal decrees and sultanic firmans referring to the privileges and rights of the patriarchate over the sacred shrines, which were classified twice or three times through the centuries, according to the marks on their back pages. These documents ended up in seven separate subseries with specific numbering and are now part of the VII.B series of the archives' current inventory. The second series consists of property titles of monasteries, churches, rural areas and buildings, and is classified in the series from IV.A. to IV. $\Gamma$ in the current inventory. It is evident why these two series

12 Most information regarding the patriarchal archives comes from the introduction to Agamemnon Tselikas' inventory: Agamemnon Tselikas, Katagrafi tou archeiou tou Patriarcheiou Ierosolymon [Register of the Jerusalem patriarchate archives] (Athens: Deltio tou Istorikou kai Paleografikou Archeiou tou Morfotikou Idrymatos tis Ethnikis Trapezas tis Ellados, 1992), 17-32. 
were the most sensitive and valuable documents, and one can understand why the patriarchate was urged to establish an archival service to protect them.

When the archives were created in the early twentieth century, these two series were placed in the first chamber of the first floor. Responsible for this work was Dimitrios Ninos, a member of the local Greek Orthodox community who was fluent both in Arabic and Ottoman, assisted by a monk named Gorgias. In 1928, another monk named Andreas became the official registrar of the patriarchate and he mainly dealt with the establishment of the Great Estate Cadaster and with improving the organization of the two aforementioned series. At the same time, the patriarchate requested from its representative in Istanbul, Vladimiros Mirmiroglou, a person with a deep knowledge of the Ottoman language, the creation of an inventory containing the sultan's orders, which were kept in the archive of the Hexarchy of the Holy Sepulchre in Istanbul and were at that time transferred to Jerusalem. In a report that Monk Andreas wrote in 1945, he informed the Holy Synod that he had created an index (kleida) of the real estate series and finally suggested the creation of a historical archive, the realization of which proved to be difficult at the time due to the lack of translators for the Arab and Turkish documents.

The content of the archives was continually expanded through the post-World War II period. Initially, the incoming and outgoing patriarchal correspondence, kept in bound volumes along with a series of files of the administrative archive, were added and placed in two rooms of the upper story. A third chamber of the first floor was filled with files, cases, and registers from the economic and the real estate commissions. The existence of the Real Estate and the Pilgrimage series was gradually undermined because documents utilized in judicial cases were rarely returned to their original place. Archimandrite Kallistos, a former librarian of the patriarchate, tried in the early 1980 os to reorganize these two basic series, without success. Later on, in 1983, the Center for Byzantine Studies of the Greek National Foundation for Research (EIE) organized a mission, headed by Chrysa Maltezou and Kritonas Chrysochoidis, to accommodate the economic series archives, but the task was not accomplished.

In response to these failures, the Historical and Paleographic Archive (IPA) of the National Bank of Greece Cultural Foundation intervened. The IPA was established in 1974 to create a microfilm (and later a digitized) database of Greek-language manuscripts and historical archives that are kept in major libraries and archives in Greece and elsewhere. It also aims to provide consultation and information about the study of Greek manuscripts in collaboration with archivists, philologists, and historians. Since the foundation of the IPA, more than 200 missions have been completed, during which almost 9,500 
manuscripts have been digitized, as well as 20 full archival fonds (including the archives of the Catholic bishops of the Cycladic islands, the Greek Orthodox patriarchates of Alexandria and Jerusalem, the archdiocese of Cyprus, several monasteries of Mount Athos and Chalki Theological School), 150 codices and dozens of books from the eighteenth and nineteenth centuries. In parallel to the above missions, the IPA maintains a specialized library. It is currently completing an index of seventeenth- and eighteenth-century Greek codices, and has organized weekly seminars on paleography since the 1990s. These seminars, well-known among Greek academic circles, have been widely attended by philologists, historians, and other students, and have trained generations of paleographers in Greece. The IPA publishes a monthly bulletin presenting news about their collection of digitized documents and archives.

\section{The Agamemnon Tselikas Missions and Inventory, 1988-92}

The director of the IPA, Agamemnon Tselikas, and his team, whether working alone or collectively, carried out nine missions over the course of 170 days from July 1988 to November 1991. The objective of these missions was to create an inventory of the patriarchal archives. This was an ambitious and demanding project, full of methodological and linguistic challenges that nonetheless resulted in an inventory published in Greek in $1992 .{ }^{13}$ One might imagine that the classification of the patriarchate archival material would come after the list of services and offices of the institution. However, the distribution of power and duties among commissions within the patriarchate was often fluid and at times very much centralized around the patriarch. Therefore, the classification according to bureaucratic procedure was not always respected and this is reflected to a large degree in the organization of the documents. Tselikas' team tried to maintain the original classification of the material and add new categories whenever possible. Even though inconsistencies in the previous classifications were occasionally detected, these were left untouched in order to preserve the history of the archive itself. At times, there are gaps between registers or files, which are due either to the loss of material or to the fact that even when this work was underway, the patriarchal services had not yet organized the material. The team also tried to keep the original writing on the boxes, even though words were sometimes spelled incorrectly. This preserves an idea of what the bureaucratic mindset could have been at different times. The matching of labels with content was always checked and, whenever there was an

13 Tselikas, Katagrafi tou archeiou [Registry of the archives]. 
inconsistency, this was mentioned. Many documents are dated according to the Muslim calendar and a few older documents according to the Byzantine calendar. Dates of both systems were maintained but the archivists also provided the date in the current Gregorian calendar. The two basic criteria for classification were the content and the form of the material. Concerning the content, Tselikas structured the material around five major themes: economy, real estate, pilgrimage, administration, and correspondence. As for the form, two different kinds of records were distinguished: the registers and the codices on the one hand, and the nonbound (or flyleaf) documents on the other. Thus, he created nine separate series and numerous subseries, which are indicated with codes combining Latin and Greek numerals.

The financial series (registers and codices) consists of twelve subseries whose codes range from I.A to I.IB. The first (I.A) contains 392 registers of an elongated shape, classified during the 1983 mission of the EIE. The majority dates from the mid-seventeenth to the mid-nineteenth centuries. They are mostly economic and income registers, diaries and volumes regarding the patriarchate's budget, expenses, and different sources of income. The following seven subseries (I.B to I.H) created during the IPA missions contain registers of income and accounting books of the patriarchate's different services and especially of the economic commission and the Holy Sepulchre from the

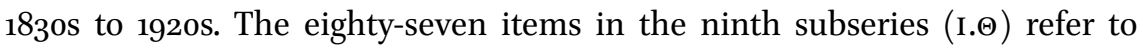
the auxiliary services of the patriarchate's branches and several monasteries in Palestine, while the items starting in 1843 and ending in 1898 of the tenth (I.I) subseries refer to institutions outside Palestine. The eleventh series (I.IA) contains 243 boxes of receipts of the economic commission starting in 1882 and ending in 1909. Finally, the twelfth series (I.IB.), "Duplicates of Food Management," consists of small duplicated sheets from 1890 to 1910, with the following inscriptions: "Usage of olive oil, soap, pulses, coffee, sugar, cod, octopus, potatoes, petrol and cheese, along with meat for the hospital, meat for the patriarchate, bread for the oil press of the Holy Cross and the harvesting of grapes."

The economic series of nonbound (or flyleaf) documents consists of five different series (codes II.A to II.E) deriving from the economic and real estate commissions, for documents of a purely an economic nature (rent collection, tax payments, loan bonds, etc.). Here, one can also find bonds and debt securities along with various documents of economic nature. These records are not only useful for the study of the internal structure of the patriarchate, but they also provide important information about the Greek Orthodox community, especially when it comes to the management of schools, hospitals, and other 
philanthropic initiatives of the patriarchate. Moreover, catalogs of suppliers to the patriarchate and remuneration statements of Arab and Greek technicians and workers of the patriarchate offer insights into the relations of the institution with the two subcommunities.

The registers of the real estate series contain three different series (codes III.A to III.Г) covering a long period from the eleventh to the early twentieth centuries. The first one (III.A) encompasses registers of dowries (inventories of movable objects of different temples and monasteries or services), along with lease and land registers in Greek and other real estate commission documents. Some real estate commission registers have economic content but are not integrated into one of the two economic series because they refer to specific edifices. Similarly, the correspondence of this commission was not placed in the correspondence series, but rather remained here. The second subseries (III.B) is part of the present-day documentation of the patriarchate and therefore remains at the secretary-general's office. A third subseries (III. ) includes nineteen land registers in Arabic and Ottoman and those that appear in the inventory as undeclared (adilon).

The nonbound (or flyleaf) documents of the real estate series contain five subseries (IV.A to IV.E). The first, which had been partly classified and registered by Dimitrios Ninos and the monk Andreas, comprises 239 tubes with a special external inscription. In their interior, one may find wrapped documents, perhaps the most valuable material of the patriarchal archives. Most of the documents are in Arabic and Ottoman and are rich in insights about diplomacy and the topography of Palestine; Jerusalem in particular. One of the oldest original documents of the archive is dated to 1166, during the Crusades. The text is in Arabic but the signature is in Greek (IV.A.218, 1). The initial numbering of the cylinders remained unmodified and the documents inside were classified in chronological order, with undated documents placed at the end. In some cylinders, the external inscription does not match the content of the documents or their actual number. This is due to problems with the earlier classification systems that were inherited by subsequent efforts. Tselikas' team preferred to leave this unchanged but noted the problem. The monk Kallistos must have arranged the second subseries of the real estate flyleaf documents (IV.B) according to city or region. These documents have been placed in green envelopes and they are dated up to the 1940s. The third subseries (IV.Г) contains property titles of the Old City of Jerusalem mostly in Arabic and Ottoman, and is sorted by neighborhood. The fourth subseries (IV.s) consists of files concerning various real estate cases with no apparent link to the patriarchate's housing service. This subseries also contains bundles of documents from 


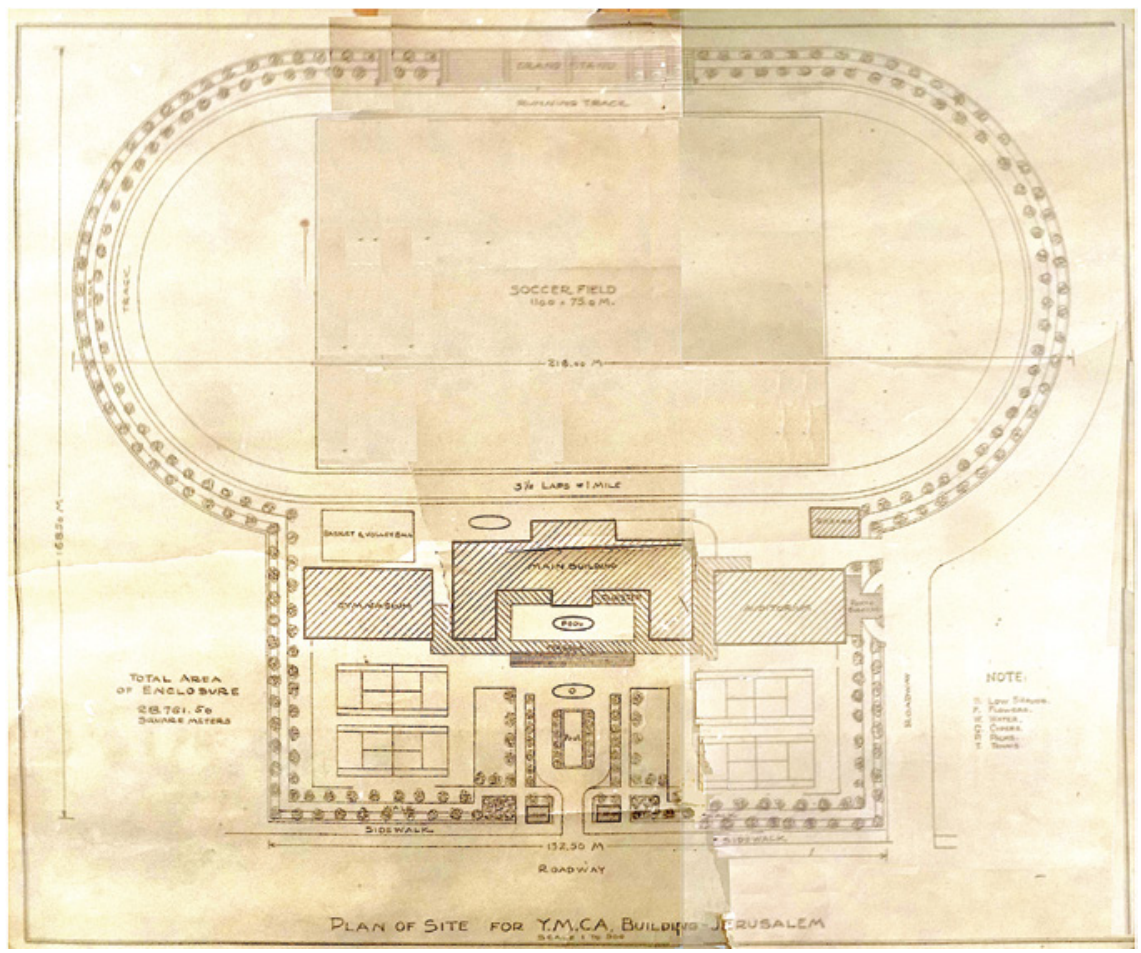

FIGURE 6.1 Plan of site for YMCA building and soccer field in Jerusalem. AEPI, IV.E, 14, JERUSALEM: YMCA BUILDING (SOCCER FIELD).

previous temporary classifications and other scattered documents. Three different files (112-14) have been added to this series, along with property titles and other official documents from the brotherhood's real estate in Bessarabia. The fifth series (IV.E) consists of architectural and urban plans of Jerusalem (fig. 6.1) and other towns and regions under the patriarchate's jurisdiction.

The pilgrimage series contains registers dealing with pilgrims (codes V.A to V.s). The material consists of donations, arrangements for the accommodation of pilgrims in monasteries and residencies, and the pilgrim's identifying information (name and birthplace) beginning in the early nineteenth century. It is a valuable source that could be used to map the profiles of Orthodox visitors to the sacred shrines. The administrative series includes codices in six separate subseries (VI.A to VI. $\mathrm{T}$ ). The first (VI.A) contains 171 official patriarchate letters glued on linen and stapled to one another. The

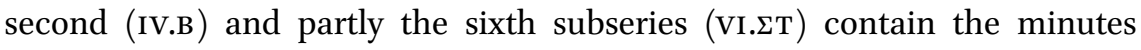
of the assembly of the Holy Synod and different sets of memoranda and 
regulations, which are still in use by the secretariat-general. The third series (IV.r) deals with the internal administration of the patriarchate, while the fourth (VI. $\Delta$ ) contains codices with information about fundraising from the Greek Orthodox laity and the clergy. The fifth part (IV.E) contains the previous inventories of the archives and the library.

The nonbound (or flyleaf) documents of the administrative series (codes VII.A to VII.E) contain some of the most valuable material of the archive and are classified in seven different subseries. The first (VII.A) contains scattered letters from several patriarchs from the mid-seventeenth to the midnineteenth centuries regarding fundraising and other issues. The subseries VII.B consists of the former pilgrimage series, whose previous classification was maintained. The 1,16o items divided in seven different sections are important from both an aesthetic and historical point of view. They include sultanic orders of the Mamluk sultans of Egypt, many of which are three to five meters long, as well as orders of the Ottoman sultans with golden and colorful monograms. They concern several matters and are dated from the thirteenth to the mid-nineteenth centuries. The third subseries (VII.厂) contains Arabic and Ottoman Turkish documents, mainly of a legal nature, and property titles of pilgrimage sites, administrative and other various cases, and is dated for the most part from the seventeenth to the late eighteenth centuries. They are particularly indicative of the variety of court cases the patriarchate was involved in during its long life. In the fourth subseries (VII. $\Delta$ ) there are administrative records concerning many different matters from the first half of the twentieth century. The external indications along with the internal classification of the letters in this subseries (the first forty-two are in metal) reveal the great change that occurred in the patriarchate's bureaucratic system in 1900 with the classification of the documents according to subject. The fifth subseries (VII.E) was created by administrative documents, but is classified by case. Among the thirty-one different cases, one finds the "Antioch affair" of 1906, the "Affair of Melbourne and Sydney" of 1901-3, and the "Cyprus affair" of $1902-7$.

The correspondence series (codices and nonbound documents from VIII.A to VIII.H) consists of eight different subseries of which only the third and the eighth contain nonbound documents while the rest consist of codices. The first series contains 311 volumes of incoming correspondence classified according to the sender's location and dating from the 1830 s to 1900. An archivist not only produces archives, but organizes and handles archives from other authors, and that is indeed what we see here. With the exception of codes VIII.B.1a and VII.B.1, the second series (VIII.B) is made up of 76 codices containing copies of outgoing letters that have retained the original numbers and 
date from 1843 to 1951 . The VIII. $\Gamma$ subseries is directly related to the series VII.s of the administrative series. The subseries VIII. $\Delta$ is the equivalent to VIII.B but containing telegram copies from 1883 to 1903 . The series VIII.E and VIII.Z contain the auxiliary books for the classification and retrieval of documents and letters in the series VII.s, VIII.B and VIII.r. Finally, the subseries VIII.H containing drafts of outgoing letters is directly related to the VIII.A subseries of these records and viII.B, where we find the final version of the very same letters.

Last but not least, the ninth series, consisting of the special correspon-

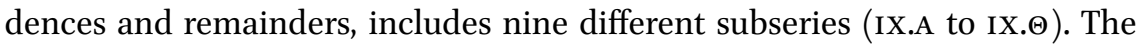
first six contain codices with copies of incoming and outgoing letters that were not integrated into the previous Correspondence series either because they did not belong to the general administration of the patriarchate or because the people who wrote them were on a special mission. One may find here the correspondence with the Russian consulate in Jerusalem along with the church branch of the Holy Sepulchre in Izmir or in Moscow. The seventh subseries contains files with letters and documents of the personal affairs of members of the Brotherhood (patriarchs included), as they were discovered in their remaining belongings after they died. In the eighth subseries (IX.H) the Tselikas team integrated in chronological order various letters in Greek, French, Russian and Arabic. This material was dispersed among several registers and files and had remained unclassified within the correspondence series.

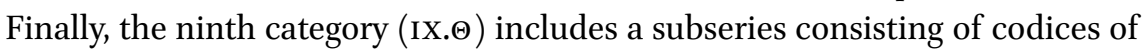
several bound original letters, copies and telegrams in Arabic.

Most of the above-mentioned material dates from the eleventh/twelfth to the mid-twentieth centuries. In the twenty-five years since the publication of the Tselikas inventory, a considerable number of twentieth-century documents has been added to the archives of the patriarchate. This material concerns the secretary-general during the interwar period and especially the years after World War II. The documents deal with the relations of the patriarchate with other churches in Jerusalem, interfaith events in which the patriarchate participated and the relations of the patriarchate with the Mandate authorities. ${ }^{14}$ It also contains school records of the postwar period, material concerning the

14 Konstantinos Papastathis and Ruth Kark, “The 'Politicization' of the 'Religious': The British Administration and the Question of the New Regulations of the Orthodox Patriarchate of Jerusalem, 1938-1941," Middle Eastern Studies 50, no. 4 (2014); Konstantinos Papastathis, "Religious Politics in Mandate Palestine: The Christian Orthodox Community Controversy in the Thirties," British Journal of Middle Eastern Studies 43, no. 3 (2016). 
Greek Orthodox presence in other Jordanian and Palestinian cities, economic records and other materials. This material has yet to be fully inventoried.

\section{Using the Patriarchal Archives: From Fraternal and Regional to Urban}

In the previous century, orientalists, often of Catholic or Protestant origins, studied the Christian communities of the Middle East through an essentialist, culturist approach, often without any consideration of internal or external dynamics. ${ }^{15}$ However, two parallel movements were in progress in the first decade of this century. The narrative presenting Christians as victims of the Muslims was accentuated in publications of public history, which tended to be emotionally intense, critical of Muslims, and lacking in historical rigor. ${ }^{16}$ In contrast, a more scientific approach dealt with the communities through anthropology and historical anthropology in order to analyze the dynamic relationship of the communities within their political and socioeconomic context, taking into account factors such as the state, territory and gender. ${ }^{17}$ For historians to be able to focus on the history of these populations and their interaction with other local religious communities, many obstacles remain. The often-fragile position of the Christian communities in an unstable political and geopolitical context, along with their almost existential

15 Otto Meinardus, Coptic Saints and Pilgrimages (Cairo: American University in Cairo Press, 2002); Meinardus, Monks and Monasteries of the Egyptian Deserts (Cairo: American University in Cairo Press, 1961); Georg Graf, Geschichte der christlichen arabischen Literatur, 5 vols. (Vatican City: Biblioteca Apostolica Vaticana, 1959); Pierre Rondot, Les Chrétiens d'Orient (Paris: Peyronnet, 1955); Jean-Pierre Valognes, Vie et mort des chrétiens d'Orient: Des origines à nos jours (Paris: Fayard, 1994). We owe many thanks to Stéphane Ancel for clarifying the historical discussion on the matter and for providing titles for the notes 15,16 and 17 .

16 Annie Laurent, Les chrétiens d'Orient vont-ils disparaitre? Entre souffrances et espérance (Paris: Salvator, 2008); Sébastien De Courtois, Le nouveau défi des chrétiens d'Orient d'Istanbul à Bagdad (Paris: Lattès, 2009);Jean-Michel Cadiot, Les chrétiens d'Orient:vitalité, souffrances, avenir (Paris: Salvator, 2010).

17 Bernard Heyberger, "Pratiques religieuses et lieux de culte partagés entre islam et christianisme (autour de la méditerranée)," Archives de sciences sociales des religions, no. 149 (2010); Sossie Andézian, "Formation des identités palestiniennes chrétiennes. Églises, espace et nation," Archives de sciences sociales des religions, no. 149 (2010); Anna Poujeau, "Renouveau monastique et historiographie chrétienne en Syrie," Archives de sciences sociales des religions, no. 151 (2010); Bas ter Haar Romeny, ed., Religious Origins of Nations? The Christian Communities of the Middle East (Leiden: Brill, 2009). 
suspicion of each other, prevents them from sharing their archival material, which is often extremely rich and quite often unexamined. This has been a problem for some Jerusalem communities and also for the Greek Orthodox community, both Arabs and Greeks. The Open Jerusalem project seeks to address this kind of problem through the opening and interconnection of different archives and sources.

Nevertheless, a fundamental question arises: are all archives appropriate for the study of citadinité? In other words, how can the Brotherhood, the community or ecclesiastical archives be useful for the study of urban citizenship? To answer such questions, we need to take into account the fact that citadinité does not exist per se. The concept is to a large degree determined by its explicit or implicit application to a limited scale (communal or at the level of the brotherhood) or to a wider one (regional or global). Both the brotherhood and the regional aspect are particularly evident in the patriarchate, an institution that is simultaneously spiritual and business-oriented. The producer and the author of the bulk of its archives remains the brotherhood. More restrained than the Greek Orthodox community, the brotherhood only concerns the senior clergy, which is predominantly Greek. The jurisdiction of the patriarchate stretches beyond the city of Jerusalem, and its head, namely the head of the brotherhood, is called "the Patriarch of the Holy City of Jerusalem and all Palestine, Syria, Arabia, beyond the Jordan River, Cana of Galilee, and Holy Zion." The question, then, is to what extent the archival material allows us to transcend the contrasting scales of the brotherhood, whose functioning has been described as that of a "closed corporation," and the regional scale of the patriarchate's jurisdiction. Does the material oscillate between the two extreme scales of analysis and finally rest on the city or does the city exist as a normative category to explore urban citizenship? A more systematic study of the Tselikas inventory and of the material may provide some preliminary answers to these questions. ${ }^{18}$ Let us examine some of the potential paradigms.

In material terms, the patriarchate identifies itself with the city of Jerusalem through its numerous properties. However, describing real estate and edifices does not suffice in addressing urban citizenship. Common urban identity is developed when people reside, live, and interact within the city. We are able to trace these aspects of citadinité through petitions, for instance. The bulk of the petitions in the archive lies in the seventh subseries of the administrative series nonbound documents (VII.Z.1-5). They are written in Greek and Arabic and cover the period from 1884 to 1911 . The first registered petitions

18 The translation of the inventory for the period $1840-1940$ is available on the website of the Open Jerusalem project (www.openjerusalem.org). 
must have started when the number of foreign language petitions addressed to the central Ottoman administration started to diminish, as Avcl, Lemire, and Özdemir show in this volume. A possible explanation is that after the Tanzimat and the consecutive set of regulations for the millets, the Greek Orthodox petitioners preferred to address their demands to their own religious institution, which was also much closer to them than Istanbul. During the aforementioned period, the patriarchate received thousands of petitions from the area of its jurisdiction, but not all of them were signed in the same way. In the petitions sent from Jerusalem, the author often added under his or her signature the term "Jerusalemite" (fig. 6.2) or "resident of Jerusalem." Most likely, the addition of this sign of urban identity stems from the hope that the patriarchate would better treat their demand. Indeed, the request of a person living in or originating from Jerusalem probably had priority over others because the patriarchate had the possibility of immediate social control over the petitioner. Petitions on subjects such as charity, dispute mediation, or even the patriarchate's intervention in releasing someone from prison could be more efficient given the positive recommendations from individuals of the same social milieu or at least in the absence of negative rumors.

Among the charitable services that the patriarchate provided to the members of the Orthodox congregation, accommodation for destitute people must have been one of the most popular. Several housing service files refer to this

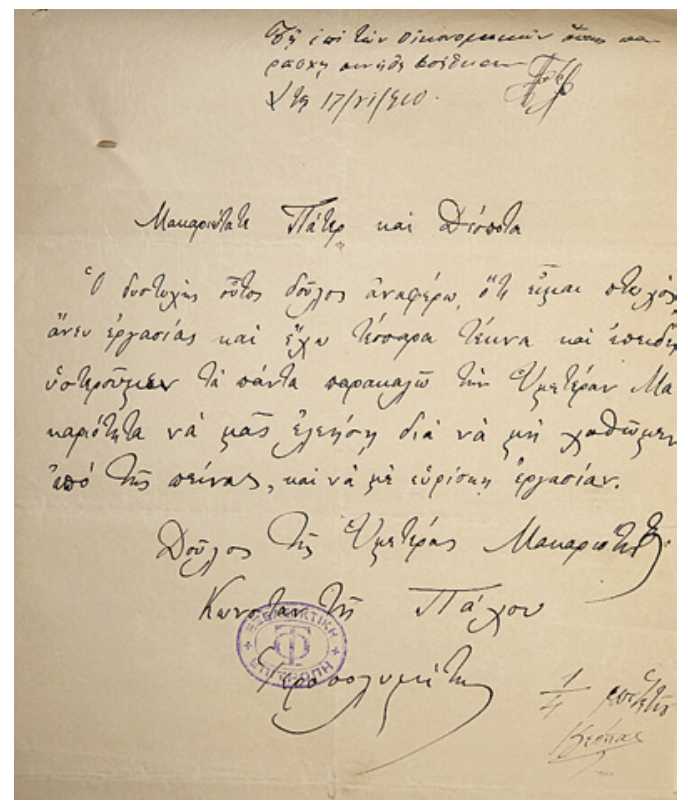

FIGURE 6.2

Petition, received on June 17, 1910, with the mention of "Jerusalemite" after the petitioner's signature. AEPI, VII. Z. 3, PETITION OF KONSTANTIS PACHOS TO THE GREEK ORTHODOX PATRIARCH. 
matter: rent payments registers are found in the real estate series (III.A.63); a memorandum on housing issues is found in the collection of real estate nonbound documents (IV.A.6o); and a document on house repairs is found in the

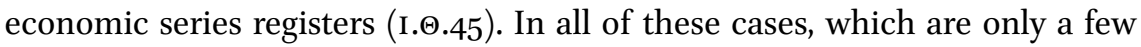
of many, the files indicate as beneficiaries "our indigenous" people (imeteroi ithageneis) that is, the Palestinian Arabs. Thus, the patriarchate distinguished the Palestinians from the Greeks (who were mentioned as such) and from Muslims (who apparently were not considered as "theirs"). It is also worth noting here that the houses let by the monastic Brotherhood of the Holy Sepulchre at very low prices were often within the Greek Orthodox monasteries of the Old City. Thus, the place of worship and the place of residence coincided.

The baptismal and wedding registers of the patriarchate may at first seem irrelevant to the study of citadinité. However, other research work based on such material shows that Jerusalem's holy character and everyday life may coexist without necessarily coinciding. ${ }^{19}$ This material, which is not inventoried and belongs to the ecclesiastical court of the Greek Orthodox patriarchate and the Church of St. James contains baptismal registers covering most of the first half of the twentieth century and wedding registers from the 1920s. The majority of the registers are in Greek, except for the St. James' baptismal records, which are in Arabic. This previously unexplored material sheds new light on the Greek Orthodox community of the city during the transition period between the Ottoman Empire and the British Mandate eras. The authors used the registers to investigate "communal affiliations, transitions of identity, the impact of modernity as well as notions of sacred space." They studied relations between Palestinian Arabs and Greeks, and between these communities and the city. Their work has shown that the feeling of belonging to the city of Jerusalem is not necessarily linked to any kind of perpetual or everyday "holiness." On the contrary, the authors argue that "the proximity to the holy sites bears little impact on private Christian life." Despite the ability to hold rituals in the holiest sites of Christianity, baptisms were commonly held at home or in parish churches (over twenty sites in the Old City alone). The way residents appropriated Jerusalem's holiness is a factor of citadinité is in stark contrast with the way institutions envisage the Holy City. Additional material from the ecclesiastical court, which comprises minutes of the courts and wills (or testaments), written sometimes both in Arabic and in Greek (fig. 6.3), permits further investigation of the above matters.

19 Merav Mack, Angelos Dalachanis and Vincent Lemire, "Matrimony and Baptism: Changing Landscapes in Greek (Rum) Orthodox Jerusalem (1900-1940)," British Journal of Middle Eastern Studies, published January 30, 2017, doi: 10.1080/13530194.2016.1273093. 


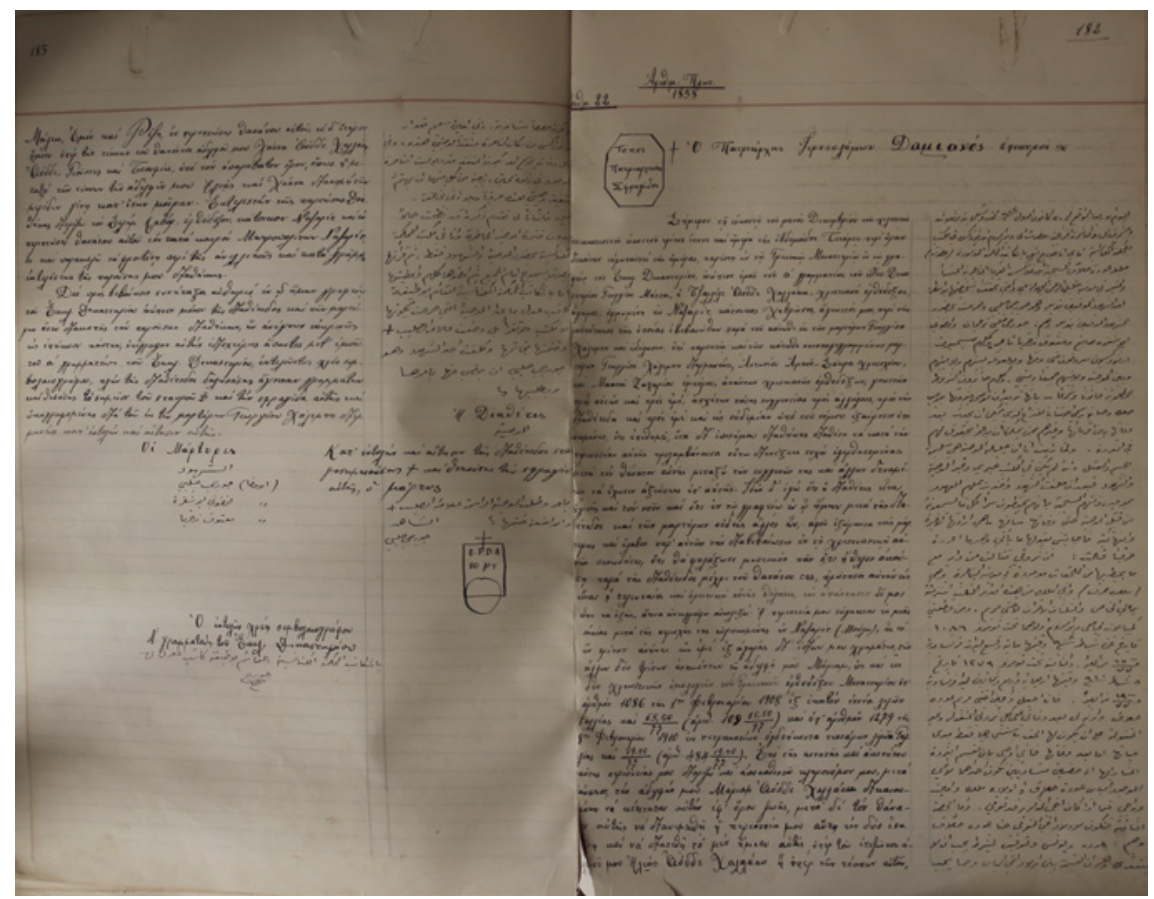

FIGURE 6.3 Testament dated December 20, 1923, in Arabic and Greek.

AEPI, ECCLESIASTICAL COURT, CODICES OF TESTAMENTS, 1858/22, 182-83.

\section{Concluding Thoughts}

Archives are one of the principal instruments in the construction of an institution or a community's identity. ${ }^{20}$ An archive's documents reflect the interactions between the communities and identities themselves, and there is an enormous concentration of such interactions in Jerusalem. That the archive inventory has now been presented in a language other than Greek for the first time is, we hope, a first sign that the Open Jerusalem project has already begun to contribute to the work of archivists in Jerusalem. That said, a number of issues remain. More so than the secrecy of documents or difficulty of access, the main problems arise from the enormous mass of the material. One of the particularities of the patriarchal material is that it involves untapped archives of a quantitative nature, which require extensive treatment. It is a time-consuming process, especially when it comes to registers. In these cases, handling the material necessitates the establishment and development of databases. The language issue often creates additional difficulties. 
For instance, the names of people of the two subcommunities (Arab and Greek) are often given in the two respective languages. Discrepancies in the transcription of names from one language to another often make it difficult to match them. This is an old challenge, for the language problem surfaces in various Jerusalem archives due to the continuous transliterations of names and places when traversing language and community frontiers. How, then, can such material be organized and prepared for future research? Practical difficulties may hinder the creation of a historical archive, but the Open Jerusalem database will mobilize all possible means to open the patriarchal archives and put them in dialogue with other Jerusalem records. Improving the accessibility of the patriarchal archives may be a great gift to academia, and to humanity on the whole. 
PART 2

Imperial Allegiances and Local Authorities 
Angelos Dalachanis and Vincent Lemire - 978-90-04-37574-1 Downloaded from Brill.com04/26/2023 02:29:03PM via free access 


\title{
Introduction
}

\author{
Beshara Doumani
}

Producing histories of "Ordinary Jerusalem" from 1840 to 1940, as this volume sets out to do, challenges prevailing public and academic discourses on modern Jerusalem. Why? First, because Jerusalem is a symbolically saturated and religiously overdetermined place in the global imaginary. For residents, visitors, scholars, and rulers, there is nothing ordinary about God's City. In their minds, it looms larger than history and stands above human machinations. How can Jerusalem be narrated when its biblically-infused temporal scale is measured in millennia rather than centuries or decades? Second, because the 1840-1940 period is historiographically overdetermined as the era of western-inspired modernity. Most narratives in the three academic fields of study in which modern Jerusalem is nestled - Ottoman, Middle Eastern, and Palestine/Israel studies - revolve around a series of ruptures that constitute the fabled "long nineteenth century": the encounter with the West as the beginning of history, top-down reforms (Tanzimat) of the centralizing state as the institutional embodiment of modern governance, and the violence of colonialism/nationalism as the handmaiden of the transformation from empire to states. How can Jerusalem be narrated in ways that transcend stories about the external impact of western hegemony? Third, 1840-1940 lives in the shadows of two traumatic historical moments that are the narrative bookends of knowledge production about Jerusalem: the 1831-40 military conquest and occupation of Bilad al-Sham by Mehmet Ali Pasha's Egyptian army, conventionally viewed as a rupture akin to Napoleon's invasion of Egypt; and the catastrophe $(N a k b a)$ of 1948, which witnessed the erasure of Palestine and the ethnic cleansing of the majority of its native population. A powerful narrative logic operates in these shadows: the inevitable destruction of Jerusalem's peaceful, tolerant, multicultural, and global character by colonial forces. How can Jerusalem's long-term inhabitants, inasmuch as they were a local demos (ahäli) under Ottoman and British imperial rule, be written into history as agents rather than as hapless observers or victims?

One way to address all three questions is to normalize Jerusalem between 1840 and 1940 by framing its history in terms of a mutually constitutive relationship between the ahāli and the state. Hence the title of Part 2, "Imperial Allegiances and Local Authorities." The word "allegiance" troubles the state/ society binary by suggesting that the state is co-opted, but also inhabits, the ahäli. Likewise, the phrase "local authorities" could mean the primacy of

(C) BESHARA DOUMANI, 2018 | DOI:10.1163/9789004375741_010

This is an open access chapter distributed under the terms of the prevailing CC-BY-NC-ND License at the time of publication. 
the local and, at the same time, the transforming presence of imperial authority. The chapters in Part 2 are not equally successful in walking this fine line, but they all strive to render Jerusalem "ordinary" by analyzing how empirewide institutions and practices of governance - police stations, petitions, sharica courts, and municipalities - were instantiated and transformed in the specific historical context and social formation of the city. Like all other chapters in this volume, they do so by introducing new archival sources and/or new research that shed light on actors, events, and relationships that have hitherto been erased and marginalized. The purpose of these chapters is not to come up with a new metanarrative, but, rather to suggest fresh lines of inquiry respectful of and firmly grounded in the messiness and complexity of the social life of the city itself.

It is in this spirit that Noémi Lévy-Aksu speaks of the "forgotten" and "cacophonic" voices of Jerusalem that come to life when one examines less the institution of police as a modern form of governance (which, ironically, can serve to reify conventional binaries) and more the on-the-ground practices of policing that shaped Jerusalem's urban culture. Focusing on the relationship between police staff and the ahăli through a social history of institutions, LévyAksu argues that "state-society and central-local oppositions are less relevant to the discussion of citadinité than a careful analysis of the patterns of alliances and exclusion that legitimized some actors and practices while marginalizing others."

The same spirit animates Yasemin Avcı, Vincent Lemire, and Ömür Yazıcı Özdemir's study of collective petitions by the ahāli of Jerusalem and its environs in the late nineteenth century. Combining discursive and quantitative approaches to an analysis of over two hundred petitions, the authors map out who sent petitions to whom, why, how, and in what languages and styles. The advent of the telegraph in 1860 and the introduction of new administrative institutions, they argue, increased the number of petitions and expanded the range of social networks that resorted to them. Beyond reinforcing a large body of literature about petitions as vehicles for both local agency and imperial authority, the authors open new windows on the transformation of political culture and regional identities in Jerusalem during the last decades of Ottoman rule.

It is difficult to think of greater institutional contrast in Jerusalem than between the shari'a court and the Russian consulate. The former, whose rich and voluminous archives date back to the first decade of Ottoman rule in the early sixteenth century, is the symbol of a communally embedded state institution central to all aspects of daily life from property to kinship relations. The latter symbolizes the European appropriation of Palestine as a geostrategic 
Holy Land. In their study of Register No. 324 (1839-40) of the Jerusalem shari'a court, Abla Muhtadi and Falestin Naïli seek to trouble the notion of rupture. They show, counterintuitively, that the new protomunicipality advisory council (majlis al-shūrā) founded by the Egyptian authorities was kept intact by the Ottoman government, but subordinated to the qadi of the shari'a court. Irina Mironenko-Marenkova and Kirill Vakh, in a thorough study of scattered archival sources relating to the Russian consulate since its founding in 1858 , nuance the geostrategic argument by showing that the Ministry of Foreign Affairs showed little interest in the consulate. Rather, it was other Russian institutions, especially the Ecclesiastical Mission and its focus on land purchase, that dominated the Russian presence in Jerusalem.

Land and real estate are the measure of power and faith in Jerusalem, and, arguably, the most important factors in understanding the inner life of the city and its relationship to the outside world. This is especially true for the 1840-1940 period, which witnessed major transformations in land relations. In his chapter, Konstantinos Papastathis asks what happens when the largest private landowner - led by a corrupt religious establishment beholden to a foreign country - faces bankruptcy, a highly disgruntled native congregation, a new imperial power after four centuries of Ottoman rule and a European settler-colonial movement obsessed with land purchase. Skillfully employing a wide range of previously untapped sources, he tells the dramatic story of how the British colonial authorities solved the financial crisis of the Greek Orthodox Patriarchate by managing the sale of large tracts of land to the Jewish Agency, while keeping in check Palestinian nationalist aspirations that resonated strongly with the Arab Christians of Jerusalem.

When it comes to imperial allegiances and local authorities in the era of reforms, no institution symbolizes the contested modern more than the municipality. Mahmoud Yazbak is keen to distinguish between the notion of public services, which, he argues, is a long-established Islamic and Ottoman practice, and the institution of the modern municipality, which he recognizes as having a strong influence on urban political culture and modes of governance. More importantly, perhaps, his comparative study of the municipal archives of Nablus, Haifa and Nazareth shows that the nature of this influence is far from clear or uniform. Rather, the workings of each municipality, the social composition of the council members, and its local role varied depending on the social structures and political economies of regional social spaces and the imperial strategies in play.

But is it enough to demonstrate the inevitable blind spots, erasures, double standards, and ideologically driven constructions of the past by the big "isms" - such as orientalism, nationalism and colonialism? As Jens Hanssen 
argues, the circling of the wagons approach of cultural defensiveness and a provincial nostalgia leaves history in the hands of the victors. Rather, the "task at hand is to produce historical theory and method out of the Palestinian experience." That is more than an academic exercise for theorists. Decolonizing knowledge production about the past is, ultimately, a cultural mobilization project for building a different future. Inspiration here comes from the fact that the formation of modern municipalities was rooted in global crises of cities undergoing rapid growth and transformation, and in an insurgent urban democratic ethos by their respective ahäli. Jerusalem, Hanssen rightly notes, is still living in a settler-colonial present and the current struggles of its ahäli draw on the not-so-distant past of late Ottoman urban democracy. 


\title{
The State and the City, the State in the City: Another Look at Citadinité
}

\author{
Noémi Léry-Aksu
}

At the core of this volume and the ambitious collective research project to which it belongs, the notion of citadinite calls for a new approach to the history of Jerusalem from 1840 to 1940. The localization and analysis of a wide range of archival sources aim to shed light on the institutions, actors, and practices that shaped the city throughout the period and defined its complex identity. The comprehensive collection of archives gathered for the project makes it possible to explore the connections and tensions between the polyphonic - not to say cacophonic - narratives that have accumulated for more than a century and to make room for forgotten voices. Beyond that, the combination of state, municipal, community, and private documents offers exceptional insight into the functioning of different institutions and groups settled in the city, and their interactions, both in everyday life and under exceptional circumstances. Despite being a city of its own, Jerusalem can be studied in a comparative perspective. This approach, in return, contributes to a broader conceptualization of citadinité. In this light, the current chapter discusses one aspect of the "documentary archipelago" available to scholars working in Mediterranean, Ottoman, and/or colonial cities: the presence of the state and its role in the construction of urban identities at the turn of the twentieth century. ${ }^{1}$

For several decades now, the historiography of Ottoman cities has been profoundly renewed. Reacting against the Weberian conceptualization of the Islamic city, historians of late Ottoman Arab, Anatolian, and Balkan cities have emphasized the political, social, economic, and cultural changes these cities underwent in the nineteenth century. ${ }^{2}$ Among them, the creation of

1 I borrow the expression "documentary archipelago" from the introduction of the volume and the description of the Open Jerusalem project in its website (www.openjerusalem.org).

2 Max Weber, The City (1922; repr. Glencoe: Free Press, 1958) According to Weber, the Islamic city lacks the main characteristics that define the city in its Western conception collective identity, political autonomy and civic culture. Weber emphasized the fragmentation of the Islamic city and its resistance to change.

(C) NOÉMI LÉVY-AKSU, 2018 | DOI:10.1163/9789004375741_011

This is an open access chapter distributed under the terms of the prevailing CC-BY-NC-ND License at the time of publication. 
municipalities has been singled out as the sign of a new approach to urban administration and citizenship. ${ }^{3}$ Acting as interfaces between the state and the city dwellers and reflecting the shared - and sometimes conflicting - interests of notables coming from diverse ethno-religious backgrounds, the municipal councils offer a privileged standpoint from which to discuss local politics, urban autonomy, and city administration in the late Ottoman context. ${ }^{4}$ Yet, municipalities were not the only institution that contributed to the transformation of the urban space and administration in the late nineteenth to early twentieth centuries. More than anything else, municipal archives highlight the multiple levels of interaction between a wide range of community organizations and private actors as well as state institutions. ${ }^{5}$ While the endogenous character of the community organizations and private actors leaves no doubt as to their role in the constitution of new urban identities, the connection between state institutions and the concept of citadinité is more problematic. The control exercised by governmental authorities certainly curbed the development of autonomous Ottoman municipalities and limited the scope of their activities; yet state reforms in infrastructure, education, justice, and security also contributed to transforming the relations between city dwellers and the urban space, often in convergence with the municipal authorities.

Much has been written on the relations between the Ottoman central state and the cities, especially in the case of the Arab provinces. ${ }^{6}$ While the centralization versus decentralization debate has largely died down, there is still little

3 While officially institutionalized through the provincial reforms promoted by the Ottoman state during the Tanzimat period, the municipalities also built on older traditions of local administration. See Nora Lafi, ed., Municipalités méditerranéennes: Les réformes ottomanes au miroir d'une histoire comparée (Moyen-Orient, Maghreb, Europe méridionale) (Berlin: Klaus Schwarz, 2005).

4 Unfortunately, few municipal archives have been preserved. Besides Jerusalem's municipal archives, there are the archives of Thessaloniki, Nablus and Bursa, which still await comprehensive studies. See also the chapter by Mahmoud Yazbak, "Comparing Ottoman Municipalities in Palestine: The Cases of Nablus, Haifa and Nazareth, 1864-1914," in this volume. Robert Ilbert's work on Alexandria remains a central reference to reflect on municipal institutions and political transitions in multicultural Mediterranean cities. Robert Ilbert, Alexandrie, 1830-1930: Histoire d'une communauté citadine, 2 vols. (Cairo: Institut français d'archéologie orientale (IFAO), 1996).

5 Yasemin Avcı, Vincent Lemire, and Falestin Naïli, "Publishing Jerusalem's Ottoman Municipal Archives (1892-1917): A Turning Point for the City's Historiography," Jerusalem Quarterly, no. 60 (2015).

6 Jens Hanssen, Thomas Philipp, and Stefan Weber, eds., The Empire in the City: Arab Provincial Capitals in the Late Ottoman Empire (Wurzburg: Ergon, 2002). 
consensus as to the nature of Ottoman rule in the provinces. Approaches emphasizing patterns of cooperation between the central and the local are challenged by the colonial paradigm developed by Ussama Makdisi and others. ${ }^{7}$ Without directly addressing this debate, this chapter proposes a few possible avenues by which to question the connections between state intervention and citadinité in the late Ottoman period. Arguing that, in many cases, the distinction between the central and the local was far from clear-cut, I propose to focus rather on the integration of state actors in the urban fabric and their interactions with local people. The first part of the chapter is a brief assessment of the literature on the state presence in late Ottoman cities. It contrasts the numerous studies on public spaces and monuments with the relative lack of interest in the functioning and staff of the state institutions on the ground. The second part is a case study drawn from my personal research on the late Ottoman police forces. In it, I discuss their integration in the urban space as well as their role in enforcing a certain idea of public order through mechanisms of cooptation and repression. Through this case, I argue that state-society and central-local oppositions are less relevant to the discussion of citadinite than a careful analysis of the patterns of alliances and exclusion that legitimized some actors and practices while marginalizing others.

\section{The State in the City: A Historiographic Survey}

The historiography on late Ottoman cities has grown so fast in the last decades that a comprehensive survey of it would be beyond the scope of this chapter. While this new literature owes much to the broader transformations in urban historiography all over the world, its main research questions are also shaped by a critical approach to academic and political traditions that have prevailed in the field for decades. Rejecting the Weberian model of the Islamic city as well as other orientalist approaches to Middle Eastern geographies, recent scholarship on Balkan and Arab cities has also distanced itself from a nationalist perspective on the Ottoman past, questioning the imprint of the Ottoman state with new theoretical and methodological tools. While important differences, and even divergences, persist in the evaluation of the role of the Ottoman state in the provincial cities, the following survey will attempt to provide insight into the conceptualization and analysis of the state presence in urban space.

7 Ussama Makdisi, “Ottoman Orientalism," American Historical Review 107, no. 3 (2002). 
From a theoretical perspective, the discussion of the Ottoman state in urban historiography has been framed more by the broader debate on Ottoman reforms and provincial rule than by a reflection on the specific urban framework. Beyond the shared assumption that state control over the provinces increased in the second half of the nineteenth century and culminated during the reign of Abdülhamid II, scholars disagree on the political meaning of this enhanced state presence. Referring to James Scott, Michael Mann and Michel Foucault, historians of Beirut, Thessaloniki, and Izmir have emphasized the new approaches to power and governance linked to the transformations of the state. ${ }^{8}$ The development of an infrastructural power relying on a network of institutions in charge of education, security, health, and public infrastructures made the state more visible at the local level and enabled it to monitor its subjects in a much more efficient way. While this approach offers a general framework to analyze comparatively the transformations in provincial administration in the late nineteenth to early twentieth centuries, recent studies of late Ottoman cities are careful to articulate this project of Ottomanization with the distinctive local dynamics of each city. The older traditions of local administration, the role of the notables, and the spread of capitalism associated with the colonial ambitions of European powers converged or concurred with state intervention to transform the urban space and social relations.

While this approach prevails in the studies of Balkan and Anatolian cities, including the Ottoman capital, in the case of Arab cities it is challenged by a more critical approach to what is perceived as the Ottoman state's increasingly colonial form of rule. Although the two approaches are not exclusive, the colonial paradigm, which has come to bear on a number of studies on late Ottoman Arab cities and provinces, questions the Orientalist stance of the Ottoman bureaucratic elites and its connections with European imperialism. Arguing that "the nineteenth-century Tanzimat reflected the birth

8 See, for instance, Eugene L. Rogan, Frontiers of the State in the Late Ottoman Empire: Transjordan, 1850-1921 (Cambridge: Cambridge University Press, 1999), 1-20; Maurus Reinkowski, "The State's Security and the Subjects' Prosperity: Notions of Order in Ottoman Bureaucratic Correspondence (19th century)," in Legitimizing the Order: The Ottoman Rhetoric of State Power, ed. Maurus Reinkowski and Hakan T. Karateke (Leiden: Brill, 2005); Jens Hanssen, Fin de Siècle Beirut: The Making of an Ottoman Provincial Capital, (Oxford: Oxford University Press, 2005), 1-21; Sibel Zandi-Sayek, Ottoman Izmir: The Rise of a Cosmopolitan Port, 1840-1880 (Minneapolis: University of Minnesota Press, 2012). Some of the theoretical references frequently used are James C. Scott, Seeing Like a State: How Certain Schemes to Improve the Human Condition Have Failed (New Haven: Yale University Press, 1998); Michael Mann, "The Autonomous Power of the State: Its Origins, Mechanisms and Results," in States in History, ed. John A. Hall (Oxford: Blackwell, 1989). 
of a distinctly modern Ottoman imperialism," Ussama Makdisi has emphasized the construction of a cultural and racial difference between the central elites and the local population as well as the violent aspects of Ottoman domination. ${ }^{9}$ In this framework, the Ottoman imperial project in the Arab provinces is conceived as an effort to counter European attempts at cultural and political domination. While reframing the modernizing project of the Ottoman state from a perspective which draws on Edward Said's analysis of orientalism and postcolonial studies, this approach paradoxically brings back some "old" concepts as well: Makdisi's emphasis on the "Arab periphery" reactivates the geographic distinction between the Arab lands and the other provinces and revives the center-periphery model from a new angle. ${ }^{10}$ This paradigm has inspired a number of attempts to broaden the geographic scope of the center-periphery model, add nuance to its argumentation and, in some cases, question its very validity.11

Despite their differences and divergences, these approaches converge in their interest in the cultural forms of Ottoman rule in the provinces and their sensibility to public space and architecture in the urban fabric. The concept of "public space" has been increasingly discussed from a theoretical and urbanistic perspective with specific reference to transformations in urban fabric. According to Shirine Hamadeh, urban and suburban environments created by the ruling class, such as public gardens or squares, facilitated a process of décloisonnement, characterized by increased contact between social classes, but also tighter regulations to maintain hierarchies and social order. ${ }^{12}$ Developed with reference to eighteenth-century Istanbul, this conceptual framework is not only a call to rethink the periodization of urban change and

Ussama Makdisi, "Rethinking Ottoman Imperialism: Modernity, Violence and the Cultural Logic of Ottoman Reform," in The Empire in the City: Arab Provincial Capitals in the Late Ottoman Empire, ed. Jens Hanssen, Thomas Philipp, and Stefan Weber (Wurzburg: Ergon, 2002), 30.

$10 \quad$ Makdisi, "Ottoman Orientalism."

11 Thomas Kuehn, Empire, Islam and Politics of Difference: Ottoman Rule in Yemen, 18491919 (Leiden: Brill, 2011); Isa Blumi, Rethinking the Late Ottoman Empire: A Comparative Social and Political History of Albania and Yemen, 1878-1918 (Istanbul: Isis Press, 2010). Özgür Türesay's critical evaluation of Ottoman orientalism questions this geography of difference and draws attention to similar discourses and politics targeting specific ethnicreligious and social categories. See Özgür Türesay, "L'Empire ottoman sous le prisme des études postcoloniales: À propos d'un tournant historiographique recent," Revue d'histoire moderne et contemporaine 6o, no. 2 (2013).

12 Shirine Hamadeh, The City's Pleasures: Istanbul in the Eighteenth Century (Seattle: University of Washington Press, 2007). 
to nuance the novelty of the Tanzimat period. It is also an opportunity to analyze transformations in the urban fabric as part of a broader reconfiguration of power relations and social interactions in nineteenth-century Ottoman cities.

The historiography of the Tanzimat period has singled out urban reforms as one of the main aspects of the modernizing project of the Ottoman state. From the widening of streets to the regulations on buildings, the regularization and modernization of the urban fabric was a core concern for the bureaucratic elite, who aimed to create healthier and safer cities and fight recurrent challenges such as fires, epidemics and riots. ${ }^{13}$ These reforms shared many features with the urban reforms achieved in European cities during the same period. They facilitated the emergence of more connected cities, where both opportunities of interclass, and intercommunal contacts, and capacity of the state to monitor them, were increased. Beyond urbanism, the transformations in provincial administration and new infrastructures also contributed to the creation of new kinds of public buildings that stood out in the urban space. Through these landmarks, the state became more visible in the public space, while opportunities for interaction between city dwellers of different backgrounds and members of state institutions increased.

Several studies have approached these buildings as symbols of power that materialized the state presence in the urban space and created a more immanent dimension to political authority. This aspect is at the core of Selim Deringil's work on Abdülhamid II and the legitimization of power, which emphasizes how architectural forms and ceremonials made the "hidden sultan" present in his absence. ${ }^{14}$ Among these symbols, Deringil pays special attention to clock towers, which dominated the urban fabric as a result of their height. Clock towers helped to introduce a new conception of time and were a convenient meeting point for city dwellers. ${ }^{15}$ Designed as symbols of power, many of these buildings were inaugurated with public ceremonies on significant dates such as the sultan's birthday or his jubilee. From a historiographic perspective, the concentration of interest in clock towers, more often studied than other kinds of public buildings such as hospitals, schools or caserns, is

13 There is an impressive literature on urban reforms and urbanism during the Tanzimat era. See, for instance, Paul Dumont and François Georgeon, eds., Villes ottomanes à la fin de l'Empire (Paris: L'Harmattan, 1992); Zeynep Çelik, The Remaking of Istanbul: Portrait of an Ottoman City in the Nineteenth Century (Seattle: University of Washington Press, 1986).

14 Selim Deringil, The Well-Protected Domains: Ideology and Legitimation of Power in the Ottoman Empire, 1876-1909 (London: I. B.Tauris, 1998).

15 Ibid., 29-30; Avner Wishnitzer, Reading Clocks, Alla Turca: Time and Society in the Late Ottoman Empire (Chicago: University of Chicago Press, 2015). 
emblematic of the main angle under which the imprint of the state in the urban space is approached. That is, the emphasis is laid on visibility and symbolism, while the inner architecture of the public buildings, their functionality, and their accessibility to the city dwellers remain little discussed.

The sources available on late Ottoman cities can at least partly account for this historiographic orientation. The material imprint of the imperial presence in the cities is the most tangible testimony of the Ottoman past in the provincial cities, from the Balkan to the Arab provinces. Although conflict, destruction, and rebuilding following political changes have deeply modified the urban fabric, every post-Ottoman city retains single or numerous vestiges of its imperial past. Interdisciplinary approaches combining art history, archeology, and architecture have placed material culture at the core of their analyses. In many cases, they also rely on photography, not only for its documentary value but also as a precious source, to understand how the Ottoman state, local actors, and foreign observers perceived and represented the city. In this respect, Abdülhamid II's photographic albums offer an extremely rich sample of public buildings and ceremonials in the late Ottoman cities. They convey a project of imperial self-representation that occupied the many faces of the modernizing state. As Wolf-Dieter Lemke underlined in the case of Arab cities, these photographs revealed "a military or administrative eye" at work, which emphasized order and regularity, while showing little of the inhabitants of the city and their daily uses of the urban space. ${ }^{16}$

The main risk of this approach is a reification of the urban space, which sometimes fails to connect the urban fabric and buildings with the social dynamics that inhabitants both witnessed and created. ${ }^{17}$ While recent years have seen innovative approaches to social diversity, marginality and mobility, state institutions and actors have been little explored. ${ }^{18}$ Who worked in the public administration and services that were modernized or created in the late Ottoman cities? What kinds of interactions and encounters occurred in the

16 Wolf-Dieter Lemke, "Ottoman Photography: Recording and Contributing to Modernity," in The Empire in the City: Arab Provincial Capitals in the Late Ottoman Empire, ed. Jens Hansen, Thomas Philipp, and Stefan Weber (Wurzburg: Ergon, 2002), 247.

17 A similar concern is expressed in the introduction of Hanssen, Philipp, and Weber, The Empire in the City: Arab Provincial Capitals in the Late Ottoman Empire, ed. Jens Hanssen, Thomas Philipp, and Stefan Weber (Wurzburg: Ergon, 2002), 17-25.

18 For examples of this new social history of cities, bringing to the forefront the social margins and the state policy regarding them, see Eugene L. Rogan, ed., Outside In: On the Margins of the Modern Middle East (London: I. B. Tauris, 2002); Ulrike Freitag, Malte Furhmann, Nora Lafi, and Florian Riedler, eds., The City in the Ottoman Empire: Migration and the Making of Urban Modernity (London: Routledge, 2011). 
public buildings and in the broader urban fabric? Besides the strong figures of governors who marked the history of the provincial cities, we know little about the anonymous figures working in state administration and involved in daily interactions with the urban dwellers. The Ottoman personnel records (sicil-i ahva $\bar{a} l$ ) contain precious information about the geographic background, education, and career of civil servants but it is difficult to single out cohorts of local bureaucrats unless information is correlated by other sources such as the annuaires orientaux. ${ }^{19}$ To what extent did local recruitment prevail? What were the educational, social background, and ethno-religious distributions of state employees? While these questions are central to discussing the colonial paradigm and patterns of integration, few answers are available.

Ottoman urban history still lacks a social history of institutions that would consider them beyond their symbolic role or official function, as living bodies with porous borders, integrated in the local configuration at multiple levels. Sources of employment and social mobility for some local inhabitants, the state organizations present in the provincial cities were involved in many services at the core of the everyday life of the urban society but also actively contributed to the symbolic or physical violence targeting individuals and behaviors considered incompatible with the urban order in the making. The second part of this chapter proposes a few ways to analyze these institutions in their urban context by focusing on a specific case: the police forces.

\section{The Police and the City: Public Order as a Shared Value?}

The process that led to the creation of modern police forces in the empire started with the abolition of the Janissaries in 1826 . Policing the cities had been one of the roles of this military corps. ${ }^{20}$ To fill the void left by their suppression, the Polis nizāmnāmesi, issued in 1845, enacted the creation of police forces but the institutionalization of these forces was a long and nonlinear process.

19 The annuaires orientaux were yearbooks published in Istanbul from 1868 to 1939 . While their aim was mainly commercial, they provided comprehensive information about trade and administration in the Ottoman Empire, as well as large listings of the registered inhabitants of Istanbul.

20 Several works published in Turkey during the 1940s gave detailed accounts of the various institutional steps of this process. See, for example, Halim Alyot, Türkiye'de Zabıta [Police forces in Turkey] (Ankara: Kanaat Basımevi, 1947). For a more recent and critical evaluation of the process, see Ferdan Ergut, Modern Devlet ve Polis: Osmanlidan Cumhuriyet'e Toplumsal Denetimin Diyalektiği [The modern state and the police: the dialectics of social control from the Ottoman era to the republic] (Istanbul: Iletişim, 2004). 
The process was accelerated during the reign of Abdülhamid II after the creation of the Ministry of Police (Żaptiye Nezāreti) in 1879. The following section will not focus on these institutional developments per se but rather try to question their impact on late Ottoman cities.

\section{Questions of Sources and Methodology}

Until recently, there have been very few studies on the history of the police and their role in the late Ottoman cities. ${ }^{21}$ Works dealing with urban transformations and social life often devote a few remarks to the topic but one can hardly say that the police have benefitted much from the renewal of urban studies in Ottoman historiography. This relative lack of interest has much to do with the narrow institutional perspective still dominating the historiography of the Ottoman police. While a few recent works on Istanbul have drawn attention to this gap and contributed to filling it, little research has been done on the provincial cities. ${ }^{22}$

The Ottoman archives include many series relevant to the study of policing in the late Ottoman cities, especially for the capital and the main port-cities of the empire. ${ }^{23}$ Yet from a qualitative perspective, these archives have many gaps. Their main flaw is that archives of the local police stations are missing. The available documents are the correspondence between the central police

21 The municipal police, which are beyond the scope of this study, are even less studied than the Ottoman state police. In the case of Istanbul, the lack of the municipal archives makes it difficult to understand the actual role of the municipal forces in policing and social control in the capital. While several Ottoman historians tend to assume that the municipal police were weak and under the tutorship of the state police, the Jerusalem municipality archives may shed light on this poor relation of urban studies.

Noémi Lévy-Aksu, Ordre et désordres dans l'Istanbul ottomane (1879-1909) (Paris: Karthala, 2013); İlkay Yllmaz, Serseri, Anarşist ve Fesadın Peşinde: Abdülhamid Dönemi Güvenlik Politikaları Ekseninde Mürur Tezkereleri, Pasaportlar ve Otel Kayıtları [In search of anarchist and mischief: internal passports, passports and hotel registers through the security policies during the Abdülhamid II era] (Istanbul: Tarih Vakfı, 2014); Nurçin İleri, "A Nocturnal History of Fin de Siècle Istanbul" (PhD diss., Binghamton University, 2015).

23 For the reign of Abdülhamid II (1876-1909), the archives of the Ministry of Police (Zabtiye Nezareti, воА.Zв) offer a great number of documents, both for the capital and the provincial cities. The correspondence between the Ministry of Police and Ylldız Palace, kept in the Ylldız Palace Series (Y.ZB), is also extremely rich, as well as the irade (sultanic decrees) and the correspondence of the Ministry of Justice, Ministry of Foreign Affairs and Ministry of War which highlight the interactions between the police, other state institutions and the foreign representations. 
stations of the capital, the Ministry of Police, and the imperial palace of Ylldız, which offer only synthetic summaries of the cases reported by the local police stations. ${ }^{24}$ The second gap is linked to the lack of some series, removed from the Ottoman archives at an unknown date to be kept at the Directorate of General Security (Emniyet Genel Müdürlüğü, EGM) in Ankara. ${ }^{25}$ No catalogue of these archives is available to "ordinary" scholars, and as such it is hard to know which series are stored there. Nevertheless, publications sponsored by the EGM shed some basic light on one of the most valuable series kept in Ankara: the staff files of the Ottoman and Republican periods. ${ }^{26}$ These files provide crucial information regarding the geographic origin of the policemen, their training, and their career. Denial of access to them does not only make impossible a prosopography of the institution but also constitutes a major obstacle to the understanding of the social dynamics which shaped the activities of the police forces and their relations with the people in the late Ottoman cities.

\section{The Police Stations in the Urban Space: A New Kind of Public Buildings}

The institutionalization of police forces had a direct impact on the urban fabric: police stations (karakol) started to be disseminated in the cities. These buildings were an important aspect of the transition from military to civil policing in the nineteenth century. Many caserns, which hosted the Janissaries, were destroyed after their suppression. Smaller wooden buildings were converted into police stations, but these did not suffice to cover the whole city. During the 1830 s, while the reorganization of policing was still in its infancy, new karakol started to be built in the Ottoman capital. The process accelerated in the mid-nineteenth century and culminated under the reign of Abdülhamid II and the early Young Turk period. In most of the provincial cities and towns, caserns and the governor's house hosted the police

24 I will come back to the limits and resources of this documentation for an interactionist perspective on policing in the last part of this chapter.

25 Unfortunately, the research and documentation center located in the buildings of the directorate is only open to the members of the police (students and instructors in the police academy or police institutes) and the few lucky academics who benefit from special authorization.

26 Eyüp Şahin, Türk polisinden seçkin biyografiler [Selected biographies of the Turkish police] (Ankara: Emniyet Genel Müdürlüğü, 2012). 
forces until the late $1870 \mathrm{os}$, when karakol started to become a widespread kind of public building. ${ }^{27}$

The construction of police stations was not only the consequence of the reorganization of the police forces, but also a component of the transformation of the urban space promoted during the Tanzimat period. Numerous instructions emphasized the necessity of building the new police stations according to the architectural and urbanistic principles promoted to order the urban fabric and protect the cities against devastating fires. Like the other public buildings, police stations were considered as signs of modernity and much attention was devoted to their architecture. However, the cost of such buildings prevented their diffusion throughout the city. ${ }^{28}$ In the early twentieth century, there were still wooden police stations, and the reuse of domestic buildings or other kinds of public buildings (schools, military barracks) was a less costly alternative to these architectural projects.

Most of the karakol built in the second half of the nineteenth and early twentieth centuries bore several distinctive features, which singled them out from their environment as public buildings. ${ }^{29}$ Their facade was adorned with the Ottoman coat of arms and the signature (tugrrā) of the sultan who reigned when they were inaugurated. Poems dedicated to the sultan could also be carved on the façade. Characterized by their neoclassical and eclectic styles, the police stations often included columns, pediments, and ornaments, as seen in the photographs from the Abdülhamid II collection. In this regard, beyond their functional role, they became one of the public symbols through which imperial authority became more visible in the urban fabric. Like the clock towers discussed earlier, they participated in the attempts to build a stronger relationship between the sultan, the state, and its subjects through new tools for the legitimization of power.

While these distinctive architectural characteristics facilitated the identification of police stations as public buildings, their integration in the urban fabric was achieved through their proximity to other buildings, such as the mosque, fountain and commercial structures. The proximity to these loci of sociability and gatherings was an asset for surveillance and quick police

27 Omri Paz, "Crime, Criminals and the Ottoman State: Anatolia between the Late 1830 and the Late 186os" (PhD diss., University of Tel Aviv, 2010).

28 Aynur Çiftçi, "Son dönem İstanbul karakolları. Anadolu yakası ve Büyükdere Topçu karakolu" [Police stations in late Ottoman Istanbul: the asian shore and Büyükdere police station] (MA diss., Ylldız Technical University, 1996).

29 The following paragraphs summarize the arguments, which I developed on Istanbul police stations. See Lévy-Aksu, Ordres et désordres, 141-54. 
intervention in case of disorder. Facilitating daily interactions between the police and the people, this spatial integration of the karakol can be observed both in old neighborhoods and in the new districts that developed in the periphery of the cities in the late nineteenth century. In this case, integration appeared as the result of a more conscious effort towards urban planning. For instance, the neighborhood of Sanaye, built in Beirut during the Hamidian period, included "a complex of urban services, including public garden, municipal hospital, prison, and karakol."30 Although the construction of prisons and karakol depended respectively on the Ministries of Justice and Police, they seem to have been integrated here in a municipal project aimed at connecting spaces of services and entertainment in the same area.

The distribution of the police stations in the cities was uneven. The density of population and the socioeconomic characteristics of the neighborhood seem to have played a role in their implantation, but the lack of comprehensive lists and maps makes it difficult to evaluate to what extent the Ottoman authorities consciously planned the distribution of these stations. In the case of Beirut, Jens Hanssen has identified twenty-eight police stations built during the Hamidian period, mostly concentrated in the southern parts of the city in Sunni or mixed neighborhoods, which raised specific challenges to public order. ${ }^{31}$ In Istanbul, my research on the police stations in the district of Tophane-Galata has shown the exceptional density of police stations in this area, especially on the seashore, which hosted port infrastructures and was one of the main entry-points to the capital. ${ }^{32}$ Similar attempts to map the police stations in other Ottoman cities would help understand the strategies of control developed by the Ottoman authorities and correlate the geography of crime and this police concentration.

\section{The Police and the People: The karakol and the Social Integration of the Police}

The role of the police stations in the urban space cannot be evaluated outside the social relations that took place inside and around these buildings. Erving Goffman's 1972 reference work on the police was based on in situ observations

30 May Davie, "Manouk Avédissian, alias Béchar afandi al-mouhandis," in Médecins et ingénieurs ottomans à l'âge des nationalismes, ed. Meropi Anastassiadou (Paris: Maisonneuve \& Larose, 2003), 233.

31 Hanssen, Fin de Siècle Beirut, 207-9.

32 Lévy-Aksu, Ordres et désordres, 289-95. 
that approached the institution and its members through an interactionist perspective, with special emphasis on the micro level. ${ }^{33}$ Obviously, the importance of observation in sociology is a major obstacle to its application to historical topics. Yet the questions raised by Goffman and his emphasis on the tensions and exchanges that characterize the functioning of the police institution can help in exploring the social role of the police in historical contexts. As underlined by Quentin Deluermoz in his study of the nineteenth-century Parisian police, an interactionist perspective on the social dynamics at the core of the police activities may be developed through attention to spatial and temporal details, the actors involved and the physical and verbal interactions mentioned in the police and judicial records. ${ }^{34}$

To what extent can such an approach be relevant to the police in Ottoman cities? The unavailability of local police station archives sets the Ottoman case apart from the French or British ones. If available, the daily logs kept by the karakol would have been the main source for a study of the interactions between the police and city dwellers. Instead, the summaries sent by the central police stations to the Ministry of Police only provide an indirect account of the daily police activities. Yet the recurrence of some places, situations, and tensions makes it possible to get an insight into the role of the police in urban life. Local newspapers also offer a complementary perspective on the Ottoman police activities in the late nineteenth to early twentieth centuries. While the reign of Abdülhamid II was characterized by a widespread use of censorship, this had little effect on the news in brief, which held much space in the newspapers of the capital and provincial cities. Much richer in detail than the police archives, the reports of crimes and incidents gave a sample of everyday violence in the capital. Despite their fragmentary and partial approach to urban realities, these pieces of news still contribute to a better understanding of the temporal, spatial, and social dimensions of policing when they are combined with police records.

These sources offer a view of policing that is more contrasted than the historiography of the Hamidian period. The police, as the main tool of law enforcement and control in the cities, played a major role in the surveillance and repression of "dangerous" individuals and groups in late Ottoman cities. The importance of spying, a mission entrusted both to the police and

\footnotetext{
33 Erving Goffman, Relations in Public: Microstudies of the Public Order (New York: Basic Books, 1972).

34 Quentin Deluermoz, "Usages de Goffman au XIX" siècle: policiers en tenue, institutions et ordres sociaux à Paris," no. 14 (2007).
} 
to a parallel organization of remunerated spies, is attested by a number of archival documents. The political elite and Young Turks were targets, but so too were non-Muslim communities; particularly the Armenians in the capital, and the working classes. Yet the aim of policing was far from limited to the suppression of political threats: like their Western European or Egyptian counterparts, the late Ottoman police devoted much attention to the social and moral challenges to public order. The recurrence of cases involving bachelors (bekār) and prostitutes in police reports and newspapers points to the stigmatization of the supposed moral depravation of these categories and the collaboration of police, notables, and well-settled neighborhood inhabitants in excluding marginal categories. The frontiers between the political, social, and moral threats were often blurred, such as in the case of the control of migrants, a traditional concern for the authorities that grew in urgency with the rise of imperial and transnational mobility. ${ }^{35}$

While a comprehensive study of all these aspects of police activity would be beyond the scope of this chapter, I would like to focus here on one main question raised by these sources: the degree of social integration of the police and the extent to which their utility was acknowledged by the population in the late nineteenth to twentieth centuries. Without underestimating the diversity of the urban contexts, I will discuss a few entries I examined in my research on Istanbul that can be beneficial to consider in a comparative perspective that includes Jerusalem and other late Ottoman cities.

The first entry brings us back to the building of the police stations. The decision to build a new karakol normally resulted from a decision on the part of the Ministry of Police, justified by the absence of similar buildings in the vicinity and/or the specific challenges to public order in a given neighborhood. However, a few cases suggest that city dwellers could also ask for the opening of a karakol in their neighborhood. This was the case in Hasköy, a neighborhood located on the Golden Horn in Istanbul, where members of the Jewish community collected money in 1884 to fund the construction of a station. According to the newspaper Tarik, which gave publicity to this piece of news, this initiative was little appreciated by the Greek inhabitants of the neighborhood. ${ }^{36}$ In 1889, the diary of the mukhtar of Kasap İlyas neighborhood mentioned a petition addressed to the Ministry of Police, signed by some inhabitants asking

36 Tarik, June 11, 1884. The transcription of the article was published in Tarih ve Toplum, no. 4 , June 1984,5 . 
for a police station. ${ }^{37}$ In this case, the mukhtar worked with the inhabitants to identify on a building plot where he suggested that the police build the new station. To what extent were these initiatives exceptional or widespread? Very few similar cases can be found in the Ottoman archives, but since the abovementioned initiatives are not recorded in the Żaptiye Nezāreti series, there may have been other petitions of this kind. In the case of Jerusalem, a few local contributions to the opening of police stations are recorded. In 1903, the engineer Karagüç was awarded by the Ottoman state for having offered half of the funding necessary for the building of four new police stations in the city. ${ }^{38}$ The next year, an Ottoman document acknowledged the role played by the police chief Şevki Bey and the Jerusalem municipality in raising funds to build a gendarmerie karakol in the city. ${ }^{39}$ For this last case, the municipal archives might provide more information on the role of the municipality in the settlement of police and gendarmerie forces in Jerusalem.

Why would urban dwellers support the construction of police stations? This question overlaps with one of the most contested issues in police studies, namely the relationship between the police and the community, and the legitimacy of the institution among the people. It suggests that police forces were considered as urban actors whose social utility was acknowledged by some components of the urban population, even in the repressive framework of Hamidian power. The fear of crime was a main factor in the social demand for police. The local and foreign notables of the city that expressed their views in the local newspapers of late Ottoman cities complained habitually about insecurity, theft and the lack of morality. Their demand for the police was part of a discourse on modernity that called for the replacement of traditional inefficient actors such as night watchmen (bekçi) by modern and competent police forces. This perspective idealized an institution that was still very weakly professionalized. Interestingly, the municipal police did not benefit from the same positive image: harsh criticisms of corrupt and inefficient $\dot{z} \bar{a} b \iota t a$ were recurrent in the same newspapers. The municipality was an easier target than the state institutions in the context of Hamidian censorship. This point of view may, however, also be indicative of the weakness of the municipal police in the Ottoman cities due both to a lack of financial resources and the broad

\footnotetext{
37 Cem Behar, A Neighborhood in Ottoman Istanbul: Fruit Vendors and Civil Servants in the Kasap İlyas Mahalle (Albany: State University of New York Press, 2003), 79.

38 ВОА, DН.МКт 780/57, 1 Şaban 1321 [October 23, 1903].

39 вОА, DH.мКт 8881/14, 5.C. 1322 [July 18, 1904].
} 
attributions given to the state police in terms of urban policing, leaving little space for the development of municipal policing. 40

The late nineteenth-century Ottoman police began to play a role in the settlement of disputes and tensions in the neighborhoods, and this contributed to increasing their legitimacy among local inhabitants. In his article "The Police and the People," Khaled Fahmy relies on the police archives to argue that the late nineteenth-century Egyptian police became an effective mechanism of recourse for ordinary Egyptians, who went to the police stations to seek help in settling legal matters of various kinds, from crime to divorce and inheritance rights. ${ }^{41}$ According to Fahmy, the police were more accessible than the judicial institutions because of their spatial proximity and lower cost. On the other hand, they could avail themselves of the authority of the state, absent in the informal ways of settling conflicts. In the Ottoman case, petitions addressed to the police by local inhabitants on the initiative of the imam and mukhtar give an insight into this recourse to the police to settle minor conflicts. The expulsion of prostitutes or women of ill repute and the closing of taverns were among the objects of these petitions, which were sometimes followed by a police investigation. One of the most documented cases I found for Istanbul was an 1890 petition initiated jointly by the mukhtar and imams of four districts in Tophane, who worked together to gather approximately one hundred signatures mainly from local craftsmen and shopkeepers (eșnăf). The petition demanded police support to set up a local fire brigade (tulumbacı), despite the opposition of the neighboring Galatasaray brigade, which operated in the districts in question. ${ }^{42}$ In this conflict of interests, the police was considered a legitimate arbiter. The file held in the archives reveals that various parties were auditioned by the police (a petition from the adverse party is also found in the file) and an investigation was carried out before the affair was placed before a commission. The result of the commission remains unknown, as is often the case.

While these sources reveal the close relations between some inhabitants and the police, they do not enable us to say with certainty whether the police were able to resolve this sort of local conflict. They also remain silent on why the police were interested in this sort of minor affair and do not give clues about the possible rewards that might stimulate the industriousness of the police officers. Nevertheless, these petitions do seem to indicate that in the

\footnotetext{
$40 \quad$ Lévy-Aksu, Ordre et désordres, $115^{-21}$.

41 Khaled Fahmy, "The Police and the People in Nineteenth-Century Egypt," Die Welt des Islams 39, no. 3 (1999).

42 BOA, Y.PRK.ZB 5/118, 26.M.1308 (H) [11 September 189o].
} 
late nineteenth-century capital, the police had become part of the networks of relations that maintained order and settled disputes in the city. In cooperation with the notables, the religious authorities and the mukhtar, they became one of the options available to inhabitants eager to protect their interests or solve their conflicts. Unfortunately, besides the petitions, the police archives shed little light on the daily encounters between the police and inhabitants. I have suggested elsewhere that their participation in infrajudiciary solutions might also have legitimized their presence in the city neighborhoods and enabled the institution to build a network of personal contacts which could be used for the purposes of surveillance and information gathering. ${ }^{43}$ The validity of such hypotheses for other Ottoman cities, where the density of police stations and number of police per inhabitants were much lower than in the capital, remains to be tested.

\section{Conclusion}

This chapter attempted to provide insight into the historiography of late Ottoman cities by focusing on the presence and role of the state. It argued that, while the scholarship on Ottoman cities has become increasingly interdisciplinary and aware of the significance of material culture, the social history of state institutions remains little studied and integrated in the analysis of urban social and political dynamics. Through the case of the Ottoman police, the chapter addressed the question of the integration of institutions in the urban fabric and the interactions between their members and the rest of society.

To what extent can such an approach contribute to our conceptualization of citadinité in late Ottoman cities? First, the diffusion of police stations and other public buildings was a major aspect of the transformation in the urban fabric. Like schools and hospitals, police stations had both a utilitarian and symbolic function, being the interface between the state and the local population. A better understanding of their interior architecture, accessibility, and their distribution in the cities would contribute to a more nuanced evaluation of the imprint of these buildings on the urban space, and their spatial differences at the infraurban level.

43 Noémi Lévy-Aksu, "Institutional Cooperation and Substitution: the Ottoman Police and Justice System at the Turn of the 19th and 2oth Centuries," in Order and Compromise: Government Practices in Turkey from the Late Ottoman Empire to the Early 21st Century, ed. Marc Aymes, Benjamin Gourisse, and Elise Massicard (Leiden: Brill, 2014), 167. 
The interactions between civil servants and the people also deserve more attention. In the case of the police, the karakol can be considered as a shared space by the different components of urban society, whether they had recourse to the police or were taken into custody. Yet this did not mean that it erased social hierarchies or offered equal resources to all the city's inhabitants. In many cases, the police seemed to encourage or legitimize the social pressure exerted by the local district or some of its inhabitants against behaviors judged contrary to social, moral, and religious conventions, sparing them the bother of a judicial process of uncertain outcome. The arbitrary side of these police interventions was especially detrimental to individuals at the margins of society such as beggars, vagrants, and prostitutes. In the context of social and political tensions, the police could also play a role in the collective stigmatization of specific social categories and outbursts of violence against them, as illustrated by the recurrent instructions regarding the surveillance of Armenians in the Ottoman capital from the 1890 s onwards. ${ }^{44}$ Despite an official ban by the authorities, the use of torture in police stations was a darker side of these interactions between the police and the people. ${ }^{45}$ In this regard, the karakol may help us explore the contrasted facets of late Ottoman citadinité and avoid its idealization: as an interface between the state and the people and as spaces of social encounters, negotiations and violence, police stations offer precious clues about the mechanisms of integration, exclusion, and repression which shaped late Ottoman urban life. Thanks to the Open Jerusalem project and the archives made accessible through it, Jerusalem may become a laboratory for this social history of the police and public order. There is little doubt that the municipal archives, the court registers (sijillāt), and the Ottoman State Archives (Başbakanlık Osmanlı Arşivi) will offer new insights into the role of the imperial and municipal police organizations and the relations between police and justice, thus contributing to a better understanding of power relations and social life in the city.

44 Lévy-Aksu, Ordre et désordres, 156-60.

45 İbrahim Kalkan, "Torture, Law, and Politics in the Late Ottoman Empire, 1840-1918" (PhD diss., New York University, 2015). 


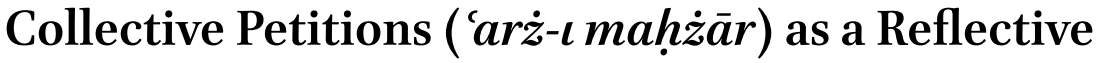 Archival Source for Jerusalem's Networks of Citadinité in the late 19th Century
}

\author{
Yasemin Avcı, Vincent Lemire, and Ömür Yazıcı Özdemir
}

Since the last quarter of eighteenth century, the creation of central archival depositories has put a great mass of archival documents produced by the imperial states at the disposal of historians conducting research on the "long" nineteenth century. ${ }^{1}$ In spite of their undeniable importance to historical studies, focusing on these documents as a dominant source poses certain methodological problems. The abundance of these documents might lead the historian to fall into the trap of a top-down, state-centric approach. At its most extreme, it might seem there is no social or economic change without state impulse. Instead, citizens appear as objects of socioeconomic developments than as subjects of historical processes. They remain historically unimportant or become simple, "silent masses." In order to establish a bottom-up approach and to hear the voices of ordinary people, historians have started to give much more importance to historical sources such as private journals, autobiographies, and diaries; so-called "ego-documents." ${ }^{2}$ Some archival materials in state archives are also valuable sources, presenting data that enable historians to overcome the methodological challenges of a state-centric approach and

1 The creation of centralized archival depositories in major European cities dates to the eighteenth century (St. Petersburg in 1720, Vienna in 1749, Warsaw in 1765 , Venice in 1770 , Florence in 1778, etc.). In France, the Revolution established the National Archives by the decree of September 7,1790 , and in 1794, the archives were opened to the public. Following France, the U K established the Public Record Office in 1838. In 1881, the Pope Leo XIII opened to the public the Archivio Segreto Vaticano, which had been established in 1611. See Jacques Le Goff, History and Memory, trans. Steven Rendal and Elizabeth Claman (New York: Columbia University Press, 1992), 87-88. The Ottoman Archives were created in 1846 under the name of Hazine-i Evrāk (Treasury of Documents). For further information, see Alev Erkmen, $\mathrm{Geç}$ Osmanlı Dünyası'nda Mimarlıkve Hafıza: Arşiv, Jübile, Âbide [Architecture and memory in the late Ottoman world: archive, jubilee, monument] (Istanbul: Bek, 2010), 37-74.

2 For the definition of the term "ego-documents," see Rudolf Dekker, "Jacques Presser's Heritage: Egodocuments in the Study of History," Memoria y Civilización 5 (2002).

(C) Y. AVCI, V. LEMIRE, AND Ö.Y. ÖZDEMIR, 2018 | DOI:10.1163/9789004375741_012

This is an open access chapter distributed under the terms of the prevailing CC-BY-NC-ND License at the time of publication. 
concentrate on the questions and theoretical issues of social history. Petitions are one of these sources.

Although studying petitions is a well-accepted way of assessing the political trends of a society, it would be naive to consider petitions as transparent mirrors of directly accessible public opinion. ${ }^{3}$ Petitions are not fully autonomous and spontaneous texts. Rather, they are framed text forms, standardized and bound by specific syntactic rules. Petitions are not always written by the person who is the signatory: a public writer, a notable, or a representative may stand between the signatory (or signatories) and the recipient of a petition. Moreover, the term "petition" covers a wide variety of concrete situations. Petitions may arise from class actions or individual requests, corporatist complaints or slanderous denunciations, or may be expressions of sincere thanks or gratitude. To analyze a set of petitions, therefore, one needs to focus just as much on what is said as on how it is said. The documentary context must also be analyzed (language, date, paper type, number of handwritten signatures). This is the methodological choice we made in this chapter. We chose not to consider petitions as a perfect observatory of a fetishized "public opinion" but rather as the complex laboratory of different forms of citadinité coexisting sometimes in contradictory ways in the mixed city of Jerusalem. ${ }^{4}$

Since the 1980s, several historical disciplines, from ecclesiastical and legal, to cultural and gender history, have used petitions as historical texts in the field of social history. ${ }^{5}$ It seems that historians have put increased attention on petitions especially in the wake of a special 2001 issue of The International Review of Social History. This issue focused on petitions as crucial, informative and reflective sources for the study of social history. In the introduction, Lex Heerma Van Voss argues that petitions are unique sources that enable

3 Yuval Ben-Bassat, "Mass Petitions as a Way to Evaluate 'Public Opinion' in the Late NineteenthCentury Ottoman Empire? The Case of Internal Strife among Gaza's Elite," Turkish Historical Review 4, no. 2 (2013).

4 Vincent Lemire, Jérusalem 19oo: La ville sainte à l'âge des possibles (Paris: Armand Colin, 2012); Lemire, Jerusalem 19oo: The Holy City in the Age of Possibilities, trans. Catherine Tihanyi and Lys Ann Weiss (Chicago: University of Chicago Press, 2017).

5 For example, see Stephen Higginson, "A Short History of the Right to Petition Government for the Redress of Grievances," Yale Law Journal 96, no. 1 (1986); Tor Hauken, Petition and Response: An Epigraphic Study of Petitions to Roman Emperors, 181-249 (Bergen: Norwegian Institute at Athens, 1998); William Mark Ormrod, Gwilym Dodd, and Anthony Musson, eds., Medieval Petitions: Grace and Grievance (Rochester: York Medieval Press, 2009); Ronald J. Krotoszynski, Reclaiming the Petition Clause: Seditious Libel, Offensive, Protest, and the Right to Petition the Government for a Redress of Grievances (New Haven: Yale University Press, 2012). 
social historians to hear the voices of ordinary, nonelite people. ${ }^{6}$ It seems that scholarly attention to petitions has also contributed to the development of research projects. For instance, in France, Paris-Est Marne-la-Vallée University historians led a collective academic research project from 2007 to 2012. Its aim was to build a database of all petitions submitted to the National Assembly and to the Senate from 1815 to 1940 , and to analyze the results by matching them with geographic, gender, and social data. ${ }^{7}$

Since the 1980s, scholars of Ottoman history have also used petitions as a historical source. ${ }^{8}$ Unlike the scholarly interest in petitioning in the earlier periods of Ottoman history, there are only a few studies devoted to examining petitions as historical texts for analyzing the late Ottoman period. Undoubtedly the most significant contribution to this field is Yuval Ben-Bassat's 2013 book Petitioning the Sultan (London: I. B. Tauris). Ben-Bassat aims to explore petitions sent by Ottoman subjects in Palestine to the sultan and central government from 1865 to 1908 . He deals with petitions submitted by villagers, Bedouins, Ottoman officials serving in Palestine, foreign nationals, Jewish settlers, and especially urbanites of Gaza and Jaffa. The sole but important limit of this book is the nonexistence of petitions sent by the inhabitants of Jerusalem. In the current chapter, we examine a set of two hundred collective petitions submitted by the urbanites of Jerusalem from 1840 to 1915. In tracing collective petitions through the computerized system of the Ottoman State Archives (Başbakanlık Osmanlı Arşivi - BOA), the first criterion was to determine which collective petitions were submitted from Jerusalem. We thus

6 Lex Heerma Van Voss, "Introduction," International Review of Social History 46 (2001): 10.

7 For further information, see http://acp.u-pem.fr/projets-de-recherche/petitions/; Also, the program of the final symposium: http://www.parlements.org/colloques/13_03_2122_ Petitionner_L_appel_aux_pouvoirs_XIX ${ }^{\mathrm{e}} \mathrm{XX} \mathrm{X}_{\text {e }}$ siecles.pdf.

8 For the pioneering studies in this field, see Hans Georg Majer, ed., Das Osmanische "Registerbuch der Beschwerden" (Şikâyet Defteri) vom Jahre 1675 (Vienna: Österreichische Akademie der Wissenschaften, 1984); Halil Inalcik, "Şikâyet Hakkı: Arz-ı Hâl ve Mahzarlar" [Right to complain: petition and collective petition], Osmanlı Araştırmaları 7-8 (1988); Michael Ursinus, Grievance Administration (Şikayet) in an Ottoman Province: the Kaymakam of Rumelia's Record Book of Complaints of 1781-1783 (London: RoutledgeCurzon, 2005). For a recent study on the subject, see Murat Tuğluca, Osmanlı Devlet-Toplum İlişkisinde Şikâyet Mekanizması ve İşleyiş Biçimi [The complaint mechanism and its functioning in the relationship between state and society in the Ottoman Empire] (Ankara: Türk Tarih Kurumu, 2016). See also Nora Lafi, "Petitions and Accommodating Urban Change in the Ottoman Empire," in Istanbul as Seen from a Distance: Centre and Provinces in the Ottoman Empire, ed. Elizabeth Özdalga, M. Sait Özervarli, and Tansu Feryal (Istanbul: Swedish Research Institute in Istanbul, 2011). 
excluded petitions sent by the inhabitants outside the city, including from villagers close to Jerusalem, and we also excluded people from other districts such as Jaffa, Hebron, Gaza, and Beersheba. Our study is based on a collection of two hundred petitions presented by the urbanites of Jerusalem, from a larger collection of the more than six hundred petitions sent by the people throughout Jerusalem province.

\section{Looking for Petitions in the Ottoman State Archives: From Inputs to Outputs}

In the Ottoman Empire, petitioning was an institution with roots in the early days of the empire. Individuals or groups of individuals from all segments of society enjoyed the right to present written appeals to the imperial bureaucracy on a broad range of social, economic, moral, and legal issues. Petitioning was a traditional way for urban or rural subjects to convince the imperial bureaucracy to intercede in their cases; namely to eliminate excessive taxation or any form of oppression $(z \ddot{u} / m)$. Petitioning was not solely a mode of lodging complaints against abusive bureaucrats and officials. Petitions were also submitted in favor of a local governor or an official. They might be sent to request an act of kindness or an advantage to the benefit of the petitioner. Some petitions were submitted in order to congratulate the government on the effectiveness of a public infrastructure project. Therefore, petitions had a dual political function: on one hand, petitioning was an institution through which the citizens of the empire involved themselves in decision making procedures, central, or local politics. On the other hand, petitions were an effective method of government and legitimation for imperial power. Petitions must be considered in the global framework of the inputs and outputs of the administrative and archival process. This strategy guided us as we searched for petitions amid the huge mass of Ottoman archives.

In accordance with the existence of an established petitioning mechanism, special registers and correspondences appeared in the воА. Prior to the second half of the nineteenth century, the first collection concerned with petitions is the Mühimme defterleri (Registers of Important Affairs)..$^{9}$ The Mühimme registers contain orders and decrees issued by the sultan after discussions by

9 The воA today houses 419 Mühimme registers dating from 1553 to 1915. For further information, see Yusuf Sarınay et al., Başbakanlık Osmanlı Arşivi Rehberi [Guidebook to the Ottoman State Archives] (Istanbul: Başbakanlık Devlet Arşivleri Genel Müdürlüğü, 2010), 7-21. 
the Dìvān-ı Hümāyūn ${ }^{10}$ (Ottoman Imperial Chancery) on all matters of interest to it. ${ }^{11}$ From the sixteenth to the mid-seventeenth centuries, responses to petitions issued as firmans were also inscribed in these registers. ${ }^{12}$

In 1649, the central bureaucracy created the Şikāyet defterleri (Registers of Complaints) as separate volumes of Mühimme registers, likely due to the increase in the numbers of complaints. This meant that the decrees issued as a result of petitions were no longer inscribed along with the other affairs recorded in the Mühimme registers. The Şikāyet defterleri ${ }^{13}$ contain the decrees and firmans issued upon appeals by the individuals or groups of inhabitants to the related governmental office or directly to the sultan himself. ${ }^{14}$ This practice continued until 1746. In that year, the central bureaucracy began to organize the Registers of Complaints geographically, in accordance with the administrative division of the empire. Thereafter, they were to be referred to as Vilayet ahkām defterleri (Registers of Provincial Decrees). In both of these

The Dīvān-ı Hümāyūn was the imperial council located at the top of the Ottoman central government. It functioned as a high court of justice and a cabinet that discussed and made decisions on all governmental affairs. See Recep Ahıskalı, "Divan-ı Hümayun Teşkilatı" [The organization of the Imperial Council], in Osmanlı, ed. Güler Eren, vol. 6 (Ankara: Yeni Türkiye Yayınları, 1999).

11 The present volumes of Mühimme registers cover a period of over three centuries, from the mid-sixteenth to the second half of the nineteenth centuries. The whole collection contains copies of more than 150,000, or perhaps even 200,000 decrees. See Uriel Heyd, Ottoman Documents on Palestine, 1552-1615: A Study of The Firman According to the Mühimme Defteri (Oxford: Clarendon Press, 1960), xv. For further information about these registers, see also Feridun M. Emecen, "Osmanlı Divanının Ana Defter Serileri: Ahkâm-ı Mîrî, Ahkâm-ı Kuyûd-ı Mühimme ve Ahkâm-ı Şikâyet” [The principal series of registers of the Ottoman Imperial Council: imperial decrees, decrees of the Ottoman Imperial Council, answers to petitions], Türkiye Literatür Araştırmaları Dergisi 3, no. 5 (2005).

12 Linda T. Darling, Revenue-Raising and Legitimacy: Tax Collection and Finance Administration in the Ottoman Empire, 1560-166o (Leiden: Brill, 1996), 248.

13 In the воА, the 'Atīk Şikāyet defterleri registers are 213 in number, dated from 1649 to 1837 (AH 1059-1252), while the Şikāyet defterleri registers are thirty-eight in number and dated from 1504 to 1819 (AH 920-1234). For further information, see Başbakanlık Osmanl,, 21-22.

14 Along with other occasions, the sultan's participation in public worship for Friday prayer (Cuma Selamlığı) was an opportunity for people to present petitions directly to him, a practice that lasted until the end of the empire. For the details of this occasion, see Mehmet Ipşirli “Osmanlılarda Cuma Selamlığı (Halk-Hükümdar Münasebetleri Açısından Önemi)" [Ottoman Friday prayer (its significance with regard to peoplesovereign relationship)], in Prof. Dr. Bekir Kütükoğlu'na Armağan [Tribute to Prof. Dr. Bekir Kütükoğlu] (Istanbul: Edebiyat Fakültesi Basımevi, 1991). 
registers (Şikāyet defterleri and Vilayet ahkām defterleri), we do not have the original petition (inputs), but we do have the decrees (hükü̈m) of the Dìvān-ı Hümāyunn, because the outcome (or outputs) of the administrative and legal process began with a petition. Despite the lack of original petitions, the ahkām registers present us with valuable information on the origin, content, and identity of petitioners as well as on the various stages of their bureaucratic, administrative, and political responses. ${ }^{15}$ The ahkām registers were thus very helpful in analyzing the causal link between petitions and decisions, and in understanding the decision-making process. Studying the ahkām registers also provides valuable information on the identity of their senders, distribution of petitions by place of origin, and petition addresses. ${ }^{16}$

The a k kām registers of the province of Damascus provide information about decrees issued by the central government upon petitions submitted by the inhabitants of Jerusalem province. The total number of these registers is nine and they span the period 1742-1908 (AH 1154-1326). These registers contain decrees related to the governmental and legal affairs of Jerusalem, Safed, Aclun, Lecun, Gaza, Nablus, Saida, Beirut, and all other administrative regions under the jurisdiction of the provincial government in Damascus. ${ }^{17}$ Although these are valuable sources of information on the final decisions made by the central government on petitions, we cannot see the text of the original petitions. The wording and formulation of the original petitions would enable us to hear the voices of ordinary people. Though many original petitions remain unavailable, Faroqhi reminds us that we have a vast number of original petitions both in the Topkapı Palace Archives and in the воА. Some collections in the BОA, namely the Maliyeden Müdevver ${ }^{18}$ (transferred from the Ministry

15 The same methodological choice (focusing on registers) was taken by the project "Pétitions adressées aux Assemblées (Chambre et Sénat) de 1815 à 1940," which was conducted from 2007 to 2012 by Paris-Est Marne-la-Vallée University. See n. 7 .

16 For an empirical study analyzing the statistical data obtained from an ahkām Register, see Fatma Acun and Ramazan Acun, "Demand for Justice, and Response of the Sultan in the Early 16th Century," Études balkaniques 2 (2007).

17 After the implementation of the Vilayet Law of 1871, the Jerusalem sanjak was detached from the province of Damascus and raised to the status of an "independent" subdivision of a province (elviye-i gayrimülhaka), connected directly with the central government in Istanbul. In this way, the governor of Jerusalem, now responsible directly to Istanbul, was regarded as a vali whose area of jurisdiction happened to be relatively small. Yasemin Avcı, Değişim Sürecinde Bir Osmanlı Kenti: Kudüs 1890-1914 [An Ottoman town in transition: Jerusalem, 1890-1914] (Ankara: Phoenix, 2004), 6o-61.

18 These registers, which contain many documents especially on fiscal affairs, are called Maliyeden Müdevver [transferred from the Ministry of Finance] because the Ministry of Finance delivered them to the воА in 1945. See Başbakanlık Osmanlı, 266-72. 
of Finance) and Kamil Kepeci ${ }^{19}$ (catalogued by Kamil Kepeci), present original petitions alongside many different types of archival documents. However, Faroqhi also notes that "most of the petitions investigated are so routine that very little trace remains of the petitioner's manner of expressing himself, so that at present, the summaries retained in the Mühimme and Şikāyet registers remain quite irreplaceable." 20

From the beginning to the end of the empire, original petitions and related correspondences are fragmentary and dispersed among many classifications in the вОА. In order to trace the individual and collective petitions of the nineteenth century, we may use the BоA's ever-growing and improving computerized system. As all Ottoman historians know, almost every file after the nineteenth century has a summary in the database. Our research in these archives showed that it is not easy to trace petitions by searching file summaries. When we carry out a catalogue search in the summaries using related

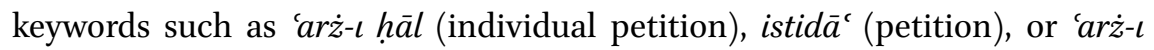
mahı̇är (collective petition), with the word "Jerusalem," few documents are found. We have been able to isolate the set of two hundred collective petitions used in this study by searching through the digital images of almost seven thousand files from various collections collected for the Open Jerusalem project from the воА. We do not claim that the collections contain just two hundred petitions: further research may result in the discovery of more petitions.

\section{Nineteenth-Century Changes: Petitioning in the Era of Tanzimat and the Telegraph}

In presenting himself as "a just and legitimate ruler," the Ottoman sultan's primary duty was to "command good and forbid evil" and to ensure that justice was rendered to the empire's subjects. In accordance with the Islamic tradition, the sultan was the "shadow of God on earth" (Hälife-i rüy-i zemin) and the creator of a temporal order to the benefit of all subjects entrusted to him by

19 This collection, which consists mainly of registers of fiscal offices, is called Kamil Kepeci Tasnifi because it was classified under the direction of Kamil Kepeci, an Ottoman archivist who began working in the вОА in 1924. For further information about this collection, see Başbakanlık Osmanlı, 263-65.

20 Suraiya Faroqhi, "Political Activity among Ottoman Taxpayers and the Problem of Sultanic Legitimation," Journal of the Economic and Social History of the Orient 35, no. 1 (1992): 5. 
God. ${ }^{21}$ As the basic source of state legitimacy and the guarantor of its just rule, the Ottoman sultan set up a mechanism that enabled every subject to complain directly to the imperial government or the sultan himself regarding the injustices they suffered. Aside from individual petitions, there were also petitions submitted in the name of a group of people. Undoubtedly, the advantage of collective petitions over individual ones was the weight given to petitions bearing many signatures. In addition, collective petitions were less risky for petitioners who were afraid of recriminations by the accused parties.

Previous studies on the Ottoman petitioning system revealed that the imperial government used the system widely, both at the provincial and central levels. ${ }^{22}$ As the registers in the воA show, before the nineteenth century, the Dīvān-ı Hümāyūn had a special office, the Dīvān-ı Hümāyūn Şikāyet Kalemi (Petitions Office of the Ottoman Imperial Chancery), which was in charge of dealing with petitions at the imperial level. ${ }^{23}$ After the examination of a petition in the Divaan, a firman was usually issued in response to petitions and was then sent to the related central government office or to the concerned provincial government authorities such as the qadi, the governor or other senior military officers in the region. At the provincial level, it was usually the qadi who examined the petitions and rendered the decision, ${ }^{24}$ but, occasionally, if the provincial governor received petitions as the sultan's deputy in the provincial district under his command, it was the vilayet Divan (provincial supreme court) which fulfilled the regular duties prompted into action by the petitioner. $^{25}$

As many decrees inscribed in the ahkām registers demonstrate, petitioners' demands were taken seriously to such a degree that they successfully convinced the government to alter its behavior. As Linda T. Darling has noted, "in the Ottoman Empire, petitioning the ruler was not a mere formality; it generated lasting and sometimes wide-ranging changes in the application of laws

21 Rifa'at Ali Abou-el-Haj, "Aspects of the Legitimation of Ottoman Rule as Reflected in the Preambles to Two Early Liva Kanunnameler," Turcica 21/23 (1991).

22 Yuval Ben-Bassat, Petitioning the Sultan: Protests and Justice in Late Ottoman Palestine (1865-1908) (London: I. B. Tauris, 2013), 31.

23 Said Öztürk, "Sosyo-Ekonomik Tarih Kaynağı Olarak Ahkam Defterleri” [Registers of decrees as sources of socioeconomic history], in Pax-ottomana: Studies in Memoriam Prof. Dr. Nejat Göyünç, ed. Kemal Çiçek (Ankara: Sota and Yeni Türkiye, 2001), 611.

24 Uriel Heyd, Studies in Old Ottoman Criminal Law, ed. M. L. Ménage (Oxford: Clarendon Press, 1973), 226.

25 Ursinus, Grievance Administration, 8-9. 
and regulations of the empire."26 In this respect, the institution of petitioning enabled the Ottoman imperial authority to preserve its legitimacy, especially during periods of political crises or changes. The petitioning system also served the Ottoman sultans as a means to monitor the activity of bureaucracy both at central and local levels, allowing the sultans to gather valuable information about their conduct.

In the Tanzimat period, the role and importance of petitioning did not diminish. On the contrary, as Ben-Bassat has noted, "it took on new importance and went through a process of revival and transformation due to both technological progress, as well as more fundamental institutional and legal changes." The reforms that changed the nature of government motivated Ottoman subjects to behave more like citizens of a modern state. They increased their expectations that the state would listen to their concerns more closely than before. ${ }^{27}$ During the Tanzimat period, the state penetrated the lives of its subjects more than ever before. Censuses, registration of lands, public education, health, tax surveys, and unification of the taxation system all meant that the Ottoman state undertook many new functions and duties that it had not fulfilled directly in the past. In the eyes of the citizens, the state ceased to be an ambiguous, ill-defined entity. It became a visible system whose presence was manifested in daily life. As a result, "there were both more possibilities to petition as well as more reasons to petition."28

Indeed, the penetration of the state into public life is not a development that occurred despite the intentions of Tanzimat reformers. The reformers' primary motivation was to achieve greater centralization, especially in the administrative apparatus. Such a goal required the establishment of a modern bureaucratic system ranging from the imperial center to the local level based on a strong and detailed recording system. The establishment of many institutions and administrative bodies such as Meclis-i İdäre (provincial administrative council), Meclis-i belediye (municipal council) and Nizāmiye courts provided Ottoman subjects with many avenues to articulate their concerns and grievances and to demand justice and redress from the government. As Gerber points out in his pioneering book on the province of Jerusalem during the late Ottoman period, the Administrative Council of Jerusalem received petitions from the residents of the district on various matters and fulfilled

\footnotetext{
26 Darling, Revenue-Raising and Legitimacy, 281.

27 Ben-Bassat, Petitioning the Sultan, 33, 39.

28 Ben-Bassat, "Mass Petitions as a Way," 139.
} 
regular duties, prompted into action by the petitioners. ${ }^{29}$ We also came across many petitions, both individual and collective, in Jerusalem municipality documents on almost every matter related to the municipal administration of the city. ${ }^{30}$

Aside from the increasing bureaucratization of government, another factor that facilitated the petitioning system in the Tanzimat period was undoubtedly the introduction of the telegraph in the 1860s. With the advent of the telegraph, ordinary people could appeal directly, easily, and affordably to the central government. The abundance of petitions in the воA, especially dating from the third quarter of the nineteenth century, proved that petitioning became a routine practice that remained affordable for everyone in the empire. The advent of the telegraph eliminated the need for petitioners to send a representative to Istanbul or to appeal to the local qadi to lodge a complaint. ${ }^{31}$ As Bektaş notes, the telegraph increased central government control over the provinces to a great extent. In certain cases, local officials and governors, even pashas, were dismissed or transferred to other provinces in response to collective telegraphic petitions. Believing their complaints would not be properly conveyed because of the bureaucracy and inefficiency of local administrations, petitioners preferred to seek contact directly with the central government. $^{32}$

Petitions were submitted directly to the sultan during Friday prayer, in which the sultan participated. This practice continued into the second half of the nineteenth century. In order to cope with the growing number of petitions submitted to the sultan during Friday prayer, the central government created a special office called the Ma'rūżāt-i Rikābiye Dāiresi (Bureau of Petitions). ${ }^{33}$ As many registers located in the BOA prove, the main functions of this office were to gather, examine, and even prepare a list of petitions and assign the issues declared in the petitions to the related governmental office. ${ }^{34}$ The emergence

29 Haim Gerber, Ottoman Rule in Jerusalem, 1890-1914 (Berlin: Klaus Schwarz, 1985), chaps. 7-9.

30 For instance, for a collective petition submitted by some of the residents of Mahane Yehuda neighborhood on May 4, 1904, on the subject of building a sewer main in their quarter, see Jerusalem Municipal Archives (JMA), Minutes of Jerusalem Municipality, vol. 9 , 1.

31 Ben Bassat, Petitioning the Sultan, 33, 180.

32 Yakup Bektaş, "The Sultan's Messenger: Cultural Constructions of Ottoman Telegraphy, 1847-1880," Technology and Culture 41, no. 4 (2000): 695.

33 BOA, İrāde Dāhiliye, 107/5390, 29 Şaban 1261/September 2, 1845.

34 For an example of this lists see, BOA, "Âmedî Kalemi Defterleri," 244, 29 Zilhicce 1331/ November 29, 1913 . 
of the office clearly signifies the Ottoman efforts to institutionalize the petitioning system, and its maintenance through the nineteenth century shows that the traditional image of the sultan as the dispenser of justice continued despite the reformed nature of the state and the improved division of labor among the bureaucratic institutions. It was only after 1908, and the end of effective rule by the sultans, that the Ottoman Parliament came to the fore to deal with the petitions. Accordingly, the Ma'rūżāt-i Rikābiye Dāiresi was put under the jurisdiction of the Ottoman Parliament, and its name was changed to Meclis-i 'Ayān İstidāc Encümeni (Senate Committee for Petitions). ${ }^{35}$

\section{When the Numbers Speak for Themselves: Statistical Data Describing the Collective Petitions of Jerusalemites}

Petitions are scattered throughout many different collections in the вОА. As figure 8.1 shows, many of the collective petitions submitted by the inhabitants of Jerusalem come from the collection of the Bāb-ı 'Āli Evrāk Odası (Sublime Porte Record Office - BEO). This bureau, established in 1851, coordinated all the correspondence between the imperial center and the provinces, the ministries, and all other state offices in Istanbul. The circulation of all official correspondence at the level of the imperial center was under its control. ${ }^{36}$

After the petitions were registered, the Ministry of Interior generally handled them. The ministry sent copies of petitions to the appropriate offices and requested the investigation of the issues raised in the petitions. Correspondence was usually conducted between the Ministry of Interior and the sanjak of Jerusalem. If a petition that was not written in Ottoman Turkish was received, it would be sent to the Translation Bureau (Tercüme Odası) at the Ministry of Foreign Affairs. There, the petitions were translated into Ottoman. The collections of the Hāriciye Nezāreti Tercüme Odası (HR.TO, Translation Bureau, Ministry of Foreign Affairs) is therefore the second collection in which many petitions were grouped. A considerable number of petitions or correspondence

35 The Committee for Petitions of the Meclis-i 'Ayān (Senate) published weekly lists of examined and resulted petitions. Five samples of these lists published as booklets may be seen in the Atatürk Library in Istanbul.

36 Murat Candemir, "Bāb-ı 'Ālı Evrāk Odası" [Record office of the Sublime Porte] (PhD diss., Istanbul University, 2002), 6o-62. 


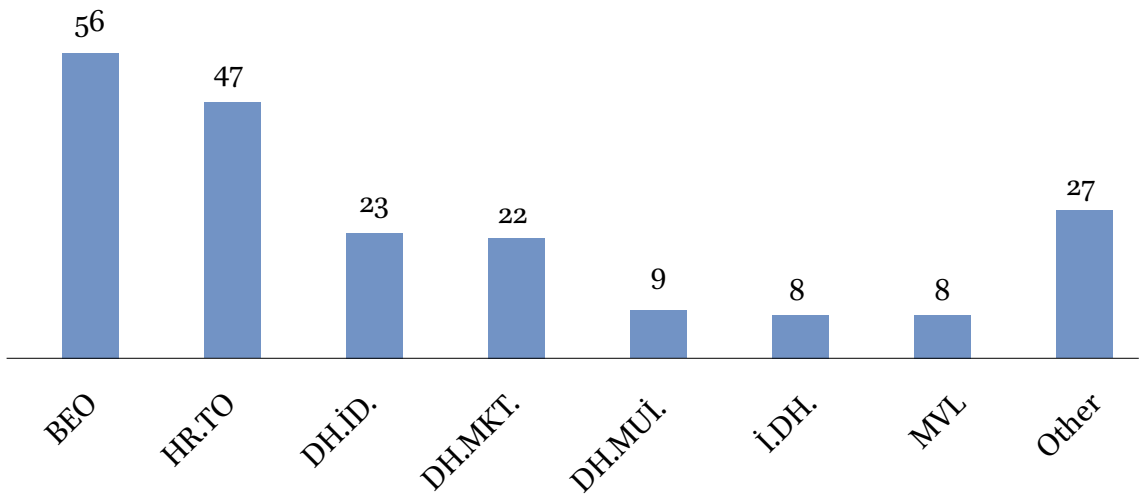

FIGURE 8.1 Classification codes, 1839-1915.

$\varpi 1840-1876 \quad \square 1876-1908 \square 1908-1915$

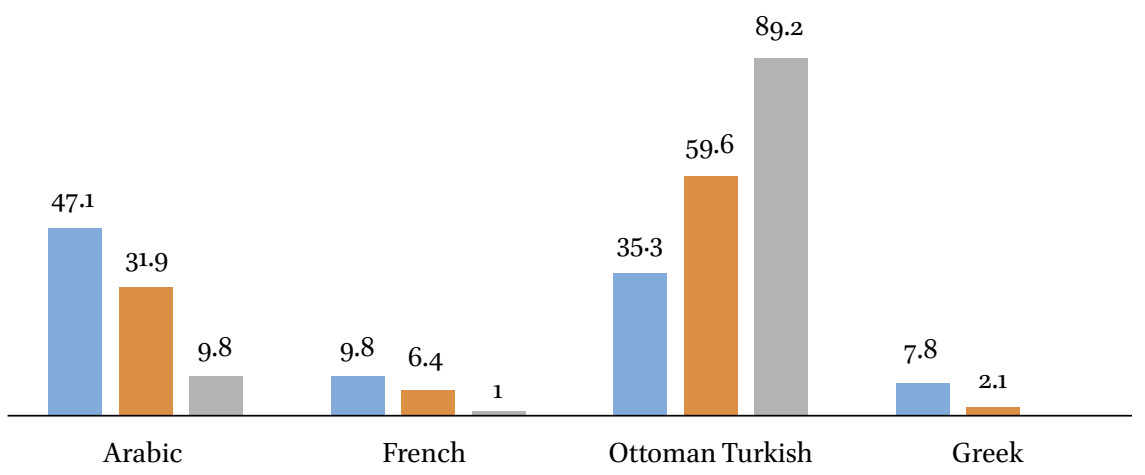

FIGURE 8.2 Original language of petitions, 1840-1915 (in percentages).

related to petitions is also found in the collections of the Ministry of Interior (DH.MKT., DH.í, DH.MUi collections, for example). ${ }^{37}$

Collective petitions were written in Arabic and Ottoman Turkish more often than French and Greek (fig. 8.2). While the preferred language was Arabic between 1840 and 1876 , from 1876 onward, Ottoman Turkish took precedence.

37 DH.мкт., Dāhiliye Nezāreti Mektūbi Kalemi (Correspondence Office of the Ministry of Interior). DH.ìD., Dāhiliye Nezāreti İdāre Evrāḳı (Administrative Documents of Ministry of Interior). DH.Mui., Dāhniliye Nez̄āreti Muhaberāt-ı 'Umūmiye İdāresi Belgeleri (Documents of the General Correspondence Office, Ministry of Interior). İ.DH., Irade Dahiliye (Imperial Decree on Interior Affairs). MvL., Meclis-i Vala (Supreme Council of Law). For further information about these collections, see Başbakanlık Osmanlı, 360-62, 377 . 
Between 1876 and 1908, the decrease in petitions written in French and Greek is striking. The permeation of Ottoman cultural domination in the region is not a valid explanation for this; on the contrary, the period under consideration saw the increased cultural penetration of Europe. It is more likely that the trend toward increased bureaucratization both at the local and central levels caused petitioners to write in Ottoman Turkish when dealing with the Ottoman bureaucracy. Petitioners would have reasoned that writing in the language of the administration was more practical and beneficial. On the other hand, because of the low literacy rate among the native population, ${ }^{38}$ collective petitions (especially when they bore a large number of signatures) were usually written on behalf of the signatories by urban notables, members of the ulema class, or sometimes even by the local officers. Moreover, if any of the signatories were not literate, they had to solicit the assistance of professionals, the 'arzuhâlcı (petition writers), who were highly informed about the petitioning process. Before the nineteenth century, the profession was organized under the guild of petition scribes (eșnāf-ı yazıctyān). ${ }^{39}$ Even after the all-out decline of guilds, there were strict rules that qualified one as an 'arżuhālcı. ${ }^{40}$ Because the petitions had to be submitted directly to the relevant local or central government bureau, petition writers needed to know which department to send the petition to and had to be familiar with legal regulations. ${ }^{41}$

The addressees of collective petitions provide critical clues about which administrative unit or figure the petitioners accepted as dispenser of justice. Petitions submitted directly by petitioners as telegraphs, without the mediation of an ulema or 'arżuhālcı, give particular hints as to what addressees

38 Due to the lack of reliable data, it is difficult to pin down the literacy rate in the Ottoman Empire. It is estimated that Muslim literacy rates were about 2-3 percent in the early 19th century and probably 15 percent at its end. See Donald Quataert, The Ottoman Empire, 1700-1922 (Cambridge: Cambridge University Press, 2000), 167. For Palestine, the first orderly survey about the literacy rates at our disposal was carried out during the general census of 1931. It was performed by the British Mandate government and applied modern methods. "The survey put the overall literacy rate among sedentary Arabs, 7 years old and up, at c. $20 \%$. Among Muslims it was c. $14 \%$ (men c. $25 \%$, women $3 \%$ ), and among Christians c. $58 \%$ (men c. $72 \%$, women c. $44 \%$ )." Ami Ayalon, Reading Palestine: Printing and Literacy, 1900-1948 (Austin: University of Texas Press, 2004), 16-17.

39 Necdet Sakaoğlu, "Arzuhalciler" [Petition-writers], in Dünden Bugüne İstanbul Ansiklopedisi [Encyclopedia of Istanbul from past to present], vol. 1 (Istanbul: Tarih Vakfi Yurt, 1993).

For an imperial decree indicating the rules for admission to the profession, see воА, İāde-i Meclis-i Valā, 318/13449, 14 Safer 1271/November 6, 1854.

41 Başak Tuğ, Politics of Honor in Ottoman Anatolia: Sexual Violence and Socio-Legal Surveillance in the Eighteenth Century (Leiden: Brill, 2007), 106. 


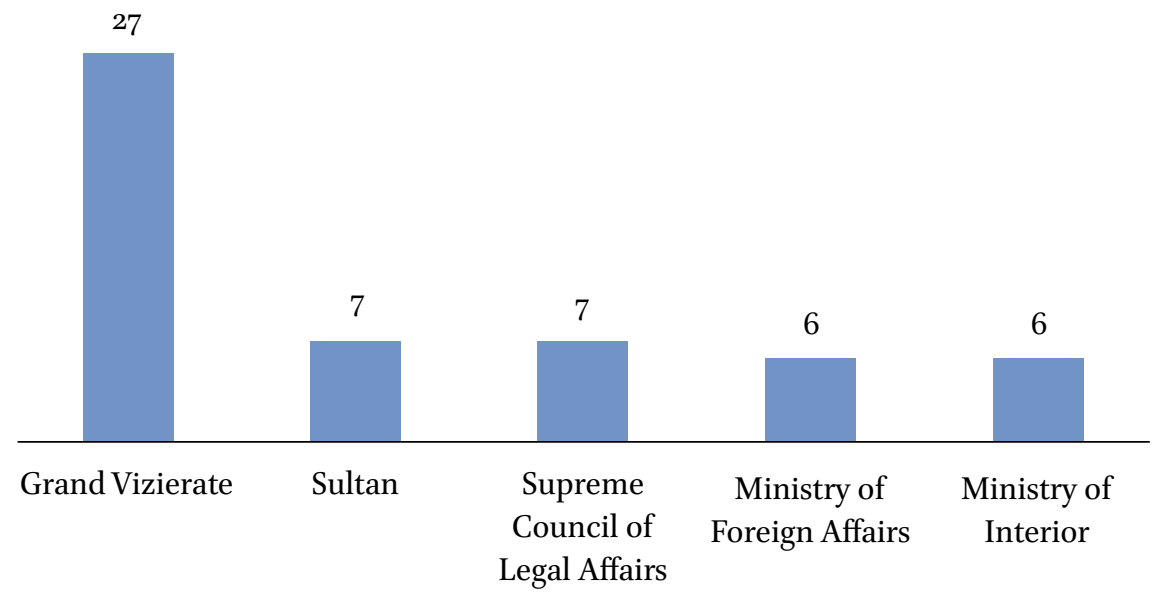

FIGURE 8.3 Addressee of collective petitions, 1840-76.

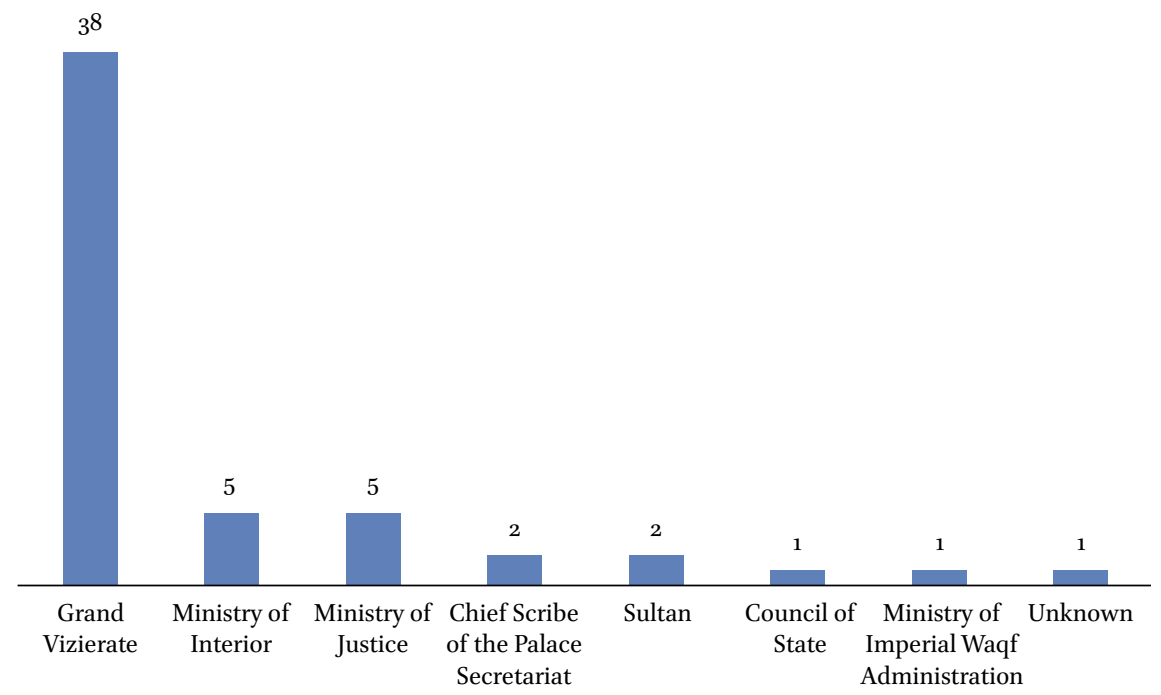

FIGURE 8.4 Addressee of collective petitions, 1876-19o8.

knew about Ottoman bureaucracy. As figures $8.3-5$ indicate, the vast majority of collective petitions were addressed to the Grand Vizierate or the ministries, especially the Ministry of Interior. This shows that the Grand Vizierate, as the absolute deputy of the sultan, was the highest authority dealing with the people's complaints or requests. The Ministry of Interior also held a prominent place as a receiver of petitions. This is because Jerusalem and its environs, a subdivision of a province (sanjak or mutașșarıflık) and not a province (vilayet) itself, were under the direct jurisdiction of the ministry. For 


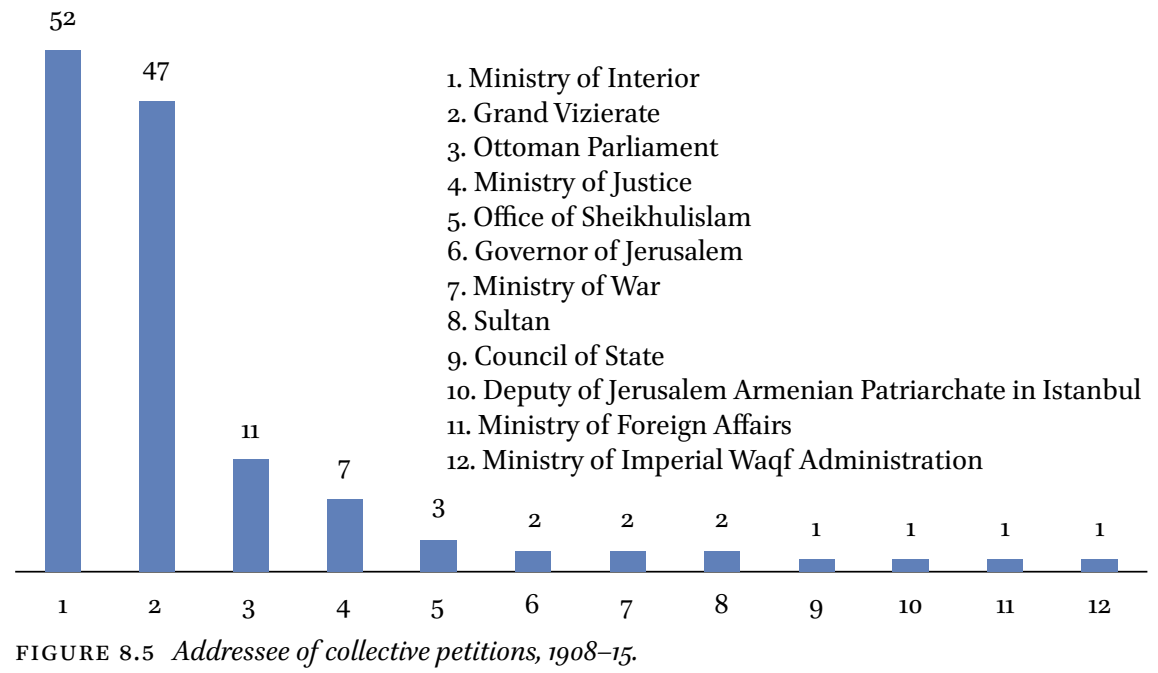

102

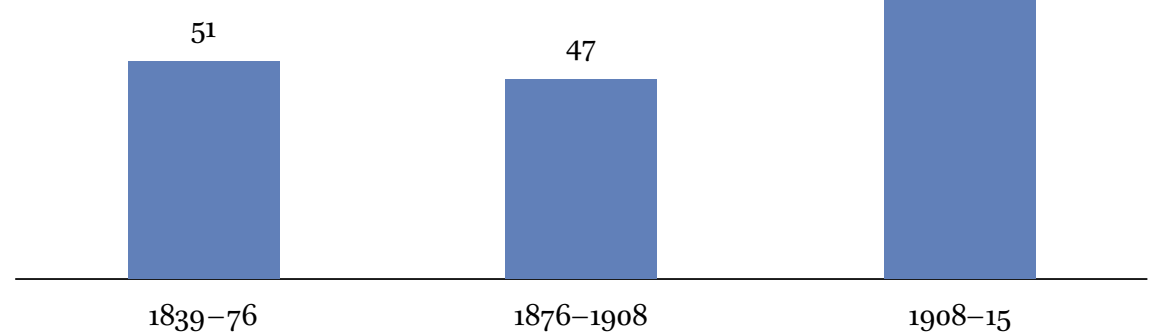

FIGURE 8.6 Date sequence of 200 collective petitions, 1839-1915.

this reason, the ministry conducted all of Jerusalem's local government affairs. We also have some petitions addressed directly to other ministries, central offices, and administrative councils, such as the Ministry of Justice, Ministry of Imperial Waqf Administration, the chief scribe of the palace secretariat (Mābeyn Başkātipliği) and the Council of State (Şūrā-yı Devlet). At times, the same collective petition was sent to more than one addressee. We have exactly thirty-five collective petitions, out of two hundred files, addressed to more than one place. It is likely that the petitioners, in writing to several addresses, thought that their complaints or requests had a better chance of reaching the Ottoman government. 
The sultan was also seen as an asylum addressee who could receive direct petitions despite the inclination towards institutionalization at every level of the administration (figs. 8.3-5). In other words, it seems that even in the age of reforms the sultan maintained his status as the dispenser of justice and the benevolent ruler. After the Young Turk Revolution in 1908, the Ottoman Parliament became another address to which the petitions were sent (fig. 8.5). Petitioning activity increases considerably after 1908. More than half of the two hundred collective petitions were dated after 1908 (fig. 8.6). This is a clear sign of the growing politicization of Ottoman subjects after the revolution. Developments such as the promotion of provincial newspapers, increase in readership, the spread of modern secular education and, most importantly, the atmosphere of relative freedom following the revolution prompted petitioning activity in Jerusalem and in many other Ottoman cities. ${ }^{42}$

Another reason for the revival of the petitioning institution in the period under discussion was the advent of the telegraph. The creation of an effective telegraph network in Jerusalem sanjak, which began with the establishment of the first telegraph line between Jerusalem and Jaffa in 1865 , resulted in a flood of telegraphed petitions from the city to the central authorities. As figure 8.7 shows, more than 70 percent of collective petitions submitted from 1839-1915 were in telegraph form. The telegraph provided the Ottoman subjects with a means to convey their petitions and complaints rapidly to the central authorities. For the first time, they established real direct contact with the imperial center. By telegraph, they could bypass the heads of the local bureaucracy and even the central authorities, and appeal directly to the sultan. The telegraph also eliminated the need to use intermediaries or travel personally to Istanbul. ${ }^{43}$ As Rogan points out, "the telegraph could be interpreted as an instrument giving subjects a political voice to reach all levels of government, to express opinions, make complaints, and petition for change. Knowing that messages sent by this technology were guaranteed to reach their intended recipients, the telegraph heightened the expectation of a response."44

42 M. Şükrü Hanioğlu, Preparation for a Revolution: The Young Turks, 1902-1908 (Oxford: Oxford University Press, 2001).

43 Ben-Bassat, Petitioning the Sultan, 35.

44 Eugene L. Rogan, "Instant Communication: The Impact of the Telegraph in Ottoman Syria," in The Syrian Land: Processes of Integration and Fragmentation, Bilad al-Sham from the 18th to the 2oth Century, ed. Thomas Philipp and Birgit Schaebler (Stuttgart: Franz Steiner, 1998), 114 . 


$$
\text { " 1839-1876 } \square \text { 1876-1908 } \square \text { 1908-1915 }
$$

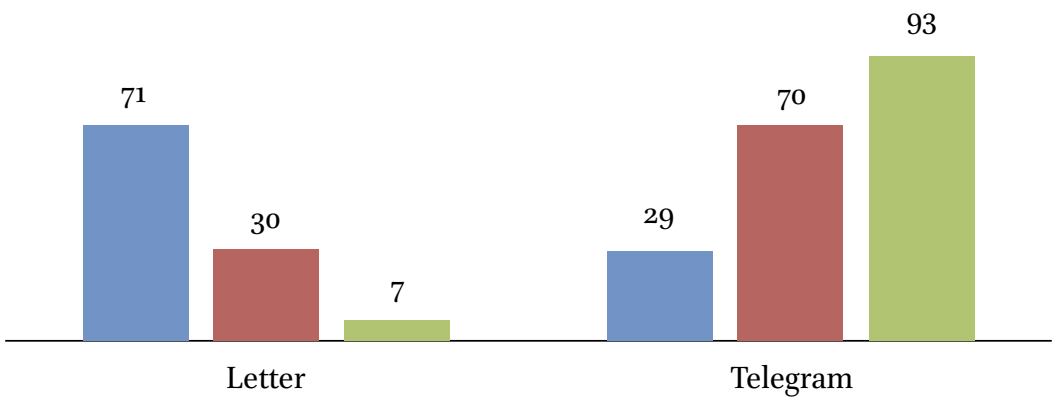

FIGURE 8.7 Form of collective petitions, 1839-1915.

\section{Topics, Wording, Signatures: Networks of citadinité through Collective Petitions}

The use of the telegraph also changed the linguistic style of the petitions. The earliest collective petitions from before the advent of the telegraph were written in flowery language. Their texts are strongly formulaic and possess a stereotypical character, particularly in the introductory lines, reserved for praying for the sultan's health or for glorifying the addressed authority. For instance, a collective petition submitted to the Grand Vizierate in 1865 to thank the government for taking precautions to prevent cholera from spreading in the province starts with a long prayer for the sultan's well-being: "May God protect our Sultan, the benefactor, the shah of shahs, the breath of earth, by endowing him with good health, luck, honors, with majesty and prosperity, and embellish him with the crown of the caliphate, symbol of sovereignty and glory, till the day of the last judgment" (fig. 8.8). ${ }^{45}$ Such petitions seem to have been written by the ulema, the local bureaucrats or professionals, and not by ordinary people. The language of the petitions in telegraphic form is simpler. The messages directly express the intention of petitioners without long lines of prayer and praise. For instance, a collective petition signed by thirty people, most of them members of Greek Orthodox clergy, expresses its purpose outright: "the nomination of the Patriarch is being conducted in contradiction to

45 BOA, Șadāret Mektūbī Ḳalemi Mühimme Kalemi Belgeleri, 344/879, 9 Cemaziye'l-âhir 1282/October 30, 1865 . 


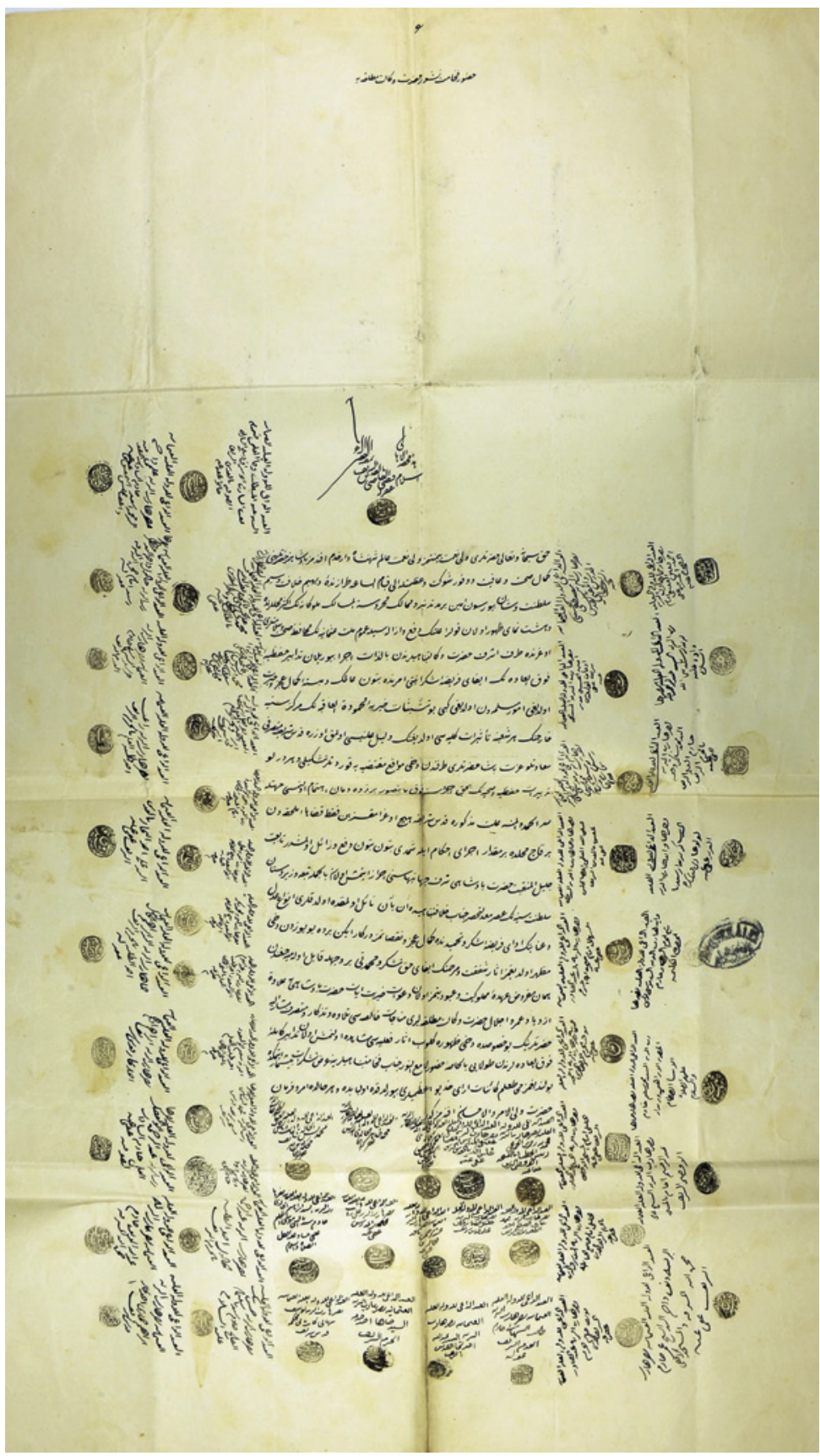

FIGURE 8.8 Collective petition signed by 55 people and submitted to the Grand Vezierate to thank the government for taking precautions to prevent cholera from spreading in the province of Jerusalem, 1865. BOA, SADÂRET MEKTUBÎ KALEMI MÜHIMME KALEMI BELGELERI, 344/879, 9 CEMAZIYE'L-ÂHIR 1282/OCTOBER 30, 1865. 


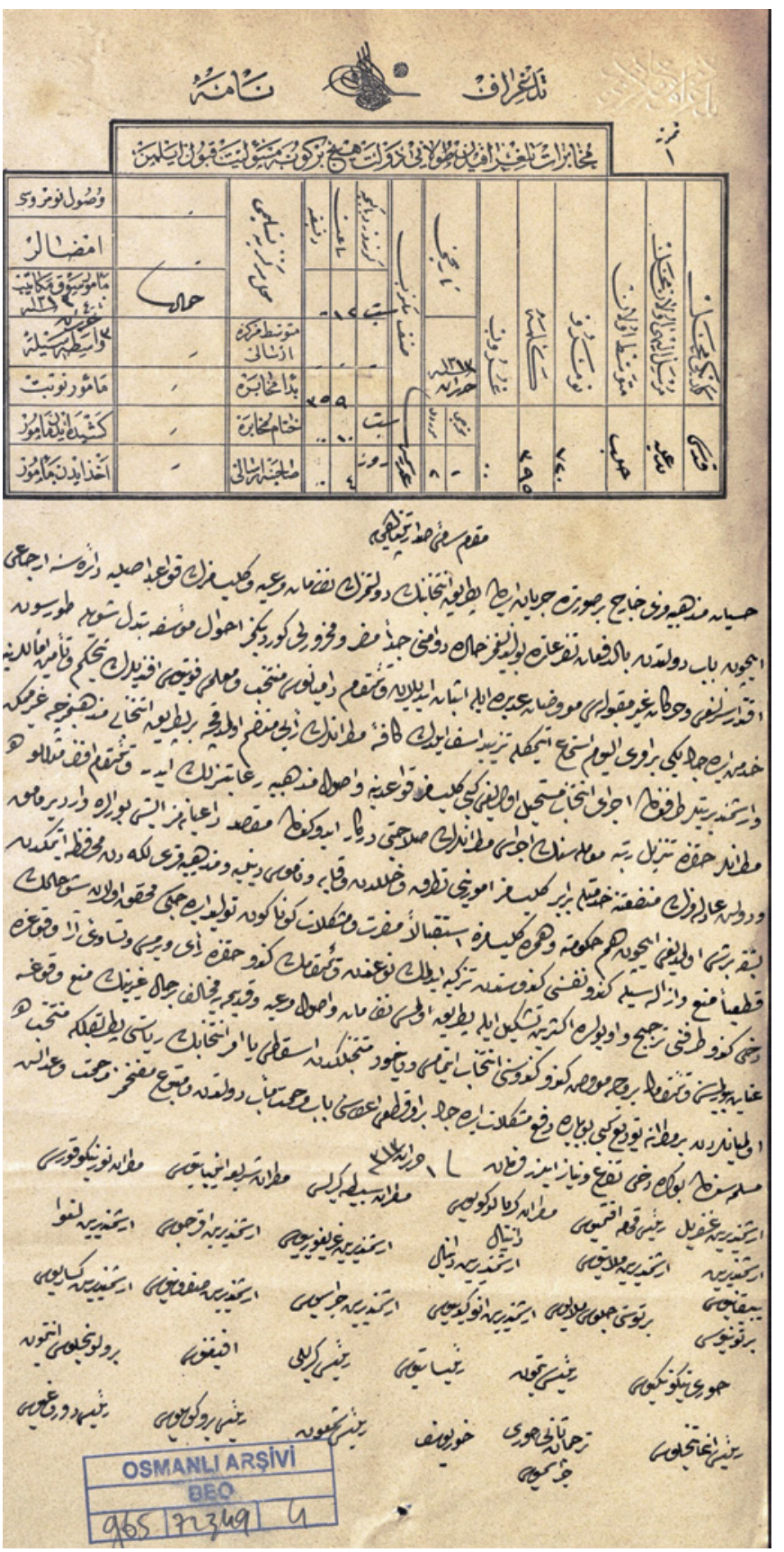

FIGURE 8.9 Collective petition signed by 30 people and submitted to the Grand Vizierate to complain about the process of nominating the Greek Patriarch of Jerusalem, 1897. BOA, BÂB-I ALî EVRAK ODASI, 965/72349, 15 MUHARREM 1315/JUNE 16, 1897. 


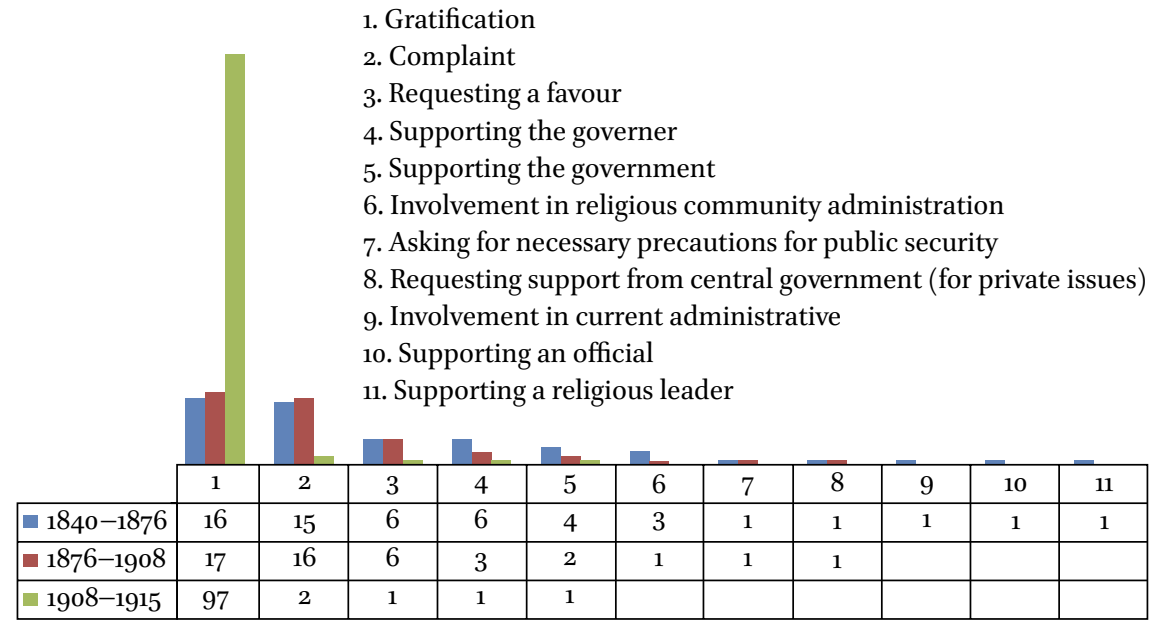

FIGURE 8.10 Subject matter of collective petitions, $1840-76$.

our denominational life" (fig. 8.9). ${ }^{46}$ Telegraphic petitions were thus formulated more freely and reflected the real voice and intention of petitioners.

Figure 8.10 shows the frequency distribution of subject matters of two hundred collective petitions. It proves that the urban dwellers of Jerusalem did not always send petitions of complaints. There are also petitions submitted that declare loyalty to the Ottoman government or congratulate the sultan on his accession to the throne. ${ }^{47}$ Likewise, petitions in favor of a certain official (usually the acting governor) were also common. A typical example is the collective petition signed by thirty-five people, submitted to the Grand Vizierate in 1852, which gratified the acting Jerusalem governor, Hafı Pasha. The petition's text reads, "as the afore-mentioned Pasha has protected and treated all the subjects fairly and justly, and used his best endeavor in the application of Beneficial Reforms (Tanzimāt-ı Hayriye), everyone is so rejoiced and happy that they are constant in performing good deeds." 48 The Ottoman local authorities, especially the mutessarif, used such petitions as a way to mobilize and demonstrate popular support for themselves. In addition, Jerusalemites also

46 “Hayat-ı mezhhebiyemizi hāric bir șūrette cereyān eden patrik intihābı." BoA, Bāb-ı ‘Ālī Evrāḳ Odası, 965/72349, 15 Muharrem 1315/June 16, 1897.

47 For instance, see the collective petitions submitted by the deputies of Greek, Syriac, and Armenian communities in order to congratulate Murad v on his accession to the throne in 1876. воА, Hārriciye Nezāreti Tercüme Odası Belgeleri, 516/65, May 28, 1876. воA, İrāde-i Meclis-i Valā, 249/9103, 1 Zilhicce 1268/September 16, 1852). 
sent petitions to the central government to express their gratification for precautions taken to ensure public security and health or to describe their contentment with the benefits of urban infrastructure improvement projects such as the water supply works in Jerusalem. ${ }^{49}$

Collective petitions expressing complaints were the second most common petitions sent from Jerusalem. Jerusalemites most often complained about the governor, a certain official, or the acting religious community leader. At times, a complaint against the Jerusalem governor was the subject of numerous collective petitions. For instance, a complaint petition submitted by forty-nine Jerusalemites in 1880 against the governor of Jerusalem, Ra'uf Pasha, broaches the subject by stating that "as we have recursively dared to submit petitions by now, the oppressions and injustices to which we have subjected by the governor of Jerusalem, Ra'uf Pasha, is well-known to His Excellency, the Minister."50 Despite these petitions, Ra'uf Pasha ruled the province of Jerusalem for eight more years. The reason behind these complaints was likely the fact that he was able to impose his authority over the powerful families of Jerusalem. Rauf Pasha's eleven-year tenure $(1877-88)$ was exceptional in Jerusalem, where officers typically served short terms in office. ${ }^{51}$

Another motivation for writing petitions was strife between religious communities. As we observe in the collective petitions, tension between the Syriac and Armenian communities about rights to perform religious ceremonies in the Church of the Holy Sepulchre came to the fore many times. ${ }^{52}$ The collective petitions are also a source of information about local politics, largely dominated by the urban notables, including the Huseyni, Khalidi, Alami and Dajani families. ${ }^{53}$ Rivalries between urban notables come up in many petitions. For example, there are petitions submitted as a way of leveling accusations. A collective petition submitted in 1885 and signed by four members of Huseyni family accused the Khalidis of using their influence and connections

49 For instance, see the collective petition, signed by ninety-one people, to thank local governors for their efforts in improving the waterways from the spring in 'Ayn Salih (in the vicinity of Bethlehem) to Jerusalem. BOA, İdāre Dāhiliye, 549/38228, 8 Muharrem 1283/ May 23, 1866.

50 BOA, Hariciye Nezâreti Tercüme Odası Belgeleri, 556/135, December 22, 1895.

51 Avcı, Değişim Sürecinde Bir Osmanlı Kenti, 24.

$5^{2}$ For instance, see the collective petition sent by the members of the Syriac community of Jerusalem to complain about Armenian infringement upon their rights in the Church of the Holy Sepulchre, see воA, Yıldız Mütenevvī Ma'rūżāt Evrāḳi, 75/144, 19 Safer 1310/ September 12, 1892 .

53 For further information about the rivalry between the urban notables, see Avcı, Değişim Sürecinde Bir Osmanlı Kenti, 121-31. 
in local government for personal gain and of breaking existing legal norms. Another example of a petition illustrating the rivalry between the Huseyni and Khalidi families is one submitted in 1910. The petition, sent simultaneously to the Grand Vizierate and to the Ministry of Interior, dealt with alleged abuses committed by the members of Huseyni family in the municipal elections of Jerusalem. It was signed by eighteen people who presented themselves as "people from the native population" (ähälìden). ${ }^{54}$ However, soon after, another petition on the same subject was signed by two people from the Khalidi family. The impression given is that the Khalidis, as the opponents of the Huseynis, might have implicitly supported the first petition. ${ }^{55}$

Considering the statistical data of collective petitions in an overall assessment, it becomes obvious that the petitioning institution enabled the residents of Jerusalem to become involved in urban politics. It also gave them a say in local administrative affairs. In sending collective petitions, they could influence the internal affairs of their religious community, hitherto handled solely by the clergy. In this respect, it makes sense that collective petitions often bore many signatures. For instance, 419 people signed one collective petition. This was a petition submitted by the members of the Syriac community against the infringement of their rights at holy sites by the Armenians (fig. 8.11). However, it is not always easy to read the seals or signatures of petitioners; at times we encounter names without official titles, faith, or profession. For this reason, it is not possible to compile clear and reliable statistical data about the identity of petitioners. On the other hand, some general remarks can be made. Collective petitions signed by the ordinary people without collaboration from notables, the ulema, or religious leaders are very rare. Those that exist are largely in telegraph form. ${ }^{56}$ More often, members of the ulema (religious scholars, qadis, imams, muftis, hatip and others), and urban notables or religious community leaders signed collective petitions on behalf of groups. ${ }^{57}$

Collective petitions usually concerned people from the same social, professional, or religious group. However, when it comes to economic matters such

54 воА, Muhaberât-1 Umumiye İdaresi Belgeleri, 71/44, 24 Safer 1328/March 7, 1910.

55 BOA, Muhaberât-ı Umumiye İdaresi Belgeleri, 91.1/40, 25 Rebiyü'l-evvel 1328/May 6, 1910.

56 For a collective petition in telegram form sent on behalf of lepers to ask the favor of reassigning the residential place which had been left for them in Jerusalem, see воA, Hāriciye Nezāreti Tercüme Odası Belgeleri, 13/552, July 15, 1875.

57 For collective petitions signed by the Greek Orthodox and Armenian patriarchs on behalf of their communities to support the acting governor in taking precautions in order to ensure public security in the vicinity of Jerusalem, see BOA, İdāre Dāhiliye, 277/17417, 26 Zilkâde 1269/August 31, 1853 . 


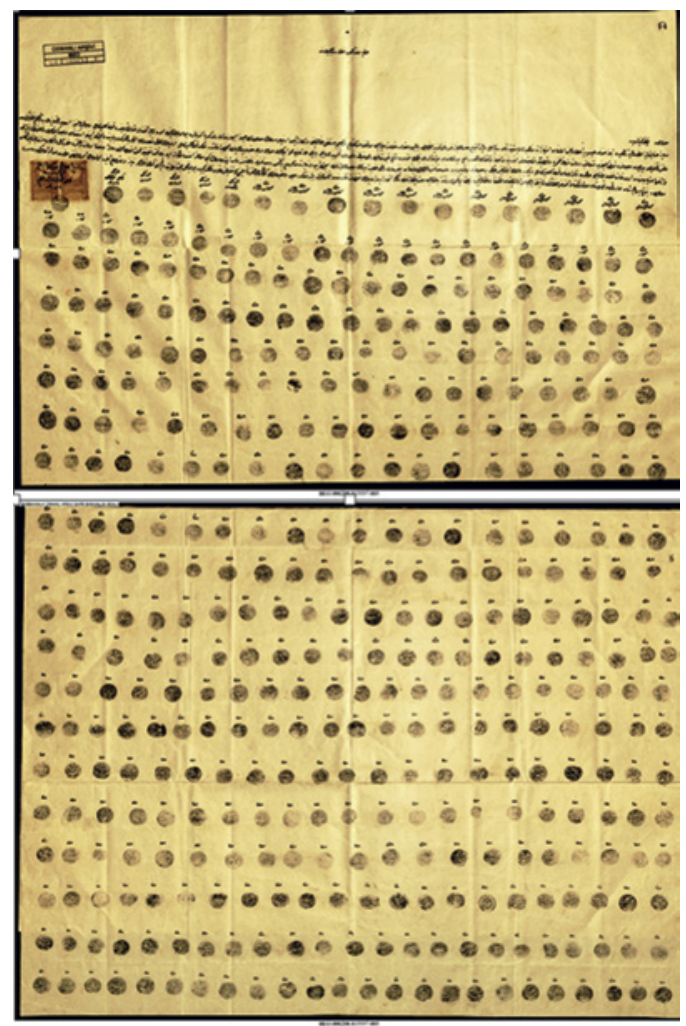

FIGURE 8.11

Collective petition signed by 419 people from the Syriac community and submitted to the Ministry of Justice to complain about Armenian infringement on their rights in the holy sites of Jerusalem, 1893. BOA, BÂB-I ALÎ EVRAK ODASI, 208/15557, 7 ZILKADE 1310/ MAY 23, 1893.

as tax deductions or exemptions and local production, there are petitions sent by people who belonged to different religious faiths. For instance, a case concerning tobacco production in Jerusalem appeared in a collective petition written in Arabic and signed by 328 people from both the Muslim and Jewish communities in 1884 . It was submitted to the Ministry of Interior in 1883 after the Ottoman Public Debt Commission turned the tobacco monopoly over to a private German-French company, the Régie co-intéressée des tabacs de l'Empire Ottoman. The Régie was in charge of selling tobacco products in the Ottoman domains. It set its own prices and chose its shops, requiring other shops selling foreign tobacco products to obtain a license from it in order to operate. ${ }^{58}$ Under these conditions, the petitioners called for state permission to produce local tobacco, which they preferred over "the disgustful and

58 Stanford J. Shaw and Ezel Kural Shaw, History of the Ottoman Empire and Modern Turkey, vol. 2, Reform, Revolution, and Republic: The Rise of Modern Turkey, 1808-1975 (Cambridge: Cambridge University Press, 1977), 233. 
intoxicating" tobacco products sold by the Régie. ${ }^{59}$ Consumer preference was indeed most likely not the main factor motivating this petition. Rather, the petitioners' hope was to dissolve the tobacco monopoly regime in order to preserve their profits from the local tobacco trade. Another example of collective petitioning by people from different religious faiths is the one signed on behalf of all the butchers of Jerusalem. Here, the rising rates of municipal taxes after the Young Turk Revolution created common ground for Muslims, Christians and Jews to complain and request justice. ${ }^{60}$

\section{Conclusion}

The right to petition the Ottoman government, not only for a redress of grievances but also for promoting requests and raising concerns, evolved into an institution which met the demands of both individuals and groups of people. The large number of archival documents in the BOA related to petitioning presents the direct proof of this conclusion. Especially after the period of Tanzimat reforms, Ottoman subjects acquired many avenues of appeal at both local and central levels to raise their concerns and grievances. Indeed, the change in the nature of government altered the relationship between the state and the individual. As reforms made the state more visible in daily life and more functional with regard to land and tax surveys, censuses, law enforcement, communication, education, and health services, it was no longer an "amorphous entity" in the eyes of its subjects. ${ }^{61}$ It meant that Ottomans had many more reasons than before to voice their opinions and grievances. Consequently, both the local government and the imperial center received petitions, in growing numbers, on almost every issue affecting individuals or groups. As the statistical data proves, particularly after the Young Turk Revolution, petitioning activity was spurred to a great extent. This was the result of factors such as the development of printed media, the expansion of secular education, and the penetration of liberal ideas. More importantly, the 1876 constitution (art. 14) consolidated the right of individuals and groups to submit petitions "on the subject of infractions of the laws or regulations committed either to their

59 вOA, Hāariciye Nezāāeti Tercüme Odası Belgeleri, 389/101, June 7, 1884.

6o BOA, Bāb-ı 'Ālī Evrāḳ Odası, 3583/268721, 7 Cemaziye'l-âhir 1327/June 26, 1909.

61 Ben-Bassat, Petitioning the Sultan, 117. 
personal prejudice or the prejudice of the public welfare." ${ }^{2}$ The concept of "the public welfare" is obviously very striking here, because it granted everyone the right to react to anything that presented a challenge to the public interest.

For Ottomans, petitioning was not solely a mode of lodging complaints. Many petitions were submitted in favor of a local governor or an official. Some petitions sought more involvement in the religious community administration. Yet others asked for favors and personal benefits. In petitioning, people could make their voices heard in political and administrative processes. Collective petitions in particular are valuable sources that should be used to analyze urban politics. They also provide insight into the concerns, claims, and expectations of Ottoman subjects vis-à-vis the changing local and imperial politics. As this study has shown, the collective petitions ('ar $\dot{z}-\iota$ maḩżarr) sent to Istanbul from Jerusalem shed light on the combined efforts by urban inhabitants to promote their shared interests. Moreover, these petitions can be studied as texts for understanding the issues of interurban networks, regional cooperation and even the nature of regional identity.

62 Article 14 states: "One or several persons belonging to the Ottoman nationality have the right of presenting petitions to the competent authority on the subject of infractions of the laws or regulations committed either to their personal prejudice or the prejudice of the public welfare and may in the same way address in the form of a complaint signed petitions to the Ottoman General Assembly to complain of the conduct of the State functionaries or employes [sic]." For the full text of the English translation of the 1876 constitution, see "The Ottoman Constitution, Promulgated the 7th Zilbridje, 1293 (11/23 December, 1876)," American Journal of International Law 2, no. 4 (1908), 367-87. 


\title{
Back into the Imperial Fold: The End of Egyptian Rule through the Court Records of Jerusalem, 1839-1840
}

\author{
Abla Muhtadi and Falestin Naïli
}

The year 1839-1840 often appears as an implicit turning point in chronologies underlying historical research on Palestine and on Jerusalem specifically. It marks the restoration of Ottoman rule over the region after nine years of Egyptian rule and the beginning of the period of Ottoman centralizing reforms in Palestine. The double significance attributed to this year - restoration and reform - translates the ambiguity of the emerging Eastern Question. On the one hand, Britain and her allies actively supported the Ottoman quest to restore rule over Greater Syria, but, on the other, all European countries wished that the door Ibrahim Pasha's rule opened for European influence in Palestine would remain open and that his reforms would endure.

The nine-year period of Egyptian rule has long been presented as a fundamental turning point in the history of Palestine. Many historians have seen the period spanning from 1831 until 1840 as the beginning of modernity in the region, while others see Bonaparte's failed Palestine expedition in 1799 as the start of the modern history of Palestine. Both groups have one conviction in common: modernity sprang from elsewhere. It either hailed from Europe or from Khedival Egypt seen as a voluntary or coerced mediator of European wishes for Palestine.

Reading local sources and looking beyond the usual timeframe are two ways of checking the veracity of this discourse on the onset of modernity in Palestine. There are two important horizons for this inquiry: one is Istanbul and Ottoman aspirations for administrative reforms, and the other is late eighteenth-century Acre and the history of a semiautonomous region, including almost half of what became mandatory Palestine. This chapter examines the court records of Jerusalem, one of the most important local sources for this period. Before we begin to address the records themselves, let us stretch the chronology into the eighteenth century and consider Ottoman imperial politics and Palestinian local leadership.

Although the Ottoman centralizing reforms known as the Tanzimat began with Sultan Abdülmecid's Noble Edict of the Rose Chamber (Hatt-ı Şerîf

(C) ABLA MUHTADI AND FALESTIN NAÏLI, 2018 | DOI:10.1163/9789004375741_013

This is an open access chapter distributed under the terms of the prevailing CC-BY-NC-ND License at the time of publication. 
of Gülhane) in 1839, his father, Mahmud II, had ushered in the reform process during his reign, notably in the army and in provincial administration. The implementation of Mahmud's reforms was only partial in the Arab provinces because the empire was engaged in wars and feared fragmentation. Nonetheless, a change in the system of taxation for instance was announced in Jerusalem just before Ibrahim Pasha's invasion of Palestine. ${ }^{1}$

Palestine was a region of the empire that had at times escaped imperial control. Since the tax-farmer Zahir al-'Umar's rise to local power in northern Palestine in the second half of the eighteenth century, that region, which belonged to the eyālet of Sidon (Saida), saw Acre emerge as a major power center in Greater Syria. While he nominally remained a servant of the provincial governor $(w \bar{a} l \bar{\imath})$ of Sidon, Zahir established semiautonomous rule in the Galilee and sought to expand it as far as Damascus in the north and Gaza in the south. ${ }^{2}$ The governors appointed in Sidon after the Ottomans' victory over Zahir were Ahmad Pasha al-Jazzar, Sulayman Pasha and 'Abdallah Pasha. These governors in many ways built on Zahir's rule and maintained the power and influence of the eyālet of Sidon, which eclipsed that of Damascus, particularly in central and southern Palestine. ${ }^{3}$

In 1826, just five years before Ibrahim Pasha's invasion of Palestine, a tax hike provoked a rebellion of the inhabitants of Jerusalem against the governor of Damascus. The rebellion was quelled by 'Abdallah Pasha, but after achieving his aim, the governor of Sidon reduced the taxes to their previous level and pardoned all the surviving rebels. ${ }^{4}$ In 1830 , the sanjak of Jerusalem came officially under the authority of the eyālet of Sidon alongside the sanjak of Nablus and the sanjak of Acre. All of Palestine was thus governed from Acre. ${ }^{5}$

The context of local challenges to imperial control provides a different framework for analyzing the Egyptian invasion in $183^{1}$ than the one usually employed in historical narratives. On the one hand, it shows how shifts in power on the provincial level - whether spurred by a local tax-farmer turned regional leader or by ambitious long-term Ottoman governors - created new demographic, economic and political realities. On the other, it implies that local political actors in Palestine seized historical opportunities to change the

1 Khaled Safi, The Egyptian Rule in Palestine, 1831-1840: A Critical Reassessment (Berlin: Mensch \& Buch, 2004), 24.

2 Ibid., $15^{-20 .}$

3 Ibid., 20-23.

4 Ibid.

5 Alexander Schölch, "Jerusalem in the 19th Century (1831-1917)," in Jerusalem in History, ed. Kamal J. Asali (Buckhurst Hill: Scorpion, 1989), 23. 
power balance in order to try and make their interests prevail. Concretely, this means that local notables and rural shaykhs chose strategic alliances depending on how they assessed their ally's proneness to satisfy their interests.

Throughout all of the upheavals Jerusalem experienced in the century preceding the Egyptian invasion, some elements of local governance and authority remained stable, namely the role of the judge (qadi) of the Islamic court (mahkama shariyya). The court was a mainstay of imperial power and, though it was a thorn in his side, Ibrahim Pasha could not eliminate it.

A critical reading of the court register (sijill) for the period bridging the end of Egyptian rule and the restoration of Ottoman rule (1839-40) allows us to map the main protagonists of this transition period. It also permits an inquiry into the workings of Ottoman restoration and reform. How did the Ottomans deal with political actors and institutions introduced by the Egyptians on the regional level? In particular, how did they deal with the advisory councils (majlis al-shürā), which had been introduced by Ibrahim Pasha as urban administrative authorities?

In general, the period of Egyptian rule in Palestine remains barely studied but largely charged with significance and ideological interpretations. Future research should take into account the Egyptian administrative archives (which were edited by As'ad Rustum in the 1930s) ${ }^{6}$ as well as the Ottoman State Archives (воА). In addition to local sources, namely the shari'a court registers, and chronicles such as the one written by a Greek monk named Neofytos who describes the period of $1821-41$ in Jerusalem. ${ }^{7}$

\section{Material Aspects of the Source: Entrée en matière}

The sharica court registers (sijillät mahkama shariayya) of Jerusalem represent the oldest and most complete collection of Ottoman court registers in Palestine, covering the period from 1529 to 1917. Microfilms dating from the Ottoman period are accessible in the Islamic Archives in Abu Dis, at the Center for Manuscripts and Documents of the University of Jordan in Amman, in the library of the University of Al-Najah in Nablus and in the library of the University of Haifa. ${ }^{8}$

6 Asad Rustum, The Royal Archives of Egypt and the Origins of the Egyptian Expedition to Syria, 1831-1841 (Beirut: American University of Beirut Press, 1936).

7 S. N. Spyridon, ed., "Annals of Palestine, 1821-1841," The Journal of the Palestine Oriental Society no. 18 (1938).

8 Musa Sroor, “Jerusalem's Islamic Archives," Jerusalem Quarterly, nos. 22/23 (2005). 
The sijill of Jerusalem for $1839-40$, bearing the number 324 , documents the transition from Egyptian to Ottoman rule from the viewpoint of the qadi and the scribe. This 156-page document, written mostly in Arabic, also contains a certain number of Ottoman texts (22 out of 361 judicial documents (hujjaj)) which are mostly copies of sultanic orders (evämir) or decrees (irade) received by the court or official orders given by the judge to other government entities.

This register opens with an introductory text giving the name of the qadi Al-Haj Muhammad Hamdi Effendi - and the name of his deputy and head scribe $(n \bar{a} i b)$ - Muhammad 'Ali al-Khalidi. The imperial order of nomination, dated October 9, 1839, is next in the register. The judge had thus been nominated by the central Ottoman government in Istanbul one year before the restoration of Ottoman rule in Jerusalem in November 1840. Throughout the period of Egyptian rule, the Ottoman central government had continued to nominate the judge of Jerusalem although the territory of jurisdiction was under the control of Ibrahim Pasha by virtue of the Kütahya agreement (1833). ${ }^{9}$

The sijill does not contain any biographical data about the judge himself, but generally, the qadi of Jerusalem was an experienced and high-ranking Ottoman judge from elsewhere in the empire, not from Palestine. This is partly due to the fact that few men from the Arab provinces studied at the Qadis' College in Istanbul..$^{10}$ Due to the religious importance of the city, the qadi of Jerusalem generally "held a higher rank within the Ottoman scholarly hierarchy ('ilmiyye) than did his administrative and military counterparts in the city."11

We learn from the court register that the $n \bar{a} \dot{i} b$, who had been nominated by the qadi, was named Muhammad 'Ali al-Khalidi. ${ }^{12} \mathrm{~A}$ few months after the register records this nomination, another judicial document is devoted to the nomination of the $n \bar{a} i b$ 's son, Yassin, as scribe. The position of $n \bar{a} \dot{ } i b$ and scribe was hereditary in Jerusalem. ${ }^{13}$ Beshara Doumani points out the inherent power of the head scribe: "The bashkätib was empowered to replace the qadi during

9 Safi, The Egyptian Rule in Palestine, 81.

10 Uri Kupferschmidt, "A Note on the Muslim Religious Hierarchy towards the End of the Ottoman Period," in Palestine in the Late Ottoman Period: Political, Social and Economic Transformations, ed. David Kushner (Leiden: Brill, 1986), 124.

11 Gudrun Krämer, A History of Palestine: From the Ottoman Conquest to the Founding of the State of Israel, trans. Graham Harman and Gudrun Krämer (Princeton: Princeton University Press, 2008), $5^{2}$.

12 Jerusalem sijill no. 324, case no. 2, October 9, 1839. He was the father of Yusuf Dhiya' alKhalidi, who would later become mayor of Jerusalem $(1870-76,1878-79)$ and deputy in the Ottoman parliament $(1877-78)$.

13 Jerusalem sijill no. 324, case no. 7, July $1,1840$. 
his absence, sickness, or during transitional periods. In addition, his intimate knowledge of local conditions and connections with other influential members of the community placed him at an advantage vis-à-vis the qadi."14

The register number 324 and the information it contains should therefore be seen in this particular institutional configuration. The court of Jerusalem seems to have been a locus of stability during changing times, with a judge nominated by the Sublime Porte despite Palestine being under Egyptian rule. The $n \bar{a} i b$, the most important officer of the court after the judge, was a member of a local notable family, whose members customarily held the office.

At the same time, this register also has to be considered in the context of the institution that produced it. In many ways, the court and the qadi, along with the mufti, symbolized the essence of the Ottoman legitimating ideology, which was centered on just rule in conformity with the shari'a. ${ }^{15}$ Therefore the court registers cannot be read as simple sources of information, but rather also have to be understood as texts legitimizing Ottoman rule.

\section{The Politics of Administrative Divisions}

As mentioned above, the Ottoman Empire had exercised limited administrative control over Bilad al-Sham prior to the Egyptian occupation of the area in 1831. At the start of the nineteenth century, Greater Syria was divided into four eyālet: eyālet al-Sham (Damascus), eyālet Tarablus (Tripoli), eyālet Saida (Sidon) and eyālet Halab (Aleppo). In 1830, the sanjak of Jerusalem had come under the authority of the eya let of Sidon alongside the sanjaks of Nablus and Acre in a new administrative division that confirmed the preeminence of the governor of Sidon over the governor of Damascus.

With the implementation of Egyptian rule under Ibrahim Pasha, the administrative divisions of Greater Syria were changed again in 1831: eyālet Dimashq al-Sham, eyālet Tarablus and eyālet Saida all came under the authority of the

\footnotetext{
14 Beshara Doumani, "Palestinian Islamic Court Records: A Source for Socioeconomic History," MESA Bulletin 19 (1985): 158.

15 This legitimating ideology can be traced back to the vast mirrors for princes literature, among which the well-known Nasîhat al mulûk (Counsel for kings) by Al Ghazali (1058$1111)$ and Ahlak-i Ala-i by Kınalızade Ali (1511-72). See Hakan T. Karateke and Maurus Reinowski, eds., Legitimizing the Order: The Ottoman Rhetoric of State Power (Leiden: Brill, 2005).
} 
hukm-dâr, the headquarters of Ibrahim Pasha's government, in Damascus. ${ }^{16}$ The eyālet were carved up into mütesellimāt, and the governors heading up each of these subdivisions were nominated by the hukm-dâr in Damascus. ${ }^{17}$ The sanjak of Jerusalem came under the authority of eyālet Dimashq al-Sham and its mutasallim (Ott. Turk. mütesellim) (governor) was nominated by the hukm-dâr. ${ }^{18}$

The Egyptian administrative divisions thus broke up the political continuity officialized by the Ottoman reorganization of 1830 . The latter was a belated official recognition of the influence the eyālet of Sidon had exercised over the Jerusalem area for many decades. When Jerusalem came again under Ottoman rule in November 1840, a letter from the governor (wālī) of Sidon, Muhammad Izzat Pasha, informed the "important personalities" of Jerusalem that the sanjak of Jerusalem was again under the authority of the eyālet of Sidon. ${ }^{19}$

\section{The Main Protagonists of the Transition}

How can we inquire into the political hierarchy in Jerusalem in the period of transition from Egyptian to Ottoman rule? One indication comes from the order in which persons are addressed by official correspondence reproduced in the court register. For example, in a letter sent in December 1840, the Ottoman victory over the Egyptian forces was announced to the following persons enumerated in this order:

1. the hăkim al-shar'i (in other words, the qadi)

2. the mufti

3. the naqïb al-ashrä $f$

4. the mutasallim

5. the descendants of the Prophet (ashräf)

6. the notables or "faces of the town" (wujūh al-balda) in general. ${ }^{20}$

\footnotetext{
16 Abla Muhtadi, Al-Quds, tarikh wa hadara [Jerusalem, history and civilization] (Amman: Dar Majdalawi lil nashr wa'l tawzi', 200o), 364 .

17 Muhammed S. al-Tarawneh, Qada' Jaffa fi al-ahd al-'uthmani [The district of Jaffa during the Ottoman period] (Amman: Ministry of Culture, 2000), 147.

18 Jerusalem sijill no. 321, case no. 4, December 14, 1836.

19 Jerusalem sijill no. 324, case no. 116, p. 43.

$20 \quad$ Ibid., case no. 161, p. 55.
} 
In this document, the preeminence of the qadi is beyond doubt: he was the first person addressed by the imperial government, followed by the mufti and the naqib al-ashräf. On the top level of the political hierarchy we thus have the Ottoman qadi, followed by the local mufti and the local naqïb al-ashräf. These three actors precede the mutasallim in this list, which represents the traditional political hierarchy. It is worthwhile noting that the same order appears in 'Adel Manna's study on the echo of the 1799 French invasion of Palestine in the Islamic court register of Jerusalem. ${ }^{21}$

\section{The Qadi}

The qadi was the highest civil juridical authority in Jerusalem. In theory, he was in charge of all civil and criminal litigation. However, the latter responsibility was limited, since the shari'a includes a relatively small number of offences. In addition to his notarial charge, he had a number of administrative responsibilities linked to religious institutions such as mosques and the many awqā $f$ (pious foundations) properties and institutions.

The qadi clearly played an important role in urban governance during the Ottoman period. This was partly a consequence of his judicial powers, which made him the adjudicator of fiscal conflicts, public security issues caused by conflicts and disputes concerning the distribution of water. 'Arif al-'Arif has pointed out that in addition to the inspection of waqf properties and the control of real estate transactions, the qadi supervised weights and measures and construction permits. ${ }^{22}$

The qadi was generally nominated for one year. Until the mid-nineteenth century, his nomination came in the form of a sultanic decree from Istanbul and was renewable, although in practice, renewals were exceptional. Administratively, he followed the sanjak's affiliation to the eya let, which Jerusalem belonged to at the time. During the Ottoman period in general, the qadi was a trusted representative of the imperial government, which expected him to closely observe the security and political situation in his region of jurisdiction and report back to Istanbul. ${ }^{23}$

21 Adel Manna, "The Sijill as Source for the Study of Palestine During the Ottoman Period, with Special Reference to the French Invasion," in Palestine in the Late Ottoman Period: Political, Social and Economic Transformations, ed. David Kushner (Leiden: Brill, 1986), 357. during the Ottoman Period, ed. Moshe Ma'oz (Jerusalem: Magnes Press, 1975), 337-38. 
When the Ottomans restored their rule in the city in November 1840 , the qadi began to sign the judicial documents (hujjaj) first as "the qadi of Jerusalem and qaimaqam for the governor of Sidon,"24 adding the title of "sirr 'askar hāla (acting army chief)" a few days later. ${ }^{25}$ The qaimaqam was the supreme commander of a region who had civilian as well as military duties. In fact, the qadi had been given full proxy (wakāla mutlaqa) by the wālì of Sidon. ${ }^{26} \mathrm{He}$ transmitted information and gave directions received from the wāli to the mutasallims of Gaza, Ramla, Jaffa and Lod, ${ }^{27}$ as well as to the acting deputy mutasallim of Jerusalem, Ahmad Agha al-Dazdar. ${ }^{28}$ This shows the prominence of his role in the transition from Egyptian to Ottoman rule. He coordinated a number of endeavors, both in the civil and military spheres. For example, the qadi ordered the mutasallims of Gaza, Ramla, Jaffa and Lod to provide for the needs of the Ottoman army which was pursuing the Egyptian army. He also ordered the replacement of some officials linked with the Egyptian administration, such as the treasurers of Jerusalem and Hebron. ${ }^{29}$ Moreover, in an effort to secure the roads in the area, he nominated village shaykhs in the Hebron and Bethlehem area and asked the people to heed their orders. ${ }^{30}$

\section{The Mufti and the naqīb al-ashräf}

The mufti, a religious scholar specializing in the interpretation of Islamic law, was under the authority of the shaykh al-Islam in Istanbul. His juridical advice (fatwa) was an important element in the court's deliberations, and in the absence of attorneys, the mufti's interpretation could function as a plea for one of the parties to a conflict brought before the qadi. ${ }^{31}$ In Jerusalem, this post was held by members of the Husayni family from the end of the eighteenth century onwards. ${ }^{32}$ In 1840, Muhammad Tahir Effendi al-Husayni was the mufti of Jerusalem. ${ }^{33}$

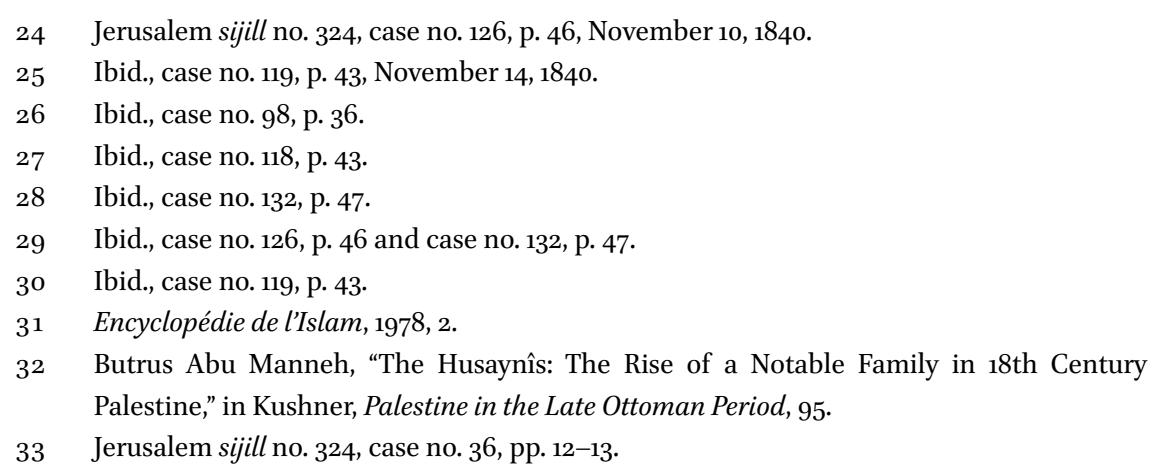


A great amount of moral authority was vested in the figure of the mufti. In 1830, the mufti of Jerusalem, Zahir al-Husayni, signed a fatwa declaring Sultan Mahmud II an infidel, at the request of Muhammad 'Ali. The fatwa, which had been written by the 'ulama' of Al-Azhar, was also signed by the naqïb al-ashrā $f$ of Jerusalem during that period, 'Umar al-Husayni. ${ }^{34}$

The naqïb al-ashrāf was tasked with defending the interests of the descendants of the prophet Muhammad, the ashrāf, even with regards to the qadi. Any legal affair involving a sharif had to be handled in collaboration with the naqīb. In Jerusalem, the naqib was nominated by the qadi after he had been chosen by the notables of the city, including the 'ulama', the ashrā $f$ and other dignitaries. The nomination of the naqib had to be confirmed by the governor and by the chief naqïb al-ashrāf on the imperial level in Istanbul. The "vote" preceding the nomination by the qadi shows that although the naqib nominally only represented the ashrāf, he was a public figure of much greater importance. ${ }^{35}$ As Butrus Abu Manneh has pointed out, the "ashräf were not a closed caste" and there was intermarriage with other families, which meant that ashrā were to be found among all social classes. ${ }^{36}$ In 1840, Muhammad 'Ali al-Husayni was the naqīb al-ashrāf of Jerusalem.

In their article about the Ottoman municipality of Jerusalem, Yasemin Avcr and Vincent Lemire quote a 1844 report from the French consulate in Jerusalem about the role of the naqīb al-ashräf. This report states that the latter had "indirect jurisdiction on the merchants' and workers' corporations" since all of those corporations were headed up by relatively poor ashrāf. Some of them were also simple merchants or craftsmen. Consequently, the naqib was involved in many, if not all, conflicts that emerged in the marketplace. ${ }^{37}$

\section{The mutasallim}

On the list of recipients cited earlier, the mutasallim figures fourth, just before the ashraf and the notables. The mutasallim was the civil governor of a town with very few military tasks, as they were assumed by the qaimaqam. Under

\footnotetext{
34 Safi, The Egyptian Rule in Palestine, 41.

35 Butrus Abu Manneh, "The Husaynîs," 96.

36 Ibid., 97.

37 Yasemin Avcı and Vincent Lemire, "La municipalité ottomane de Jérusalem, 1867-1917," in Municipalités méditerranéennes: Les réformes urbaines ottomanes au miroir d'une histoire comparée (Moyen-Orient, Maghreb, Europe méridionale), ed. Nora Lafi (Berlin: Klaus Schwarz, 2005), 20.
} 
Egyptian rule, the mutasallims of Palestinian cities were generally appointed from among local leaders, who were either from Jerusalem or from nearby towns such as Hebron. Only in 1835-36 do we find a Damascene, Hassan Bey, occupying this function. ${ }^{38}$ It was probably no coincidence that the first governor of Jerusalem after the 1834 rebellion was not from Palestine. During and after the rebellion, four former mutasallims of Jerusalem were killed or executed because of their involvement on the side of the rebels. ${ }^{39}$

The replacement of the mutasallim of the Egyptian government was one of the first decisions after Jerusalem came under Ottoman rule again: on November 6, 1840, a letter from Muhammad Rüstem, the military governor of Damascus, announced that Ahmad Agha al-Dazdar was the interim mutasallim (bi-l-wakäla). It is interesting to note that Ahmad Agha had been the mutasallim of Jerusalem until June 23, 1840, when the Egyptian hukm-dâr of Damascus decided to replace him with Husayn Rashid Effendi. ${ }^{40}$ Although Ahmad Agha had served in the Egyptian administration, he was considered the right person for the interim period. This is an indication of the Ottoman approach to this period of transition, which was characterized by a preference for continuity whenever possible, and also a sign that the Egyptians had probably been right in doubting Ahmad Agha's loyalty to the Khedive. ${ }^{41}$

It is not clear if the Ottomans had a particular policy, before and immediately after the period of Egyptian rule, on nominating a mutasallim who was not from the city in which he exercised his function. However, once the position of mutasallim was changed into mutessarif in 1843 , this official was always from elsewhere. ${ }^{42}$

\section{The majlis al-shürā}

The majlis al-shürā was the major new element in the local governance system established by the Egyptian authorities. This advisory council was under the authority of the Diwān al-shürā in Damascus, which reported to Ibrahim

\footnotetext{
38 Safi, The Egyptian Rule in Palestine, 68.

39 Ibid., 343 .

$40 \quad$ Jerusalem sijill no. 324, case no. 3, p. 2.

41 Safi, The Egyptian Rule in Palestine, 255.

42 Ziyad Al-Madani, Madinat al-Quds wa-juwarha fì awakhir al-'ahad al-'uthmani, 1246/18311336/1918 [The city of Jerusalem and its surroundings at the end of the Ottoman period, 1246/1831-1336/1918] (Amman, 2004), 26-28.
} 
Pasha and was overseen by Muhammad 'Ali himself. ${ }^{43}$ These advisory councils were established in all towns of more than two thousand inhabitants. ${ }^{44}$ Their role was to coordinate the Khedival administrative policies and collect tax revenues. They also had a judicial function as well as an important role in urban governance. ${ }^{45}$ The majlis al-shürā were in charge of fixing price levels, auctioning public charges such as customs, supervising army supplies and mediating complaints from the town's population. ${ }^{46}$ As such, it was a precursor of the municipality. ${ }^{47}$

Khaled Safi has pointed out that Muhammad 'Ali and Ibrahim Pasha had two important political goals in creating the majlis al-shürā: first, they wished to curtail the power of the 'ulama' and the Islamic court, and, second, to confine the shari'a to personal status issues. Muhammad 'Ali could not count on an alliance with the 'ulama' since they were traditionally loyal to the sultan, so he had to empower other segments of local society in an effort to balance out the 'ulama"s influence. While the latter were also members of the majlis al-shürā, the other members of the council owed their new status to Muhammad 'Ali's policies and were thus prone to remain loyal to him. The councils counted between twelve and twenty-two members, ${ }^{48}$ many of whom were urban notables and merchants whose economic and political power increased through their membership of the advisory council and reached new heights after the 1834 revolt and the subsequent weakening of the rural shaykhs..$^{49}$

When Ottoman rule was restored in Jerusalem, the first official correspondence to be sent by the qadi was destined for the majlis al-shürā. He reassured the members of the council that it was going to be maintained as an institution and confirmed the council president in his function. The council president was the head of the teachers ('umdat al-mu'alimin) of Jerusalem, Al-Shaykh Muhammad Effendi Abu al-Sa'ud. The qadi also announced that the membership of the council would be increased by two Muslims, Shakir al-Muwaqat and Nijim al-Din al-Jamai. The confessional composition of the council was thus as follows: eleven Muslims, two Christians and one Jew. The qadi asked

43 Judith Mendelsohn Rood, Sacred Law in the Holy City: The Khedival Challenge to the Otttomans as seen from Jerusalem, 1829-1841 (Leiden: Brill, 2004), 98.

Safi, The Egyptian Rule in Palestine, 84.

45 Mendelsohn Rood, 2002 101; Muhtadi, Al-Quds tarikh wa hadara, 364.

46 Safi, The Egyptian Rule in Palestine, 85.

47 Avcı and Lemire, "La municipalité," 90.

48 Ibid., $83-84$.

49 Ibid., $87-88$. 
the council to forward summaries of all affairs to him so that he could elucidate them. ${ }^{50}$

Interestingly, the mutasallim is not mentioned in this letter. During the last months of Egyptian rule, the qadi, in a similar letter to the council, had requested that the affairs also be sent to the mutasallim "for information." ${ }^{51}$ It seems that during the period of transition, the mutasallim played a less important role compared to the qadi and the majlis al-shürā.

In the letter the qadi sent in December 1840, the members of the council are enumerated in what must be their relative importance:

1. The president of the council, Muhammad Effendi Abu al-Sa'ud

2. The naqīb al-ashräf, Muhammad 'Ali al-Husayni

3. Khalil Effendi al-Khalidi

4. 'Uthman Effendi Abu al-Sa'ud

5. Muhammad Darwish 'Ali Effendi Zada

6. Shakir al-Muwaqat

7. Nijim al-Din al-Jamaci

8. Ibrahim al-Muhtadi

9. Muhammad al-Suradi

10. Jarallah, the council's scribe

11. Wafa, the council's assistant scribe

12. Khawāja Runsio, representative of the Jewish community

13. Yusuf (?), representative of the Franji community

14. Yaqub Khan Ahad, representative of the Armenian community. ${ }^{52}$

The first element, which should be noted, is the position of the naqib al-ashräf: second after the council's president. Khalil Effendi al-Khalidi and 'Uthman Effendi Abu al-Sa'ud, the following two people on the list, have not yet been identified apart from their being from notable Jerusalem families. Fifth on the list, Muhammad Darwish Ali Effendi Zada was the representative of the Imaret soup kitchen, a major public charity and waqf institution founded by Hasseki Sultan. ${ }^{53}$ Nijim al-Din al-Jamai, seventh on the list, was the head preacher of Jerusalem. ${ }^{54}$

\footnotetext{
5o Jerusalem sijill no. 324, case no. 122, p. 44, December 9, 1840.

51 Ibid., case no. 11, p. 4.

$5^{2}$ Jerusalem sijill no. 324, case no. 122, p. 44, December 9, 1840.

53 Ibid., case no. 123, p. 44.

54 Ibid., case no. 133, p. 47.
} 
It is also important to consider the representatives of Christian communities. The presence of a Franji - Latin - and Armenian representative on the council and the absence of a representative of the Greek Orthodox (Rūmī) community is striking, given the demographic realities in Jerusalem. The preference for Latins over Greek Orthodox may have been the result of Egyptian efforts to please the European powers. It would be interesting to see how this evolved in the following few years as the Ottomans adapted the majlis al-shūrā to their way of governing.

In the letter, the qadi asked the council members to do their work diligently and to transmit summaries of all issues brought before them to him. ${ }^{55}$ In which capacity did he address the council: as qadi or as qaimaqam? A comparison with the sijill for 1837 reveals that the qadi was not involved in the workings of the majlis al-shūrā at all during that period, so the situation in 1840 was exceptional and probably due to his concomitant status of qaimaqam.

It has been argued that the majlis al-shūrā prefigured the role of district council (majlis idārat al-liwä'), which was introduced later on. ${ }^{56}$ This is true in terms of the composition of the council and its status within the larger political hierarchy. However, in terms of responsibilities, the majlis al-shūrā actually played a role similar to that of the municipality (majlis baladi; baladiyya), which was founded in Jerusalem in the 186os. As mentioned earlier, the majlis al-shürā attributed public charges after auctions, fixed prices, supervised army supplies and received and mediated complaints from the population. We can therefore contend that between 1831 and 1867 , the majlis al-shürā, the naqīb $a l-a s h r a \bar{f}$ and, to a lesser degree, the qadi formed the basis of premunicipal urban governance in Jerusalem.

\section{Conclusion}

In the sijill for 1839-40, we thus have new elements to understand the transition from Egyptian back to Ottoman rule and how this affected urban governance in Jerusalem. The Ottomans relied primarily on the qadi, who had been nominated by Istanbul, and on the mufti and the naqïb al-ashrāf, who were two local notables nominated by the qadi. The mutasallim, who had during some time

55 Ibid., case no. 122, p. 44, December 9, 1940.

56 Shimon Shamir, "Egyptian Rule (1832-1840) and the Beginning of the Modern Period in the History of Palestine," in Egypt and Palestine: A Millennium of Association, 868-1948, ed. Amnon Cohen and Gabriel Baer (Jerusalem: Ben-Zvi Institute for the Study of Jewish Communities in the East, 1984), 221. 
been presented as an almost omnipotent tyrant ruling the area, is relatively less important during the very sensitive period of transition from Egyptian to Ottoman rule.

The analysis of the two letters reproduced in the sijill - the first announcing the Ottoman victory in December 1840, and the second addressed by the qadi to the majlis al-shüra - reveals that the Ottomans pursued a double strategy. On the one hand, they reaffirmed the traditional sociopolitical hierarchy by according much importance to the ashrä $f$ and the notables, as we can see in the list of recipients of the first letter. On the other hand, they actively integrated the majlis al-shürā into the structures of urban governance. Instead of abolishing this advisory council, they subordinated it to the qadi and increased the number of Muslims in it, as evidenced in the second letter. The fact that the Ottomans maintained the majlis al-shūrā should not just be seen as simple Ottoman compliance with European wishes, but should also be considered as coherent with the Ottoman drive for reform as part of the Tanzimat and also as part of the reform ambitions predating the latter. 


\title{
An Institution, Its People and Its Documents: The Russian Consulate in Jerusalem through the Foreign Policy Archive of the Russian Empire, 1858-1914
}

\author{
Irina Mironenko-Marenkova and Kirill Vakh
}

The founding of the Russian Consulate (1858-1914), which would play a significant role in shaping contemporary Jerusalem, contributed to the construction of the first district for Russian pilgrims outside of the Old City walls. At that time, the Russian representative office, which dealt with complex ecclesiastic and humanitarian issues, was situated in the diplomatic circle of European missions in the Holy City.

The history of the Russian presence in the Holy Land has been recently reintroduced into the Russian research field. ${ }^{1}$ Research has focused on ecclesiastic and diplomatic aspects in Russian foreign policy in the Christian Orient, ${ }^{2}$ and

1 The topic of the Russian presence in Palestine was examined in the Russian research literature of the second half of the nineteenth century in parallel with the development of diplomatic and philanthropic institutions. Soviet historians had no interest in such issues; at that time, however, important research appeared outside Russia. See Theofanis G. Stavrou, Russian Interests in Palestine, 1882-1914: A Study of Religious and Educational Enterprise (Thessaloniki: Institute for Balkan Studies, 1963); Theofanis G. Stavrou and Peter Weisensel, Russian Travelers to the Orthodox East from the Twelfth to the Twentieth Century (Columbus: Slavica, 1986); Derek Hopwood, The Russian Presence in Syria and Palestine, 1843-1914: Church and Politics in the Near East (Oxford: Clarendon Press, 1969); Joseph N. Hajjar, L'Europe et les destinées du Proche-Orient, 3 vols. (Damascus: Dar Tlass, 1988). In the twenty-first century, the topic got a new impetus in Russia under the influence of the growing Russian ecclesiastical presence in Palestine. See, for instance, Alexandr Alexeevich Kornilov, "Sozdanie i operativnye zadachi rossijskogo konsul'stva v Ierusalime, 1858-1859" [Creation and strategic goals of the Russian consulate in Jerusalem, 1858-59], accessed January 12, 2018, http://www .ippo.ru/old/history/do/kons/2/index.html; Kirill Vakh, "Osnovanie rossijskogo konsul'stva v Ierusalime v svete novykh arkhivnykh dokumentov" [Foundation of the Russian consulate in Jerusalem from the viewpoint of new documents], Vostochnyj arkhiv 31, no. 1 (2015).

2 Boris Fedorovich Iamilinets, Rossiia i Palestina. Otcherk politicheskikh i kul'turno-religioznykh otnoshenii. XIX-nachalo XXv. [Russia and Palestine: essay on political, cultural and religious relations, 19th-early 2oth centuries] (Moscow: Institut Vostokovedenia RAN; St. Petersburg:

(C) IRINA MIRONENKO-MARENKOVA AND KIRILL VAKH, 2018 | DOI:10.1163/9789004375741_014 This is an open access chapter distributed under the terms of the prevailing CC-BY-NC-ND License at the time of publication. 
there are new publications and surveys of archive documents on the Russian presence in Palestine. ${ }^{3}$ However, there are still no comprehensive works on the activity of the Russian consulate in Jerusalem, or on the consuls themselves.

The archive of the Russian Consulate in Jerusalem has not been preserved as an entity of documents. Until now, scholars could access single consular reports only - those kept in copies or in originals in some Russian archives. We need to detect, systematize, and describe the main body of diplomatic documents issued by the Russian consulate in Jerusalem during its existence. Our research, which aims at revealing the contents of the consular archive based on the documents preserved in other archives, intends to be a step in this direction. This study examines the reasons and circumstances behind the foundation of the Russian Consulate in Jerusalem, and outlines the responsibilities entrusted to Russian consuls there. We then characterize the Russian Consulate archive collections and discuss a range of issues they present.

Letnii Sad, 2003); Iakushev Mikhail Il'ich, Antiokhijskii I Ierusalimskii Patriarkhat v politike Rossiiskoi imperii, 1830-natchalo XX v. [The patriarchates of Antioch and Jerusalem in the politics of the Russian Empire, 1830-early 2oth century] (Moscow: Indrik, 2013); Irina Iur'evna Smirnova, Mitropolit Filaret i Pravoslavnyi Vostok: iz istorii mezhtzerkovnykh sviazei [Metropolitan Filaret and Orthodox Orient: a history of interchurch relations] (Moscow: Rosspen, 2014); Jevguenii Mikhailovich Kopot', “Kvoprosu ob interpretatsii greko-arabskogo protivostoiania i vlianii Rossii v Antiokhiiskom patriarchate vo vtoroi polovine XIX v.: po materialam AVPRI" [An interpretation of the confrontation between Greeks and Arabs and the Russian influence in the patriarchate of Antioch in the second half of the 19th century: documents from the Archive of Foreign Policy of the Russian Empire (AFPRI)], Vestnik Moskovskogo Universiteta 13, no. 3 (2011).

3 Theophilus C. Prousis, "Archival Gleanings on Russian Trade and Consulates in the Near East," Balkanistica no. 17. (2004); Prousis, "A Guide to AVPRI Materials on Russian Consuls and Commerce in the Near East," Modern Greek Studies Yearbook 16-17 (2000/2001); Prousis, "AVPR (Arkhiv Vneshnei Politiki Rossii) and the Orthodox East," Modern Greek Studies Yearbook 12-13 (1996/1997): 473; Nikolai Nikolaevich Lisovoi, ed., Rossiia v Sviatoi Zemle. Dokumenty i materialy [Russia in the Holy Land: documents and materials], 2 vols. (Moscow: Mezhdunarodnye otnoshenia, 200o); Lisovoi, ed., Rossiia $v$ Sviatoi Zemle. Dokumenty i materialy [Russia in the Holy Land: documents and materials], Vol. 3 (Moscow: Indrik, 2015); Olga Nikolaevna Kopylova, ed., Rossiia i Khristianskii Vostok v dokumentakh Gosudarstvennogo arkhiva Rossijskoj Federatsii, XIX-XX vv. Annotirovannyj ukazatel' del i dokumentov [Russia and the Christian Orient: documents of the State Archive of the Russian Federation, 19th2oth centuries; annotated index of dossiers and documents] (Moscow: Indrik, 2015). 


\section{Establishing the Russian Consulate in Jerusalem: A Diplomatic and Ecclesiastic Challenge}

The Russian Consulate in Jerusalem was founded in 1858 , soon after the Crimean War (1853-56). At that time, various countries had already established missions in Jerusalem: Britain (1838), Prussia (1842), France and Sardinia (1843), the United States of America (1844), Austria (1849), and Spain (1854) all had active missions in the Holy City. A possible explanation for the Russian "delay" is that, for a long time, St. Petersburg had perceived Palestine as a strictly ecclesiastic territory. Until the Crimean War, the Greek Orthodox Patriarchate of Jerusalem dealt with Russian pilgrims, in agreement with the Russian authorities. In exchange, the Russian Embassy in Constantinople provided diplomatic and political support for the patriarchate. In fact, since 1820, the only Russian diplomatic mission in Palestine had been the vice-consulate in Jaffa. From 1838, Jerusalem was under the jurisdiction of the Russian Consulate General in Beirut, which was responsible for all of Palestine. In 1847 , St. Petersburg sent the Russian Ecclesiastical Mission (REM) to the Holy City to control Russian pilgrims, and to provide a direct channel of ecclesiastic communication between the Russian Synod and the Greek Orthodox Patriarchate in Jerusalem. The REM suspended its activities during the Crimean War, and in 1857 it was revived under the guidance of Bishop Kirill Naumov (1857-63), who replaced Archimandrite Porfyrii Uspenskii $(1847-54) .{ }^{4}$

According to a project of the Minister of Foreign Affairs, Alexander Mikhailovich Gorchakov (1856-82), the objective of the REM under Bishop Kirill was to serve Russia's ecclesiastic and diplomatic interests in Palestine. In practice, this meant that the mission had a political role to play. Since there was still no consulate in Jerusalem, Bishop Kirill received instructions and tasks from three different sources: the Minister of Foreign Affairs, the Director of the Asian Department of the Russian Ministry of Foreign Affairs, and the Russian ambassador in Constantinople. The head of the REM reported to each of the three bodies, while the consul general in Beirut was instructed to provide him with regular support and assistance. As an ecclesiastic institution, the mission was subordinate to the Synod of the Russian Church. From 1857 until 1862, however, it was under the control of the Russian Ministry of Foreign Affairs.

Surprisingly, the establishment of the Russian Consulate in Jerusalem was not a result of the interests of the Ministry of Foreign Affairs. At its head, Gorchakov believed that Russia needed an ecclesiastic mission rather than a

4 See the chapter by Lora Gerd and Yann Potin, "Foreign Affairs through Private Papers: Bishop Porfyrii Uspenskii and his Jerusalem Archives, 1842-186o," in this volume. 
political mission in the East. ${ }^{5}$ The foundation of the consulate was supported by the Naval Ministry, the Russian Steam Navigation and Trading Company (ROPIT), created in 1856, and by Kyrillos II, the Greek Orthodox Patriarch of Jerusalem. Kyrillos II was concerned about the French interest in repairing the cupola of the Holy Sepulchre, which they had expressed during the Crimean War. The patriarch feared that the French initiative could lead to a revision of the Status Quo of property rights on the parts of the Holy Sepulchre. ${ }^{6}$ Kyrillos II supported the establishment of a permanent consulate in Jerusalem since he did not want to appeal to Protestants either (Britain or Prussia). The Greek government did not have enough power or legal rights to get involved on equal terms with France and, therefore, a stronger Russian presence in Jerusalem best suited Kyrillos II's agenda. He clearly preferred Orthodox Russia to Catholic France. In a discussion with the head of the REM, Bishop Kirill, which took place in Constantinople in late January $185^{8}$, the patriarch noted that the mission "could not replace a constant consulate in Jerusalem, and that made its opening only more urgent."7 In a message to Gorchakov, A. P. Butenev, the Russian envoy in Constantinople, confirmed that "the Patriarch of Jerusalem eagerly recommended founding a Russian Consulate in the Holy City".

According to Gorchakov, the REM was the unique and authentic ecclesiastic and diplomatic mission of the Ministry of Foreign Affairs in Palestine. Other diplomats could be sent to support the mission, but the minister believed that any Russian structure in Jerusalem, even a consular one, should be subordinate to the head of the REM. Gorchakov's divisive opinion was the root cause of long-lasting competition between the consulate and the REM. Thus, it was at his own risk that Butenev, under the pressure of the patriarch, and possibly with the approval of Bishop Kirill, ordered N. S. Marabutti, the vice-consul in Jaffa, to move to Jerusalem and "to remain at the disposal of our Ecclesiastical mission ... until further notice." ${ }^{9}$ Kyrillos II who wanted to see a Greek in this position, recommended Marabutti to Butenev as a suitable candidate.

5 Fedor Ivanovich Titov, Preosviatchennyj Kirill Naumov, episkop Melitopol'skii, byvchii nastoiatel' Russkoi Dukhovnoi Missii v Ierusalime [The most reverend Kirill Naumov, bishop of Melitopol, ex-chief of the Russian ecclesiastical mission in Jerusalem] (Kiev, 1902), 116-17.

6 Oleg Viktorovich Anisimov, Rossiia i Napoleon III. Bor'ba za Sviatye mesta Palestiny [Russia and Napoleon III: the struggle for the holy places in Palestine] (Moscow: Indrik, 2014).

7 AVPRI, col. 161, St. Petersburg Main Archive, IV-2, cat. 119. 1858-6o. No. 22. F. 17r. (translated from French).

8 Ibid., fol. $20 v$ (translated from French).

9 Ibid., fol. 18r (translated from French). 
In St. Petersburg, members of the ROPIT insisted on the establishment of an independent consulate in Jerusalem. The proposal was first presented by Boris Pavlovich Mansurov as part of the Jerusalem Project of Russia, in December 1857. Mansurov had the support of Grand Duke Konstantin Nikolaevich, the tsar's brother. ${ }^{10}$ The tsar approved the opening of the consulate on the condition that a program to improve the living conditions of Russian pilgrims in the Holy Land would be implemented in early February 1858. The task of organizing the project, which included choosing the first Russian consul, was commissioned to the ROPIT, and to Mansurov in particular. The ROPIT agreed to subsidize the new consulate and to pay for the travel expenses of its personnel from Russia to Jerusalem. During the first year, the ROPIT paid all the expenses of the consulate. ${ }^{11}$

Mansurov proposed Vladimir Ippolitovich Dorgobuzhinov, a colleague from the Naval Ministry, for the position of consul. On February 10, 1858, in a private message to Butenev, Mansurov requested the return of Marabutti from Jerusalem to Jaffa. ${ }^{12}$ Even though the responsibility of establishing the consulate was given to Mansurov, the consulate was officially subordinate to the Russian Embassy in Constantinople. On the commission of Gorchakov, Butenev compiled a formal instruction for Dorgobuzhinov. He stressed that the main aim of the consulate in Jerusalem was:

to save our bishop both from police surveillance over the arriving Russian worshippers and from direct contacts with Turkish authorities and foreign consuls in Jerusalem. These exchanges occur not only on completely nonreligious issues but also on spiritual affairs, that, as it often happens, demand explanations or negotiations with these authorities. Thus, we ask that the consulate deal with surveillance of our worshippers and that it manage our relations with the Turkish administration as well as with the consuls of other foreign states. ${ }^{13}$

10 Mansurov described the plan of actions in a secret note published in the printing office of the Naval Ministry without the author's name and without a title, in thirty copies. See Boris Pavlovich Mansurov, Pravoslavnye poklonnikiv Palestine [Orthodox pilgrims in Palestine] (St. Petersburg, 1857), 209. AVPRI, col. 161. St. Petersburg Main Archive. IV-2. cat. 119. 1858-6o. no. 22, fol. 64v. Message from B. P. Mansurov to the envoy in Constantinople A. B. Lobanov-Rostovskii.

12 AVPRI, col. 161. St. Petersburg Main Archive. IV-2. col. 119, 1858-60, no. 22, fol. 21v. (translated from French).

13 "A. P. Butenev's instruction for the Jerusalem consul, V. I. Dorgobuzhinov," in Lisovoi, Rossiia v Sviatoi Zemle vol. 1. (2015), 220. 
Thus, the consulate was to fulfill functions that were previously reserved for the head of the REM and, prior to that, (especially for the surveillance of Russian pilgrims), for the Greek Orthodox Patriarchate. However, the abovementioned instruction subordinated the consul to Bishop Kirill.

Mansurov outlined the acquisition of land lots in Jerusalem and in other places visited by Russian pilgrims as well as the construction of infrastructure on those lots as the primary focus for the new consul. For these activities, the consul was subordinate to the Palestine Committee in St. Petersburg. According to the staff list of the Ministry of Foreign Affairs, the first Russian Consulate in Jerusalem involved two people: a consul and a secretary. In reality, the situation was quite different. By mid-January 1859 , there were many more people serving there, including Consul V. I. Dorgobuzhinov, Secretary A. K. Krivoshein, one member of the chancellery (or scribe) P. D. Levitov, one dragoman (interpreter), M. O. Shakhashiri, recommended to Mansurov by the consul general in Beirut, Mukhin, and two consular Muslim guards, kawas, designated among the local people.

While the consulate was being established, French diplomats worked together with the Sublime Porte for the reconstruction of the cupola of the Holy Sepulchre. Soon after Dorgobuzhinov arrived in Constantinople, in early August 1858, the French ambassador, Édouard Thouvenel, invited him to a formal private dinner during which they discussed the progress of the work on the cupola. Butenev described that conversation in a message to Minister Gorchakov, praising the behavior of the new consul. ${ }^{14}$ Considering this message, we may claim that Dorgobuzhinov had been well prepared before his visit to Jerusalem. He was well informed and able to appeal to the interests of both the Greeks and the Russians. At the same time, he found points of compromise for further cooperation with the French.

This contributed to the strengthening of relations between Russia and France in the 1850 s after the Crimean War, and Napoleon III expressed interest in joint projects to consolidate the relationship between the two countries. It became clear that Kyrillos II's request for the establishment of the Russian consul to Jerusalem was a positive move. The patriarch realized that France would not create conflict with the Russians, and therefore, the Russian presence would be much more useful for the Greek Orthodox Patriarchate in Jerusalem than it had been previously.

14 Ibid., $36-39$ (translated from French). 


\section{The Russian Consul in Jerusalem: In the Interstices of Wars and Counterpowers}

From the inauguration of the consulate in 1858 until the First World War, fifteen consuls and administrators served in Jerusalem. ${ }^{15}$ For many of them, their service in Jerusalem proved challenging and for some, detrimental to their careers. Some fell sick and even died because of the harsh climate and poor living conditions. Dorgobuzhinov suffered a serious ear infection that almost left him deaf. The success of his diplomatic career suffered as a result of the conflict that he had with Bishop Kirill. His successor, K. A. Sokolov (186o-62), spent two winters in Jerusalem. He fell sick and died in Constantinople without medical treatment. Consul A. N. Kartsov (1863-67) caught smallpox in Jerusalem. Consul V. F. Kozhevnikov spent fifteen years in Jerusalem overall; he died suddenly due to an acute lung condition on Holy Thursday in March $1885 .{ }^{16}$ He left his adopted son, a local Arab boy, in Jerusalem. N. N. Illarionov had to ask the Ministry of Foreign Affairs to transfer him to another place because of a conflict with the head of the REM, Archimandrite Antonin (Kapustin). ${ }^{17}$ Consul D. N. Bukharov also had a conflict with Archimandrite Antonin (Kapustin) and was removed following orders from Grand Duke Sergei Alexandrovich, Chairman of the Imperial Orthodox Palestinian Society. ${ }^{18}$

15 Vladimir Ippolitovich Dorgobuzhinov (consulate administrator, 1858-60), Konstantin Alexandrovich Sokolov (consul, 1860-62), Nikolai Fedorovich Gladkoy (consulate administrator, 1862), Andrei Nikolaevich Kartsov (consul, 1862-67), Trofim Pavlovich Yuzefovich (consulate administrator, 1864 and 1874-75), Vassilii Fedorovich Kozhevnikov (consul, 1867-76; consul general, 1879-85), Nikolai Nikolaevich Illarionov (consul, 1876-79), Semen Mikhailovich Dmitrevskii (consulate administrator, 1885), Alexander Alexandrovich Guirs (consulate administrator, 1885-86), Dmitrii Nikolaevich Bukharov (consul, 188688), Aleksei Petrovich Beliaev (consulate administrator, 1888-89), Victor Alexandrovich Maksimov (consulate administrator, 1883-84, consul, 1889-91), Sergei Vasilievich Arsen'ev (consul general, 1891-97), Alexander Gavrilovich Yakovlev (consulate general administrator, 1894-95; consul general, 1897-07), and Aleksei Fedorovich Kruglov (consul general, 1908-14).

16 Not only Russian diplomats suffered from the severe living conditions in Jerusalem. Kozhevnikov noted that, on May 16, 1883, the French consul, Langlais, died suddenly from a heart attack. AVPRI, col. 180. Constantinople embassy. cat. 517/2. no. 1828, fol. 114v.

17 Lucien J. Frary, "Russian Missions to the Orthodox East: Antonin Kapustin (1817-1894) and his World," Russian History 40, no. 1 (2013).

18 Together with the opening of its diplomatic mission in Palestine, the Russian government arranged the everyday life of Russian pilgrims. The construction of pilgrims' houses in Palestine was supervised by the Palestinian Committee (1859), headed by Grand Duke Konstantin Nikolaevich, later transformed into the Palestinian Commission (1864). One 
The development of relations with the Turkish authorities and European colleagues relied heavily on the character of the individual consuls. We know, for instance, that in 1874 , the appointment of Kozhevnikov to Jerusalem was delayed because the Ambassador in Constantinople, Nikolai Pavlovich Ignat'ev, considered that the neutral disposition of the consulate's administrator, Yuzefovich, made him a better candidate to organize the elections of a new patriarch:

Personal collisions of Mr. Kozhevnikov with some of foreign consuls, with the head of our Ecclesiastical Mission, with many members of the local Orthodox clergy and with the most important persons among the Greek party, particularly his prior long-lasting enmity with Palestinian Governor 'Ali Bey, started in Tyrnovo and were renewed some time ago in Jerusalem. In the case of his return to the place of his service at the moment of crisis, this will only stir up passions and damage the success of the program, which is currently being developed by Mr. Yuzefovich. ${ }^{19}$

However, the Jerusalem consul was still in a delicate position because he did not have the same level of freedom and authority that most Russian consuls had in other places. This was because three other representatives of the Russian authorities also existed in Jerusalem: the Russian Ecclesiastical Mission, the Palestinian Committee (later, the Palestinian Commission at the Asian Department of the Ministry of Foreign Affairs), and the Imperial Orthodox Palestinian Society. Interactions between them were neither easy nor successful. A consul often served as a mediator in St. Petersburg's attempts to instill peace and order among the Russian delegates in Jerusalem.

The history of the Russian Consulate in Jerusalem can be divided into several stages. The initial period $\left(185^{8-62)}\right.$ was connected with the names of Mansurov, Dorgobuzhinov, and Sokolov, and with the activity of the Palestinian Committee. During this time, the main lots were purchased and the construction of the first Russian churches and residences in Jerusalem began.

of the key figures of these institutions was B. P. Mansurov. In 1882, the Imperial Orthodox Palestinian Society was established to replace these institutions; a brother of Tsar Alexander III, Grand Duke Sergei Alexandrovich, headed it. It was a public organization for the benefit of Russian pilgrims and supported Orthodoxy in the Holy Land. It also sponsored research work.

19 AVPri, col. 161/1 St. Petersburg Main Archive, V-A2, cat. 181/2. Political reports no. 436, 1875 , fol. $7 \mathrm{~V}-9 \mathrm{v}$. Message of the Constantinople ambassador, N. P. Ignat'ev, to the director of the Asian Department of the Ministry of Foreign Affairs, P. N. Stremoukhov, March 31, 1875 . 
The second period (1862-76) may be considered the golden age of Russian diplomacy in the Orthodox East, with Constantinople Ambassador Ignat'ev as one of its leading figures. He directed the actions of all Russian representatives in the Holy City with a firm hand, and ensured their work was well-coordinated and efficient. During the Russian-Turkish War (1877-78), the activity of the consulate was suspended. Over the following two years, the Ministry of Foreign Affairs made attempts to define the relations between the consulate and the REM, and to enlist the responsibilities of the consulate.

The third period (1881-1914) was the golden age of the Imperial Orthodox Palestinian Society. The consulate and the REM had to follow the lead of the Society, which was a public institution but, in fact, expressed government interests.

The everyday activity of the consulate was devoted to Russian subjects merchants, monks, permanent residents, travelers, and numerous pilgrims. Diplomats arranged money and documents for remittance. They controlled their compatriots and provided meetings for dignitaries. Throughout their work, they had the constant support of the Greek Orthodox clergy and the local Greek Orthodox Arabs.

For the period from the mid-nineteenth century until World War I, the documents of the consulate convey that there were several cases that attracted the attention of Russian diplomats in Jerusalem. In the first half of the 186os, the Russian and French governments represented the interests of the Greek and Catholic clergy in the Holy Land, respectively. They were both involved in reconstructing the cupola of the Holy Sepulchre. The Russian and French architects M. I. Eppinger and C. Mauss supervised this work. All technical and decorative characteristics of the project were endorsed in the consulates in Jerusalem, and then in the embassies in Constantinople. Finally, the ministries in Paris and Petersburg approved the project. ${ }^{20}$

In 1872 , following a conflict with the Greek clergy in Jerusalem, Patriarch Kyrillos II was displaced. The Russian consulate tried to return the patriarch to the Jerusalem See, and also made efforts to soften and neutralize the anti-Russian orientation of the Greek Orthodox Synod. Russian diplomats contributed to the reconciliation between the Greek Orthodox Arab

20 On the restoration of the cupola, see Anisimov, Rossiia $i$ Napoleon III; Anisimov, "Frantsuzskii konsul Edmond de Barrère i problema remonta rotondy Sviatogo Groba v Ierusalime, arkhivnye dokumenty. Publikatsia Olega Anisimova" [French consul Edmond de Barrère and the problem of the reconstruction of the Holy Sepulchre's dome: documents from archives published by Oleg Viktorovich Anisimov], Ierusalimskii pravoslavnyi seminar 5 (2010). 
population, which did not accept the new patriarch or the Greek clergy. The Russians set a necessary condition for reconciliation: the replaced patriarch could no longer be pronounced schismatic. Documents on those events allow us to observe the process of Russian diplomacy on different levels. There were discrepancies between the instructions from Petersburg and Constantinople and the activity of Russian representatives on site in Jerusalem. Reports of the Russian consulate indicate that the German consul was involved in the replacement of Patriarch Kyrillos II.

Construction of Russian pilgrim and ecclesiastic buildings on the lots bought by the head of the REM, Archimandrite Antonin (Kapustin), began in the late 186os. In Jerusalem, among those lots were the Siloam Monolith (the Tomb of the Pharaoh's Daughter), a lot on the Mount of Olives, and a third lot in 'Ayn Karim. The lots were acquired under the name of the dragoman of the REM, the Ottoman subject Ya'qub Khalebi. Documents on these transactions reflect the legal and habitual practice of the Ottoman Empire on land property rights. For example, when the Russian Pilgrims' Hospital was opened in 1863, the Russian Consulate obtained documents on the sanitary situation in Palestine. As such, the daily life of pilgrims was interpreted from a new point of view.

During the Russian-Turkish War of 1877-78, the consulate was evacuated, and the archives and the buildings were placed under the protection of the Prussian consul:

In the case of a possible break with Turkey, who would take over the management of the buildings - the monastery [the Patriarchate of Jerusalem], or the Spanish Consul? Are there obstacles we might face when we attempt to receive our buildings and property back from the monastery after our return? It seems better to seek protection from the Spanish Consul, from whom we cannot expect any claims, and whose protection might be more efficient than that of the monastery, which won't dare to fight for Russian possessions against the Turkish rage. Naturally, the best way would be to pass everything to the German Consul, but Germany may break relations with Turkey simultaneously with us. ${ }^{21}$

After the war, the consulate was active in the affairs of Russian property in Palestine, and remained involved in the matters of the Greek Orthodox

21 AVPRI, col. 180, Constantinople embassy, cat. 517/2, no. 780 , fol. $26 \mathrm{v}-\mathrm{r}$. Instruction of the attorney in Constantinople, E. P. Novikov, to the Jerusalem consul, N. N. Illarionov, October 13,1876 . 
Patriarchate (for instance, the election of Patriarch Damianos in 1897). The activity of charitable institutions and schools founded by the Palestinian Society also demanded much attention. Moreover, the position of Jews arriving in the Holy Land, and their future, became a topic of discussion.

\section{In Search of the Lost Archives of the Jerusalem Consulate}

Since 1879 , the consulate in Jerusalem was headed by a consul general. In 1891, the consulate obtained the status of consulate general. The official Russian presence in Jerusalem was maintained until World War I, when Russia and the Ottoman Empire found themselves on opposite sides. When the Great War began, Russian diplomats left Jerusalem for Egypt. The archives were lost during this period. The Ottomans may have plundered the archives of the consulate general in 1916. This hypothesis is supported by a note from the American consul, who protected Russian property in the Holy Land from $1915 .{ }^{22}$ Russian constructions located along the walls of the Old Town were surrounded by an enclosure. They were well-equipped with sufficient stores and provisions. The Ottomans used the Russian settlement for their own garrison; breaking diplomatic laws, they plundered the Russian compound and put it out of commission. In 1917, having driven the Ottoman troops out of Jerusalem, the British took over the Russian edifices, including the consulate building. For a long time, they served as a citadel and a center of British military administration in Palestine.

There is not sign of the diplomatic documents that were lost in 1917, or later in the British Mandate period. The disappearance of such a large quantity of documents is strange, given that the archive of the REM, located in the same building complex, was largely preserved. It is possible that the archive was temporarily relocated to Russian monasteries - to Ayn Karim or the Mount of Olives - which were never occupied by Ottoman or British troops.

The library and documents kept at the St. Sergios town residence of the Imperial Orthodox Palestinian Society also remained intact until the Six Days War in 1967. When the building was surrendered to Israeli tenants and a state protector was appointed, the documents were partly plundered. The loss of the documents of the consulate in Jerusalem, however, was not permanent. Below, we will examine the ways these documents circulated in the Russian Ministry of Foreign Affairs, and particularly in the consulate in Jerusalem. 
The consulate was subordinate to the Russian embassy in Constantinople, which was controlled by the Asian Department of the Ministry of Foreign Affairs, in existence since 1819. The Asian Department was the only one of three departments of the Ministry of Foreign Affairs created on a geographical principle. It focused on Oriental policy, on the affairs of Russian subjects in the East, and on the training of translators and dragomans for Russian missions in the region. The Asian Department (renamed the First Department in 1897) consisted of two sections: the Far East and the Middle East. In the Middle Eastern section, there was a political desk, which worked on enciphering and deciphering telegrams. It also worked on Slavic, Greek, and Turkish desks (later, Persian and other desks were formed). Two or three people worked at each desk.

The consulate in Jerusalem, like any other diplomatic establishment, had incoming and outgoing documents. Incoming papers comprised two different groups: documents from official institutions and private documents from individuals. We can categorize incoming documents into those sent from inside or outside Palestine. Incoming documents from Russian state institutions, such as the embassy in Constantinople, the consulate general in Beirut, and the Ministry of Foreign Affairs in St. Petersburg, were kept in copy. This was a procedure that was compulsory in any formal correspondence. Copies of documents sent to the Russian Consulate from the Patriarchate of Jerusalem and from other Ottoman and European institutions in Palestine were preserved in the archives of those organizations.

There is another problem regarding private messages and addresses sent to the consulate. We cannot estimate their quantity. Sometimes, such documents - whether copies or originals - were resent from the consulate to the embassy or even to the Asian Department. One can find, for instance, messages from the Patriarch of Jerusalem, ${ }^{23}$ members of the Synod of Jerusalem, ${ }^{24}$

23 AVPRI, col. 161, St. Petersburg Main Archive, II-9, cat. 46, 1840, no. 15. pt. 1, fol. 6o6v-9v. In December 1866, Patriarch Kyrillos wrote to the Constantinople envoy, A. B. LobanovRostovskii, with an appeal to reject the transfer of Consul A. N. Kartsov, who had developed good relations with the Patriarchate of Jerusalem. St. Petersburg did not agree to the patriarch's request. See message, December 22, 1866.

24 AVPRI, col. 161/1, St. Petersburg Main Archive, V-A2, cat. 181/2, political reports, no. 433, 1873 , fol. $2 \mathrm{v}-3 \mathrm{v}$. See, for instance, the appeal of the Synod of Jerusalem to the Orthodox community of Bethlehem on the excommunication of Patriarch Kyrillos, November 8, 1872 . 
Greek and Arab priests, ${ }^{25}$ Arab and Jewish communities, ${ }^{26}$ as attachments to consular reports or to messages sent to the Ministry of Foreign Affairs from the embassy in Constantinople. Incoming documents were kept as drafts or copies among the documents of the embassy in Constantinople, the Asian Department, and the chancellery of the Ministry of Foreign Affairs.

Outgoing documents consisted of reports and telegrams from consuls to the embassy and to the Ministry of Foreign Affairs, as well as private and semiformal (called "confidential") messages to various officials of the Ministry of Foreign Affairs, both in Constantinople and in St. Petersburg. Consuls often sent copies of their reports addressed to the embassy in Constantinople to the Asian Department. Originals of outgoing documents are preserved in the corresponding collections of the archive of the Ministry of Foreign Affairs.

During the nineteenth century, the Ministry of Foreign Affairs possessed three different archives. There was the St. Petersburg Main Archive of the Ministry of Foreign Affairs, the State Archive of the Ministry of Foreign Affairs in St. Petersburg, and the Moscow Main Archive of the Ministry of Foreign Affairs. The main documents on Russian history until the early nineteenth century were kept in the older Moscow Archive (founded on the base of the Collegium of Foreign Affairs in 1724). Documents from later decades were passed to the Russian State Archive of Ancient Acts (RGADA). In the St. Petersburg State archive (also called the State Archive of the Russian Empire, made up of documents of nondiplomatic character from the Ministry of Foreign Affairs in 1834), materials on the tsars and their family, notorious criminal trials, industry, culture, and history of peoples of Russia were kept. In 1864, the State Archive of the Russian Empire was united with the St. Petersburg Archive of the Ministry of Foreign Affairs. Later, its collections were passed to the RGADA.

The main documents on the current activity of the Ministry of Foreign Affairs, including those on the activity of the consulate in Jerusalem, were kept in the St. Petersburg Main Archive. These materials were passed on to the

25 AVPRI, col. 161/1, St. Petersburg Main Archive, V-A2, cat. 181/2, political reports, no. 433, 1873, fol. 39v-49r. In March 1873, for instance, Priest Iskhak, from the settlement of Beit Jala, alleged to the Russian Consulate and the REM that Greek clergymen had instigated the local Turkish authorities to arrest him because of his refusal to recognize the newly elected Patriarch Prokopios.

26 AVPRI, col. 180, Constantinople embassy, cat. 517/2, no. 1809, fol. 12v-13v. See, for instance, a message from the head of the Jewish community to Consul A. N. Kartsov, December 25, 1863, about French travelers exporting Judaic marble coffins and gravestones. 
Archive of Foreign Policy of the Russian Empire (AVPRI). Its collections were organized based on document provenance and subject.

In the process of publishing the formal correspondence of the Russian consuls in Jerusalem from $1858-80$ during the reign of Tsar Alexander II, ${ }^{27}$ we revealed the main corpus of originals, drafts, and copies of the documents in question at the (AVPRI). The corpus was essentially identical to the archive of the Russian Consulate in Jerusalem for the selected period. The following is a description of the collections of the AVPRI. The collections contain documents on the activity of the Russian Consulate in Jerusalem and on the Russian presence in Palestine.

Collection 133 (Chancellery of the Ministry of Foreign Affairs), 1797-1917. 28837 doc. Catalogue 469, 1830-1869; Catalogue 470, 1870-1917.

Documents are classified by year. They include incoming and outgoing correspondence from the embassy in Constantinople on the affairs in Jerusalem, original messages from Russian ambassadors and envoys in foreign states; their letters, reports, telegrams, and instructions, and notes, and telegrams from the Ministry of Foreign Affairs.

Collection 180 (Embassy in Constantinople), 1800-1914, 12519 doc.

Catalogue 517/2, 1856-1914.

The collection contains the following materials: tsars' rescripts, relations from envoys in Constantinople, correspondence between the Ministry of Foreign Affairs and the mission (or embassy, since 1867), correspondence between the mission and Ottoman authorities, diplomatic corps in Constantinople, Russian consular offices in the Ottoman Empire (including Jerusalem), correspondence with Russian envoys in other countries, messages on ecclesiastic matters, on Russian property in the Ottoman Empire, on the Russian-Turkish wars, on peace treaties, on the situation in the Balkans, on the policy of the Great Powers in the Ottoman Empire, international conferences, directives from the embassy in Constantinople to Russian consulates in the Ottoman Empire, and correspondence with private persons. The collection contains thematic files on correspondence between ambassadors and the consulate in

27 Graf N.P. Ignat'ev i Pravoslavnyi Vostok: dokumenty, perepiska, vospominania [Count N. P. Ignat'ev and the Christian Orient: documents, correspondence, memoirs], vol. 2 (Moscow: Indrik, forthcoming in 2018). 
Jerusalem over several years. In addition, there are many thematic files on various events in Jerusalem and Palestine. ${ }^{28}$

Collection 149 (Turkish desk), 1818-1917. 11967 doc.

Catalogue 502/1, Catalogue 502/2.

This collection contains documents with data about the consulates in Beirut and in Constantinople, consular regulations in the East, consular jurisdiction, consulate personnel, quarantines, epidemic diseases, sanitary council, pilgrims, hajj, grasshopper plague, earthquakes, capturing boats, contraband, research works and excavations, Jews, private persons abroad, military duty, vagrants, deserters, school manuals, taxes in Turkey, courts, and jails. Among the documents of this section of the Asian Department, the most important ones for the activity of the Russian Consulate are documents on the preparation and arranging of expeditions and archaeological excavations in Palestine, as well as documents on Russian pilgrims in Jerusalem.

Collection 142 (Greek desk), 1825-1917. 6733 doc.

Catalogue 497.

There are documents on nonpolitical affairs taken from the Second Political Department connecting Greece, Greek subjects, and the activity of Russian consular institutions in Greece, as well as documents on Palestine reflecting the position of the churches, sanitary conditions, court and police affairs, and the history of the Patriarchate of Jerusalem. This collection also contains magazines, documents of the Palestinian Committee, and the Palestinian Commission at the Asian Department, which arranged the acquisition of land lots, the construction of town residences in Jerusalem, and dealt with the common life of pilgrims.

Collection 161 (St. Petersburg Main Archive), 180o-1905. 91686 doc., in general, 173 catalogues.

There are materials of the former State Main and St. Petersburg Main Archive. The documents were gathered by the central apparatus of the Ministry of Foreign Affairs and by the Collegium of Foreign Affairs, consular and diplomatic offices abroad. The majority of the documents are from $1800-85$. The collection is divided into five artificial ranks, which are divided into groups. The documents are classified according to the following topics.

28 For instance, a trip of Russian grand dukes to Palestine (1881, 1888), election of Patriarch Damianos (1897) and so on. 
In the First Series, there is a complex group of documents connected to Jerusalem. A significant section of this group is unavailable to researchers. Topics include:

I-1 catalogue 12. Reports on the affairs in Turkey, Greece, Egypt, and Serbia (1822-79).

I-1 catalogue 19. Highly confirmed projects of messages on the affairs in the Middle East (1816-55).

I-9 catalogue 8. Materials on commissioning diplomatic envoys, information on events in Turkey, materials on the clergy, and ecclesiastic affairs. Notes and memoirs. Materials on railway construction and the telegraph (1774-1905).

I-1o catalogue 28 . Printed copies of agreements, conventions, treatises (particularly with Turkey).

Many documents on Palestine are kept in the Second Series (1763-190o), including:

II-3 catalogue 34. Russian trade relations with countries of the Middle East, reports of consulates and the general situation in the consulates (1783-1869).

II-3 catalogue 35. Russian trade relations with countries of the Middle East, reports of consulates and the general situation in the consulates (1869-96). II-9 catalogue 46. Spiritual affairs, monastic properties, Russian pilgrims in Palestine.

II-9 catalogue 83. The Ecclesiastical Mission in Jerusalem.

II-1o catalogue 49. Professor Pomialovsky's trip to Palestine (1864-91).

IV-1o catalogue 129. Private messages of the administrator of the consulate in Jerusalem on the situation in Jerusalem (1801-1879).

IV-16 catalogue 134. On the protection of rights of Orthodox clergy in the East by the Russian government.

IV-18 catalogue 137. Documents related to a water-supply system project in Jerusalem.

Collection 161/1 (Political reports on the Middle East and Central Asia) St. Petersburg Main Archive, 1802-87. RankV-A ${ }_{2} 1203$ doc., catalogue 181/2.

The collection contains selected reports on the Middle East, including political reports from Russian consuls in Jerusalem. This collection is divided into numerous series and catalogues, and includes many thematic files on events in Jerusalem. 
Collection 161/3 (Political Department of the St. Petersburg Main Archive), 180685. 261 doc.

Catalogue 233.

There are documents of special political importance (with a stamp specifying "eternal storage"), notes and references on various issues, particularly on ecclesiastic matters in the East and the situation in Jerusalem.

Collection 337/1. Palestinian Commission, 1865-89. 4 doc.

Catalogue I (765).

Registers of incoming and outgoing papers, journals of sessions of the Palestinian Commission.

Collection 337/2 (Russian Imperial Orthodox Palestinian Society), 1844-1928.

Catalogue $873 / 1-13$

The collection contains numerous documents of the Russian Imperial Orthodox Palestinian Society, and its predecessors - the Palestinian Commission at the Asian Department, (Catalogue 765) on activities in the Holy Land and in Jerusalem - on Russian construction projects in Jerusalem, manuscripts on travels to Palestine, on the common life of pilgrims, and on the administrative structure of Palestine.

Catalogue 1. (1879-1918), 778 doc.

There is material on the Russian Imperial Orthodox Palestinian Society, correspondence with administrators of the town residence, material on schools and ambulances in Palestine, material on the trips of members of the tsar's family to the Holy Places, on arrival of crews from Russian boats to Jerusalem, reports of medical institutions, personnel at the teaching institutions of the Russian Imperial Orthodox Palestinian Society in Palestine, and correspondence with consulates and the Ecclesiastical Mission.

Catalogue 9. (1897), 4 doc.

Plans of constructions and photographs of churches and town residences in Jerusalem.

Collection 208. Consulate in Beirut (Lebanon), 1820-1914. 686 doc.

Catalogue 819.

The Russian Consulate in Lebanon was initially located in the city of Jaffa. In 1839, it was transferred to Beirut. In this collection, there is correspondence between the consulate and the mission (embassy in Constantinople), the 
consulate general in Alexandria (the consulate in Beirut was subordinate to it until the 1840s), correspondence with vice-consulates, and agencies subordinated to the consulate in Beirut (including the Jerusalem consulate), material on trade, sea travel, railways, ecclesiastic matters (propaganda, clergy, etc.), pilgrims, the Russian Imperial Orthodox Palestinian Society, educative institutions, court cases, sanitary issues, military duty, exhibitions, financial matters, magazines, and books.

Collection 313. "Vice-consulate in Jaffa" (Turkey). 1820-66. 5 doc.

Catalogue 823 .

There are instructions from the Ministry of Foreign Affairs, the mission in Constantinople, and correspondence with consulates general in Egypt.

Topics in the archives between local and central levels and between the religious and the profane

In the AVPRI collections, there are numerous documents with data on the following broad topics:

Russian policy in Palestine, communication with local and central Ottoman authorities

The Ambassador in Constantinople evaluated the work of his subordinates in Palestine based on their interactions with Ottoman officials. Sometimes, meetings with the grand vizier and other senior officials in the capital could influence instructions sent by the Sublime Porte and could bring change in Jerusalem. In 1869, for instance, Constantinople Ambassador N. P. Ignat'ev informed the Jerusalem consul, V. F. Kozhevnikov, of the following:

Because of the commissioning of Kiamil Bey, the first secretary of the local Ministry of Foreign Affairs, to the position of Governor of Jerusalem, I suppose it is worth familiarizing you in advance, in general, with the character and the direction of this person, with whom you are to keep direct official relations. Kiamil Bey served in the diplomatic field and was in the Turkish mission in St. Petersburg. He was Chairman of the Commission on the matter of the expropriation of the ecclesiastic royal estate by the governments of Moldavia and Wallachia, and recently was the head of the department on spiritual affairs of various confessions in the Sublime Porte. Kiamil Bey is therefore closely acquainted with the situation in Jerusalem, and he knows all details about the Holy Places. Serving in the Sublime Porte, he did not miss a chance to be compliant, 
and demonstrated good decision-making capabilities. During our latest meeting, I did not fail to attract his attention to the necessity - for the sake of the interests of the Porte itself - of keeping kind relations with the Consulate entrusted to you, as well as to protecting the principle of the Status Quo in the process of renovating objects or monuments in Jerusalem, preventing possibly growing controversial questions, and solving problems on the spot. You are, Sir, to make all efforts to support Kiamil Bey in his current mood and to prevent any Western influence from overcoming this well-disposed but weak-willed Governor of Jerusalem..$^{29}$

\section{Aspects of Daily Life in Palestine}

Russian consuls wrote to St. Petersburg about the quantity of Turkish troops located in Palestine, about interrelations between Muslims and Christians, conflicts among numerous Christian confessions, Bedouin rebellions, epidemics, etc. In August 1860, Consul Sokolov wrote to Envoy A. B. Lobanov-Rostovsky in Constantinople:

Christian dwellers of the Holy City and its surroundings were stricken with panic following rumors of a riot. Although such suppositions had no grounds, and the behavior of Muslims was not especially suspicious, families have not gone out for several days. The clergy took measures to save treasures kept in various monasteries and churches. The Governor of Jerusalem, Sureyya Pasha, had at his disposal only one infantry battalion and few ordinances located in the citadel. He ordered to place guards at the main bazaars and streets and stationed commissioning officers to watch the order everywhere. Then he invited the most influential Muslims and declared that he would not allow any disturbances and would severely punish responsible persons if anything happened. That measure had a beneficial influence on the mood of local dwellers. News of the arrival of Fuad Pasha with his troops to Beirut somewhat soothed the fears of the Christian clergy. ${ }^{30}$

29 AVPRI, col. 180, Constantinople embassy, cat. 517/2, no. 1814, fol. 107v-r. Instruction from the Constantinople ambassador, N. P. Ignat'ev, to the Jerusalem consul, V. F. Kozhevnikov, September 24, 1869 .

30 AVPRI, col. 18o, Constantinople embassy, cat. 517/2, no. 1805 , fol. $45 \mathrm{v}-\mathrm{r}$, $48 \mathrm{v}-\mathrm{r}$. Report from the Jerusalem consul, K. A. Sokolov, to the Constantinople envoy, A. B. LobanovRostovskii, July 25/August 6, 1860. 
In March 1877, Consul N. N. Illarionov informed the councilor of the embassy in Constantinople, A. I. Nelidov, of the following:

At the end of the previous week, at some hours' distance from Hebron at Dura, there was a bloody clash because of the property rights to a land lot between two Bedouin tribes with the participation of some Muslim dwellers of that place. The clash was quite serious, because up to 100 people were reported to be murdered. Given the usual feuding here, new clashes could easily happen again, not only between Bedouins, but also among settlers. Settlers indeed number among the murdered. Clashes with Bedouins happen here from time to time, and they serve as a quite convenient case for persons sent by the governor to remedy the situation, and for the pasha himself. Often such disturbances between Bedouins are aroused by interested persons. It is said that the events happened at Hebron may be result of the activity of supporters of the mutessarif of Jerusalem, Faik Bey. This could give him the chance to return soon to Jerusalem from Damascus, where he had been called because of a claim against him. ${ }^{31}$

\section{Interactions between Russian and European Diplomats in the Holy Land}

Protecting the interests of Catholics and Orthodox Christians in Palestine was one of the missions of Russian and French diplomats. They were regularly involved in conflicts connected with property rights or certain privileges in churches of the Holy Land. Visits of dignitaries to Jerusalem and joint efforts in cases of epidemic diseases also called upon the presence of diplomats. Thus, in November 1871, Consul V. F. Kozhevnikov sent the following circular message to members of the diplomatic corps in Jerusalem:

Our agent in Jaffa just has informed me about four recent cases of cholera in Saint Jean d'Acre; two of them led to death. Because the epidemic may manifest itself in Jaffa or even in Jerusalem, it seems reasonable and cautious to have local authorities take measures in order to prevent the spread of the disease. I ask you, my dear colleague, for your benevolent

31 AVPRI, col. 180, Constantinople embassy, cat. 517/2, no. 1822, fol. 14V-15v. Report from Consul N. N. Illarionov to the Constantinople embassy councilor, A. I. Nelidov, March 4, 1877 . 
assistance, asking you to be so kind and inform me about a possible collective effort which could provide for Your Excellency's services and the mastery of foreign medics living in Jerusalem. ${ }^{32}$

\section{Interaction between Russia and the Patriarchate of Jerusalem and with Other Eastern Churches}

Russia provided material and political support for Eastern Orthodox churches. Foremost among these was the Patriarchate of Jerusalem. The Russian government kept a close watch on church incomes received by Eastern clergy from estates in Bessarabia. In September 1867, Constantinople Ambassador N. P. Ignat'ev informed the consul in Jerusalem, V. F. Kozhevnikov, of the appointment of a new archbishop of Sinai:

The Imperial Embassy cannot recognize the consecration of the new archbishop as final and real until he is recognized in this new rank by patriarchs and the Holy Synod. Until then, the Embassy finds impossible to take into account the aforesaid petition by Patriarch Kyrillos. Possessing the right and keeping the moral obligation to observe the use of income from Sinaitic properties in Russia, the Embassy treats as necessary to solicit the sequestering of this income until the question of the correctness and appropriateness of the election of the new archbishop is cleared, and until we receive enough guarantees of the rational and correct usage of these moneys. ${ }^{33}$

On the other hand, the Russian government and St. Petersburg regularly observed how the rights of the Orthodox were protected in their disputes with Catholics and Armenians. In spring 1869, a fire in the Grotto of the Nativity in Bethlehem destroyed part of the decoration. The Russian consul was invited to mediate in squabbles between Orthodox and Catholic Christians regarding the restoration of icons and curtains. He tried to reach a compromise between the demands of the Latin clergy, supported by the administrator of the French Consulate, Sienkiewicz, and the demands of Patriarch of Jerusalem.

32 AVPRI, col. 161/1, St. Petersburg Main Archive, V-A2, cat. 181/2, political reports, no. 430, 1871 , fol. 108v-r. Copy of a circular from the Jerusalem consul, V. F. Kozhevnikov, to members of the consular corps in Jerusalem, November $15 / 27,1871$.

33 AVPRI, col. 180, Constantinople embassy, cat. 517/2, no. 1812, fol. $73 \mathrm{~V}-74$ r. Draft of an instruction from the Constantinople ambassador, N. P. Ignat'ev, to the Jerusalem consul, V. F. Kozhevnikov, September 28, 1867. 
The problem was even discussed in the embassies in Constantinople, as well as by governments in St. Petersburg and Paris.

\section{The Diplomatic History of Russia, Interactions of the Consulate in Jerusalem with the Embassy in Constantinople, with the Ministry in St. Petersburg, and with the Vice-Consulate in Jaffa}

The diplomatic system was quite complicated, and could be easily disrupted by local circumstances and personal factors. In May 1860, the vice-consul in Jaffa, N. S. Marabutti, responded to Consul V. I. Dorgobuzhinov's reprimand about the delay in sending the pilgrim's passports:

Without a secretary, and having many duties, I am not always able to write and send you worshippers' passports in an hour or two before the departure of Russian mail after a steamship arrives, and I do not dare to send them with foreign mail, not knowing to whose account the sending costs could be put; as well as I cannot use "departure of worshippers' caravans" for sending passports, which I should organize by myself, as you, perhaps, do, Sir, in Jerusalem when they return to Jaffa. ${ }^{34}$

\section{Daily Life and Habits of Russian Pilgrims}

Material from the consulate gives us statistical data on pilgrims, their accommodations, and interactions inside the groups and with the Greek clergy. There is also information on steamships used by worshippers. In September 1866, for instance, Embassy Secretary Vasilevskii wrote in a private message to the Constantinople ambassador, N. P. Ignat'ev, about the difficult situation of Russian pilgrims who had returned from Jerusalem to Jaffa and planned to travel home but the Russian steamship was delayed:

A group of 14 worshippers have come recently from Jerusalem to Jaffa and want to return to Russia. They asked the Russian agent of the Society of the steamship line to trade their return tickets from Jaffa to Odessa, bought in an office in Odessa. They asked him to pay a refund for those tickets and to allow them to buy new tickets for a foreign steamship. The

34 AVPRI, col. 180, Constantinople embassy, cat. 517/2, no. 1805, fol. 33r-34v. Copy of a message from the Russian vice-consul in Jaffa, N. S. Marabutti, to the Jerusalem consul, V. I. Dorgobuzhinov, May 22, 1860. 
agent of our steamship company, Mr. Marabutti, having no instruction for such a case from his bosses, refused the request of our worshippers. As a result, the 9 female worshippers from the general group of 14 worshippers, having no money for other tickets for a foreign steamship, stayed in Jaffa to wait for the Russian steamship. In their state of abject poverty, they had to beg for alms in the street, and are dying of starvation. ${ }^{35}$

The pilgrims were in a dire state. Unable to support themselves, they returned to Jerusalem and lived at the expense of the head of the REM, Archimandrite Antonin. The consulate asked the Ambassador to order the steamship company to give money for the return tickets.

\section{Conclusion}

Comprehensive analysis of archival documents of the Russian Consulate in Jerusalem allows us to examine certain questions about the influence of diplomats in that region, and encourages us to look at communication among the Russian Consulate in Jerusalem, European diplomats, Christian churches, and local Turkish authorities. The most important sphere of activity of the Russian Consulate in Jerusalem was ecclesiastic and diplomatic. The consulate shared its responsibilities with the Russian Ecclesiastical Mission, the Palestinian Commission, and, later, with the Imperial Orthodox Palestinian Society. If we are to use the Russian archives to study the history of Russian communities in Jerusalem and to study the realities of the daily life of the Holy City, we should pay particular attention to the materials of the Russian Synod, the Russian Ecclesiastical Mission in Jerusalem, the Palestinian Commission at the Asian Department, and the Imperial Orthodox Palestinian Society. These documents may elucidate the joint national project of the Russian Empire in the Holy Land, implemented there from 1857 to 1917.

35 AVPRI, col. 18o, Constantinople embassy, cat. 517/2, no. 1811, fol. 3V-r. Private message from A. Vasilievskii to N. P. Ignat'ev, September 15, 1866. 


\title{
Diplomacy, Communal Politics, and Religious Property Management: The Case of the Greek Orthodox Patriarchate of Jerusalem in the Early
} Mandate Period

\author{
Konstantinos Papastathis
}

The Greek Orthodox Patriarchate of Jerusalem might be regarded as the prime Christian institution in the Holy Land for multiple reasons. First, it has had a continuous historical presence in the city since the early days of the church; second, local Christians belonged to the Orthodox creed until the beginning of the nineteenth century, and third, it has praedominium (the predominant position) over the Holy Places. The patriarchate's status as the central Christian institution is suggested at a symbolic level via the annual ritual of the Holy Fire, where the heads or representatives of the Oriental churches take the light from the Orthodox Patriarch on Holy Saturday. Despite its privileged position, the early Mandate period found the patriarchate in a critical state. The recent change in regime meant the threat of losing ground in relation to the other churches and was viewed by many within the patriarchate's administration as an opportunity to change the balance of power. In particular, the Arab Orthodox congregation dynamically put forward its claims against the Greek religious establishment over the institution's centralized and ethnocentric administrative structure, as well as the patriarchate's management of its extensive religious properties. ${ }^{1}$ Taking into account the size of

1 Anton Bertram and John W. A. Young, The Orthodox Patriarchate of Jerusalem: Report of the Commission Appointed by the Government of Palestine to Inquire and Report upon Certain Controversies between the Orthodox Patriarchate of Jerusalem and the Arab Orthodox Community (London: Oxford University Press, 1926); Derek Hopwood, The Russian Presence in Syria and Palestine, 1843-1914: Church and Politics in the Near East (Oxford: Clarendon Press, 1969); Panayiotis J. Vatikiotis, "The Greek Orthodox Patriarchate of Jerusalem between Hellenism and Arabism," Middle Eastern Studies 30, no. 4 (1994); Sotirios Roussos, "The Greek Orthodox Patriarchate and Community in Jerusalem," in The Christian Heritage in the Holy Land, ed. Anthony O'Mahony, Goran Gunner, and Kevork Hintlian (Jerusalem: Swedish Christian Centre, 1995); Daphne Tsimhoni, "The Greek Orthodox Patriarchate of Jerusalem during the Formative Years of the British Mandate in Palestine," Asian and African

(C) KONSTANTINOS PAPASTATHIS, 2018 | DOI:10.1163/9789004375741_015

This is an open access chapter distributed under the terms of the prevailing CC-BY-NC-ND License at the time of publication. 
the congregation, ${ }^{2}$ as well as its importance for social operations, this controversy had a political character and, as such, the role of the British administration in its development was crucial.

In the eyes of the Arab congregation, the Greek bureaucracy was the "outgroup"; intruders who had usurped the Arab cultural legacy. This dispute was not simply viewed as an intercommunal issue, but more broadly as part of the national struggle for emancipation from foreign rule, both political and religious. ${ }^{3}$ 'Issa al-'Issa was editor of the newspaper Filastin, the most influential Arab newspaper in Mandatory Palestine particularly with regards to the anti-Zionist cause and the nation-building process. ${ }^{4} \mathrm{He}$ plainly described the state of affairs: "It is true that Palestine is under two mandates, one the British and the other the Zionist, and it is true that the Orthodox community is under three mandates: the British, the Zionist, and, thirdly, the Greek."5 The demands of the laity were for: a) the establishment of a mixed council for the administration of communal affairs, including finances; b) free admission of the Arabs to the hierarchy; and c) substantial participation of the laity in patriarchal elections. ${ }^{6}$

The Greek establishment viewed these demands as a Trojan horse for the gradual deconstruction of the allegedly Greek national character of the institution. This idea was based on the ethno-phyletist narrative of ellinorthodoxia,

Studies 12, no. 1 (1978); Anthony O'Mahony, "Palestinian-Arab Orthodox Christians: Religion, Politics and Church-State Relations in Jerusalem, c. 1908-1925," Chronos: Revue d'Histoire de l'Université de Balamand, no. 3 (2000).

2 According to the 1922 census, the Arab Orthodox congregation had 33,369 members and made up 45 percent of the total Christians. See John Bernard Barron, Palestine: Report and General Abstracts of the Census of 1922 (Jerusalem: Greek Convent Press, 1923).

3 Elie Kedourie, "Religion and Politics," in The Chatham House Version and Other Middle Eastern Studies, ed. Elie Kedourie (1970, repr. Chicago: Ivan R. Dee, 2004); Noah Haiduc-Dale, Arab Christians in British Mandate Palestine: Communalism and Nationalism, 1917-1948 (Edinburgh: Edinburgh University Press, 2013); Laura Robson, "Communalism and Nationalism in the Mandate: The Greek Orthodox Controversy and the National Movement," Journal of Palestine Studies 41, no. 1 (2011).

4 Salim Tamari, "Issa al Issa's Unorthodox Orthodoxy: Banned in Jerusalem, Permitted in Jaffa," Jerusalem Quarterly, no. 59 (2014); Noha Tadros Khalaf, Les mémoires de Isa al-Isa:journaliste et intellectuel palestinien (1878-1950) (Paris: Karthala, 2009).

5 Extracted from Haiduc-Dale, Arab Christians in British Mandate, 111.

6 Konstantinos Papastathis and Ruth Kark, "Orthodox Communal Politics in Palestine after the Young Turk Revolution (1908-1910)," Jerusalem Quarterly, nos. 56-57 (2013-14); Papastathis and Kark, "Colonialism and Religious Power Politics: The Question of New Regulations within the Orthodox Church of Jerusalem during the British Mandate," Middle Eastern Studies 50, no. 4 (2014). 
that is, the equation of Orthodoxy with the Greek "Royal Race.." It claimed that all Orthodox patriarchates should remain in Greek hands and be ruled by or have a privileged relationship with the Greek state. Other nations' claims over the shared religious tradition were treated as an attempt to corrupt religious authenticity. ${ }^{8}$ For the practical implementation of ellinorthodoxia, Athens protected all Greek-dominated institutions diplomatically, supported them financially, intervened in their administrative affairs, and had a say in the election of their senior officials. However, the control Athens held over these institutions was limited due to its dependency on the Great Powers, which exercised colonial rule over many countries of the Middle East. Since the beginning of the Mandate, Greece had endeavored to intervene in patriarchal affairs, but in such a way as to not offend the British, who backed Athens' territorial claims over Eastern Thrace and Asia Minor.

British policy in relation to the Christian communities was determined by the administration's colonial objectives. The end of Ottoman rule and the subsequent regime change fueled Catholic hopes for a change in the modus operandi of the custodianship of the Holy Places, which had been regulated according to the Status Quo agreement. ${ }^{9}$ The British viewed the question as a constant source of interreligious conflict that could potentially open a kind of wineskin of Aeolus, allowing continuous interference by European powers, notably France, in the affairs of the new British "colony." Therefore, maintaining the Status Quo at any cost was vital to British interests. Despite the fear of conflict, the British administration decided to draw from its colonial experience in India in adopting the divide and rule strategy, in order to prepare the ground for the implementation of the Balfour Declaration. In the case of the Christian communities, this doctrine meant maintaining the Ottoman communitarian

7 Paraskevas Matalas, "To Patriarcheio Ierosolymon kai i ellinorthodoxia [The patriarchate of Jerusalem and Greek Orthodoxy]," in Orthodoxia, ethnos kai ideologia [Orthodoxy, nation and ideology], ed. Moraitis School (Athens: Moraitis School, 2007), 116.

8 Konstantinos Papastathis, "Secularizing the Sacred: The Orthodox Church of Jerusalem as a Representative of Greek Nationalism in the Holy Land," in Modern Greek Studies Yearbook $3^{0-31}(2016)$.

9 In this context, the "Status Quo" is generally defined as "the arrangements existing in $185^{2}$ which corresponded to the Status Quo of 1757 as to the rights and privileges of the Christian communities officiating in the Holy Places." Further, these rights and privileges "have to be most meticulously observed, and what each rite practiced at that time in the way of public worship, decorations of altars and shrines, use of lamps, candelabra, tapestry and pictures, and in the exercise of the most minute acts of ownership and usage has to remain unaltered." (Lionel George Archer Cust, The Status Quo in the Holy Places (1929, repr. Jerusalem: Ariel Publishing, 1980)), 11. 
pattern of social operation, that is, the millet system..$^{10}$ As a matter of policy, the Palestinian Arab body was not treated as a unified collective group. The political representation of its interests was not recognized on a national basis, but rather on a sectarian one. Within this context, the British had to mitigate the reactions of the indigenous population as a means of stabilizing their rule, that is, they needed to accommodate Arab requests to the best of their ability.

\section{New Archival Material}

The chapter deals directly with the normative framework regulating the institutional status of the patriarchate. As such, the vast majority of the records used in its research are legal documents and political texts (civil law, diplomatic reports, and correspondence, etc.) written in English and Ottoman Turkish, which were the official state languages, or in Greek, which was the working language of the institution. Documents in Greek include church law and diplomatic reports and correspondence. The sources are extracted from published collections of documents, from the British National Archives, the Greek Foreign Ministry, and the Orthodox Patriarchate of Jerusalem. They are of great value because they reflect the policy-making of three major players in the affair under discussion. The British had the political power and thus the capability of controlling the land market; the patriarchate was one of the biggest private landowners in the region, a part of whose properties were actually sold or leased; ${ }^{11}$ and Athens controlled part of the religious establishment and considered the patriarchate to be a Greek institution bound to adhere to the directions of the Greek state.

The files studied contain archival material, which reveals the views and actions of all parties involved, including the Jewish Agency and the Arab Orthodox congregation. Research with a clearer focus on the Palestinian and

10 Rashid Khalidi, The Iron Cage: The Story of the Palestinian Struggle for Statehood (Oxford: Oneworld Publications, 2007), 48-64.

11 Itamar Katz and Ruth Kark, "The Church and Landed Property: The Greek Orthodox Patriarchate of Jerusalem," Middle Eastern Studies 43, no. 3 (2007); Katz and Kark "The Greek Orthodox Patriarchate of Jerusalem and its Congregation: Dissent over Real Estate," International Journal of Middle East Studies 37, no. 4 (2005); Konstantinos Papastathis, "Church Finances in the Colonial Age: The Orthodox Patriarchate of Jerusalem under British Control, 1921-1925," Middle Eastern Studies 49, no. 5 (2013); Konstantinos Papastathis and Ruth Kark, "The Politics of Church Land Administration: The Orthodox Patriarchate of Jerusalem in Late Ottoman and Mandatory Palestine, 1875-1948," Byzantine and Modern Greek Studies 40, no. 2 (2016). 
Jewish sources would contribute to a more comprehensive understanding of the affair, but time, language, and space constraints make this impossible here. Material from the patriarchate is extremely understudied, and with the exception of works by Sotirios Roussos and the author, little attention has been paid to the archives of the Greek Ministry of Foreign Affairs. ${ }^{12}$ Scholars such as Daphne Tsimhoni, Itamar Katz, and Ruth Kark have conducted research in the British Public Record Office regarding the Orthodox Church in Jerusalem. However, none of them have focused on the specific property sales under discussion here.

This chapter suggests that the British administration managed to control the financial affairs of the patriarchate and to sell its land to the Jewish Agency at the expense of the Arab Orthodox population, without putting public order at risk. This affair should be examined in the context of colonialism and the nationalization process given its direct relation both to the Status Quo question and to the dispute between the Greek hierarchy and the Arab congregation with regard to the process of laicizing the church administration. The chapter is divided into three main parts. The first part is a discussion of church land acquisition and administration; the second part deals with the state policy in relation to religious real estate, and the third part analyzes real estate management in relation to domestic political considerations as well as to diplomatic priorities of the key internal and external players involved, namely the Brotherhood, the Arab Orthodox, the British authorities, and the Greek government.

\section{The Patriarchate's Administration of Real Estate: A Powerful Lever}

The purchase of land in Palestine by the patriarchate served two main purposes: the acquisition of properties for its own use and in order to assert dominance over other denominations in areas of religious significance. The expropriation of properties by Prince Alexandru Cuza in Wallachia $(1863)^{13}$ and in Greece

12 Sotirios Roussos, "Greece and the Arab Middle East: The Greek Orthodox Communities in Egypt, Palestine and Syria, 1919-1940" (PhD diss., soAs, University of London, 1994).

13 Chrysostomos A. Papadopoulos, Istoria tis ekklisias ton Ierosolymon [History of the church of Jerusalem] (1910, repr., Thessaloniki: Pournaras, 2010), 792-806; Spyridon Antiochos, Ypomnima peri ton en Roumania monastiriakon ktimaton ton Agion Topon [Memorandum on the monastery properties of the holy places in Romania] (Athens: D. G. Efstratiou, 1901); Nikolaos Levidis, Ta en Roumania ellinika monastiriaka ktimata [The Greek monastery estates in Romania] (Athens: A. Konstantinidis, 1893). 
immediately after its independence, ${ }^{14}$ or the blocking of the flow of revenues from the Bessarabia estates because of the Russo-Turkish wars were also factors influencing land acquisition in Palestine. Having property at its disposal allowed the patriarchate to further develop its social work (charity and education) as well as reduce conversions of the native Orthodox population to other denominations. ${ }^{15}$

The patriarchate acquired its properties by exploiting the favorable Ottoman legal framework that applied to land acquisition and administration. According to this framework, the patriarchate could not own private property, but only waqf, ${ }^{16}$ that is, pious endowments donated for charitable purposes for the benefit of the "poor,"17 and typically administered by a religious institution or family trustees. As Kermeli has argued, the church/monastery waqf could only belong to the subcategory of family waqf. ${ }^{18}$ In this regard, it should be noted that the patriarchate was structured institutionally as a monastic brotherhood. This status was directly linked to property management: the upper hierarchy could block communal claims to coadminister the waqf properties since the law stipulated that the well-being of the "poor monks" and/or pilgrims was the waqf's main concern. Thus, various Ottoman legal decrees such as firmans, orders, berats and church regulations designated the patriarch, and mütevelli (administrator-curators of the endowments) as the only competent authorities to manage the waqf properties. ${ }^{19}$

The purchased properties were both urban and rural. As James Finn, the British consul in Jerusalem (1846-63), noted: "besides maintaining without diminution its ancient property, ... [the patriarchate] has for several years past pursued a scheme of buying up houses, or shops, or waste ground, or even fractions (kirfits [sic] or twenty-fourth parts) of such properties all over the

14 Athanasios Ilias, Ta metochia tou Panagiou Tafou kai tis Monis Sina stin Ellada [The monastery dependencies of the Holy Sepulchre and of Sinai Monastery in Greece] (Athens: Akritas, 2003).

15 Katz and Kark, "The Church and Landed Property."

16 Robert H. Eisenman, Islamic Law in Palestine and Israel: A History of the Survival of Tanzimat and Sharia in the British Mandate and the Jewish State (Leiden: Brill, 1978), $5^{2-69 .}$

17 Aleksandar Fotić, "The Official Explanations for the Confiscation and Sale of Monasteries (Churches) and their Estates at the Time of Selim II," Turcica 26 (1994), 43.

18 Eugenia Kermeli, "Ebū's Su'ūd's Definition of Church Vakfs: Theory and Practice in Ottoman Law," in Islamic Law: Theory and Practice, ed. Robert Cleave and Eugenia Kermeli (London: I. B. Tauris, 1997).

19 Papastathis and Kark, "The Politics of Church Land Administration." 
city indiscriminately, till it is believed that more than a quarter of the whole [within the city walls] has come into their hands as free-hold purchase."20 Moreover, certain patriarchal officials, such as Archimandrite Nikiforos or Priest Benjamin, proceeded to make large acquisitions of properties outside the walls of Jerusalem (for example in present-day Rehavia, Talpiyot, Katamon, the Mount of Olives), which were further improved through plantation and cultivation. In the early 1920s, the patriarchate had become the trustee of vast plots of real estate, estimated at about $63^{1}$ properties. ${ }^{21}$ According to Tamari, the patriarchal waqf together with the Russian land endowments were more numerous than "Muslim, Jewish and Catholic endowments put together."22 Katz and Kark identified 355 of these properties, of which 176 alone covered an estimated 36,779 metric dunams (one dunam is equal to 1,ooo square meters). ${ }^{23}$ Of the total area of goo dunams in the Old City of Jerusalem, 317 dunams belonged to the patriarchate. ${ }^{24}$

\section{The British Financial Commission: An Ambiguous Intermediary}

In 1920, the patriarchal debt amounted to 500,00o Egyptian pounds (LE) (LE 1 equaled $£_{1}$ ), which led to the institution of the threshold of bankruptcy. ${ }^{25}$ Patriarchal debt had risen as a result of several main developments; the flow of pilgrims to Jerusalem had waned during the World War I, Russian support had ceased after the October Revolution, and poor administration and endemic corruption had led to the borrowing of large sums on high interest rates. Revenues could cover neither the principal nor the interest on the loans, and the patriarchal property was under moratorium and faced being confiscated.

In this state of affairs, Patriarch Damianos considered the sale of real estate to be the only effective measure as contracting a new loan in order to settle the debt would probably add to the financial burden of the church.

$20 \quad$ James Finn and Elizabeth Anne McCaul Finn, Stirring Times: Or Records from Jerusalem Consular Chronicles of 1853 to 1856, vol. 1 (London: G. K. Paul, 1878), 32-33, 82-83.

21 Anton Bertram and Charles Harry Luke, Report of the Commission Appointed by the Government of Palestine to Inquire into the Affairs of the Orthodox Patriarchate of Jerusalem (London: Oxford University Press, 1921), 195.

22 Tamari, "Issa al Issa's Unorthodox Orthodoxy," 21.

23 Katz and Kark, "The Church and Landed Property," 385.

24 Anwar H. M. Musaee et al., "Waqf Land in the West Bank and Investment Current State of Affairs," Asian Social Science 10, no. 14 (2014): 30.

25 Bertram and Luke, Report of the Commission, 191. 
Selling properties outside of the city walls, situated in today's western Jerusalem, served three purposes. First, sales would neutralize Arab Orthodox demands for the coadministration of the institution. Since land management and the revenue it generated were said to fuel the congregation's opposition, the sale of properties would lead to reduced Arab interest in questioning Greek authority. Secondly, Damianos estimated that the income from these sales would be sufficient to pay the debt as well as to maintain a bank reserve, which would provide annual interest covering the basic needs and liabilities of the patriarchate. Last but not least, he was concerned about the new city planning regime, according to which the patriarchal agricultural holdings would become urban plots, thus increasing the burden of land taxes. ${ }^{26}$

Following this line of thought, Damianos made a provisional agreement with the Jewish-owned Palestinian Land Development Company (PLDC) for the sale of a large portion of the Nikiforia estate, where the Talpiyot neighborhood was created. Moreover, the synod authorized the sale of a large property in Jaffa Market as well as the rest of the agricultural properties in Jerusalem. However, High Commissioner Herbert Samuel did not approve Damianos' plans, which were in any case inaccurate. The mandatory authorities decided instead to manage the sale of immovable property themselves. ${ }^{27}$ Indeed, the Orthodox Patriarchate Ordinance of 1921 stipulated the appointment of a commission for the liquidation of debts that would have full control over the patriarchal finances. Specifically, the commissioners would decide on the management of all properties and their revenues, and would have the right to sell real estate or contract loans and assume the direct administration of any department, property, or operation of the patriarchate. ${ }^{28}$ In short, the British could decide for the institution without its consent and enjoy immunity for their actions. By gaining financial control, they acquired power over the Jerusalem Orthodox Church. The commission's operation under this colonialist normative framework was not founded solely on an orientalist line of thought, but was also fueled by British cautiousness towards Damianos, who had been accused by his fellow clerics of maladministration, and, worse, for expropriating patriarchal revenues for personal use. The British were well-informed of various real estate transactions such as the renewal of leases in Jerusalem at a very low

26 Historical and diplomatic archive of the Greek Ministry of Foreign Affairs (AYE)/43/1, "Patriarch Damianos to Mavroudis, Head of the 2nd Political Department of the Greek Ministry of Foreign Affairs," October 12, 1920.

27 Papastathis, "Church Finances in the Colonial Age."

28 Bertram and Luke, $327-32$. 
price $^{29}$ and the "giveaway" of valuable assets in Bethlehem ${ }^{30}$ and in Crete. ${ }^{31}$ British suspicions about Damianos' credibility were confirmed when on the date of the commission's establishment, Damianos contracted an overdraft from the French bank Crédit Lyonnais. The amount was LE 32,075 and it bore an interest rate of 7 percent compounded quarterly, which raised the patriarchal debt even higher. ${ }^{32}$

The sale was not cancelled, but merely postponed until the commission's establishment so that it could control the sum of money. ${ }^{33}$ In principle, the commission did not oppose the sale of land to a Zionist organization. Given their strong financial position, the Jews were at that time the main group who were both interested in acquiring land and able to afford it. The underlying problem was that such a transaction carried the risk of dislodging the existing residents, triggering an Arab protest. Therefore, the commission asked for assurances that the rights of tenants and lessees would be respected, as well as those of the occupants of houses, who were entitled to free accommodation by virtue of their being parish priests. Before the settlement of these claims, the transfer could not be allowed. ${ }^{34}$ To this end, the commission's chairman, J. B. Barron, communicated to the president of the PLDC, Dr. Jacob Thon, that the ratification of the sale was subject to the following amendments: a) the encashment had to be credited to the account of the commission; b) the purchase price had to be settled in cash, not by bills, notes of hand, or other forms of negotiable paper issued in the past by the patriarchate; and c) any existing contract between the patriarchate and the tenants or lessees had to be respected. ${ }^{35}$

The names and the sizes of the plots within Jerusalem (Talpiyot area) that were sold are provided in table 11.1. Together with these properties, some other

29 AYE $/ 39 / 3$, "Financial Commission to Patriarch Damianos," August 16, 1922.

30 The National Archives of the UK (TNA): Foreign Office (FO) 286/781, "Pro-memoria attached to the dispatch of the Greek diplomatic legate in London A. R. Rangabe to the Secretary of State for Foreign Affairs Earl Curzon," no. E1769/263/88, October 24, 1921.

$31 \mathrm{AYE} / 42 / 4$, "Greek Consul in Jerusalem to the Greek Foreign Office," no. 172, April 29, 1921.

32 TNA:Colonial Office ( $\mathrm{CO}$ ) 733/200/4, "Report on the Finances of the Orthodox Patriarchate of Jerusalem for the Financial Year, 1926-1927."

33 Archive of the Greek Orthodox Patriarchate of Jerusalem (AEPI), Special File: Governmental Financial Commission of the Holy Convent, "H. Samuel to Patriarch Damianos," no. 2017, August 16, 1921.

34 AE PI, Special File: Governmental Financial Commission of the Holy Convent, "J. B. Barron to Patriarch Damianos," no. 1164, October 1, 1921.

35 AEPI, Special File: Governmental Financial Commission of the Holy Convent, "J. B. Barron to Dr. Thon," October 1, 1921. 
plots of land (Janzir and Fuga; Marj Sarqui and Marj Charbi) were sold to the PLDC. The agreed price for all of the land amounted to LE 206,115.99, and was to be paid in installments. ${ }^{36}$ It was decided that not all of the properties were to be urban properties, that is, within the city walls, or estates attached to Holy Places or Orthodox monasteries and churches. This is why the great majority of the properties on lease status were agricultural land parcels. ${ }^{37}$ In 1920 , when the patriarchate began negotiations, the price for these estates had been fixed at LE 500,000, payable in cash, and a year later the price was reduced to LE $300,000 .{ }^{38}$ Due to "felonious interventions from outside and inside the patriarchate,"39 as well as to the attitude of the purchaser, who took advantage of the patriarchate's urgent financial problem, the price was further reduced. ${ }^{40}$ The commission finally changed the terms of the transaction, namely the rate and time period of the six installments. ${ }^{41}$ The overall amount received from the sale of land during the first year of the commission's operation was estimated to have reached LE $57,837 \cdot{ }^{42}$

$36 \mathrm{AYE} / \mathrm{B} / 35 / 4$, Jerusalem (1924), "Report of the Commissioners on the Finances of the Orthodox Patriarchate for the Six Months ended August 31, 1923."

37 AYE, 2nd Department, File Jerusalem 1, "Antonios Spiliotopoulos' Report concerning the current state of affairs in the Patriarchate of Jerusalem and the Convent of the Holy Sepulchre to the Council of the Holy Sepulchre Association," Athens, April 20, 1929.

38 AYE /48/4: Palestine Mandate - Patriarchate of Jerusalem, "Greek Consul in Jerusalem to the Greek Foreign Office," no. 496, August 15, 1928.

39 These "interventions" referred to the mistaken appropriation by the government of patriarchal land close to Jaffa Gate (32,00o square pics). This dispute had its roots in Ottoman times. In 1910, the patriarchate made this part of Nikiforia available to the mutessarif of Jerusalem on the condition that it would be used only for the erection of governmental offices. Although the patriarchal condition was rejected, thus rendering the gift void, the mutessarif proceeded to the registration of the area as governmental land. This registration, despite the Ottomans not gaining possession of the land at any time, was the reason why the commission mistakenly excluded this plot from the sale to the PLDC (TNA: CO 733/151/15, "Dispute between the Orthodox Patriarchate of Jerusalem and the Government of Palestine in regard to a plot of Land forming part of the Nikiforieh Property").

$40 \quad$ Alexandreia, no 2, June 1924 (AYE/B/35/4: Jerusalem (1924)).

41 AYE $/ B / 35 / 4$ : Jerusalem (1924), "Report of the Commissioners on the Finances of the Orthodox Patriarchate for the Financial Year ended August 31, 1922."

TNA: $\mathrm{CO} 733 / 200 / 4$, "Report on the Finances of the Orthodox Patriarchate of Jerusalem for the Financial Year, 1926-1927." 
TABLE 11.1 Land sold to the PLDC

\begin{tabular}{llllll}
\hline Site & $\begin{array}{l}\text { Area in sq. pics } \\
\text { (approximately } \\
\text { o.574 sq. meters) }\end{array}$ & $\begin{array}{l}\text { Equivalent } \\
\text { in acres }\end{array}$ & $\begin{array}{l}\text { Equivalent } \\
\text { in dunams }\end{array}$ & $\begin{array}{l}\text { Price per sq. } \\
\text { pic (LE) }\end{array}$ & $\begin{array}{l}\text { Total value } \\
\text { (LE) }\end{array}$ \\
\hline Anthimos & 32,289 & 4.58 & 20.32 & 200 & $64,578.00$ \\
Antiochos & $30,378.8$ & 4.31 & 19.12 & 200 & $60,757.60$ \\
$\begin{array}{l}\text { Chrysanthos } \\
\text { and Nektarios }\end{array}$ & $22,456.5$ & 3.18 & 14.11 & 75 & $16,842.38$ \\
Bourra & $22,652.2$ & 5.05 & 22.40 & 50 & $16,326.10$ \\
Total & $\mathbf{1 0 7 , 7 7 6 . 5}$ & $\mathbf{1 7 . 1 2}$ & 75.95 & $\mathbf{5 2 5}$ & $\mathbf{1 5 8 , 5 0 4 . 0 8}$ \\
\hline
\end{tabular}

SOURCE: AYE/B/35/4, JERUSALEM (1924), “REPORT OF THE COMMISSIONERS ON THE FINANCES OF THE ORTHODOX PATRIARCHATE FOR THE SIX MONTHS ENDED AUGUST 31, 1922."

However, the PLDC did not adhere to the terms of their agreement and asked for an extension in order to complete the payment. ${ }^{43}$ This request was granted by the commission, and in accordance with the agreement made in June 1923, the company undertook to bring the payments made by December 31, 1923, up to the sum of LE 99,115.99, and to submit by the same date new and better proposals for the liquidation of the balance of LE 107,000. ${ }^{44}$ The interest on the overdue payments was reckoned at the rate of 6.5 percent. ${ }^{45}$ Another important aspect of the affair is that the members of the Arab Orthodox Congress in Haifa (July 1923), which represented a great majority of the lay community, declared their confidence in the financial commission and requested its extension, in spite of the sales of land to the PLDC. ${ }^{46}$ Throughout the 1920s, a large part of the Nikiforia estate was gradually sold or leased piece by piece to various

$43 \mathrm{AYE} / \mathrm{B} / 35 / 4$ : Jerusalem (1924), "Report of the Commissioners on the Finances of the Orthodox Patriarchate for the Six Months ended August 31, 1923."

44 Ibid.

45 Ibid.

46 Bertram and Young, 275-76. 
vendees. ${ }^{47}$ Moreover, during the same period other plots of land outside of the city walls (for example, on King George Avenue, King David Street, Rehavia) were sold on very bad terms. ${ }^{48}$ In light of this, the patriarchate accused the commission of maladministration, renounced its decisions, and demanded its disestablishment. ${ }^{49}$ Furthermore, the commission was responsible for the surrender of patriarchal land to the municipality, without compensation, for the construction of new roads on King George Avenue and Talbieh Road, as well as for the widening of existing roads such as West Nikiforia road, Birkat alSultan Road, Harririeh Road, and Lower Janzier Road. ${ }^{50}$ The aggregate value of the plots taken amounted to LE $30,176.89 .{ }^{51}$ During the 1930s, the patriarchate leased 122 dunams in the Rehavia quarter to the Jewish National Fund (JNF), as well as 67 dunams in the Mamilla commercial district and Ben-Yehuda Street. After the partition of Palestine, under heavy pressure and facing the threat of having its properties confiscated by the State of Israel as allegedly "abandoned property," the patriarchate leased another 509 dunams located on Talbieh Road and in Rehavia to the JN F "for much less than their market value."52 Israel further developed the policy of leasing church-owned land after the 1967 War by exploiting the patriarchate's fear of losing its rights over the Holy Places. ${ }^{53}$

47 TNA: Treasury (T) 161/269, "Report of the Commission on the Finances of the Orthodox Patriarchate of Jerusalem together with the Statements of the Accounts as at the 13th of September, 1926, Appendix III," January 26, 1927.

48 AEPI, File: Protest to Financial Commission, "Patriarch Damianos to the Secretary of State for the Colonies," April 9/22, 1925.

49 AEPI, File: Protest to Financial Commission, "Patriarch Damianos to the High Commissioner for Palestine," September 9/22, 1925.

5o TNA: CO 733/142/16, "Attorney General N. Bentwich to the Chief Secretary: Claim by the Orthodox Patriarchate against Jerusalem Municipality," October 22, 1926.

51 TNA: CO 733/192/8, "Commission on the Finances of the Orthodox Patriarchate of Jerusalem to the Acting Chief Secretary (enclosure 1: 'Judgement')," no. 25/OP/S.-320/83, Jerusalem, April 5, 1930.

$52 \quad$ Uri Bialer, Cross on the Star of David: The Christian World in Israel's Foreign Policy, 19481967 (Bloomington: Indiana University Press, 2005), 179-86; Bialer, "Horse Trading: Israel and the Greek Orthodox Ecclesiastical Property, 1948-1952," Journal of Israel History 24, no. 2 (2005): 205-10.

53 Michael Dumper, The Politics of Sacred Space: The Old City of Jerusalem in the Middle East Conflict (Boulder: Lynne Rienner, 2002), 113-15. 


\section{British Policy on Church Land Administration and the Greek Proposal}

In 1919, the Greek government offered a loan to cover the patriarchate's debt. The Greek loan would allow the patriarchate to pay all its dues without either losing its property or putting the institution under extreme financial pressure. For over twenty years, the clergy had been in a very poor state; 54 church buildings could not be renovated without external funding 55 and many churchfunded schools were closed down. The major conditions put forward by the Greek government for the loan were the deposition of Patriarch Damianos, who was considered pro-Arab, and the enactment of new regulations that would allow the election of a patriarch with ties to Athens. The British were aware of the Greek plans, and according to Athens' diplomatic representative in Jerusalem, Georgios Tzormpatzoglou, British high officials such as the military governor of Jerusalem, Ronald Storrs, were not against the implementation of these regulations. ${ }^{56}$ However, after Damianos' refusal to resign, Athens backed out, requesting that the patriarch never act "without the knowledge and approval of the local representative of the Greek government, to the orders of which [Damianos] had from now on to adapt his administrative policy. The patriarchate should become a dependency of the Consulate."57 Another important condition was the mortgaging of the entire ecclesiastical property to the Greek state. ${ }^{58}$ However, the Foreign Secretary, Lord Curzon, refused the Greek loan ${ }^{59}$ despite the fact that the financial advisor to the Palestine government, Colonel Gabriel, "expressed himself in full agreement with the representative of the National Bank of Greece." ${ }^{\prime 0}$ The British therefore decided instead

54 AYE, 2nd Department, File 57.1: League of Nations Mandate for Palestine and Patriarchate of Jerusalem, "Greek Consul in Jerusalem to the Greek Foreign Office," no. 77, March 1, 1927. AYE, 2nd Department, File Jerusalem 1, "Antonios Spiliotopoulos' Report concerning the current state of affairs in the Patriarchate of Jerusalem and the Convent of the Holy Sepulchre to the Council of the Holy Sepulchre Association," Athens, April 20, 1929. AYE /43/3 (1920): "Tzorbatzoglou to the Greek Foreign Office," no. 11629, November 14, 1919. AYE $/ 43 / 4$ (1920): "Statement of the General Consul of Greece in Jerusalem Mr. G. Tzorbatzoglou conveyed to His Beatitude the Patriarch of Jerusalem Mr. Damianos by Archimandrite Epiphanios, Secretary of the Holy Synod."

$5^{8}$ Bertram and Luke, Report of the Commission, 31-33.

59 TNA: T 1/12483, "J. Tilley to the Secretary of the Treasury," no. 177153/M.E. 44.A., February 12, 1920.

6o TNA: FO 371/4240, "Greek Ambassador (D. Caclamanos) to Curzon of Kedleston," no. 4907, December 2, 1919 . 
to rule the patriarchate themselves via the creation of the financial commission that took full control over the management.

The question that reasonably arises is why the patriarchal bureaucracy accepted the restriction of its powers and competencies to a minimum, conceding financial management to the commission. First and foremost, the patriarchal debt was under moratorium, and the danger of the latter's revocation was evident. In the event of this, the patriarchate would lose all of its immovable property, and thus would cede its ability to perform its religious and social mission. Such a state of affairs would inevitably threaten the cohesion of the church and obstruct the clergy from performing their duties in the Holy Places. On the other hand, the dominance of Damianos and his apparatus within the brotherhood was still contested by a significant opposing faction that had important links to the Greek political and religious power networks. ${ }^{61}$ The support eventually given to Damianos by the British would have been put at risk had he not consented to their plans. In other words, it was a give-andtake agreement through which Damianos consolidated his authority within the church in return for accepting the government's proposal. The fact that Damianos opposed the commission later should not be read as a sign of disingenuousness, but should rather be attributed to the commission's policy of blocking him from any access to patriarchal revenues. In any case, as early as 1923, Damianos had eliminated all dissenting voices within the patriarchate and thus was no longer as reliant on the British for securing his rule.

Two interconnected factors influenced British policy for establishing the commission: the Status Quo of the Holy Places and the dispute within the Orthodox community between the Greek hierarchy and the Arab laity. In particular, the acceptance of the Greek loan would have diminished the role of the British government as the diplomatic patron of the Orthodox Patriarchate, in favor of Communist Russia, as Lloyd George himself had proclaimed at the San Remo Conference (April 1920). ${ }^{62}$ The new administration's image would have suffered could it not support an important religious institution under its protection and had to accept Greek support. More importantly, it would have been an additional argument for the French government to preserve its traditional status as the diplomatic protector of the Catholic community within the Ottoman Empire under the capitulation regime, the abolition of which was a prime aim of London. At that time, negotiations between the Great Powers

$61 \mathrm{AYE} / 29 / 1$, "Greek Consul General in Jerusalem to the Greek Foreign Office," no. 129, April 22, 1921.

62 Ernest L. Woodward and Rohan Butler, eds., Documents on British Foreign Policy, 1919-1939, 1st ser., vol. 7 (London: HM Stationery Office, 1958), 166. 
concerning the operation of the mandate were at a standstill due to disagreement on the structure and competencies of the future commission responsible for the Holy Places. ${ }^{63}$ A Greek hold over the patriarchate with blessings from the British would have meant the emergence of a new actor in the religious power plays within Palestine, signifying a change in circumstances regarding the administration of the Holy Places. This alteration, however, instead of breaking the traditional state of affairs (that is, each community should be under the protection of a state power), would have effectively led to its maintenance. Instead of restructuring the Status Quo agreement in line with the postwar political landscape, the acceptance of the Greek initiative would have resulted in the reproduction of the antebellum institutional framework as defined in the Berlin Treaty (1878), making room for other states to claim protective rights over their nationals as well. The British did not intend to open a Pandora's box but rather to eliminate the specter of other states' presence in Palestinian affairs.

Had the British accepted the Greek loan, the patriarchate would have become, in practice, an institution under the absolute control of Athens. ${ }^{64}$ In turn, Arab Orthodox reactions would have triggered a highly unwelcome development in a time of extreme social unrest directed against the administration (for example, the Nabi-Musa Riots of 1920 and the Riots of May 1921). For the British authorities, safeguarding public order was the key to stabilizing power. ${ }^{65}$ More importantly, the British handling of the affair should be interpreted within the context of the strategy, mentioned earlier, of further developing existing internal divisions within the society. Society was not seen as a coherent collective body, but as a summation of distinct entities differentiated from each other along sectarian lines. By allowing Athens to take full control of the patriarchate, the British would have instead given a further boost to the close identification between the Arab Orthodox and Muslim communities. In other words, it was in their best interest to support the cause of the congregation, whose elite members played an important role in domestic politics

63 Bernardin Collin, Le problème juridique des lieux-saints (Cairo: Centre d'études orientales; Paris: Sirey, 1956), 69-103; Paolo Pieraccini, Gerusalemme, Luoghi Santi e comunità religiose nella politica internazionale (Bologna: Dehoniane, 1997), 203-51; Walter Zander, "On the Settlement of Disputes about the Christian Holy Places," Israel Law Review 8, no. 3 (1973): 342-51.

64 Tsimhoni, "The Greek Orthodox Patriarchate of Jerusalem," 87, 90-96.

65 Sotirios Roussos, "The Greek Orthodox Patriarchate and Community of Jerusalem: Church, State and Identity," in The Christian Communities in Jerusalem and the Holy Land: Studies in History, Religion and Politics, ed. Anthony O'Mahony (Cardiff: University of Wales Press, 2003), 44. 
and actively participated in the national struggle. This way, the Arab Orthodox would be more likely to adopt a more compliant stance towards their rule. Rejecting the Greek offer was therefore imperative because it contributed to the creation of an image of the British as a guarantor of the legitimate rights of the Arab Orthodox, who would then have nothing to fear from the application of the Balfour Declaration. ${ }^{66}$ In conjunction to this, the possibility of an Arab Christian uprising would be another significant argument for the French to maintain their privileges established in the Status Quo agreement, hence disputing the absolute dominance of the British in the region.

\section{Concluding Remarks: Between Political and Financial Issues}

From a political perspective, the British established the commission due to the political significance of the financial management of the patriarchate's immovable property at the time of Jewish expansion in Palestine. In the event that the commission had not been formed, after the rejection of Athens' offer of a loan, the patriarchate would have had two options: either declare bankruptcy or proceed to the sale of its real estate. The first option would signify the loss of every single patriarchal property, which would have to be ceded to the creditors. In that case, the Zionist immigrants at the time of the third aliyah (1918-23) would have missed the opportunity to purchase land, a part of which was in the symbolic center of their community, Jerusalem. It should be noted that in 1918, Jewish organizations had begun buying portions of the debt in order to demand the foreclosure of the mortgaged properties after the end of the moratorium. ${ }^{67}$ The value of the promissory notes acquired was estimated to be between LE 150,000 and 200,000. ${ }^{68}$ However, this assessment was far from accurate. The debt purchased was rather small in comparison to the portfolio of the other creditors, who amounted to 1,90o individuals and institutions. ${ }^{69}$ The second option for the patriarchate would have been the

66 Konstantinos Papastathis, "To keno exousias sto Patriarcheio Ierosolymon, 1917-1918" [The power vacuum within the Orthodox patriarchate of Jerusalem, 1917-1918], Historica $5^{1}(2009): 364-66$.

$67 \mathrm{AYE} / \mathrm{B} / 35$ (9), Special File Jerusalem, Mission of K. Korizis, "Greek Consul in Alexandria to the Greek Foreign Office"; File B/35 (9), Special File Jerusalem, Mission of K. Korizis, "London Embassy to the Greek Foreign Office," no. 5757, July 27, 1918.

$68 \mathrm{AYE} / 42 / 4$, "Greek Consul General in Jerusalem to the Greek Foreign Office," no. 268, July 8,1921 .

69 TNA: T 161/269, "Report of the Commission on the Finances of the Orthodox Patriarchate of Jerusalem together with the Statements of the Accounts as at the 13 of March, 1926, Appendix VII" (attached to the Dispatch of F. M. Plummer to L. Amery), May 12, 1926. 
direct sale of extended tracts of land to the Zionist Commission. The British Foreign Secretary, Lord Curzon, had already rejected this idea, however. ${ }^{70}$ Taking into account the national claims of the Arab population, as well as the congregation's reactions against any transaction without its consent, the sale of real estate had to be controlled so as to avoid social unrest. The establishment of the financial commission was therefore a necessary measure. It facilitated the recovery of land for the Zionists and secured necessary funding for the settlement of the patriarchal debt. In addition, it controlled transactions by not allowing sales of extended land estates and diminished the possibility of further Arab upheaval against the government. In this regard, the struggle of the Orthodox laity against the Greek hierarchy should not be underestimated. As Angelos Anninos pointed out, looking back at his service as the Greek consul in Jerusalem (1921-22) where he closely followed patriarchal affairs, the British would have never given away the financial management and control of patriarchal real estate transactions. These elements had been the key to British dominance over both the hierarchy and the lay community, since the dispute between them remained closely tied to patriarchal assets and the distribution of the revenues therefrom. ${ }^{71}$ Disturbing the financial balance would have meant surrendering a degree of power, a move the British were not willing to make.

$70 \quad$ TNA:T 1/12483, "J. Tilley to the Secretary of the Treasury," no. 177153/M.E. 44.A., February 12, 1920.

71 AYE /42/4, "Greek Consul in Jerusalem to the Greek Foreign Office," no. 241, June 23, 1921. 


\title{
Comparing Ottoman Municipalities in Palestine: The Cases of Nablus, Haifa, and Nazareth, 1864-1914
}

\author{
Mahmoud Yazbak
}

It has been suggested that the European presence in Ottoman cities and the subsequent pressure on the Ottoman administration led to the creation of Ottoman municipalities. This theory implies that local Muslim societies were stagnant and lacked the required resources for social and urban change. ${ }^{1}$ Based upon findings from three Palestinian Ottoman cities: Nablus, Haifa, and Nazareth, this chapter claims that urban services had been established long before the foundation of the municipalities or the presence of Europeans in Palestine. In this respect, the law regarding municipalities and their establishment was not a true innovation. When they were created, Ottoman municipalities took on public services that had been present many years before. However, at the local level, the institution of the municipality, which was part of the overall reform process, produced new systems of social and political change. ${ }^{2}$

Until the 1870s, the presence of Europeans in Haifa and Nazareth was too limited to exert serious pressure on the Ottoman authorities. Nablus was the main town in the mountainous region of central Palestine, and it served as a hub for the commerce, manufacturing, and administration of its hinterland. Culturally, Nablus remained largely unaffected by the rising commercial, cultural, and missionary ties that allowed Europe to penetrate into Palestine in the $1850 \mathrm{os}$. With a predominantly Muslim population of 20,000, the town was inhabited by just a few hundred Christians and Samaritans. Nablus remained largely stable; it was unaffected by immigration, and preserved its autonomous cultural identity long after the mid-nineteenth century. It had succeeded

1 For a thorough discussion of these theories see Mahmoud Yazbak, "The Municipality of a Muslim Town: Nablus, 1868-1914," Archiv Orientalni 67, no. 3 (1999): 339-341.

2 In this chapter, I do not discuss at length the urban services provided by the municipal council, a theme I deal with in "Municipality of a Muslim Town," 348-59. Among other aspects, that article discusses the municipal budget and municipal services such as town planning, sanitation and lighting, supervision of markets, police and security and other aspects of services.

(C) MAHMOUD YAZBAK, 2018 | DOI:10.1163/9789004375741_016

This is an open access chapter distributed under the terms of the prevailing CC-BY-NC-ND License at the time of publication. 
in maintaining autonomous rule to a large extent, and Nablus' elite resisted changes that could have altered its traditional social structures. ${ }^{3}$

Haifa was rebuilt in the 1750 s, and continued to develop until the 1830 s. It had a suitable anchorage for steamships, and it became the main port of northern Palestine and the Hawran. In 1905, when the Ottoman government made it one of the central stations of the Hijaz Railroad, Haifa's port became second in importance to Beirut. The population of Haifa grew from about two thousand in the mid-nineteenth century, to about twenty thousand at the turn of the century. Muslims made up half of the population; the rest was made up of Christians and other religious minorities. Since the town was too young to have a well-established traditional elite, it proved easier for new immigrant families in Haifa to become part of the elite than in older towns such as Nablus. ${ }^{4}$

Nazareth is located in a strategic point in the southern Galilee Mountains, overlooking the Esdraelon valley. It came to life in the 1750s, when it became a government base. Its prominent and powerful governor, Dahir al-'Umar, gave permission for four churches to be built in the town: Greek Orthodox, Roman Catholic, Maronite, and Latin. This encouraged general settlement in Nazareth and led to further regeneration in the area. Dahir's successors continued his policy, and its population grew to about four thousand in the 185 os, and to ten thousand in the 1880 s. $^{5}$ Since it was one of the holy places for Christianity, Nazareth began to attract many missionary societies during the second half of the nineteenth century. In less than fifty years, forty-four missionary establishments had been set up in the town. ${ }^{6}$ Muslims made up

3 Mahmoud Yazbak, "Nabulsi Ulama in the Late Ottoman Period, 1864-1914," International Journal of Middle East Studies 29, no. 1 (1997); Beshara B. Doumani, Rediscovering Palestine: Merchants and Peasants in Jabal Nablus, 1700-19oo (Berkeley: University of California Press, 1995), 9, 23, 68, 73-74, 107. Cf. also Butrus Abu-Manneh, "The Islamic Roots of the Gulhane Rescript," Die Welt des Islams 34, no. 2 (1994).

4 For a thorough study of Ottoman Haifa, see Mahmoud Yazbak, Haifa in the Late Ottoman Period, 1864-1914: A Muslim Town in Transition (Leiden: Brill, 1998); Muhammad Rafiq (al-Tamimi) and Muhammad Bahjat, Wilayat Bayrut [Province of Beirut], 3rd ed., 2 vols. (Beirut: Dar Lahd Khatir, 1987), vol. 1, 387-89.

5 Mahmoud Yazbak, "Europe, Cotton and the Emergence of Nazareth in 18th-Century Palestine," Oriente Moderno 93, no. 2 (2013).

6 Tamimi and Rafiq, Wilayat Bayrut, 378, 383; As‘ad Mansur, Tarikh al-Nasira min Aqdam Azmaniha Ila Ayamina al-Hadira [History of Nazareth from early times to our days] (Cairo, 1924), 124; Chad Fife Emmett, "The Christian and Muslim Communities and Quarters of the Arab City of Nazareth" (PhD diss., University of Chicago, 1991), 51. 
one-third of the town's population, and the remainder were Christians of different denominations. ${ }^{7}$

However, two forces of change emerged in the middle of the nineteenth century, affecting the nature of society in Palestine. Istanbul began implementing direct rule and sought to put an end to autonomous local forces. Meanwhile, Europe moved in to undermine the traditional local economic relations and push society towards capitalization. Naturally, these trends affected the empire as a whole, but were felt particularly in Palestine. In Nazareth and Haifa, where the European presence became larger and Christian communities more dominant, these effects were felt more strongly than in Nablus.

\section{The Sources}

Nablus' local archives, the Ottoman and British Mandate municipal archives, as well as private family papers, are much richer than documents from Nazareth and Haifa. This is mainly because Nablus was not significantly affected by the Palestinian Nakba in 1948, and its local institutions were not destroyed or burned in wartime. The people of Nablus were not expelled from their homes as families were in Haifa and other Palestinian cities that became part of the Israeli state after 1948 were. Therefore, collections of documents can still be found intact in the houses of members of the old elite who served in administrative positions. ${ }^{8}$ The local archives of Nablus contain an almost complete series of the sharia court's sijillät from the sixteenth century until the end of Ottoman rule. Many of these archival collections have been photocopied by a team at al-Najah University in Nablus, and are kept at the university's Center of Advanced Studies. A copy of them is also kept at the Jordanian University in Amman as part of the Bilad al-Sham Studies Centre archives.

Nablus' municipal archives from the Ottoman period contain eighty volumes of the municipal council's protocols, which are divided into a collection of two volumes of the local elections to the municipal council (the

7 Justin McCarthy, The Population of Palestine: Population History and Statistics of the late Ottoman Period and the Mandate (New York: Columbia University Press, 1990), 59; Titus Tobler, Nazareth in Palästina (Berlin: Reimer, 1868), 65-68.

8 See for example, Mahmoud Atallah, Fahras Makhtutat Al-Tuffaha [An index of manuscripts of the Tuffaha family] (Nablus, 1993); see also the manuscripts of the Al-Jaqqah family, kept in the library of al-Najah University in Nablus. 
administrative council and the Ottoman parliament), a large collection of forty-five volumes related to municipality budgets, incomes and expenditures, seventeen volumes containing the municipality's council decisions and minutes, and sixteen volumes on miscellaneous topics (see tables 12.1-4).

Original volumes of the above collections are kept at the municipal archives of the city of Nablus, located in the municipal library in the Shwitra neighborhood. These collections were filmed by Al-Najah University of Nablus, and are stored on $16 \mathrm{~mm}$ microfilms at the Documentation, Manuscripts and Publication Centre of the university, a division of the university's general library. Similar microfilmed copies are also held at the Jordanian University in Amman, in the Bilad al-Sham Studies Centre archives. The microfilmed copies of the municipal archival collections of Nablus are available upon request, and include four microfilms corresponding to about four thousand A4 pages. The first microfilm was labeled arbitrarily by Al-Najah University librarians as the "first collection" (al-Majmu'a al-Ula) and comprises sixteen volumes. The collection is made up of detailed registers or daftars (Ott. Turk. s. defter) of daily incomes and expenditures of the municipality of Nablus (Daftar Yawmiyyat wa Waridat wa Musarafat Baladiyyat Nablus). ${ }^{9}$ The expenditures includes detailed lists of salaries and payments paid to all employees of the municipality. At the end of each day, all items of expenditures and incomes were calculated and signed by the municipal scribe (kätib) and the treasurer (amin sunduq). At the end of each month, all expenditures and incomes of the municipal treasury were calculated, signed, and sealed by the mayor, the treasurer, the municipal scribe, and members of the municipal council. At the end of each financial year, similar annual calculations were made and signed by the mayor and council members.

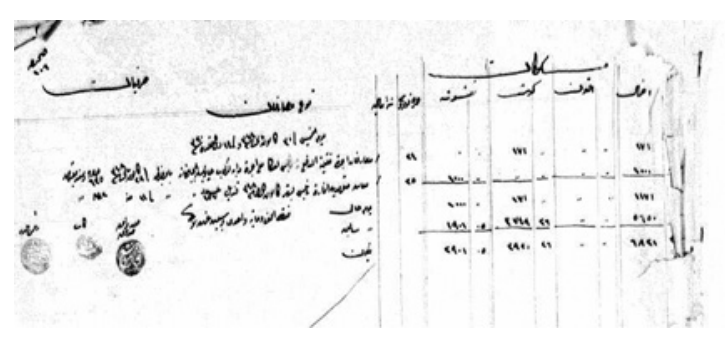

FIGURE 12.1 Municipal Archives of Nablus, expenditures document, first collection, vol. $1,106$.

9 Municipal Archives of Nablus (MAN), div. 1. 


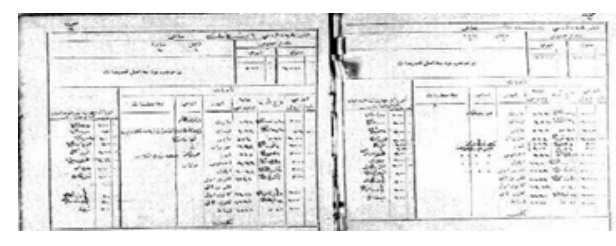

FIGURE 12.2

Municipal Archives of Nablus, document of printed headers, first collection, vol. 3,3 .

The volumes of the first collection are legible and remain in good condition. Some are written in Arabic and others in Ottoman (see table 12.1). The scribe wrote with a clear hand and the pages are generally well organized. However, the pages of certain daftars are missing. The first daftar, for example, begins on page 92 and ends on page 107. Most of the other daftars of the first collection are complete and each volume contains around seventy pages. The third volume of this collection includes more notes in Ottoman Turkish than the previous two volumes. From the third volume (1903) on, the scribe stopped using dual calendars, that is, Rumi (fiscal) and the Hijri. In 1903, Istanbul began to supply the municipalities with daftars that included printed headers and tables in the Ottoman language. These headers and tables showed all of the information that was to be filled in by the scribes (fig. 12.2), who abided only by the fiscal calendar. Our documents do not include any official order concerning the shift from dual calendars to the fiscal calendar, but it is safe to say that it may have reflected the increasing Turkish influence coming from Istanbul.

A new format of these daftars appeared with the fourth volume. While the previous three volumes included the daily activities of the financial department of the municipality, the fourth volume included just one detailed registration of the income of the municipal treasury. Almost all the details of the monthly registers were written in Ottoman Turkish and were examined by an inspector representing the wilayya (province). The inspector visited the municipality from time to time. It seems that the daftars were written in Turkish to facilitate the job of the inspectors, who did not read Arabic. Volume 6 shows that at the end of December 1906, the inspector paid a visit to the municipality of Nablus. He inspected all incomes, expenditures, and accounts, and reported them to the wāli. ${ }^{10}$ The last pages of daftars 11-14 included a synopsis of expenditures and incomes and calculations of the annual municipal budget. It seems that this new regulation was intended to keep a closer eye on expenditures, and to make sure that the municipal treasury ended the fiscal year with a positive net budget. 


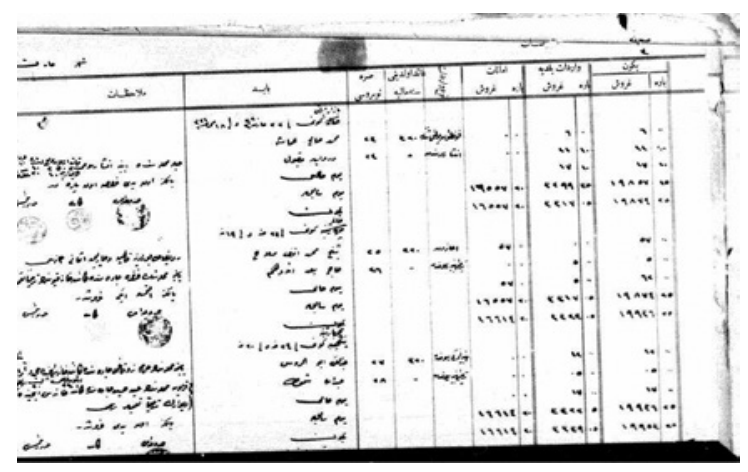

FIGURE 12.3

Municipal Archives of Nablus,

first collection, vol. 1, 3 .

An innovation called daftar shatib began to appear from volume 16 onwards. The daftar shatib was a draft register, or a document detailing fixed and anticipated expenditures. Each page of this daftar was dedicated to a separate source of expenditures. For example, each employee had a dedicated page where all payments paid to him throughout the year were registered (fig. 12.3).

For a reason that remains unclear, the municipal archivists decided to create a second collection of municipal volumes. All volumes of this new collection are related to the municipal budget and are labeled collectively as "ijmāli (summary or total) incomes of Nablus Municipality for the year." Each page of these volumes contains a summarized list of the total monthly income of the municipal treasury. Each volume is approximately 20 to 30 pages long. I have included the first and second collections in table 12.1 because they are related to the budget. I have also mentioned their titles and the time periods to which they relate.

The first two registers in table 12.1 are entitled ijmāli incomes (wäridat) of the municipality of liwa (district of) al-Balqa for the years 1292 Maliye (fiscal year) (M) (1876) until $1298 \mathrm{M}$. (December 1882). When the municipality of Nablus was established, it included in its jurisdiction not only the city of Nablus itself, but also all the towns of the liwa. From mid-1882, the jurisdiction of the municipality of Nablus was limited to the city of Nablus itself. Examining the contents of these two volumes reveals that each volume was divided into monthly records, and each record included a detailed registration of every item. At the end of each month, the municipal registrar calculated the incomes and the document was signed by members of the municipal council and the mayor. Before 1882, the mayor was referred to as the "mayor of the liwa of al-Balqa." In mid-December 1882, he became the mayor of Nablus. 
TABLE 12.1 Inventory of the daftars of the budget: Income and expenditure of the Municipality of Nablus (first and second collections)

Coll. Vol. Title of daftar

Fiscal year

Pages

Notes

Maliye AD (March-February)

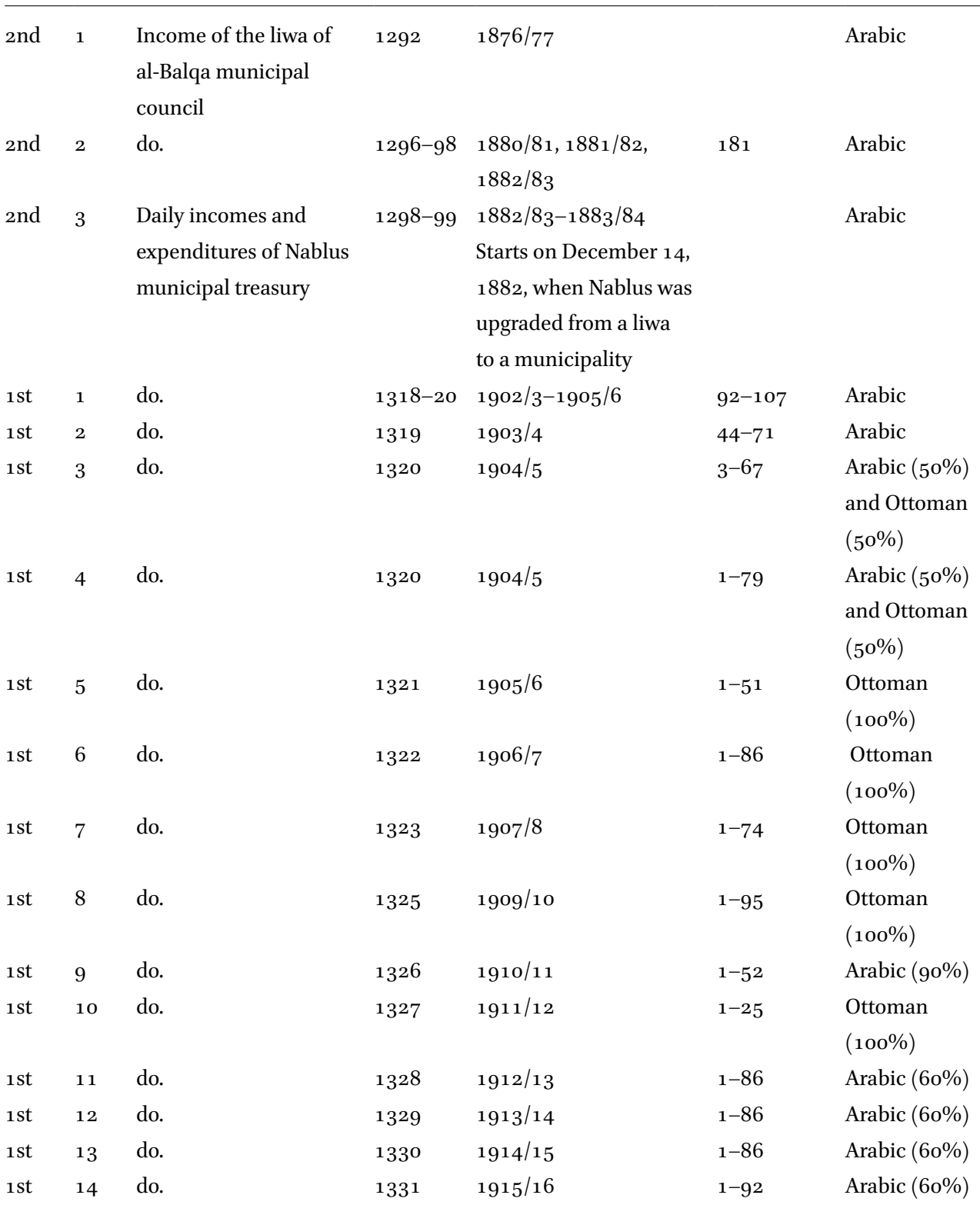




\begin{tabular}{|c|c|c|c|c|c|c|}
\hline \multirow[t]{2}{*}{ Coll. } & \multirow[t]{2}{*}{ Vol. } & \multirow[t]{2}{*}{ Title of daftar } & \multicolumn{2}{|c|}{ Fiscal year } & \multirow[t]{2}{*}{ Pages } & \multirow[t]{2}{*}{ Notes } \\
\hline & & & Maliye & AD (March-February) & & \\
\hline 1st & 15 & do. & 1333 & $1917 / 18$ & $1-168$ & $\begin{array}{l}\text { Ottoman } \\
(100 \%)\end{array}$ \\
\hline 2nd & 4 & $\begin{array}{l}\text { Total (ijmāli) income } \\
\text { of Nablus municipal } \\
\text { treasury }\end{array}$ & $1305^{-8}$ & $1889 / 1990-1893 / 94$ & $1-47$ & \\
\hline 2nd & 6 & do. & $1317-19$ & $1901 / 2-1903 / 4$ & $1-50$ & \\
\hline 2nd & 7 & do. & 1322 & $1906 / 7$ & $1-59$ & \\
\hline 2nd & 8 & do. & 1323 & $1907 / 8$ & $1-54$ & \\
\hline 2nd & 9 & do. & 1324 & $1908 / 9$ & $1-55$ & \\
\hline 2nd & 10 & do. & 1325 & $1909 / 10$ & $1-49$ & \\
\hline 2nd & 11 & do. & 1326 & $1910 / 11$ & $1-53$ & \\
\hline 2nd & 12 & do. & 1327 & $1911 / 12$ & $1-57$ & \\
\hline 2nd & 13 & do. & 1328 & $1912 / 13$ & $1-58$ & \\
\hline 2nd & 14 & do. & 1330 & $1914 / 15$ & $1-74$ & \\
\hline 2nd & 15 & do. & 1331 & $1915 / 16$ & $1-6 o$ & \\
\hline 2nd & 16 & do. & 1332 & $1916 / 17$ & $1-79$ & \\
\hline 2nd & 17 & do. & 1334 & $1918 / 19$ & $90-91$ & \\
\hline
\end{tabular}

The records of these two volumes include income paid to the municipal treasury of fines as well as licenses and services such as taxes due on the Nablus slaughterhouse and other slaughterhouses in the liwa: al-Salt, Jenin, Inbta, and elsewhere. The income registers show clearly that, beginning in 1881, the municipality of Nablus started to issue building permits against fixed fees. The amount of these fees reflected the construction activity in the city.

Table 12.2 includes registers entitled "draft register of fixed and anticipated expenditures." Each daftar of this collection is dedicated to one year and is divided into months. Usually the daftar shatib and the ijmäli daftars are dedicated to the fixed monthly salaries of municipal employees. Each page is dedicated to an employee and to the salaries he received throughout the year.

At the end of each month, the registrar, mayor, and members of the municipal council signed and declared that, "According to the above registration of 
TABLE 12.2 Draft daftars (shatib) of expenditure of Nablus municipality (third collection)

\begin{tabular}{|c|c|c|c|c|c|c|}
\hline \multirow[t]{2}{*}{ Coll. } & \multirow[t]{2}{*}{ Vol. } & \multirow[t]{2}{*}{ Title of daftar } & \multicolumn{2}{|l|}{ Fiscal year } & \multirow[t]{2}{*}{ Pages } & \multirow[t]{2}{*}{ Notes } \\
\hline & & & Maliye & AD (March-February) & & \\
\hline 3 rd & 2 & $\begin{array}{l}\text { Draft daftar } \\
\text { (shatib) of } \\
\text { expenditure } \\
\text { of Nablus } \\
\text { municipality }\end{array}$ & $1312-16$ & $1896 / 97-1900 / 1$ & 85 & \\
\hline 2nd & 5 & do. & $1316-21$ & $1900 / 1-1905 / 6$ & & \\
\hline 3 rd & 3 & do. & 1319 & $1903 / 4$ & 46 & \\
\hline 3 rd & 4 & do. & 1320 & $1904 / 5$ & 73 & Ottoman $(90 \%)$ \\
\hline 3 rd & 5 & do. & 1322 & $1906 / 7$ & 100 & \\
\hline 3 rd & 6 & do. & 1324 & $1908 / 9$ & 88 & \\
\hline 3 rd & 7 & do. & 1325 & $1909 / 10$ & 85 & \\
\hline 3 rd & 8 & do. & 1326 & $1910 / 11$ & 88 & \\
\hline 3 rd & 9 & do. & 1327 & $1911 / 12$ & 205 & \\
\hline 3 rd & 10 & do. & 1329 & $1913 / 14$ & 100 & \\
\hline 3 rd & 11 & do. & 1330 & $1914 / 15$ & 106 & \\
\hline 3 rd & 12 & do. & 1331 & $1915 / 16$ & 130 & \\
\hline $3^{\text {rd }}$ & 13 & do. & $133^{2-34}$ & $1916 / 17-1917 / 18$ & 160 & \\
\hline $1 \mathrm{st}$ & 15 & do. & 1333 & $1917 / 18$ & $1-173$ & Arabic $(60 \%)$ \\
\hline
\end{tabular}

month , the salaries and expenditures of the treasury of the municipality of Nablus amounted to ; we hereby sign this statement." This statement was repeated at the end of each month.

In table 12.3, I have put together all registers labeled "Minutes, Decisions and Correspondence" (madabit, qararāt and murāsalat). For reasons that remain unclear, the librarians of the municipal archives have divided this collection into two, making them the fourth and fifth collections. Municipal decisions made by the municipal council are numbered serially in each register. On average, each register contains around 400 decisions made over the course of the year. All municipal decisions are written in Arabic. However, these registers contain hundreds of letters, regulations, and orders received from different governmental offices in the wilāya (province) or from Istanbul. Usually, this 
TABLE 12.3 Daftars of minutes, decisions, and correspondence (Madabit, Qararāt and Murāsalat) ( fourth and fifth collections)

\begin{tabular}{|c|c|c|c|c|c|c|}
\hline \multirow[t]{2}{*}{ Coll. } & \multirow[t]{2}{*}{ Vol. } & \multirow[t]{2}{*}{ Title of daftar } & \multicolumn{2}{|c|}{ Fiscal year } & \multirow[t]{2}{*}{ Pages } & \\
\hline & & & Maliye & AD (March-February) & & \\
\hline $4^{\text {th }}$ & 1 & $\begin{array}{l}\text { Minutes, } \\
\text { decisions and } \\
\text { correspondence }\end{array}$ & 1292 & $1876 / 77$ & 122 & $\begin{array}{l}\text { Arabic } \\
(80 \%)\end{array}$ \\
\hline 4th & 2 & do. & 1319 & $1903 / 4$ & 146 & $\begin{array}{l}\text { Arabic } \\
(80 \%)\end{array}$ \\
\hline 4th & 3 & do. & 1320 & $1904 / 5$ & 202 & \\
\hline 4th & 4. & do. & 1321 & $1905 / 6$ & 144 & \\
\hline 4 th & 5 & do. & 1322 & $1906 / 7$ & 147 & \\
\hline 4 th & 6 & do. & 1323 & $1907 / 8$ & 219 & \\
\hline 4th & 7 & do. & 1324 & $1908 / 9$ & 312 & \\
\hline 4th & 8 & do. & 1325 & $1909 / 10$ & 320 & \\
\hline $5^{\text {th }}$ & 1 & do. & 1325 & $1909 / 10$ & 284 & \\
\hline 4th & 9 & do. & 1327 & $1911 / 12$ & 326 & \\
\hline 4 th & 10 & do. & 1328 & $1912 / 13$ & 322 & \\
\hline $5^{\text {th }}$ & 2 & do. & 1328 & $1912 / 13$ & 286 & \\
\hline $5^{\text {th }}$ & 3 & do. & 1329 & 1913 & 302 & \\
\hline $4^{\text {th }}$ & 11 & do. & 1330 & $1914 / 15$ & 287 & \\
\hline $5^{\text {th }}$ & 4 & do. & 1330 & $1914 / 15$ & 301 & \\
\hline 4th & 12 & do. & 1332 & $1916 / 17$ & 288 & \\
\hline $5^{\text {th }}$ & 5 & do. & 1333 & $1917 / 1918$ & 291 & \\
\hline
\end{tabular}

material was received in Turkish, and was copied into the registers without translation. The text of municipal decisions fills three to five lines, though in some cases the decision covers an entire page. Almost all correspondence sent from the municipal council to administrative bodies in the wilayya or Istanbul was written in Turkish. An inventory of these collections appears in table 12.3.

In table 12.4, I have compiled all of the registers collected by the Nablus municipal librarians into four collections (sixth, seventh, eighth, and ninth). The archival groupings are once again unclear, but it seems safe to conclude that these divisions are arbitrary. Most of the registers in the sixth collection, as 
they appear in table 12.4, are related to municipal cleaning services. Additional cleaning-related registers are found in the seventh collection. Therefore, I have grouped them in table 12.4. These registers include information about the town's neighborhoods and the fees collected from houses for the cleaning service. The cleaning registers make it clear that Nablus began numbering houses in 1897 in order to improve services and to improve the efficiency of fee collection. The sixth collection includes two registers of the parliamentary elections held in the liwa of Nablus in 1913. These two registers were kept in the municipal archives because the municipal scribes of Nablus were chosen to manage these elections. The reason why the municipal archivists decided to add these two records to this collection remains ambiguous.

It seems that the municipality of Nablus encountered trouble in collecting these fees. Therefore, a new register dedicated to reporting all debts of house owners who did not pay the cleaning fee was created. This register is titled daftar baqāya al-tandhifāt (remnants of debts of cleaning services), and it is kept in the seventh collection.

TABLE 12.4 Daftars (sixth, seventh, eighth and ninth collections)

\begin{tabular}{|c|c|c|c|c|c|}
\hline \multirow[t]{2}{*}{ Coll. } & \multirow[t]{2}{*}{ Vol. } & \multirow[t]{2}{*}{ Title of daftar } & \multicolumn{2}{|l|}{ Fiscal year (Maliye/AD) } & \multirow[t]{2}{*}{ Pages } \\
\hline & & & Starts & Ends & \\
\hline 6 th & 1 & $\begin{array}{l}\text { Daftar for the } \\
\text { parliamentary } \\
\text { elections }\end{array}$ & $\begin{array}{l}\text { 1o Kanunusani } 1327 \\
\text { Rumi calendar }(\mathrm{R}) / \\
\text { January } 23,1913\end{array}$ & $\begin{array}{l}16 \text { şubat } 1328 \mathrm{R} / \\
\text { March 1, } 1913\end{array}$ & 67 \\
\hline 6 th & 2 & do. & $\begin{array}{l}\text { Kanunuevvel 1327 R/ } \\
\text { January } 1913\end{array}$ & & 35 \\
\hline 6 th & 3 & $\begin{array}{l}\text { Daftar for } \\
\text { cleaning services }\end{array}$ & $\begin{array}{l}1 \text { Mart } 1307-1318 \mathrm{R} / \\
\text { March } 13,1891-1903\end{array}$ & & 92 \\
\hline 6 th & 4 & do. & $\begin{array}{l}1 \text { Mart } 1310 \mathrm{R} / \text { March } \\
\text { 13, } 1894\end{array}$ & & 160 \\
\hline 6 th & 6 & do. & $\begin{array}{l}1 \text { Mart 1313 R/ } \\
\text { March 13, } 1897\end{array}$ & $\begin{array}{l}\text { Teşrinsani } 1315 \mathrm{R} / \\
\text { November } 13,1897\end{array}$ & 166 \\
\hline $7^{\text {th }}$ & 1 & $\begin{array}{l}\text { Daftar of unpaid } \\
\text { debts for } \\
\text { cleaning services }\end{array}$ & $\begin{array}{l}1 \text { Mart 1307-27 şubat } \\
1318 \mathrm{R} / \text { March 13, } \\
1891-\text { March 12, } 1903\end{array}$ & & 182 \\
\hline
\end{tabular}


Coll. Vol. Title of daftar Fiscal year (Maliye/AD)

Pages

Starts Ends

\begin{tabular}{|c|c|c|c|c|c|}
\hline $7^{\text {th }}$ & 2 & $\begin{array}{l}\text { Daftar of money } \\
\text { collected } \\
\text { (tahṣīlāt) for } \\
\text { cleaning services }\end{array}$ & $\begin{array}{l}1 \text { Mart } 1310 \text { R/ } \\
\text { March 13, } 1894\end{array}$ & $\begin{array}{l}27 \text { şubat } 1310 \mathrm{R} / \\
\text { March 11, } 1895\end{array}$ & 160 \\
\hline $7^{\text {th }}$ & 3 & do. & $\begin{array}{l}1 \text { Mart } 1313 \mathrm{R} / \\
\text { March 13, } 1897\end{array}$ & $\begin{array}{l}27 \text { şubat } 1315 \mathrm{R} / \\
\text { March 1, } 1898\end{array}$ & 168 \\
\hline $7^{\text {th }}$ & 4 & do. & $\begin{array}{l}1 \text { Mart } 1317 \text { R/ } \\
\text { March 14, } 1901\end{array}$ & $\begin{array}{l}27 \text { şubat } 1317 \mathrm{R} / \\
\text { March 12, } 1902\end{array}$ & $15^{2}$ \\
\hline 8 th & 1 & $\begin{array}{l}\text { Daftar of orders } \\
\text { (Ar. awāmir, Ott. } \\
\text { Turk: evāmir) of } \\
\text { the wilāya }\end{array}$ & $\begin{array}{l}1 \text { Mart } 1316 \mathrm{R} / \\
\text { March 14, } 1900\end{array}$ & $\begin{array}{l}\text { şubat } 1318 \mathrm{R} / \\
\text { March } 1903\end{array}$ & 82 \\
\hline $9^{\text {th }}$ & 1 & $\begin{array}{l}\text { Daftar of } \\
\text { monthly subsidy } \\
\text { (payment for the } \\
\text { needy) of liwa } \\
\text { al-Balqa }\end{array}$ & $\begin{array}{l}\text { 1 Mart } 1293 \text { R/ } \\
\text { March 13, } 1877\end{array}$ & $\begin{array}{l}27 \text { şubat } 1294 \mathrm{R} / \\
\text { March 11, } 1879\end{array}$ & 69 \\
\hline $9^{\text {th }}$ & 2 & $\begin{array}{l}\text { Daftar of } \\
\text { population } \\
\text { census }\end{array}$ & $1299 \mathrm{R} / 1883$ & $1324 \mathrm{R} / 1908$ & 33 \\
\hline $9^{\text {th }}$ & 3 & $\begin{array}{l}\text { Daftar of } \\
\text { incomes of } \\
\text { contract stamps }\end{array}$ & $1303 \mathrm{R} / 1887$ & $1324 \mathrm{R} / 1909$ & 41 \\
\hline $9^{\text {th }}$ & 4 & $\begin{array}{l}\text { Daftar of } \\
\text { gazhane (Ar. } \\
\text { kazkhanah) }\end{array}$ & $1304 \mathrm{R} / 1888$ & & 44 \\
\hline $9^{\text {th }}$ & 5 & $\begin{array}{l}\text { Daftar records } \\
\text { of incoming } \\
\text { (received) letters }\end{array}$ & $1321 \mathrm{R} / 1905$ & $1324 \mathrm{R} / 1909$ & 46 \\
\hline $9^{\text {th }}$ & 6 & $\begin{array}{l}\text { Daftar of } \\
\text { minutes and } \\
\text { decisions of } \\
\text { different offices }\end{array}$ & $1331 \mathrm{R} / 1915$ & & 47 \\
\hline
\end{tabular}




\begin{tabular}{|c|c|c|c|c|c|}
\hline \multirow[t]{2}{*}{ Coll. } & \multirow[t]{2}{*}{ Vol. } & \multirow[t]{2}{*}{ Title of daftar } & \multicolumn{2}{|c|}{ Fiscal year (Maliye/AD) } & \multirow[t]{2}{*}{ Pages } \\
\hline & & & Starts & Ends & \\
\hline 3 rd & 1 & $\begin{array}{l}\text { Daftar of } \\
\text { monthly salaries } \\
\text { of municipal } \\
\text { employees }\end{array}$ & $1316-21$ & $1900 / 1-1905 / 6$ & 68 \\
\hline 3 rd & 14 & $\begin{array}{l}\text { Reports of the } \\
\text { municipality } \\
\text { inspector }\end{array}$ & 1334 & 1918 & 130 \\
\hline
\end{tabular}

Compared to the wealth of municipal archives from Nablus, local sources from Ottoman Haifa are very rare. The town was largely destroyed during the Nakba - 95 percent of Haifa's Palestinians were expelled from their homes and the Ottoman city was mostly cleansed. However, a photocopy of the sijill of the Haifa shari'a court from the 1870 s is kept in the library of Haifa University, ${ }^{11}$ and the municipal records from the Mandate period are well organized. ${ }^{12}$ These two sources shed some light on the activities of Haifa's Ottoman municipality. Unfortunately, there is a total lack of municipal documents or other governmental documents from Ottoman Haifa.

Similarly, the municipal archives of Ottoman Nazareth have completely disappeared. No Ottoman municipal records or files can be found. The municipal archives of Nazareth from the Mandate period are poor and many records are missing. ${ }^{13}$ However, shari'a court records from the Ottoman period were recently discovered and are now kept at the Israel State Archives in Western Jerusalem. Missionary institutions and churches have kept registrations and documents from the late Ottoman period, which may reveal details about

11 University of Haifa Library, Micr. 911. The microfilmed collection contains seventeen rolls and goes from 1872 to 1948 . The Ottoman collection contains twelve volumes from 1872 until 1917. However, a new collection of the sijillät of Haifa was recently discovered in Nablus Municipal Archives. This collection contains seven volumes and covers the years 1864-72.

12 The historical municipal archives of Haifa are kept in the municipal archives offices in the German colony. They are well organized and the large amounts of files from the Mandate period are open to researchers. Unfortunately, no files from the late Ottoman period exist.

13 Unfortunately, the municipality of Nazareth does not possess historical archives of the Ottoman and Mandate periods. 
the municipal activities during the Ottoman period. ${ }^{14}$ Additionally, a local Protestant priest, As'ad Mansur, left behind a source which is vital to the reconstruction of Ottoman Nazareth history. He wrote a book during the last years of Ottoman rule and published it in 1924. In it, he recorded many events from the late Ottoman period and documented important information about the town's municipal council. ${ }^{15}$ In 1908, when Palestinian local newspapers started to appear, Mansur's work became an important source of information about the activities of municipal councils in Palestine.

\section{Public Urban Services before the Municipalities}

Until the 1840 , there was no tangible Western presence in Palestine apart from some consuls and vice-consuls in the coastal towns and Jerusalem. In inland towns such as Nablus, Western influence was hardly felt before the end of Ottoman rule. However, in spite of the absence of Europeans, there were definite changes in the city's socioeconomic and political structures post-Tanzimat. ${ }^{16}$ Nablus offers a near ideal case study if we wish to trace how municipal councils were introduced, and then functioned, far from European intervention or influence.

Some municipalities in Palestine were established before the 1871 amendment of the Vilayets Law, which referred to the municipality for the first time. The law was a product of the central government's strategy to use municipalities to reinforce its policies. Indeed, while members of the council were elected, the mayor was nominated by the mutessarif, who was responsible to the province's wälì.

Consultative council documents from Nablus show that waste was collected daily and the councilors noted that "cleaning the town is a precondition for maintaining public health,"17 suggesting that public services existed in the town a full two decades before the official municipality was established there. During his visit to Nablus in 1863, Henry B. Tristram, an English clergyman and

14 Mahmoud Yazbak, "Nablus, Nazareth and Haifa: Three Ottoman Towns in an Age of Transformation, 1840-1914," in Essays on Ottoman Civilization, Proceedings of the XIIth Congress of Ciepo (Prague: Academy of Sciences of the Czech Republic, Oriental Institute, 1998).

15 Mansur, Tarikh al-Nasira, 158, 168, 176.

16 Doumani, Rediscovering Palestine, 9, 23, 68, 73-74; Abu-Manneh, "Islamic Roots."

17 Records of majlis al-shūrā of Nablus, vol. 1, p. 55 (these manuscripts are kept in the library of al-Najah University of Nablus). 
scholar, observed that because of efforts made by the consultative council as early as the 1840 , the streets of Nablus were cleaner than those of Jerusalem at the time. ${ }^{18}$

In 1855, a similar effort was made by the local administration in Haifa, two decades before the municipality was established. Mary Rogers, the sister of the British vice-consul in Haifa, wrote that her brother urged the local Ottoman administration "to cleanse the guttered streets of Haifa ... and advised the removal of the dust heaps by the sea shore ... the appeal was favorably heard, the work actually commenced immediately, and Haifa underwent sweeping and scraping ... and the dust heaps were ... shoveled into the sea."19

Similar actions were taken by nearly every local society and administration years before municipalities were established. ${ }^{20}$ Granted, services such as these were very limited and often not well-regulated. After the establishment of municipalities, urban services expanded and were regulated by laws. ${ }^{21}$

\section{Establishing Municipalities}

The first municipality in Palestine was established in 1863 in Jerusalem. ${ }^{22}$ Nablus followed in 1868, while other towns such as Nazareth and Haifa were established as municipalities only after the 1871 amendment. The establishment of a municipality in Nablus occurred earlier than in other towns, and was likely related to the upgrading of the administrative status of the town: in 1868, it became the center of a mutasarifiyya, which formed part of the vilayet of Syria instead of the sanjak of Jerusalem. The city's population was more than 20,000, and a consultative council (majlis al-shürā), the forerunner of the administrative council (majlis al-idāra), was in place there by the early 1840 .

The earliest mention we find of a city council functioning in Haifa is in a sijill entry from $\mathrm{AH} 1290$ (1873), which contains the testimony of a municipal council member before the shari'a court. ${ }^{23}$ The first head of municipality we

18 Henry B. Tristram, The Land of Israel: A Journal of Travels in Palestine (London: Society for Promoting Christian Knowledge, 1882), 106.

19 Mary E. Rogers, Domestic Life in Palestine (1862; repr., London: Kegan Paul, 1989), 143.

20 Many examples are listed in Yazbak, "Municipality of a Muslim Town," 341-42.

21 A long list and thorough discussion of the new municipal urban services (security, supervision of markets, sanitation, lighting, town planning, etc.) are discussed in Yazbak, "Municipality of a Muslim Town," 348-59.

Bahjat Sabri, "Liw' al-Quds Athna al-Hukm al-'Uthmani, 1840-1873" [The Jerusalem liwa during Ottoman rule, 1840-1873] (PhD diss., 'Ain Shams University, 1973), 69.

23 Sijill of Haifa, AH 8 Muharram $1290\left(1873^{-74}\right)$. 
hear of by name is Mustafa Bey al-Salah, in the salname (official annual) of $1298(1881 / 82)$, though it is not clear whether he was the first council member. Mustafa Bey al-Salah was a Muslim and the son of 'Abdallah Bey al-Salah, who had been a prominent figure in the local administration for many years. ${ }^{24}$ Members of the al-Salah family served various administrative positions and were considered among the richest families in the city and Haifa's qada' (subdistrict). Until the end of Ottoman rule, only Muslim mayors headed Haifa's municipal council. The salname of Syria of $1880-81$ reported that four Christians and two Muslims sat on the municipal council, ${ }^{25}$ and no more than six members ever sat on the council until the end of Ottoman rule. It seems that the religious affiliation of the council's members reflected the demographic structure of the city. A similar division can be detected in other Palestinian municipal councils. Usually, the municipal council consisted of six to twelve members according to the size of the population. ${ }^{26}$

The municipality of Nazareth was founded in 1875 , and its first mayor was Tannus Qa'war, a member of the Greek Orthodox community. He served in this position consecutively for ten years. Before his nomination as mayor of Nazareth, he headed his community for many years and served in various administrative positions such as head of the Nizāmi (civil) court in Nazareth and a member of the general council of the vilayet of Beirut. ${ }^{27}$ From 1875 to the end of the Ottoman period, eleven different mayors served Nazareth, some of them serving more than one term. All of the mayors were local men and were affiliated with four or five of the town's elite families. Unlike in Haifa and Nablus, where mayors were only Muslim, both Muslim and Christian mayors served in Nazareth. ${ }^{28}$ Nazareth's Christian majority is a likely explanation for these nominations. The religious affiliation of the municipal council members also reflects the demographic structure of the town's population. The municipal council of Nazareth consisted of seven elected members; two were Muslims and the rest were Christians. The Christian members represented the

24 Yazbak, Haifa in the Late Ottoman Period, 24.

25 Ibid., 77; Salname of Syria, 1298 (1880-81), 198.

26 Omar Bey Salih al-Barghuti, "Local Self-Government: Past and Present," The Annals of the American Academy of Political and Social Sciences 164 (1932): 36; Young Georges, "Municipalités provinciales," in Corps de droit ottoman recueil des codes, lois, règlements, ordonnances et actes les plus importants du droit intérieur, et d'études sur le droit coutumier de l'Empire ottoman (Oxford: Clarendon Press, 1905-6), 69-84.

27 Mansur, Tarikh al-Nasira, 97, 100, 302; Salname of Syria, 1298, 199; 1299, 221; 1300, 215 (Abbas Fahum was mayor for a short period); 1301, 218 (Tanus Qa'war was renominated); 1302, 171.

28 Frederic John Scrimgeour, Nazareth of Today (Edinburgh: William Green, 1913), 98. 
three Christian denominations living in Nazareth: Greek Orthodox, Roman Catholics, and Maronites. ${ }^{29}$

According to the 13 salnames of $1880-1908$, six members consistently sat on Haifa's municipal council. Our sources provide data on seventy-eight members. During the period under investigation, thirty-one people belonging to twenty different families were elected to the municipal council, some serving more than one two-year term. Eleven of the families were Muslim, among whom turnover appeared to be more rapid than among the remaining nine Christian families. Muslim families sent twenty-nine members to the council and Christian families sent forty-nine. Muslim members served an average of two years, while Christian members served much longer terms and often more than one. While the Christian community rallied around their representatives, who represented most of the Christian sects in the city, it would seem that competition among the A'yan resulted in a quicker turnover of the Muslim representatives. That fact that more Christians served on Haifa's municipal council than Muslims was due to the presence of three Christian denominations in Haifa, and to the entire Christian franchise joining forces to back a limited number of families. The Muslim elite representatives lost votes due to their disunity and intracommunal competition. In most years, Haifa's municipal council comprised more Christian members than Muslim. The Christians managed to maintain both a relative and an absolute majority in the council though they remained outnumbered by the Muslims. ${ }^{30}$ The salnames also reveal that Haifa's municipal council represented only two of the three existing communities - Jews did not sit on the council despite a stipulation in the legislation that members of all the asnaf (communities and strata) could be elected to it. Although Ottoman Jews were allowed to vote, they were not large enough in number to gain representation on the council.

As a body of local government, the municipal council promoted the inclusion of non-Muslims in public life and official positions. The composition of Haifa's municipal council proves that the stipulation made by the Vilayets Law, that the administrative council of the qada' should be of "Muslim and non-Muslim"31 members, was fully adopted by the local government in its constituency even though the Muslims lost out as a result. However, officials serving in the administration on behalf of the central government (the mutasarrif and qaimaqam) would not allow the appointment of a Christian mayor

\footnotetext{
29 Mansur, Tarikh al-Nasira, 302.

30 For a thorough discussion of the Haifa municipal council's members, see Yazbak, Haifa in the Late Ottoman Period, $81-83$.

31 Ibid., 82, n. 263.
} 
in Haifa, even when the majority in the council demanded as much, because the Muslims remained the majority of the population. In Nazareth, on the other hand, with its predominantly Christian population, the government did appoint a Christian mayor from time to time.

\section{Municipal Elections and a Shift in Societal Stratification}

Before the Tanzimat and the establishment of new local governmental offices such as administrative and municipal councils, a deep social change took place in Palestine. By the mid-nineteenth century, all of Palestine was subject to the administrative changes that the Ottomans imposed throughout the empire. A second decisive factor for the transformation of Palestine during the second half of the nineteenth century was the economic and political infiltration of the country by the West.

The increased monetization of the economy by the mid-nineteenth century opened the way for urban merchants to become large landowners, causing a shift in societal stratification. However, this economic source of power alone was not enough for the new upstart merchants to arrive at positions of leadership and authority as they lacked an adequate stage on which they could demonstrate their political interests and power. These positions could be accessed through local administrative institutions created by the Tanzimat, of which the municipal council was a prime example.

Nouveau riche Muslim and Christian families, previously unknown, succeeded economically and competed with established families. ${ }^{32}$ Tracing the members of the municipal councils of Haifa, Nablus, and Nazareth, we find that besides members of the old established elite, individuals from upcoming families had made their way to top positions in administrative institutions in general and municipalities in particular. New faces in fact worked their way to the top of local societies. In Haifa and Nazareth, where large non-Muslim groups lived, the changing societal stratification led to open competition for administrative posts. In Nablus, which had only a small non-Muslim minority, such competition did not occur.

According to the Municipalities Law, only those in a town who could show they had economic resources were eligible to take part in the municipal elections. Eligible candidates were males aged twenty-five or older who had paid

32 For a thorough discussion of these families, see Yazbak, Haifa in the Late Ottoman Period, chap. 4, 112-58; Yazbak, "Municipality of a Muslim Town," 342-44; Yazbak, "Europe, Cotton and the Emergence." 
an annual property tax of at least 50 qurush. ${ }^{33}$ Candidates for the municipal council had to be of upright character, and were required to possess property and land with a yearly income of at least 5,00o qurush, and pay property tax of at least 100 qurush. ${ }^{34}$ Those who met these criteria usually belonged to the economic and social elite. In Nablus, for example, the municipal archival sources show that out of a total population of 30,000 (with 6,261 males over 25 years old), ${ }^{35}$ only 304 people satisfied these conditions; of these, only 114 were eligible as candidates. ${ }^{36} \mathrm{~A}$ similar picture emerged during the municipal elections in Jerusalem at the end of the nineteenth century. In these elections, fewer than 700 Muslims and 300 Christians were eligible out of a total population of around $20,000 .^{37}$

The property tax (wirko) department put up lists with the names of all those eligible to vote and run for office in public places in the town. ${ }^{38}$ Headed by the mayor, an election committee composed of two respected representatives of each quarter was chosen by the mukhtars and imams of the neighborhood to supervise and run the ballot. Since elections were held once every four years, voters elected double the number of members required for the municipal council: half of them served in the first session (two years) and the others in the second. ${ }^{39}$ The election committee not only supervised the voting procedure but also had the power to choose which successful candidates would serve in the first session of the municipal council. This resulted in various coalitions in the town increasing pressure on the mukhtars and imams to select their members and representatives.

In practice, the committee members reflected the balance of power in the town. Even though membership of the municipal council, like other local elected governmental institutions, was unremunerated, it was seen as recognition of prominent social status within society (na'ilin al-qadr lahum wa-l-itibār

33 Mahmoud Yazbak, "Elections in Late Ottoman Palestine: Early Exercises in Political Representation," in Late Ottoman Palestine: The Period of Young Turk Rule, eds. Yuval BenBassat and Eyal Ginio (London: I. B. Tauris, 2011), 51, n. 3. MAN, d. 4, b. 3, c(ase) no. 64; al-Dustur, trans. Nawfal Nawfal, vols. (Beirut, AH 1301), vol. 2, 410, 433; Haim Gerber, Ottoman Rule in Jerusalem, 1890-1914 (Berlin: Schwarz, 1985), 116.

35 MAN, d. 6, b. 1, p. 14.

36 Ihsan al-Nimr, Tarikh Jabal Nablus wa al-Balqa [History of Nablus and Balqa], 4 vols. (Nablus, n.d.), vol. 3, 26.

37 Yazbak, "Elections in Late Ottoman Palestine," 36, n. 5.

38 MAN, d. 4, b.1, no. 364. misc., 9 Nisan 1330 M/June 22, 1914.

39 MAN, d. 6, b. 2, misc., 9 Nisan 1330 M/June 22, 1914; Yazbak, "Elections in Late Ottoman Palestine," 55 . 
bayn aqranahum $).^{40}$ Being elected to the municipal council opened doors to other governmental institutions in the locality. This was because members of local governmental institutions such as the Agricultural Bank, the court of first instance (mahkamat al-bidaya), the orphanage treasury, the education board, the communications board, and others, were chosen from among council members. ${ }^{41}$ Besides respect and prominence, membership in local governmental institutions gave the municipal councilor a genuine opportunity to influence the council's decisions and protect his interests and those of his supporters and coalition. Prominent social figures competed fiercely for these posts, which led to the formation of family coalitions, or, as they were called in Nablus, jam 'iyyat, "family leagues" as a basis for forming "election lists."42

The jamiyyat were created to promote members of the families that belonged to them. In other words, they were pressure groups that worked to ensure the election of their own candidates to the administrative institutions in town. Crucial to the jamiyyat was that their founders did not belong to the old ruling elite. Though the old elite had lost power to an extent, it continued to use its legacy as a means of integrating into the new administrative institutions. The rising elite, on the other hand, could have no chance of winning municipal elections without newly formed coalitions. ${ }^{43}$ These were coalitions of prominent figures of society and families who cooperated to win administrative posts, thereby to bid more easily for government iltizām (tax farming).

Although they involved only the wealthy elite, the municipal elections became an important instrument through which participants affirmed their social position. Together with the changing material power bases that made wealth the prominent factor in helping members rise through social structures, elections opened the way for others, especially merchants, to participate in local administration. Traditional social forces, the old ruling elite, and the 'ulama', who held their posts almost always through inheritance, found themselves dislodged unless they possessed the required means of accumulating wealth (large tracts of land, commerce, and the iltizām). Municipal elections paved the way for the nouveaux riches to make their way into administrative posts and to influence political developments in the town.

\footnotetext{
40 Al-Najah University Archives and Manuscripts, Nablus, Records of Majlis al-Shura of Nablus, vol. 1, case no. 80 .

41 MAN, d. 5, b. 2, no. 169; d. 4. b. 1, no. 406; d. 4, b. 7, no. 126.

42 Al-Nimr, Tarikh Jabal Nablus, vol. 3, 56-65; Muhammad 'Izzat Darwazih, Mudhakarrat wa Tasjilat [Memories and remembrances], 2 vols. (Amman, 1984), vol. 1, 177-80.

43 For a thorough discussion of the jam iyyat see Yazbak, "Municipality of a Muslim Town," 344-48.
} 
In Haifa and Nazareth, there was no societal factionalism. As a result, coalitions such as the jamiiyyat could not develop. Intercommunal strife and continuous development in both towns contributed to this state of affairs. Only toward the end of Ottoman period in Haifa do we find anything vaguely resembling the family coalitions of the towns in central Palestine. By then, obtaining positions in the administration had become of vital importance both for the upstarts as a way of integrating into the elite as for the established families in order to hold onto their legacies. This led to a blurring of the borders between the town's three elite groups. The 'ulama' families were no longer content with positions solely in the 'ilmiyya institutions. The tujjär (large-scale merchants) looked for positions in the new administrative offices, competing with the families of the old elite. However, these attempts remained secondary to the main arena of competition for power in Haifa and Nazareth: established prominent Muslim families vying for authority against new upstart Christian families.

\section{From Nablus to Jerusalem and Back}

The municipal council (Ar. majlis baladiyya; Ott. Turk. meclis-i belediye) of Nablus came into existence in 1868, shortly after the establishment of the municipality of Jerusalem. Other municipalities in Ottoman Palestine such as Haifa and Nazareth were established only after the publication of the Ottoman municipality law in 1877. However, municipal archival registers in Palestine are found only in Jerusalem and Nablus. Researchers have not yet succeeded in discovering other municipal archives from Ottoman Palestine. Comparing our findings from the Nablus municipal archives as presented in tables 12.1-4 with those of Jerusalem (discussed by Avcı, Lemire and Naïli), ${ }^{44}$ it becomes evident that these archives provide a great wealth of information not only about the administrative evolution of the town, but also about social, economic, cultural, and political issues in late Ottoman cities. Vincent Lemire and the research team of the Open Jerusalem project are now bringing to life the municipal archives of Jerusalem. In light of this development, and even after the publication of my "The Municipality of a Muslim Town: Nablus, 1868-1914" in 1999, researchers have not chosen to consult the municipal archives of Nablus. ${ }^{45}$ Comparing findings from the municipal archives of Nablus and Jerusalem

\footnotetext{
44 Yasemin Avcı, Vincent Lemire, and Falestin Naïli, "Publishing Jerusalem's Ottoman Archives (1892-1917): A Turning Point for the City's Historiography," Jerusalem Quarterly, no. 60 (2015).

45 Yazbak, "Municipality of a Muslim Town," 339-6o.
} 
could develop our understanding of how much autonomy existed for municipal action against centralizing policies.

The Nablus notebooks from 1876 have been preserved, while the notebooks from Jerusalem exist from 1892 onwards. It is difficult to explain why municipal registers from previous years have disappeared. Comparing the notes of Avcr, Lemire and Naïli about the municipal registers of Ottoman Jerusalem with those of Nablus, we observe that the scribes in Nablus wrote their notes in a clearer hand, and contents were easier to read. As in Jerusalem, notebooks (qararāt) were used in Nablus to report the council's decisions and activities. The qararāt notebooks included a large roster of building reports. Deep reading and analysis of these documents enables researchers to follow building patterns and the changing landscape of the city. As in Jerusalem, Nablus daftars mix Arabic and Ottoman languages in continuous alternation. We could not find an explanation for this, given that all Nablus municipal council members were locals who had mastered Arabic.

The municipal archives of late Ottoman Nablus and Jerusalem reveal aspects of the cities' history and the scattered information about the municipalities of Haifa and Nazareth allows researchers to look into neglected aspects of the cities, especially urban activities. In this respect, municipal archives also reveal the extent to which the city's population cooperated with the new administration and showed a willingness to accept new regulations. Regulations regarding buildings permissions are a fine illustration of this. The municipal archives of Jerusalem and Nablus demonstrate that the population of the two cities cooperated with and paid fees for building permissions. The municipalities actively applied construction regulations and infrastructure planning measures in new neighborhoods such as the Shwitra neighborhood in Nablus, Jaffa road in Haifa, and outside the walls of Jerusalem. 


\title{
Municipal Jerusalem in the Age of Urban Democracy: On the Difference between What Happened and What Is Said to Have Happened
}

\author{
Jens Hanssen
}

There is a secret agreement between past generations and the present one. Then our coming was expected on earth. Then, like every generation that preceded us, we have been endowed with a weak Messianic power, a power to which the past has a claim.

WALTER BENJAMIN

History means both the facts of the matter and a narrative of those facts. MICHEL-ROLPH TROUILLOT

What is the relationship between the act of writing urban history and historical processes themselves? How can Jerusalemites, Beirutis, or Baghdadis reclaim their urban pasts when their archives have been confiscated by occupation forces, destroyed by civil war and looted during European, American, and Israeli occupations? ${ }^{1}$ Can the urban fabric of Aleppo and other Syrian towns, bombed to smithereens by the Syrian government over the past seven years, be rebuilt without the institutional memory of their municipalities? What role might urban history play in national reconciliation once the twin tyrannies of

1 Gish Amit, "Salvage or Plunder: Israel's 'Collection' of Private Palestinian Libraries in West Jerusalem," Journal of Palestine Studies 40, no. 4 (2011); Nadya Sbaiti and Sara Scalenghe, "Conducting Research in Lebanon: an Overview of Historical Sources in Beirut (Part I)," Middle East Studies Association Bulletin 37, no. 1 (2003); Hala Fattah et al., "Opening the Doors: Intellectual Life and Academic Conditions in Post-War Baghdad," The Iraqi Observatory, July 15, 2003, accessed January 1, 2018, https://www.h-net.org/about/press/opening_doors/.

(C) JENS HANSSEN, 2018 | DOI:10.1163/9789004375741_017

This is an open access chapter distributed under the terms of the prevailing CC-BY-NC-ND License at the time of publication. 
Assadist and IsIs rule have ended? Can Palestinian and Israeli cities become models of coexistence after the structures of occupation and Zionist supremacy are dismantled, or will they turn into war zones?

Historians do well to stay away from guessing the future, but we cannot afford either to omit our own present-past or Arab Jerusalem's past-futures. As Paul Ricoeur reminds us, "the unfulfilled future of the past forms perhaps the richest part of tradition." ${ }^{2}$ With the publication of this book, its editors have moved their magnificent three-stage project from the logistical and methodological rescue operations of locating archives and inventorizing their contents to the "historiographical operation" of revision and recontextualization of Jerusalem's history between 1840 and $1940 .^{3}$

In the second part of this chapter, I offer my version of Jerusalem's recontextualization by arguing that, along with other Arab provincial municipalities in the late Ottoman empire, the capital of Palestine was a site of urban experiments in democracy. Though Arab municipalities have been disempowered since World War I, recalling the forgotten promise of this history today - with Benjamin - "carries a hidden inventory by which it points to redemption." First, however, we need to consider what historical forces have kept this promise unfulfilled and how the Open Jerusalem project relates to these forces.

\section{Unsilencing the Past: "Open Jerusalem" Meets "Teaching the Palestinian Revolution"}

When at the height of the anticolonial struggle, Frantz Fanon declared that "for the colonized subject, objectivity is always used against him," he could not have foreseen the extent to which in late settler colonialism, the denial of objectivity, too, is working against the colonized subject. ${ }^{4}$ In Silencing the Past, Michel-Rolph Trouillot offers a powerful critique of how the academic writing of history has tried to complete what the French, British, Spanish, and American armies have been working unsuccessfully to defeat; namely the

2 Paul Ricoeur, "Identité narrative et communauté historique," Cahier de Politique Autrement (October 1994).

3 The term "historiographical operation" is a gesture toward Michel de Certeau's, The Writing of History, trans. Tom Conley (New York: Columbia University Press, 1988).

4 Frantz Fanon, The Wretched of the Earth, trans. Richard Philcox (1961; repr. New York: Grove Press, 2005), 37 . 
Haitian Revolution. ${ }^{5}$ The problem, Trouillot insists, is not simply archival but rather the historiographical denial of the very possibility of Haiti's independence struggle.

Silencing does not imply the inability to speak but rather the suppression of both the act of speech and its effects and afterlives. Thus, on its own, the reconstruction of the late Ottoman municipal horizon I offer in the second part of this chapter does not suffice. As David Scott reminds us, the contextualist methods of new historicism - not unlike the old historicism that Benjamin dissected in On the Concept of History - have failed to look beyond the past's horizons. Content in the wisdom that what happened is not exactly what is said to have happened, such historians leave the field of interpretation to the victors of history. Even someone of the caliber of Quentin Skinner, according to Scott, "having discharged his duty of reconstructing the past, bows and exits just at the point at which the question arises of determining and judging the stakes in the present of the rehistoricizing intervention." ${ }^{\prime 6}$

What is important to note for the three-stage Open Jerusalem project is that this silencing occurs at four moments in the process of historical production: when actors enter the historical record (silences in creation of fact); when historical facts are assembled (silences produced by the archive); when data is retrieved (silences produced in historical narratives); and finally the silences produced by particular theoretical choices. ${ }^{7}$ In "Permission to Narrate," a famous critique of Noam Chomsky's The Fateful Triangle which in some ways anticipated Trouillot's third moment of silencing, Edward Said concluded that anti-imperial criticism of Israel and us Middle East policy is one thing, and writing the Palestinian struggle into history quite another. ${ }^{8}$ Since the end of the Cold War, as Joseph Massad and others have argued, some postcolonial theorists' disavowal of postcolonial studies' radical, third-world roots has

5 Michel-Rolph Trouillot, Silencing the Past: Power and the Production of History (Boston: Beacon Press, 1995). For a recent expansion of this indictment of Haitian historiography of the complicity of the Western literary canon and Caribbean theorizing in the denial of indigenous genocide survival, see Melanie Newton, "The Race Leapt at Sauteurs: Genocide, Narrative and Indigenous Exile from the Caribbean Archipelago," Caribbean Quarterly 6o, no. 2 (2014).

6 David Scott, Conscripts of Modernity: The Tragedy of Colonial Enlightenment (Durham: Duke University Press, 2004), 54.

7 Trouillot, Silencing the Past, 26. For a comprehensive overview of both the silences and the pitfalls of unsilencing Palestinian history, see Beshara B. Doumani, "Rediscovering Ottoman Palestine: Writing Palestinians into History," Journal of Palestine Studies 21, no. 2 (1992).

8 Edward Said, "Permission to Narrate," Journal of Palestine Studies 13, no. 3 (1984). 
perpetuated the long-standing empirical silencing of Palestinians. ${ }^{9}$ Trouillot's fourth moment of theoretical silencing is therefore something the Open Jerusalem project has to reckon with as much as with the modes of fact archive - and narrative assemblage. The task at hand is to produce historical theory and method out of the Palestinian experience.

If Haiti has been punished for achieving independence in 1804 against all the brutal odds of history and historiography, and if these odds still punish Palestine for the defeat of 1948, "a touch of perversity" inhabits both forms of vituperation. ${ }^{10}$ To channel Trouillot, the more Zionist settlers and mercenaries conquered and displaced Palestinian men and women, the more the West wrote and talked about Judeo-Christian civilization. Indeed, Trouillot's reading of Haiti readily applies to the Palestinian revolution's impossibility: the practice of expulsion "invented, then perpetuated the [Palestinians'] position at the bottom of the human world."11 The contradiction is that the Israeli catalogue of structural violence and physical erasure - from the Law of Return in 1950 to the recent criminalization of Nakba commemorations - evinces an acute anxiety that Palestinian historicity, that is, the fact of being in and of history, unsettles the triumphant self-perception that what happened is what must have happened.

The only historian who is capable of fanning the spark of hope in the past is the one who is convinced that even the dead will not be safe from the enemy [even] if ... he has never ceased to be victorious. ${ }^{12}$

At this juncture, it is important to insist that even after 1948, Palestinians were agents, actors, and subjects of history and not just refugees, the only analytical category that has elicited global empathy and allowed them to enter the all-too

Joseph Massad, “The 'Post-colonial' Colony: Time, Space and Bodies in Palestine/Israel," in The Pre-occupation of Postcolonial Studies, ed. Fawzia Afzal-Khan and Kalpana SeshadriCrooks (Durham: Duke University Press, 200o); Massad, "Affiliating with Edward Said," in Edward Said: A Legacy of Emancipation and Representation, ed. Adel Iskander and Hakem Rustom (Berkeley: University of California Press, 2010). For a trenchant critique of postcolonial studies' culturalist turn in general and the battle over Edward Said's legacy in particular, see Neil Lazarus, The Postcolonial Unconscious (Cambridge: Cambridge University Press, 2011), esp. 183-203. Meanwhile, Zionist scholars worry about the continued theoretical threat of postcolonialism to Israel: Donna Robinson Divine and Philip Carl Salzman, eds., Postcolonial Theory and the Arab-Israel Conflict (London: Routledge, 2008).

10 Trouillot, Silencing the Past, 75.

11 Ibid., 77.

12 Benjamin, "Thesis VI," On the Concept of History. 
dominant Arab-Israeli conflict literature. A different pedagogical approach to tap into Palestinians' hidden inventories of history has just been launched by Oxford University. ${ }^{13}$ The Palestinian Revolution website offers an array of English and Arabic documents, memoires, interviews, and other teaching materials from the Nakba to the Israeli siege of Beirut in 1982. Focusing on the history of little-known revolutionary cadres, the project brings to life the local, regional, and internationalist dimensions of liberation struggle during these years. Karma Nabulsi's and Abdel Razzaq Takriti's "Teaching the Palestinian Revolution" offers a productive counterpoint for Open Jerusalem, and its pedagogy merits exposition to conclude this section:

Today, Palestinian history is predominantly taught at most Arab institutions under the heading of "the Palestinian Cause," al-Qadiya al-Filastinya, while in Europe and the United States it generally features under "ArabIsraeli Conflict" courses. Around these syllabi, dozens of textbooks, readers, and documentary source collections have been developed. As much as they provide valuable teaching material, they also restrict what can be taught and learnt, and especially what can be understood; their emphasis is on top-down state, diplomatic and military themes in history and politics, as well as overarching economic and social superstructures. In these perspectives, the Palestinian people are generally seen as objects of politics and history. Teaching the Palestinian revolution opens up different possibilities ... While taking account of the role of external historical forces, the focus here is entirely on the Palestinians themselves: their popular structures, movements, cadres, philosophies, songs, poetry, art, tactics, and strategies, rather than policies and designs drawn up by others.

The testimonies of dozens of cadres of the Palestinian revolution raise what Scott called "the stakes in the present of the rehistoricizing intervention." Against this backdrop, let me turn to recontextualizing Jerusalem in the late Ottoman family of municipalities.

13 Website of The Palestinian Revolution, accessed January 17, 2018, http://learnpalestine .politics.ox.ac.uk/. 


\section{Ottoman Municipalities in the Arab Provinces}

I have borrowed the concept of urban democracy in my title from the historian Donald Read. ${ }^{14}$ Social historians and discourse analysts of Europe and its colonies have demonstrated how demophobia - fear of crowds - was expressed in myriads of late-nineteenth century literary texts and archival documents; and how it shaped modern governmentality. ${ }^{15}$ In contrast, Read's Age of Urban Democracy shows how the exponential population growth in late Victorian England led to the rise of mass participation in the political process. His argument helps us to understand how political culture came to be structured not only by the menace of mass mobilization or the fear of grassroots change writ large, the totalitarian aftermath after World War I, and the increasingly coercive practices of the liberal state after World War II notwithstanding. The emergence of "municipal socialism" in France that William Cohen observed in fin-de-siècle Lyon, in particular, presents an example of the promises of electoral street campaigns and the improvement of life in cities under enormous demographic pressure. ${ }^{16}$

I have begun this section with these general remarks in order to challenge the tendency to write victors' history when judging hopeful beginnings such as the admittedly rocky history of Ottoman municipalities by the subsequent events of colonial occupation. Lamenting the "enormous condescension of posteriority" as did E. P. Thompson is not a license "to blot out everything [we] know about the later course of history."17 Nor would Benjamin want the "secret agreement" of generations to be governed by nostalgia for a golden age irretrievably lost to the overpowering forces of capitalist modernity.

Ottoman municipalities that cropped up all across the Arab provinces - first in Tunis (1858) and Beirut (1861), then Jerusalem (1863), Tripoli, Libya (1867), Nablus, Baghdad, and Damascus (1868) - were not borne out of an inherent

14 Donald Read, The Age of Urban Democracy, England, 1868-1914, rev. ed. (London: Longman, 1994).

15 Timothy Mitchell, Colonising Egypt (Cambridge: Cambridge University Press, 1988); Mary Poovey, Making a Social Body: British Cultural Formation, 1830-1864 (Chicago, University of Chicago Press, 1995); Patrick Joyce, The Rule of Freedom: Liberalism and the Modern City (London: Verso, 2003).

16 William Cohen, Urban Government and the Rise of the French City: Five Municipalities in the Nineteenth-Century (New York: St. Martin's Press, 1998), 21-58. For an overview of how municipalities dealt with the challenges of urbanization in the modern Middle East, see Vincent Lemire, "Urbanités, municipalités, citadinités," in Le Moyen-Orient fin XIXe-XXe siècle, ed. Leyla Dakhli (Paris: Seuil, 2016).

17 Benjamin, “Thesis VII," On the Concept of History. 
democratic impulse and were not conceived as mere replicas of European urban governance models. ${ }^{18}$ As in Europe, these institutions were set up in response to a mixture of immediate urban crises, particularly in public health, the structural transformation of - and economic rivalry between - cities, and the ascent and self-assertion of an Arabo-Ottoman merchant class against foreign rivals. What necessitated the appointment of a municipal council in Beirut was the precipitous influx of refugees in the wake of the civil war in Mount Lebanon and the Damascus massacres in the summer of $1860 .{ }^{19}$

The Tanzimat politicians in Istanbul had heralded municipal reform as a civilizational leap forward. ${ }^{20}$ In 1858 , they created the municipal authority of the Sixth District of Galata and Pera as a model not only for other districts but also for the cities and towns of the entire empire. ${ }^{21}$ The Ottoman provincial law of 1867 put cities on a new political footing: "Every town shall be counted as a municipality." ${ }^{22}$ Elections were supposed to be held every two years for half

18 William Cleveland, "The Municipal Council of Tunis, 1858-1870: A Study in Urban Institutional Change," International Journal of Middle East Studies 9, no. 1 (1978): 42, and Nora Lafi, "Les pouvoirs urbains à Tunis à la fin de l'époque ottomane," in Municipalités méditerranéennes: Les réformes urbaines ottomanes au miroir d'une histoire comparée (Moyen-Orient, Maghreb, Europe méridionale), ed. Nora Lafi (Berlin: Klaus Schwarz, 2005), 232; for Beirut, Jerusalem and Damascus, see, in the same volume, Jens Hanssen, "The Origins of the Municipal Council in Beirut (1860-1908);" Yasemin Avcı and Vincent Lemire, "De la modernité administrative à la modernisation urbaine: une réévaluation de la municipalité ottomane de Jérusalem (1867-1917);" and Stefan Weber, "Laménagement urbain entre régulations ottomanes, intérêts privés et participation politique: la municipalité de Damas à la fin de l'époque ottomane (1864-1918) 142, 95, 181, respectively; for Nablus, see Mahmoud Yazbak, "The Municipality of a Muslim Town: Nablus 1868-1914," Archiv Orientální 67 (1999): 341; for Baghdad, see National Archives of the UK (TNA), FO 195/803A, No. 25, August 26, 1868. See also Mahmoud Yazbak's chapter, "Comparing Ottoman Municipalities in Palestine: The Cases of Nablus, Haifa and Nazareth, 18641914," in this volume.

19 Jens Hanssen, Fin de Siècle Beirut: The Making of an Ottoman Provincial Capital (Oxford; New York: Oxford University Press, 2005), 116-25.

20 Official memorandum, dated March 1856. Reproduced in Osman Nuri Ergin, Mecelle-i Umur-u Belediye [Book of municipal affairs], vol. 1 (Istanbul: Arşak Garoyan Matbaası, 1922), 1377-79.

21 On the Tanzimat reforms as a series of test balloons, see Jens Hanssen, "Practices of Integration: Centre-Periphery Relations in the Ottoman Empire," in The Empire in the City: Arab Provincial Capitals in the late Ottoman Empire, ed. Jens Hanssen, Thomas Philipp, and Stefan Weber (Wurzburg: Ergon, 2002).

22 Quoted in İlber Ortayli, Tanzimattan Sonra Mahalli Idareler (1840-1878) [Local administrations after the Tanzimat] (Ankara: Sevinç Matbaası, 1974), 166. 
the council, although by some accounts, in Jerusalem the first free elections were not held until 1908. In Beirut, they were organized early on by an electoral college of reputable elders and rotated from district to district for up to two weeks. The successful candidates were often Arab merchants and intellectuals from long-established families, but unlike on the provincial councils, Muslim and Christian clergy were conspicuously absent. Moreover, in a confessionally mixed city such as Beirut, sectarian block-voting was nipped in the bud by the vigilant press. The fact that the first four mayors were Egyptian-born reminds us that, unlike in provincial capitals with a long history in Islamic empires, Beirut had only recently experienced urban growth and a rise in stature. ${ }^{23}$

Although municipal elections were public affairs, these new democratic practices hardly constituted universal suffrage, nor can we speak of mass participation before 1908. They were severely circumscribed by class, gender, and urban residence biases. Voters had to be male Ottoman citizens over twentyfive and affluent enough to file taxes in excess of fifty piasters a year. Candidates were required to be above thirty years of age and own urban property taxed at a minimum of $5^{0,000}$ piasters. ${ }^{24}$ Moreover, budgetary autonomy was often threatened by deficits, and interference from provincial governors could not always be prevented by the local media. From the imperial perspective, the implementation of municipal reforms by elected members contributed a great deal to Ottoman pacification and considerable prosperity in Arab provincial capitals, especially after the Ottoman reassertion of power over the Arab provinces had generated so much urban sectarian violence in Aleppo (1850), Nablus (1856), Jidda (1858) and, finally, in Dayr al-Qamar, Zahleh, Hasbayya and Damascus in the summer of 1860 .

It is no coincidence that the emergence of provincial municipalities occurred in the decade between the enactment of the Ottoman land code of 1858 , which "henceforth provided the reference point in all property matters" for the empire, and the citizenship law in 1869 , which tied rights and duties to birthplace and residency. ${ }^{25}$ These and other laws regulated the operations of

23 Hanssen, Fin de Siècle Beirut, chap. 5.

24 "Belediye Kanunu," see Ottoman State Archives (воА), Yildiz Esas Evraki, 37/302/47-112 (1877).

25 Huri Islamoğlu, "Politics of Administering Property: Law and Statistics in the NineteenthCentury Ottoman Empire," in Constituting Modernity: Private Property in the East and West, ed. Huri Islamoğlu (London: I. B. Tauris, 2004), 292; and Ariel Salzmann, "Citizens in Search for a State: The Limits of Political Participation in the Late Ottoman Empire," in Extending Citizenship, Reconfiguring States, ed. Michael Hanagan and Charles Tilly (Lanham: Rowman \& Littlefield, 1999), 45. 
late Ottoman governmentality in which, from the local perspective, municipal councils were sites of governmental accountability and sources of citizenship. If today access to Ottoman state archives provides a much-needed perspectival complement to European sources, and the "view from above" provincializes the "view from outside," we are still desperately short on the view from within municipal archives. In Beirut, whose archive was destroyed in a flood in 1983, I could only reconstruct the inner workings of councils by reading the municipal sections in the press.

Once municipalities were fully functioning in the Arab provinces, Nahda newspapers hailed these new institutions as political panacea for overcoming sectarian strife and securing economic growth. After 1867, some intellectuals, among whom Cairene 'Abdallah Abu al-Sa'ud, the Beirutis Butrus and Salim alBustani (1819-83, 1848-84), and the Damascene Adib Ishaq (1856-84), began to discuss the meanings and applications of democracy (al-dimukratīyya), free$\operatorname{dom}(a l-h u r r \bar{y} y a)$, equality (al-musawāt), and voting rights (haqqal-intikhāb). These were concepts that were introduced to the Arabic political lexicon a generation earlier in the pages of the Arabic press. ${ }^{26}$ Still skeptical that "democracy had ever existed, or will ever rule except on paper" some ten years after the first Beirut municipal council elections, Bustani nevertheless reminded his readers that "in this day and age, we can say that democracy is rule based on elections governed by laws ... as for the [recent Ottoman] elections, they are expressions of public opinion [al-rayy al-'amm]."27

These and countless other interventions in political affairs by literary figures - al-Bustani sat on the municipal council for two years - demand from urban historians today to move beyond the politics of notables. Albert Hourani's influential paradigm has helped us enormously to challenge racist conceptions of a timeless Islamic city. Nevertheless, it conveyed the idea that cities in the Middle East were governed by communal factions until the end of colonial rule. Notable families often had multiple members on councils, ${ }^{28}$ but

26 'Abdallah Abu al-Sa'ud, Al-Dars al-tamm fi al-tarikh al-'amm [A complete lesson in general history] (Cairo, 1872); Salim al-Bustani, Iftitahat Majalla al-Jinan al-Bayrutiyya, 18701884, [Editorials of the Beirut journal al-Jinan, 1870-1884] 2 vols., ed. Y. Khuri (Beirut: Dar al-Hamra', 1990); Adib Ishaq, al-Kitabat al-siyyasiyya wa al-ijtima 'iyya [Political and social writings], ed. N. 'Allush (Beirut: Dar al-Tali'a, 1978).

27 Butrus al-Bustani, Da'irat al-Ma'arif [The encyclopedia], vol. 8 (Beirut: Librairie du Liban, 1956), 233 .

28 For an example of the predominance of one family - the Çalabis - see for example, Baghdad Salname (1896/7), 219-22: elected members of the provincial council: 'Abd al-Qadir Pasha, Shakir al-Alusi, Ibrahim Zaybaq, Mutawalli Na'man, Menakhim Salih, Rizqallah 'Abbud; 1. Municipal circle: Mustafa Jamil (mayor), elected members: Mahmud 
the sparse evidence that exists from Beirut suggests that municipal coalitions coalesced across lines of kinship and sectarianism. Instead, economic interests (merchants versus landowners), educational background (Muslim, missionary, state schools), and professional affiliations played a role. But ultimately, councilors represented the interests of the quarters that elected them.

Although a revised municipal ordinance of 1877 stipulated that there was going to be one municipal circle per 40,000 inhabitants, this was rarely implemented. Beirut retained a single unified municipality until at least 1908 for a population that by then had topped 100,000. Ottoman yearbooks indicate that Damascus had four municipal councils in 1884/86, two in 1897 and three between 1905 and 1909 for a population that reached 250,000 in $1911 .{ }^{29}$ Baghdad's yearbooks for 1892/3, 1896/7, and 1900/01 consistently featured three municipal circles (da'ire) for a voting population that reached approximately 67,000 by $1896 .^{30}$

Imperial capitals and colonial cities generally tended to have a poorer record of municipal governance than provincial cities. In Istanbul, as in Cairo, municipal experiments were discredited by the colonial attitudes of the European diplomats, and councilors were appointed state officials. ${ }^{31}$ The democratic deficit in imperial and national capitals is well-established. Paris, for example, only began electing mayors in 1977, and the sense of the provinces teaching the Ottoman imperial government a lesson in democracy is well captured in the playfully arrogant exclamation in a 1877 parliamentary session by the Tripoli deputy, Niqula Nawfal: "We are from the provinces, we have been

Sayrit, 'Abd al-Fattah Effendi, Habib Ef., 'Abd al-Qadir Çalabi, Mutawalli Hasan, Hajji Khalil Çalabi; 2. Municipal Circle: Ahmad Bey al-Rubay'i (mayor), Sayyid 'Abd al-Razzaq Ef., Sayyid 'Abdallah Çalabi, Hajji 'Ali Çalabi, Mahmud Çalabi; 3. Circle: Hajji Amin Çalabi, Sayyid Musa Ef., Sayyid 'Abd al-Qadir Çalabi, 'Abdallah Dawud Ef., 'Abd al-Majid Çalabi, Yusuf Çalabi.

29 Stefan Weber, Damascus: Ottoman Modernity and Urban Transformation, 1808-1918, 2 vols. (Aarhus: Aarhus University Press, 2009), vol. 1, 37-38; vol. 2, 7. For urban populations, see also Ernest Weakley, Report upon the Conditions and Prospects of British Trade in Syria, Cd. 5707 (London: HMsO, 1911), 32.

30 On the problem of reading population statistics in Baghdad's Ottoman yearbooks, see Christoph Herzog, Osmanische Herrschaft und Modernisierung im Irak: Die Provinz Bagdad, 1817-1917 (Bamberg: University of Bamberg Press, 2012), 687-94.

31 Steven T. Rosenthal, The Politics of Dependency: Urban Reform in Istanbul (Westport: Greenwood Press, 1980). Alexandria's urban administration faced similar foreign interference. See Michael Reimer, "Urban Regulation and Planning Agencies in Mid-NineteenthCentury Alexandria and Istanbul," Turkish Studies Association Bulletin 19, no. 1 (1995). 
voting since the beginning of the Tanzimat. Istanbul, however, has encountered elections only this year." 32

These developments point to the need for a double historiographical revision at the intersection of urban and intellectual history. First, it was the rapid material transformation of cities, rather than the mimicry of grand European ideas of democracy, that led first to a profound legal and administrative recalibration. We can hypothesize that it was only then that there was more widespread critical discourse on the merits of the democratic process. Second, and with this hypothesis in mind, the foundational doomed-to-failure narratives by orientalist urban historians such as Gabriel Baer, or by political economists such as Stephen Rosenthal, have set the defeatist paradigm that still structures late Ottoman urban historiography. ${ }^{33}$ Relying largely on European sources, both shared the assumption that municipalities were Western, thus alien, constructs in the Middle East. On their authority, the Zionist historian Ruth Kark could claim that "this new [municipal] institution did not have its roots in the Muslim Middle East but rather influenced by European, and particular French, concepts." ${ }^{4}$

Such widespread views have inoculated urban research, especially on Palestine, against the municipal revolution that took place in the late nineteenth century. Instead, scholarship continued to deploy "folklorist ... religious, or patrimonial approaches" on outmoded and doomed-to-disappear urban heritage: guilds and suqs, timeless religious communities and their sacred places or the honeycombed features of domestic architecture and urban morphology. ${ }^{35}$ Research projects such as Nora Lafi's challenge this antimodern trend. Her project, which aims to trace urban government's structural continuity between pre-Tanzimat urban administration and late Ottoman municipalization, offers a useful counternarrative. On its own, however, this narrative also takes a "transformophobe" position. In effect, if not intent, it does not allow for the possibility that a complete overhaul of urban government was deemed desirable and necessary, not least because late Ottoman cities such as Beirut

32 Tarik Hakki Us, Meclis-i Me'busan Żabıt Ceridesi [The official gazette of the Chamber of Deputies] (Istanbul, 1939-1954), April 17, 1877 session, 84-85, taken from İlber Ortayli, Studies on Ottoman Transformation (Istanbul: Isis Press, 1994), 115. Nawfal came from a family of Nahdawis and was the official Arabic translator of Ottoman legal texts like the constitution of 1877. Hanssen, Fin de Siècle Beirut, 115.

33 Gabriel Baer, Studies in the Social History of Modern Egypt (Chicago: University of Chicago Press, 1969). See chapter "The Beginnings of Municipal Government," 190-209.

34 Ruth Kark, "The Jerusalem Municipality at the End of Ottoman Rule," Asian and African Studies 14, no. 2 (1981): 117.

Lemire, "Urbanités, municipalités, citadinités," 117. 
grew so much that only new political structures and procedures could possibly address real concerns about public health and safety, social welfare, and European financial and cultural encroachment. ${ }^{36}$ While criticism and protests against some of the effects of the Tanzimat were amply found, none of the alternative political ideas called for a return to a pre-Tanzimat Ottoman Empire.

In Fin de Siècle Beirut, I criticize the elite nature, reformist politics, and public morality discourse emanating from municipal politics in fin-de-siecle Beirut. In the book, I harbor disappointment at the lack of radical politics on and around municipal councils, compared to the Mediterranean anarchists whom Ilham Khouri-Makdisi resurrected for us, or compared to the municipal socialism that William Cohen spotted in France. ${ }^{37}$ Like elsewhere in the world, elections remained a privilege of the male elite until suffragettes fought for women's rights to vote in the interwar years. Yet, I could not dismiss the archival evidence of enormous public investment in the municipality, both on the pages of Beirut's biweekly newspapers, most of which had a section on baladiyyat - municipal news - and in highly contested election campaigns. Nor could I help noticing that municipal councils were by no means willing conduits for European finance capitalism. Rather, various European legal codes were adopted - at least in theory - to defend the city against European business interests. The most radical, if symbolic, act in this regard was the stipulation in the 1877 municipal reform law that foreign residents were henceforth barred from municipal councils.

After World War I, the age of urban democracy came to an end with the imposition of the mandate state system over the fluid provincial borders around the Syrian desert. ${ }^{38}$ Fearing that, like in European cities, municipalities would become dens of socialists, colonial regimes did not remove property

36 Lafi, Municipalités Méditerranéennes. More recently, Lafi adopts the fruitful paradigm of transnational municipalism and acknowledges the multidirectional forms of governance modeling simultaneously among Ottoman cities and between them and European and Asian municipalities. See "Mediterranean Connections: The Circulation of Municipal Knowledge and Practices during the Ottoman Reforms, c. 1830-1910," in Another Global City: Historical Explorations into the Transnational Municipal Moment, 1850-200o, ed. Pierre-Yves Saunier and Shane Ewen (New York: Palgrave Macmillan, 2008).

Ilham Khuri-Makdisi, The Eastern Mediterranean and the Making of Global Radicalism, 1860-1914 (Berkeley: University of California Press, 2010); Cohen, Urban Government, 21-58.

38 Salim Tamari, “The Great War and the Erasure of Palestine's Ottoman Past," in Transformed Landscapes: Essays on Palestine and the Middle East in Honor of Walid Khalidi, ed. Camille Mansour and Leila Fawaz (Cairo: American University in Cairo Press, 2009). On the 
requirements for election candidates. Gender discrimination and municipal elitism was consolidated and confessionalized. While Damascus, Beirut, Baghdad, Jerusalem, and Amman were favoured as colonial capitals, the rest of the Ottoman family of provincial capitals - Hama, Nablus, Aleppo, and Mosul, for example - suffered marginalization in the new national economies, as they were cut off from their historical trade routes by national borders and state centralization in the 1950s. Municipal councils continued to exist, but the mantra of national development reduced them to their technocratic functions. In the 196os, 70s, and 8os, decolonization's new authoritarian regimes applied the tabula-rasa principles of high modernism to the capitals of new independent nation-states. In the name of modernization, urban planning destroyed much of the historical urban tissue colonialism had left to decay. The remaining urban fabric in Syria is being demolished by Russian and Syrian air force bombardments before our eyes.

Before we conclude with the municipal history of Jerusalem, it bears acknowledging that in the 21st century, mayors of provincial and state capitals have begun to assert their authority against the pressures of national governments and capitalist dictates to privatize urban infrastructure and public services. ${ }^{39}$ Recently in Beirut, the formidable municipal election campaign of the group Beirut Madinati, somewhat exuberantly hailed as the Lebanese Indignados, offered a vision of politics that, had it been elected, might have generated an democratic urban revolution out of the severe crises that the city faces..$^{40}$ The fact that many cities in the Middle East are ravaged by war and others, like Beirut, are barely coping with their millions of refugees should encourage historians to do what we are best at in moments of contemporary dejection - to return to the past with renewed urgency.

\section{Jerusalem: Municipal History under Siege}

One of the most pernicious urban myths fabricated by colonialism, whether in the British, French, or Israeli variety, was its denial of the corporeal city. Despite all the above evidence of institutionalization in - and urban residents'

British suspension of municipal authorities in Iraq, see Charles Tripp, A History of Iraq (Cambridge: Cambridge University Press, 2007), 38.

39 The successful remunicipalizaton of water management in Paris in 2008 and Barcelona in 2013, for example, has energized the agency of municipalities in national and global politics.

Website of Beirut Madinati, accessed January 17, 2018, http://beirutmadinati.com. 
attachments to - Tanzimat cities that constitute urban corporeality, colonial canards about social fragmentation, religious and ethnic segregation, and lack of public spirit continue to haunt Zionist historiography and urban planners. I have showed elsewhere how the entanglements between urban sociology and orientalism renewed and perpetuated the Islamic city paradigm until the Algerian struggle for self-determination from 1954-62 offered critical historians a new perception of cities under colonial rule. ${ }^{41}$

Orientalist scholarship on the Islamic city worked hand in hand with heritage preservation and colonial aesthetics in North African cities. Hubert Lyautey, resident-general of Morocco from 1912-25, and a seasoned officer on the French imperial circuit, developed the dual-city - or, with Janet AbuLughod, urban-apartheid - approach. ${ }^{42}$ Lyautey used urban planning as a means to square European health and security concerns with the aesthetic appeal of Muslim architecture:

Touch the indigenous city as little as possible. Instead, improve their surroundings where, on the vast terrain that is still free, the European city rises, following a plan which realized the most modern conceptions of large boulevards, water and electrical supplies, squares and gardens, buses and tramways, and also foresee future expansion..$^{43}$

The Algerian War of Independence turned back the colonial gaze and exposed the ways in which colonial knowledge and power reinforced each other to perpetuate European domination. Studies on the nature of the Islamic city were replaced by studies on the colonial production of this category. The works of Fanon in Algeria, in particular, have highlighted how socio-economic and racial difference acquired physical form in a bifurcated dual city:

41 The Islamic city paradigm owed its longevity to a curious isnad, or chain of authorization: in the early 196os, the Chicago School of Urban Research collaborated with Gustave von Grunebaum, who had incorporated Max Weber's urban sociology into his orientalism. Weber had used Snouck Hurgronje's book on Mecca (1888) to compare "Occidental” and "Oriental" urban essences. For more details on this scholarly genealogy, see Jens Hanssen, "History, Heritage and Modernity: Cities in the Muslim World Between Destruction and Reconstruction," in The New Cambridge History of Islam, vol. 6, ed. Robert Hefner (Cambridge: Cambridge University Press, 2010).

42 Janet Abu-Lughod, Rabat: Urban Apartheid in Morocco (Princeton: Princeton University Press, 1980).

43 Lyautey quoted in Gwendolyn Wright, The Politics of Design in French Colonial Urbanism (Chicago: University of Chicago Press, 1991), 79. 
The settlers' town is strongly built, all made of stone and steel. It is a brightly-lit town; the streets are covered with asphalt ... [It] is not the prolongation of the native city. The colonizers have not settled in the midst of the natives. They have surrounded the native city; they have laid siege to it ... The native town is a crouching village, a town on its knees, a town wallowing in the mire. ${ }^{44}$

Since Fanon's "cri du casbah," a host of scholars have deconstructed the epistemological foundations of colonial violence in North Africa along with scholars' and architects' complicity in it. Urban underdevelopment in Algiers and elsewhere is not due to the pathology of a religion or civilization, as Gustave von Grunebaum asserted, but is rather a consequence of colonialism. Even though 'Abdallah Laroui rightly cautions against the romantic understanding of Algiers' history in Fanon's anticolonial manifestos, ${ }^{45}$ The Wretched of the Earth and $A$ Dying Colonialism have opened a space for charting an analytical shift in urban studies more generally. On the one hand, Muslim cities are conceived as sites of larger political, economic, and cultural transformations - colonialism, capitalism, nation-building, and modernity - in the Middle East. On the other, the experiences of urban dwellers are taken to hold the key to measuring the effects of these transformations.

If decolonization and Arab socialism failed to resurrect the late Ottoman municipal experiment in the second half of the twentieth century, it is perhaps understandable: the governments of newly independent states were worried about national unity and state sovereignty after decades of colonial rule and were optimistic about the potential of rapid, state-led development and welfare. The urgency of the municipal question has not receded in the current global moment of urbicide, however. Nowhere is this question more urgent than in the history of modern Arab Jerusalem. Jerusalem and the Palestinian territories it is supposed to serve as a national capital never had the luxury of a postindependence moment. Palestine still lives in a settler colonial present. ${ }^{46}$

44 Fanon, The Wretched of the Earth, 30; and Frantz Fanon, A Dying Colonialism, trans. Haakon Chevallier (1959, repr., New York: Grove Press, 1967), 51.

45 'Abdallah Laroui, Lidéologie arabe contemporaine: essai critique (Paris: François Maspéro, 1967), 5 .

46 For an astute analysis of the admixture of Israeli settler colonialism and colonialism, see Lorenzo Veracini, "The Other Shift: Settler Colonialism, Israel, and the Occupation," Journal of Palestine Studies 42, no. 2 (2013): 28: "The difference is absolutely critical: while a colonial society is successful only if the separation between colonizer and colonized is retained, a settler colonial project is ultimately successful only when it extinguishes 
Despite a Fanon-inspired paradigm shift in Middle East studies, in recent years, a variant of the dual cities approach has entered the field: the divided city ${ }^{47}$ Research questions about governing diversity and overcoming sectarian geographies may apply to places like Berlin, Beirut, or Belfast. But to speak of a divided city in Jerusalem, beyond stating the obvious, potentially obfuscates the colonial structure of the dual city. For the academic study of Palestinian cities under occupation in general, Jerusalem and its historical port of Jaffa in particular have been key elements in the Zionist narrative appropriation of Palestinian land. ${ }^{48}$ Zionist historiography cast Palestinian cities as a fragmented patchwork of religious and ethnic communities, devoid of any urban spirit of public welfare. This view, which is steeped in Weberian modernization theory, set the historical stage for foreign intervention and Ashkenazi settlers. ${ }^{49}$

itself - that is when the settlers cease to be defined as such and become 'natives,' and their position becomes normalized."

47 For example, Jon Calame and Esther Charlesworth, Divided Cities: Belfast, Beirut, Jerusalem, Mostar and Nicosia (Philadelphia: University of Pennsylvania Press, 2009).

48 Alexander Schölch, Palästina im Umbruch, 1856-1882: Untersuchungen zur wirtschaftlichen und sozio-politischen Entwicklung (Stuttgart: Franz Steiner, 1986); Jakob Eisler, Der deutsche Beitrag zum Aufstieg Jaffas, 1850-1914: Zur Geschichte Palästinas im 19. Jahrhundert (Wiesbaden: Harrassowitz, 1997); Muhammad Tarawina, Qada Yafa fi al-'ahd al-'uthmani: dirasa idariyya iqtisadiyya ijtima'iyya, 1281-1333 h/1864-1914m [The district of Jaffa in the Ottoman period: administrative, economic and social studies, AH 1281-1333/ M 1864-1914] (Amman: Jordan Ministry of Culture, 200o); Tahir Adib al-Qalyubi, 'A'ilat wa shakhsiyyat min Yafa wa qada'iha [Families and personalities from Jaffa and its district] (Beirut: al-Mu'assasa al-'Arabiyya, 2006); Salim Tamari, Mountain Against the Sea: Essays in Palestinian Society and Culture (Berkeley: University of California Press, 2009); Anthony Travis, On Chariots with Horses of Fire and Iron: The Excursionists and the Narrow Gauge Railroad from Jaffa to Jerusalem (Jerusalem: Benjamin Shapell Family Manuscript Foundation; The Hebrew University Magnes Press, 2009); Johann Büssow, Hamidian Palestine: Politics and Society in the District of Jerusalem, 1872-1908 (Leiden: Brill, 2011); Yuval Ben-Bassat and Eyal Ginio, Late Ottoman Palestine: the Period of Young Turk Rule (London: I. B. Tauris, 2011); Farid al-Salim, Palestine and the Decline of the Ottoman Empire: Modernization and the Path to Palestinian Statehood (London: I. B. Tauris, 2015), and many others have done important reconstructive work.

49 See, for example, Ruth Kark, "The Traditional Middle Eastern City: The Cases of Jerusalem and Jaffa During the Nineteenth Century," Zeitschrift des Deutschen Palästina Vereins 97, no. 1 (1981). Recent colonial discourse analyses have offered powerful critiques of such orientalist constructions. See Mark Levine, Overthrowing Geography; Jaffa, Tel Aviv, and the Struggle for Palestine, 1880-1948 (Berkeley: University of California Press, 2005) and Michelle U. Campos, Ottoman Brothers: Muslims, Christians, and Jews in Early TwentiethCentury Palestine (Stanford: Stanford University Press, 2010). However, their uncritical 
Even the urban architecture that has withstood willful and ongoing destruction since 1948 continues to serve as a display for Israel's extinction narrative of Palestinian cities. This form of heritage preservation has much in common with how the survival of the old walled cities of Aleppo, Damascus, Algiers, or Fez into the twentieth century reassured the French public of the success of their government's civilizing missions. While Israeli civilian agencies have demolished Palestinian homes in and around Jerusalem and Jaffa at an accelerating pace, the preservation of some old, urban nuclei provides the new Israeli cities and "clean" settlements with affective claims to technological progress and cultural supremacy. ${ }^{50}$

Arab Jerusalem has been without a municipality since Israel conquered it in $1967 .{ }^{51}$ This has made it possible for Israeli mayors of West Jerusalem, particularly Teddy Kollek (in office 1967-93) to de-Arabize East Jerusalem in the name of biculturalism. ${ }^{52}$ In the two decades before Israeli annexation, Jordanian authorities were busy refashioning the Hashemite king as the protector of the Holy Sites, upgrading Jerusalem and incorporating it into the kingdom. ${ }^{53}$ Meanwhile, the municipality of Arab Jerusalem fought the Hashemites' neglect and betrayal of other parts of the city, particularly Shaykh Jarrah and Silwan. ${ }^{54}$

adoption of the colonial/national telos has continued to isolate Palestine from wider late Ottoman intersections.

Adnan Abdelrazik and Khalil Tofakji, Israeli Colonial Policies and Practices:De-Arabization of East Jerusalem (Jerusalem: Arab Studies Society, 2008); David Hughes, Nathan Derejko and Alaa Mahajna, Dispossession and Eviction in Jerusalem: The Cases and Stories of Sheikh Jarrah (Jerusalem: Civic Coalition for Defending the Palestinians, 2009).

$5^{1} \quad$ Walid Khalidi, "Israel's 1967 Annexation of Arab Jerusalem: Walid Khalidi's Address to the UN General Assembly Special Emergency Session, 14 July 1967," in Journal of Palestine Studies 42, no. 1 (2012); Thomas Abowd, Colonial Jerusalem: The Spatial Construction of Identity and Difference in a City of Myth, 1948-2012 (Syracuse: Syracuse University Press, 2014); Usama Halabi, Baladiya al-Quds al-'arabi [The municipality of Arab Jerusalem] (Jerusalem: Passia, 1993).

52 Oscar Jarzmik, "Theodore 'Teddy' Kollek, the Palestinians, and the Organizing Principles of Israeli Municipal Policy, 1967-1987" (PhD diss., Toronto University, 2016).

53 Kimberly Katz, Jordanian Jerusalem: Holy Places and National Spaces (Gainesville: University Press of Florida, 2005).

54 Daniel Rubenstein, "The Jerusalem Municipality under the Ottomans, British, and Jordanians," in Jerusalem: Problems and Prospects, ed. Joel Kraemer (New York: Praeger, 1980). 
The British employed similar strategies of the symbolic upgrading and systematic demunicipalization of Ottoman Jerusalem. ${ }^{55}$ Before the Mandate period, the northern districts of Palestine had been under the administration of the province of Beirut. In 1918, they were placed under the jurisdiction of Jerusalem, which became the de facto capital of Palestine. British officials quickly replaced municipal electoral processes with government appointments, reduced the council's Muslim membership, and added ten British bureaucrats to establish a sectarian quota whose structure remained in place until $1948 .{ }^{56}$ While other British mandates in the region established parliaments and cabinets, colonial authorities factionalized Palestinian politics by granting newly invented institutions, such as the position of mufti, as family fiefdoms. With the increase of Zionist settlers in the city, the British divided Jerusalem into a dozen electoral wards in 1934, but it was only in the Fitzgerald Plan of 1945 that Jerusalem was bifurcated into a Jewish West and an Arab East. $^{57}$

Compared diachronically to these and many other British policies of political de-development and demunicipalization, the late Ottoman municipality of Jerusalem appears like a time and a place for urban democracy, even under the autocratic rule of Sultan 'Abdülhamid II. However, compared synchronically to other late Ottoman municipalities such as Nablus and especially Beirut, Jerusalem was a slow starter. The reason for this seems to lie less in its smaller size or remote location than in the same factors that stifled the democratic experiments of Istanbul, Alexandria, and Cairo: European diplomatic and religious interests. But it may also be that we simply do not know enough about the inner workings of the municipality of late Ottoman Jerusalem. ${ }^{58}$ We know

55 See Falestin Naïli, "La dé-municipalisation de la gouvernance urbaine et de l'espace politique post-ottoman: le cas de Jérusalem," Les carnets de l'Ifpo, February 7, 2017, accessed January 17, 2018, http://ifpo.hypotheses.org/7428.

56 Mu’tasem Hasan Ahmed Naser, “Jerusalem Municipality and Political Conflict: 1918-1942," International Journal of History and Philosophical Research 4, no. 1 (2016).

57 Michael Dumper, The Politics of Jerusalem Since 1967 (New York: Columbia University Press, 1997), 27.

$5^{8}$ Recent work in Arabic, Turkish and French has begun to change this. Mahmud Nahar al-Shannaq, Baladiyyat al-Quds al-shariffi al-'ahd al-'uthmani: dirasat [The municipality of Jerusalem in the Ottoman period: studies] (Ramallah: Filastin: Wizarat al-Ilam, 2010); Yasemin Avcı, Degişim sürecinde bir Osmanlı kenti: Kudüs (189o-1914) [An Ottoman city in the period of transformation:Jerusalem, 1890-1914] (Ankara: Phoenix, 2004), and Vincent Lemire, La soif de Jérusalem: essai d'hydrohistoire (1840-1948) (Paris: Publications de la Sorbonne, 2010). 
that of the sixteen Jerusalem mayors between 1863 and 1910, only four were not from the Khalidi, 'Alami, and Husayni families. ${ }^{59}$ We still have very little information about the composition of Jerusalem's municipal council. In this light, the work of the Open Jerusalem team on the recently discovered minutes of the municipal council meetings is promising, not just for Jerusalem but also for other municipalities, where no such documents have been found. ${ }^{60}$ It may just carry forward the "weak messianic power" of late Ottoman democracy.

59 Büssow, Hamidian Palestine, 554-55.

6o Yasemin Avcl, Vincent Lemire and Falestin Naili, "Publishing Jerusalem's Ottoman Municipal Archives (1892-1917)," Jerusalem Quarterly, no. 60 (2014). 


\section{PART 3}

\section{Cultural Networks, Public Knowledge}


Angelos Dalachanis and Vincent Lemire - 978-90-04-37574-1 Downloaded from Brill.com04/26/2023 02:29:03PM via free access 


\title{
Introduction
}

\author{
Edhem Eldem
}

Was Jerusalem an Ottoman city at the turn of the twentieth century? The answer may seem obvious. On paper, most of the actors of Ottoman Jerusalem's cultural and intellectual networks were indeed Ottoman subjects, soon to become citizens. This is certainly true of Khalil Sakakini, Said al-Husayni, Ruhi al-Khalidi, Wasif Jawharriyeh as a child (as Issam Nassar's contribution makes clear), and perhaps even of Pinhas Grayevsky. It was less true, however, of Eliezer Ben-Yehuda (as Hassan Ahmad Hassan and AbdulHameed al-Kayyali discuss), the Franciscan friars of the Custody of the Holy Land, and thousands of Jewish settlers intent on making a fresh start in the Promised Land. Yet labels and nationalities are tricky, and one recalls the bon mot attributed to Yorgo Boşo Efendi, deputy of Serfidje (today's Servia, in Greece): "I am as Ottoman as the Ottoman Bank." We are still trying to figure out what he may have really meant.

There is no doubt that Ottomanness in Jerusalem before World War I was contextual, and likely to change according to circumstances. As Yair Wallach points out in his chapter in this volume, Sakakini is a case in point when he brandishes his carte de visite in a gesture of allegiance to the springtime of Ottoman peoples in the wake of the Young Turk Revolution. Yet should we not instead see Sakakini as an exception, and a short-lived one at that, to a growing estrangement of Jerusalem from a gradually dissolving Ottoman commonwealth? How Ottoman could the city's cultural networks really have been if Arabs and Jews were discussing their ownership rights over Palestine (see the contributions by Wallach and Jonathan Gribetz), if Jewish newspapers were forging the future of the Hebrew language (Gribetz), and if Christian authorities were setting up printing houses that served primarily sectarian goals, as in the cases of the Tipografia di Terra Santa and the St. James Armenian Printing House (cases studied by Leyla Dakhli and Arman Khatchatryan, respectively)? The chapters in this part examine these case studies and, in so doing, address the question of Ottomanness.

The Ottoman archives give a rather telling image of the ambiguous presence of the state in the cultural life of the city. Apart from a number of events typical of the Hamidian period, such as the opening of an imposing primary school

1 Tarık Zafer Tunaya, Türkiye'de Siyasal Partiler [Political parties in Turkey], vol. 3 (Istanbul: Hürriyet Vakfı Yayınları, 1987), 173.

(C) EDHEM ELDEM, 2018 | DOI:10.1163/9789004375741_018

This is an open access chapter distributed under the terms of the prevailing CC-BY-NC-ND License at the time of publication. 
in $1890,{ }^{2}$ the state generally seemed to be "in the backseat," trying to catch up with local initiatives by granting (or not) its support and permission. Not surprisingly, requests concerning printing presses and publishing houses were particularly frequent, in ways that resonate with some of the contributions in this part. Thus, in October 1907, the "Latin monasteries of Jerusalem and Jaffa, under French protection" obtained full exemption from customs dues on two August Fomm printing presses weighing two tons, worth 27,000 piasters $\left(£_{250}\right){ }^{3}$ In 1903, the central bureaucracy had to deal with requests from Menahem Shmoyil and Aaron Weiss, two Austrian subjects, and Moshe Azrail, an Ottoman subject, to open printing houses in Jerusalem. Shmoyil and Weiss' project involved publications in "diverse languages" (elsine-i muhtelife); Azrail's was deemed particularly important because it would become the first Sephardic printing house in a market dominated by a multitude of Ashkenazi ventures. ${ }^{5} \mathrm{~A}$ few years later, just months before the revolution, an Ottoman subject and Jerusalemite by the name of Nikola Petro obtained permission to set up a press dedicated to the printing of kart dö vizit (business cards). ${ }^{6}$

The voices of Ottomans from the center may give a better idea of the growing distance that appears to have developed between Istanbul and Jerusalem. In his memoirs, Mehmed Tevfik Bey [Biren] (1867-1956), governor of Jerusalem from 1897 to 1901, recalls the awkward position in which he found himself in an unfamiliar cultural and social environment. Particularly striking was his ambiguous stance with respect to the consuls of the Great Powers, whose local power and prestige by far exceeded his own, but whose company he enjoyed much more than he did the locals'. At a public lecture organized by the Latin community, Tevfik Bey was offered a chair next to a throne-like seat reserved for the French consul. He was spared the embarrassment of having to leave by the consul himself, Ernest Auzépy, "a very civil and delicate man," who chose not to come, "probably realizing how inappropriate the situation would have been." To Tevfik Bey, the French and British consuls had become "proper friends," a qualification he never used for any of the local inhabitants of Jerusalem:

2 Ottoman State Archives (вОА), MF. мкт. 120/94, 29 Muharrem 1308/September 14, 1890; FTG 1876 , ca. 1890 .

3 BOA, ŞD. 601/75, October 9/22, 1323/1907.

4 вОА, DH. мКт. 688/34, February 8/21, 1318/1903-August 24/September 6, 1319/1903.

5 вОА, DН. МКт. 682/6, March 15/28, 1319/1903-September 4/17, 1319/1903.

6 воА, DH. Мкт. 1240/15, February 27/March 11, 1323/1908.

7 Fatma Rezan Hürmen, ed., Bir Devlet Adamının Mehmet Tevfik Bey'in (Biren) II. Abdülhamid, Meşrutiyet ve Mütareke Devri Hatıraları [The memoirs of a statesman: Mehmet Tevfik Bey (Biren) during the constitutional and armistice periods], vol. 1 (Istanbul: Arma Yayınları, 1993), 95 .

8 Ibid., 96. 
There were several famous families in the district of Jerusalem, known by the names of Husayni, Khalidi, Nashashibi, Alami, Dawudi. The Husaynis and the Khalidis, who had accumulated the greatest power and had become rivals, could never get along. Those who had the preference of the local government would increase their power and eliminate the others. ${ }^{9}$

Relations with the locals were tense. In July 1898 , a local Jew warned the governor to drink only milk that was milked in plain sight, for fear that "the Arabs would put a spell on it, to loosen him up as they had İbrahim Pasha." Tevfik Bey started drinking cocoa in the morning, instead of milk: "A spell on milk would have done me no harm, but I was worried they would mix it with something or dip their filthy hands in it." 10

The protracted rivalries between bell and clock towers in the city were arguably the strongest indications of Ottoman fragility in Jerusalem. In 1901, at a time generally associated with the erection of clock towers to celebrate Abdülhamid II's silver jubilee, it was Kaiser Wilhelm II who had a 47-meter tower built to accompany the Church of the Dormition, for which he had, during his visit in 1898 , forcefully obtained a plot of land right next to the Muslim-controlled tomb of David. ${ }^{11}$ The clock tower became a bone of contention between the Ottoman and German governments because its use as a bell tower infuriated the local Muslim population. The German chancellery tried to justify the situation by arguing that such practice "should have no harm in a city - like Jerusalem - where the population is used to hearing the sound of bells," but it was finally forced to accept that the bells be silenced by removing the clappers, levels, and ropes. ${ }^{12}$

A victory for the Ottomans? Perhaps, if we are to believe that the monks of Mount Zion really kept to their promise. More significantly, the belated realization of the state's own clock tower was a source of Ottoman frustration. The decision was taken only in May 1907, based on a rather clear argument: "While the city of Jerusalem is filled with clock towers showing alla franca time, that there should not be a single clock tower to display the sunset-based (ezāni $)$

\footnotetext{
$9 \quad$ Ibid., 102.

10 Ibid., 104-5.

11 BOA, i. HUS. 87/74, March 11/24, 1317/1901; BEO 1637/122736, March 13/26, 1317/1901; HR. sYs. 410/2, 6 Zilhicce 1318/March 27, 1901; DH. M KT. 2470/28, March 27/April 9, 1317/1901. For an account of the events that led to the granting of the deed, see Hürmen, Bir Devlet Adamı, 123-34. 
time is unacceptable from the viewpoint of both religion and wisdom." It was therefore decided to spend some 1,500 liras, collected from the population, to build "a very strong and beautiful tower in the elegant Arab architectural style."13 The project was signed and supervised by a non-Muslim Jerusalemite, Pascal Mina. This last-minute effort by the empire to mark the city with its imprint, while at the same time paying lip service to some form of regionalism, was short-lived. It had the misfortune of being on the path of Allenby's victorious march into the city and of attracting British criticism as "an ultra-hideous clock tower." It was dismantled and moved to Allenby Square outside the city walls, only to be demolished in $1934 ;^{14}$ a tragic end that echoes the fragility of the Ottoman presence and domination in the last decades of the empire.

13 вОА, Dн. мКт. 1174/42, April 24/May 7, 1323/1907; Ү. РRк. Uм. 80/69, October 15/28, 1323/1907.

14 Uzi Baram, "Out of Time: Erasing Modernity in an Antique City," Archaeologies:Journal of the World Archaeological Congress 8 no. 3 (2012): 339-42. 


\title{
Reading the City, Writing the Self: Arabic and Hebrew Urban Texts in Jerusalem, 1840-1940
}

\author{
Yair Wallach
}

One afternoon in October 1908, after a long day of political meetings and private lessons, the teacher and writer Khalil al-Sakakini (1878-1953, fig. 14.1) sat on the balcony of the al-Asma'i newspaper's offices in Jerusalem, near Jaffa Gate. As he noted in his diary, "Officer Jalal Effendi, a member of the Committee for Union and Progress (CUP), passed by. He asked for my visiting card. I wrote on the card that I wished to join the committee and handed it back to him."1 Sakakini, a Jerusalem-born Arab Christian who had been educated in an Anglican missionary school, had just returned from New York with high hopes for the future of the Ottoman Empire after the 1908 Young Turk Revolution. He would soon establish a radically modern school and name it the Constitutional School (alMadrasa al-Dustūriyya). Like other members of Jerusalem's young intelligentsia, he sought to join the revolutionary ruling party. To do so, Sakakini did not write a long letter of motivation or go through interviews; his application consisted of a small piece of card, his visiting card. In giving his card to Jalal Effendi, Sakakini proved himself to be what Stephen Sheehi called one of the Ottoman "new men": worldly, aspiring and modern people, worthy members of a party that sought to radically transform the empire. ${ }^{2}$

Sakakini's visiting card is one example of what I call "urban texts," texts displayed in an urban environment. These texts vary considerably in terms of substance, format, and content. Ephemeral or enduring, fixed or transitory, elaborate or plain, banal or unusual, mass-produced or handcrafted, ancient or recent, these texts take many forms but they all are encountered in urban public settings such as streets, markets, and sites of worship. Textual density is one of the characteristics that distinguishes urban space from rural areas.

1 Khalil al-Sakakini, "Nyu Yurk, Sultana, Al-Quds, 1907-1912" [New York, Sultana, Jerusalem, 1907-1912], in Yawmiyyat Khalil al-Sakakini [Diaries of Khalil Sakakini], vol. 1, ed. Akram Musallam (Ramallah: Khalil Sakakini Cultural Centre; Institute for Jerusalem Studies, 2003), 320-21.

2 Stephen Sheehi, "Portrait Paths: Studio Photography in Ottoman Palestine," Jerusalem Quarterly, no. 61 (2015): 24 .

(C) YAIR WALLACH, 2018 | DOI:10.1163/9789004375741_019

This is an open access chapter distributed under the terms of the prevailing CC-BY-NC-ND License at the time of publication. 
In modern Jerusalem, like in other locales, urban texts functioned within distinctly urban economies of exchange, piety, and power. Collectively, urban texts form a significant corpus, which arguably makes up the majority of texts read by urbanites, and yet is typically understudied. The study of urban textuality is located at the crossroads of several disciplines. Sociolinguists study the "linguistic landscape" of (mostly contemporary) urban signage in multilingual contexts to examine social hierarchies of languages and cross-language influence. ${ }^{3}$ Studies by anthropologists, cultural and art historians have emphasized the historical transformation of textuality and its meaning. ${ }^{4}$

As I show in this chapter, urban texts are a valuable source for social and cultural history: they tell us much about perceptions of communal identities and urban space, the structures of power and their legitimizing discourses. But urban texts are not merely historical sources. My argument is that these texts were tools to achieve radical transformations of state and society in late Ottoman and British Mandate Palestine. Textual media are social technology whose nature is contested and changing. In 1840, texts in Arabic and Hebrew in the urban space were anchored in the word of God. By 1940, text was employed by the colonial state, the Zionist colonial-national movement, Arab nationalism, and a capitalist economy. With modernity, Arabic and Hebrew public texts gained unprecedented presence in urban visual culture but lost their much of their sacred aura. Urban text underwent a process of dematerialization as inscriptions chiseled in stone gave way to posters and cardboard signs.

\section{Textual Citadinité and Sources}

The category of urban textuality invites the question of textual citadinité: in which ways did inscriptions, graffiti, and shop signs contribute to, or undermine, notions and practices of urban citizenship in Jerusalem? Was there a multilingual textual arena of inclusive urban interaction between Arabic, Hebrew, and other languages? Or is it more accurate to speak of parallel writings of the city by separate groups, indifferent or hostile to each other? As this

3 Yasir Suleiman, Language and Society in the Middle East and North Africa: Studies in Variation and Identity (Richmond: Curzon Press, 1999); Elana Shohamy, Eliezer Ben Rafael, and Monica Barni, eds., Linguistic Landscape in the City (Bristol: Multilingual Matters, 2010).

4 Irene A. Bierman, Writing Signs: The Fatimid Public Text (Berkeley: University of California Press, 1998); Brinkley Morris Messick, The Calligraphic State: Textual Domination and History in a Muslim Society (Berkeley: University of California Press, 1993); Juliet Fleming, Graffiti and the Writing Arts of Early Modern England (London: Reaktion, 2001). 
chapter shows, there is no simple answer to these questions. One can point to Jerusalem as a city-cosmos of texts, with instances of urban texts operating across dividing lines. And yet we can also speak of parallel textual economies in isolation or in conflict with each other. With the transition from the late Ottoman inclusive discourse of development and progress to a Mandatory logic of separate communities, urban texts were increasingly understood against the Zionist-Arab conflict and its social ramifications.

The study of historical urban textuality requires a variety of sources, archives, and methodologies. The first question is which texts were visible and to whom. To survey the city's texts, we have to examine the built environment (where urban texts survived in situ), photographic documentation of Jerusalem, ${ }^{5}$ epigraphic collections, ${ }^{6}$ historical ephemera, and others. These sources can give us an idea about which texts were visible in the city, where they were and which languages they were written in. But in order to understand the social significance and operation of texts, we have to look beyond these sources. The crux of this inquiry is the epistemology of text: how Jerusalemites used textual media - traditional and modern alike - to understand and rewrite their world, their city, and themselves. To answer this question, we need evidence of how contemporaries perceived texts, their roles and status. Such evidence may be found in a variety of sources such as historical newspapers, memoirs, and diaries.

In this chapter, I look at two cases of urban text. Sakakini's visiting card is an example of an ephemeral text through which the Palestinian educator crafted his public persona as a humanist intellectual, enthusiastic in his embrace of modernity and the ruptures it entailed. Sakakini used the card to navigate the promises of a progressive post-1908 Ottoman Empire, though it proved to be a short-lived political experiment. The visiting card is mentioned in his diaries as well as in the memoirs of his student Wasif Jawhariyyeh. The diaries and memoirs, published in recent years by the important initiative of

5 On early photography of Jerusalem, see Issam Nassar, Laqatat Mughayira:Al-Taswir Al-Mahalli Al-Mubakkir Fi Filastin, 1850-1948 [Alternative shots: early local photography in Palestine, 1850-1958] (London: Mu'assasat 'Abd al-Muhsin al-Qattan, 2005); Guy Raz, Tsalame ha-'Arets: me-Reshit Yemey ha-Tsilum ve-'ad ha-Yom [Photographers of the land: from early photography to this day] (Tel Aviv: ha-Kibuts ha-me'uhad, 2003). Substantial photographic collections on Jerusalem include the Library of Congress, Central Zionist Archives, the Jewish National and University Library.

6 For Islamic inscriptions, see Archibald G. Walls and Amal Abul-Hajj, Arabic Inscriptions in Jerusalem: A Handlist and Maps (London: World of Islam Trust, 1980). 
the Institute for Palestine Studies, provide a wealth of information for social historians of modern Jerusalem. ${ }^{7}$

My second example is a corpus of Hebrew stone inscriptions in Jerusalem, self-published in the late 1920 s by Ashkenazi Jerusalemite scholar Pinhas Ben Tsvi Grayevsky (1873-1941). ${ }^{8}$ Against the background of the British Mandatory regime and its support of Zionism, the realm of an inclusive urban arena was shrinking. Through the inscriptions, Grayevsky sought to salvage Jerusalem's Jewish communities' heritage at a moment when Hebrew was being reclaimed by a secular, national, and settler colonial project. I am particularly interested in how Grayevsky framed and justified his study.

\section{Sakakini's Visiting Card: The Waltz of Etiquettes}

In the early twentieth century, the visiting card was the most widely used artifact of textual self-representation among western educated elites. Emerging in early modern Europe among the aristocracy, visiting cards were tools through which one gained access to polite society. Cards had to be left in advance in order to arrange visits and be given interviews. There was a strict code regulating their use as part of upper-class etiquette. The word etiquette itself comes from an Old French word meaning "label" or "ticket," perhaps because it describes the process of assigning roles and identities through labelling. ${ }^{9}$ Upper-class etiquette was a rigid system for the regulation of social interaction, prescribing and proscribing the actions of those who moved in high society. Within this system, the visiting card was a vital instrument through which one could present oneself to the reading gaze of others. By the early twentieth century, visiting cards had spread well beyond their European aristocratic origins in terms of class, function, and geography. Cards were widespread among

7 Khalil al-Sakakini, Yawmiyat Khalil Al-Sakakini [Diaries of Khalil Sakakini], ed. Akram Musallam, 8 vols. (Ramallah: Khalil Sakakini Cultural Centre; Institute for Jerusalem Studies, 2003); Salim Tamari and Issam Nassar, The Storyteller of Jerusalem: The Life and Times of Wasif Jawhariyyeh, 1904-1948 (Northampton: Olive Branch Press, 2014).

8 Pinhas M. Ben Tzvi Grayevsky, Sefer 'Avne Zikaron: 'Avne Kodesh bi-Rushalayim [Book of memorial stones: sacred stones in Jerusalem], 15 vols. (Jerusalem: Tzukerman, 1928).

9 Elaine Hernen, "Names Are Everything: For Oscar Wilde, Posing as a Letter and Visiting Card," Vides: MLA Volume of Interdisciplinary Essays 1 (2013), accessed January 17, 2018, https://open.conted.ox.ac.uk/resources/documents/names-are-everything-oscar-wilde -posing-letter-and-visiting-card-elaine-hernen. 
Jerusalem elites, as Maria Chiara Rioli demonstrates in this volume. ${ }^{10}$ The Franciscan Printing Press collection holds 1,500 cards printed between 1880 and 1906, with a wide array of positions and identities, from the Ottoman governor to local midwives. The press was used by all denominations, overwhelmingly by men but also by some women. From instruments for gaining access to the domestic domain, visiting cards became highly charged objects of social capital; circulated, exchanged, and displayed in the public sphere. Stephen Sheehi argues that in early twentieth-century Ottoman Jerusalem, the visiting card cannot be thought of outside the context of Ottoman reforms in education, print media, and land commodification: "the aesthetic of the carte was the aesthetic of the ideology of Osmanlilk modernity and Nahda discourses ... of "progress and civilization."'11 Middle-class professionals and businessmen carefully collected cards they received from others, using them to create a textual map of the people they knew, a kind of catalogue of one's social network, influence, and connection. Like personal portraits, the exchange of cards "tethered individuals to collectives ... and individuals and collectives to institutions and the state."12 Without a card, one could not be read by the world, or in other words, one did not exist as an individual of worth. The card was a textual mask one would wear in public, more important even than clothing and appearance in gaining respectability. The text on visiting cards, while brief and "factual," could communicate one's social standing and make one's status readable to a wider public. In E. M. Forster's 1910 novel Howard's End, the charged encounter between strangers at a concert is mediated through visiting cards. When Leonard Bast is introduced to the Schlegel sisters, he is unsure about their trustworthiness until he looks at their visiting card. The sisters' respectable address in west London - noted by the postcode letter "W" on their visiting card - is sufficient to reassure him..$^{13}$ The social hierarchy of urban residential areas is coded and displayed in the most succinct manner possible. The card allowed its holder to determine her or his own terms of legibility by choosing words, style and, sometimes, photographs. This choice always operated within, or against, the expected norms.

The visiting card stood in contrast to another modern textual artifact: stateproduced personal documents. In the Ottoman Empire, this took the form of the nüfüs tezkeresi, the identity card, a certificate issued on a printed form to

10 See her chapter, "Introducing Jerusalem. Visiting Cards, Advertisements and Urban Identities at the Turn of the 2oth Century," in this volume.

11 Sheehi, "Portrait Paths," 26.

12 Ibid., 31.

13 Edward M. Forster, Howards End (New York: Penguin, 200o), 30. 
every male beginning in the late nineteenth century. Headed with a large tuğrāa, the sultan's emblematic signature, the nüfüs recorded the person's name, date of birth, religion, father, and place of abode, as well as physical description. It was compulsory for every male citizen to hold such a certificate. It had to be presented in a variety of circumstances, including appointments for a government position, dealings with the police, marriage, and real estate transactions. Despite being a personal document, the certificate was not normally obtained directly by the person or his family, but rather through appointed community representatives, the mukhtars. It was no surprise therefore that it was prone to contain spelling errors and incorrect details. ${ }^{14}$ One had little control over the recorded details. In contrast with this mass-produced, officially, and universally prescribed form, the visiting card was a middle- and upper-class document through which the individual had far greater room for self-representation. It was written and phrased by the individual who possessed it, and the choice of languages was similarly a personal decision. The cards in the Franciscan collection varied not only in design, but also in language. Most cards were written in European languages, but cards were also created in Arabic, Ottoman, Hebrew, Armenian, and other languages. Producing one's

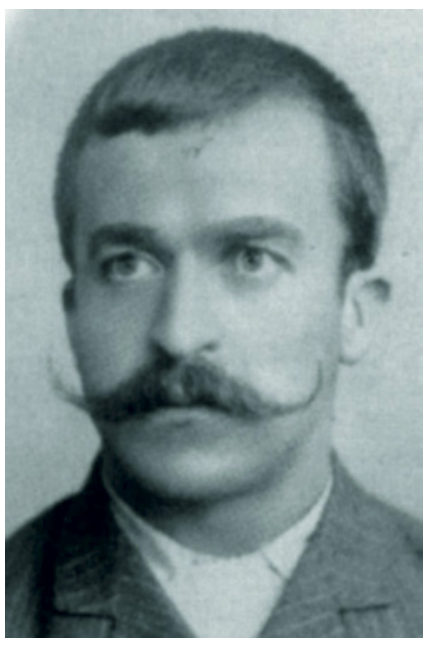

FIGURE 14.1

Khalil Sakakini.

DATE AND PHOTOGRAPHER UNKNOWN, CREATIVE COMMONS.

14 Will Hanley, "Papers for Going, Papers for Staying: Identification and Subject Formation in the Eastern Mediterranean," in A Global Middle East: Mobility, Materiality and Culture in the Modern Age, 1880-1940, ed. Avner Wishnitzer, Liat Kozma, and Cyrus Schayegh (London: I. B. Tauris, 2014). For errors in recording personal details, see the account of Gad Frumkin, Derekh Shofet bi-Rushalayim [The way of a judge in Jerusalem] (Tel Aviv: Dvir, 1954), 106. 
visiting card was similar to producing one's portrait in a photographer's studio. With the turn-of-the-century fashion for photographic cartes de visite, a representative portrait was often featured on the reverse of the card.

A young, aspiring intellectual handing a scribbled visiting card to an army officer on the balcony in the city center: the scene reads like a play in which participants perform a modern ritual in the public gaze. A secret ritual of a very different kind followed it. A day after he forwarded his visiting card with a request to join the CUP, Sakakini was invited to a secret nighttime ceremony during which he was admitted to the party. Blindfolded, his right hand placed on the New Testament and his left on a pistol, he swore that he would defend the constitution and the homeland with his life. The choice of the New Testament in a Muslim-dominated party (for Sakakini was Christian) reflected the secular nature of the new constitutional regime, which rose above religious differences and allowed equality for Christians and Jews. By allowing its members to swear on "their" holy scriptures, without discrimination, the cuP pointed towards making religion a matter for individuals and congregations rather than for the secular state. At the same time, these two artifacts - the holy book and the lethal weapon - instilled a sacred quality in the ceremony. The power of God's word and the power of the pistol underlined the oath Sakakini took, confirming that this was a commitment of life and death. When the blindfold was removed, Sakakini found himself in front of three officers, their faces and bodies covered. The anonymous functionaries who had read his card also observed him in person as he took the oath blindfolded. They represented the new state machinery: impersonal, ideological, and omniscient. The panoptic quality of the ceremony communicated the aspirations of the revolutionized Ottoman state. The CUP promised a place to all citizens, regardless of their religion, but also sought to place them firmly under its gaze.

This quasi-religious nighttime ceremony took place in a house outside the walled city. It should be noted that Jerusalem, as recorded in Sakakini's diaries, is a modern city in which there is no clear distinction between the Old City within the walls and the New City without. Sakakini's professional life revolved around the Jaffa Gate city center, within the walls and outside them. Here he worked, gave private lessons, and socialized in cafes, and it was here that he gave his card to the CUP officer. Sakakini's initiation to the party took place both inside the walls and outside them.

For Sakakini, the visiting card opened the door to the party; his initiation as a party member, on the other hand, required the New Testament. These two artifacts offered radically different roles for textuality. The first was of text as an ever-changing medium of mobility and transformation of self and society. The second was of text as a sacred, unchanging source of stability with power 
of life and death. While Sakakini swore his allegiance on the second text, the scripture receded into the role of a ritual object of faith, while the visiting card assumed an aura of its own, a magical artifact through which one could remake oneself. We do not have the original card Sakakini handed to the CUP, but we know what was written on it. Sakakini's visiting card would later become famous within his social circle. It stated plainly "Khalil Sakakini. A human being, God willing." Sakakini's students, friends, and acquaintances in Jerusalem were familiar with this motto and understood it at once as a statement of simplicity and authenticity, and as an expression of impatience with social pretense and fake conventions. As one of his students wrote: "those who have known [him] can testify that it is hard to describe al-Sakakini with words ... he was loyal and just, and liked everyone to be human in every sense of the word. To this effect, he printed the [aforementioned] statement on his visiting card ... he mocked those who led a manipulative life, and who were many, in his view."15 Sakakini prided himself on his honesty and direct manners, and his willingness to stand by his principles. On numerous occasions, he paid a high personal price for his principles, when he confronted the social consensus and those in power. But the statement "a human being, God willing" was also a rejection of social categorization and labelling. Not only was it a rejection of his own confessional identity as a Greek Orthodox Christian (he was famously excommunicated by the church for his political activism), but it was a sweeping rejection of nationalism and organized religion in general. As he wrote in 1917, shortly before his arrest by the Ottoman police for sheltering an American Jew:

[W]herever I am, I am simply a human being, nothing else. I don't belong to political parties or religious factions. I consider myself a patriot wherever I am, and strive to improve my surroundings whether they are American, British, Ottoman or African, whether they are Christian, Muslim or pagan. I only work to serve knowledge, and knowledge has no homeland. What is a patriot? If being a patriot means to be sound of body, strong, active, enlightened, moral, affable and kind, then I am a patriot. But if patriotism means favouring one school over another and showing one's brother hostility if he is from a different school or country, then I am no patriot. ${ }^{16}$

15 Tamari and Nassar, The Storyteller of Jerusalem, $15^{2}$.

16 Quoted in Salim Tamari, “Khalil Sakakini's Ottoman Prison Diaries," Jerusalem Quarterly, no. 20 (2004): $7-23$. 
With his strong belief in humanism, and his equally strong Jerusalemite identity, Sakakini was the embodiment of Jerusalemite nonsectarian, urban citizenship. Describing himself as a human being was a rejection of the social identities imposed by groups, nations, and creeds. But "human being" is not to be understood as the authentic kernel hiding beneath the false layers of imposed identities. Rather, for Sakakini, humanist simplicity itself was a product of rigorous self-fashioning, an attestation of his commitment to Enlightenment values and his individualistic outlook. "Human being" was not a description but an aspiration, a pledge, a call to arms, as Sakakini made obvious by the suffix "God willing." Being human was not a given, but something to be achieved. Sakakini's self-definition as a "human being", and nothing else, became part of his lifelong project of fashioning himself as a modern individual, much of it inspired by his admiration of Western culture. This selffashioning involved a strict daily regime of exercise, cold showers, a vegetarian diet, and obsessive writing and reading. This was a continuous disciplining of body and soul, of self-articulation through constant writing of thousands of pages in diaries and letters, as well as published articles and books including a draft of his own obituary. The role of Jerusalemite humanist writer and educator was the most important role Sakakini played, and the one he performed throughout his adult life alongside the many other identities and ideas he adopted and rejected, always with fervor and great excitement. As his contemporaries attested, Sakakini was a deeply theatrical person who enjoyed performing in front of friends and colleagues. A "human being" was not the naked truth hiding behind a social mask: it was a mask in itself. Sakakini's visiting card was the textual manifestation of this mask: a statement of simplicity and humility, but also a carefully worded, publicly proclaimed ideological persona. It was this humanist mask that Sakakini chose to wear in public, circulating it to friends and colleagues in the form of his visiting card.

Sakakini was apparently soon disillusioned with the CUP, and he does not mention in the diaries any further activities within the framework of the local party, nor any sense of affiliation to it. By the First World War, his diary documents severe criticism of the CUP-led Ottoman government and its repressive measures against the population. His 1908 accession to the party captured a moment of optimism among the "new men" of the Ottoman Empire, the burgeoning middle class of professionals rising to claim a role in economy and decision-making. Yet as Bedross Der Matossian points out, the enthusiasm soon dissipated, especially among national and ethnic groups who felt they had been denied a place in the centralized CUP machinery. ${ }^{17}$

17 Bedross Der Matossian, Shattered Dreams of Revolution: From Liberty to Violence in the Late Ottoman Empire (Stanford: Stanford University Press, 2014). 
When British forces arrived in Jerusalem in 1917, the local sense of urban citizenship was at its zenith. The shared predicament of the war created strong bonds of cross-confessional urban solidarity. Perhaps the most famous example of this solidarity is Sakakini's aforementioned decision to give shelter to an American Jew fleeing Ottoman intelligence; both were arrested and exiled to Damascus. ${ }^{18}$ This sense of solidarity was soon to change. The establishment of the British Mandate over Palestine and its commitments to the Zionist movement led to an inevitable clash between the Arab indigenous majority and the Jewish communities, both local and migrant-settlers alike. This conflict severely undermined the possibility of a nonsectarian, locally-defined, inclusive sense of belonging. The upheaval disrupted Arab-Jewish relations, but it also turned upside down the structures of local Jewish communities. The diverse Ottoman Jewish communities were replaced by a Zionist-led Jewish Yishuv. This transition was reflected in the Hebrew textual landscape of Jerusalem and is captured in Grayevsky's mammoth project to document the city's Hebrew stone inscriptions. At a time when Sakakini was embracing the future, Grayevsky wanted to salvage the past. Sakakini's unreserved embrace of new textual artifacts and the social transformation they entailed stands in contrast to Grayevsky's desperate attempt to preserve traditional textual artifacts in a world of uncertainty and turmoil.

\section{Salvaging Hebrew Stone Inscriptions: Engraved Memories}

A Jewish Jerusalemite intellectual contemporary of Sakakini's, Grayevsky was far less well-known. ${ }^{19}$ It is doubtful if the two ever met. Unlike Sakakini, Grayevsky received no formal Western education, and was schooled in an Ashkenazi yeshiva. However, a keen autodidact, he managed to expand his horizons beyond Orthodox literature. Born and raised in the Ashkenazi confines of Jerusalem to parents who immigrated from Belarus, he worked as a teacher of Talmud and a clerk in a Jewish hospital and probably never travelled away from Palestine. Grayevsky was rooted in the Ashkenazi society in

18 Tom Segev, One Palestine, Complete:Jews and Arabs under the British Mandate, trans. Haim Watzman (London: Little, Brown, 2000), 13-32.

19 Although many of Grayvesky's prolific publications have been used by historians such as Yehoshua Ben-Arieh, there is no study of his overall œuvre. On Grayevsky as an Orthodox historian, see Kimmy Caplan, "Trends and Characteristics in the Study of Orthodoxy in the Israeli Academy," Zion 74 (2009). 
Palestine that developed in the nineteenth century through migration from eastern Europe. It was a society that remained embedded and dependent on eastern European networks of charity, patronage, scholarship, and commerce. This milieu was conservative in outlook and is generally seen as having been hostile to ideas of Jewish enlightenment (the Haskalah). And yet Grayevsky was inspired by ideas of Hebrew cultural revival and Jewish settlement and immigration. As a local Jerusalemite, self-taught Orthodox maskil and proto-Zionist, Grayevsky shows the relative fluidity among Jerusalem's late Ottoman Jewish communities, often missed in the historiography's misleading dichotomies of "Old" and "New" Yishuv.

In November 1917, the British government issued the Balfour Declaration, and five weeks later British forces occupied Jerusalem. Local Jewish communities found themselves in a new and confusing situation. The local Jewish establishment was swept aside by the newly arrived Zionist leadership. The World Zionist Organization was legally recognized by the authorities as the representative of Jews in Palestine, and its officials left very little room for local Jewish elites. Against this backdrop, in the 1920 s and 1930s, Grayevsky authored no fewer than 170 booklets chronicling the history of Jerusalem's Jewish - mainly Ashkenazi - communities. His work is a curious mix of pietistic local scholarship, antiquarian fascination, and protonational historiography. Driven by his motivation to ensure the legacy of the Orthodox Ashkenazi communities in Jerusalem, he attempted to write them into the story of "Jewish revival" in Palestine. By stressing the active Orthodox role in the growth of the Yishuv, Grayevsky was offering an alternative narrative to the dominant Zionist one, which depicted Palestine's local Jewish communities as reactionary, diasporic in character, and unproductive.

In 1928, following the 1927 Palestine earthquake, Grayevsky set out on a mammoth project to collect and document Hebrew stone inscriptions in Jerusalem in a multivolume book called Stones of Memory. ${ }^{20}$ Self-published and funded by donations, this fifteen-volume series was far from a rigorous scientific enterprise, as Grayevsky himself acknowledged in his apologetic introduction. Unlike epigraphic conventions, the corpus was organized not by inscription date but by location. Jumping between sites in an erratic manner, the collection is eclectic in its focus and commentary. In the introduction to the series, Grayevsky explained his motivation for the project: 
Because of their antiquity, some of the [stones] are already broken, their letters disappearing. Others have been rendered over with lime and plaster so the inscriptions are no longer visible. Yet others I have had to scrub, clean and wash until I could read them. And some are no longer in their original place ... To save them from the ravages of time, and to revive their memory, I have, with God's help, undertaken the job of copying and publishing them in a book for eternal memory. ${ }^{21}$

The name of the series, Stones of Memory, recalls other books of the same title that collected burial inscriptions from Jewish cemeteries in Toledo, Frankfurt, and other places. These books aimed to ensure eternal memory for those buried and to allow readers to pray for them. Indeed, volumes 8 to 14 of Grayevsky's series consist of epitaphs in Jewish cemeteries in Jerusalem, Jaffa, and some Zionist colonies, with full names and dates of burial. The bulk of the work, however, was a survey of foundation and commemoration stones of Jewish institutions such as hospitals, old age homes, and synagogues. The first seven volumes of the series list nearly two thousand inscriptions from Jerusalem. In a clear aberration from the Jewish memorial genre, Grayevsky also included ancient inscriptions excavated in Jerusalem by archaeologists, not only in Hebrew but also in Greek and Latin. He listed Islamic inscriptions from Jerusalem and Hebron and Samaritan inscriptions from the synagogue near Nablus, which he received through his communications with Muslim and Samaritan religious scholars. He included endorsements from these scholars in his publications.

The interesting eclecticism of Grayevsky's enterprise points towards an inclusive textual imaginary that acknowledges formal and semantic similarities between Islamic and Jewish inscriptions. Although Grayevsky's focus was on Hebrew inscriptions, he made it clear that his interests in Jerusalem's textual landscape were broader. But what kind of common denominator was there between these different inscriptions? The collection pointed to two possible understandings of nonsectarian commonalities. The first was the similarities and mutual respect between Abrahamic religions, as indicated by Grayevsky's expressed gratitude to the Muslim and Samaritan religious scholars. The second possible commonality was a shared interest in the scientific study of the past and especially the study of inscriptions (epigraphy) as a Western science. The inclusion of archaeological discoveries in Jerusalem pointed in that direction. Despite his admitted shortcomings, Grayevsky hoped to contribute to a scientific discourse and the scholarly production of historical knowledge.

21 Ibid., 3. 


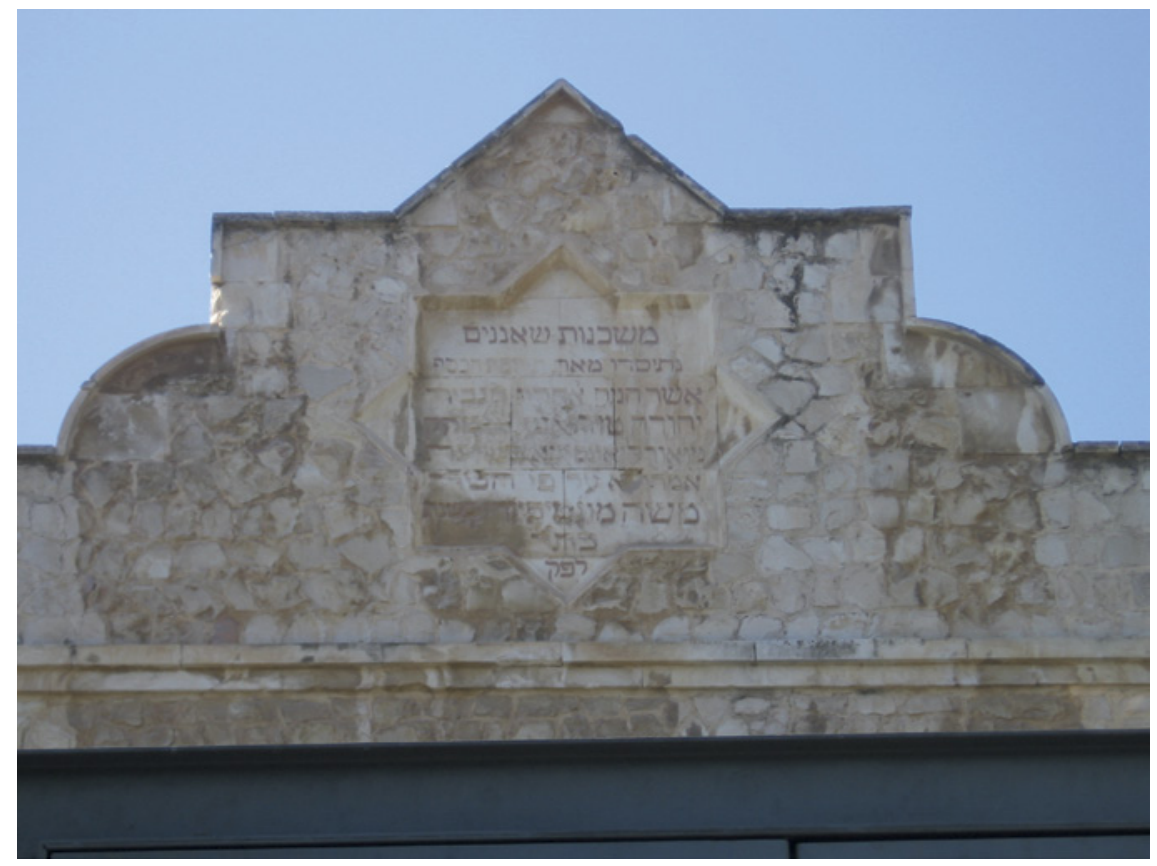

FIGURE 14.2 Dedication inscription of the Mishkenot Sha'ananim alms houses outside Jaffa Gate, built in 1860. This was among the earliest Hebrew dedication inscriptions in Jerusalem.

YAIR WALLACH, 2006.

These two options - Abrahamic respect and reverence, or alternatively, a common belief in European scientific study - provided two dissimilar directions for an inclusive intellectual production that could bind Hebrew inscriptions with Islamic ones, and a Jewish scholar with his Muslim and Christian counterparts. And yet it was clear that such Jerusalemite alliances were secondary to Grayevsky's main interest, which lay firmly within the emerging Jewish society in Palestine. In his introduction, Grayevsky presented the inscriptions as vital historical sources, carrying a "wealth of information" on the early history of community leaders and donors who built the Yishuv from the "ruins" of Jerusalem. The book's hagiographic account of these benefactors aimed to insert Jewish donors and pious community leaders into the national narrative of Jewish "revival" in Palestine.

Grayevsky's description of the "antiquity" of Hebrew inscriptions notwithstanding, the memorial stones he documented were in fact not ancient at all. In a corpus of nearly two thousand inscriptions, only ten dated before 1850. Two-thirds of the dated inscriptions were erected after 190o. This is not 
surprising given the modern history of Jews in Jerusalem. Up until the 1830s, Jerusalem had no more than two thousand Jews, constituting less than a quarter of the city's population. The sixteenth-century Sephardic ben Zakay Synagogue complex was the only recognized Jewish house of prayer in the city. ${ }^{22}$ Correspondingly, Hebrew inscriptions were almost nonexistent in the city's streets. This state of affairs changed dramatically in the coming decades. Rapid Jewish immigration, mostly from eastern Europe, but also from North Africa, central Asia, and other parts of the Middle East, was transforming the city. By 1910, the number of Jews had risen to forty-five thousand, composed of an Ashkenazi majority, a large Sephardi community, and smaller Mizrahi congregations. ${ }^{23}$ There were now hundreds of new synagogues and religious schools in the city, and a prominent element in all of them were stone inscriptions commemorating individuals who donated to the construction, repair, or upkeep of these institutions. As late as the 1910s, these inscriptions were the dominant form of monumental public writing in Hebrew, and they were visible throughout the city. No real difference can be detected in inscriptions in the Old City and extramural neighborhoods: in visual and textual format, date and use, most inscriptions were almost identical.

The act of placing the inscription was given great importance. The memorial stone at the entrance to the main Ashkenazi Synagogue, Ha-Hurva, built between 1857 and 1864, was erected long before the completion of the building. The elders "remembered their promise to the charitable Yehezkel Re'uven [a Baghdadi Jew], to fix above the synagogue's lintel a large stone commemorating his great benevolence to the Ashkenazi congregation by building this synagogue." 24 Chiseled deep into heavy stones and painted routinely to ensure their visibility, the inscriptions promised the benefactors' name would be displayed forever in the Holy City. Jewish institutions typically relied on many donors rather than a single patron. When the money to build the Ha-Hurva

22 The small heterodox Karaite community used an older, tenth-century synagogue. See Yoram Erder, "The Mourners of Zion: The Karaites in Jerusalem in the Tenth and Eleventh Centuries," in Karaite Judaism: A Guide to its History and Literary Sources, ed. Meira Polliack (Leiden: Brill, 2003).

23 Yehoshua Ben-Arieh, Jerusalem in the Nineteenth Century: Emergence of the New City (New York: St. Martin's Press; Jerusalem: Yad Izhak Ben-Zvi, 1986), 241; Uziel O. Schmelz, 'Ukhlusiyat-Yerushalayim: Temurot ba-'Et ha-Hadasha [Modern Jerusalem's demographic evolution] (Jerusalem: Jerusalem Institute for Israel Studies, 1988), 17.

24 David Kroyanker, "Ha-Beniya ba-Ir ha-'Atika" [Jerusalem architecture: the Old City] Adrikhalut Bi-Rushalayim 6 (Jerusalem: Keter, 1993), 191. 
Synagogue ran out, fundraisers were sent to Europe to "sell" the windows of the synagogue to donors, and the window lintels were full of names. ${ }^{25}$

Many inscriptions were visible, if not legible, to a wider urban population passing by regardless of religious or ethnic identity. And yet it is clear that the primary function of these texts was within Jewish communal circles, defining ethnic and religious boundaries. Jews in Jerusalem were fragmented in dozens of communities, differing in cultural praxis, occupations, organization, oral tradition, and areas of residence. The congregational affiliation was often mentioned explicitly or implicitly in the inscription. There were instances of cross-ethnic support and charity, such as the Ha-Hurva Synagogue mentioned above, where an affluent Jewish Baghdadi patron donated to an Ashkenazi synagogue, where his family would not normally pray. But in most cases, support came from within the relevant ethnic congregation and its own support network, extending far and wide. The overwhelming majority of inscriptions commemorated overseas benefactors. From Bialystok to Newark, Bombay to $\mathrm{Fez}$, Jewish donors claimed a space in Jerusalem, extricating the city from its immediate locale. The Hebrew inscriptions made Jerusalem sites into nodes in global networks of piety, a complicated constellation of ethnic and religious communities. Hebrew functioned in these inscriptions as a common sacred language, binding a wide array of local congregations with worldwide Jewish diasporas. It protected and enshrined pious institutions of prayer, learning and welfare, and the memory of their benefactors. The inscriptions were neither national nor colonial; they did not invoke a mythical biblical past or lay national claim to these sites and to the city.

Stones of Memory portrays the dramatic appearance of Hebrew in the urban space of Jerusalem in the second half of the nineteenth century. As such, Grayevsky's description of the stones as "ancient" appears strange and misleading. I suggest this description referred not to the actual inscriptions but to the medium of inscriptions. By the 1920s, memorial inscriptions were becoming "history," an anachronistic mode of commemoration. The 1927 earthquake, which destroyed many buildings and prompted Grayevsky to record these inscriptions, highlighted their physical vulnerability. And yet more damaging to the longevity of the stones was the political, social, and cultural earthquake of Zionism. The communities the inscriptions spoke to and for - communities, which mostly arrived in the nineteenth century - found themselves challenged by a new kind of Jewish community, identity, and culture, whose approach to Hebrew was an abrupt disruption of longer textual traditions. Rather than a sacred tongue of a global network of communities, the Zionist movement

25 Ibid. 
presented a bold vision of the Hebrew language as a secularized tongue of a nation "like all other nations." It used Hebrew to rewrite the landscape of Jerusalem in a dramatic project of remaking land and people. Zionist activists celebrated shop signs in Hebrew, lobbied British authorities to display Hebrew signs on government buildings, demanded the use of Hebrew in telegrams, and erected street name plates in Hebrew. They cared little for grassroots commemoration: their textual practice was tied to the settler ethos of claiming the land and denying its recent history - even its recent Jewish history. Grayevsky's corpus was a desperate attempt to salvage the stones and their inscribers by

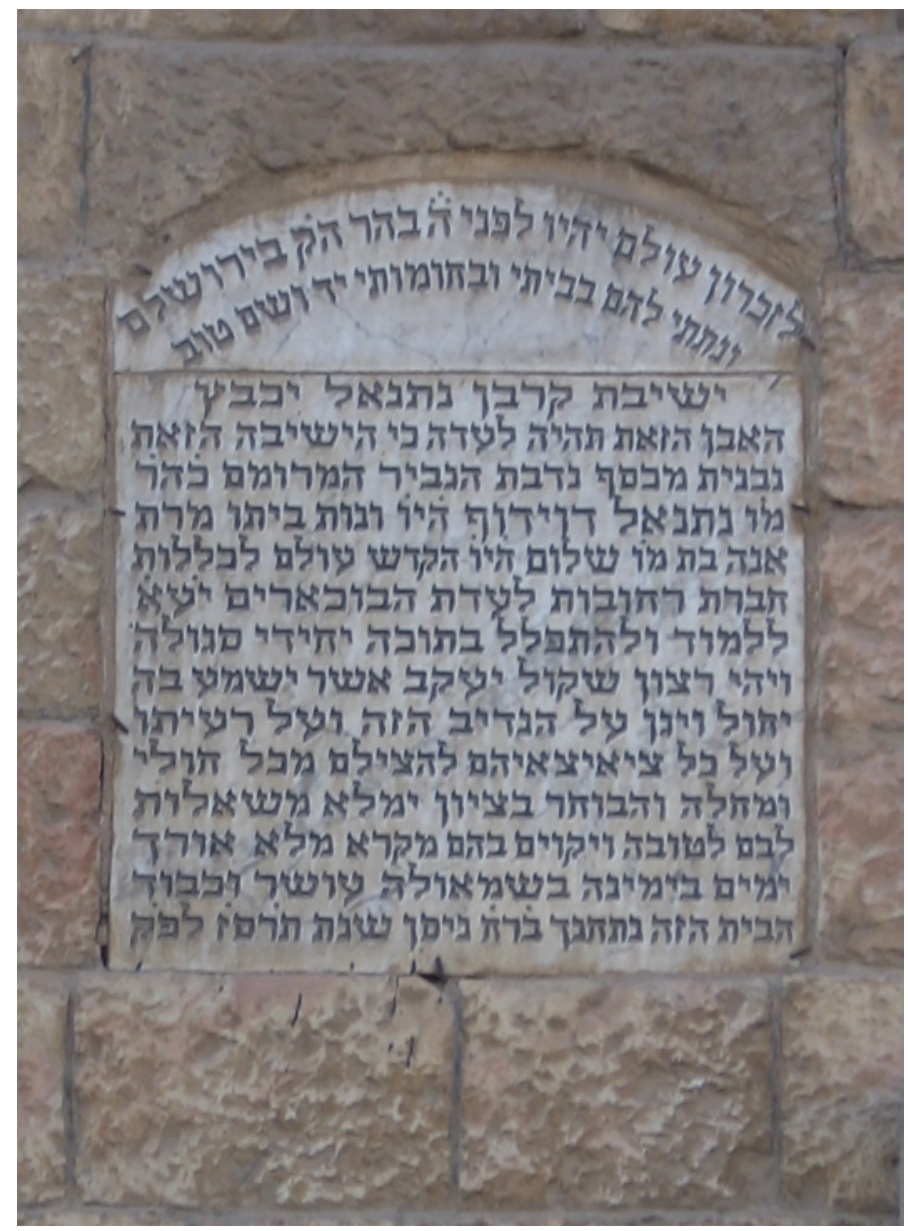

FIGURE 14.3 Dedication inscription of the Jewish religious seminary (yeshiva) in the Bukharan Quarter, built in 1927.

YAIR WALLACH, 2006. 
writing them into the Zionist narrative. But his project failed: nothing proves this better than the fact that his remarkable corpus was entirely ignored by subsequent Jewish historians of Jerusalem.

\section{Conclusion: Between Textuality and Temporality}

Sakakini's visiting card and the Hebrew stone inscriptions were very different forms of urban textuality. Sakakini's card was an ephemeral piece of card, displayed only in specific moments of encounter; the heavy stone inscriptions were affixed to specific locations, visible to many but read by few. Yet both of these forms were texts visible in the urban realm of modern Jerusalem. Both of these examples were produced in the early twentieth century, and both operated against the tension of competing frameworks of textuality: the pious, sacred text and the modern, transitory one.

Sakakini's Ottoman Jerusalem was a modern city full of promise for development, freedom, and progress. His nonsectarian humanism relied on a fresh rewriting of the city and its people, in an Ottoman Empire that, after 1908, appeared to offer civic liberties regardless of confessional and ethnic identity. Grayevsky saw Mandatory Jerusalem through the prism of traditional pious Jewish congregations. Against British support for Zionism and the Mandatory perception of Jerusalem as a polarized city, local Jewish communities attempted to define their place within a Zionist narrative, rather than a Jerusalemite or Palestinian one. Grayevsky's Jerusalem was very different to Sakakini's, and yet it is interesting to note that both these cities extended inside and outside the walls. The sharp distinction between the sacred "Old City" and the modern "New City," which was a cornerstone of British urban planning, is not found in the two men's writing.

When writing social history, urban texts present themselves as a rich and largely untapped corpus. Increasingly surrounded by urban texts of new kinds, urban subjects in early twentieth-century Jerusalem came to understand and define themselves and their world through what they read - advertisements, shop signs, name plates, and business cards. New textual media facilitated new modes of subjectivity, as people defined themselves through reading and writing in Arabic and in Hebrew. Sacred textuality, firmly anchored in divine order, was sacrificed in favor of a new textuality of flux, promising personal and social emancipation. New signs unsettled religious communities and created crisis and displacement, foreshadowing an open-ended process of renaming and redefinition, not only of buildings but also of subjects, through artifacts such as the visiting card. As Grayevsky's case shows, this could raise a series of 
questions regarding "traditional" uses of sacred languages. As Sakakini's case shows, ephemeral, urban texts were means to write the city and oneself. Both writers - Sakakini the modernist and Grayevsky the "traditionalist" - sensed the crisis of text and its wider social and political manifestations. Questions of textual validity and the link between sacred language and its modern incarnation are present in the stories of both these very different men. 


\title{
Arab-Zionist Conversations in Late Ottoman Jerusalem: Sa id al-Husayni, Ruhi al-Khalidi and Eliezer Ben-Yehuda
}

\author{
Jonathan Marc Gribetz
}

Face and discourse are tied. The face speaks. It speaks, it is in this that it renders possible and begins all discourse ... [I]t is discourse and, more exactly, response or responsibility which is this authentic relationship [with the Other].

EMMANUEL LÉVINAS ${ }^{1}$

What might a Zionist and an Arab have said to each other had they met in late Ottoman Jerusalem? How might they have attempted to understand one another's values and concerns and how might they have responded? Fortunately, we needn't guess. ${ }^{2}$ In this chapter, I analyze accounts of two such conversations that took place in Jerusalem in 1909 and were recorded

1 Emmanuel Lévinas, Ethics and Infinity: Conversations with Philippe Nemo, ed. Philippe Nemo, trans. Richard A. Cohen, 15th ed. (Pittsburgh: Duquesne University Press, 2006), 87-88. See also "Ethics and the Face" in Emmanuel Lévinas, Totality and Infinity: An Essay on Exteriority (Pittsburgh: Duquesne University Press, 2016), 194-219.

2 I am grateful to Angelos Dalachanis and Vincent Lemire for inviting me to participate in this volume and for their feedback on this chapter. I was introduced to the late Ottoman Palestinian world of Muhammad Ruhi al-Khalidi by my mentor Rashid Khalidi, to whom I remain deeply indebted. Thanks to Yfaat Weiss, Yoni Furas, and Yoni Mendel for inviting me to present the keynote lecture at the Franz Rosenzweig Minerva Research Center (at the Hebrew University) workshop on "Pedagogy of Separation: Hebrew and Arab Education in British Mandate Palestine" in summer 2016. This lecture led me back to one of the conversations analyzed here, and thus to the beginnings of this chapter. Thanks to Emanuel Beška, Sarit Kattan Gribetz, Dotan Halevy, Ethan Katz, Nadirah Mansour, and Derek Penslar for their critical comments.

(C) JONATHAN MARC GRIBETZ, 2018 | DOI:10.1163/9789004375741_020

This is an open access chapter distributed under the terms of the prevailing CC-BY-NC-ND License at the time of publication. 
on the pages of the Jerusalem-based Zionist Hebrew newspaper Ha-Tsevi. ${ }^{3}$ In both cases, the interlocutor was the paper's founding editor, Eliezer BenYehuda. His interviewees were two of the three recently-elected representatives of the Jerusalem district in the Ottoman parliament: Sa'id al-Husayni and Muhammad Ruhi al-Khalidi. ${ }^{4}$ Ben-Yehuda's reports on these conversations were published just days after the respective encounters, and scholars of the Arab-Zionist encounter have long been interested in them. In his now-classic 1976 book The Arabs and Zionism before World War I, Neville Mandel noted that al-Husayni and al-Khalidi "both were clearly opposed to Jewish settlement in Palestine" and "made their attitudes known through interviews with ha-Zevi." Mandel noticed that al-Husayni and al-Khalidi explained their opposition to Zionism in different ways: while al-Husayni contended that Palestine could not practically "support large-scale Jewish immigration," al-Khalidi, who in Mandel's view, was "more forthright and original" than his fellow parliamentarian, articulated the position that "the Arabs were in Palestine as of right and they did not owe the Jews anything."5 Mandel was a careful reader and his insights, now more than four decades old, remain instructive and compelling for any study of the early years of the Arab-Zionist conflict.

And yet, I contend, these two conversation accounts still have more to tell us about the Arab-Zionist encounter in late Ottoman Jerusalem. Because Mandel read these texts specifically to discern what they reveal about Palestinian Arab perspectives on Zionism in the years before the First World War, he was not concerned with the genre of the texts and the immediate contexts in which they were produced. In my view, however, the fact that these texts emerged from dialogue is critical. Thus, while I share Mandel's interests in early Arab responses to Zionism, I also read the interviews to ascertain in what ways the

3 The first interview, with Sa'id al-Husayni, was published on November 1, 1909, as "Two conversations. A: My conversation with Sacid Effendi," Ha-Tsevi 26, No. 28 (17 Heshvan 1841 after the destruction), 1-2. The second interview, with Muhammad Ruhi al-Khalidi, was published on November 2, 1909, as "Two conversations. B: My conversation with Ruhi al-Khalidi," Ha-Tsevi 26, No. 29 (18 Heshvan 1841 after the destruction), 1-2. On Ben-Yehuda and his newspaper Ha-Tsevi, see Hassan Ahmad Hassan and Abdul-Hameed al-Kayyali's chapter, "Ben-Yehuda in His Ottoman Milieu: An Analysis of Jerusalem's public sphere as reflected in the Hebrew Newspaper Ha-Tsevi," in this volume.

4 On the first postrevolution parliamentary election in Palestine, see Michelle U. Campos, Ottoman Brothers: Muslims, Christians, and Jews in Early Twentieth-Century Palestine (Stanford: Stanford University Press, 2011), 109-29. The third delegate elected from the broader Jerusalem province was Hafiz al-Sacid of Jaffa.

5 Neville J. Mandel, The Arabs and Zionism before World War I (Berkeley: University of California Press, 1976), 76. Mandel later changed his name to Yosef Lamdan. 
act of conversation with the Other - face-to-face engagement in which one is compelled to answer questions and provide clarifications and rationales affected both the articulation and the substance of the views expressed. In other words, I do not read these interviews as though they were prewritten speeches that might have been delivered uninterrupted at a podium or as though they were essays or diary entries that might have been written in the solitude of the author's private study. The statements found in these texts emerged in the context of interpersonal encounter, through questions, and they followed the dynamics of a historical conversation in a particular setting: a journalist's office in the Ottoman-ruled city of Jerusalem. Moreover, the questioner was neither a fellow Arab nor an ostensibly neutral journalist from abroad; he was, rather, a prominent Zionist, an active member of the movement that was the primary topic of concern in the conversations. This fact no doubt informed the way the parliamentarians answered the questions, and also permits us to study these conversations not only for what they reveal to us about the interviewees but also for what they show us about the interviewer. Ben-Yehuda was a critical actor in these encounters and his role in them should not be ignored.

What we have in these articles is Ben-Yehuda's version of the encounters. As far as I am aware, we do not have al-Husayni's or al-Khalidi's notes from the same conversations. ${ }^{6}$ Thus, while I hope to demonstrate that there is much to be gained by reading these texts closely and carefully for what was said, what was not said, and how each participant explained himself and clarified his views over the course of the conversations, we must continually be mindful that we are reading the encounters as filtered through the memory, the records, the Hebrew translation (Ben-Yehuda did not indicate in which language he conversed with al-Husayni, but with al-Khalidi he spoke French), ${ }^{7}$ and the

6 The Khalidiyya Library, the family's remarkable collection of Islamic manuscripts, newspapers, journals, and books, is a most valuable source for studies of late Ottoman Jerusalem; I remain grateful to Haifa al-Khalidi for welcoming me over the course of many weeks into the family library. I have not found there, though, any independent record of these conversations. On French as the language of conversation between Ben-Yehuda and al-Khalidi, see below. As will be addressed below, al-Husayni studied and apparently had a working knowledge of Hebrew, so it is possible that he spoke with Ben-Yehuda in that language. However, BenYehuda would likely have remarked on this in his account, and the fact that he did not suggests that they did not converse in Hebrew. Ben-Yehuda employed Arabic in his linguistic and dictionary work and, living in late Ottoman Palestine, he surely used some level of Arabic in daily life. In 1908, he recalled that in 1892 "I understood, then, only very little Arabic," apparently implying that he had since learned significantly more. See "Hanukkah," Ha-Tsevi 25, No. 56 (24 Kislev 1840 after the destruction [1908]), 2. See Yosef Lang, Daber 'Trit! : Haye Eliezer ben-Yehuda [Speak Hebrew! The life of Eliezer Ben-Yehuda] (Jerusalem: Yad Yizhak 
conscious and unconscious biases of an engaged interlocutor who presented these accounts on the pages of his own ideologically-committed newspaper.

This newspaper is one of numerous Jewish periodicals from late Ottoman and Mandate Palestine that have been digitized and made freely available on the internet through a joint venture between the National Library of Israel (NLI) and Tel-Aviv University. ${ }^{8}$ To date, seventeen Jewish periodicals from the pre-1948 period in Palestine have been digitized and made available on this website: Ha-Levanon (1863), ${ }^{9}$ Havatselet (1863, 1870-1911), Yehuda viRushalayim (1877-78), Ha-Tsevi/Ha-Or (1884-1902, 1908-15), Hashkafa (18961900, 1902-8), Ha-Me’asef (1896-1914), Ha-Po'el ha-Tsa'ir (1907-70), Ha-Herut (1909-17), Moriya (1910-15), Do'ar ha-Yom (1919-36), Palestine Bulletin/Palestine Post (1925-32, 1932-50), Davar (1925-96), Kol ha-Am (1937-75), Ha-Tsofe (1937-2008), Ha-Mashkif (1939-49), Hed ha-Mizrah (1942-44, 1949-51), and 'Al ha-Mishmar (1943-95). This archive of searchable periodicals offers researchers a veritable treasure trove of sources that can be analyzed to learn about many aspects of Palestine's late Ottoman and Mandate-era history - if mostly from the perspectives of its diverse Jewish communities. The perspectives of non-Jews, however, occasionally found their way into these papers as well, as we shall see below. The NLI has more recently started to scan its collection of Arabic periodicals from late Ottoman and Mandate Palestine through the Jrayed project. ${ }^{10}$ Thus far, twenty-seven periodicals have been at least partially scanned, with searchable authors and titles. Those published in Jerusalem

Ben-Zvi, 2008), 31, n. 109; 177, 266, 716. Lang appears to misunderstand the Arabic mawjūd in his interpretation of this story. Ben-Yehuda is not, however, listed by Eliezer Beeri as a writer and reader of Arabic. See Eliezer Beeri, Reshit ha-Sikhsukh Yisra'el-Arav, 1882-1911 [The beginning of the Arab-Israeli Conflict, 1882-1911] (Tel Aviv: Sifriyat Poalim, 1985), 187-88. On Arabic readers upon whom Ben-Yehuda relied, see Lang, Daber Tvrit!, 220, n. $21 ; 716 ;$ n. 165 . In the end, it seems most likely that, like Ben-Yehuda and al-Khalidi, BenYehuda and al-Husayni also conversed in French. I am grateful to Israel Bartal, Michelle Campos, Liora Halperin, Hanan Harif and Arieh Saposnik for discussing this matter with me.

8 Website of Historical Jewish Press, accessed January 18, 2018, http://web.nli.org.il/sites/ JPress/English.

9 Ha-Levanon, which used these Latin-script names over the course of its years of publication - Halbanon, Libanon, and The Lebanon - was initially published in Jerusalem but, after the first year, moved to Paris, then Mainz, and then London. Menucha Gilboa, Leksikon ha-Itonut ha-'Trit ba-Me'ot ha-Shemone-'Esre ve-ha-Tesha''Esre [Lexicon of Hebrew press in the eighteenth and nineteenth centuries] (Jerusalem: Mosad Bialik, 1992), 186-95. 
include al-Nafa'is al-'Asriyya (1908-24), Mira'at al-Sharq (1919-39), al-Akhbar al-Kanasiyya (1925-), al-Miya al-Hayya (f. 1935), al-Salam wa-l-Khayr (f. 1937), al-Muntada/al-Qafila (1943-47), al-Wahda (f. 1945), al-Ghadd (1945-47), alMustaqbal (1945-48), al-Dhakhira (1946-47), and al-Minbar (1947-48). This electronic archiving of the diverse newspapers of late Ottoman and Mandate Palestine opens endless windows onto the city's many communities and neighborhoods - and perspectives. In peering through one such window, the present chapter is indebted to this press archival project.

\section{Conversation Partners}

Before we examine the reports of these interviews, let us introduce the figures involved, though for those more familiar with late Ottoman Jerusalem none of the three require an introduction. ${ }^{11}$ Eliezer Ben-Yehuda (1858-1922) was born Eliezer Yitshak Perelman in Luzhki, a Lithuanian village in the Russian Empire, to a Hasidic Jewish family. ${ }^{12}$ He received the standard young Jewish boy's education in a heder before leaving to study in a yeshiva. In the yeshiva in Polotsk, Perelman was exposed not only to Talmudic literature, the core of the elite Jewish male curriculum, but also, clandestinely, to secular and linguistic writings in Hebrew. Eager to pursue his secular studies, he travelled to Paris in 1878. During his four years there, he came to espouse a form of Jewish nationalism focused on the Land of Israel and the Hebrew language (he signed his first major published essay on the subject with the name Eliezer Ben-Yehuda, a name he used from that point forward). In 1881, he immigrated to Palestine and settled in Jerusalem where, from the start, he engaged in Hebrew journalism. At first, he found employment on the staff of an existing Hebrew newspaper, Havatselet (Lily). Later he founded his own newspaper, which, over the years, had different names: Ha-Tsevi (The Gazelle), Ha-Or (The Light), and Hashkafah (Outlook). ${ }^{13}$ Ben-Yehuda's papers were generally edited by him and his family, especially his wife Hemda and his son Itamar Ben-Avi (son of "Avi," which

11 The biographical information I provide here on Ben-Yehuda and al-Khalidi has appeared previously in Jonathan Marc Gribetz, Defining Neighbors: Religion, Race, and the Early Zionist-Arab Encounter (Princeton: Princeton University Press, 2014).

12 For a thorough biography of Ben-Yehuda, see Lang, Daber 'vrit!

13 Initially, from 1896 to 1900 , Hashkafa was published as a diaspora-oriented supplement to Ha-Tsevi, but later, from 1902 to 1908 , it replaced Ha-Tsevi, which closed due to tensions with the Ottoman authorities. See "Hashkafa," Historical Jewish Press, accessed January 18, 2018, http://web.nli.org.il/sites/JPress/English/Pages/hashkaf.aspx. 
literally means "my father," but is also an acronym of Eliezer Ben-Yehuda). In conjunction with his Hebrew journalism, Ben-Yehuda also aimed to help transform Hebrew from only a written language into one of daily spoken use as well. His linguistic project included the creation of neologisms for modern items and concepts and the production of a new, multivolume Hebrew dictionary to help define and expand the vocabulary of Palestine's newly Hebrew-speaking Jewish population. But it was in his role as a journalist - not a linguist - that, nearly three decades after his immigration to Palestine, Ben-Yehuda met with his partners in the conversations under analysis here: Sacid al-Husayni and Muhammad Ruhi al-Khalidi.

Sacid al-Husayni (1878-1945) hailed from one of the most notable Muslim families in Jerusalem. Members of the Husayni family had regularly held the positions of Hanafi mufti of Jerusalem, shaykh al-haram, and naqīb al-ashräf since at least the eighteenth century. ${ }^{14}$ The family owned significant property within and beyond Jerusalem. ${ }^{15}$ Sa'id's father, Ahmad Rasim al-Husayni, had received a traditional Islamic education and, after a career in commerce, was appointed naqīb al-ashrā $f .{ }^{16}$ In contrast, according to historian Rashid Khalidi,

14 For Sa'id al-Husayni's biographical data, I rely largely on Rashid Khalidi, Palestinian Identity: The Construction of Modern National Consciousness (New York: Columbia University Press, 1997), 68-69. See also Muhammad Y. Muslih, The Origins of Palestinian Nationalism (New York: Columbia University Press, 1988), 82. On the Husayni family's religious administrative positions in Ottoman Jerusalem, see Butrus Abu-Manneh, "The Husaynīs: The Rise of a Notable Family in 18th Century Palestine," in Palestine in the Late Ottoman Period: Political, Social, and Economic Transformation, ed. David Kushner (Jerusalem: Yad Izhak Ben-Zvi, 1986). Abu-Manneh notes that those who held these religious and other administrative positions were, since the late eighteenth century, the descendants of Sayyid 'Abd al-Latif b. 'Abdallah b. 'Abd al-Latif (d. 1775).

15 See entry on "al-Ḥusayni, Sa'id," in Adil Manna, A'lam Filastinfi awakhir al-'ahd al-'uthmani: (1800-1918) [The notables of Palestine at the end of the Ottoman Period, 1800-1918] (Beirut: Institute for Palestine Studies, 1995), 129-30. See also "Sacid al-Ḥusayni" in Muhammad 'Umar Hamada, Alam Filastin: min al-qarn al-awwal hatta l-khamis 'ashara hijri, min alqarn al-sabi' hatta l-ishrin miladi [The notables of Palestine: from the first century until the fifteenth century AH, from the seventh century until the twentieth century AD], vol. 4 . (Damascus: Dar al-Qutaiba, 2000), 31.

16 On the naqīb al-ashräf, see Abla Muhtadi and Falestin Naill's chapter, "Back into the Imperial Fold: The End of Egyptian Rule as Portrayed in the Court Records of Jerusalem, 1839-1840," in this volume, as well as Vincent Lemire and Yasemin Avcl, "De la modernité administrative à la modernisation urbaine: une réévaluation de la municipalité ottomane de Jérusalem (1867-1917)," in Municipalités méditerranéennes. Les réformes urbaines ottomanes au miroir d'une histoire comparée (Moyen-Orient, Maghreb, Europe méridionale), ed. Nora Lafi (Berlin: Klaus Schwarz, 2005). 
Sacid "received a modern education from the outset, culminating in a time at a school run by the Alliance Israélite [Universelle] sufficient for him to learn Hebrew."17 Al-Husayni's Hebrew knowledge was put to use as he served for some time as the Ottoman censor of the Hebrew press. In 1905, he was elected head of the Jerusalem city council;18 he also served other Ottoman official roles in the Jerusalem province, including as head of the government's education division. ${ }^{19}$ After the Young Turk Revolution and the reinstitution of the Ottoman parliament, he was elected in 1908 as one of the representatives of the province of Jerusalem. Toward the end of the Great War, al-Husayni joined the Arab Revolt and, immediately after the war, served briefly as foreign minister of Faysal's short-lived government in Syria under Prime Minister 'Ali Rida al-Rikabi. ${ }^{20} \mathrm{Al}-\mathrm{Husayni}$ lived almost until the end of the British Mandate

17 Khalidi, Palestinian Identity, 69. See also Mandel, The Arabs and Zionism, 65. On the Alliance schools in Palestine, including the vocational school for boys founded in Jerusalem in 1882, see Jacob M. Landau, "The Educational Impact of Western Culture on Traditional Society in Nineteenth Century Palestine," in Studies on Palestine during the Ottoman Period, ed. Moshe Ma'oz (Jerusalem: Magnes Press, 1975), 501-2. On the efforts and opposition to teaching Hebrew in the Alliance's Jerusalem school system, see Michael M. Laskier, "Aspects of the Activities of the Alliance Israélite Universelle in the Jewish Communities of the Middle East and North Africa: 1860-1918," Modern Judaism 3, no. 2 (1983): 157. For an example of the schedule of subjects taught in the Alliance's Jerusalem school in the late nineteenth century, see the 1892 "École de l'Alliance Israélite à Jérusalem: Programme des Classes," vol. 2, p. 316, in the Alliance Israélite Universelle's file at the Central Archives for the History of the Jewish People in Jerusalem. The languages included in the academic program were Arabic, French, Hebrew, and Turkish. According to Ben-Arieh, "the first to recognize the importance of the [Alliance] school were not Jews but gentiles, among them the district governor and the Khalidi and alHusseini families." Yehoshua Ben-Arieh, Jerusalem in the 19th Century: Emergence of the New City (Jerusalem: Yad Yizhak Ben-Zvi, 1986), 269. On Arab students in a different Alliance school in Palestine, the Mikveh Israel agricultural school near Jaffa, see Amin Khalaf and Dotan Halevy, "Ke-Gerim ba-'Arets: Bet ha-Sefer ha-Hakla'i Mikveh Yisra'el ve-Talmidav ha-Aravim, 1870-1939" [Foreigners in their country: the Mikveh-Israel Agricultural School and its Arab students, 1870-1939], Zmanim 135 (2016).

Manna, Alam Filastin, 129. According to Michael Fischbach, al-Husayni was mayor of Jerusalem from 1902 to 1906. See Philip Mattar, ed., Encyclopedia of the Palestinians (New York: Facts on File, 2005), s.v. "al-Husayni (family)."

19 Campos, Ottoman Brothers, 121.

20 Manna, Alam Filastin, 129-30; Muslih, The Origins of Palestinian Nationalism, 119; Hamada, A'am Filastin, 4:31. 
era and, according to historian Adel Manna, largely avoided politics during that period. ${ }^{21}$

In the Ottoman parliament, al-Husayni's senior colleague from Jerusalem (and the candidate who ultimately won the most votes in the final round of voting ${ }^{22}$ was Muhammad Ruhi al-Khalidi (1864-1913). Al-Khalidi grew up in Jerusalem's Old City in a home just steps away from Bab al-Silsala, the Chain Gate entrance to the Noble Sanctuary/Temple Mount complex. ${ }^{23}$ Like the Husaynis, the Khalidis were among the small number of elite Sunni Muslim Arab families in Ottoman Jerusalem that played central roles in the economic, political, and religious life of the holy city. Muhammad Ruhi's uncle, Yusuf Ziya' al-Khalidi (1829-1906), ${ }^{24}$ served as mayor of Jerusalem and as one of Jerusalem's representatives in the first, short-lived Ottoman parliament. Muhammad Ruhi (known as Ruhi) was educated in Sunni religious schools in Jerusalem. The Shāfíi mufti of Jerusalem certified that al-Khalidi had completed training in all the classical subjects of the Islamic curriculum. He continued his religious studies in Nablus, Tripoli, and Beirut as his father Yassin took up various Ottoman-appointed religious positions in these different cities. By the age of fifteen, al-Khalidi had been granted a scholarly title in the Ottoman Islamic religious hierarchy by none other than the Shaykh al-Islam in Istanbul. ${ }^{25}$ If al-Khalidi's education began in a distinctly religious context, it soon extended into realms beyond traditional pious training (and, in this sense, his experience can be seen as a parallel to Ben-Yehuda's). As al-Khalidi became a young man, he acquired those elements of a Western education that began to be offered in the new Ottoman state schools, ${ }^{26}$ and, like al-Husayni, even at the Jewish Alliance Israélite Universelle school in Jerusalem, where he

21 Manna, Alam Filastin, 129-30. Manna notes one exception: in 1928 al-Husayni was a member of the Islamic conference for the defense of the Aqsa mosque and the Islamic holy place.

22 Campos, Ottoman Brothers, 121.

23 This presentation of al-Khalidi's biography follows the one I provide in Gribetz, Defining Neighbors.

24 In a letter written on March 1, 1899, in French, to Zadoc Kahn, al-Khalidi rendered his name Yusuf Zia al-Khalidy. The letter is found in the Central Zionist Archives, file Hig7.

25 Khalidi, Palestinian Identity, 76-77.

26 Al-Khalidi studied at the Rüşdiye schools in Jerusalem and Tripoli and at the Sultaniye schools in Beirut. Ibid. For a concise overview of the development of various forms of education in Palestine, see Ami Ayalon, Reading Palestine: Printing and Literacy, 1900-1948 (Austin: University of Texas Press, 2005), 19-39. See also Rashid Khalidi, "Intellectual Life in Late Ottoman Jerusalem," in Ottoman Jerusalem: The Living City, 1517-1917, ed. Sylvia Auld and Robert Hillenbrand (London: Altajir World of Islam Trust, 2000), 225. 
too studied briefly. ${ }^{27} \mathrm{Al}$-Khalidi's secular studies began in Palestine, but they continued with much greater intensity when he left the Levant. In 1887, at the age of twenty-three, al-Khalidi went to the Ottoman capital, where he studied at the Mekteb-i Mülkiye (Civil Service School). Following more than six years of study in Istanbul, al-Khalidi, nearly thirty, traveled to Paris -the city from which Ben-Yehuda had migrated just six years earlier. There he undertook a three-year course in political science and then enrolled in the École Pratique des Hautes Études. Under some of the most distinguished French orientalists of the day, he studied the philosophy of Islam and Eastern literature. Al-Khalidi even went on to a brief career as an academic in France, teaching Arabic to students and scholars of oriental studies. In 1898, al-Khalidi transitioned from academia to politics, taking up the position of Ottoman consul general in Bordeaux. He served in this role for a decade, until 1908, the year of the Young Turk Revolution in the Ottoman Empire, when he returned to Palestine in his bid for a seat in the new parliament.

Though Jews and Christians were among the numerous parliamentary candidates from the Jerusalem district, the winners were three Muslims; Jewish and Christian candidates appear to have split their respective communities' votes and thus none emerged victorious. ${ }^{28}$ Nonetheless, despite some controversy in the midst of the election, during which Sa'id al-Husayni was accused by some of anti-Semitism, the Jewish community appeared to welcome optimistically the election of Jerusalem's parliamentarians. At a celebration thrown for the three in Jerusalem in October 1908, David Yellin, an unsuccessful Jewish candidate for the same office, played on the meaning of the Arabic names of the three winners: Ruhi (my spirit) "will revive the spirit;" Sacid (happy) "will make us happy;" and Hafiz (guard) "will guard and protect our rights." ${ }^{29}$

After the parliamentarians' first year in office, some in the Jewish community of Palestine were less confident than Yellin may have been at that postelection party. It was precisely in this context of concern that Ben-Yehuda arranged to interview al-Husayni and al-Khalidi, just before they were to return to Istanbul after their visit back to their hometown in October 1909. In

27 Khalidi, Palestinian Identity, 77. According to al-Khalidi himself, he did not know Hebrew, though it is not clear whether he meant that he had never studied Hebrew or that he never advanced sufficiently in the language to become proficient. See "Interview with Ruhi Effendi: Our Representative in Constantinople," Ha-Tsevi 25, No. 20 (7 Heshvan 1840 after the destruction/November 2, 1908), 1.

28 Campos, Ottoman Brothers, 119.

29 Ha-Tsevi, October 27, 1908, 2. Cited also in Campos, Ottoman Brothers, 126. All translations of $\mathrm{Ha}$-Tsevi articles are my own. 
his introductory remarks, Ben-Yehuda explains, "I wanted to hear from them before they departed their thoughts on the status of matters in the empire generally, and I wanted in particular to hear their thoughts on and attitude toward the issues that most concern us Jews." Ben-Yehuda notes that he sought out these interviews and wished to address the matters most sensitive to his community and to his readers because "it is always preferable to know the state of the issue as it is, whether good or bad." ${ }^{30}$

In Ben-Yehuda's opinion, understanding the perspectives of Jerusalem's parliamentary representatives was critical at this point not simply because these were influential individuals but because Ben-Yehuda anticipated that a debate on the issue of Zionism would soon take place in parliament. ${ }^{31}$ "The hour is very important," Ben-Yehuda wrote in Ha-Tsevi, as "there is no doubt that one of the first questions that the parliament will deal with after it is opened now is the question of Jews' coming to the Land of Israel." Ben-Yehuda reasoned that, while "the fate of this question will not depend entirely on the three representatives from the Land of Israel alone," he believed that their perspective as natives and representatives of the province would be granted "great weight on the parliament's scales in deciding this way or that." This was not only because their views would be respected but also because "with them will go also the representatives of Syria and, one thinks, all of the Arab representatives." Ben-Yehuda assumed that the Arab delegates in the parliament would fall in line with whatever position Palestine's own Arab representatives presented. He acknowledged that, "notwithstanding their large number in our parliament," the Arab members "do not alone control the fate of the question" of Jewish immigration to Palestine. But he insisted that while there may be

30 The record of the conversation described here is found in "Two conversations. A: My conversation with Sa'id Effendi."

31 On the parliament's first consideration of Zionism in 1909, see Mandel, The Arabs and Zionism before World War I, 72. On the eventual debates on Zionism in the Ottoman parliament in 1911, see ibid., 93-116; Louis Fishman, "Understanding the 1911 Ottoman Parliament Debate on Zionism in Light of the Emergence of a 'Jewish Question," in Late Ottoman Palestine: The Period of Young Turk Rule, ed. Yuval Ben-Bassat and Eyal Ginio (London: I. B. Tauris, 2011); Julia Phillips Cohen and Sarah Abrevaya Stein, eds., "A Debate on Zionism in the Ottoman Parliament (1911)," in Sephardi Lives: A Documentary History, 1700-1950 (Stanford: Stanford University Press, 2014); Emanuel Beška, "Anti-Zionist Attitudes and Activities of Rūḥ̄ Al-Khālidī," in Arabic and Islamic Studies in Honour of Ján Pauliny, ed. Zuzana Gažáková and Jaroslav Drobný (Bratislava: Univerzita Komenského v Bratislave, 2016), 184-88. See also chap. 7 in Vincent Lemire, Jerusalem 19oo: The Holy City in the Age of Possibilities, trans. Catherine Tihanyi and Lys Ann Weiss (Chicago: University of Chicago Press, 2017). 
some in the parliament who view the issue differently from the representatives of Jerusalem and the Arab provinces, "it seems we do not have many friends among the rest of the elements in parliament and we are not even certain how the few Jewish representatives will relate to this question." In other words, BenYehuda concluded that there was no denying the fact that "the opinion of our parliamentarians, [those] of Jerusalem, is crucial."

\section{"What is the Meaning of 'Mass'?" Defining Terms, and Positions, in Conversation}

At their meeting on Friday, October 29, 1909, Ben-Yehuda explains that he implored al-Husayni to speak candidly even about sensitive and uncomfortable matters, "even on matters and questions that are close to me and touch me most personally as a Jew." Ben-Yehuda recalled telling al-Husayni that "we live now in a free country, ${ }^{32}$ consisting of many groups and nations. Each group and each nation guards its interests and we have to get used to this and accept it, to live in personal friendship with one another, even as the group and national questions separate us." Ben-Yehuda notes that he assured al-Husayni that he would only put on the record that which al-Husayni permitted and that "I would not publish anything except that which he permitted me to publish." Ben-Yehuda presumably knew that al-Husayni could read Hebrew and had previously served as Hebrew press censor - a censorship regime that led to BenYehuda's brief imprisonment in $1893 .{ }^{33}$ So Ben-Yehuda was, we might imagine, especially careful both to record the conversation accurately but also to be sure not to include elements of the conversation al-Husayni wished not to make public.

Initially Ben-Yehuda posed a number of questions about matters of general concern to the empire. First, he asked about politics at the highest level of the imperial administration, focusing particularly on the seemingly tense relationship between Grand Vizier Hilmi Pasha, on the one hand, and the Young Turks

32 In Hebrew, "mamlakha hofshit," lit. free kingdom.

33 Eliezer Ben-Yehuda, Eli'ezer ben-Yehuda be-Vet ha-Asurim, Hanuka 654/1893: Igrot [Eliezer Ben-Yehuda in prison, Hannukah 654/1893], ed. Yehoshua Kaniel (Jerusalem: Yad Izhak Ben-Zvi, 1983). On the corresponding Ottoman archival documents, see Michael Talbot, "Jews, Be Ottomans!' Zionism, Ottomanism, and Ottomanisation in the Hebrew-Language Press, 1890-1914," Die Welt des Islams 56, nos. 3/4 (2016): 368-70. 
and the Committee of Union and Progress newspaper Tanin, on the other. ${ }^{34}$ Al-Husayni responded that he had not noticed any major opposition to Hilmi Pasha. Ben-Yehuda then turned to ordinary constituent concerns: policing, postal services, and taxes, contending that nothing had changed since the reinstitution of the parliament. "What," Ben-Yehuda asked, "did the parliament do during its first session?" From the written source we have, it is difficult to discern the tone of the question but, on the surface, the question does not sound particularly obsequious, as Ben-Yehuda seems to think that, in fact, the parliament had not accomplished very much at all. ${ }^{35}$ Nonetheless, the question permitted al-Husayni to tout the parliament's accomplishments; his answer to this question is the longest of all. Despite the many challenges, boasted alHusayni, the parliament approved a budget and "instituted many good laws in all areas of internal governance," though one cannot expect "to turn everything around overnight." After al-Husayni presented this defense of the work done in the parliament's first session, Ben-Yehuda asked about what to expect from the second session that was about to begin. Again al-Husayni noted the task of setting the government's budget and other routine matters. It is worth noting that, at least as far as Ben-Yehuda presents the conversation to his readers, he did not probe further on any of the matters al-Husayni discussed in his answers. He asked the question, listened to al-Husayni's response, and moved on to the next subject.

This dynamic changed when Ben-Yehuda finally broached "perhaps the most difficult point in our conversation," namely the question of Jewish settlement in Palestine. Again, Ben-Yehuda notes that he beseeched al-Husayni to be frank in his answer to how he would relate to this question should it soon appear on the parliamentary agenda. Al-Husayni reportedly responded as follows:

Sir, I believe the Jews have many important merits. They are intelligent, sharp, nimble, industrious, work-loving, energetic and frugal. The Jews will truly be able to be a model for other residents in the empire, and there is no doubt that they will bring much benefit to the empire and its residents anywhere they settle. Therefore, Turkey [the Ottoman Empire]

On Tanin, see Hasan Kayalı, Arabs and Young Turks: Ottomanism, Arabism, and Islamism in the Ottoman Empire, 1908-1918 (Berkeley: University of California Press, 1997), 54.

35 This sentiment appears even more clearly in the account of Ben-Yehuda's interview with al-Khalidi the following day, when Ben-Yehuda reports that he asked al-Khalidi: "What about the issue of the necessary reforms in all spheres of domestic leadership? Thus far we see almost nothing in reality." 
must accept them with truly open arms. However, both for the Jews' own sake, and for the sake of the empire and the rest of its residents, it is best that the Jews settle in all provinces of the empire and not concentrate in one place [be-maḳom ehad].

Here, al-Husayni, speaking directly to, and presumably looking in the eyes of a Jew, lavishes praise on his interlocutor's people. But al-Husayni insists that, for everyone's sake, Jewish immigrants to the Ottoman Empire ought to scatter throughout it rather than concentrate in "one place." 36

Ben-Yehuda expressed agreement with this view. "I agree in essence," he responded. We must recall that Ben-Yehuda, just a few years earlier, openly supported the so-called "Uganda Plan" to found a Jewish state, at least temporarily, in East Africa. Indeed, he had published a book of his essays on the subject in 1905 called Ha-Medina ha-Yehudit: Ma'amarim Shonim 'al Devar Hatsa'at Mizrah Afrika (The Jewish state: various articles on the East Africa proposal). ${ }^{37}$ Having lived in Ottoman Jerusalem since the early 1880s, Ben-Yehuda was well aware of the challenges that faced the Jewish national colonial project in Palestine and in the Ottoman Empire more broadly. ${ }^{38}$ By 1909 , as he sat with al-Husayni, however, the East Africa proposal was no longer on the table and, notwithstanding the Territorialist splinter group, Palestine was once again the primary focus of Jewish nationalist aspirations.

Unlike earlier in the conversation, Ben-Yehuda, upon hearing al-Husayni's answer, did not simply move on to the next topic. He followed up and delved deeper, wishing to know what al-Husayni's answer implied for Palestine. BenYehuda asked: "But is there one place [makom ehad, repeating, at least in his translation, the very phrase al-Husayni had used] in the empire in which it is not desirable for Jews to settle? Let us speak directly: Is it undesirable that Jews

$3^{6}$ Calling upon Jewish immigrants to scatter throughout the empire was a standard Ottoman position at this time. See the reports on the visit of Ottoman parliamentarians to London in July 1909 (and note the newspaper's rejection of this Ottoman demand). "Jews and Turkey," The Jewish Chronicle, July 23, 1909, 4. On Ottoman perceptions of Jews as "potentially useful agents of Mediterranean commerce" and as "agents of colonial development," see Jacob Norris, Land of Progress: Palestine on the Age of Colonial Development, 1905-1948 (Oxford: Oxford University Press, 2013), 80.

37 Eliezer Ben-Yehuda, Ha-Medina ha-Yehudit: Ma'amarim Shonim 'al Devar Hatsa'at Mizrah Afrika [The Jewish state: assorted articles on the East Africa proposal] (Warsaw: Medina, 1905).

38 See, especially, the implied contrast to the challenges of settling Palestine in ibid., 23-24. 
continue to settle in Palestine?"39 To this, al-Husayni responded: "My opinion is there is not space in this land for mass immigration [le-viat mehagrim behamon rav]. There is no room and the land is not prepared for it."

Ben-Yehuda pursued the matter once again, pushing al-Husayni to articulate in detail the implications of his position, this time by calling upon al-Husayni to define his terms. "But what is the meaning of 'mass' [hamon rav]?" in "mass immigration," Ben-Yehuda asked, noting that "this concept is not clear." Al-Husayni reportedly replied as follows:

Of course, I am not speaking of individuals who wish to come to settle here, and not even of families, not of tens and not even of hundreds. I am speaking of mass immigration, in the tens of thousands, in the hundreds of thousands. For a mass immigration of this sort, my opinion is that there is no room in Palestine and that it will damage not only the land generally but also the Jews and the newcomers themselves. But, as I said, the settlement of individuals, of families, even of tens and hundreds, I do not see any reason not to want this, and Turkey must accept the Jews coming not en masse everywhere in the empire, with no exception.

Here, al-Husayni, addressing a Zionist Jew who had immigrated to Palestine with his wife more than two decades earlier, did not delegitimize his interviewer's own immigration. "Tens and hundreds" - it is not clear in the text whether he meant "tens and hundreds" of individuals or of families - could still immigrate to Palestine without any problem. Through Ben-Yehuda's probing, al-Husayni was compelled to identify a threshold number for his concern about Jewish immigration: "tens of thousands" or "hundreds of thousands."

The conversation yielded two important conclusions that might not otherwise have emerged in this way. First, Ben-Yehuda expressed agreement in principle with al-Husayni's reservations about concentrating Jews in one location within the Ottoman Empire. The suggestion that it might not be wise for Jews to become demographically concentrated in a single place was not to be expected from a former advocate of the East Africa proposal. On the contrary, Ben-Yehuda had been attracted to the East Africa proposal precisely because it permitted immediate Jewish demographic concentration and autonomy in a single place. One might wonder whether Ben-Yehuda expressed agreement with al-Husayni simply in order to gain a more sympathetic answer to his next question. However, this appears not to have been the case given that 
Ben-Yehuda chose to publish this agreement for his readers to see rather than omitting that sentiment from his article. It seems Ben-Yehuda actually did agree, at least in principle, with al-Husayni's concern in this regard. Second, while al-Husayni might, in other contexts, have simply stated his opposition to mass Jewish immigration to Palestine, by meeting with a Zionist Jew who had himself settled in Palestine, al-Husayni was compelled to be more precise, to identify the potentialities that truly worried him, and those that were not of real concern. In an era in which the Jewish population of Palestine had barely reached fifty thousand, ${ }^{40}$ hearing from a Palestinian Arab political leader that there would be no opposition to the immigration of hundreds or even thousands of Jews to Palestine was, indeed, significant.

Ben-Yehuda reports that he discussed the matter further and in more detail with al-Husayni, but these more private statements were not permitted to be published. The only off-record statement Ben-Yehuda wrote was this: "Sacid Effendi acknowledges the cultural benefit of the Jewish element in this land. With one condition: that we will all be equal, Arabs and Jews, that is, that the Jews will also be Ottomans like the Arabs, and not foreigners standing under the protection of foreign governments." Earlier that same year, Ben-Yehuda had undertaken an aggressive, four-month campaign (with the motto "Jews, be Ottomans!") to persuade Jewish immigrants to Palestine to adopt Ottoman citizenship in order to participate in Ottoman electoral politics. ${ }^{41}$ Therefore, al-Husayni's call for Jewish Ottomanization was not unwelcome, even if BenYehuda's motivations were entirely different from those of his interlocutor.

\section{"We Didn't Conquer the Land from You": Personal and National History in Conversation}

As we see, a careful look at Ben-Yehuda's conversation with al-Husayni reveals far more than the latter's view that Palestine cannot "support large-scale Jewish immigration," as Mandel noted. The dynamic conversation, at least as it is recorded on the pages of Ha-Tsevi, compelled each participant more clearly to articulate his views and, perhaps, even to moderate them. Let us turn now to the second of the two interviews Ben-Yehuda conducted with Jerusalem's

40 See Justin McCarthy, The Population of Palestine: Population History and Statistics of the Late Ottoman Period and the Mandate (New York: Columbia University Press, 1990).

41 Talbot, "Jews, Be Ottomans!," 379. See also Arieh Bruce Saposnik, Becoming Hebrew: The Creation of a Jewish National Culture in Ottoman Palestine (Oxford: Oxford University Press, 2008). 
parliamentarians, the interview with Ruhi al-Khalidi that took place on Saturday, October 30, 1909. ${ }^{42}$

This interview, which Ben-Yehuda published on November 2, 1909, was not his first with al-Khalidi. Exactly one year earlier, soon after the Young Turk Revolution and the new parliamentary elections, Ben-Yehuda published a report on a meeting he had with al-Khalidi in the latter's "small, European salon" in Jerusalem. In this article, "An Interview with Ruhi Effendi: Our Representative in Constantinople," Ben-Yehuda described al-Khalidi in glowing terms. "Of the three representatives" of the Jerusalem province in the Ottoman parliament, "there is no doubt that Ruhi Effendi is the most interesting not only because of his past but also because of his education and the feelings that beat in his heart." Ben-Yehuda's report highlighted al-Khalidi's European orientation - "the French language and European culture greatly attracted his heart" - and his liberal approach to politics. More than once in the course of the hour-long interview, conducted in French ("Ruhi Effendi speaks beautiful, fast French," remarked Ben-Yehuda), al-Khalidi justified this liberal approach in religious terms. "Despotism is not Islamic," he told BenYehuda. "On the contrary, the law $\left[\right.$ tora $\left.^{43}\right]$ of Islam leans toward liberalism [le-hafshanut]."44 The interview, according to Ben-Yehuda, was most congenial, as he and al-Khalidi talked and laughed. In their conversation, the two focused almost exclusively on broad, imperial matters - on the sultanate, the Young Turk Revolution, freedoms, the need for members of the old guard to continue to participate in the government, and the Shaykh al-Islam. "It would have been interesting to know what Ruhi Effendi's attitude is toward the Jews, the Arabs and the Land of Israel," Ben-Yehuda wrote at the end of his article, but they ran out of time. These matters were surely on Ben-Yehuda's mind during the interview, but raising them would clearly have altered the friendly, collegial tone; Ben-Yehuda, it seems, therefore hesitated in raising the question of Jews and Arabs in Palestine until it was too late. Al-Khalidi, however, promised that there would be another opportunity to continue the conversation.

A year later, al-Khalidi kept his promise. Ben-Yehuda reintroduced alKhalidi in respectful terms to Ha-Tsevi's readers as a "modern man" (ish hadish), a politician who served as Ottoman consul in Bordeaux, and thus engaged with the political world, and who also participated in the world of

42 The record of the conversation described here is found in "Two conversations. B. My conversation with Ruhi al-Khalidi."

43 Torah, in this context, could alternatively be rendered "instruction."

44 Later in the interview, al-Khalidi apparently declared that "among the camp of muftis there are a great many liberals [Hafshanim] because the law of the Muslims is truly liberal [hofshit]." 
letters and the academy, through his writing and research on Islam and the Arabs. According to his report, Ben-Yehuda began the conversation by telling al-Khalidi that he wished to speak with him

not only as an acquaintance and friend ever since the bad days, when we had to close the door behind us and to whisper out of fear that perhaps the spies of [Sultan] 'Abd al-Hamid were sneaking on us and listening to our words, but also to speak with him about the status of matters in the empire generally and about issues that particularly concern us Jews.

At the start of his conversation with al-Khalidi, Ben-Yehuda highlighted their apparently long friendship and their shared loathing of the prerevolutionary order, which Ben-Yehuda called the "rule of tyranny." Ben-Yehuda also acknowledged that the issues he was to raise were personally significant, speaking as he did not of Jews but of "us Jews [lanu ha-yehudim]."

As in his interview with al-Husayni the previous day, Ben-Yehuda's first question concerned broader imperial politics, focusing especially on Grand Vizier Hilmi Pasha. Al-Khalidi was effusive in his praise of Hilmi Pasha with whom he had a close, personal relationship. Unlike al-Husayni, who saw no threat to Hilmi Pasha's rule, however, al-Khalidi viewed the days of his governance as numbered, though he doubted there was anyone at that time who was properly prepared to succeed him. Ben-Yehuda then asked about whether Hilmi Pasha had demonstrated sufficient independence from the sultan noting a report about Hilmi Pasha's having exhibited excessive deference to the sultan. Al-Khalidi reminded Ben-Yehuda that the prerevolutionary ethos of submissiveness to the sultan would take time to dissolve. However, he suggested that it was not a critical problem in the independent constitutional governance of the empire. The conversation then turned to specific policies, including land taxes, policing and the postal system. Ben-Yehuda's article offers some details about these discussions, noting that al-Khalidi continued to remind Ben-Yehuda that the parliament had only had one year of activity and that the necessary reforms would take time.

Unlike the previous year, Ben-Yehuda raised the issues that mattered most to him early in the conversation, which left sufficient time for them to be discussed. It is impossible to know the exact reason why Ben-Yehuda broached these topics in 1909 when he had failed to do so in 1908. A variety of explanations include: an increased sense of urgency about what the parliament would do concerning Zionism, his greater sense of familiarity with al-Khalidi, a heightened confidence from being in his own office rather than in al-Khalidi's salon, or simply that he regretted not having had the conversation in 1908. 
In any case, the final subject of the conversation was indeed the "difficult topic," namely Jewish immigration to Palestine. In this more uncomfortable but most important part of the conversation, Ben-Yehuda began with the matter of the so-called "Red Note" policy limiting the length of Jews' visits to Palestine. ${ }^{45}$ According to his report, Ben-Yehuda did not simply ask al-Khalidi for his views on the policy; Ben-Yehuda first asserted his own perspective. "This note," he told al-Khalidi, "is an affront to our rights as Ottoman citizens and an offense to our honor in the eyes of the people of the land." This was BenYehuda's entry point into a broader conversation about "the matter of Jews coming here" - a subtle way of naming Zionism and Jewish immigration to Palestine. Before recounting the conversation about these issues, Ben-Yehuda notes with appreciation that al-Khalidi did not hold back his views and BenYehuda deemed it important to share them with his readers "even though they are not particularly pleasant to us" (af'al pi she-'enam ne'imim lanu be-yoter). It was important for his readers to learn these views, noted Ben-Yehuda, so that they knew what to expect from al-Khalidi once the issue of Zionism appeared on the parliament's agenda.

Al-Khalidi reportedly began his response by noting that he already had an opportunity to discuss this topic in London at a dinner for Palestine's Ottoman parliamentarians hosted by "the Zionists," "led by Sir Claude Montefiore." (This meeting was actually hosted by Francis Abraham Montefiore, honorary chairman of the English Zionist Federation; Claude Montefiore was not a Zionist but rather an avowed anti-Zionist Anglo-Jew, as will be discussed below. ${ }^{46}$ Then al-Khalidi presented his assessment of the problem:

45 On the tazkra or Red Note (sometimes rendered Red Paper or Red Slip) policy that limited Jews' visits to Palestine generally to three months, see Gur Alroey, An Unpromising Land: Jewish Migration to Palestine in the Early Twentieth Century (Stanford: Stanford University Press, 2014), 131-32; Mandel, The Arabs and Zionism, 15. The policy was abolished, at least in name, in 1913. As Mandel notes, "the Ottoman Government had abolished the Red Slip to please the Jews, and retained the other restrictions so as not to displease the Arabs." See ibid., ${ }^{169-70 .}$

46 The Jewish Chronicle of London reported that this Saturday luncheon was hosted by Francis Montefiore and welcomed "Talaat Bey (President of the Deputation), Nissim Mazliah Effendi (Secretary), Dr. Riza Tewfik Bey, Sassoon Eskell Effendi and Ruhil (sic) Khalidi Bey (member for Jerusalem)." The newspaper report does not mention al-Khalidi's contributions to the discussion. See "Zionism: The Turkish Delegates and the Zionist Movement," The Jewish Chronicle, July 30, 1909, 21. On this lunch meeting, see Mandel, The Arabs and Zionism, 74-75. For the Montefiore family tree, see Joseph Jacobs et al., "Montefiore," Jewish Encyclopedia, www.jewishencyclopedia.com/articles/10960-montefiore. 
In general, I think that the brotherhood and closeness between Jews and Arabs is most natural and most desired. Are we not truly brothers close in family, spirit, religion, and language, and also somewhat in history. However, I do not see on the side of the Jews, especially among the Ashkenazic Jews, an inclination to come closer to us. ${ }^{47}$ I see the Germans, for example, or the Americans [in Palestine] approaching us. The Jews, and especially the Ashkenazic Jews, are an entirely different world and they do not come in contact with us.

Sitting in Ben-Yehuda's office, al-Khalidi told his Ashkenazi Jewish interlocutor that despite the natural affinities between Jews and Arabs, Palestine's Ashkenazic Jews were keeping the communities apart and squandering the possibilities of Jewish integration and acculturation among the Arabs. ${ }^{48}$ In contrast, even though they lacked such innate connections with the Arabs, the Germans (presumably he had in mind the Templars) and the Americans who had established colonies in Palestine had become better incorporated into broader Arab society.

Interestingly, al-Khalidi agreed with Ben-Yehuda that the "Red Note" policy should be cancelled. In fact, al-Khalidi claimed, he had just spoken about this matter the previous day with Subhi Bey, the Ottoman governor of Jerusalem, who shared this view. ${ }^{49}$ As al-Khalidi put it, "for individual Jews, the gates of the land must certainly be open, without interference. However, to establish Jewish colonies - this is a different question." Al-Khalidi was speaking here to a Jew who moved to Palestine as an individual, with his family, and who had settled in the city of Jerusalem rather than a separate Jewish colony. Al-Khalidi did not seem especially worried about offending his interviewer, openly blaming Ashkenazi Jews for tensions between Palestine's Arabs and Jews.

Al-Khalidi's insistence on the distinction between individuals and groups was part of a broader liberal discourse in the fin-de-siècle Ottoman Empire. It likely had particular resonance with him following his years of study,

47 Le-hitkarev elenu would seem to mean something like "integration" or "acculturation."

48 This statement strikes me as an early case of the generally self-serving and self-fulfilling, though never entirely disprovable trope of "ein partner le-shalom" (there is no partner for peace). On the other hand, especially as their numbers increased and social interaction with non-Jews was less essential for day-to-day life, there were undoubtedly ways in which non-Arabic speaking European Jews were less integrated than other minority populations among Palestinian Arab society. See, for example, Glenn Bowman, "Sharing and Exclusion: The Case of Rachel's Tomb," Jerusalem Quarterly, no. 58 (2014): 41-43. 
scholarship, and political activity in France. It was in France 120 years earlier, that the Count of Clermont-Tonnerre famously declared in the National Assembly that "the Jews should be denied everything as a nation, but granted everything as individuals." ${ }^{50}$ This statement regarding the limits of toleration in the modern liberal state was echoed in the position al-Khalidi articulated in this conversation. Moreover, if the mention of Claude (instead of Francis) Montefiore in Ben-Yehuda's article was more than an accident, and al-Khalidi had in fact met also with Claude during his visit to London, then he would have encountered a passionate advocate for the "denationalization of Judaism." The founder of England's Liberal Judaism movement, Claude Montefiore asserted that he was "an Englishman of the Jewish persuasion."51 Al-Khalidi's conversation with Ben-Yehuda in Palestine was thus informed by previous conversations with other Jews in Paris, Bordeaux, and London.

As he continued his response to Ben-Yehuda's assertion that Jews' rights were violated through the "Red Note" visa limitations, al-Khalidi turned to what he viewed as a violation of Arab rights. In this instance, however, the tool was not law but economic inequality. "The Jews have the financial ability," noted al-Khalidi, "and are able to buy much land and evict the Arabs from their land and the inheritance of their ancestors." Just as Jewish rights were abused by Ottoman law, Arab rights were ravaged through the exploitation of economic privation.

If al-Khalidi said more on this matter, Ben-Yehuda chose not to record it. Instead, what immediately follows, presented as the final part of al-Khalidi's response to Ben-Yehuda's opening question about Jewish immigration, is one of the most fascinating statements of the late Ottoman Arab-Zionist encounter: "We conquered the land not from you [anu kavashnu et ha-arets lo mikem].

5o Paul R. Mendes-Flohr and Jehuda Reinharz, eds., The Jew in the Modern World: A Documentary History (Oxford: Oxford University Press, 1995), 115.

$51 \quad$ Quotes from "Zionism" entry in Universal Jewish Encyclopedia, vol. 10, 665. See Geoffrey Alderman, "English Jews or Jews of the English Persuasion? Reflections on the Emancipation of Anglo-Jewry," in Paths of Emancipation:Jews, States, and Citizenship, ed. Pierre Birnbaum and Ira Katznelson (Princeton: Princeton University Press, 1995), 138. On Montefiore, See Claude G. Montefiore, Liberal Judaism: An Essay (London: Macmillan, 1903); Edward Kessler, ed., An English Jew: The Life and Writings of Claude Montefiore (London: Vallentine Mitchell, 2002). Later, in 1916, Claude Montefiore would write that "the Jewish religion destroyed the Jewish nation many centuries ago" and that Zionism was "a very dangerous movement" that could "even imperil" Jewish emancipation. "No wonder," he wrote, "that all anti-Semites are enthusiastic Zionists." See "An Englishman of the Jewish Faith [Montefiore]," "Zionism," Fortnightly Review (November 1916), 819-26. I learned of this pseudonymous article in Jonathan Schneer, The Balfour Declaration: The Origins of the Arab-Israeli Conflict (New York: Random House, 2012), 305. 
We conquered it from the Byzantines who were ruling it then. We owe nothing to the Jews [ein anu hayavim kelum le-ha-yehudim]. The Jews were not here at the time that we conquered the land ..." ${ }^{52}$ Here, al-Khalidi implicitly acknowledged something that he later made explicit in a manuscript he wrote on the subject of Zionism - Al-Sayunizm, ay al-mas'ala al-Sahyuniyya (Zionism or the Zionist Question $)^{53}$ - namely that the Jews had been in Palestine before the Arabs or Muslims. The Jews' return, however, could not be seen as the righting of a historical injustice. Those who were currently living in Palestine (that is, the Arab population), and who were, as al-Khalidi saw it, being financially ejected from their lands, were not the descendants of those who took Palestine from the ancient Jews. If we follow al-Khalidi's logic, the situation would be entirely different were the descendants of the Byzantines to attempt to resettle in Palestine. To the Jews, though, Arabs and Muslims "owe nothing," as the Jews were no longer in Palestine, or at least were no longer ruling Palestine and populating it en masse when the Arab Muslim forces arrived and conquered it in the seventh century.

Sometimes what is omitted from a dialogue can reveal as much as what is included. After hearing such a fundamental challenge to the historical justice of Zionism, Ben-Yehuda apparently did not tackle it. He responded passionately, but, as far as his account tells us, only to al-Khalidi's accusations regarding the impact of Zionist land purchases on Palestine's peasant farmers. "But, sir," BenYehuda retorted, "up until now, the Jews have purchased almost no property from the fellahin." He elaborated:

Up to this point, they have only purchased from particular individuals who owned the land and, mostly, whose families owned the land for decades even before the Jews arrived here. What harm did the Jews cause to the fellahin in doing this? On the contrary, haven't the fellahin in the areas surrounding the Jewish colonies been enriched? Haven't the Jews been a model? Haven't the fellahin learned from the Jews advanced methods of agriculture that have improved their conditions?

$52 \quad$ Ellipsis in original.

53 On this manuscript, see Walid al-Khalidi, "Kitab al-sayunizm aw al-mas'ala al-sahyuniyya li-Muḥammad Ruhi al-Khalidi al-mutawaffa sanat 1913" [The Book Zionism or the Zionist Question by Muhammad Ruhi al-Khalidi, who died in 1913], in Dirasat Filastiniyya: Majmu'at abhath wadi'at takriman li-l-duktur Qastantin Zurayq [Palestinian studies: a collection of studies dedicated in honor of Dr. Constantin Zurayk], ed. Hisham Nashshabah (Beirut: Institute for Palestine Studies, 1988); and Jonathan Marc Gribetz, "Reading Mendelssohn in Late Ottoman Palestine: An Islamic Theory of Jewish Secularism," in Secularism in Question: Jews and Judaism in Modern Times, ed. Ari Joskowicz and Ethan Katz (Philadelphia: University of Pennsylvania Press, 2015). 
The Jews, according to Ben-Yehuda, primarily purchased land from wealthy landowners rather than from fellahin. For Ben-Yehuda this meant that the Zionists could not have harmed the fellahin. ${ }^{54}$ Rather, the opposite was the case: the fellahin had in fact substantially benefited from Zionist immigration - both from increased employment opportunities and from the more efficient agricultural methods they learned from the Jewish immigrants. Just as previous Jewish immigration had not hurt the fellahin, further immigration would only improve the lives of Palestine's Arab peasants. "This land [arets] still has a great deal of land [karka'ot] in the hands of rich individuals, [land] from which the Arab fellahin have no benefit," contended Ben-Yehuda. "These lands will suffice for many, many Jewish colonies. And what harm," asked BenYehuda rhetorically, "will this Jewish settlement bring even to the fellahin, let alone to the land [as a whole]? Are not the Jewish colonies [net] income for the state [medina]? Are they not bringing new life to the land and to the fellahin?" Ben-Yehuda articulated a broad defense of both the ethics of Zionist land purchases and the positive effects of these practices on Palestine's Arab peasant farming population and, more generally, on the region. Despite this, he apparently chose not to answer al-Khalidi's more basic challenge to Zionism, that the Arabs "conquered the land not from you."

For al-Khalidi, this challenge to the historical legitimacy of the Zionist enterprise mattered and could not be ignored. Thus al-Khalidi could at once reply to Ben-Yehuda that "of course, I do not deny this," that is, the material benefits brought by Zionism to Palestine's population, and at the same time conclude that "in any case, we will definitely take the necessary measures to prevent the [fulfillment] of the Zionists' big ideas ..." ${ }^{n 5}$ It is not clear which "big ideas" alKhalidi had in mind. It could have been the historical justification of Zionism, increased immigration, broader colonization, autonomy, or statehood; what is certain is that each of these ideas was important to al-Khalidi. He may have said more about this but all we have is an ellipsis. The conversation apparently then ended, when al-Khalidi's assistant entered to announce it was time for the parliamentarian's next appointment.

54 Even some Zionists in Palestine disagreed with Ben-Yehuda's assessment. This was precisely the problem Yitshak Epstein addressed in his critical essay "Hidden Question" two years earlier. Yitshak Epstein, "She'ela Na'alama" [The hidden question] Ha-Shiloah 17 (July-December 1907), 193-206. For an English translation and commentary, see Alan Dowty, “'A Question That Outweighs All Others': Yitzhak Epstein and Zionist Recognition of the Arab Issue," Israel Studies 6, no. 1 (2001): 34-54. 


\section{Time Frames and City Limits}

At the end of his presentation of the second interview, Ben-Yehuda declares that he reported the conversation exactly as it took place. "I think that there is no use in closing [our] eyes and stopping [our] ears," he explained. Rather, "it is necessary to know the situation as it is." The respective encounters between Ben-Yehuda, on the one hand, and al-Husayni and al-Khalidi, on the other, were not merely informational. Ben-Yehuda was not simply curious about what the parliamentarians thought; as we have seen, he wished also to engage with them, to persuade them, and they responded in kind. In other words, while Ben-Yehuda asserted the necessity of "know[ing] the situation as it is," conversation, as such, was also meant to alter that very situation. It is worth considering the extent to which such conversations might actually have informed and influenced their participants rather than merely offering them a forum in which to articulate their positions. In this regard, I would highlight two underlying aspects of these conversations.

First, notwithstanding the tensions and opposing interests between the communities represented by Ben-Yehuda, on the one hand, and al-Husayni and al-Khalidi, on the other, these intellectual and political leaders were willing to speak to one another. Moreover, the act of conversation and what was learned during it appear to have had an impact. In the course of conversation, each expressed positions that many in their own communities would likely have rejected. Al-Husayni told Ben-Yehuda that he believed Palestine could comfortably welcome many more Jewish immigrants (though not tens or hundreds of thousands), and Ben-Yehuda told al-Husayni that he agreed that it would be best for Jews to settle widely in the Ottoman Empire, not only in Palestine. Al-Khalidi, for his part, expressed openness to the immigration of Jews (but not to separate Jewish colonies) and acknowledged the material benefits Jewish immigration had brought to Palestine, while Ben-Yehuda seems to have accepted al-Khalidi's assertion that because they did not conquer Palestine from the Jews, the Arabs "owe nothing to the Jews." These are not positions, one suspects, that any of these three individuals would likely have embraced in solitude or among their own communities. ${ }^{56}$ These are perspectives that emerged in and through conversation.

$5^{6}$ When Zionists in London were confronted with the demand that Jews not concentrate in any one place in the Ottoman Empire, The Jewish Chronicle replied forcefully: "the fear that concentration of Jews within the Empire would create a Jewish question is really untenable. Our Turkish guests ignore the fact that, in a sense, a Jewish question has long existed and must always exist in Turkey. While Jewish sentiment, the world over, clings 
The fact that these conversations happened in Jerusalem, a city, is significant. Modern cities can promote social segmentation, isolation, and anomie, but they can also permit interaction and engagement across social borders. Vincent Lemire regards the cultivation of "living-together" as the "hallmark of all urban culture." ${ }^{57}$ The shared city, however, can permit more than "livingtogether"; in the case of late Ottoman Jerusalem, it offered the possibility of "speaking-together," of learning about the neighbor and revising one's perspective not only on the Other's needs and ambitions but also on one's own. These conversations in late Ottoman Jerusalem are illuminating examples of this latter potential in citadinité.

However, there can be limits: even when speaking to one another, these men were not always having the same conversation. We saw this most clearly in the encounter between Ben-Yehuda and al-Khalidi on the issue of the morality of Zionist immigration. In this instance, al-Khalidi was concerned with long-term rights and obligations based in history. ${ }^{58}$ In contrast, Ben-Yehuda focused on contemporary, mundane economics. This disconnect, I would note, is common in the history of the Arab-Zionist encounter, though not always along the same lines. When Zionists speak in the long term, for example, of rights emanating from their ancestors' historic presence in the ancient Land of Israel, Arabs may speak in the short term: "who cares about ancient history? Look what's happening right now!" As we see with al-Khalidi and BenYehuda, the inverse is true as well. When the Arab leader al-Khalidi spoke with the long view, the Zionist Ben-Yehuda responded with the shorter and more mundane view: "who cares about the seventh century? Look what's happening right now!"

The underlying question was (and, we might say, remains): when is the starting point for telling the history of Jerusalem? Does the history that truly matters for today start with the Jebusites? David and Solomon? The Babylonians?

affectionately and tenaciously to the ancient land of promise, while Jews are ready to make personal sacrifices in order to be knit to the soil, whether in life or in death, so long a Jewish question awaits the hand of wise and competent statesmanship. Wise and competent statesmanship would not seek to close its eyes to the question or, in face of palpable facts, deny it ... Let the Jews come in, let them concentrate in the country, let them even control the local Government - of course subject to their becoming Ottoman subjects." See "Jews and Turkey," The Jewish Chronicle, July 23, 1909, 6.

57 See the conclusion in Lemire, Jerusalem 1900.

$5^{8}$ On al-Khalidi's historical interests, see also Nasir al-Din al-Asad, Muhammad Ruhi alKhalidi: ra'id al-bahth al-tarikhi al-hadith fi Filastin [Muhammad Ruhi al-Khalidi: pioneer of modern historical research in Palestine] (Cairo: Ma'had al-Buhuth wa-l-Dirasat al-Arabiyya, 1970); Beška, "Anti-Zionist Attitudes and Activities of Ruhi al-Khalidi," 182. 
Cyrus? Herod? Jesus? Constantine and Helena? Muhammad? Umar? The Crusades? Saladin? Suleiman I? The students of Elijah of Vilna? The independent mutașsarıflk? Hibbat Zion? Or something else? The particular beginning one chooses in recounting the relevant history of the city (discounting that which preceded as irrelevant prehistory or trivia) can do more to determine the imputed meaning and implications of that history than any event recorded (or ignored) along the way. In this 1909 Arab-Zionist conversation, the problem of time framing - when to start the narrative - was already evident.

If substantive Arab-Zionist conversation was already challenging in the late Ottoman period, it is, of course, even more so after the century of violence and destruction that has since ensued. And yet today such conversations are all the more crucial and urgent. 


\title{
Ben-Yehuda in his Ottoman Milieu: Jerusalem's Public Sphere as Reflected in the Hebrew Newspaper Ha-Tsevi, 1884-1915
}

\author{
Hassan Ahmad Hassan and Abdul-Hameed al-Kayyali
}

Newspapers are important primary sources for local, social, and urban history because they provide the necessary details for an analysis of daily life. When they are crosschecked and compared with other historical sources, they can be of great help to historians seeking to construct, deconstruct, and/or reconstruct the public sphere of a place from the bottom up. Such comparisons may help historians avoid the influence of ideology, mythology, and collective memory when interpreting the past. In the context of Ottoman Palestine, especially after the Young Turk Revolution of 1908, the local press emerged as an important new tool in the practice of citadinité. It played a central role in legitimating the city as a shared space and encouraged readers to participate responsibly in urban life. ${ }^{1}$ This chapter illustrates the role of the newspaper editor, writer, and intellectual Eliezer (Perlman) Ben-Yehuda (1858-1922) in his Ottoman milieu and shows how the wealth of information that appeared in Ha-Tsevi (Hebrew: הצבי) and its sibling paper Ha-Or (האור) constitute a major source for Palestinian history, particularly with respect to the public sphere and citadinité in Jerusalem.

To begin, we examine the reasons for the spread of Hebrew newspapers in Palestine generally, with a particular focus on Jerusalem, by exploring the influence of the Tanzimat and the 1908 Young Turk Revolution alongside the social dynamics created by Jewish immigration. We analyze Ben-Yehuda's life, which has been mythologized in other writings, by highlighting the interactions and conflicts he witnessed in Ottoman Jerusalem. We present a short reading of Jerusalem's public sphere as reflected in Ha-Tsevi. Our reading explores the relations between Jewish communities and Ottoman institutions around various issues including drinking-water shortages, hygiene, tourism, infrastructure, the administrative space of Jerusalem, and community interrelations

1 Michelle U. Campos, Ottoman Brothers: Muslims, Christians, and Jews in the Early TwentiethCentury Palestine (Stanford: Stanford University Press, 2011), 170.

(C) HASSAN AHMAD HASSAN \& ABDUL-HAMEED AL-KAYYALI, 2018 | DOI:10.1163/9789004375741_021 This is an open access chapter distributed under the terms of the prevailing CC-BY-NC-ND License at the time of publication. 
in the city's public sphere. Finally, we consider the work of urban geography scholar Yehoshua Ben-Arieh on Ben-Yehuda's works and writings, and compare it to our own interpretation.

\section{The Hebrew Press in Jerusalem: An Overview}

To date, there have been many efforts to explain the spread of Hebrew publications and newspapers in Palestine. Some scholars see it as the continuation of the Haskalah ${ }^{2}$ as experienced by central and western European Jews. The arrival and spread of the Haskalah in Palestine was inseparable from the first wave of Jewish immigration and the establishment of new communities, the so-called New Yishuv, from 1882 onwards. The Ashkenazi and Sephardi communities who were called the Old Yishuv had settled in Palestine prior to that year. They had their own newspapers and their views differed from those of the Haskalah. ${ }^{3}$

The appearance of the Jewish press in Palestine developed in the geopolitical context of the Eastern Question, dating from the late eighteenth to early twentieth centuries, set against the background of the gradual dismemberment of the Ottoman Empire and European-Russian rivalry. Alongside these developments, the region was affected by the internal issues of Tanzimat and Jewish immigration. ${ }^{4} \mathrm{Ha}$-Tsevi and other Hebrew publications were subjected to the Ottoman press law (al-Tanzimāt al-Suhufiyya) of January 6,1857 , according to which printing presses could be established for works, pamphlets, or newspapers only with the permission of the Sublime Porte. Foreigners could not set

2 Literally, "wisdom" or "understanding," but used in Neo-Hebrew in the sense of "enlightenment," "liberalism". The Haskalah, or Jewish Enlightenment, was an intellectual movement of Jewish character in Europe that lasted from about the 1770 s to the 1880 s. See Herman Rosenthal and Peter Wiernik, "Haskalah," Jewish Encyclopedia, http://www.jewishencyclopedia.com/articles/7318-Haskalah; Shira Schoenberg, Jewish Virtual Library, https://www.jewishvirtuallibrary.org/jsource/Judaism/Haskalah.html. For a detailed and comparative study of the Haskalah with the Nahda (Arab renaissance movement in late nineteenth and early twentieth centuries), see Lital Levy, "The Nahda and the Haskala: A Comparative Reading of 'Revival' and 'Reform,', Middle Eastern Literatures 16, no. 3 (2013).

3 See Israel Bartal, "Mevaser U-Modica le-'Ish Yehudi: Ha-'Itonut ha-Yehudit ke-'Afik shel Hidush" [The Jewish press as a conduit of modernization], Cathedra, no. 71 (1994).

4 Rina Cohen Muller, "La presse hébraïque, un vecteur de l'entrée des Juifs dans la modernité," Yod. Revue d'études hébrä̈ques et juives, no. 17 (2012). 
up a press or print newspapers without the authorization of the Ministry of Foreign Affairs. ${ }^{5}$

The Young Turk Revolution of the summer of 1908 inaugurated a new political reality and ushered in a boom of publishing initiatives all over the Empire. No fewer than fifteen Arabic-language newspapers were established in Palestine by December 1908; another twenty appeared by the outbreak of World War I. ${ }^{6}$ Hebrew-language newspapers had begun to appear in Palestine as early as 1863 . From then until 1914, new periodicals, weeklies, and newspapers sprung up in Palestine two or three times a week. The first paper was the Jerusalem-based Hebrew weekly Ha-Levanon (הלבנון; lit. "Lebanon”). It was first published in 1863, and remained in print until 1886. In the first six months of 1863, a second Hebrew paper called Havatselet (חבצלת; lit. "the Lily") began publication. It was connected to the Hasidic movement and persisted until 1911 under the editorship of Rabbi Israel Bak, who also set up the first Hebrew printing press in Jerusalem. The Ottoman authorities later closed down these two publications. However, in 1885 , Havatselet resumed printing and was joined by a new newspaper, Ha-Tsevi, which had started printing earlier in October 1884 and was edited by Ben-Yehuda. Ha-Tsevi was more news-oriented than Havatselet and focused less on opinion pieces. In 1901, the Ottoman authorities gave Ben-Yehuda permission to publish his own newspaper, Hashkafa (השקפה; lit. "Outlook"), from 1896 to 1900 , and later from 1902 to $1908 .^{7}$

Ha-Me'asef (המאסף; lit. "the Collector") was also in circulation in 1896. Its editor, Ben-Zion Abraham Cuenca, was one of the most prominent figures of the Sephardic community in Jerusalem at the time. The newspaper, which remained in circulation until 1914, published an array of responses, ${ }^{8}$ articles, and commentaries on religious matters and affairs, sent in by writers worldwide. At first, Ha-Me'asef was published weekly as a supplement to Ha-Tsevi/

5 Philip Sadarove, The Egyptian Press and Ottoman Press Law, in al-Dawla al-Uthmaniyya: Bidayatwa Nihayat [The Ottoman state: beginning and end] (English section), ed. Muhammad Arnout and H. Abu Al-Sha'ar (al-Mafraq: Publications of Al-Bayt University, 2001), 30.

6 Ami Ayalon and Nabih Bashir, Introduction: History of the Arabic Press in the Land of Israel/ Palestine, Arabic Newspapers of Ottoman and Mandatory Palestine, http://web.nli.org.il/sites/ nlis/en/jrayed/Pages/History-of-the-Arabic-Press.aspx. Wide selections of the Palestine newspapers of late Ottoman and mandatory periods are available on the Jrayed website, initiated by the National Library of Israel: http://web.nli.org.il/sites/nlis/en/jrayed/pages/ default.aspx.

7 Rebecca L. Torstrick, Culture and Customs of Israel (Westport: Greenwood Press, 2004), 70.

8 She'elot u-teshuvot (lit: questions and answers) were replies from rabbinic scholars to submitted questions about Jewish law. See https://global.britannica.com/topic/responsa-Judaism. 
Havatselet and, from its third year onwards, it was issued independently once a month. ${ }^{9}$

Ha-Ariel (האריאל) was available in Jerusalem from 1874 to 1877 , under the editorship of Michael Cohen. The newspaper was a descendant of Ha-Levanon founded on the initiative of Cohen, Yoel Moshe Salomon, and Yechiel Brill. ${ }^{10}$ Sha'are Tsiyon (שערי ציון) was first issued in Jerusalem in 1876 as a bilingual weekly newspaper in Hebrew and Yiddish, and shut down in 1885. It was edited by Isaac Gastzinni, Haim Peres, and Abraham Moses Luncz and was considered a competitor to Havatselet. ${ }^{11}$

Daily publications did not appear until the fall of 1908. It was at this point that $\mathrm{Ha}$-Tsevi/Ha-Or, under the editorship of Ben-Yehuda and later his son Itamar Ben-Avi, became a daily. Over the next six years, until the outbreak of World War I, the press of the then-small Jewish Yishuv advanced significantly. Additional daily publications were the Ha-Herut (החרות; lit. "Freedom") from 1909 until 1917, and Moriya (מוריה; lit. "Mount") from 1910 until 1915. These coincided with the appearance of ideological weeklies affiliated with different labor movements (Ha-Po'el, Ha-Tsa'ir and Ha-'Ahdut), which often attacked the daily publications including Ben-Yehuda's newspaper. World War I led to the closing of all newspapers except for Ha-Herut, which continued to appear until $1917^{12}$

\section{Ha-Tsevi and Ben-Yehuda in Focus}

Ha-Tsevi/Ha-Or was one of the several newspapers published in Ottoman Palestine by Ben-Yehuda, the most prominent figure in the revival of Hebrew as an everyday spoken and written language. Ben-Yehuda initially wanted to call his paper $\mathrm{Ha}$-Or but did not succeed in obtaining a license from the Ottoman

$9 \quad$ Historical Jewish Press (hereafter HJP), "Hameasef," National Library of Israel and TelAviv University, http://web.nli.org.il/sites/JPress/English/Pages/HMA.aspx.

10 Yechieal Limor, "Kronika shel Mavet Yadu'a be-Mahshava Merosh: 'Al Goralam Shel 'Itonim Yomiyim be-Yisra'el" [Chronicle of a death foretold: about the fate of daily newspapers in Israel], Keshr 25 (1999).

11 Geda'on Fox, "Bibliyografiya, 'Itonim ve-Kitve 'Et Yehudiyim bi-Rushalayim, 1854-1923" [Jewish newspapers and periodicals in Jerusalem, 1854-1923], Cathedra, no. 6 (1977): 193.

12 HJP, “Ha-Tsevi," http://web.nli.org.il/sites/JPress/English/Pages/hazvi.aspx; HJP, "The Yishuv and State of Israel Press Section," http://web.nli.org.il/sites/JPress/English/Pages/ sec_Yishuv.aspx. 
TABLE 16.1 Hebrew newspapers in Jerusalem, 1863-1914

\begin{tabular}{|c|c|c|c|c|}
\hline & Newspaper & $\begin{array}{l}\text { Years of } \\
\text { publication }\end{array}$ & Editors & Localization/availability \\
\hline 1 & Ha-Levanon & $1863-86$ & $\begin{array}{l}\text { Yechiel Brill, Michael Cohen, } \\
\text { Yoel Moshe Solomon, } \\
\text { Meyer Marcus Lehman }\end{array}$ & $\begin{array}{l}\text { National Library of Israel/ } \\
\text { Historical Jewish Press website }\end{array}$ \\
\hline 2 & Havatselet & $1863^{-1911}$ & $\begin{array}{l}\text { Israel Bak, Israel Dov Frumkin, } \\
\text { Eliezer Ben-Yehuda ( } 1882 \\
\text { temporary editor) and others }\end{array}$ & $\begin{array}{l}\text { National Library of Israel/ } \\
\text { Historical Jewish Press website }\end{array}$ \\
\hline 3 & Ha-Ariel & $1874-77$ & Michael Cohen & - \\
\hline 4 & Sha'are Tsiyon & $1876-85$ & $\begin{array}{l}\text { Isaac Gastzinni, Haim Peres, } \\
\text { Abraham Moses Luncz }\end{array}$ & - \\
\hline 5 & $\mathrm{Ha}-\mathrm{Tsevi} / \mathrm{Ha}-\mathrm{Or}$ & $\begin{array}{l}1884-1902 \\
1909-15\end{array}$ & $\begin{array}{l}\text { Eliezer Ben-Yehuda, } \\
\text { Yechiel Michel Pines, } \\
\text { Hemdah Ben-Yehuda, } \\
\text { Itamar Ben-Avi }\end{array}$ & $\begin{array}{l}\text { National Library of Israel/ } \\
\text { Historical Jewish Press website }\end{array}$ \\
\hline 6 & Hashkafa & $\begin{array}{l}1896-1900 \\
1902-08\end{array}$ & Eliezer Ben-Yehuda & $\begin{array}{l}\text { National Library of Israel/ } \\
\text { Historical Jewish Press website }\end{array}$ \\
\hline 7 & Ha-Me'asef & $1896-1914$ & Ben-Zion Abraham Cuenca & $\begin{array}{l}\text { National Library of Israel/ } \\
\text { Historical Jewish Press website }\end{array}$ \\
\hline 8 & Ha-Herut & $1909-17$ & Hayyim Ben-Attar & $\begin{array}{l}\text { National Library of Israel/ } \\
\text { Historical Jewish Press website }\end{array}$ \\
\hline 9 & Moriya & $1910-15$ & Isaac Jacob Yellin & $\begin{array}{l}\text { National Library of Israel/ } \\
\text { Historical Jewish Press website }\end{array}$ \\
\hline
\end{tabular}

authorities. ${ }^{13}$ The newspaper was therefore called $\mathrm{Ha}$-Tsevi, which was a translation of the first portion of the surname of the license holder: Rabbi Isaac Hirschensohn ("Hirsch" in German is equivalent to "Tsevi" in Hebrew and means "stag"). Three editors were in charge in addition to Ben-Yehuda: Yechiel Michel Pines (1886-87), Hemdah Ben-Yehuda (1909), and Itamar Ben-Avi (1910-12).

From 1884 to 1890 , the newspaper was issued weekly as $\mathrm{Ha}$-Tsevi. From 1890 to 1893 , it continued as a weekly, but its name was changed to $\mathrm{Ha}-\mathrm{Or}$ and a

$13 \quad \mathrm{Ha}$-Or is a Hebrew word meaning "light." The political implications and assumptions of the time led the Ottoman authorities not to grant a newspaper license under this name. 
note was added to the first page specifying that it was an extension of Ha-Tsevi. From 1893 to 1901, it was reissued as a weekly newspaper under the name Ha-Tsevi. From 1902 to 1907, it stopped publication and Hashkafa appeared as a substitute. As a result of the Young Turk Revolution and the flood of news that came in its wake, Ben-Yehuda ran it as a daily paper until 1910 under the name $\mathrm{Ha}$-Tsevi. Between 1910 and 1911, it was issued as a daily, again under the $\mathrm{Ha}-\mathrm{Or}$ name but without any reference to Ha-Tsevi. From 1911 to 1913, the reference "previously Ha-Tsevi" was included. In 1914, it was issued as a weekly, biweekly, and then daily paper again, though on an intermittent basis. It continued to be published with interruptions in $1915 .{ }^{14}$

Ha-Tsevi issues are available on the Historical Jewish Press (HJP) website, initiated by the National Library of Israel and Tel-Aviv University. ${ }^{15}$ There are 1,887 issues on the website with 7,670 pages digitized in transcripts and PDF files. The newspaper is nearly always four pages long and features headings related to Jerusalem in almost all issues. By 1887 , the paper had already begun to publish "sections from a large book of words in a new order" which would become a preface to the chapters of Ben-Yehuda's famous dictionary. ${ }^{16}$ These sections include translations of world literature and essays written by Jewish authors, descriptions of travel throughout Palestine, and articles on the history and geography of the land. In 1895, Ben-Yehuda initiated a special women's section, "Ezrat Nashim" (Women's Gallery), the first of its type in the Hebrew press. In 1897, another special section appeared on agriculture and the working of the land called "Ha-'Ikar ha-Yehudi" (Jewish farmer). This section became a separate weekly publication a year later. ${ }^{17}$

Ben-Yehuda may be regarded as the originator of New Hebrew, which he claimed was a necessity for the "regenerated nation." He sought to transform Hebrew into a spoken language in all spheres of life. Most of his new vocabulary

14 Menocha Galboa, Leksikon ha-Itonut ha-Ivrit ba-Me'ot ha-Shemone-'Esre ye-ha-TeshaEsre [Lexicon of the Hebrew press in the eighteenth and nineteenth centuries] (Tel Aviv: Hotsaat Mosad Byaliq, 1992), 308-14, http://jnul.huji.ac.il/dl/newspapers/hazevi/ html/hazevi.pdf; HJP, "Ha-Tsevi," http://web.nli.org.il/sites/JPress/English/Pages/hazvi .aspx.

15 HJP, http://web.nli.org.il/sites/JPress/English/Pages/hazvi.aspx.

16 For the dictionary of Ben-Yehuda, see Eliezer Ben-Yehuda, Milon ha-Lashon ha-Tvrit haYeshana ve-ha-Hadasha [The dictionary of the Hebrew language, ancient and modern], 16 vols., ed. Moses Segal and Naphtali Tur-Sinai, (Jerusalem: Hotsa'at Makor, 1980). An incomplete electronic version of the dictionary is also available online: http://benyehuda .org/ asaf/full_dict.html.

HJP, “Ha-Tsevi," http://web.nli.org.il/sites/JPress/English/Pages/hazvi.aspx. 
was coined either from Talmudic literature or from the Arabic language. ${ }^{18}$ In 1918, Ben-Yehuda described the impact of Arabic on his philological studies in the prolegomenon of his dictionary:

Arabic, in particular, was a kind of source of salvation for me in the linguistic research of our language. First, because it lives at this moment, we are standing on solid ground when explaining the meaning of its words ... The deeper I went into Arabic language research, the wider the gates of understanding of the Hebrew language opened before me; the Arabic vocabulary enabled me to discover the authentic explanation of many biblical words. ${ }^{19}$

The paper was well-known for its struggle against the Old Yishuv and the halukkah system, ${ }^{20}$ and for its support of the New Yishuv as well as for its favorable attitude towards Baron Edmond James de Rothschild (1845-1934), a French member of the Rothschild banking family and a strong supporter of Zionism. The newspaper fought in favor of reforms in the Ashkenazi community, which reached their peak with the controversy surrounding the shemittah ${ }^{21}$ (1889). ${ }^{22}$ A stinging article by Ozer Dov Lipschitz in issue 44, published in 1886, led to the outbreak of conflict between Ha-Tsevi and the Sephardic community in the city. The dispute resulted ultimately in the declaration of a boycott against the newspaper in the following year (1887). The boycott was connected to writings in which Ben-Yehuda denounced the Sephardic community for

18 Gotthard Deutsch and Judah David Eisenstein, "Ben Judah, Eliezer," Jewish Encyclopedia, http://www.jewishencyclopedia.com/articles/2876-ben-judah-eliezer; İlker Aytürk, "Revisiting the Language Factor in Zionism: The Hebrew Language Council from 1904 to 1914," Bulletin of the School of Oriental and African Studies 73, no. 1 (2010).

19 Scott Bradley Saulson, "Eliezer Ben-Yehudah's Hamavo Hagadol: Introduction, Translation, Annotation" (PhD diss., University of South Africa, 1985), 70-71.

20 The halukkah (חלוקה) was an organized collection and distribution of charity funds for Jewish residents of the Yishuv in Palestine.

21 The sabbath year (shemittah: שמיטה, literally "release"), also called the sabbatical year or shevi'it (שביעית, literally "seventh"), is the seventh year of the seven-year agricultural cycle mandated by the Torah. During shemitțah, the land is left to lie fallow and all agricultural activity, including plowing, planting, pruning and harvesting, is forbidden by halacha (Jewish law). See Judah Eisenstein, Jewish Encyclopedia, http://www.jewish encyclopedia.com/articles/12967-sabbatical-year-and-jubilee. 
using Christian missionary medical services and for hiring a Jewish convert to Christianity as the community's secretary. ${ }^{23}$

Ben-Yehuda pursued an uncompromising line against those who followed what he called the halukkah and "shenorer"24 system, just as he opposed ignorance, superstition, and squalor in the streets of Jerusalem. News about his positions reached the authorities and ultimately led to his arrest and the closing of the newspaper from December 1893 to January 1895. Ben-Yehuda had a bitter ongoing conflict with writers of the second wave of Jewish immigration (1903-14) and with writers of the Hakhame Odessa school, who objected to his flamboyant and "yellow" (צהוב) writing style as well as his use of new Hebrew spellings that they saw as "gaudy" and "vociferous" (צעקני). For them, his Hebrew innovations strayed away from Biblical Hebrew; the true, sacred Hebrew. Among Ben-Yehuda's less controversial ideas was his undertaking to establish a large academy in Jerusalem that would constitute a national intellectual center for the whole of the Jewish people: the Academy of the Hebrew Language.

With around three hundred copies sold among Yishuv residents in 1886, the paper's circulation remained modest and Ben-Yehuda was forced to supplement his income with teaching. In 1887, he travelled to Russia and succeeded, with great effort, in obtaining three hundred additional subscribers, but as time passed they did not remain loyal to his publication. In the end, a monthly stipend of two hundred francs from Baron Rothschild allowed Ben-Yehuda to leave his teaching position behind and concentrate on the paper. Ha-Tsevi reached its peak in 1909, with 1,200 copies sold. ${ }^{25}$

\section{Jerusalem's Public Sphere as Reflected in Ha-Tsevi}

Ha-Tsevi not only contains a wealth of information on the Jewish communities of Jerusalem; it is an important source of information on the city's public sphere and citadinité, granting a perspective into Palestinian history in the late Ottoman period. This chapter presents a selection of Ha-Tsevi news material on the city's public sphere collected from nine hundred print issues. A systematic, elaborate, and in-depth analysis of Jerusalem's public sphere as reflected in Ha-Tsevi lies beyond the scope of this chapter. However, this reading takes the first steps in revealing the relations between the Jewish communities and

\footnotetext{
23 Galboa, Leksikon Ha-Itonut Ha-'Tvit, 308-14.

24 Shenorer (שנארער; also spelled schnorrer) is a Yiddish term meaning "beggar" or "sponger."

25 HJP, “Ha-Tsevi," http://web.nli.org.il/sites/JPress/English/Pages/hazvi.aspx.
} 
Ottoman institutions around the issues of drinking-water shortages, hygiene, tourism, infrastructure, the administrative space of Jerusalem, and community interrelations in the city's public sphere.

\section{Relations between Jewish Communities and Ottoman Institutions}

Interactions between Jewish communities and Ottoman institutions inside and outside Jerusalem preoccupied Ha-Tsevi and Ben-Yehuda. Readers of the newspaper repeatedly encounter the names of Ottoman officials such as alShaykh Yusuf, chief of the local army, Arif Bey, head of education, Bisharah Bey, translator for the governor (mutessarif), and others. These names appear, for example, when the officials visited Jewish schools in Jerusalem to supervise exam procedures. ${ }^{26}$ On another occasion, the governor paid a visit to the "Torah and Work" School and praised what he saw. ${ }^{27}$ Officials from the Ottoman army also visited Jewish religious schools to make sure they were observing the terms of the students' exemptions from military service. ${ }^{28}$ Ben-Yehuda wanted his readers to know the names of prominent figures from Jerusalem's different communities who sent their children to study at the city's Jewish schools. ${ }^{29}$ Sometimes, he published numbers of the non-Jewish pupils enrolled in the Jewish schools of Jerusalem. ${ }^{30}$

\section{Drinking Water Shortages}

The shortage of drinking water in Jerusalem in the late Ottoman period was an enormous problem as well as a source of constant concern to Jerusalemites and to the city's institutions. ${ }^{31} \mathrm{Ha}$-Tsevi frequently highlights the initiatives taken by the municipality to overcome this problem, and provides details about its effects on the city's public sphere. One issue of the newspaper describes the shortage: due to the high temperatures, the water-shortage problem increased

\footnotetext{
$26 \quad$ Ha-Tsevi, September 19, 1888.

27 Ha-Tsevi, August 7, 1898.

28 Ha-Tsevi, May 10, 1911.

29 Ha-Tsevi, September 19, 1888.

3о Ha-Tsevi, September 30, 1887.

31 For further details on the subject, see Vincent Lemire, La soif de Jérusalem: essai d'hydrohistoire (1840-1948) (Paris: Publications de la Sorbonne, 2010).
} 
in the city as its wells were about to run out and the sellable water was polluted due to the negligence of well owners. ${ }^{32}$

Ha-Tsevi explains how the Ottoman central government instructed Jerusalem municipal officials to bring water from wells outside the city. An engineer from Beirut was brought to Jerusalem in order to oversee the process. ${ }^{33}$ Furthermore, the governor appointed a committee to consider bringing clean water to the city and using canals to get rid of wastewater. The names of the committee members were also published. ${ }^{34}$ Later, at the beginning of the twentieth century, Ha-Tsevi reports how a German and a French company came together to find a solution to the water problem in Jerusalem in the form of formal agreements with the Ottoman government. ${ }^{35} \mathrm{Ha}$-Tsevi also gives an account of a fifty-year trade license contract that the Jerusalem municipality intended to grant to another French company to sell drinking water to the city. ${ }^{36}$

Ha-Tsevi provides a glimpse of the social interactions among Jerusalemites looking to find a solution to secure the city's water supply. An article in the paper describes how one hundred Jewish and Arab workers participated in a project organized by the municipal engineer to bring drinking water to the city from the al-'Arrub spring outside of Jerusalem. ${ }^{37}$ Other articles deal with the newspaper's own participation in the efforts to overcome the water shortage. The city governor, accompanied by the mayor and other officials, visited a spring near Jerusalem. The visit aimed to study how well water might be routed to the city. The Ha-Tsevi delegate promised to support the project. ${ }^{38}$

\section{Hygiene}

In its coverage of Jerusalem's public sphere, Ha-Tsevi deals with the hygienic conditions of the city. Certain issues contain reports by Jerusalem residents about their concern regarding epidemics and transmission of sickness by local or foreign visitors. Ha-Tsevi records the number of persons affected by fever and flu, and the increase in these numbers. It also highlights initiatives taken by authorities such as limiting the number of passengers coming by train from

\footnotetext{
$32 \quad$ Ha-Tsevi, September 30, 1887.

33 Ha-Tsevi, October 20, 1893.

34 Ha-Tsevi, October 23, 1908.

35 Ha-Tsevi, February 6, 1911.

$36 \quad$ Ha-Tsevi, October 5, 1911.

37 Ha-Tsevi, March 15, 1911.

38 Ha-Tsevi, October 28, 1908.
} 
Jaffa to Jerusalem in an attempt to contain diseases. ${ }^{39}$ Another issue of the paper includes official telegrams sent to the city governor to impose quarantine on all travelers coming from "Egypt and the Hijaz" because of cholera in those regions. ${ }^{40}$

The lack of a "cleaning culture" in some quarters of the city, especially those areas outside of the city walls, was a concern. Ben-Yehuda strongly criticized the absence of cleanliness in some Jewish quarters of the city and warned against epidemics and illnesses among Jewish inhabitants. There are many articles on the subject in Ha-Tsevi, with some discussing the spread of specific illnesses such as measles in certain neighborhoods. The sanitary state of some Jewish quarters in Jerusalem and outside of the city, in the areas of Me'ah She'arim and Mishkenot, as well as the problem of cleanliness and sewage in the nearby neighborhood of Bet Yisra'el, was discussed.

Articles appear describing the municipality's efforts to preserve the city environment in light of the challenges imposed by the lack of hygiene. BenYehuda sent letters of thanks to Salim Effendi, the mayor of Jerusalem, and to the city governor for bringing a cleaning machine similar to the one existing in Cairo, in order to reduce dust. ${ }^{41}$ In a long article praising the municipality's cleanliness efforts, Ben-Yehuda complains about an inability to control the quality of agricultural products sold in city markets. ${ }^{42}$ The newspaper republished an announcement already distributed to city residents regarding regulations on litter collection at marketplaces that warned those who failed to follow them of imprisonment. ${ }^{43}$

\section{Tourism Season}

In light of the dependence of a considerable part of the city's economy on travelers and pilgrims who visited the city due to its status as a holy place for followers of Islam, Judaism, and Christianity, Ha-Tsevi features articles covering the tourism sector. Groups of tourists from western Europe, Russia, and North America were an important source of economic interaction within the city. Jerusalem witnessed periods of recession when the number of pilgrims

\footnotetext{
39 Ha-Tsevi, July 21, 1893.

$40 \quad$ Ha-Tsevi, May 22, 1896; January 18, 1911.

41 Ha-Tsevi, April 10, 1896.

42 Ha-Tsevi, October 23, 1911.

43 Ha-Tsevi, June 3, 1898.
} 
and travelers decreased following disturbances and unrest in the city. Articles in certain Ha-Tsevi issues describe this phenomenon. There were also positive reports: in one issue about the tourism season in the city, the newspaper highlighted the number of pilgrims/travelers who arrived from Europe, Asia, and America, stating that all of Jerusalem's hotels were fully booked. ${ }^{44}$ In another detailed piece on tourism, Ha-Tsevi depicted Jerusalem as a European city. ${ }^{45}$ The newspaper stresses the importance of the tourism season ${ }^{46}$ and discusses the difficulties encountered by some merchants. It cites complaints from many interviewees, including merchants and coach riders. One of the complaints was: "American tourists buy nothing from the city and don't pay tips." ${ }^{4}$

\section{Infrastructure}

Ha-Tsevi also provides us with much information about the infrastructure of Jerusalem, from the leveling and sprinkling of the roads to the Jerusalem-Jaffa Railway. ${ }^{48}$ The newspaper congratulates its readers on the inauguration of the road from Jerusalem to Hebron thanks to carriages. ${ }^{49}$ Another news piece discusses the municipality's intention to level Jaffa Street and to sprinkle it with water to limit dust. It mentions how residents overlooking the street may be asked to cover some of the expenses. ${ }^{50}$

Another article describes in detail the commencement of a paving project using natural materials, supervised by engineer 'Amin al-Aqqad. ${ }^{51}$ The newspaper also covers the construction of the Jerusalem-Jaffa Railway, beginning with the issuance of a firman authorizing Yousef Navon (1858-1934), a JewishJerusalemite businessman, to start the process. ${ }^{52}$ Another infrastructure

\footnotetext{
44 Ha-Tsevi, March 10, 1893.

45 Ha-Tsevi, March 3, 1911.

46 Ha-Tsevi, May 11, 1888 (Highlighting the pilgrims and travelers from France); Ha-Tsevi, December 5, 1911 (Highlighting the pilgrims and travelers from Russia).

$47 \quad$ Ha-Tsevi, March 9, 1911.

48 See Sotirios Dimitriadis' chapter, "The Tramway Concession of Jerusalem, 1908-1914: Elite Citizenship, Urban Infrastructure, and the Abortive Modernization of a Late Ottoman City," in this volume.

49 Ha-Tsevi, May 25, 1888.

50 Ibid.

$51 \quad H a-T s e v i$, May 22, 1911.

$5^{2}$ Ha-Tsevi, October 26, 1888.
} 
project reported on is the laying of the cornerstone for the railway. ${ }^{53}$ Later on, readers learn that the manager of the French railway company in Jerusalem has arrived to inspect the Jerusalem-Jaffa Railway. ${ }^{54}$ Finally, on May 15, 1896, Mr. Fadoul announced that train carriages were ready to transport passengers from Jerusalem to Jaffa at a price of 15 qirsh per passenger. The inauguration of the railway provoked strong reactions from Jewish coach owners, who reduced the cost of transport to half a majidi (an Ottoman currency named after Sultan Abdülmecid I (d. 1861), equal to 20 qirsh) to compete with train fare..$^{55}$

Ha-Tsevi also contains rich information about Jerusalem's building infrastructure. There are many articles related to irregular buildings and the problems resulting from them. The newspaper makes suggestions to the government, such as punishing those who violated building regulations, especially those relating to the digging of wells under houses, which could overflow in winter and cause the houses to collapse. ${ }^{56} \mathrm{Ha}$-Tsevi also published information on tenders to establish electricity infrastructure in Jerusalem and its suburbs, including the conditions of eligibility for those interested in submitting offers. ${ }^{57}$

\section{The Administrative Space of Jerusalem}

Ha-Tsevi focused on the administrative space of Jerusalem and covered extensively the designation, resignation, and the deposition of city officials such as the governor, mayor, and the municipal council. The names of Rashad Pasha, Ibrahim Pasha, Yassin Effendi, 'Ali Rida Bey, Jawid Bey, Husayn Effendi alHusayni and many others are mentioned in issues of the newspaper in relation to arriving or departing delegations and the organization of meetings by the governor, his deputy, the mayor, and other officials. ${ }^{58}$ The newspaper is a very helpful tool in constructing the actual administrative structure of the city at the time and speaks volumes about the interactions of Jerusalemite Jews with the communities and officials of the local administration.

One article in Ha-Tsevi states that Jewish officials visited government headquarters (al-Saraya) to congratulate the new governor, Subhi Bey. Among them

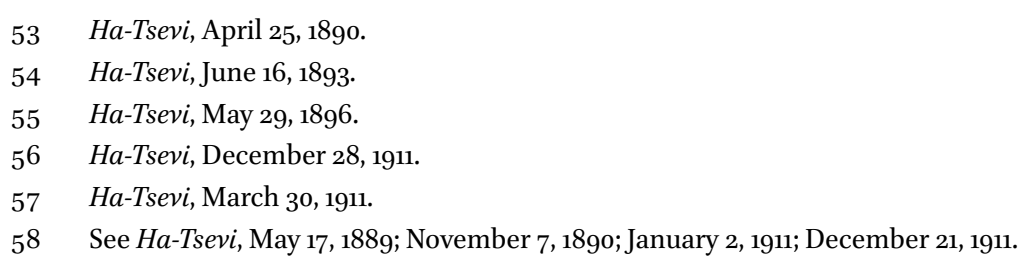


were Ben-Yehuda and a number of rabbis. ${ }^{59} \mathrm{Ha}-\mathrm{Tsevi}$ also reported on the inauguration of a new hospital in the city owned by the Rothschild family. The inauguration was attended by the governor, Ra'uf Pasha, and the mayor. ${ }^{60}$ Earlier Ha-Tsevi had issued a report on the summoning of the headmen (mukhtars) of the Ashkenazi community by the government to pay 6,500 qirsh in military taxes. ${ }^{61}$

Another article details a meeting between the Jerusalem governor, Mecid Bey, and a Jewish delegation to discuss the procedures imposed on the Jews of Palestine and Jerusalem in order to obtain Ottoman citizenship. ${ }^{62}$ Drawing on the decision of the Ottoman authorities to invalidate the capitulations granted to foreign consulates and their nationals, Ha-Tsevi and Ben-Yehuda encouraged Jerusalemite Jews to consider obtaining Ottoman citizenship. Ben-Yehuda called on western Jews to replace their names with Hebrew ones and become Ottomans. ${ }^{63}$ This created much controversy, but controversy that must be seen within the wider context of Ottoman laws, regulations governing Jerusalem, taxes, military service, and parliamentary elections. The newspaper showed interest in publishing these laws and regulations for its Jewish readers, especially for Sephardi Jews, most of whom were considered Ottoman citizens.

\section{Intercommunal Relations in Jerusalem's Public Sphere}

The interactions between ethnic and religious communities and between different subgroups of the same religious community occupied a major place in the articles and news of Ha-Tsevi throughout its existence. Missionaries were a recurring theme. Ben-Yehuda must have seen their continued endeavor to infiltrate Jewish communities in Palestine, and particularly in Jerusalem, as a fertile source of material. He did not hesitate to criticize the Ashkenazi and Sephardi communities who sought to benefit from the services of missionaries. Numerous news items and references in articles written by Ben-Yehuda reported complaints by Jews that Jewish figures were sending their children to

\footnotetext{
$59 \quad H a-T s e v i$, October 2, 1908.

6o Ha-Tsevi, September 4, 1888.

61 Ha-Tsevi, June 19, 1885.

$62 \quad H a-T s e v i$, November 22, 1914.

63 Ha-Tsevi, November 15, 1914.
} 
Christian missionary schools. The newspaper even published individual testimonies of Jewish parents who sent their children to these schools. ${ }^{64}$

In 1914, Ben-Yehuda republished a letter from 1912 warning the Jews of Jerusalem from having any dealings with Christian missionary schools, calling for their boycott; these included the Missionary Girls School and English Mission Hospital. ${ }^{65}$ The newspaper was filled with news related to the activities of these missionaries, their ambitions, places they lived, and finally, the attitude of Ha-Tsevi towards them. ${ }^{66}$ This conflict with the leaders of the Old Yishuv reached its peak in 1886, with the announcement of the famous "boycott" of Ha-Tsevi ${ }^{67}$ in direct response to the newspaper's constant attack on the clergy, who were accused of getting help from Christian missionaries.

The newspaper related information about the Christian missions and their activities in Jerusalem, missionaries visiting the city, ${ }^{68}$ assemblies of Christian churches, and their efforts to consolidate their influence in the city through the construction of new churches and modern luxurious buildings. ${ }^{69}$ It published news regarding disputes between the different Christian denominations, such as arguments between the Armenian and Greek churches during the Christian holidays $^{70}$ and another "between a few priests of the Catholic Church who prevented two Russians from the Palestinian-Russian Society from visiting the Church of the Nativity. Therefore, they were all engaged in hand-to-hand fighting during which the Russians fatally shot two priests and injured one."71

With regards to Jewish-Muslim relations, Ha-Tsevi focused on covering the dynamics of contact between the two communities. The coverage was limited to the official level. The newspaper details the exchange of visits between the heads of the Jewish communities and notables of the city with their Muslim counterparts and of city officials during religious and public festivals. Ha-Tsevi is replete with accounts of meetings between Jerusalem notables and Rabbi Bashi (Yaakov 'Elyashar). The rabbi also visited the Jerusalem governor, who received him with great hospitality. ${ }^{72} \mathrm{Ha}$-Tsevi contains a news item

\footnotetext{
64 Ha-Tsevi, June 12, 1885; October 23, 1911.

65 Ha-Tsevi, July 17, 1914.

66 Ha-Tsevi, December 4, 1885.

67 Ha-Tsevi, February 5, 1886. It commented on a letter in Havatselet newspaper by the Sephardi chief rabbi (Haham Bashi) who attacked Ha-Tsevi under the headline of "Ha-Tsevi under boycott," Ha-Tsevi, December 18, 1885.

68 Ha-Tsevi, May 12, 1893.

69 Ha-Tsevi, June 26, 1885; February 17, 1893.

70 Ha-Tsevi, June 6, 1911.

71 Ha-Tsevi, November 3, 1893 .

72 Ha-Tsevi, February 10, 1893.
} 
about Salim Effendi, president of the Municipal Council, who congratulated Mr. Irnisberg on his position as head of the Bet Yacakov synagogue. ${ }^{73}$ Furthermore, readers learn about a committee, headed by "The Judge- al-Qadi" and "al-Mufti," that was preparing to receive an army that would pass through the city. The article discusses the Jews' participation in these preparations. ${ }^{74}$

Ha-Tsevi does not provide evidence that distinctions were made between Muslim and Christian Arabs. This is in contrast to what Abigail Jacobson points out in her article on the Ha-Herut Hebrew newspaper from 1912 to 1914. She concludes that the Sephardi Ha-Herut made a clear distinction between Muslim and Christian Arabs, identifying the Christians as the "worst enemy" of the Jewish communities. ${ }^{75}$ In his analysis of interviews published in Ha-Tsevi in 1909 between Ben-Yehuda and the Ottoman Palestinian intellectual and politician Muhammad Ruhi al-Khalidi, Jonathan Gribetz explores how the use of Judaism as a counterpoint facilitated the construction of a Palestinian Arab national identity that united Christian and Muslims on religious and textual grounds. He concludes that this association of Christianity and Islam, in explicit contradistinction to Judaism, is a phenomenon that developed further in the years immediately following World War I. ${ }^{76}$

All in all, Ha-Tsevi devotes more space to news about Jewish communities in Palestine and in Jerusalem than to the public sphere of Jerusalem as a whole. A clear understanding of the nature of mobilization among the Jewish communities in Palestine and in Jerusalem in particular would require an additional study of the articles published in Ha-Tsevi. Such a study could examine the notion of the kolelim ${ }^{77}$ in different Jewish communities, conflict between those communities (disunion and emergence mechanisms), budgets and

73 Ha-Tsevi, January 10, 1896.

74 Ha-Tsevi, December 11, 1914.

75 Abigail Jacobson, "The Sephardi Community in Pre-World War I Jerusalem: Debates in the Hebrew Press," Jerusalem Quarterly, no. 14 (2001).

76 Jonathan Marc Gribetz, Defining Neighbors: Religion, Race, and the Early Zionist-Arab Encounter (Princeton: Princeton University Press, 2014), 235. See also Jonathan Marc Gribetz's chapter, “Arab-Zionist Conversations in Late Ottoman Jerusalem: Said alHusayni, Ruhi al-Khalidi and Eliezer Ben-Yehuda," in this volume.

77 The word kolel (pl. kolelim or kolels) stems from the Hebrew root " $k$ l"l' meaning a collective. It was initially applied to a communal body; to the small groups of Jews who moved together from specific European towns and countries to Palestine. Funds that arrived were thus divided according to congregation or kolel. For more details, see Adam Ferziger, The Emergence of the Community Kollel: A New Model for Addressing Assimilation (Beersheba: Rappaport Center for Assimilation Research and Strengthening Jewish Vitality, Bar Ilan University, 2006), 15-16. 
regular donations to each community, and taxes imposed by the authorities for the exemption from military service. A study could also look at news about Rabbi Bashi, the Jewish institution of Jerusalem, religious schools or yeshivot, elections of Jewish committees, Jewish immigration from and to Jerusalem, visits paid by Jewish figures from outside the city, and various conflicts. These subjects are all covered at various moments in Ha-Tsevi and the other Hebrew newspapers.

\section{Ha-Tsevi and Ben-Yehuda in the Works of Yehoshua Ben-Arieh}

The remainder of this chapter will examine previous treatments of Ha-Tsevi and its editor in academic writings. The work of Yehoshua Ben-Arieh is a particularly salient example. One of Ben-Arieh's best-known works is his two-volume book Jerusalem in the 19th Century. The first volume, The Old City, appeared in English in 1984, and the second, Emergence of the New City, was published in 1986. Ben-Arieh regularly quotes Ben-Yehuda on Jerusalem's public sphere and discusses the cultural role he played in the city. These quotes tend to bolster the image of Jerusalem that Ben-Arieh seeks to present in his book.

Scholarly reviewers of Ben-Arieh, particularly late-Ottoman specialists such as Alexander Schölch and Justin McCarthy, have pointed out some methodological problems related to his writings. Schölch suggests that the sources used in Ben-Arieh's book determine the picture that emerges. The problems and developments are viewed through the eyes of Europeans and members of the Jewish communities and focus on European activities. Ottoman rule and the Arab communities are dealt with in a rather cursory manner. ${ }^{78}$ McCarthy, on the other hand, contends that Ben-Arieh provides a descriptive, not analytical history. And yet, when reading his book, one cannot help but wonder what Ben-Arieh was trying to convey with his "marvelous" pictures and anecdotes. Why were things the way they were? ${ }^{79}$

Most of Ben-Arieh's citations of Ben-Yehuda illustrate the development of Jewish neighborhoods particularly beyond the city walls, and make no mention of the public interactions among the social components of Jerusalem within their Ottoman context. However, attentive readers of Ben-Yehuda find many indications of such interactions, as the current chapter has shown. For

78 Alexander Schölch, review of Jerusalem in the 1gth Century: The Old City, by Yehoshua BenArieh, Middle East Journal 40, no. 2 (1986).

79 Justin McCarthy, review of Jerusalem in the 19th Century: The Old City, by Yehoshua BenArieh, The American Historical Review 91, no. 2 (1986). 
Ben-Arieh, the New Jerusalem is merely the "Jewish Jerusalem." Such terminology creates an artificial barrier that divides Jerusalem's public sphere and hides, in consequence, the city's interactions. In his descriptions, for example, Ben-Arieh uses a series of ideological and heroic terms such as the "Father of the Hebrew Language" to qualify Ben-Yehuda and the "Father of Jerusalem's Neighborhoods" for Yosef Rivlin. ${ }^{80} \mathrm{He}$ frames the period in the city's history as a battle between the modern, Jewish Jerusalem and the old, Muslim Jerusalem. In this context, Ben-Arieh cites Ben-Yehuda's long description of the "New" Jerusalem, published in Mevaseret Tsiyon (1883-84), ${ }^{81}$ which the Jews built outside the Old City " 30 years ago" when not a single building stood there. Its construction was made possible through an initiative of Moses Montefiore in 1855 to house the impoverished Jewish inhabitants of Jerusalem and "to extricate them from the narrow confines of the city." ${ }^{82}$

On another occasion, Ben-Arieh cites Ben-Yehuda and an issue of Mevaseret Tsiyon in an apparent attempt to convey the impression that all of the features of Jerusalem outside its walls were purely Jewish. Ben-Yehuda states: "And here [in Jerusalem] my eyes behold beautiful houses and gardens, and all this belongs to Jews! This can only mean that the city has begun to shake off its dust, and it is being rebuilt by Jews." ${ }^{33}$ Later, Ben-Arieh mentions a description of Claude R. Conder (1848-1910), who lived in Jerusalem in the early 1870 , stating that the first sight to greet the visitor from the West was the great Russian church, with its white walls and heavy lead roofs in neo-Byzantine style, adding that "some claimed that the Russian hospice dominated the whole city." 84 Indeed, the image of "New Jerusalem" and its builders that this quote conveys is entirely different from the impression provided by Ben-Yehuda's observation.

The ideological and ethnic background of travelers and journalists passing through Jerusalem was often reflected in their description of Jerusalem outside its walls. However, Ben-Arieh often fails to acknowledge this. Ben-Yehuda, who was an ardent supporter of the New Yishuv, saw the outer city of Jerusalem as purely Jewish. Conder, meanwhile, saw in it the "great Russian Church" and mentioned only in a cursory manner the Jewish neighborhoods outside the walls. Ben-Arieh tends to divide all civil activities in Jerusalem on a religiousethnic basis. He presents two main classifications in this regard: Jewish and

\footnotetext{
80 Yehoshua Ben-Arieh, Jerusalem in the 19th Century: Emergence of the New City (Jerusalem: Yad Izhak Ben-Zvi; New York: St. Martin's Press, 1986), 113.

81 An appendix of Havatselet was edited by Ben-Yehuda.

82 Ben-Arieh, Emergence of the New City, 75 .

83 Ibid., $120-21$.

84 Ibid., 145 .
} 
non-Jewish activities, with the latter referring to the activities of the Muslim and Christian communities.

The activities of the municipality of Jerusalem were discussed in Ben-Arieh's work under the broad category of "the Muslim population" or "the activities of the Muslim community." Ben-Arieh's quotes originate almost exclusively from Ha-Tsevi, Ha-Or, and Hashkafa. As such, Ben-Yehuda is his main source on the subject. In his first volume on Jerusalem in the nineteenth century, Ben-Arieh cites Ben-Yehuda three times in a discussion of the activities of the municipality. The first citation concerns the formation of the municipal hospital in 1891. The second is about the repairs of the city's Turkish baths in 1904, and the third deals with Rashid Bey's decision to arrange a horse race in Jerusalem in 1906. ${ }^{85}$ Ben-Arieh concludes by referring to Haim Gerber's assessment that, for the greater part of the nineteenth century, the government exhibited no desire to develop Jerusalem. The city was far from being its principal concern, and the question of Jerusalem's progress was hardly of interest to it. ${ }^{86}$

In the second volume, Ben-Arieh depends entirely on second-hand sources. He suggests that the contribution of the Muslim community to the development of the new city was limited, particularly in the early stages, in comparison to other communities. He states as evidence the absence of government or municipal plans for the city or even suburbs beyond the walls. Muslim settlement outside the city walls relied on private construction by rich families such as the al-Husayni, al-Nashashibi and Jarallah families. Such construction was scattered over a wide area but remained concentrated in a number of quarters in the area north of the Old City such as al-Husayni and al-Shaykh Jarrah. There were no public buildings, religious institutions, or services such as mosques, market-places, and shops. ${ }^{87}$ However, Ben-Arieh's conclusions are based on those of Ruth Kark and Shimon Landmann. ${ }^{88}$

Having outlined plans by the Ottoman authorities to move the government headquarters beyond the walls, Ben-Arieh shifts to the relocation of the Jerusalem Municipality in 1890 to a building opposite the Howard (Fast) Hotel at the intersection of Jaffa and Mamilla Roads. He refers to Hashkafa

85 Yehoshua Ben-Arieh, Jerusalem in the 1gth Century: The Old City (Jerusalem: Yad Izhak Ben-Zvi; New York: St. Martin's Press, 1984), 124-25.

86 Ibid., 125 .

87 Ben-Arieh, Emergence of the New City, 349-55.

88 Ruth Kark and Shimon Landman, "The Establishment of Muslim Neighborhoods in Jerusalem, Outside the Old City, During the Late Ottoman Period," Palestine Exploration Quarterly, no. 112 (1980). 
while reporting the establishment of the municipal hospital and the Museum of Antiquities near the Jaffa Gate outside the Old City. Ben-Arieh quotes BenYehuda in $\mathrm{Ha}$-Or on the construction of new law courts near Herod's Gate and on the necessity of providing space for petition-writers and stamp-sellers. ${ }^{89}$

Citing other sources, Ben-Arieh states that the Jerusalem Municipality and the local Ottoman authorities extended their administrative activities to the area outside the walls through a series of initiatives and projects that included, first, the Pasha appointing a headman for each Jewish neighborhood in Jerusalem, and not for each community, as was previously the case; second, the municipality and local authorities carrying out population censuses; and, third, greater efforts being dedicated to city cleaning and paving new carriage roads. ${ }^{90}$ For Ben-Arieh, many of these actions continued in the first decade of the twentieth century as the Jerusalem Municipality stepped up its activities, particularly after the elections to the municipal council in 1909 and 1910.

Under the subtitle "Municipality of Jerusalem," Ben-Arieh continues his presentation of the "non-Jewish activities" in the city. He quotes most of his material from Ben-Yehuda in $\mathrm{Ha}-\mathrm{Or}$ newspaper from 1909 to 1913. Among the activities quoted from $\mathrm{Ha}$-Or are the municipal elections of 1910, when three Jews were elected to the Municipal Council, tasks awaiting the new municipality, the increase in the size of the Jerusalem police, the paving of sidewalks by skilled workers brought from Egypt, an attempt to pave a part of Jaffa Road with asphalt, and other plans to pave main roads in the city. ${ }^{91}$ Drawing on issues reported in $\mathrm{Ha}-\mathrm{Or}$, Ben-Arieh states that in mid-1911, Jerusalem witnessed considerable improvement in public hygiene, the installation of additional lamps, the planting of trees along the main road, and budget approval for ten public conveniences in the city equipped with running water. ${ }^{92}$ Referring to Ben-Yehuda, Ben-Arieh confirms that in 1913, the Jerusalem Municipality was dealing fully with the problem of roads, having sponsored extensive repairs. In addition, sanitation had improved ${ }^{93}$ Ben-Arieh completes his analysis by concluding that the Jerusalem Municipality had indeed increased its activities both in volume and scope, but they were cut short by the outbreak of World War I. ${ }^{94}$

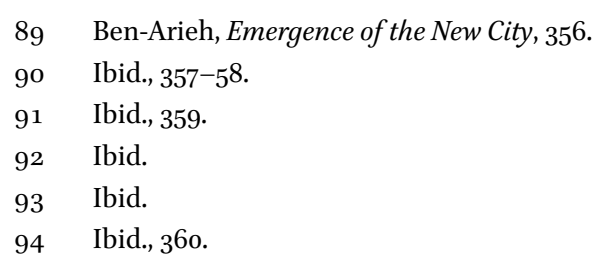


Ben-Arieh considers Ben-Yehuda as an invaluable source of information regarding Jerusalem outside its walls and in the Old City, but he falls short of presenting any in-depth analysis of the information he provides. Rather, he depends on second-hand sources to come up with conclusions that are consistent with the "Jewish" image of "New Jerusalem." If Ben-Arieh had read BenYehuda alongside other contemporary Ottoman sources, such as the records of the religious court, waqf, and the Jerusalem Municipality records themselves, this could have given an accurate picture of Ben-Yehuda in his PalestinianOttoman milieu. To a large extent, Ben-Arieh describes Jerusalem in a context that is separate from its Ottoman milieu, as though it were an independent city and not subject to Ottoman laws and administration. In other words, he reads Jerusalem in a selective and partial manner that demonstrates only the development of Jerusalem as a Jewish city, limiting himself to meager information about the Muslim and Christian communities and about interactions among city inhabitants. This reading contradicts our preliminary reading of Ha-Tsevi, which concluded that Ben-Yehuda always considered his publication to be a Hebrew-Jewish newspaper issued in an Ottoman environment and that he was aware of its authorities, governors, local notables, and municipal council.

\section{Conclusion: Urban Citizenship in Question}

Looking back upon his arrival in Jaffa and then Jerusalem in 1881, Ben-Yehuda states in his memoirs, written during World War I, that the Arabs in Palestine were acting as "citizens of the country," while he found himself in the land of his ancestors no more than a stranger or an intruder without any political or civil rights. Later, in the same memoir, he mentions that his arrival in Jerusalem did not stir his emotions as a Jew, declaring that the citizens of the country were simply "those who lived there" and participated in its public life. ${ }^{95}$ These declarations contradict the above paragraph quoted from Ben-Arieh ${ }^{96}$ in which Ben-Yehuda describes his arrival in Jerusalem with enthusiasm. BenYehuda appears to have been a man of contradictions on many levels; more

95 Eliezer Ben-Yehuda, Ha-Halom ve-Shivro [The dream and its interpretation], http:// benyehuda.org/by/haidan_harishon.html. For an analysis of Ben-Yehuda's civic sense during his arrival in 1881, see Vincent Lemire, Jerusalem 19oo: The Holy City in the Age of Possibilities, trans. Lys Ann Weiss and Catherine Tihanyi (Chicago: University of Chicago Press, 2017), 165-67.

96 Ben-Arieh, Emergence of the New City, 75 . 
effort is needed to interpret or reconcile these complex dimensions and if possible, to produce an acceptable interpretive framework.

Menachem Klein, who has written extensively on Jerusalemite Jews, maintains that at the end of the nineteenth century, Jews from the city's new neighborhoods mixed with the Arabs of the Old City in the open area outside the gate. ${ }^{97} \mathrm{He}$ suggests that at that time, Muslims took part in Jewish religious celebrations and vice versa. Believers from both faiths prayed together for rain at Nabi Samu'il, the tomb of Prophet Samuel, north of Jerusalem. Businessmen from both communities made transactions freely. Jewish and Arab families shared backyards, attended the same schools, and sometimes also intermarried. ${ }^{98}$ These complex relations are absent from both the Jewish and Arab national narratives and what prevails instead is a case of disinheritance of the past or at least part of it.

Drawing on this, a major question still lies beyond the details and remains to be answered: How does civic modernity emerge in Ben-Yehuda's view, and how does his own Hebrew-Jewish project fit into an Ottoman or Jerusalemite project led by Arabs and others? The answer to this question requires continuing work on Ha-Tsevi and other sources of Ben-Yehuda, particularly the memoirs he produced in the last years of his life. In-depth comparisons and cross-checking with local Ottoman sources will then be necessary, and time must be taken to develop more arguments that link text with context and that pave the way for future studies on Ha-Tsevi and Ben-Yehuda.

97 Menachem Klein, Lives in Common: Arabs and Jews in Jerusalem, Jaffa and Hebron, trans. Haim Watzman (London: Hurst, 2014), 4.

98 Menachem Klein, "The Brief Moment in History when a Common Israeli-Palestinian Identity Existed," interviewed by Nir Hasson, Haaretz, April 2, 2016, http://www.haaretz .com/israel-news/.premium-1.711988. 


\title{
Men at Work: The Tipografia di Terra Santa, 1847-1930
}

\author{
Leyla Dakhli
}

In 1847, the Franciscan Printing Press (FPP) was established in the Christian neighborhood of the Old City, inside St. Saviour's Convent, the Franciscan Custody of the Holy Land's headquarters. The year 1847 was also the year that Pius IX reaffirmed the Vatican's direct presence in the region, reestablishing another major Catholic institution in the area ${ }^{1}$ - the Latin Patriarchate of Jerusalem, suppressed after the Crusaders' defeat. It was a period marked by the "rediscovery of the Holy Land" by European powers and Christian religious leaders. ${ }^{2}$ This is reflected in the FPP's purpose: evangelistic outreach and proselytizing. ${ }^{3}$ But the opening of the printing house soon took on a symbolic role

1 Apostolic letter Nulla celebrior, published on July 23, 1847. See Paolo Pieraccini, Il ristabilimento del Patriarcato latino di Gerusalemme e la Custodia di Terra Santa. La dialettica istituzionale al tempo del primo patriarca, mons. Giuseppe Valerga (1847-1872) (Cairo: Franciscan Centre of Christian Oriental Studies; Jerusalem: Franciscan Printing Press, 2006).

2 The research for this chapter was conducted in close collaboration with Maria Chiara Rioli. For a general history of the presence of the Franciscans in Jerusalem and Palestine, see Giuseppe Buffon, Les Franciscains en Terre Sainte (1869-1889): Religion et politique: une recherche institutionnelle (Paris: Cerf; Éditions franciscaines, 2005); Paolo Pieraccini, Cattolici di Terra Santa (1333-200o) (Florence: Pagnini, 2003); Andrea Giovannelli, La Santa Sede e la Palestina: La Custodia di Terra Santa tra la fine dell'impero ottomano e la guerra dei sei giorni (Rome: Studium, 200o). For the global context, see Henry Laurens, La question de Palestine. Vol. 1, L'invention de la Terre Sainte (1799-1922) (Paris: Fayard, 1999).

3 Agostino Arce, Catalogus descriptivus illustratus operum in Typographia Ierosolymorum Franciscali Impressorum, 1847-1880 (Jerusalem: Typis franciscalibus, 1969); "Centenario de la Imprenta franciscana de Jerusalén 1847-1947," Tierra Santa, November-December (1946); Margherita Camorani, "Il primo secolo della tipografia francescana dal 1846 al 1947" (MA diss., Università Cattolica del Sacro Cuore di Milano, 2013); Claudio Baratto, "La tipografia francescana di S. Salvatore," in La Custodia di Terra Santa e l'Europa: I rapporti politici e l'attività culturale dei Francescani in Medio Oriente, ed. Michele Piccirillo (Rome: Il Veltro, 1983), 207-11; Alessandro Mombelli, La Custodia di Terra Santa (Jerusalem: Tipografia dei PP. Francescani, 1934), 84-87.

(C) LEYLA DAKHLI, 2018 | DOI:10.1163/9789004375741_022

This is an open access chapter distributed under the terms of the prevailing CC-BY-NC-ND License at the time of publication. 
even though it was not the first printing house established in the city. Indeed, the Armenians began their printing activity in $1833^{4}$ and the Greek Orthodox Patriarchate of Jerusalem - though it had printing houses in Bessarabia and in Istanbul since the seventeenth century - did so in Jerusalem in $1853 .{ }^{5} \mathrm{Jewish}$ printing also followed. However, the FPP established a new locus for intellectual production in different languages. An essential aspect was that the Franciscans were the first to print books in Arabic in Jerusalem. It was recognized as a major place to print religious volumes, schoolbooks for the Catholic missionaries in the region, and all sorts of material related to the task assigned to the Franciscans in the Holy Land. A close look at the FPP as a workplace also reveals a microcosm where the city's balances of power are visible; namely between the missionaries and Jerusalem's inhabitants.

The FPP was part of the Franciscans' microcosm in the Holy Land. St. Saviour's had space for study and devotion, liturgy and faith, and, in keeping with its spiritual dimension, it represented a town inside the town of Jerusalem. The compound was the site of diverse productions and the workshops were not limited to the highly symbolic and strategic activity of the press. Upon entering the convent, one could see a foundry, a woodworking workshop, a textile workshop (men's tailoring), and a shoemaking workshop. Each of these workplaces told its own story, representing the singular relationship between the convent and the city, with the custody at once self-sufficient, and, increasingly, complementary to Jerusalem. Each activity addressed a practical and spiritual requirement of the order. However, the custody's activities were also turned towards the city, providing locals with new services. Moreover, the Franciscan workshops opened their doors to workers from outside the convent - a reflection of the direct relationship between the custody and the environment in which it was built. The printing press, as one of these microcosms, is articulated in the different works conducted inside and outside the convent.

4 See Arman Khachatryan's chapter, "The St. James Armenian Printing Press in Jerusalem: Scientific and Educational Activities, 1833-1933," in this volume.

5 Agamemnon Tselikas, "I typografia ton Ierosolymon: I typografiki kai ekdotiki drastiriotita tou ekei orthodoxou patriarcheiou" [Printing in Jerusalem: the printing and editorial activity of the Orthodox patriarchate], Epta Imeres, supplement to Kathimerini, April 7, 1996; Ilarionas A. Alexandridis, To typografeion tou Ierou Koinou tou Panagiou Tafou, itoi syntomos perigrafi tis istorias aftou apo tis idryseos tou mechri ton kath'imas chronon (1853-1911) [The printing house of the Brotherhood of the Holy Sepulchre, that is, its short description and history from its establishment to the present day (1853-1911)] (Jerusalem, 1911). 
The FPP still exists. It is now located in the more peripheral area of Beitphage, while its archives are kept in the heart of the convent. ${ }^{6}$ The Franciscan archives are invaluable sources for history in the Middle East and beyond - for centuries the institution maintained strong international ties. This chapter is based on some of the papers kept in the archives: mainly, the director's journals, account books for the various activities, workers' salaries, material purchased, order lists, and the work carried out. ${ }^{7}$ Furthermore, information related to the FPP and its delicate position between Rome, the Franciscan Custody, and the Latin Patriarchate, can also be traced in the archives of the Congregation for the Propagation of the Faith in the Vatican. ${ }^{8}$

\section{Family Portrait: Locating the Tipografia}

The FPP is buried deep in the convent's most majestic area: a room with high arched ceilings which still houses Jerusalem's first printing press, imported from Leipzig, a land of excellence when it came to printing and printing technology (fig. 17.1). ${ }^{9}$ The space obeys a logic of its own: its organization revolves around the printing process, that is, the various tasks the printing press workers had to perform: composition, inking, illustration treatment (photo-engraving), printing, and finishing (folding, cutting and sewing sheets, and binding). This is apparent at first glance. It is a symbiotic universe where trades and experience come together to produce the final product, the printed word.

Initially, the written work produced was heavily tied to the friars' primary activities, that is, evangelizing, teaching, and learning. The FPP's first printed products were evangelical texts, prayers, schoolbooks, and language textbooks (mostly Italian-Arabic, to allow the monks, whose shared language was

6 The author is deeply grateful to the Franciscan Custody for its hospitality, and would like to give special thanks to Fra Sergey Loktionov and Fra Narcyz Klimas for their continued help and support.

7 The custody is clearly aware of the importance of this documentary heritage and puts every effort towards ensuring its preservation. The result of this work is reflected in the monumental inventory, which the archivists continue to update. Andrea Maiarelli, ed., L'Archivio storico della Custodia di Terra Santa (ASCTS), 1230-1970, 3 vols. (Milan: Edizioni Terra Santa, 2012).

8 See in particular Archives of the Congregation for the Propagation of the Faith (ACPF), SC, Terra Santa e Cipro, vol. 24, fols. 59-68, Fra Remigio Buselli to Card. Alessandro Barnabò, May 29, 1866.

9 On books and printing in another time and place, see Roger Chartier, Inscrire et effacer: Culture écrite et littérature (XI $-X V I I I^{e}$ siècle) (Paris: Gallimard, 2005). 


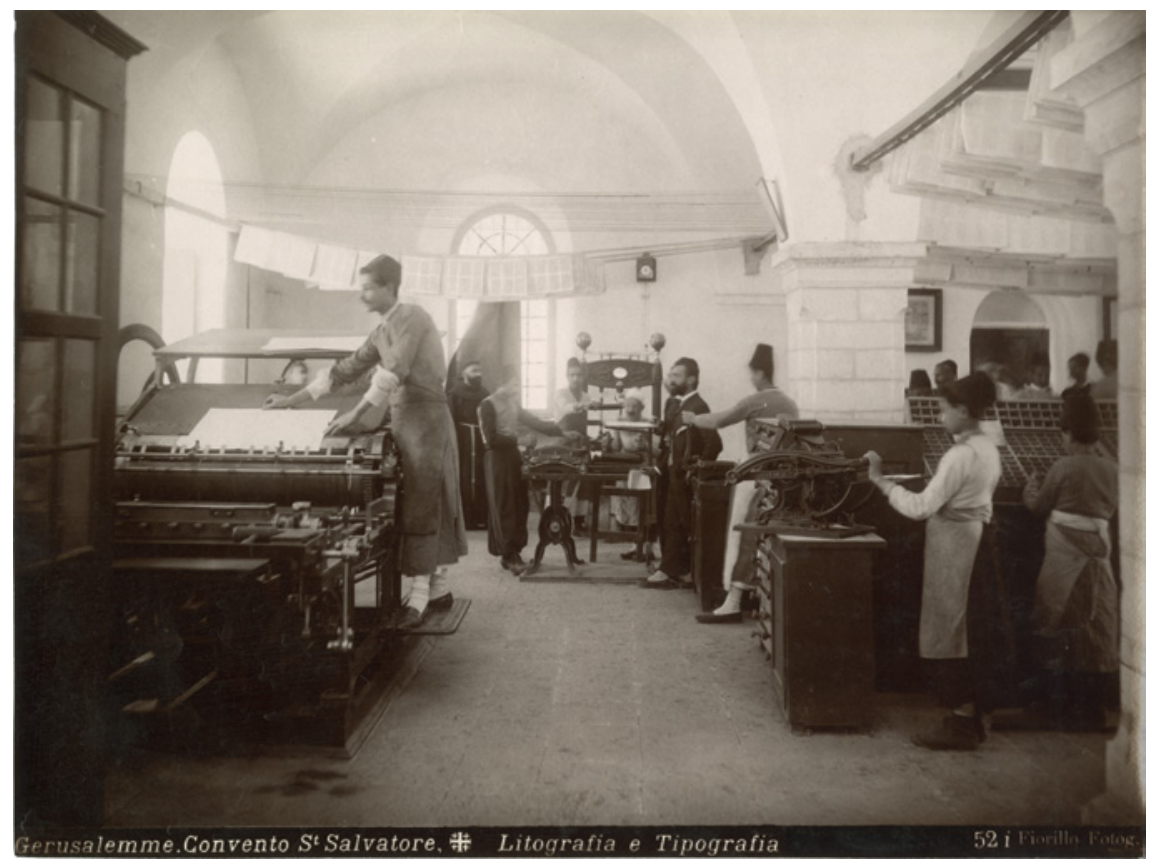

FIG URE 17.1 Lithography and printing press of St. Saviour's Convent, Jerusalem.

PHOTOGRAPHIC ARCHIVE OF THE FRANCISCAN CUSTODY OF THE HOLY LAND.

Italian, to interact with and influence the world around them). The production of written work would gradually be assigned to workers, whom we can become familiar with thanks to the documents kept in the custody. The archives show us a world of men marked by a clear hierarchy and the increasing specialization of skills.

A monk was always in charge of managing the FPP (and sometimes of all of the convent's manufacturing units). He enlisted the help of two clergymen who serve as foremen, supervising the workspace. These three were generally Europeans. Then came the lavoranti (workers) - as they were called in the Italian vocabulary of the convent - either "imported" from further afield for their specific set of skills, or, as we will see later on, trained within the institution itself (often children from the orphanage).

The space in which the FPP had set up shop quickly became too cramped. In the 1880 s, additional storage space was needed for books and materials. Premises were set up in what the director called the "old school," which, according to our research, was adjacent to the FPP. The largest room thus became a 
manufacturing area, and was also open to customers placing orders and paying for products.

It is difficult to establish with any certainty whether - and when - the FPP was involved in book distribution and sales. While the bookselling activity which nowadays operates under the name Franciscan Book Corner on the Jaffa Gate - came about at a later date, all evidence points to the fact that the FPP also functioned as a reseller for books printed elsewhere. Holy Land guidebooks for pilgrims, printed in various languages and distributed directly in Casa Nova, the nearby guesthouse, were among the top sellers. On December 10,1898 , for instance, the register states that a guidebook arrived from Mainz. It had been written by Fra Lavinio, and subsequently translated into German to sell to German-speaking pilgrims. The FPP also fulfilled a number of commercial orders for businesses or social occasions - visiting cards, cards to send with bouquets, menus for ceremonies and parties, ${ }^{10}$ as well as seasonal orders such as graduation certificates, Ramadan calendars, and almanacs at the end of the year.

The archives clearly indicate that the FPP collaborated with other workshops of the Custody of the Holy Land as well as with other printing houses in the city and abroad belonging to other communities. Various parts, the types for instance, were repaired and sometimes even manufactured at the foundry. In September 1879, for example, when the foundry workers were asked to take broken pieces one by one rather than all at once in order to organize and stagger their work. The Franciscan convent - a microcosm unto itself - had its own internal logic dictated by the complementarity of activities and a concerted effort to gradually rationalize the workflow. This rationalization concerned both objects and people throughout the period studied: unfinished products were dispatched to various workshops and workers received training to perform various tasks, thereby becoming specialized in certain areas and building an identity as workers. Among this new hierarchy, the staff at the press were highly ranked.

\section{The fin-de-siècle Workshop: Colonialities of Power}

Let us take a look at the way work was organized in the FPP workshop. A few pieces from the archives help us refine our vision of the daily work at the press.

10 See Maria Chiara Rioli's chapter, "Introducing Jerusalem: Visiting Cards, Advertisements and Urban Identities at the Turn of the 2oth Century," in this volume. 
I studied a notebook belonging to the director who took over in $1879,{ }^{11}$ and ledgers kept by directors after that. The picture that emerges is that of a small company where social hierarchies and colonial and imperial domination are quite apparent, reflecting the power relationships in the city and the country at large. Very strict paternalism towards the workers was typical of work relationships. The workers were men from Jerusalem, its surroundings, and the Bilad al-Sham region. This local status distinguished them from the missionaries. Nonetheless, a hierarchy of skills, status, and age would gradually emerge among the workers.

It is time to introduce one of the FPP directors who arrived in the summer of 1879 and remained at the FPP until the following summer. His name is Fra Guido Corbelli of Cortona, "entrato il 22 luglio del 1879" (entered on July 22, 1879), as he wrote on the first page of his notebook. ${ }^{12}$ Using a different pen, he added: "fine Agosto 1880" (end of August 1880), upon his election as custos of the Holy Land, a position he held until 1886.

At the head of the FPP, Fra Guido also dutifully recorded the names of the directors who preceded him for posterity. In August 1879, he added the following comment to the first page of his notebook: "I forgot to mention at the beginning of this book that the director of the Tipografia, until May of this year, was Fra Francesco Salesio Angeli, from Hungary." This was a way for Fra Guido to put himself on the map, to write himself into a lineage, a continuity. It was both a form of loyalty towards his predecessors and a way of setting his own work apart. It may be seen as a form of self-promotion that would come to characterize his assignation, as we will see. Fra Guido's accession to the role is (self)-described as the outcome of a series of accidents following the death of the secretary of the custody, Fra Barnaba of Terni, "who suffered sunstroke" in Cairo on July 3, 1879. The conditions under which Fra Guido was appointed are noteworthy, as death was widely considered to be one of the possible outcomes of a mission. ${ }^{13}$ From this date onwards, the Franciscan documents refer to him as the new direttore of the F PP, and of the St. Saviour Casa Nova

\footnotetext{
11 Fra Guido, continuous until 1880, resumed in 1897-98.

12 Historical archive of the Custody of the Holy Land (ASCTS), "Brevi notizie sulla tipografia e sui direttori della medesima." Memorie della tipografia, July 22, 1879-May 24, 1899.

13 There is no shortage of reading material and imagery relating to the risks involved in a religious mission - multiple publications have focused on the history of Christian missions alone. Heleen Murre-van den Berg's annotated bibliography is incomparable to navigate your way around the abundance of documentation: "The Study of Western Missions in the Middle East (1820-1920): An Annotated Bibliography," in The Social Dimension of Christian Missions in the Middle East, ed. Norbert Friedrich, Uwe Kaminsky, and Rolan Löffler (Stuttgart: Franz Steiner, 2010).
} 
(the "new house" the Franciscans opened for lodging the pilgrims in the midnineteenth century). His job was difficult and he made sure, early on, that this was known. He was in charge not just of the press, but also of other workshops in the custody: the falegname (carpentry), fabbroferrajo (ironworks), calzolajo (shoemaking), and sarto (tailoring).

His duties involved those of any workshop manager, but he also had spiritual missions such as the weekly spiritual conference he gave to the workers on Wednesdays. The conference was supposed to be held in the "old school," but in reality it soon moved to the Casa Nova's third-class refectory. ${ }^{14}$ The conference was just one of the many aspects of the spiritual tutelage the workers received: workers' attendance at morning mass was checked, as well as their observance of the various religious holidays, and making confession (usually at the end of a day's work).

However, it would not make sense to draw too clear a distinction between spiritual and temporal tasks. Fra Guido's journal, together with annotations on stipendi (payslips), provide a very clear indication that Christian morals were strongly tied in with work itself. Christian morals focused on key values, which gave work a pivotal and redemptive role. In short, the father-director was a spiritual leader just as much as a workshop leader, and he took his spiritual responsibility very seriously. We know whose souls Fra Guido undertook to elevate, because he consigned their names and the date of their arrival at the Tipografia in a series of notebooks. ${ }^{15}$

According to the account of Fra Paolo Greganti, FPP founder Fra Sebastian Frötschner (1807-91) was initially sent to train with the best printers in Vienna. He then purchased a printing press with a few types and travelled to the Holy Land, where he set about recruiting staff. "He chose an adult who struck him as intelligent, as well as three young people aged between 13 and 15, who had been part of our parish school, and taught them - very patiently - the basics of the art of composition."16 Fra Guido's successors also kept a list of staff whose first names were spelled according to the various languages spoken in the FPP.

\footnotetext{
14 ASCTS, "Brevi notizie sulla tipografia e sui direttori della medesima," August 27, 1879.

15 ASCTs, "Brevi notizie sulla tipografia e sui direttori della medesima," Memorie della tipografia, July 22, 1879-May 24, 1899. Ibid., f. 3. The workers were: Habasc Mikail (1851), Caruz Abdallah (1852), Hallac Samaan (1854), G res Kalil (1859), Lonzo Anton (1860), Curdi Stefan (1869), Tarscia Samaan (1869), Haddad Habib (1870), Arab Bisqual (1871), Lonzo Calman (1873), Gattas Mikail (1874), Nisnas Mikail (1875), Caruz Anton (1879), Salib Manauel (1879), Aooda Anton (1879), Chittane Anton (1879), Stefan Bschiara (1879). The names are spelled as written by the priest.

16 Fra Paolo Greganti, “Centenario della Tipografia francescana di Gerusalemme (18471947)," La Terra Santa (1947).
} 
Anton could thus become Antonio; Stefan, Estefan, or Stefano, etc. The same changing - rules of usage applied to family names. This list of men (n. 15) shows the progression and the development of the FPP, a development which accelerated in the year of Fra Guido's appointment in 1879. The names of the workers reappear alongside the tasks listed in the workshop, as this example from September 1865 shows:

1. Storie de' Crociate II. P. Arab. Sign. Arab. Sign. 9. Antonio Losso, Raffaele ed Abdallah.

4. Catechismo Diocesano arabo, II. Ediz., Lign. 1., Albina, Raffaele Ed Abdallah.

5. Firmante di fanulleria per il consulato d'Austria cop. 200, 1/2 forma, Carlo, Raffaele ed Abdallah.

6. Lettere d'uffizio per il Lloyd in Giaffa cop. 200, 1/2 forma, Carlo, Raffaele ed Abdallah - per il consolato d'Austria.

The director was assisted by two representatives of the Franciscan order: Fra Giuseppe Weißman of Baden and Fra Alfonso of Capua, "Terziario" (Terciari). On top of their supervisory work, both had specific finishing and binding duties that required a certain technical know-how. There was another skilled worker in the team, usually recruited from outside of the local breeding grounds: the Arabic proofreader, usually Lebanese (at the time when Fra Guido arrived, "Don Giacomo Auad" [Ya'qub 'Awad], whose name, as many others, had already been "Italianized" and somehow ennobled, held this position). In August 1879, the ledger features one more person: Camillo Albino, who was in charge of handing out salaries to the workers. ${ }^{17}$

In the years that followed, staff turnover was fairly low. This makes it easier to follow the evolution of workers' salaries and careers as well as their gradual specialization. Upon leaving the workshop they received a pension, which they would occasionally supplement by coming back to work on a specific order. They also supplemented their salaries by working overtime and were paid for each completed piece. A close reading of the logbook of orders and work carried out reveals that Steven Sabella was a reliable and reputable worker (late nineteenth century) and that Gamil Abdallah was a good pieceworker (around 1915). ${ }^{18}$ The most experienced and skilled workers, those who built a career working in the press, feature frequently in the logbook. They received

17 ASCTs, "Brevi notizie sulla tipografia e sui direttori della medesima," August 23, 1879, p. 9

18 ASCTS, "Lavoranti a cottimo," January 1922-December 1923. 
regular pay rises until they finally retired (for example, Sabella in 1942). $\cdot{ }^{19}$ In the ledger for the 1920 (by which point the printing press had its own ledgers), ${ }^{20}$ the workers were listed by type of job - three in total: compositori (typesetters), legatori (bookbinders) and stampatori (printers). ${ }^{21}$ Being a good person involved fulfilling criteria of competence and leading what the documents usually call a "Christian life." As a result, one worker might be given a letter of recommendation to help him find work elsewhere, while another would not be granted such a letter because he was suspected of being "of ill repute."

\section{Obeying the Rules: Managing the Workers}

Within the hierarchy of values, it seems that silence took precedence. The FPP's entire work ethic was built around silence - a commandment that was more reminiscent of religious life than of a traditional working environment, where conversations would likely be heard amid the ticking of machines.

The other golden rule was less unusual: scrupulous timekeeping. The foreman (that is, the workshop director or an assistant) was the keeper of time. The obsession with silence and concentration was tied in with the imperative not to "waste time" ("perdere tempo"). As the ledger for 1880 shows, punishments were harsh: "Quest'oggi è stata tolta una terza parte della paga settimanale ai lavoranti Salub, Caruz, Chitane et Bsciara, perché invece di lavorare perdevano tempo a discorrere anche dopo d'essere stati avvisati" (Today one third of the weekly pay was kept from the workers Salub, Caruz, Chitane and Bsciara because instead of working they were losing time talking, even after being warned). This focus on timekeeping is unarguably born from morality rather than a mere drive towards efficiency. The objective was to combat sloth - "ozio" in the friars' Italian - since laziness is a cardinal sin. Distraction was tracked and punished. In September 1880, the ageing worker Caruz was punished for losing his focus and having made too much noise ("fatto baruffo"). ${ }^{22}$ One has to keep in mind that this obsession with time is also one of the characteristics of colonial powers and imperial orders. In the case of Jerusalem, the application

\footnotetext{
19 ASCTs, "Paga settimanale dei lavoranti," September 28, 1936-December 31, 1943.

20 In the previous file, the workers (totaling 84 ) were divided into 11 different positions: 13 typesetters, 7 printers, 7 type founders, 13 bookbinders, 1 painter, 14 carpenters, 2 millers, 5 tailors, 15 farriers, 4 cobblers or shoemakers, 3 coopers. Ascts "Paga settimanale dei lavoranti," March 6, 1915-November 1915.

21 ASCTS, "Stipendi," August 29, 1921-November 27, 1926.

22 ASCTs, "Brevi notizie sulla tipografia e sui direttori della medesima," August 23, 1879.
} 
of a certain order of time is one of the ways to get along, to give a common rhythm to the city, as shown by the Ottoman projects of city clocks as well as by the installation of Church clocks. ${ }^{23}$

There were other serious crimes such as theft (furti) and poorly executed work or, more generally, carelessness. On March 27, 1899, Stefano Curdi was issued a warning because his binding was sloppy. From the very first warning he was told that unless the binding was done with more care, he would have to fix it at his own expense. What emerges from a close study of the way that incidents and misdeeds were handled is that they were managed "internally" The workers were threatened with collective punishment until the culprit turned himself in. Sometimes the culprit would come forwards, failing which another technique was used. For example, a statement from the two friars in charge of supervising the workshop would be issued. The friars certainly did not need encouragement to play their part as foreman - Fra Giuseppe and Fra Alfonso were prone to complaining about workers mocking them. ${ }^{24}$

There was a degree of solidarity between workers. They did not denounce one another and were happy to collectively shoulder responsibility for a wrongdoing such as a damaged machine or wasted paper. (In early 1880 , the director's journal contains an account of such an episode.) In retaliation, the director set up a much tighter surveillance system headed by Fra Guiseppe. Each morning, he drew up a list of tasks and would check progress at the end of the day before reporting back to management: "così la sera vedrò il lavoro d'ognuno, e se m'accorgo di pigrizia e negligenza diminuirò la paga giornaliera del lavorante trascurato" (this way, in the evening I will be able to review what each worker has done and, should I notice any laziness or negligence, I shall reduce the daily pay of the worker in question). It is difficult to determine the efficacy of this system and how frequently it was used. However, one thing is certain: over the period we studied (until the late 1920s) any and all breaches of discipline and substandard work were systematically reported in the payroll and resulted in lasting financial sanctions. The closest parallel is perhaps the

23 Avner Wishnitzer, Reading Clocks Alla Turca: Time and Society in the Late Ottoman Empire (Chicago: University of Chicago Press, 2015); Giordano Nanni, The Colonisation of Time: Ritual, Routine and Resistance in the British Empire (Manchester: Manchester University Press, 2012).

24 "Si sono lagnati che alcuni lavoranti, particolarmente Chittane, Caruz e Salib, si burlano di loro. Ho chiamato i detti tre lavoranti, e li ho severamente ripresi" (They complained that some workers - specifically Chittane, Caruz and Salib - had made a fool of them. I called the aforementioned three workers and gave them a good scolding); Ascts, "Brevi notizie sulla tipografia e sui direttori della medesima," August 23, 1879 . 
way the guild functioned in the Middle Ages, ${ }^{25}$ specifically in the keeping of a religious register, the compulsory performance of charitable acts, and the obligation to hand over money to the head of the guild for immoral behavior (drinking, cheating, etc.). At the FPP, there was no practice of making donations in honor of the saints, but workers accused of immorality saw their salaries slashed until they had made amends for their behavior.

Work was organized according to a strict timetable. It included Christian time and was centered around mass, the main feature. This aspect of the FPP likens it to a precapitalist universe, predating the standardized hours in factories, ${ }^{26}$ but the similarities stop there: the Jerusalem of that period ran on many different clocks. Therefore, we might just as easily liken the ecclesiastics' timekeeping - the intense focus on time management, speed, and efficiency when performing tasks - to timekeeping in factories. Indeed, orders coming in increasingly set the pace at the workshop. Accordingly, it became increasingly commonplace for employees to work paid overtime in order to finish a specific order.

\section{Reciprocal Duties and Social Care}

The payoff in the Franciscans' paternalistic system was the privileges and protection they procured. Let us leave to one side the spiritual protection provided by the Franciscans. It seems the workers did not much care for it, because they preferred to arrive a little later than the 6 o'clock morning mass (the archives contain numerous mentions of this shortcoming). Before the arrival of Fra Guido, working at the press appears to have been considered a true privilege, in particular compared to other workshops. Did the workers appreciate the respectability, the difficulty, or the novelty of their work level? We do not have the answers. We do know, however, that Fra Guido took it upon himself to put an end to these privileges that had previously set the FPP workers apart from the others. He put an end to benefits, bonuses, and presents for name days. He enlisted the help of his superiors in doing so, frequently asking the custos himself to support his decisions.

25 Jennifer Kermode, ed., Enterprise and Individuals in Fifteenth-Century England (Stroud: Alan Sutton, 1991).

26 Peter Stabel, "Labour Time, Guild Time? Working Hours in the Cloth Industry of Medieval Flanders and Artois (13th-14th Centuries)," Tijdschrift voor Sociale en Economische Geschiednis 11, no. 4 (2014). 
To compensate for all this, there was a system of donations and rewards for overtime work when orders piled in or when a job was being "put to bed" (see the ledgers), as well as for celebrations such as the new year. Until 1879, on their saint's day, workers received five to ten francs. The new director did away with this benefit on September 29, 1879, purportedly because workers in other workshops did not have the same rewards. The director's decision may well also have been a response to the increase in the workforce and the access to cheaper labor with more deeply-rooted loyalty: that is to say, workers came increasingly from the orphanage.

The orphans were at the heart of the custody's plan for what one might call self-subsistence. The idea was to offer the children from the orphanage a job in one of the workshops. Thus, they would start out as apprentices (fig. 17.1) whose roles were to return parts to their proper place, help with composition, and generally learn how to perform the various tasks in the workshop. Their pay was relatively low compared to the salaries the workers received. Once trained, they participated fully in the workshop. Training the children from the orphanage was undoubtedly a way to circumvent an issue Fra Guido often commented on in his notebook: local workers' lack of discipline and their tendency to become distracted, a shortcoming he attributed directly to their life outside of the convent. Indeed, local workers had dependents (their family) and obligations that prevented them from having the flexibility the job required.

Some workers received protection from influential members of their family. Fra Guido seems to have sought a free hand in his workshop and took kindly to intervention from the outside. The most notable example of interference is the recruitment of an Arabic proofreader closely linked to the Latin Patriarch (the nephew of the patriarch's chancellor). The new recruit was soon found to be grossly incompetent. ${ }^{27}$ The whole affair became a confrontation between the missionary - who was not a local - and the town's most powerful and notable inhabitants. The proofreader had been hired on his relative's recommendation and was entrusted unto the director's care by the custos himself. As such, he immediately received preferential treatment (sixty francs a month pay and day

27 The difficulty of hiring good proofreaders has characterized the history of the FPP since its establishment. Writing to Cardinal Alessandro Barnabò, prefect of the Congregation for the Propagation of the Faith, on the possible transfer of the FPP to the dependence of the Roman dicastery, Patriarch Giuseppe Valerga highlighted how the friars had a lack of capable proofreaders ("manchino di persone idonee alla correzione"). ACPF, SC, Terra Santa e Cipro, vol. 24, fols. 3-4, January 3, 1866. 
lodgings to work at the custody). ${ }^{28}$ In Fra Guido's account of the case the proofreader arrived on August 16, 1879, and the issue lasted several weeks. Fra Guido highlighted both his concern with safeguarding the interests of his institution and his order, and with upholding the rule of good work and of moral conduct. On August 28, that is, barely two weeks after he was recruited, the proofreader was severely admonished, and Fra Guido commented that he had "been forced to warn his uncle."29 One month later, the director was "at the end of his tether." In a desperate bid to save his nephew's position, the uncle stepped in and swore he would ensure his protégé would not hand in poorly executed work by personally pitching in with the proofreading. In spite of these concessions and everyone's best efforts, Giuseppe Maria Tannous (the nephew) was only allowed to retain his position in the workshop for the sake of maintaining good relations between the Latin Patriarchate and the custody. The available documentation - the notebook kept under Fra Guido's and his successors' management - is rife with accounts of the way mistakes or sloppiness at work were handled. Whether it was a damaged machine or poor-quality binding, everything was consigned to the notebook and subsequently deducted from salaries. Warnings added up and could lead to dismissal.

Paternalism took many different forms, including leniency. Thus, in late September 1930, composer Antonio Dopieralo was fired for negligence at work and frequent tardiness. He was hired again a week later "per carità verso i parenti" (as a charitable act towards the relatives). He was dismissed permanently in December 1930, for the same reasons. ${ }^{30}$ Amid growing rationalization of work, the workers' potential poverty became the only valid reason for coming to their aid. In the journal and in the notebooks, frequent reference is made to "poor workers" who received aid in various forms: including clothing ("un cappotto per un povero lavorante" [a jacket for a poor worker]), healthcare (medical, mostly), or direct financial aid (mostly advances on their salary to face unexpected expenses).

28 ASCTs, "Brevi notizie sulla tipografia e sui direttori della medesima," Memorie della tipografia, August 23 and 16, 1879, 8-9.

29 "Ho ripreso fortemente il correttore della tipografia (Tannus) perche corregge molto male, e non toglie i spropositi. Ne ho anche avvertito suo zio" AsCTs, "Brevi notizie sulla tipografia e sui direttori della medesima," Memorie della tipografia, 10.

$30 \quad$ ASCTs, "Stipendi," December 4, 1926-May 16, 1931. Note in pencil, "cacciato via condotta non buona sempre in ritardo" (fired for negligence in work, always late). 


\section{Religion of the Books}

The FPP had pride of place among the workshops in the custody, primarily because of the importance of what it manufactured. The workshop manufactured schoolbooks that were sent out to the entire network of missionary schools in the region, dictionaries and tools to learn languages and help spread the mission's message, church books, and religious books, almanacs, and all of the small publications needed for ritual life. ${ }^{31}$ Books also allowed the custody to play a crucial part in the transmission of texts and languages. As printing developed, the FPP acquired more and more types, and specialized in translation from European languages to Arabic. Along with Beirut's Catholic Printing Press and its Oriental Library, the FPP became the more pragmatic side of the Arab world's Nahda. Beyond that, the very foundations of the order - which considered labor and social work to be aspects of priesthood - hinged on the FPP, which trained workers and gave them regular work for a lifetime, as well as offering orphans training in skills. In a context predating labor law, the FPP microcosm revealed the hierarchy established by the presence of missionaries in Palestine, as well as the opposition which developed in reaction to it, namely among workers with a longer length of service. In the workshop, this opposition expressed itself through group solidarity (in particular when the friars were trying to identify a wrecker), go-slows, and minor acts of disobedience (in particular frequent refusals to be silent and slack attendance at spiritual conferences). The skills the workers developed were specialized and rare enough as to render them indispensable, meaning that they could sometimes branch out on their own or even offer their services to competitors, whose numbers were growing since the beginning of the twentieth century. Occasionally, retired workers were called back to finish an order or work on a difficult task.

An entire slice of life in the city of Jerusalem emerges when one leafs through the FPP's archives at the custody: not only do we observe the men's working lives and their family ties (or lack thereof), but we also gain access to a great cluster of papers - reading material, cards, labels, and headed paper destined for its own journey through the city and beyond. The FPP provides a glimpse of the history of work and workers in the region, showing how missionary practices joined the evolution of capitalism and managerial practices from old-school paternalism to modern management of work flow and workforce.

31 On almanacs and their relation to order and time, see Özgür Türesay, "Le temps des almanachs ottomans: usage des calendriers et temps de l'histoire (1873-1914)," in Les Ottomans et le temps, ed. François Georgeon and Frédéric Hitzel (Leiden: Brill, 2011). 


\title{
The St. James Armenian Printing House in Jerusalem: Scientific and Educational Activities,
} 1833-1933

\author{
Arman Khachatryan
}

St. James Armenian Printing House (SJAPH) is recognized as the first printing house in Jerusalem. Established in 1833, in the Armenian Patriarchate of Jerusalem, it quickly became a wellspring of religious, scientific, and educational literature in the Middle East. The SJAPH was integrated into the multiethnic and religiously diverse fabric of Jerusalem and took part in the city's urban citizenship processes of citadinité. By publishing works that reflected the debates and ideas of the times, the SJAPH positioned itself as a center for intellectual life in the city. For a century, it published religious and theological works along with prominent Armenian historical, philological, and geographical studies that emerged from St. James Convent. The publishing house ensured the circulation of translations and creative works in Armenian, and also published translated texts. In 1886, the religious-philological journal Sion was founded, and soon became the official organ of the patriarchate.

This chapter is based on secondary literature produced by religious and academic authorities on unexploited materials from the patriarchate's archives, works from the Calouste Gulbenkian Library, archives in Jerusalem and Sion, the official periodical of the patriarchate. It is constructed into three sections: the first part introduces the SJAPH, focusing on its establishment and technical capacities. The second section discusses the administrative, legal, and political challenges it faced during the Ottoman and British periods, while the third part explores the publishing activity of the SJAPH, its scientific and educational role, and its readership.

\section{The Establishment of St. James Armenian Printing House: A Brief Narrative}

The founding of the SJAPH was the outcome of an Armenian printing movement that began in Venice in the fifteenth century and reached its peak during the nineteenth century. The first Armenian book was published in Venice,

(C) ARMAN KHACHATRYAN, 2018 | DOI:10.1163/9789004375741_023

This is an open access chapter distributed under the terms of the prevailing CC-BY-NC-ND License at the time of publication. 
where an Armenian community settled in the twelfth century. Printing a book in a foreign language was easier to accomplish in Venice because censorship was less severe there. ${ }^{1}$ In the early nineteenth century, Armenian printing houses grew in places where Armenian communities or churches, either Apostolic or Catholic, had clerical representation. Printing houses were usually founded either by individual clerics or by the church itself. The Jerusalem Patriarchate under Zakaria Ter Petrosian, a well-educated bishop of St. James Convent, decided to establish a printing house.

In his mid-teens, Zakaria Ter Petrosian left for the holy city of Etchmiadzin with three friends, joining a small group of students under the tutorship of Nerses Ashtaraketsi, the future catholicos (religious leader) of all Armenians (1843-57). Unhappy with the atmosphere created by the conflict between two rival catholicoses, Daniel and Davit, Ter Petrosian traveled to Constantinople. There he met two Catholic monks from the Mekhitarist Order on St. Lazarus Island in Venice. Ter Petrosian was seeking higher education, and the monks convinced him to join the Mekhitarists' seminary in Saint Lazarus. Upon graduation, the Mekhitarists asked him to join their order. He refused, instead choosing to retain his initial faith and return to Constantinople. There, he approached the Vicar of the See of Jerusalem and expressed his desire to work. He was soon appointed as the assistant to Kirakos Vardapet Mnatsakanian, Patriarch Teodoros Vanetsi's secretary. ${ }^{2}$

Ter Petrosian's experience influenced the establishment of the printing house. In the religious centers of Constantinople, he had learned about seminary activity and printing houses, and was impressed by the literary and educational activities of the Mekhitarists. He conceived the role of the seminaries and the printing house as a means for the development not only of the convent's religious life, but also of the spiritual culture of the Armenian people. His idea to establish a printing house in the Armenian Convent in Jerusalem stemmed from a desire to publish the Armenian classic manuscripts of the Apostolic Church. The Mekhitarists, who were Catholics, refused to do so. ${ }^{3}$ In 1829 , when Ter Petrosian became the locum tenens of Jerusalem in Constantinople, he started to prepare the printing press and purchased letter matrices at his own expense. In May 1830, he was exiled to Cyprus based on

1 Rafael Ishkhanian, Hay Girk'ē 1512-1920 [The Armenian book, 1512-1920] (Yerevan: Publishing House of AS ASSR, 1981), 22-26.

2 Haig Aram Krikorian, Lives and Times of the Armenian Patriarchs of Jerusalem: Chronological Succession of Tenures (Sherman Oaks: H. A. Krikorian, 2009), 383.

3 Tigran Sawalaniantz, Patmut'iwn Yerusaghémi [History of Jerusalem], 2 vols. (Jerusalem: St. James Press, 2000), 1025. 
a royal command of Amira Harutiun Pezechian. His exile was in response to a request Ter Petrosian made to Sultan Mahmud II, to restore the Armenian rights to Golgotha. The request had been made without the agreement of the Armenian patriarch of Jerusalem and the Amiras (influential Armenian leaders) of Constantinople. From exile in Cyprus, he wrote to Agha Petros Yusufian, an Armenian merchant in Trieste, and asked him to offer a printing press to the patriarchate as a gift. Yusufian accepted the proposal. He bought a wooden press, as well as lead letters and letter matrices, and sent it to Jerusalem in 1830. However, lacking other necessary materials, the SJAPH could not begin printing right away. Ter Petrosian was freed from exile a year later and returned to Jerusalem.

In the beginning of 1833, Ter Petrosian went to Egypt to seek permission from Mehmet Ali Pasha to acquire printing equipment and operate the printing house. A wealthy Armenian from the town of Akn, Alikhan Yeghiazarian, supported Ter Petrosian in his efforts, and offered the convent a lithographic press. ${ }^{4}$ In 1833 , the first book was printed by the SJAPH. From then until 1835, only three small books were printed because of the lack of equipment and financial resources. ${ }^{5}$ In 1835, upon Ter Petrosian's request, Patriarch Poghos held a meeting about the printing situation and the expansion of the religious seminary more broadly. Ter Petrosian explained the importance of having a printing house and a seminary for the convent. The attendees voted unanimously for the establishment of both as soon as possible. Ter Petrosian was also allocated a separate fund to spend on prioritized expenses. A sum of 40,000 kurus $^{6}$ bequeathed by Samuel Vardapet, the nuncio (representative) of the Armenian Patriarchate of Jerusalem in India, was allocated for the expenses of the SJAPH. ${ }^{7}$ After Kirakos became the Armenian patriarch of Jerusalem (1846-50), he ordered a new set of letter matrices to be sent from Constantinople by Hovhannes Myuhentisian, the creator of the new matrices. With the new letters, Bishop Petros Berdumiants's work Meknut'iwn T'ght'oyn Poghosi ar Yep'esats'is (Interpretation of the Epistle of Paul the Apostle to the

4 Ibid., 987 .

5 Anahit Muradian, Yerusaghemi Hay Tpagir Grk'i Matenagitut'yunē (1833-1996) [Bibliography of Armenian books printed in Jerusalem (1833-1996)], ed. G. A. Suqiasian (Yerevan: Lusabats Press, 2011), 11.

6 In 1844, the Turkish gold lira was equivalent to one hundred silver kurus.

7 Sawalaniantz, Patmut'iwn Yerusaghémi, 988. 
Ephesians) was printed. The work was 804 pages long, making it the most voluminous work published since the establishment of the printing house. ${ }^{8}$

At the time, the SJAPH was still situated impractically in some of the convent's northeastern rooms, and its printing equipment remained outdated. ${ }^{9}$ The patriarch ordered a printing press from Vienna with the inscription "I Yar'ajadimut'iwn Hayerēn Matenagrut'ean Yerusaghém K'aghak'i, Yorineal i Vienna, 1849" (For the development of Armenian printing in Jerusalem: made in Vienna, 1849). Though both Patriarch Kirakos and Ter Petrosian wished to build new facilities for the SJAPH, this wish remained unfulfilled because of insufficient finances. During the rule of the next patriarch, Hovhannes (1850-6o), the patriarchate finances improved, but most of the convent budget was spent on buying land and property, as well as on building construction. ${ }^{10}$ The problem of the SJAPH's facilities remained unaddressed, though the Armenian patriarchate had already received a permit to build a printing house. ${ }^{11}$

The SJAPH began to function more regularly during the patriarchal rule of Yesayi (1864-85). The National Administration of Constantinople, a representative executive body linked to the Armenian Patriarchate of Constantinople that was elected by the Western Armenian public, asked Yesayi to further develop the convent's seminary, the SJAPH, and the manuscript archive and museum. A year later, the National Administration elected Yesayi as Armenian patriarch of Jerusalem. On April 5, 1865, Patriarch Yesayi arrived in Jerusalem and concentrated his efforts on the scientific-educational activity of the convent. First, he initiated the renovation of the SJAPH's facilities. Previous patriarchs had intended to construct a new building, but restricted financial resources prevented him from doing so. Instead he decided to repurpose an existing building situated in the southern part of St. James Church, built by Patriarch Yeghiazar in 1675, which had previously been used as a stable for the horses and donkeys of pilgrims. The area of the stable was about 1,00o square meters. A year after the SJAPH had moved to the new building, a close friend of the patriarch, Jakob Ashegian, donated a large printing press with the

Petros Berdumiants, Meknut'iwn T'ght'oyn Poghosi ar Yep'esatsis [Interpretation of the Epistle of Paul the Apostle to the Ephesians] (Jerusalem: St. James Press, 1850).

9 Malachia Ormanian, Haykakan Yerusaghém: Nkaragir At'oroy Srbots Yakobeants' [Armenian Jerusalem: description of St. James Convent of Jerusalem] (Jerusalem: St. James Press, 1931), 72.

10 Sawalaniantz, Patmut'iwn Yerusaghémi, 987.

11 Firman from Süleyman Pasha to the Armenian Patriarchate of Jerusalem, 1850, Folder 30, Old and New Licenses of the Printing House of the Holy See, the Archives of the Armenian Patriarchate of Jerusalem, Jerusalem. 
following inscription: "I Sb. Yerusaghém 1866 ógost. 14. Tpagrut'ean Mamuls Yishatak é Talastc'i Ashēgean Mets. Yakob Aghayi, vor Bnaki yAghek'sandria" (To Holy Jerusalem, August 4, 1866: This printing press is a souvenir from Jacob Ashegian Agha from Talas living in Alexandria). ${ }^{12}$

Part of the printing house started to be used as a place for molding and storing books, journals, and the paper used for printing. Ashegian donated about 300 Ottoman liras to renovate this part of the SJAPH. To commemorate him, the following inscription was placed on the northern wall of the SJAPH: "Erkrord Masn Tparanis Yaweleal Ibr Granots ew Dzularan Norogetsav i Patriargut'ean T. Yesayeay S. Ark'episkoposi, i Yishatak Metsahambaw Ashēgean mhi. Yakob Éféntii i Kesarioy T’alas Geghjén, 1871" (The second part of the printing house, also bookstore and smelting house, was renovated by respectful Ashegian Jacob Effendi from Kesario Talas, during the years of Patriarch Yesayi, 1871). ${ }^{13}$ The letter foundry was in a separate room with all its amenities. The SJAPH was equipped in accordance with modern standards, and had a hydraulic water printing press for the bindery, a lithographic press, binding machines, samplers, and other secondary equipment. It also had a quick-printing press, an aquatint machine, a cylinder press, a bookbinder and foundry equipment, a hand printing press, lithographic and headline presses, and cutting machines. It possessed not only Armenian matrices, but also Latin, Arabic, Greek, and Hebrew characters, ornamental figures, ornaments for corners and circles, khazes ${ }^{14}$ - in short, anything that could be used in printing. ${ }^{15}$ Apart from these, the SJAPH had the possibility to establish sections for galvanism and color pictures by Patriarch Yesayi, who had learned about them in Manchester, London, and Paris in 1863. However, due to a lack of professionals skilled in these areas, these sections did not succeed. ${ }^{16}$

During the years of Patriarch Yesayi (1865-85), the SJAPH flourished and received donations from various individuals. For instance, in 1881, Lady Soghome Astvatsaturiants, a resident of Akkerman, gifted a torno for galvanism to the SJAPH. In addition to the printing press that he donated and the expenses he paid for the renovation of the SJAPH, Ashegian earmarked 10

12 Mesrop Nshanian, Aknark mē Yerusaghémi S. Yakobeanc Tparanin vray [Essay on St. James Armenian Printing House of Jerusalem] (Jerusalem: St. James Press, 1912), 42-47.

13 Ibid., 47-48.

14 Khazes are the symbols in the traditional system of musical notation used to transcribe religious Armenian music.

15 Ormanian, Haykakan Yerusaghém, 75.

16 Garegin Levonian, Hay Girqe ew Tpagrut'yan Arvestē [The Armenian book and the art of typography] (Yerevan: Haypethrat, 1946), 194. 
percent of the profit from his properties in Jerusalem for printing textbooks. Other philanthropists supported the printing house by covering the expenses of book publication. In 1871, Set Abgarian, the son of the wealthy merchant Harutiun Abgarian, and the first sheriff of the city of Kolkata, paid for the second publication of Zhamanakagrut'iwn Tear'n Mikhaye'li Asorvoy Patriarki Haneal $i$ Hnagoyn Grch'agré (Chronology by Patriarch Michael Asory). ${ }^{17}$ Kirakos Karukeants, a pilgrim from Kharberd who visited Jerusalem in 1872, paid for the publication of Patmutiwn Hayastaneants'Arak'elakan Surb Yekeghets'voy (History of the Holy Apostolic Armenian Church). ${ }^{18}$ During the years of Patriarch Harutiun Vehapetian (1889-1910), donors continued to sponsor the printing of some books. For instance, in 189o, Abraham Pasha Bartogh and Poghos Bey Ashegian, wealthy men from Alexandria, supported the publication of Zhamanakagrakan Patmut'iwn Surb Yerusaghémi (Chronological history of Holy Jerusalem) by Astvatsatur Hovhannisian. ${ }^{19}$ Another voluminous work, Hamabarbar' Hin ew Nor Ktakaranay (Concordance, Old and New Testaments), was published in 1895 by Tadewos Astvatsaturian, a member of St. James Convent. A senior priest from Kolkata, Hovhannes Khachikian, donated 100 British pounds for publishing this massive work. The printing process took four years and the patriarchate spent about 6oo Ottoman liras on this approximately 1,6oo-page tome. ${ }^{20}$

\section{Under Ottoman and British Rule: Working in Spite of Imperial Censorship}

During the patriarchate of Harutiun Vehapetian (1889-1910), ${ }^{21}$ more than seventy books were printed. Compared with those published during the rule of the previous patriarch, Yesayi, ${ }^{22}$ these books were superior both in quality and

17 Mikhayil Asori, Zhamanakagrut'iwn Tear'n Mikhayeli Asorwoy Patriark'i Haneal i Hnagoyn Grch'agré [Chronology by Patriarch Michael Asory] (Jerusalem: St. James Press, 1871).

18 Melikisedek Murateants, Patmut'iwn Hayastaneants' Ar'ak'elakan Surb Yekeghets'woy [History of the Holy Apostolic Armenian Church] (Jerusalem: St. James Press, 1872).

19 Astvatsatur Hovhannisian, Zhamanakagrakan Patmutiwn Surb Yerusaghémi [Chronological history of holy Jerusalem] (Jerusalem: St. James Press, 189o).

20 Tadewos Astvatsaturian, Hamabarbar' Hin ew Nor Ktakaranay [Interpretation of the Old and New Testament] (Jerusalem: St. James Press, 1895).

21 Harutiun Vehapetian was elected as the Armenian Patriarch of Jerusalem in 1885, but he stayed in Constantinople until 1889 .

22 Around two hundred large and small books were published during the reign of Patriarch Yesayi. Additionally, the Sion journal was published for eleven years. 
quantity. The reason for this is most likely that when Patriarch Vehapetian took the throne, censorship increased throughout the Ottoman Empire. Ottoman censorship, which came to the fore after the 1860 , was grounded in the sultan's regime, and reflected his desire to prevent any opposition. ${ }^{23}$ In 1888 , an unpublished censorship policy was in use. According to that policy, a statement was issued about the written works that were welcome, that is, articles on "the dearest Sultan's life and well-being" and the economic development of the country. Banned works included multipoint petitions on assassination attempts on coroneted persons and articles on demonstrations and strikes. ${ }^{24}$ Under such conditions, Zhamanakagrakan Patmutiwn Surb Yerusaghémi (Chronological history of Holy Jerusalem) was included on the list of banned books. ${ }^{25}$ This work covered the history of the struggle of the Armenian Church in Jerusalem from its beginning until the author's day, and it is likely that some ideas in this book contradicted the interests of the Ottoman government. Harutiun Vehapetian did not want to oppose the Ottoman government or to endanger the patriarchate and the convent.

After the death of Vehapetian, the patriarchal throne of Jerusalem remained vacant for eleven years, from 1910-21. As a result of World War I, the Armenian patriarchate of Jerusalem endured grave economic hardship. Thousands of Armenian refugees, survivors of the Genocide, settled in the Armenian Convent. In order to provide them with shelter and food, the patriarchate borrowed money at high interest rates and cut down on expenses. They even reduced the number of students in the theological seminary. However, the SJAPH stopped functioning only for a few years, from 1918-24. Three small booklets were nevertheless published between 1921 and $1924 .{ }^{26}$

In 1915, the Ottoman government unexpectedly sued the head of the SJAPH, Mesrop Nshanian, accusing him of opening the printing house without the consent of the city's educational authorities. The clerical board presented the licenses they had (royal edicts, vizier decrees, etc.) and announced that the administration of Jerusalem had always recognized the SJAPH as functioning legally. The patriarchate argued that the government had granted it a license for passing printing materials through the customs house of Jaffa.

\footnotetext{
23 Albert Kharatian, "Osmanyan Grak'nnut'yunē ew Arewmtahay Mamumlē (1870-1890)" [Ottoman censorship and the press of western Armenia in 1870-189o], HistoricalPhilological Journal, no. 4 (1985): 103.

24 Ipek K. Yosmaoğlu, "Chasing the Printed Word: Press Censorship in the Ottoman Empire, 1876-1913," The Turkish Studies Association Journal 27, nos. 1-2 (2003): 24-27.

25 Nshanian, Aknark mēe, 62-68.

26 Muradian, Yerusaghemi, 74-75.
} 
Moreover, the administration of Jerusalem frequently used the printing services of the SJAPH. However, the court ruled that the government had given a license only for the construction of the building and not for publishing activities. Based on that decision, the SJAPH was closed down, the head of the printing house was imprisoned for 100 days and the convent was fined 50 Ottoman pounds. The patriarchate applied to the court of appeals, but the decision was not overturned. Later, the patriarchate moved the trial to the Constantinople appeals body. The trial had been going on for more than two years when the British Mandate began, effectively putting it to an end. ${ }^{27}$

When Yeghishe Durian was elected patriarch of Jerusalem in 1921, he aspired to reopen the SJAPH. Finally, in May 1925, he succeeded in getting a license from the British to do so. ${ }^{28}$ The patriarch applied to Ruhi Bey Abdul Hadj, the director of the press office, to receive his agreement to reopen the printing house. In his application, the patriarch informed him that the patriarchate had received a privilege from the Ottoman Empire to open the SJAPH in 1833; however, it had closed down because of technical problems. He also mentioned that the patriarchate had declared the existence of the SJAPH to the British military authorities after they entered Jerusalem. He noted that by solving the financial and technical problems, and taking into consideration the need to publish religious literature, the patriarchate was requesting "due registration of our printing house in accordance with the legislation ordinances on the matter by the Palestine government and to which we found ourselves to follow in all its dispositions." The patriarch concluded by emphasizing that the director of the SJAPH, Bishop Mesrop Nshanian, would always be ready to provide any information about the printing house for the government representative's inspection. ${ }^{29}$

The British authorities licensed the SJAPH on the condition that it would not publish news that might threaten the safety of the country, raise enmity between religious communities, be libel or false, or include slander, as such actions were condemnable by law. ${ }^{30}$ The official promulgation decreed that

27 Mesrop Nshanian, "Tparan Ar'ak'elakan At'or'oyn Srboc Yakobeanc Yerusaghémi, Harivrameay Yobeleanin art'iw 1833-1933" [Printing House of St. James Apostolic See, Jerusalem, on the Hundredth Anniversary (1833-1933)], Sion, no. 11 (1933).

28 Archive of the Armenian Patriarchate of Jerusalem (AAPJ), Yegishe Durian to Ruhi Bey Abdul Hadj, November 18, 1925, doc. 4444/30, vol. 57, General Correspondence of the Armenian Patriarchate of Jerusalem, nos. 3741-4447, July 1-November 19, 1925.

29 Ibid.

30 AAPJ, Yegishe Durian to Ruhi Bey Abdul Hadj, November 29, 1925, doc. 4483/30, vol. 58, General Correspondence of the Armenian Patriarchate of Jerusalem, nos. 4448-4951, November 20, 1925-April 24, 1926. 
before distribution, a copy of any book or pamphlet printed by the SJAPH was to be sent to the chief secretary, the district commissioner, and the director of education. ${ }^{31}$

Thanks to the contributions of new donors, work in the SJAPH expanded. As a result, everything in the printing house and bindery was put in order. Patriarch Durian bought several pieces of printing equipment with his private resources, and donated a mechanical printing press worth about 100 British pounds to the convent. ${ }^{32}$ At the beginning of 1930 , the SJAPH was functioning at full capacity, and a need arose to acquire a printing machine and binding equipment. The problem remained unresolved until 1932. On May 12 of that year, Patriarch Torgom Gushakian turned to Sargis Hovakimian, asking for three printing machines. The latter met the patriarch's request and donated 1,00o British pounds for the printing equipment. This donation was used to purchase a printing press and a binding and a folding machine; all were electrical and of modern German production. A specialist was sent to the SJAPH to install this new equipment. ${ }^{33}$

On October 22, 1933, on Holy Translators' Day, the general assembly made a decision to celebrate the 1ooth anniversary of the SJAPH of the Holy See. For the occasion, Sion dedicated its November issue to coverage of the SJAPH's history and activities. A liturgy was dedicated to all the benefactors and workers of the press. On the same day, an opening ceremony showcasing the new equipment was organized, and that evening, there was a symposium in the Gulbenkian Library dedicated to the SJAPH anniversary. ${ }^{34}$

\section{The Publishing Program: An Intellectual and Multilingual Hub}

In 1833, the SJAPH's first publication, which was sixteen pages in length, was Tetrak Aghót'amatoyts' vasn Jermer'and Aghót'asirats', Vork' ka'm Andzamb ew ka'm Mtók' Nerkayanan i S. Tnórinakan Teghisn K'ristosi Astutsoy Meróy [A booklet for those who pray fervently and visit the places of the Christ either

\footnotetext{
31 AAPJ, Yegishe Durian to Ruhi Bey Abdul Hadj, November 28, 1925, doc. 1680/30, Printing Press of the Holy See; Notes Exchanged with the Government.

32 "Surb Yakobi Matenadaranē" [St. James Archive of Ancient Manuscripts], Sion, no. 11 (1927): 319 .

33 AAPJ, Annual Summary of Director's Assembly, May 1, 1932-April 30, 1933, December 12, 1933 .

AAPJ, Annual Summary of Director's Assembly, May 1, 1933-April 30, 1934, June 23, 1934.
} 


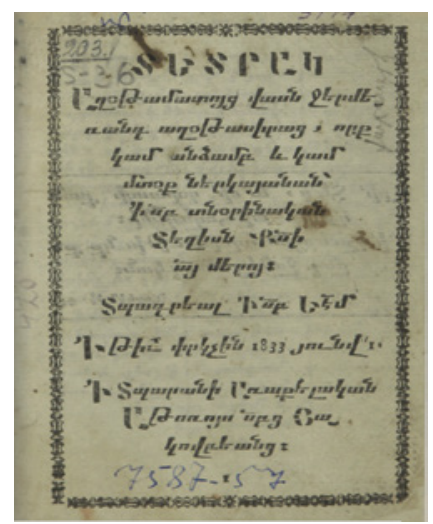

FIGURE 18.1

Cover of the SJAPH's first publication, Tetrak Aghót'amatoyts' vasn Jermer'and Aghót'asirats', Vork' ka'm Andzamb ew ka'm Mtók‘ Nerkayanan i S. Tnórinakan Teghisn K'ristosi Astutsoy Meróy [A booklet for those who pray fervently and visit the places of the Christ either physically or mentally], 1833 . 2004 AF, NATIONAL LIBRARY OF ARMENIA.

physically or mentally] (fig. 18.1). ${ }^{35}$ The next year, they produced "Tesut'ivn Ant'aram Tsaghik Metsats'usts'éin" (Commentary of the hymn for the Holy Virgin, unfading flower), ${ }^{36}$ a 29-page book published by Vardan Vardapet (Archimandrite). The main mission of the SJAPH was to ensure that the publishing and printing activity satisfied religious needs. Armenian clerics and churches needed religious literature, but such books were not published by other printing presses because it was not profitable. For centuries, the heads of the Armenian Church and Armenian narrators had created religious, religioushistorical, historical, literary, and other works that needed to be published or republished. As a spiritual center, the Armenian patriarchate of Jerusalem sought to upgrade itself as a scientific-educational center and become a center for Armenian typography in the Middle East. From its establishment until 1940, the SJAPH published about 526 books, booklets, and calendars, as well as Sion; the official organ of the patriarchate. ${ }^{37}$

As the patriarchate's printing house, the SJAPH published a great number of spiritual, ceremonial, and religious literature that proved controversial,

Tetrak Aghót'amatoyts'vasn Jermer'and Aghót'asirats', vork' ka'm Andzamb ew ka'm Mtók' Nerkayanan i S. Tnórinakan Teghisn K'ristosi Astutsoy Meróy [A booklet for those who pray fervently and visit the places of the Christ either physically or mentally] (Jerusalem: St. James Press, 1833), http://greenstone.flib.sci.am/gsdl/collect/armbook/books/tetrak axotamatujc1833_index.html.

36 Vardan Vardapet, Tesut'iwn Ant'aram Tsaghik Metsats'ustséin [Commentary on the hymn for the Holy Virgin Unfading Flower] (Jerusalem: St. James Press, 1834), http://greenstone. flib.sci.am/gsdl/collect/armbook/books/tesutyun_antaram_index.html.

Muradian, Yerusaghemi, 11-94. 
and brought on a considerable backlash. Two books, Mashtots' Canonov Mkrtutean (Canons of baptism), published in $1843^{38}$ and Khorhrdatsut'iwn Srbazan Pataragi (Thoughts during the liturgy) by Nerses Lambronatsi, published in $1842,{ }^{39}$ aroused Armenian Patriarch of Constantinople Astvatsatur's anger, prompting his demand that the SJAPH close down. This reaction was in response to the fact that in some of the sections, especially in Lambronatsi's work, the writer expressed a positive attitude towards the Roman Church. This caused Patriarch Astvatsatur to question Armenian Patriarch of Jerusalem Zakaria's fidelity towards the Armenian Church. His suspicion was exacerbated by the fact that Patriarch Zakaria was educated by Catholic Mekhitarists, and had been preaching Catholic principles. Dissemination of Mashtots' Canonov Mkrtut'ean was completely halted. However, the Armenian Patriarch of Constantinople's attitude did not intimidate Zakaria. He refused to close down the SJAPH, and boldly initiated new publications. ${ }^{40}$ Due to popular demand, religious and ceremonial books were republished several times (fig. 18.3).41

The SJAPH also published a great number of books on rights over the Holy Places, biographies, philological and linguistic works, as well as books on Armenian art and culture. ${ }^{42}$ For instance, Khndir Srbazan Tegheats' ew nora Pashtonakan K'nnut'iwnē (Issues on the Holy Places and their official examination $)^{43}$ published in 1871 , on Patriarch Yesayi's order, is on the rights of Armenians to the Holy Places, and describes the rows between Armenians and other Christian groups in that regard.

38 Mashtots' Canonov Mkrtut'ean [Canons of baptism] (Jerusalem: St. James Press, 1843), http://greenstone.flib.sci.am/gsdl/collect/armbook/books/mashtoc_1843_index.html.

Nerses Lambronatsi, Khorhrdatsutiwn Srbazan Pataragi [Thoughts during the liturgy] (Jerusalem: St. James Press, 1842), http://greenstone.flib.sci.am/gsdl/collect/armbook/ books/xorhrdacutiin_pataragi_srbazan_index.html.

40 Sawalaniantz, Patmut'iwn Yerusaghémi, 1025-26.

41 The following books had more than two editions: Dzer'ats' u Tsots'i Zhamagrk'er [Handbooks of prayers], Dzaynak'agh Sharakan [Armenian chants], Tonats'uyts' [Liturgical calendar], Tagharan ew Khorhrdatetr [Songbook and advice book], while for instance, Saghmos [Psalm], Narek and Aghotagirk' [Prayer book], as well as Ateani ew Chashu Avetaranner [Board and dinner gospels], Nor Ktakaran [New Testament], were printed five or six times, while Ephrem the Syrian's Girk'Aghot'its' Asats'eal Srboyn Yephremi Khurin Asorvoy [A Prayer book by St. Ephrem the Syrian] was published six times, between 1848 and 1933 .

42 Muradian, Yerusaghemi, $11-93$.

43 Khndir Srbazan Tegheats' ew nora Pashtonakan K'nnut'iwnē [Issues on the Holy Places and their official examination] (Jerusalem: St. James Press, 1871), https://archive.org/details/ khndirsrbazanteoopatrgoog. 
Apart from religious and ritualistic books, the SJAPH also published works of Armenian historians and philosophers in addition to novels and dramas. In particular, works by the following authors were published: Yeghishe, Hovhan Mandakuni, Vrtanes Qertogh, Anania Shirakatsi, Narekatsi, Nerses Shnorhali and Mateos Urhaietsi. In 1865, the SJAP H published Vasn Vardanay ew Hayots' Paterazmin (The history of Vardan and the Armenian war) by Yeghishe. ${ }^{44}$ Patmagrut'iwn Yovhannu Kat'oghikosin Amenayn Hayots' (History of Catholicos Yovhann of All Armenians) by Yovhann Draskhanakertsi, was the first voluminous work published by the SJAPH in $1843 .{ }^{45}$ Apart from the Chronological History of St. Jerusalem by Astvatsatur Hovhannisian, significant historiographical works were published in 1931, such as Patmut'iwn Yerusaghémi (History of Jerusalem) by Tigran Sawalanyantz, Haykakan Yerusaghém (Armenian Jerusalem) by Malachia Ormanian, which included background about the Armenian religious presence in Jerusalem, and the rights of Armenians to the Holy Places.

Among the books published by the SJAPH, there are numerous works authored by clerics of the convent and teachers of the Theological School, who also translated works mainly from French, German, Italian, English, Turkish, and Arabic. These cover a wide range of topics, from moralistic works and translations, to logics, cosmography, psychology, and philosophy. ${ }^{46}$ Among the books printed by the SJAPH, a unique place should be given to textbooks, dictionaries, Armenian alphabet books, and religious calendars (the latter have been published annually since 1867). A significant role is attached to alphabet books, which were essential for the teaching of Armenian. In 1837, they entered the publishing schedule. Among textbooks, K'erakanut'iwn Gaghghiarén Lezui Hayerén Bats'atrut'eamb (Grammar of French with Armenian explanations) by Yeghiazar Muradian is particularly noteworthy. ${ }^{47}$

44 Mkrtich Aghavnuni, "Nakhnik‘ Voronts' Vorewé Mek Gortsē Tpagrvats é S. At'or'oys Tparanin mej" [Ancestors whose works have been published in the printing house of the See], Sion, no. 11 (1933): 375 .

Hovhannes Draskhanakerttsi, Patmagrut'iwn Yovhannu Kat'oghikosi Amenayn Hayots [History of Catholicos Yovhann of All Armenians] (Jerusalem: St. James Press, 1843), http://greenstone.flib.sci.am/gsdl/collect/armbook/books/patmagrutyun1843_index .html.

46 For instance, in 1934 The Psychology of the Future by Émile Boirac was translated by Patriarch Yegishe Durian; in 1932 a work entitled Psychology by George L. Fonsegrive was translated by Patriarch Torgom Gushakian.

Yeghiazar Muradian, K'erakanut'iwn Gaghghiarén Lezui Hayerén Bacatrut'eamb [Grammar of French with Armenian explanations] (Jerusalem: St. James Press, 1869), 120 pages, http://greenstone.flib.sci.am/gsdl/collect/haygirq/book/qerakanutyun_gaxx_index.html. 
Although the SJAPH was functioning under the auspices of the patriarchate, it also published several books on morality, psychology, philosophy, logics, geography, mathematics, and medicine. An example is Tramabanut'iwn kam Aruest Banakan (Logics or rational art) by Grigor Peshtmalchian, published in 1854 with an introduction by Patriarch Hovhannes. ${ }^{48}$ This substantial work includes grounded knowledge on logics. Another work is Nor Dasagirk' Tiezeragrut'yan (A new textbook of cosmography) by Sahak Khapaian (Catholicos of Cilicia, 1902-39) on geometry, space, physical objects, and phenomena. At the end of the book, there are exercises and maps on cosmography ${ }^{49}$ This textbook was republished in 1884 , which attests to its high demand. ${ }^{50}$ Another popular textbook was Nakhnakan Dasagirk' T'uagitut'yan (Primary textbook of arithmetic) by Stepan Papaziants, published in 1869, for the fourth time. ${ }^{51}$ Vahan Jacobian, a member of St. James Convent, initiated the publishing of another arithmetic textbook titled Nor T'uagitut'iwn (New arithmetic). The first volume was published in 1880 , and the second was published a year later. ${ }^{52}$ In 1884 , the two volumes were published together as a book. ${ }^{53}$

After the reopening of the SJAPH in 1925, a publishing movement called Durian Matenashar (Durian series) began. In 1929, on Patriarch Yeghishe Durian's fiftieth priesthood anniversary, the special committee elected by the general assembly made a decision to build a library named after the patriarch, to honor his name and legacy. ${ }^{54}$ The donated money constituted about 3,00o British pounds, the greatest part of which was donated by Petros Crete from Greece, Poghos Nubar, the founder of Armenian General Benevolent Union,

48 Grigor Peshtmalchian, Tramabanutiwn kam Aruest Banakan [Logics or rational art] (Jerusalem: St. James Press, 1854), http:/greenstone.flib.sci.am/gsdl/collect/haygirq/ book/tramabanutyun1854.pdf.

49 Sahak Khapaian, Nor Dasagirk' Tiezeragrut'yan [A new textbook of cosmography] (Jerusalem: St. James Press, 1876), http://greenstone.flib.sci.am/gsdl/collect/haygirq/ book/nor_dasagirq1876_index.html.

50 Sahak Khapaian, Nor Dasagirk' Tiezeragrut'yan [A new textbook of cosmography] (Jerusalem: St. James Press, 1884), http://greenstone.flib.sci.am/gsdl/collect/haygirq/ book/nor_dasagirq1884_index.html.

$5^{1} \quad$ Stepan Papaziants, Nakhnakan Dasagirk' T'uagitut'yan [Primary textbook of arithmetic] (Jerusalem: St. James Press, 1869), http:/greenstone.flib.sci.am/gsdl/collect/haygirq/ book/naxnakan_dasagirq_index.html.

52 Muradian, Yerusaghemi, 46-47.

53 Ibid., 50.

54 "Yaveluats, Handés Bacman Norakar'oyc Kuilpénkean Matenadaranin Ar'ak'elakan At'or'oyn Srboc Yakobeanc" [Appendices, the opening ceremony of the newly built Gulbenkian Manuscripts' Archive of the Apostolic See of St. James], Sion, no. 11 (1932): 355. 
and Armenak Bey Kamsarakan, a tobacco tradesman and writer from Egypt. ${ }^{55}$ However, this sum was still not enough to construct a new library building. For this reason, the president of the special committee, Archbishop Torgom Gushakian, met with Calouste Gulbenkian, an Armenian benefactor, in Paris. Gulbenkian promised to cover all the expenses of the new archive in memory of his parents, Sargis and Tiruhi Gulbenkians. On September 16, 1929, upon hearing of this promised donation, Patriarch Yeghishe Durian decided to name the library after the donor and to continue fundraising with the aim to publish new and classic works on Armenian studies. This book series was afterwards called the Durian Matenashar (Durian series), in honor of the patriarch. ${ }^{56}$ To realize the idea of the Durian Matenashar, a decision was made to build a trading center called Durianashen (Built by Durian) on one of the patriarchate's donated properties. The profits gained in the center were to be directed towards the publication of the Durian Matenashar. ${ }^{57}$

The SJAPH also published technical booklets and lists of published books. In 1934, Tarats'uts'ak Tparani Srbots' Yakovbeants' (Lists of St. James Printing House) was published. In it, matrices of letters, various symbols and numbers, Armenian khazes and sound marks, corner ornaments, frames, patterns, and flowers were pictured. This booklet was designed to showcase the capabilities of the printing house for clients. Judging from the list of alphabets in the SJAPH, it was possible to print French, English, Italian, Hebrew, Greek, Arabic, and Persian appendices in Armenian books or together with Armenian translations to give corresponding terms and proper names in the original languages. Besides, the matrices in the mentioned languages were sufficient to enable the printing of documents, business cards, tickets, announcements, and other administrative materials.

The languages of the books published in the SJAPH were Armenian, Grabar (old Armenian), and Armenian-lettered Turkish (ALT). The most well-known work published in ALt was Zanazanutiwn Hing Daruts' (The differences between five centuries) by Patriarch Poghos $(1763-1853) .{ }^{58}$ The first of its three volumes was printed in 1838 . By 1867 , Zanazanut'iwn Hing Daruts' had been republished twice. This book included Arabic and Persian dictionaries

\footnotetext{
55 Astghik Chamkerten, Yerusaghém ew Kuilpénkeanner [The Gulbenkians in Jerusalem] (Lisbon: Calouste Gulbenkian Foundation, 2007), 81.

56 "Yaveluats, Handés Bacman Norakar'oyc Kuilpénkean Matenadaranin," 356.

57 "Pashtonakan Yaytararut'iwn" [Official Announcement], Sion, no. 6 (1933): 192-95.

58 Poghos Adrianapolsetsi, Zanazanut'iwn Hing Daruts' [The differences between five centuries] (Jerusalem, St. James Press, 1840), http://greenstone.flib.sci.am/gsdl/collect/ armbook/books/pesh_tehr_index.html.
} 
explained in Armenian and Turkish, which were published in both 1844, and $1881 .{ }^{59}$ The SJAPH published a number of books on various topics in ALT. Beginning in the eighteenth century, ALT literature fostered the spread of Catholicism among Armenians and reached the Armenian diaspora in the West, in the Mekhitarist unions in Trieste and Vienna. To fight against the religious-moralistic publications of Catholic and Protestant preachers, the Armenian Apostolic Church published hundreds of religious and doctrinal works, preaching books, and works on the history of the church and religion. Among ALT publications, there were also dictionaries, historiographical, philosophical and fictional works. ${ }^{60}$ Thus, the SJAPH, functioning under the patronage of the Armenian Apostolic Church, played a significant role in the publication of ALT literature.

Another achievement of the SJAPH was the publication of Sion, the official journal of the Armenian patriarchate of Jerusalem, which was the most considerable publishing initiative of Patriarch Yesayi. Yesayi realized this initiative in $1866,{ }^{61}$ as soon as the SJAPH started to run regularly (fig. 18.2). The cover stated: "Sion Journal: National, Philological, Literary and Political." The first four pages of the inaugural issue outlined the journal's mission, which was "freedom to think and to speak." The journal's publishers stated that they wished to discuss various topics "both educational and entertaining." Even though there was no mention of anything religious on the cover, the board of the journal published religious articles in what became the official journal of the convent. ${ }^{62}$

In 1877 , the publication of Sion ceased, apparently due to external and internal conflicts of the Holy See. The issue of the Holy Places was exceptionally heated at that time, and inner hardships were weakening the convent and creating serious debts. ${ }^{63}$ Publication of Sion was put on the agenda once again when Patriarch Durian reopened the SJAPH. The patriarchate referred to Ruhi Bey Abdul Hadj once again asking the British government for a license to

59 Hasmik Stepanian, Hayatar' T'urk'eren Grakanut'yuny [Turkish literature in Armenianlettered Turkish] (Yerevan: Armenian National Academy of Sciences, 2001), 61.

6o Hasmik Stepanian, Hayatar' T'urk'erén Grk'eri ew Hayatar' T'urk'erén Parberakan Mamuli Matenagitut iwn (1727-1968) [Bibliography of Armenian-lettered Turkish books and press (1727-1968)] (Istanbul, Türkuaz Press, 2005), 17-18.

61 Ferman from the mutessarif of Jerusalem, Izzet Pasha, to the Armenian Patriarchate of Jerusalem, November 29, 1865, folder 30, Old and New Licenses of the Printing House of Saint See, the Archives of the Armenian Patriarchate of Jerusalem, Jerusalem.

62 "Azat Baroyakanut'yan" [Free morality], Sion, no. 2 (1866): 319.

63 Garegin Levonian, Hayoc Parberakan Mamule [The Armenian press] (Alexandrapol: Abraham M. Malkhasian Press, 1895), 283. 


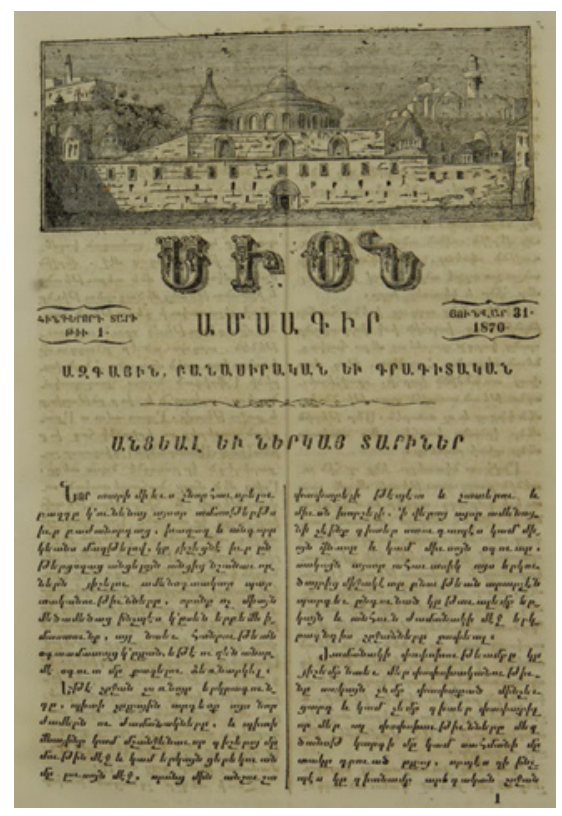

FIGURE 18.2

First page of the January 1870 issue of the SJAPH journal Sion, with the image of St. James Armenian Cathedral. POGHARIAN COLLECTION, 287, N. 1, 1870, FUNDAMENTAL SCIENTIFIC LIBRARY, YEREVAN.

republish Sion and to register it. ${ }^{64}$ It is clear that Sion followed the publishing rules and regulations of the time. After each publication, four copies were sent to the government for censorship. However, during the British Mandate years, this was a mere formality. Mesrop Nshanian's letter to the government informs us of the trusting relationship that existed with the editorial staff of Sion, who were permitted to publish their journal without it being examined. ${ }^{65}$ In an editorial, Bishop Babken Kuleserian, the journal's next editor, expressed hope that the journal would entertain the intellectual life of the convent, advance and empower refugees with religious inspiration, and cherish the crystal-clear purity of the mother tongue, while at the same time remaining reasonable and critical. In 1930, Babken Kuleserian brought together all the materials of the new phase of Sion and assessed it. According to him: "With its various topics, Sion sought to reflect the values of the past to show the Armenian nation that they are not just a worthless mass, but a nation with the right to live on and

64 AAPJ, November 18, 1926, doc. 5824/30, Printing Press of the Holy See; Notes Exchanged with the Government.

65 AAPJ, Calouste Gulbenkian Library, Mesrop Nshanian to Smbat Gazazian, October 18, 1927, Letters of Archbishop Mesrop Nshanian, 1924-28, vol. 1. 
develop, a nation that has had a role in the history of civilized people and can still play an important role if it keeps close to its traditions." 66

Judging by the publications and technological capacities of the SJAPH, it can be inferred that its readership was largely Armenian. In 1870, the SJAPH started publishing a catalogue of its published works, making it possible for Armenians worldwide. Though Sion had a fixed price (the annual subscription was $\$ 1.50$ and each issue cost LE 2), the patriarchate attempted to encourage its distribution to all Armenians. An announcement was printed in the first issue of the journal in 1927, in which the patriarchate explained that Sion could reach orphanages, benevolent organizations, poor schools, and pilgrim clerics if kind-hearted and educated Armenians made donations covering five to ten issues. The patriarchate promised to mention the names of benefactors in their next issue. Moreover, clerics who could find subscribers among their acquaintances would receive free issues of the journal. ${ }^{67}$ The patriarchate aimed to cover the expenses of publishing the journal, but it also wished to make Sion an outstanding and popular publication among Armenians.

\section{Conclusion: The St. James Armenian Printing House, from Local to Global}

The SJAPH was the result of a scientific-educational movement that emerged from the Mekhitarists in Venice in the fifteenth century. The main responsibility of the Jerusalem Patriarchate was the protection of the religious and ethnic rights of Armenians regarding the Holy Places. Together with this responsibility, some members of St. James Convent started engaging in scientific-educational activities. They did not limit publication to historical, critical, religious, and fictional works of Armenian historians and philologists. The brotherhood also encouraged and published the works of Mekhitarists. Neither financial issues nor Ottoman censorship could dissuade Armenian clerics from publishing and spreading scientific and philological works on the history, culture, literature, and church history of the Armenian people. Moreover, they did not limit themselves to publishing only Armenian authors. Foreigners were published as well.

Many Armenian benefactors and donors came to the fore to support these initiatives through covering the expenses of books, buying printing equipment,

66 Editorial, Sion, no. 1 (1927): 2-5.

67 Editorial, Sion, no. 1 (1927): cover page. 


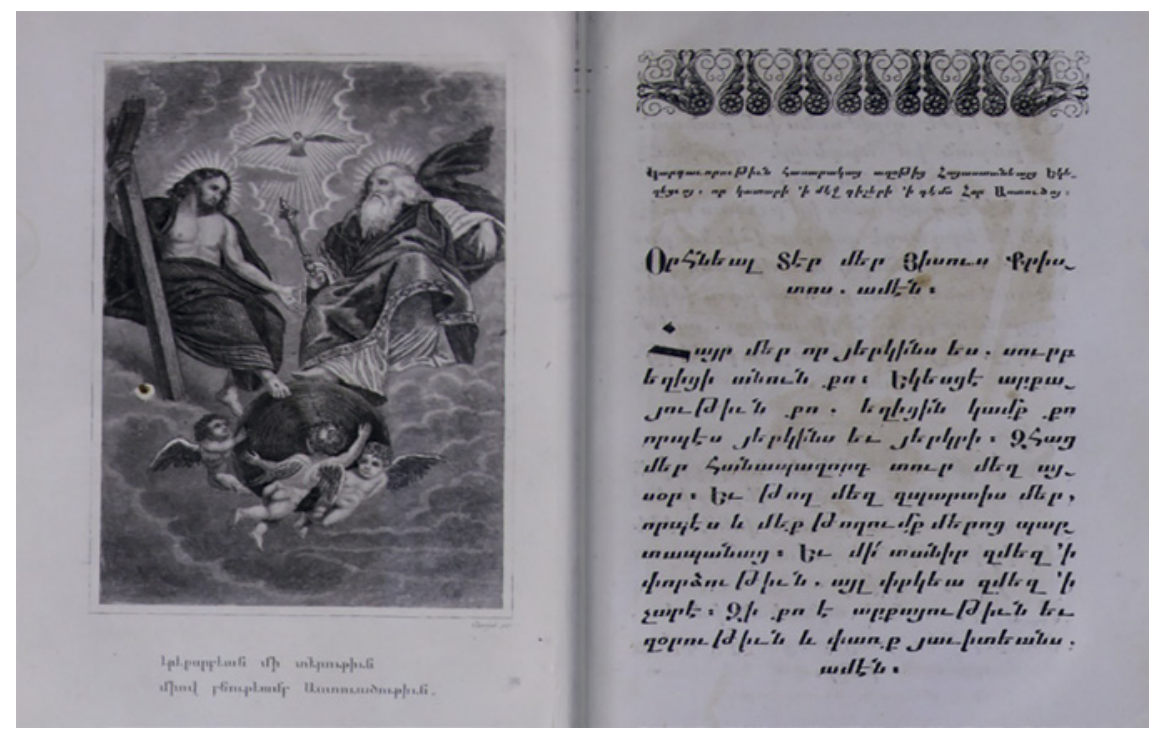

FIGURE 18.3 Page from Zhamagirk' Hayastaneats' S. Ekeghets'wots' [Prayer book of the Holy Armenian Church], published by SJAPH in 1881.

264 J-21, NATIONAL LIBRARY OF ARMENIA, YEREVAN.

and renovating the building of the printing house. It was obvious, however, that the steady running of the printing house could not be ensured by donations alone. To solve this problem, the patriarchate built the Durianashen building and used its profits to publish the Durian Matenashar.

Considering the hundreds of books published by the SJAPH over a 100year period, we can conclude that the printing house relied on the financial, human, and other resources of the patriarchate, but also on individuals who supported it financially or technologically. Its activity was not merely religious, but encompassed nearly all branches of science. Its educational leg published numerous textbooks and alphabet books. The SJAPH was not just a printing house, but a respected publishing house that became a center for the circulation of Armenian knowledge, translation, ideas, and thought in the Middle East. 


\title{
The Wasif Jawharriyeh Collection: Illustrating Jerusalem during the First Half of the 2oth Century
}

\author{
Issam Nassar
}

This chapter briefly examines the photographic collection of the Jerusalem diarist Wasif Jawharriyeh (1897-1972), whose life in the city spanned the last two decades of Ottoman rule and the British Mandatory period in Palestine. ${ }^{1}$ In 1948 , following the fall of his neighborhood in the western suburbs of Jerusalem to Israeli control, Jawharriyeh left Palestine and ended up in Lebanon, where he passed away in 1972. Although he was a well-known figure while living in Jerusalem, he fell into oblivion until his diaries were discovered and published some thirty years after his death. ${ }^{2}$ Although his reputation as the "storyteller of Jerusalem" spread after the publication of the diary, during his time in the city, his claim to fame was his musical career as an amateur oud player. A native of Jerusalem, Jawharriyeh came from a Christian family with deep roots in the city. He was the son of Girgis Jawharriyeh, a prominent notable in the Greek Orthodox Arab community during the last few decades of Ottoman rule, and a devout administrator of the property of the Husayni family, two of whom became mayors of Jerusalem during Wasif's life.

His published memoirs span the years he spent living in Jerusalem, from as early as 1904 until his forced departure in 1948. Although he continued to record his life in diaries through the next two decades, the published version only includes his time in Jerusalem. Following publication, the Jerusalem diaries were hailed by historians as an invaluable source of insight into Jerusalem's

1 Salim Tamari, "Jerusalem's Ottoman Modernity: The Times and Lives of Wasif Jawhariyyeh," Jerusalem Quarterly, no. 9 (2000).

2 First published in Arabic in two volumes: Salim Tamari and Issam Nassar, Al-Quds al-Uthmaniyya fi al-Mudhakkirat al-Jawhariyya: al-Kitab al-Awwalmin Mudhakkirat al-Musiqi Wasif Jawhariyya, 1904-1917 [Ottoman Jerusalem in the Jawhariyyeh memoirs: the first book of the memoirs of the musician Wasif Jawhariyya, 1904-1917] (Beirut: Institute for Palestine Studies, 2003); Salim Tamari and Issam Nassar, Al-Quds al-Intidabiyya fil al-Mudhakkirat alJawhariyyeh, 1918-1948 [British Mandate Jerusalem in the Memoirs of Wasif Jawhariyyeh, 1918-1948] (Jerusalem: Institute of Jerusalem Studies, 2005). Then selections were published in English: Salim Tamari and Issam Nassar, The Storyteller of Jerusalem: The Life and Times of Wasif Jawharriyeh, 1904-1948, trans. Nada Elzeer (Northampton: Olive Branch Press, 2014).

(C) ISSAM NASSAR, 2018 | DOI:10.1163/9789004375741_024

This is an open access chapter distributed under the terms of the prevailing CC-BY-NC-ND License at the time of publication. 
social history, and have been used in a number of studies and documentary films. ${ }^{3}$ In addition to moments from his personal life, Jawharriyeh documented political events such as Jerusalem's receiving the news of the Ottoman revolt in 1908, from Istanbul, as well as the years leading to the Great War and of the war itself - including his service in the Ottoman navy in the Dead Sea, the fall of Jerusalem to the British in 1917, and life during the British Mandate. He described the social life and the fabric of the city through special occasions, festivities, cuisine, music, and art scenes. Life in Jerusalem, marked by political events and changes, is the focus of the images in the photograph albums Jawharriyeh collected. These albums are examined here as forms of archival material and show how precious this collection is for the study of the history of Jerusalem, and Palestine in general.

The archive, as embedded in the meaning of the term, combines the ideas of time, space and order. As Jacques Derrida argued, it synchronizes the principles of time, space, and authority: while time and space relate to the historical, material, and ontological, authority relates to order and power. ${ }^{4}$ Archives are collections of artifacts amassed in a certain order to serve a particular power structure. In their official archives, states collect materials that reflect how they control society, exercise their authority, and preserve their memory as institutions. Although the collected materials are classified according to certain organizational principles such as period, location, and institution, the most important principle is often the exercise of power and control. States and institutions are not the only authorities that create archives: individuals also make archives, synchronizing their own authority over time and space. When individuals collect, they may not use the term "archive" to describe their collections and may not necessarily think in archival terms. Nevertheless, the dynamics of collecting and ordering in the individual obey the same principle of the exercise of power that may be observed in the state. An individual's power, however, is governed by personal needs and desires.

Individuals collect documentary artifacts for various reasons. Some people preserve official documents needed for their survival in the legal and political structures in which they live, such as birth certificates, passports, property deeds, and educational or professional credentials. Others collect artifacts for sentimental value in their personal, familial, or communal lives. In many

3 One such film is 1913: Seeds of Conflict, produced by Ben Loeterman for PBS in 2014, and an example of a study is Rachel Beckles Wilson, Orientalism and Musical Mission: Palestine and the West (Cambridge: Cambridge University Press, 2013).

4 Jacques Derrida and Eric Prenowitz, "Archive Fever: A Freudian Impression," Diacritics 25, no. 2 (1995). 
cases, individuals build collections in order to attest to the way they regard themselves and their role in the world around them. History buffs, for example, collect documents that they deem historically significant. Music lovers and art enthusiasts do the same for the subjects that move them. No matter the nature of the collection, owners arrange elements of their archives in relation to time, place or assumed significance. In doing so, they exercise their authority and judgment on what they choose and the manner in which they assemble and order it. Although individual collections are often not of great importance to state authorities, for historians they bring to light both practices and sources for historical documentation. Historians use such materials not only as evidence of events, but as pathways through which they can construct the worldview of the periods they study. Such is the case of the albums under scrutiny here.

\section{Producing Images, Creating Albums}

The first published volume of Jawharriyeh's memoirs in Arabic includes a digital disk with some of his songs, but only a handful of images from his collection of photographs are found in the book. ${ }^{5}$ His collection of more than nine hundred images could not fit into a single publication. For this reason, the photographs were divided into seven albums designed to accompany the diary. Collecting photographs was not a common practice in Palestine at the time, though it later became popular. Photographs were expensive and rare as they were produced manually with glass or celluloid negatives. In most cases, photographers were professionals and were not easy to come by. Although the period during which Jawharriyeh's collection was assembled covers more than six decades after the invention of photography, the art was still in its infancy and only a handful of studios served the public demand. The earliest images of Jerusalem and Palestine were taken decades before, principally by nonresident European photographers whose intention was to feed the lust of European viewers for images from the Holy Land. Collecting pictures in albums was a new trend, born of the desire of tourists and pilgrims to document their voyages.

With the rise in the number of photographic studios in Jerusalem in the first two decades of the twentieth century, arranging photographs in albums gradually became a popular practice among residents, though it remained largely limited to the wealthy. Most of the earlier local albums were of a familial nature, consisting of portraits of family members and social occasions such as weddings and visits of important guests. However, with the establishment of

5 Tamari and Nassar, Al-Quds al-Intidabiyya. 
Israel, self-declared as the state of the Jewish people, a mass ethnic cleansing of the native non-Jewish population of Palestine took place. Exiles often left in a hurry, abandoning valuable items in their homes. Photographs, albums, family papers, and property deeds were often left behind in the drawers and cabinets in which they were stored. The failure to establish a Palestinian state also meant that many archival documents were lost to the people, although some survived in the archives of the various occupying powers that possessed the land before and after the mass expulsion. Jawharriyeh's albums bear witness to the years before great change, standing as documentary evidence of bygone times. They are a visual documentation of life in a liminal period in the history of the city, and they exhibit a native's perspective of it and its society.

\section{Creating Albums, Producing Archives}

The albums at hand document a life that spanned a period close to five decades, during which Jerusalem and Palestine changed hands from the large Ottoman Empire to a much smaller entity ruled by the even larger British colonial empire. This period witnessed the start of the Jewish Zionist immigration to the country and the creation of the Israeli state. These events coincided with the temporary burial of the Palestinian project of an independent state. I argue that the Jawhariyyeh albums are important because they bear witness to the loss of their original subject in a material sense, that is, Jerusalem in a time of more or less peaceful coexistence. Images from Palestine before its conquest have become foundational elements in the collective nostalgia of the Palestinians. ${ }^{6}$ The albums are chronologically organized and contain photographs of leaders, rulers, elites, and locations. Together they fueled a powerful narrative of loss and longing for homeland that was central to the identity construction of the Palestinians in exile. The collection commences in the late Ottoman period and finishes shortly before the events of 1948. Jawharriyeh kept a separate notebook for each of the albums in order to describe the photographs. In addition to the pictures themselves, these notebooks are valuable sources of information about the period. From today's standpoint, the albums can be described as records documenting the liminal period separating Ottoman rule in Palestine and the creation of the state of Israel. In this sense,

6 Elias Sanbar, ed., Jérusalem et la Palestine: le fonds photographique de l'École biblique de Jérusalem (Paris: Hazan, 2013); Sanbar, Les Palestiniens: la photographie d'une terre et de son peuple de 1839 à nos jours (Paris: Hazan, 2004); Walid Khalidi, Before Their Diaspora: A Photographic History of the Palestinians, 1867-1984 (Washington, DC: Institute for Palestine Studies, 1984). 
they function as an infusion of memories before Jawharriyeh's departure from Palestine in the aftermath of the Palestinian catastrophe of 1948. The events of that year had acquired meaning within the collective Palestinian memory, not only as references to a lost past, but also as a defining moment in the historical narrative of Palestinians.

While amassing what he referred to as the "Jawharriyeh Collection," Jawharriyeh saw himself as the guardian of Jerusalem's memory. The cover of his albums states that the collection was established in 1924, but it is unclear if the date refers to the photographic albums or the entire body of materials. The first album is devoted to the Ottoman period. In fact, he wrote in the accompanying notebook that he adorned the album with the emblem of the Ottoman state and he dedicated it to both the Ottoman sultan and the governor of Jerusalem. Dedicating a personal collection - an album in this case - to a ruler seems unusual, especially since the album was probably created at a time when the Ottoman state was no longer in existence. Such an act of dedication could serve as an indication of his intention in collecting the photographs and fashioning them in an album. It is highly unlikely that Jawharriyeh had any contact with the sultan, and chances are slim that the sultan would ever have had the opportunity to see the albums. Still, by including such a dedication, he intended to give merit to the album as a public work and showcase it as if it were a published book. The sultan to whom he dedicated the album was removed from power in 1909, when Jawharriyeh was no more than a teenager. In his own memoirs, he showed disapproval, if not outright animosity, towards this specific sultan. However, the dedication reads as follows:

I adorn this book with the emblem of the Ottoman state ... his royal majesty Sultan Abdülaziz, one of the great kings of the Ottoman state who was followed in the high position by his brother Sultan Abdülhamid, and with a photo of his Excellency Ra'uf Pasha, the mutessarif of Jerusalem.

Jawharriyeh failed to include the picture of the sultan, but he reserved an empty space for it in the album. It is very likely that he was echoing his father's admiration for the specific regime that was overthrown and replaced by one that was significantly different and perhaps had elements of an anti-Arabness that were more dominant than those of its predecessor. His father, Girgis Jawharriyeh, was a "lawyer in his younger years and stood out as a Christian lawyer at Jerusalem's Muslim shari'a law courts" ${ }^{7}$ during the period of both

7 Tamari and Nassar, The Storyteller of Jerusalem, 35. 


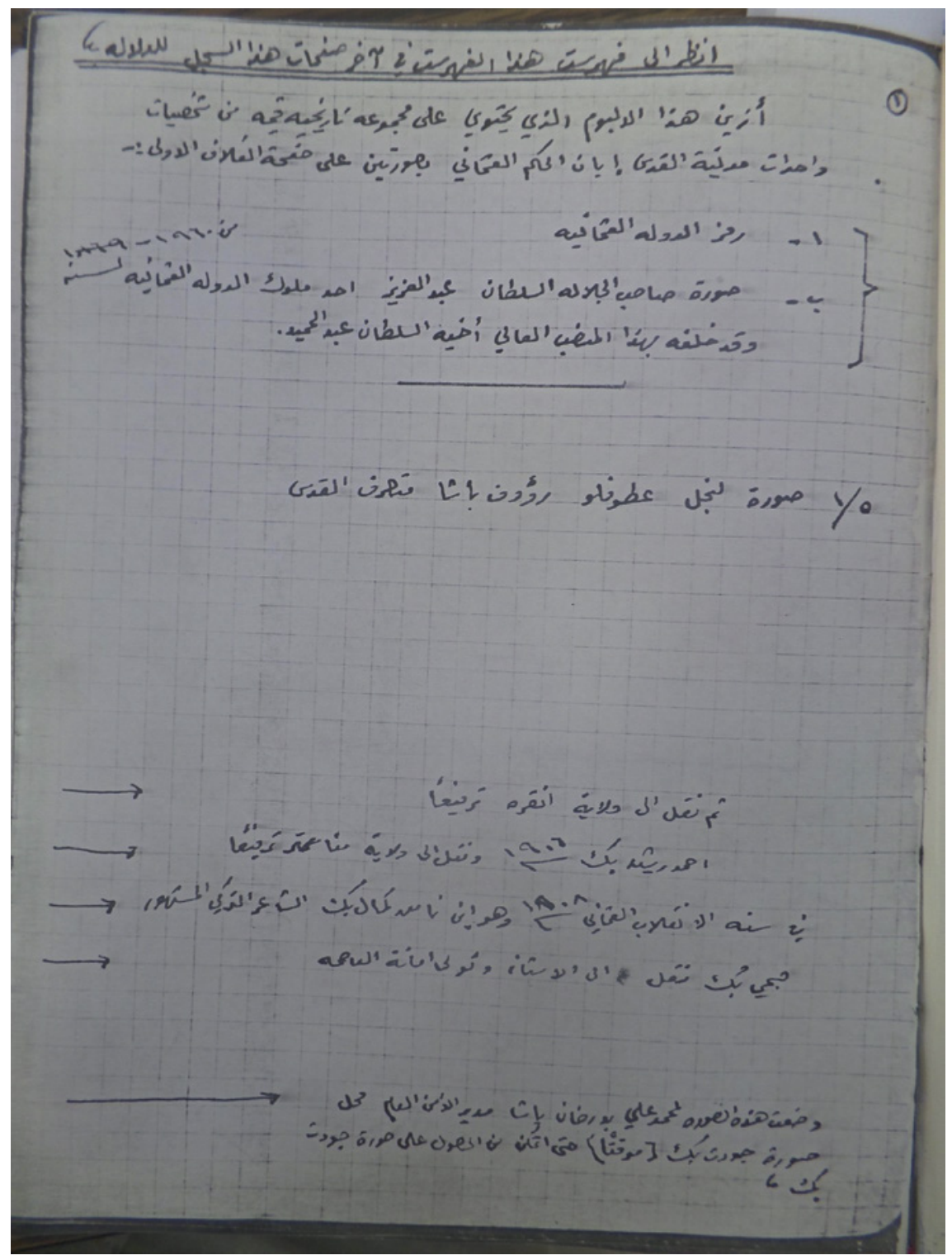

FIGURE 19.1 The page in the notebook where WasifJawharriyeh announces the inclusion of the photographs of the sultan.

JAWHARRIYEH COLLECTION. 
Sultan Abdülhamid (1876-1909) and governor Ra'uf Pasha (1877-89), whose picture appeared in the first album.

The dedication to the Ottoman sultan and the governor of Jerusalem may therefore be read as a gesture by which Jawharriyeh wished to honor his father rather than reflect his own politics. Indeed, based on his writings, Jawharriyeh appears to have been an opponent of the Hamidian regime. Another possible explanation for the dedication is that he wanted to reflect the dominant discourse of the periods he was documenting. Photographs of other authority figures included in his albums lend support to this explanation. There is, for example, a photograph of Jamal Pasha, the head of the fourth Ottoman army in Palestine during the Great War, who is often referred to in the memoirs as "the butcher." ${ }^{8}$ Other photos include British governors and high commissioners, whom Jawharriyeh also opposed, considering them as enablers of the Zionist colonization in Palestine.

Although Jawharriyeh fails to provide the names of the photographers or the individual sources for each of the photographs he inserted in his album, he does mention in his notebooks how he came to acquire the pictures:

I was able, thank God, to collect the rare and historical pictures from a number of individuals, for whose affection I am indebted, such as Sheikh Khalil al-Khalidi, Ahmad Sameh al-Khalidi, Ismail Bek al-Husseini, Ragheb al-Nashashibi, Beshara Habib and others. May God rest their souls.

The names above are those of some of the most important notables of Jerusalem at the time. Mentioning them serves Jawharriyeh well in placing himself as a member, or at least an acquaintance, of the city's elites. The above note refers to the portrait photographs that he placed at the beginning of the first album, rather than to photos in the album that were public in nature, such as events, processions, and locations that would have been obtained at any of the tourist shops in the city. The sheer number of portraits of notables, Ottoman officials, governors, city mayors, and members of the Greek Orthodox clergy that Jawharriyeh included in the album, constitute an important and unique visual archive. The second half of the album is devoted to the Great War in Palestine. Photographs include a number of portraits of Ottoman officers and leaders, including Jamal Pasha. Most of the images can be traced to two photographic collections, those of John Whiting of the American Colony Photo Department, ${ }^{9}$

8 Ibid., 199.

9 Partially accessible here http://www.loc.gov/pictures/collection/matpc/colony.html\# department. 


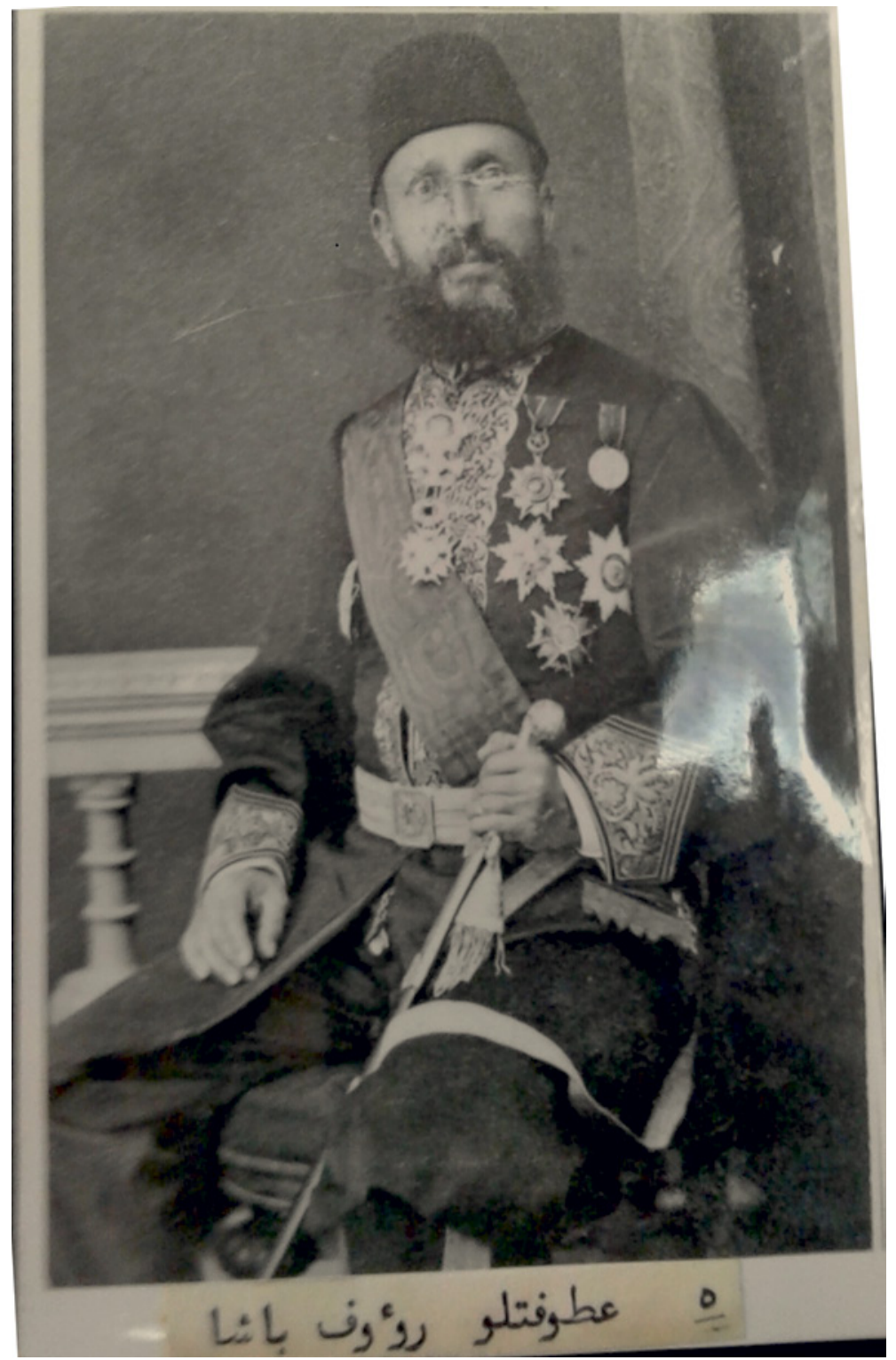

FIGURE 19.2 Ra'uf Pasha, the mutessarif of Jerusalem, as he appeared in the first album.

JAWHARRIYEH COLLECTION. 
and the Arab photographer Khalil Ra'ad. ${ }^{10}$ Both photographers were employed at points to document the Ottoman war effort in southern Palestine and the Sinai Peninsula. However, like elsewhere, Jawharriyeh failed to credit the photographers. This may be understood as an indication of his disinterest in the pictures in themselves as artifacts, but may also be interpreted in terms of his interest in the individuals photographed. It is very likely in this case that the images were bought by Jawharriyeh directly from the shops in Jerusalem's Jaffa Gate.

In the section on the war, the photographs he includes illustrate the lives of the Ottoman soldiers at various locations. Jawharriyeh himself was conscripted into the Ottoman navy in the Dead Sea, but the album lacks any images from that location. There are a few pictures of Jerusalem during World War I, including an image of the hanging of a deserter outside the Jaffa Gate. Khalil Ra'ad, whose studio was located across the street from where the hanging took place, was the photographer.

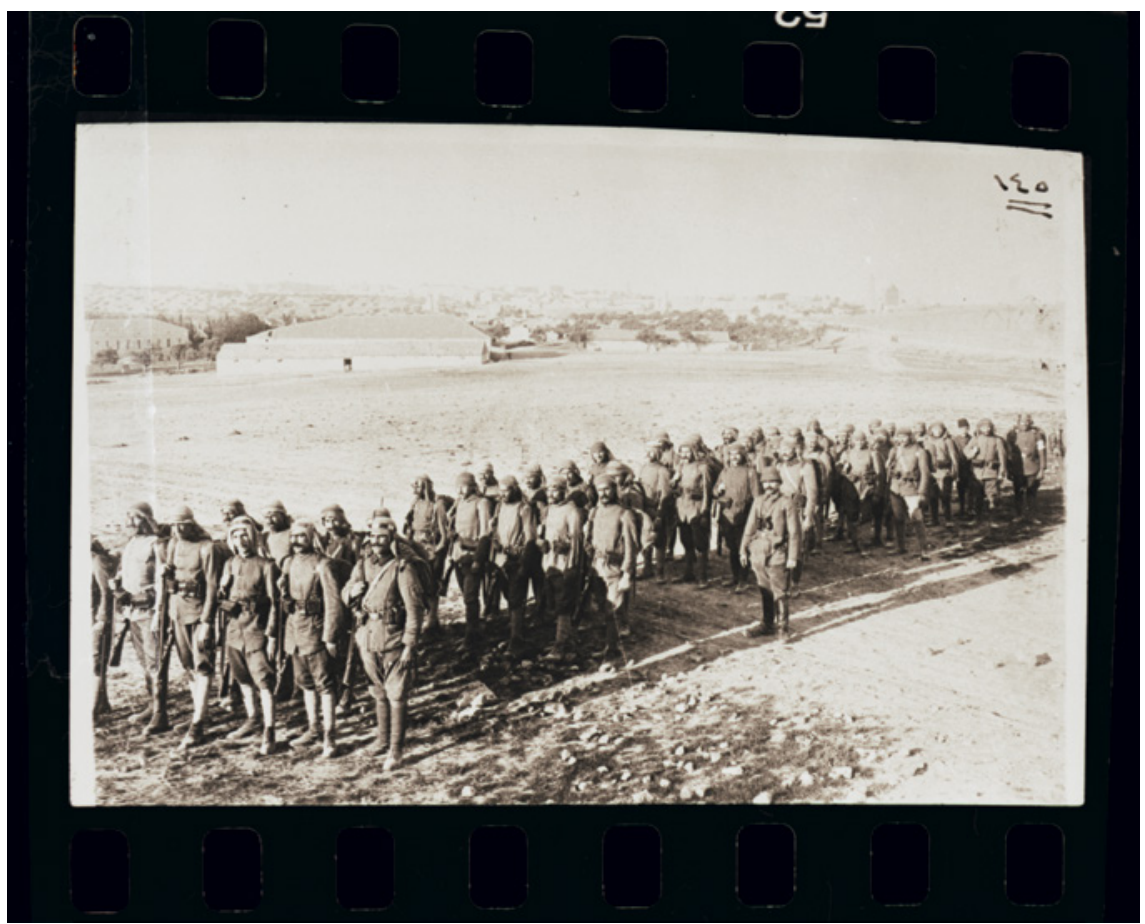

FIgure 19.3 Ottoman troops in Palestine.

JAWHARRIYEH COLLECTION.

Khalidi, Before Their Diaspora. 
Jawharriyeh presented his albums as historical records of the times more than as a reflection of his personal feelings, or the ties he might have had with the leaders whose photographs adorned his albums. The figures he featured in his albums always appeared at their best, posed in formal portraits and exuding an aura of authority, rather than in images that showed them behaving ruthlessly, as in the case of the images of Jamal Pasha, who is referred to in the memoirs as "al-Safah" (the butcher). His album of the Ottoman period ends with a famous photograph showing the surrender of Jerusalem to the British forces on December 9, 1917, in which the mayor of the city and his entourage posed with the white flag of surrender next to the two soldiers they encountered on that day. Taken by Lars Larson, a photographer from the American Colony group in Jerusalem, this image has appeared in numerous publications with various captions usually providing the names of the two British officers. In this sense, it is a fortuitous example of simultaneous, nonintersecting histories in which the people of the city are often left out. While Jawharriyeh failed to mention the names of the two officers, he listed the names of everyone else present, in his caption; he even described where he was at the time of the event, despite not featuring in the photograph whatsoever. By inserting himself into the story, he was, in fact, exercising his authority as an archivist and narrator. In his memoirs, he wrote:

On this day, my brother Khalil, my mother, my brother Fakhri, and I were at my sister Afifeh's home on the western side of Saint Julian Street. I recall that on that day all Christian denominations rang their church bells to celebrate this happy occasion and held services in their churches. After Hussein Bey al-Husseini officially surrendered the city, the American Colony in Jerusalem published a photograph of historic value, which I have kept in the Jawharriyeh Collection. ${ }^{11}$

Jawharriyeh was not present at the surrender event, but he kept a picture of it in his collection. As the selection above from the memoirs shows, he witnessed the event from a distance through the ringing of the church bells. By keeping the photograph in his collection, as well as narrating the event in his diary, he managed to insert himself into the event as a witness. He recalls in some detail what he and others in his family were doing at the exact time of the surrender. Though it was a mundane day for Jawharriyeh on a personal level, it was a significant moment in history. He inserted himself into an event of great 
historical significance through exercising the power to fashion time and place such that the surrender of the city occurred when he was visiting his sister, rather than when the British won the battle or when the Ottomans withdrew, or at any other possible objective historical reference point.

Jawharriyeh, again, failed to credit the photographer of the image of the surrender. With the exception of some of the portraits, he rarely referred to the ways he came to acquire the pictures. The failure to name the photographer stands in contrast to the careful documentation that accompanied his memoirs. To him, the connection with the subject of the picture is more important than the photograph itself or its author.

The albums also include photographs of religious processions in Jerusalem. This is in line with the descriptions of such festivities that appeared in the published memoirs.

Still, unlike the memoirs in which the festivities of all religions are described - Jewish, Christian, and Muslim - the majority of the photos in the

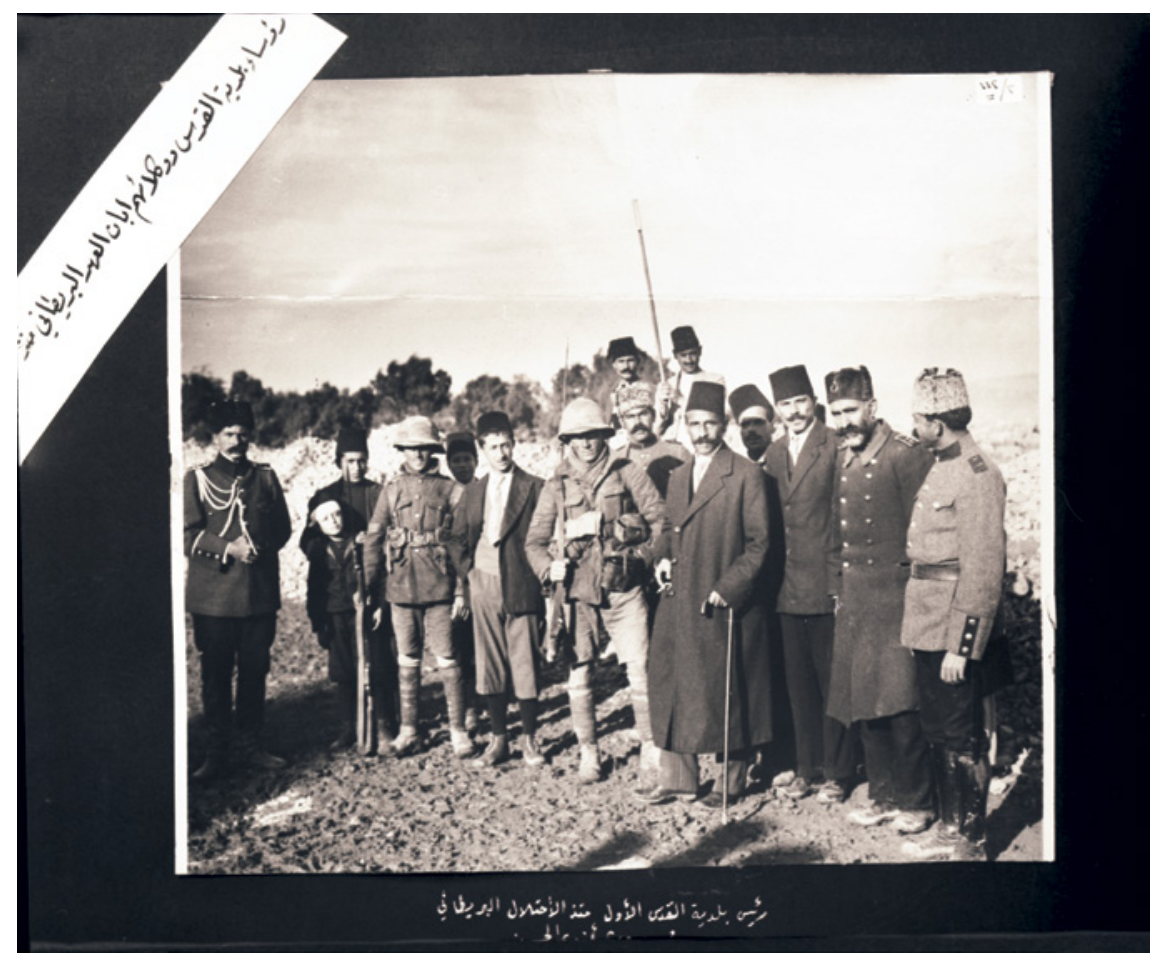

FIGURE 19.4 The mayor's entourage upon the surrender of Jerusalem, December 1917. JAWHARRIYEH COLLECTION. 


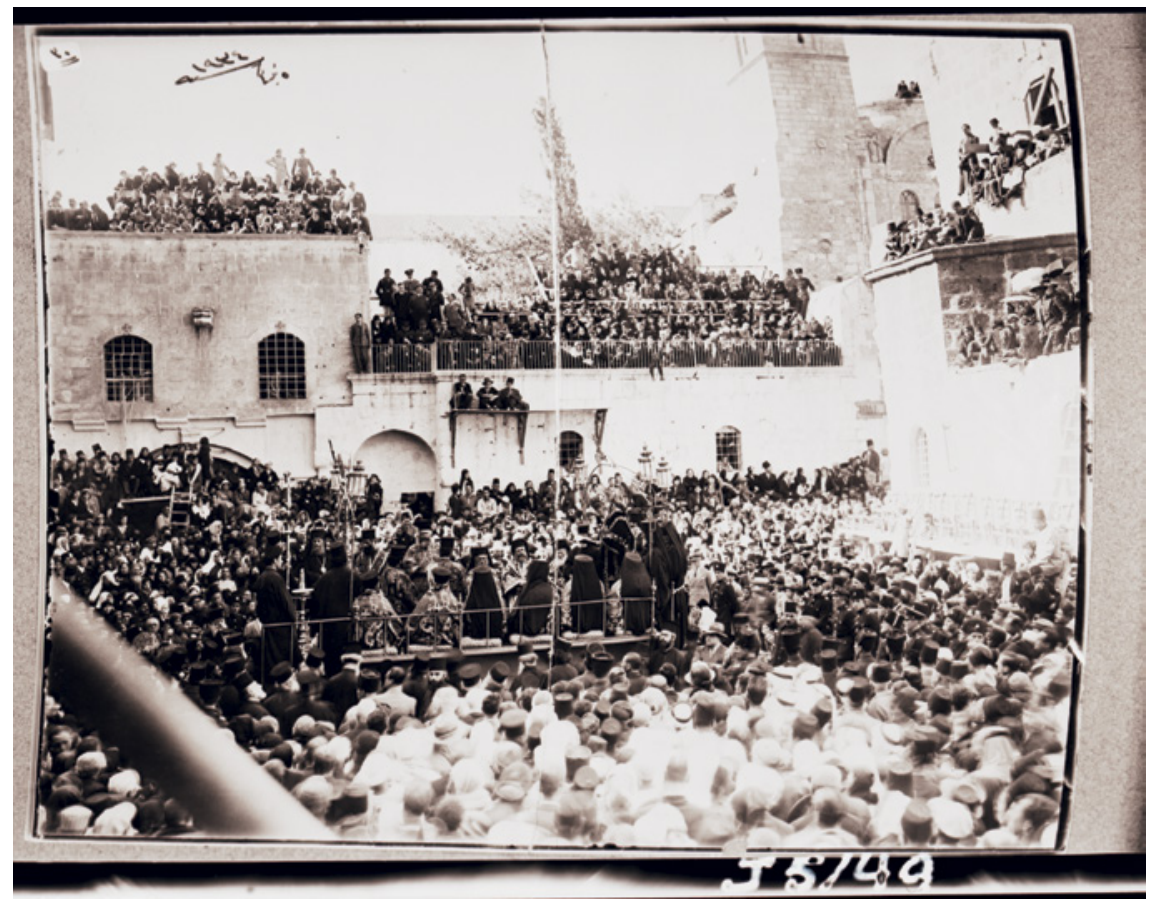

FIGURE 19.5 The procession of the patriarch leaving the Church of the Holy Sepulchre. JAWHARRIYEH COLLECTION.

albums seem to represent Christian, and particularly Orthodox processions, though a few images of the Muslim festival of Nabi Musa were included. ${ }^{12}$

As a member of the Greek Orthodox community with strong ties to Patriarch Damianos, who is mentioned several times in the memoirs, Jawharriyeh devoted an entire section in the first album to the Orthodox clergy in the city. ${ }^{13}$

12 Roger Friedland and Richard Hecht, "The Nebi Musa Pilgrimage and the Origins of Palestinian Nationalism," in Pilgrims and Travelers to the Holy Land, ed. Bryan F. Le Beau and Menachem Mor (Omaha: Creighton University Press, 1996); Kamal al-'Asali, Mawsim al-Nabi Musa fî Filastin: Tarikh al-mawsim wa-l-maqam [The mawsim of Nabi Musa in Palestine: History of the mawsim and the sanctuary] (Amman: Matba'a al-Jami'a alUrduniyya, 1990).

13 Damianos I (July 10, 1848-August 14, 1931) was the Greek Orthodox Patriarch of Jerusalem from 1897 to 1931. See also Konstantinos Papastathis' chapter, "Diplomacy, Communal Politics and Religious Property Management:The Case of the Greek Orthodox Patriarchate of Jerusalem in the Early Mandate Period," in this volume. 
The album includes fifteen pictures of the various priests of the city as well as a number of images of what he described in his notebook as "the Arab men of the Patriarchate of Jerusalem." This part on the Orthodox men and priests directly follows a long section on the notables of the city, which included images of mayors, judges, writers, local members of the Ottoman administration, and others. Although in the second album we find similar photographs of the British administrators of the city, the collection in the first album is very significant as it constitutes an archive not found anywhere else. All of the photographs of the "elites" are studio portraits, which makes the photographed subjects appear at their best, in an authoritative manner, corresponding to how Jawharriyeh represented them in his diaries.

In the second album, we find an entire section devoted to the bloody events of 1929 in Palestine, when riots and clashes between Jews and Muslims broke out at the Wailing Wall. The clashes spread to the nearby city of Hebron, where a massacre of Jewish residents took place. The albums document the aftermath of the massacre. This is an interesting addition that further enhances the significance of the collection, as Jawharriyeh documents the loss of Jewish life at the hands of his fellow Arabs of Palestine. Still, in the memoirs, Jawhariyyeh decries Vladimir Jabotinsky's faction as being responsible for the riots that led to the massacres: ${ }^{14}$

The Revisionist Zionist Party, led by Vladimir Jabotinsky, began to actively call Jews to arm and resort to force, and publicly demanded the takeover of the Wailing Wall in al-Buraq. ${ }^{15}$

Another important section that runs through the albums, particularly the second album, is devoted to the visits of Egyptian, Syrian, and Lebanese artists, singers, and musicians to Jerusalem. In the albums, we find pictures of famous artists such as the dancers Tahiya Carioca and Badia Massabni, singers Farid al-Atrash, Amin Hassanayn, violin player Sami al-Shawa, and comedian Ali alKassar. While some of these pictures resemble portraits usually given to fans by artists, others were clearly taken in Jerusalem and show the visitors with their hosts. In some instances, a written dedication to Jawharriyeh appears on the pictures, as in the case of Sami al-Shawa, who, according to Jawharriyeh,

14 Ze'ev (Vladimir) Jabotinsky was a revisionist Zionist leader in Palestine who emigrated from Russia and formed a number of militant paramilitary groups, including the infamous Irgun organization.

Tamari and Nassar, The Storyteller of Jerusalem, 202. 


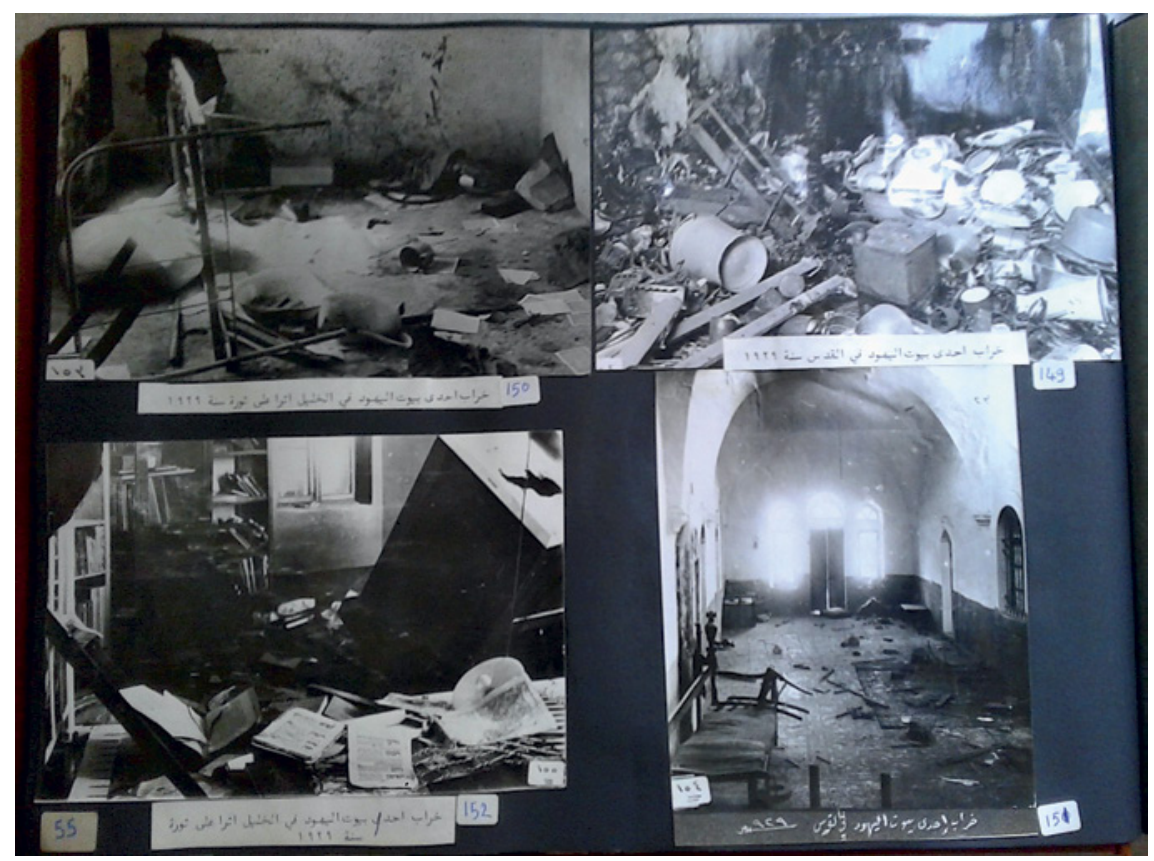

FIGURE 19.6 Page from the album showing the destruction of Jewish homes in Hebron and Jerusalem in 1929.

JAWHARRIYEH COLLECTION.

became a close friend and a frequent visitor to Jerusalem. Al-Shawa became "like a member of the Jawharriyeh family," Jawharriyeh wrote in his memoir. "Whenever he was in Jerusalem, he would stay with us, as though he was one of us." 16

\section{Conclusion}

It is not possible in this short chapter to fully account for the content of the albums; further scholarship will be needed to pursue the topic. However, it is worth noting that Wasif Jawharriyeh's provide a valuable and voluminous visual archive about Jerusalem and its history. In addition to what has been detailed above, they include images of markets, celebrations, riots, troops and many social activities. To do the collection in this study justice, it would be

16 Ibid., 180. 


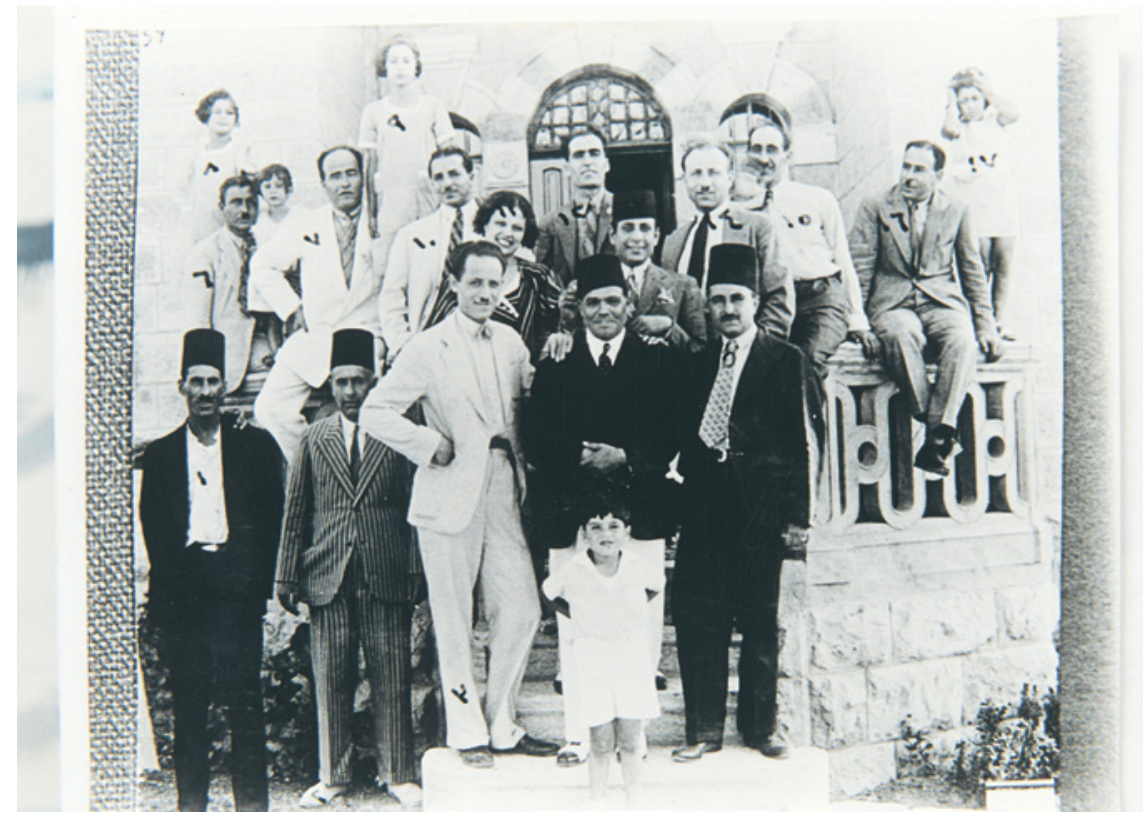

FIGURE 19.7 Visit of Ali al-Kassar to Jerusalem. JAWHARRIYEH COLLECTION.

necessary to provide a description and analysis of each and every one of the more than nine hundred images included in the collection, a task that goes beyond the scope of this contribution. Nevertheless, this introduction will acquaint the reader with the albums and their scope. What makes this collection so valuable is not only its archival nature in terms of photographs, but also the narrative that holds it together: in other words, that which makes it Jawharriyeh's story of Jerusalem. The fact that personal pictures are rare in the collection only adds to its value as an archive of the city, and perhaps as a testimony of the collector to his role as a self-declared chronicler of the city. One might speculate that Jawharriyeh was himself in the pictures through his consistent and apparently intentional absence. In leaving himself out of the images, he not only suggested how we should view him in the context of the city's social order - that is, as someone who was close to the leaders and notables - but also, as a gauge of what was significant. 


\section{PART 4}

Sharing the City: Contacts, Claims and Conflicts 
Angelos Dalachanis and Vincent Lemire - 978-90-04-37574-1 Downloaded from Brill.com04/26/2023 02:29:03PM via free access 


\title{
Introduction
}

\author{
Gadi Algazi
}

This part presents a set of chapters focusing on multiple claims, conflicts, and forms of contact between the inhabitants of Jerusalem. Each chapter is typically based on a distinct archival collection and follows a distinctive methodology - quantitative analysis of distribution of properties or persons (Salim Tamari), a record-based history of the deliberations of a particular institution (Roberto Mazza), or a critique of shared assumptions (Louis Fishman). Behind the archives, however, lurk different social worlds - confessional and ethnic groupings, institutions embedded in local and supralocal settings, legal forms and repertories, and modes of accounting. While showcasing the value of different collections and forms of evidence, the chapters also exemplify the difficulties involved in linking them to create multilayered accounts from a plurality of perspectives, a true history of the city.

Julia Shatz illuminates an assumption underlying several of the chapters of this section: "By following the trajectories of institutions ... we can traverse narrative and archival chasms that otherwise present obstacles to creating a unified history of the city." The difficulties, however, are considerable; perhaps therein lies the attraction of this part.

History is often about change. Our accounts of change usually depend on some notion of a unified subject acting and undergoing significant changes within a given timeframe: a person, a group, or an institution. These may be narrative accounts in which protagonists make their way through webs of circumstances; or accounts of a process, constructed around heterogeneous yet structured entities - a class, a community, not just "a society" but a "social system" transformed through time. The assumed unity of such subjects might be a pious fiction; its coherence sometimes relies on rhetorical gestures or unquestioned assumptions (consider the transformations of a kinship group through several generations).

In this respect, the following chapters, when read together, raise several intriguing questions. Did Jerusalem, especially around 1900, constitute such a unified subject? Can its economic structure, its internal divisions, the pattern of relations between different communities, its particular position, and the marked presence of distant actors authorize telling a story of the city as a whole? To what extent were institutions, many of them embedded in heteronomous contexts, sufficiently related to enable us to say something about

(C) GADI ALGAZI, 2018 | DOI:10.1163/9789004375741_025

This is an open access chapter distributed under the terms of the prevailing CC-BY-NC-ND License at the time of publication. 
"the city" rather than merely about particular entities or groupings - the ProJerusalem Society, examined by Roberto Mazza, or the Sephardic Kolel, analyzed by Yali Hashash? Could indications for change in specific contexts - the uses of Muslim waqf, meticulously examined by Salim Tamari, or the politics of distinct elite groups - be extrapolated to yield productive hypotheses about others? Can citadinité - a concept used by the authors in different ways and even challenged by Louis Fishman - provide a common frame of reference?

Can we trace the same actors as we move among heterogeneous contexts? Often not: many of them are not likely to appear in records produced in another confessional community or by a supralocal institution. Should we look for structural effects connecting different social milieux, while allowing for variance in the way they affect them? What methodologies are available to do this? Should we privilege a specific factor like disease, as Philippe Bourmaud does, a particular institution (the waqf), a textual form (the list), or a project which cuts across common divisions such as the tramway, studied by Sotirios Dimitriadis? Would any single archival collection shed enough light on others for us to recognize concretely how different they were, or how they were related - or would it just lend credence to impressionistic assumptions about assumed commonalities or radical differences? Jerusalem is a difficult place to think with/in. 


\title{
"The Preservation and Safeguarding of the Amenities of the Holy City without Favour or Prejudice to Race or Creed": The Pro-Jerusalem Society and Ronald Storrs, 1917-1926
}

\author{
Roberto Mazza
}

The Beginnings in the Middle of Transition

On September 6, 1918, twelve individuals met at the residence of the military governor of Jerusalem. ${ }^{1}$ The room was filled with tension as the governor was trying to win the confidence of those who were still skeptical and suspicious of British rule. A few months earlier, in December 1917, General Allenby had led the British troops into Jerusalem, ending Ottoman rule in the city and paving the way for greater British success in the region. Though the conquest of Jerusalem proved to be a relatively easy military task, the control of the city required a larger set of skills. All aspects of the conquest and the takeover had been carefully planned in London. While Allenby's military operations were unfolding in Palestine, the Foreign Office and War Office were discussing the future asset of Jerusalem. Most of the policies adopted in relation to Jerusalem were a reflection of wartime agreements, including the Sykes-Picot Agreement and Balfour Declaration. British policy makers, starting with Mark Sykes, were aware of and sensitive to the tensions between the different religious communities in Jerusalem. From the very early stages, the British aimed to avoid clashes between the Christians and Muslims, and among the different

1 Jerusalem Municipal Archives (JMA), 361, Pro-Jerusalem Society, Minutes, no. 1, Jerusalem, September 6, 1918. The twelve individuals were: Ronald Storrs, Ferdinando Diotallevi (Custos of the Custody of the Holy Land), Dr Eder (representative of the Jewish community), Father Ippolytos (representative of the Greek Orthodox Church), Kamil Effendi Husayni (Grand Mufti), Musa Kasim Pasha (president of the municipality), Bishop Kud (representative of the Armenian Orthodox Church), S. G. Salama (vice-president of the municipality), Father Abel, Mr C. R. Ashbee, Major Richmond and Mr J. Spafford. The composition of the council was very fluid and changed at every meeting.

(C) ROBERTO MAZZA, 2018 | DOI:10.1163/9789004375741_026

This is an open access chapter distributed under the terms of the prevailing CC-BY-NC-ND License at the time of publication. 
Christian communities. Indeed, they anticipated that conflict would arise at the end of Ottoman rule. ${ }^{2}$

Three weeks before the occupation of Jerusalem took place, the War Office formalized the policies to be adopted for the administration the city. Internal security was paramount, so Allenby proposed that Muslim holy places should come under the control of Indian Muslim troops. The British were to be in control of Christian and Jewish troops. ${ }^{3}$ British concerns at that juncture were security and the risk that communities would turn against each other. By the end of November 1917, when the occupation of Jerusalem was on the agenda in London, it was only a matter of time before it would become a reality. The Foreign Office advocated strong civilian rule, while the War Office suggested keeping the city under martial law until the future of Jerusalem and the region became clearer. In the end, military rule proved to be a relatively long period of transition that was superseded by civilian rule only in the summer of 1920, with the establishment of the British Mandate for Palestine. ${ }^{4}$

Military rule was established de facto in Jerusalem when General Allenby entered the city on December 11, 1917, and read a short proclamation declaring martial law. More importantly, his declaration emphasized that the British would protect all holy places according to existing customs and beliefs. ${ }^{5}$ According to international law, the military administration of occupied territories should have preserved the status quo ante bellum. In other words, the British were committed to making only minor changes dictated by the necessity of the war effort. ${ }^{6}$ Within the boundaries of the status quo, the military administration established departments of health, law, commerce, and finance in order to restore essential services. ${ }^{7}$ As Jerusalem was now under British rule, General Allenby appointed Colonel Ronald Storrs as governor of the city. This

2 On Jerusalem during World War I, see Abigail Jacobson, From Empire to Empire: Jerusalem Between Ottoman and British Rule (Syracuse: Syracuse University Press, 2011); Roberto Mazza, Jerusalem: From the Ottomans to the British (London: I. B. Tauris, 2009).

3 The National Archives of the UK (TNA): FO 317/3061, War Office to Headquarters in Cairo, November 21, 1917.

4 Mazza, From the Ottomans to the British, 129.

5 TNA: FO 371/3061, General Allenby Reports, Jerusalem, December 11, 1917.

6 Bernard Wasserstein, The British in Palestine: The Mandatory Government and Arab-Jewish Conflict, 1917-1929 (Oxford: Basil Blackwell, 1991), 20; John McTague, "The British Military Administration in Palestine, 1917-1920," Journal of Palestine Studies 7, no. 3 (1978): 56.

7 Palestine Royal Commission Report (London: HMSO, 1937), 113. For a more details on the British Military Administration, see Mazza, From the Ottomans to the British; Jacobson, From Empire to Empire; Naomi Shepherd, Ploughing Sand: British Rule in Palestine, 1917-1948 (London: John Murray, 1999). 
appointment proved crucial for the development of the city in the interwar period. In the early days of British rule, Storrs was immediately involved with the delivery of supplies for the city and, in a fashion that would characterize his governorship, he placed the distribution of food and medicine in the hands of the municipality, under the supervision of the representatives of all religious communities. ${ }^{8}$

Newly appointed governor Storrs had been Oriental Secretary to the British Residency in Cairo, and though he was given the title of colonel, he had no previous military experience. He was meant to serve as a bridge between the military administration on the ground and the political establishment in London. His appointment as governor was not an accident of war. Rather, one might argue that he sought the appointment, which he may have seen as the climax of his career. His work in Cairo proved to be an ideological matrix for his work in Jerusalem. ${ }^{9}$ Eventually he would serve from 1918 to 1920 as military governor of Jerusalem and from 1920 to 1926 as civil governor. Despite his long tenure in the city, in twenty-first-century Jerusalem, there are no memorials, statues, or plaques dedicated to him. Forgotten though he appears to be now, his decisions left an indelible mark on the city. ${ }^{10}$

The main purpose of this chapter is to discuss the establishment of the ProJerusalem Society in 1918, its composition, and its aims. It will also analyze the

TNA: FO 141/746, Military Administrator's Report, Jerusalem, December 15, 1917; TNA: FO 141/688, Clayton to Headquarters, Jerusalem, December 22, 1917.

A look at the various editions of Storrs' memoirs is revealing of the nexus established between his education in Britain, his work in Egypt and then his role in Jerusalem. It is not a surprise that after his governorship in Jerusalem, his work in Cyprus and Northern Rhodesia turned into a disaster as he had no knowledge or appetite to work outside the Middle East. Noah Haiduc-Dale suggests also the importance of looking at studies on India and Africa in order to appreciate the sectarian divisions that emerged during Storrs tenure. See Noah Haiduc-Dale, "Rejecting Sectarianism: Palestinian Christians' Role in Muslim-Christian Relations," Islam and Christian-Muslim Relations 26, no. 1 (2015). Noah Hysler Rubin, similarly, reminds us that Patrick Geddes, before working in Jerusalem, practiced in India what he learned at home in Britain, and then exported to Palestine the amalgamated version of his theories. See Noha H. Rubin, "Geography, Colonialism, and Town Planning: Patrick Geddes' Plan for Mandatory Jerusalem," Cultural Geographies 18, no. 2 (2011): 235 .

In 2010 the Eretz Israel Museum in Tel Aviv organized the first and only exhibition on Storrs, his work in Jerusalem and his relations with the local communities. See Dalia Karpel, "Discerning Conqueror," Haaretz, November 12, 2010, accessed January 15, 2018, https:/www.haaretz.com/israel-news/discerning-conqueror-1.324306; "The First Governor," Eretz Israel Museum, accessed January 15, 2018, http://www.eretzmuseum.org .il $/ \mathrm{e} / 20 /$. 
ideology and symbolism that it adopted, with a particular focus on preservation and sectarian harmony. Though a number of articles have been dedicated to the study of the Pro-Jerusalem Society, an assessment based on the minutes of its council and on the parallel activities of the Town Planning Commission has yet to be written. Most of the literature available relies mainly on the publications of the Pro-Jerusalem Society and on British administration reports. The minutes shed light on the internal dynamics of those organizations, showing how the decision-making process worked and eventually translated into action. In presenting the society's activities, I will focus on a particular decision first proposed by the society and later adopted by the Town Planning Commission: the adoption of Jerusalem - white - stone as the only visible building material allowed. This decision changed the way the city would look and develop.

The citadinité or urban citizenship shared by the inhabitants of Jerusalem was challenged by the new order brought by the British. Sectarianism was superimposed onto the Ottoman order; the city's diverse inhabitants were compartmentalized, at the expense of Jerusalem as a world city. More importantly, though, the history of the local communities was segmented into a large number of narratives that favored certain communities over others and regularly excluded one or more of these communities. This chapter will assess the extent to which urban planning, which not only relates to maps and borders, but also includes materials and regulations, impacted citadinité and its representation. ${ }^{11}$

\section{A Comment on Sources: A Complex and Partly Hidden Archipelago}

Scholars wishing to examine the Pro-Jerusalem Society have, for the most part, relied on limited sources: the publications of the Pro-Jerusalem Society, British documents, material from the Central Zionist Archives (CZA) and local newspapers, and, more seldom, diaries and memoirs. Plans have been scrutinized through the lenses of sociology, arts and architecture, politics, anthropology, religion, and indeed history. The narratives produced often view the city from the perspective of one or more communities, but rarely discuss it as a global entity. On the one hand, this may be the result of a careful choice - to prove or disprove claims - but on the other, the archival complexity of Jerusalem often acts as a deterrent to write a comprehensive history of the city. A good example

11 Citadinité is a term proposed for the study of Jerusalem by the Open Jerusalem project. See the introduction of the volume. 
is represented by the Pro-Jerusalem Society and Town Planning Commission from 1917 to 1926, which coincided with the governorship of Storrs. The minutes of the society's council are not to be found at the Jerusalem Municipal Archives, but in fact are available at the czA. Unfortunately, some of the minutes are missing. For this chapter I also relied on the minutes of the Town Planning Commission available at the Municipal Archives. Building permits, known as ruksah, seem, however, to have disappeared. After searching in several institutions in Jerusalem, I came to the conclusion that this material may simply be buried in some corner of the municipality. It is also possible that, due to its possibly controversial nature, it has been hidden. In order to overcome this issue, I relied on material from different archives in the city and abroad. I also perused material from the Custody of the Holy Land and the Latin Patriarchate and looked at material available in the French and Italian consular archives. The holdings of the renovated Israeli State Archives are now available online and material related to urban planning is available in a number of files related to the British Mandate. None of the archives visited contain a specific section dedicated to urban planning, but a global history of the city and its plans needs to be brought to life, patiently, one step at a time.

\section{The Establishment of the Society: Between Patrimonial Ideology and Demunicipalization}

Early in 1918, Storrs conceived the idea of establishing a society, or a "committee of the three races," as he put it to Sykes, with the purpose of developing a common spirit among the communities of Jerusalem. ${ }^{12}$ The Pro-Jerusalem Society was born as a nongovernmental organization designed to assist the military governor in "the preservation of the interests of Jerusalem, its districts, and inhabitants." ${ }^{13}$ Storrs mobilized local leaders with the intent to promote and achieve sectarian harmony. He wished to establish a system that would preserve the interests of everyone and prevent one community's interests from being imposed over the others..$^{14}$ At this stage, the Pro-Jerusalem Society was involved in the cleaning, reconstruction, and preservation of the

12 Storrs Papers, Box III/1, Pembroke College, Cambridge. Storrs to Sykes, undated. As the first council was convened in September 1918, this letter must have been written earlier.

13 Charles Robert Ashbee, ed., Jerusalem, 1918-1920: Being the Records of the Pro-Jerusalem Council during the Period of the British Military Administration (London: John Murray, 1921), vii.

14 JMA, 361, Pro-Jerusalem Society, Minutes, No. 1, Jerusalem, September 6, 1918. 
Old City. "Can one make Jerusalem modern?" asked Storrs. "Yes, gentlemen, one can; but on one condition, its destruction."15 The twelve individuals that met for the first time on September 6, 1918, agreed to establish a council that would help and advise the government in all issues related to the character of the city; in other words, its religious milieu. The minutes of the first meeting of the society's council show that it was not going to interfere in the work of the municipality and that the responsibilities of the municipality would remain the same. ${ }^{16}$ In reality, the activity of the two institutions seems to have been blurred; the governor often had the last word. With the establishment of the Town Planning Commission, the role of the municipality became even more unclear, and it may be argued that the first years of British rule marked a process of demunicipalization. ${ }^{17}$ In other words, the Jerusalem municipality was deprived of many of its functions. It was reduced to a secondary role, which emphasized British, rather than local, rule over the city.

The rapid establishment of the Pro-Jerusalem Society several months after the British took Jerusalem suggests that there was a sense of urgency in gaining control of the physical environment. ${ }^{18}$ This sense of urgency had been expressed as early as April 1918, when the governor issued a public notice whose paramount purpose was to preserve the aspect of the city: "No person shall demolish, erect, alter or repair the structure of any building in the city of Jerusalem or its environs within a radius of 2,500 meters from the Damascus Gate (Bab al-Amud) until he has obtained a written permit from the Military Governor."19 Similarly, the governor proposed forbidding the use of red brick and corrugated iron. As we shall see later, this was a decision that would mark the future development of both Old and New Jerusalem. ${ }^{20}$ The establishment of the ProJerusalem Society was also meant to legitimize British rule, and the preservation of the Old City was a means of debasing the improvements introduced

15 Ibid.

16 Ibid.

17 I must thank Falestin Naïli, who coined this word while reviewing an earlier version of this chapter. Municipalities of other cities in British Palestine were empowered with new functions. A good example of this is Haifa, suggesting there were inconsistencies in the ways in which the British ruled Palestine. Above all, it reinforces the view that Jerusalem was considered somewhat unique.

18 Inbal Ben-Asher Gitler, “'Marrying Modern Progress with Treasured Antiquity': Jerusalem City Plans during the British Mandate, 1917-1948," Traditional Dwellings and Settlements Review 15, no. 1 (2003): 41.

19 Ashbee, Jerusalem, 1918-1920, v.

20 JMA, 361, Pro-Jerusalem Society, Minutes, no. 1, Jerusalem, September 6, 1918. 
by the late Ottoman administration. ${ }^{21}$ Inbal Ben-Asher Gitler is right when he suggests that preservation was turned into a "nobody does it better" propaganda tool. ${ }^{22}$ The extent of the control exercised over the city becomes clear in the last report signed by Storrs before the Pro-Jerusalem Society was dissolved in 1926. Storrs wrote that "during the eight years of the society's existence stringent control has been exercised on new building and particularly in the Old City ... Shop signs have been controlled under a regulation originated by the society. All streets both in the Old and New City have been named."23

\section{Which lingua franca, and for What Purpose?}

The aims of the Pro-Jerusalem Society were embedded in its establishment and were highly publicized. Once the society became officially recognized and incorporated in the British Mandate after 1920, its membership and donations grew. According to clause no. 7 of the society's charter, "any person may become a member of the Society on payment of an annual subscription of not less than $£_{5}$ or a donation of not less than $£_{25}{ }^{24}$ In the spirit of the society, the list of its members and donors includes Jerusalemites from all communities, financial institutions, and a number of British officials. Quarterly reports and other society publications reassured members of its development. Members were apprised of how donations turned into visible assets and were constantly reminded of the society's mission, which was sevenfold:

21 Here is a selection of works discussing Jerusalem municipality in the late Ottoman era: Vincent Lemire, Jerusalem 19oo: The Holy City in the Age of Possibilities, trans. Catherine Tihanui and Lys Ann Weiss (Chicago: University of Chicago Press, 2017); Yasemin Avcı and Vincent Lemire, "De la modernité administrative à la modernisation urbaine: une revaluation de la municipalité ottomane de Jérusalem (1867-1917)," in Municipalités méditerranéennes: les réformes urbaines ottomanes au miroir d'une histoire comparée (MoyenOrient, Maghreb, Europe méridionale), ed. Nora Lafi (Berlin: Klaus Schwarz, 2005); David Kushner, To Be Governor of Jerusalem: The City and District during the Time of Ali Ekrem Bey, 1906-1908 (Istanbul: Isis, 2005); Haim Gerber, Ottoman Rule in Jerusalem, 1890-1914 (Berlin: Klaus Schwarz, 1985); Salim Tamari, "Confessionalism and Public Space in Ottoman and Colonial Jerusalem," in Cities and Sovereignty: Identity Politics in Urban Spaces, ed. Diane Davis and Nora Libertun de Duren (Bloomington: Indiana University Press, 2011); Johann Büssow, Hamidian Palestine: Politics and Society in the District of Jerusalem 1872-1908 (Leiden: Brill, 2011).

22 Gitler, "Marrying Modern Progress," 53.

23 JMA, 361, Pro-Jerusalem Society, Ronald Storrs, Jerusalem, November 24, 1926.

24 JMA, 361, The Pro-Jerusalem Society Quarterly Bulletin, March 1922. 
1. The protection of and the addition to the amenities of Jerusalem and its district.

2. The provision and maintenance of parks, gardens, and open spaces in Jerusalem and its district.

3. The establishment in the district of Jerusalem of Museums, Libraries, Art Galleries, Exhibitions, Musical and Dramatic Centres, or other institutions of a similar nature for the benefit of the Public.

4. The protection and preservation with the consent of the Government, of the Antiquities in the district of Jerusalem.

5. The encouragement in the district of Jerusalem of arts, handicrafts, and industries in consonance with the general objects of the Society.

6. The Administration of any immovable property in the district of Jerusalem which is acquired by the Society or entrusted to it by any person or corporation with a view to securing the improvement of the property and the welfare of its tenants or occupants.

7. To cooperate with the Department of Education, Agriculture, Public Health, Public Works, so far as may be in harmony with the general objects of the Society. ${ }^{25}$

Raquel Rapaport has noted that by 1937, Storrs considered aims one, two and five as the most important. At least, these were the aims that had been achieved by the society. ${ }^{26}$ One of its underlining purposes was to promote harmony between the communities. In an attempt to start on the right foot, the meetings of the society's council were conducted in French. It was generally believed that French would serve as the most appropriate lingua franca, but it was also chosen in order to demonstrate British benevolence and lack of colonial-imperial spirit. ${ }^{27}$ We have no written records of linguistic problems at council meetings, but it is possible that they turned into a babel of tongues or resulted in pure silence. While carefully examining the minutes of the council, I noted that some members are never reported as saying anything; perhaps what they said was not worth recording, or they may have simply sat silent

\footnotetext{
25 Ashbee, Jerusalem, 1918-1920, vii.

26 Raquel Rapaport, "Conflicting Visions. Architecture in Palestine during the British Mandate" (PhD diss., University of Cardiff, 2005), 54.

27 The minutes of the Pro-Jerusalem Society's council can be found at the Jerusalem Municipal Archives and the Central Zionist Archives; the meetings and minutes were conducted in French, though translation was available. See Ronald Storrs, The Memoirs of Sir Ronald Storrs (New York: G. P. Putnam's Sons, 1937), 327.
} 
around the table. In line with this behavior was certainly the custos of the Custody of the Holy Land, Father Diotallevi. Though the records show a fairly good attendance, it seems as if he chose to be silent throughout the meetings, which reached a lively pitch at times. In his diary, he only mentioned that he would attend the council, but he never reported anything about it. ${ }^{28}$

Sectarian harmony, however, transcended languages, and Storrs promoted the idea of common interest in the image of an Old City that would look ancient but would function as a modern city. Storrs may have been the mind behind this idea, but it was Charles Ashbee, in his role as civic adviser who translated it into action. Ashbee understood the Old City as a place where, for centuries, sectarian rivalries and hatred prevailed, but now under British rule all parties would meet together and "regard the Holy City as a Trust for all mankind, put the sectarian interests as far as possible on one side, and see what they could do."29

Sectarian harmony was based on a major misconception: the idea that communities were divided in Jerusalem and in conflict with one another. In this view, local inhabitants were romanticized and orientalized, understood in a sense as "authentic" actors in a religious theme park. Such a mythologization served to make Jerusalem seem more biblical and less modern. ${ }^{30}$ Paradoxically, the Pro-Jerusalem Society imposed a model that was based on the sectarianization of the city. Benjamin Hyman has suggested that Ashbee and Storrs were painstakingly working towards the segregation of the Old City from the New City. I will return to this hypothesis later, but for the moment, I argue that this segregation encouraged the "unmixing" of the local population, and brought centuries of relatively peaceful coexistence and, more importantly,

28 Ferdinando Diotallevi, Diario di Terrasanta: 1918-1924, ed. Daniela Fabrizio (Milan: Biblioteca Francescana, 2002).

29 Charles Robert Ashbee, "Pro-Jerusalem" The American Magazine of Art 12, no. 3 (1921): 99. Details on Ashbee can be found in many publications, here is just a sample: Fiona MacCarthy, The Simple Life: C. R. Ashbee in the Cotswolds (Berkeley: University of California Press, 1981); Alan Crawford, C. R. Ashbee: Architect, Designer \& Romantic Socialist (New Haven: Yale University Press, 2005).

30 On the romanticization of local inhabitants, see Lorenzo Kamel, Imperial Perceptions of Palestine: British Influence and Power in Late Ottoman Times (London: I. B. Tauris, 2015). As for the concept of sectarianism, I borrow the definition suggested by Ussama Makdisi, The Culture of Sectarianism: Community, History, and Violence in Nineteenth Century Ottoman Lebanon (Berkeley: University of California Press, 200o), $5^{-6}$, who defines it as "a practice that developed out of, and must be understood in the context of, nineteenthcentury Ottoman reform. Second, it is a discourse that is scripted as the Other to various competing Ottoman, European, and Lebanese narratives of modernization." 


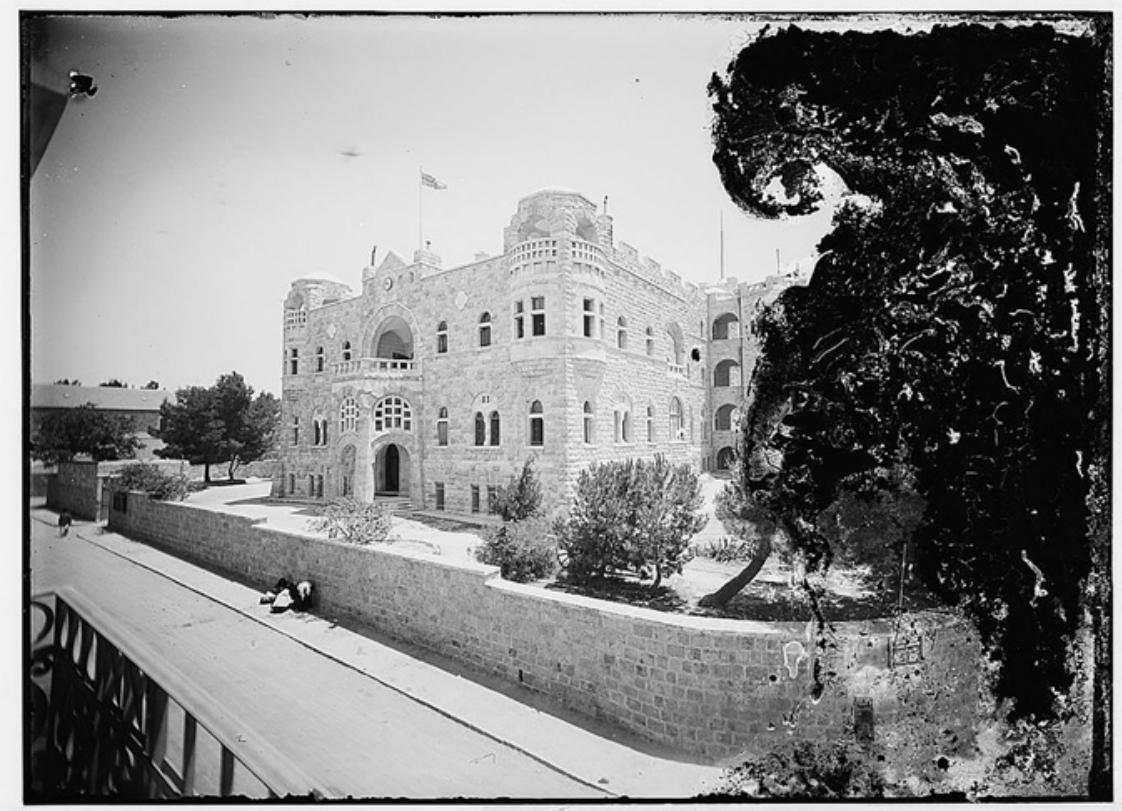

FIGURE $20.1 \quad$ Newer Jerusalem and suburbs. St. Paul's Hospice, a government office near Damascus Gate.

G. ERIC AND EDITH MATSON PHOTOGRAPH COLLECTION/LIBRARY OF CONGRESS PRINTS AND PHOTOGRAPHS DIVISION.

active cohabitation, to an end. ${ }^{31}$ Jerusalem had been a multicultural, multiethnic and multilinguistic city, but at this point in its history this order was challenged and homogenization became the paramount objective. Citadinité was restricted and fragmented; the shared space Wasif Jawhariyyeh and Gad Frumkin had described in their writings was rapidly disappearing. ${ }^{32}$

31 Benjamin Hyman, "British Planners in Palestine, 1918-1936" (PhD diss., London School of Economics and Political Science, University of London, 1994), 394.

32 Salim Tamari and Issam Nassar, eds., The Storyteller of Jerusalem: The Life and Times of Wasif Jawhariyyeh, 1904-1948 (Northampton: Olive Branch, 2014); Gad Frumkin, Derekh Shofet bi-Rushalayim [The path of a judge in Jerusalem] (Tel Aviv: Dvir, 1954). Yair Wallach, "Shared Space in Pre-1948 Jerusalem? Integration, Segregation and Urban Space through the Eyes of Justice Gad Frumkin, Elect," working paper no. 21, Conflict in Cities and the Contested State, accessed January 15, 2018, http://www.conflictincities.org/PDFs/ WorkingPaper21.pdf. 


\section{Old City versus New City}

The Old City was the main target of the activities of the Pro-Jerusalem Society. Several projects intended to turn intramuros Jerusalem into an open-air museum. The cleaning of the Citadel was designed to bring back the former glory of what was understood to be the city of David: a site of memory and a site of power. It was not an easy task to clean and restore the Citadel, meant to become a showcase of British power. The Citadel, once used as a locus of the local military power, was transformed into a place for secular cultural activities and performances. Storrs and Ashbee divested the Citadel of its religious significance and imbued the newly reopened monument with a colonial spirit. In 1921, Storrs opened an exhibition displaying the drafts of the urban renewal plans and Palestinian arts and crafts produced under the aegis of the Pro-Jerusalem Society. ${ }^{33}$

A second important project developed in the Old City was the restoration of the walls and of the ramparts. ${ }^{34}$ Ashbee declared that Jerusalem was the finest medieval city still standing: "the most perfect example of Medieval City circumvallation." 35 The idea was to clean the walls so that people could

33 Since Israel's taking of Jerusalem from the Jordanians in 1967 , the Citadel has been transformed into a Municipal Museum. Its purpose is to show the role Jerusalem has played in Jewish history and in the life of the Jewish nation. See http://www.tod.org.il/en/museum/ about-the-museum/. While Ashbee and Storrs wanted to attribute to the Citadel an imperial - and secular - character, the Israeli authorities imbued the place with religious significance. Despite the suggestion that all three faiths are equally represented in the museum's exhibitions, the Jewish identity is indisputably predominant. Rather than choosing the name "Citadel," the name "Tower of David," wrongly attributed to the place by the Byzantines, was kept, thereby creating an artificial nexus with the ancient Jewish king. See Menachem Klein, Lives in Common. Arabs and Jews in Jerusalem, Jaffa and Hebron (London: Hurst, 2014), 15-16.

34 In relation to this project, Storrs ordered the removal of the Ottoman clock tower that had been built in 1907 by Abdülhamid II as a symbol of modernization. In 1922 the clock tower was removed on the ground of "un-slightness," as stated by Storrs. See Palestine Post, September 27, 1934. From the records of the Pro-Jerusalem Society's council, it is clear that the clock tower was going to be short-lived as it did not fit the criteria of aesthetics and protection of the Crusader character of the city. See Ashbee, Jerusalem, 1918-1920, 62. Also Geddes condemned the clock tower as a vulgar modern decoration. Central Zionist Archives (CZA) Z4/10202, Patrick Geddes, "Jerusalem Actual and Possible: A Preliminary Report to the Chief Administrator of Palestine and Military Governor of Jerusalem on town planning and city improvements," November 1919.

Simon Goldhill, Jerusalem: City of Longing (Cambridge: Belknap Press of Harvard University Press, 2008), 172-74; Ashbee, "Pro-Jerusalem," 101. 
walk around the city and, with the reconstruction of the ramparts, that visitors and inhabitants could enjoy the most "beautiful and romantic park promenade in the world." ${ }^{36}$ The restoration of the walls was, however, not just a matter of creating a space for the enjoyment of a city landmark. It was a sign of the segregation between the Old and New City. ${ }^{37}$ The Old City was intended as a city of the mind, as Gitler has argued, dedicated to spiritual, cultural and religious life. ${ }^{38}$ The green belt around the Old City proposed by Ashbee may be interpreted as a way to isolate it from the New City. I argue that his plan created the impression that the Old City and the neighborhoods that developed outside its walls were blended together in order to respect the Mandate policy of avoiding religious segregation in urban planning. The reality was rather different. Though city dwellers may have crossed the fictitious borders between the two entities, visitors and pilgrims were certainly less keen to spend time in the New City. Segregation may have not existed officially, but it undoubtedly pervaded the daily lives of Jerusalem's inhabitants.

The publications of the Pro-Jerusalem Society suggest that it was involved in town planning deemed essential to protect Jerusalem from violent changes, but above all, to make sure that principles of adaptability, the grasp of social and architectural norms, and the effective administrative machinery would be respected. ${ }^{39}$ Though Ashbee discussed the plans presented by McLean and Geddes in a publication of the Pro-Jerusalem Society, the minutes of its council suggest that planning was never really discussed. Plans were adopted, but never fully scrutinized. Both Ashbee and Storrs were well aware of the potential for contention between the communities involved. McLean's plan was presented to the Municipal Council; Geddes' plan was never presented to anybody, and Ashbee's plan was presented to the Town Planning Commission that superseded the Pro-Jerusalem Society. ${ }^{40}$

36 Ashbee, "Pro-Jerusalem," 101.

37 Gitler, "Marrying Modern Progress," 44.

38 Ibid., 54 . Gitler suggests that the city was not segregated but the Old City became a sort of "spiritual zone." It is indeed true that, unlike the great majority of colonial cities, Jerusalem did not experience the creation of a European area vs. an indigenous one. Nevertheless, a form of segregation occurred as the Old City was designed to host pilgrims and visitors, mainly coming from Europe and America.

Ashbee, Jerusalem, 1918-1920, 11. See also Jonathan Rokem, "Politics and Conflict in a Contested City: Urban Planning in Jerusalem under Israeli Rule," Bulletin du Centre de recherche français à Jérusalem, no. 23 (2012); Rubin, "Geography, Colonialism, and Town Planning," 231-48.

JMA 829, Jerusalem Town Planning Commission, Minutes, no. 5, September 1, 1921. Members of the commission (many were also part of the council of the Pro-Jerusalem 
The New City was different from the Old City. The former would house different ideologies, which would accommodate the necessities of the Zionists, now cashing in on the promise made by the British with the Balfour Declaration. ${ }^{41}$ In this sense the Pro-Jerusalem Society proved its limits, including the fact that the society was more the expression of individuals like Storrs and Ashbee and their visions rather than a coherent organization with goals that would transcend the will of a few characters. In relation to the New City, the ProJerusalem Society was, for the most part, involved with projects in developing the establishment of libraries, exhibitions, musical and dramatic centers, as defined in the charter. Ashbee also worked towards the development of local arts and crafts and local industries, which were then employed in the reconstruction in the Old City. A dichotomy between the Old and New City emerged under the Ottomans when the first neighborhoods outside the walls were built and people, mainly wealthy residents, began to move out, suggesting a contrast between a more secular and modern city outside the walls vis-à-vis a less modern and more religious city within them. The Pro-Jerusalem Society with its influence, the Town Planning Commission, and British planners certainly amplified this division, but it would be a mistake to create a barrier between the two entities. Both were part of the same fabric.

\section{Symbolism: Holiness in the Foreground}

The emblem of the Pro-Jerusalem Society (fig. 20.2) comprises four small Christian crosses drawn inside a Star of David outflanked by a Muslim crescent. The idea was to convey the message that harmony between city dwellers and those who cared about it was possible. Despite the symbolism and the declared interest to preserve and protect the city, the Pro-Jerusalem Society seems to have forgotten one key element: Jerusalemites. The minutes of the society's council are filled with details about discussions in relation to the walls, the markets, arts and crafts and other activities, but overall very little was discussed in relation to the inhabitants of the city. One exception was the debate over the materials to be employed in the restoration of old buildings

Society) stated that, in fact, "the plans of the City upon which the present and the late administration had been working during the last 2 years ... had been discussed at different times ... they had not yet been put in any uniform scale before this commission." 


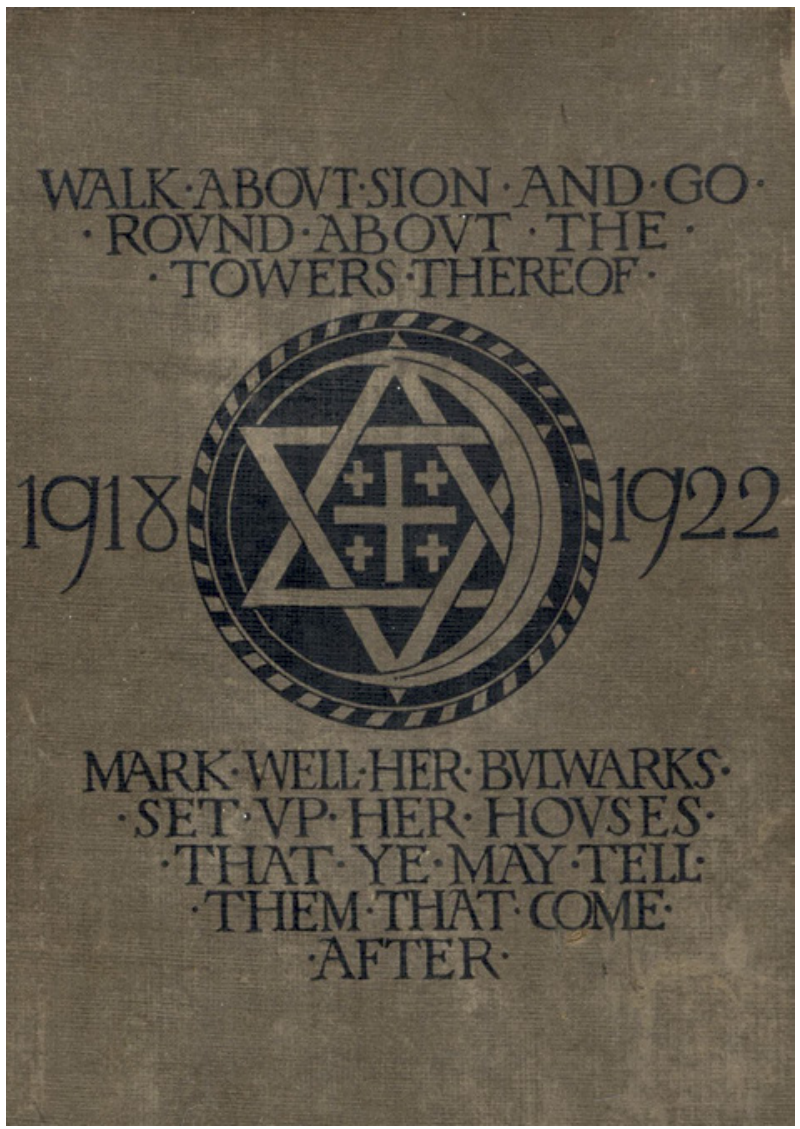

FIGURE 20.2 The emblem of the Pro-Jerusalem Society, as depicted on the cover of Charles Robert Ashbee, Jerusalem, 1920-1922.

LONDON: JOHN MURRAY, 1924.

and the construction of new ones. Like any ritual city, Jerusalem was often, if not always, appropriated and therefore transformed by its new rulers. ${ }^{42}$ From King David, who reunited the kingdom of Israel and made Jerusalem his new capital, through to the Roman, Muslim and Crusader conquerors, everyone adapted the city according to their purposes and visions. Following the

42 Jeff Halper, "On the Way: The Transition of Jerusalem from a Ritual to Colonial City, 180o1917," Urban Anthropology 13, no. 1 (1984). 
Six Days War in 1967, Ben Gurion promoted plans to remove the very same walls Storrs and Ashbee had regarded as a symbol of Jerusalem. ${ }^{43}$

A symbolic act of quasi-colonial control and of ideological value was the operation of renaming and numbering the city's streets. The preservation of the biblical image of the city was the primary concern of the society, a close second to imperial politics. Naming the streets was therefore understood as a modernizing necessity. The naming criteria were, however, different compared to other colonial cities. ${ }^{44}$ The symbolism of the Pro-Jerusalem Society was transformed from an innocuous logo to real allocation of names and numbers. The names chosen for Jerusalem's streets reflected British imperial history in part. A special subcommittee was formed; in 1926, Storrs wrote that "all streets both in the Old and New City have been named. Suitable ceramic plates made by the Bezalel School of Arts have been erected in the New City and a complete set for the Old City made in the society's ceramic factory." 45 Naming was not an easy task. Ashbee wrote that the "list is so full of history, poetry and folklore that it is well worth careful study."46 Storrs eventually chose saints, prophets, scholars, and kings belonging to the history of all religious communities, which symbolized his attempt to achieve a sectarian balance. He personally chose names such as St. Francis Street and St. Paul Road, Richard Cœur de Lion Street and Saladin Road. One road was also dedicated to a woman, Queen Melisende. ${ }^{47}$ These names were indeed linked to the history of the city, however, none of them truly symbolized the unity of Jerusalem. On the contrary,

43 Meron Benvenisti, City of Stones: The Hidden History of Jerusalem, trans. Maxine Kaufman Nunn (Berkeley: University of California Press, 1996), 136.

44 There are many works dedicated to the topic of street naming. Here is a sample I have used to compare Jerusalem with other colonial cities: Liora Bigon, "Urban Planning, Colonial Doctrines and Street Naming in French Dakar and British Lagos, c. 1850-1930," Urban History 36, no. 3 (2009); Brenda S. A. Yeoh, "Street Names in Colonial Singapore," Geographical Review 82, no. 3 (1992); Liora Bigon, ed., Place Names in Africa: Colonial Urban Legacies, Entangled Histories (Cham: Springer, 2016); Seamus Conboy, "Changing Dublin Street Names, 1880's to 1940's," Dublin Historical Record 64, no. 2 (2011).

45 JMA 361, Pro-Jerusalem Society, Ronald Storrs, Jerusalem, November 24, 1926. CzA A $53 / 172$, Minutes of the Street Naming Committee. The archives hold the minutes of four meetings held between October 1923 to January 1924. The members of the subcommittee discussed a list of names proposed for the Old and New City. Names were written in English, Arabic and Hebrew.

46 Charles Robert Ashbee, Jerusalem, 1920-1922: Being the Records of the Pro-Jerusalem Council during the First Two Years of the Civil Administration (London: John Murray, 1924), $26-28$.

Storrs, Memoirs, 331-32. 
when one reflects on the history of Jerusalem, some of these names suggest cleavage, division, and conflict than unity and peace. As mentioned earlier, naming the streets of Jerusalem granted the British a degree of physical control, while local Jerusalemites viewed it as the radical transformation of their local environment. Anonymity in Jerusalem was almost unknown, even outside the walls, and every person was easily located. In Ottoman Jerusalem streets were known by more than one name, however, this did not affect the knowledge of the city fabric and mail was still delivered to the right mailbox. ${ }^{48}$ In the long term, street naming brought a practical amelioration for the city dwellers. On the other hand, the same process suggests that Jerusalemites lost a key element defining the concept of citadinité. Toponyms based on groups' heritage and history were imposed on Jerusalemites, once again fostering sectarianism and reducing the sense of Jerusalem as global city. ${ }^{49}$

\section{Red Brick and White Stone: A Political Reading}

With the formulation of the town planning ordinance, Jerusalem's Town Planning Commission began operation in 1921. Ashbee was then a member and secretary of the commission and member of the Central Commission. Nearly all building permits and plans underwent his scrutiny and decision. ${ }^{50}$ The Town Planning Commission was meant to represent the progress that the British Mandate would bring to Palestine. However, this was not a democratically elected institution, and membership came to include officials, professionals, and local representatives. The authority of the commission was limited, but crucially included the authorization of constructions of building and streets. The Pro-Jerusalem Society was partly superseded by the new institution, which then debated all building permits submitted to the municipality. The vision of the Old and New City as planned by the Pro-Jerusalem Society was now

48 On the naming of the streets, see Yair Wallach, "The 1920s Street-Naming Campaign and the British Reshaping of Jerusalem" (paper presented at the Second World Congress for Middle Eastern Studies, Amman, June 11-16, 2006), and Wallach, "Reading in Conflict: Public Text in Modern Jerusalem" (PhD diss., Birkbeck College, University of London, 2008).

49 Maoz Azaryahu, "Naming the Streets of (Arab) Jerusalem during the British Period, 19201948," Horizons in Geography, nos. 6o-61 (2004).

5o Hyman, "British Planners," 406-7. 
transferred to the commission, which became the official British approach to the urban development of the city. ${ }^{51}$

Jerusalem possessed "an appeal to the imagination that not Rome, nor even Athens could rival." Storrs and Ashbee clearly disliked physical evidence of nineteenth-century modernity. ${ }^{52}$ When asked to grant a concession to run a street-car line to Bethlehem and the Mount of Olives, Storrs replied through several newspapers: "the first rail section would have to be laid over the dead body of the military governor." 53 The argument was soon closed and both the minutes of the society's council and the Town Plan Commission do not report any major discussion of public transportation around the Old City. The topic was left untouched until 2011, when the contemporary Jerusalem municipality opened a very controversial tram line. I argue that the unilateral decision by Storrs proved to be a crucial barrier for the future development of communal relations in Jerusalem. Local inhabitants were deprived of a facility that could have created new meeting points or fostered relations between communities.

One of the most consequential decisions imposed by the commission, as discussed by the society's council, was the imposition of Jerusalem white stone. ${ }^{54}$ This is a limestone material available in a number of quarries in Palestine. In the eyes of Storrs and Ashbee, the white stone of Jerusalem was a key material representing a visible connection with the biblical past of the city. ${ }^{55}$ The council had already argued during its first meeting that the Old City could have not been modernized without its destruction. Following this declaration of principles on September 30, 1918, the council met for the second time and Storrs, in his capacity of governor, proposed the banning of use of red brick and corrugated iron in construction and renovation in the Old City. According to Storrs, celestial Jerusalem was not meant to be contaminated by more modern

51 JMA 829, Jerusalem Town Planning Commission, Minutes, January 19, 1921.

$5^{2}$ The Times, “The New Era in Jerusalem," London, December 30, 1920.

53 Storrs Papers, press cuttings.

54 Not many works are available on building materials in Palestine. A good work dealing briefly with this topic is Jacob Norris, Land of Progress: Palestine in the Age of Colonial Development, 1905-1948, trans. Orit Gat (Oxford: Oxford University Press, 2013). A work dealing with Tel Aviv and Jaffa is Sharon Rotbard, White City, Black City: Architecture and War in Tel Aviv and Jaffa (London: Pluto, 2015).

55 The conceptualization and problematization of building materials in Palestine is not yet a common topic. To this extent, I relied on the work of Olivia Muñoz-Rojas Oscarsson on Franco and post-Franco Spain. See Olivia Muñoz-Rojas Oscarsson, Ashes and Granite: Destruction and Reconstruction in the Spanish Civil War and its Aftermath (Eastbourne: Sussex Academic Press, 2011). 
and cheaper materials. Kamil al-Husayni, representing the Muslim community, but certainly voicing the concern of several other members of the council, suggested that the idea was good in principle but that it would be difficult for the dwellers of the Old City, who for the most part belonged to the lower classes, to access the more expensive white stone. ${ }^{56}$ According to the minutes, a discussion followed and it was decided to look for public funding in order to balance the cost for the preservation of the Old City. Al-Husayni touched upon a very delicate issue to the extent that the topic was then postponed and rarely discussed again.

In May 1922, the red-brick question was back on the table, this time not at the Pro-Jerusalem Society, but the Town Planning Commission. It was agreed that silicate bricks could be used on the following conditions:

1. For internal or "carcase" work without restrictions.

2. For external work:

a. In all the industrial zones shown in red on the Zoning Plan.

b. In the garden cities of Talpieh, Bonsh Bayi, and Jinjriah without restrictions.

c. Elsewhere in the new city subject to the special approval in each case of the Jerusalem Town Planning Commission

3. Its external use in the Old City is absolutely prohibited. ${ }^{57}$

Following this decision, the commission had to deal with a large number of cases regarding the erection or reparation of buildings without the necessary permits. Al-Husayni's argument resurfaced: despite being local and indeed more suitable for the aesthetic of the Old and New City, white stone was more expensive and many could not afford it.

In time, the white stone was imposed on every building in the region and local Palestinians developed a sense of pride in it. ${ }^{58}$ Materials often come to represent and symbolize the history of a city or a region. However, more than just a choice, the white stone was a colonial burden that limited the possibilities of the local population, narrowed their development and, in the long term, disentangled those lives in common that had developed throughout the centuries in Jerusalem. ${ }^{59}$

$5^{6} \quad$ JMA, 361, Pro-Jerusalem Society, Minutes, no. 2, Jerusalem, September 30, 1918.

57 JMA, 829, Town Planning Commission, Minutes, no. 12, Jerusalem, May 4, 1922.

58 Goldhill, Jerusalem: City of Longing, 136.

59 For example, the myth of the white city and the Bauhaus style in Tel Aviv has been debunked by Rotbard, White City, Black City. 


\section{Conclusion: Back to the Everyday Archives}

In recent years, a growing amount of literature in relation to the Pro-Jerusalem Society and the urban planning of the city has been published or is in the pipeline for publication. Ashbee's and other plans have been scrutinized from different perspectives; however, very little attention has been paid to the minutes of the society's council and of the Town Planning Commission. Similarly, Storrs, who was the mastermind of the Pro-Jerusalem Society and the governor of Jerusalem, has been largely forgotten in the public sphere. Preliminary analyses of this material suggest a lack of a long-term vision concerning the development of the city. ${ }^{60} \mathrm{~A}$ number of projects, such as the restoration of the ramparts and the renovation of the cotton market, were carried out. The commission established a more organized work division and formalized requests and permits. In 1922, Clifford Holliday, who succeeded Ashbee, pointed out that the existing plans for Jerusalem were inadequate. He also reminded us that until 1926, the process of planning was practically supported by the force of Storrs' personality and interest. ${ }^{61}$ This may explain why Storrs disappeared from public discourse after his departure. Though as a person he was, so to speak, ancient history, his legacy as an actor of local urban planning was not.

Despite the quite harsh judgement reserved by Holliday on Ashbee and his criticism of Storrs - he was certainly right to believe they were "amateurs" - we should remember that some of the decisions made by the society and commission have resulted in long-term consequences that are still visible in the city. For instance, renaming the streets of Jerusalem symbolized the extent of British control; similarly, the adoption of white stone, in itself a rather innocuous act, had large and likely unintended consequences.

One of the leading principles of the Pro-Jerusalem Society was "the preservation and safeguarding of the amenities of the Holy City without favour or prejudice to race or creed." ${ }^{2}$ Though preservation was certainly achieved, prejudice was a leading principle of the society. Rapaport has argued that Ashbee brought about a clear vision for Jerusalem, one that was meant to create a harmonious urban community. ${ }^{63}$ The fact is that a sectarian balance existed in Jerusalem prior to the arrival of the British; citadinité as a counterweight to

6o Raquel Rapaport, "The City of the Great Singer: C. R. Ashbee's Jerusalem," Architectural History 50 (2007). Rapaport argues the opposite, suggesting that he had a consistent vision.

61 Hyman, "British Planners," 433-34.

62 Ashbee, Jerusalem 1920-1922, 71.

63 Rapaport, "The City of the Great Singer," 201. 
segregation and conflict was a powerful tool that emerged within the boundaries of the late Ottoman reforms and was shaped and implemented by the local population. It was the lack of local agency, taken away from the British and partly shared with the Zionists, that led to the failure the aims of the ProJerusalem Society and subsequently of the British administration. Lives in common were gradually transformed into lives in isolation. 


\title{
Governing Jerusalem's Children, Revealing Invisible Inhabitants: The American Colony Aid Association, 1920s-1950s
}

\author{
Julia R. Shatz
}

The Spafford Children's Center is today located between Damascus Gate and Herod's Gate, along the high wall of the Old City in a compound purchased from an Ottoman general over a century ago. The center is a nongovernmental and humanitarian charitable institution that provides a wide range of educational, medical, and cultural services to the underserved Palestinian population of East Jerusalem. The center has served the children of East Jerusalem, in various iterations, over the span of nearly a century. It began as a group of interrelated welfare projects run by the American Colony Aid Association (ACAA), the social service branch of the American colony in Jerusalem. In the late 1920s, the ACAA established a baby home, an infant welfare center and a community playground, to address the needs of local children. The organization transitioned the baby home into a full-fledged children's hospital in the late 1930s. It served families from all over the West Bank after 1948 and transformed into its current iteration as a multiservice social welfare center following the Israeli occupation of East Jerusalem in 1967. Descendants of the original founders continue to sit on the center's board of trustees, which also includes local physicians, businessmen, and community leaders. ${ }^{1}$ Over the long course of its history, the ACAA has been funded through local and international donations from individual, nonprofit, and corporate donors.

The Spafford Children's Center and the ACAA are longstanding Jerusalem institutions that illuminate the way daily life was governed for the city's children. Studying institutions like these offers scholars several means of recovering a more robust history of Jerusalem. The institutions' longevity lends a unique historical perspective through which to view the city. Founded in the 1920s, the center and its institutional predecessors have survived three political eras in East Jerusalem - the British Mandate, Jordanian rule, and the current period

1 Friends of the Spafford Children's Center, Autumn Newsletter 2016, accessed January 19, 2018, http://www.spaffordcenter.org/archives/702.

(C) JULIA R. SHATZ, 2018 | DOI:10.1163/9789004375741_027

This is an open access chapter distributed under the terms of the prevailing CC-BY-NC-ND License at the time of publication. 
of Israeli control. Although they were strongly affected by these political transformations, as nongovernmental institutions their fates were not tied to any single political regime. These types of institutions are important in crafting histories of the city that do not hew to the ruptures of 1948 and 1967. By following the trajectories of institutions that existed in the social realm, we can traverse narrative and archival chasms that otherwise present obstacles to creating a unified history of the city.

Examining nongovernmental organizations engaged in social welfare allows us to tell more complete stories about the operation of daily governance in Jerusalem throughout different historical periods. Thousands of children and families passed through the care of the Spafford Baby Home, clinic, hospital, playground, and children's center, receiving medical attention, educational services and supplemental food aid. On the whole, these families were poor, socially marginalized, and politically underrepresented. By looking at the institutions that served them, these populations become visible in the historical record, in some cases, for the first time. Moreover, many immediate aspects of the everyday life of this population were governed by organizations such as the ACAA. The ACAA and similar organizations formed a network of social governance that may have had more interaction with these populations on a routine basis than the institutions of traditional government did. It is now common to speak of the "NGO-ization" of governance in the post-197os era, during which responsibility for governance and the welfare of the population has shifted from the state to nonstate entities. ${ }^{2}$ For the Global South, scholars have argued that the rise of NGOs and international development aid organizations functions as a type of neoliberal neocolonialism. ${ }^{3}$ In the case of Palestine, specifically, "NGO governance" is most associated with a lack of political statehood and with refugee status, especially following the 1967 War

2 Matthew Hilton, "Politics is Ordinary: Non-Governmental Organizations and Political Participation in Contemporary Britain," Twentieth Century British History 22, no. 2 (2011); Akira Iriye, Global Community: The Role of International Organizations in the Making of the Contemporary World (Berkeley: University of California Press, 2004); Matthew Hilton et al., eds., The Politics of Expertise: How NGOs Shaped Modern Britain (Oxford: Oxford University Press, 2013), 188-217; Thomas Davies, NGOs: A New History of Transnational Civil Society (Oxford: Oxford University Press, 2014).

3 Islah Jad, “The NGO-isation of Arab Women's Movements," IDs Bulletin 35, no. 4 (2004); Julie Hearn, “The 'NGO-isation' of Kenyan Society: USAID \& the Restructuring of Health Care," Review of African Political Economy 25, no. 75 (1998); Kiprono Lang'at, "Deconstructing Neo-Colonialism and Liberalism: Kenya and the NGOs: A Discourse Analysis," International Education Journal 9, no. 2 (2008). 
and Israeli occupation of Gaza and the West Bank. ${ }^{4}$ The story of the ACAA and its role in the operation of social welfare governance, suggests, however, that the relationship of civic voluntary associations to governance and the state has a much longer history than the current literature suggests.

Finally, the history of the ACAA reveals a great deal about the relationship between the local and the international in the everyday governance of Jerusalemites. Scholars have argued that globalization is a process born out of the interactions between global and local culture - a concept Roland Robertson and other sociologists have termed "glocalization..5 Much of the focus of such works has been on the globalizing economy or the globalization of ideas and discourse. As children have become increasingly universalized subjects of governance and care throughout the twentieth century, institutions such as the ACAA have come to represent a different form of "glocalization" the glocalization of humanitarian governance. ${ }^{6}$

This chapter argues that the ACAA and the projects it oversaw were nodes in a larger ad-hoc system of nongovernmental social welfare associations that was at once deeply embedded in the local environs of Jerusalem, and connected to a transnational network of knowledge, personnel, and capital. The essay explores this social welfare network by tracing the development of the ACAA and its work through two distinct eras of its existence. First, it begins with a brief discussion of the history of the American colony and its potential as an archive for new histories of Jerusalem. Second, it examines the establishment of the ACAA during the years of the British Mandate, when its initial social welfare projects emerged within a framework of voluntary associations, colonial governance, and novel global ideas about child welfare. Finally, it looks at the work of the ACAA after 1948, when both the local and international

4 Leila Farsakh, "Undermining Democracy in Palestine: The Politics of International Aid since Oslo," Journal of Palestine Studies 45, no. 4 (2016); Sibille Merz, "'Missionaries of the New Era': Neoliberalism and NGOs in Palestine," Race \& Class 54, no. 1 (2012).

5 Roland Robertson, Globalization: Social Theory and Global Culture (London: Sage, 1992). In the words of Vanessa Ogle, "It has become commonplace to assert that globalization somehow involved the interactions between the global and the local." Vanessa Ogle, "Whose Time Is it? The Pluralization of Time and the Global Condition, 1870s-1940s," The American Historical Review 118, no. 5 (2013): 1379.

6 "Humanitarian governance" is a term employed by Keith Watenpaugh to refer to the creation of protostate entities by subnational groups in the absence of the state. I use the term here to refer to the network of nonstate organizations that indeed provided protostate services in the form of social welfare but did so in concert with the state. Keith Watenpaugh, Bread from Stones: The Middle East and the Making of Modern Humanitarianism (Berkeley: University of California Press, 2015). 
environment had significantly altered in the wake of the Nakba, the emergence of a refugee population, and the rise of international development organizations. The story of the ACAA and other voluntary and nongovernmental organizations involved in social welfare and the care of children offers a new historiographical framework for understanding and narrating a longer history of governance in Jerusalem through the twentieth and twenty-first centuries.

\section{The American Colony: New Archival Potentials}

The origins of the ACAA were in the social welfare projects of the American Colony following the First World War. By the end of the war, the colony had been long established as part of Jerusalem's social service network. The colony was initially founded in 1881 , when the American Spafford family, along with a few friends, emigrated from Chicago to Jerusalem and settled in the Old City as a Christian utopian society committed to communal living and philanthropic service. Unlike the many Christian missionary societies that proliferated throughout the city and its environs at that time, the colony was not interested in proselytization nor was it connected to any larger organization. Colony members instead pursued farming, photography, archaeology, and craft-making. Members worked as nurses and teachers throughout Jerusalem. During and immediately following the war, they ran a soup kitchen to aid Jerusalemites through the locust plague and famine of $1915^{-16}$, and employed poor and widowed women in a dress-making and handicrafts workroom.

In the view of the colony members themselves, their institution and its social works stood in contrast to the similar endeavors of other foreign religious bodies in Palestine. The memoirs of Bertha Spafford Vester, the daughter of the original founders of the colony and its leader through much of the twentieth century, emphasized the distinction between the colony and the Protestant missions that worked in the area. She wrote that other missions were suspicious of the colony because it did not evangelize and operated differently than traditional missionaries. She attributed the missionaries' resentment to the colony members' particular successes in their social welfare work. ${ }^{7}$

While identified as "the Americans" by local missionary groups, the American Colony members did not see themselves as an outpost for American

7 Bertha Spafford Vester, Our Jerusalem: An American Family in the Holy City, 1881-1949 (Jerusalem: Ariel Publishing, 1950), 121. 
interests. ${ }^{8}$ When the United States entered the First World War, the majority of American citizens evacuated Jerusalem. Vester, however, stayed and met with Jamal Pasha to offer her nursing services for wounded Ottoman soldiers. ${ }^{9}$ He permitted the colony to continue its work uninterrupted, and the colony members remained in Jerusalem for the duration of the war. The Ottoman authorities gave the colony purview over one of their military hospitals and enlisted its photography department to document the war and locust plague. ${ }^{10}$

Although the members of the colony thought of their institution as independent and locally embedded, it was deeply intertwined with foreign political authorities and dependent on a transnational financial network. Vester remembered helping the American consul in Palestine, Dr. Otis Allan Glazebrook, to sort and secure British property in Palestine as the Americans took over responsibility for the British consulate at the war's outbreak; Vester and her husband personally housed British and French valuables and title deeds until the end of the war." The colony was also well connected in the United States. When they lacked funds to continue their workroom and soup kitchen during the locust plague, Vester appealed to the Michigan lumber industry titan Edward F. Loud who loaned the colony $\$ 5,000$, and collected additional donations to keep the soup kitchen open. ${ }^{12}$ With the arrival of British forces in Jerusalem in 1917, and the subsequent inauguration of the British Mandate government, the colony became more deeply intertwined with the administrative authorities, politically, socially, and personally.

The American Colony is a well-known entity in Jerusalem as a historical site and hotel, but it also recently joined a growing network of East Jerusalem archives. In 2014, the American Colony Hotel opened its private archive to researchers, following several years of professional cataloguing and organizing. The archive in East Jerusalem complements an additional collection of materials that the colony gave to the Library of Congress in $2005 \cdot{ }^{13}$ The

8 This may have also been due to the fact that while the founding group of the colony consisted solely of Americans, a large Swedish contingent joined the colony in 1896 .

9 Vester, Our Jerusalem, 260.

10 The records of the American Colony Photography Department can be accessed at both the American Colony Archive in East Jerusalem and through the Library of Congress, in the Matson (G. Eric and Edith) Photograph Collection, accessed January 19, 2018, http:// www.loc.gov/pictures/collection/matpc/colony.html.

11 Vester, Our Jerusalem, 248-49.

12 Ibid., 256.

13 Library of Congress, American Colony in Jerusalem, https://www.loc.gov/collections/ american-colony-in-jerusalem/. 
materials in the East Jerusalem archive contain a wide range of items including family artifacts and papers, records of the ACCA, correspondence with financial backers in the United States, and the works of the photography department. Given the colony's longevity in Jerusalem through several political eras and its work in the social sector, the archive offers a unique lens into daily life in the city. It is from these archives that the story of the ACAA, its work, and the lives of the people it cared for can be thoroughly told.

\section{The Mandate Years: A New Network of Welfare}

The ACAA emerged in the late 1920s, as the central organization that oversaw three interrelated social welfare projects of the American colony - the Anna Spafford Baby Home, an infant/child welfare center, and a community playground. Its stated mission was to "further goodwill among all people and to help the less fortunate help themselves"14 through community health and education interventions. The three primary ACAA projects developed out of each other. By the mid-1930s, they had formed a robust social welfare network that aimed to address the physical, social, and moral needs of children of all ages. The first project was the baby home, which led to the idea of establishing a child welfare center that could provide outpatient services and a community playground that would serve as a communal space for all the youth of Jerusalem.

Like the American Colony itself, the origin of the baby home is shrouded in a kind of mythology, which is repeated in Vester's memoir, in all fundraising speeches made on behalf of the ACAA, and in the Spafford Children's Center's contemporary materials. The story goes that on Christmas Eve 1925, Vester encountered a Bedouin man traveling with his sick wife and newborn son. They had journeyed to Jerusalem only to find the hospital closed on account of Christmas. Vester helped the woman gain admission to the hospital, but she died in the morning. The man begged Vester to take in his son, which she did. Soon after, Vester was asked to take in more orphaned babies and the baby home ${ }^{15}$ was born. ${ }^{16}$

\footnotetext{
14 American Colony Aid Association (ACAA), Annual Report of the American Colony Aid Association for the Year 1927-1928, 1.

15 Named so after Vester's mother.

16 Vester, Our Jerusalem, 328.
} 
The origin story of the baby home, with its sense of miraculous coincidence and overt Christian allusions, was certainly a compelling tale to sell the project to potential funders. It also, however, obscured the larger context in which the baby home and the ACAA's broader work of infant and child health care arose. The baby home did not emerge sui generis or simply from the good will and generosity of Vester and other members of the colony. In the 1920s, the baby home and the ACAA's related child welfare projects were pieces of a multi-institutional network of infant clinics and centers in Jerusalem that had emerged out of local, colonial, and global movements for child health care.

When the ACAA began its infant welfare projects, infant mortality and children's health were issues of great concern to doctors, government officials, and social reformers in Jerusalem and throughout Palestine. The war had exacerbated the effects of poverty and deprivation experienced by segments of the Palestinian population, particularly in urban areas. When the occupying British military administration introduced mandatory birth registration in 1918, the newly formed Department of Health was able to officially establish rates of infant mortality in Palestinian cities and towns. In 1920-21, the first year that the department recorded such statistics, the infant mortality rate in Palestine - defined as deaths of children under the age of one year ranged between 123.3 per 1,00o live births in the villages and 209.6 per 1,00o live births in the towns. ${ }^{17}$ The large discrepancy between the urban and rural areas reflected broader inequalities in public health. The impacts of war and poverty were felt more acutely in cities and towns at first, where dilapidated infrastructure and poor sanitation exacerbated the spread of epidemics and infectious diseases. Towns and cities were more likely to suffer from incomplete or defective water systems, which increased rates of infection. Jerusalem, which had a limited piped water system and ample cistern water supply, had comparatively lower infant mortality rates than other urban areas..$^{18}$

The concerns about infant (and maternal) mortality, combined with emerging globalized scientific knowledge about pregnancy, childbirth, and infant care, resulted in the establishment of several postnatal and child welfare clinics throughout Palestine. Voluntary associations of various stripes were the initial impetus behind the founding of many of the clinics, although the Department

17 "Report on the Palestine Administration, July, 1920-December, 1921," in Palestine and Transjordan Administration Reports, vol. 1, 1918-1924 (Farnham Common: Archive Editions, 1995), 266.

18 Ibid. For a robust account of the "hydro-history" of Jerusalem, see Vincent Lemire, La soif de Jérusalem: essai d'hydrohistoire, 1840-1948 (Paris: Publications de la Sorbonne, 2010). 
of Health came to operate half of them by the end of the Mandate period. ${ }^{19}$ Infant welfare centers employed nurses to oversee the clinics' primary work weighing newborns, conducting preventative medical exams for children, treating childhood eye diseases, and instructing mothers in the best feeding and infant care practices of the day. During the Mandate period, these clinics were the only site of interaction with a public health system for many of their patients. The Department of Health did little in the way of direct service work, preferring to contract those duties to voluntary associations when possible. ${ }^{20}$ And while the government mandated birth registration, it was these clinics that kept the primary records on the health of poor populations in a given locality.

The work of all three sites sought to address the physical, social, and moral development of the children and families they served. The ideals of modern medical care and public health that undergirded these projects could not be extricated from colonial ${ }^{21}$ notions of social development and progress. The workers at the baby home, which was intended to care for orphaned and destitute infants, offered courses in "mothercraft" to the poor women of Jerusalem and its surrounding villages. In addition to providing preventative and medical care to infants, the child welfare station also offered instruction to poor mothers in proper hygiene, nutritious cooking, and sewing.

The goal of the mothercraft classes was to instruct the poor women of Jerusalem in the methods of "scientific childrearing." Scientific childrearing was both a global epistemological movement of the early twentieth century, and a contemporary framework for child care in that period. Quite simply, the discourse of scientific childrearing argued that caring for children was a science like any other. It held that there were universal principles about childrearing

19 By 1939, the Department of Health recorded over eighty infant welfare clinics in Palestine. Government of Palestine, Department of Health Annual Report for the Year 1939.

20 It was the official policy of the Department of Health to rely completely on voluntary associations for the direct service work, freeing the department to focus on broad public health issues as well as the care of British colonial officials. In reality, the financial insolvency of many such associations following World War I led the department to take a more active role in direct medical work than initially anticipated.

21 I used "colonial" here not to refer to the political relationship between the British government and the population of Palestine, but as a framework for understanding the unequal relationships of power between welfare organizations such as the ACAA and those whom they served. Movements for child welfare both intended to colonize the practices and knowledge of poor communities and were used by both colonial states and their nonstate collaborators to intervene in the family, social, and political lives colonized populations. 
and its authorities were academics and professionals. ${ }^{22}$ In this context, women had to be taught how to be mothers. Social reformers of all affiliations across Jerusalem embraced this framework. The famous Palestinian physician, Tawfiq Canaan, wrote an article decrying Palestinian mothers' ignorance and reliance on superstition as the root causes of infant mortality and disease. ${ }^{23}$ Scientific childrearing and the assumption of maternal ignorance likewise informed the work of the ACAA, whose annual report of 1930 began thus:

Mothercraft is a word that seems to have been especially coined for the need of this country. The philosophy here is "Allah makes mothers, nature takes care of them, and if anything goes wrong, Allah willed it." Mothers must be taken out of this environment and showed another side of life. ${ }^{24}$

The work of the baby home and child welfare station was thus double-sided: on the one hand, the aim was to provide necessary health services and to fill the gaps left by the Department of Health. On the other hand, these institutions took on roles as architects and disseminators of knowledge and mediators of appropriate and healthy social behavior.

The activities of the community playground were likewise rooted in concerns for both the health and social-moral development of Jerusalem's young population. The initial impetus for the playground's construction was healthoriented: the observation that the children in the urban areas of Jerusalem had more significant health problems than children in the countryside. The ACAA assumed this difference resulted from the lack of open spaces in which children could play, which added to the general problems of sanitation in the city. ${ }^{25}$ The playground was also intended, however, as a space for moral development, where children were given the opportunity to "bring their better natures forward" in learning how to work together and get along. ${ }^{26}$ The playground was also conceived as a space to prevent the development of young men's darker

22 Discourses of scientific childrearing proliferated in social reform circles throughout the globe in the late nineteenth and early twentieth centuries, in the United States, Europe, and the Middle East. Following World War I, this discourse, and the academic and professional experts who promoted it, also permeated new international child welfare organizations, such as Save the Children and the League of Nations' Child Welfare Committee.

23 Tawfik Canaan, "The Child in Palestinian Arab Superstition," Journal of the Palestine Oriental Society 7 , no. 4 (1927).

24 ACAA, Annual Report of the American Colony Aid Association for the Year 1929-1930, 12.

25 ACAA, Annual Report of the American Colony Aid Association for the Year 1927-28.

26 ACAA, Annual Report of the American Colony Aid Association for the Year 1929-30, 20. 
natures. The government probation officer brought his charges to use the playground and praised it as an important measure in preventing delinquency. ${ }^{27}$ As with the baby home and the child welfare station, the logic of the playground necessitated trained professionals to oversee it. Like motherhood, playing could not be assumed to be instinctive or inherently productive. As such, it had to be regulated, organized, and supervised according to the best academic knowledge of the moment. The ACAA enlisted teachers and social worker volunteers, as well as the abovementioned probation officer, to organize the activities of the playground to best bring out its potential for social and moral progress. ${ }^{28}$

The baby home, child welfare station and community playground were not alone in serving the poor children of Jerusalem and its surrounding areas. In 1925, the Department of Health opened an infant welfare clinic in Jerusalem, initially serving a few hundred infants and mothers. ${ }^{29}$ Hadassah, the Zionist medical organization, also opened two child welfare stations in Jerusalem in connection with their private hospital in the early 1920s, and, by the end of the decade, had five clinics in operation. The American Colony cooperated with Hadassah and the other voluntary organizations that undertook infant centers in nearby towns and cities. The physician who oversaw the baby home and child welfare clinic, Dr. Helena Kagan, was formerly the head of pediatrics at the Hadassah-Rothschild hospital in Jerusalem, and was the volunteer doctor at Hadassah's first child health clinic. Although the organizations cooperated with each other and often shared knowledge and resources, the infant welfare system in Jerusalem was explicitly uncoordinated, which at times led to conflict. In a report on their infant welfare centers for 1927, a Hadassah committee complained that the colony had not consulted them before opening a clinic in the same neighborhood of the Old City as one of their own. ${ }^{30}$ Since the American colony's clinic duplicated the work that Hadassah was doing in that area, the committee decided to shut down their clinic to concentrate on another sector of the city. ${ }^{31}$

Through the 1930s, thousands of Jerusalem's children passed through ACAA institutions. In its first year in operation, the child welfare station registered only 236 infants, but by the mid-1930s, it averaged around 3,500 infants a

\footnotetext{
27 ACAA, Annual Report of the American Colony Aid Association for the Year 1931-32, 25.

28 ACAA, Annual Report of the American Colony Aid Association for the Year 1929-30, 21.

29 Government of Palestine, Department of Health Annual Report for the Year 1928, 54.

30 Center for Jewish History (сJH), Record Group 2 (Hadassah Medical Organization) $14 / 46 / 2$.

31 Ibid.
} 
year. ${ }^{32}$ The community playground boasted annual attendances ranging from 21,000 to 57,837 children in the peak year of $19355^{33}$ Although all three institutions were located in the Muslim Quarter of the Old City, and thus served a mostly Muslim population, children of all religions and ethnicities used the ACAA's services. That the social welfare sites were multiethnic and multireligious is not to suggest that they were apolitical spaces, or that scholars should project back into them a kind of utopian historical counterfactual. The political climate of the city greatly affected the children's interactions, as in 1929, when the ACAA reported tensions on the community playground due to the Wailing Wall uprising, or during the 1936-39 Great Revolt, when Jewish children stopped using the playground altogether. ${ }^{34}$ The multicommunal character of these spaces, along with the ACAA's cooperation and collaboration with social welfare organizations of different communities, however, challenges the totality of institutional bifurcation and segregation assumed by the dual society model of Mandate Palestine.

The baby home, child welfare station and community playground were governed by the American Colony in conjunction with several Jerusalemite individuals and funded through a transnational network of private and corporate capital. The advisory committees for both sites consisted of women members of the colony. Dr. Kagan was the attending physician at both institutions, working alongside a Palestinian Arab male physician. They were aided by a collection of nurses culled from the colony, nearby missionary outfits and the local population. Each year, as one of several private institutions in Palestine that trained local nurses and midwives, the baby home hosted five or six Palestinian Arab probationer nurses. Elite American, British, and Palestinian women who were engaged in philanthropic and social welfare works in the city volunteered time at the child welfare station. ${ }^{35}$ The community playground was a microcosm of the amalgamation of community organizations that defined social welfare for the Jerusalemite population in the Mandate years. The Supreme Muslim Council requested use of the playground for the children in its orphanages. ${ }^{36}$ Locals from Jerusalem institutions volunteered at the playground: a senior pupil from the Syrian Orphanage taught a carpentry class, members of the American School of Oriental Research volunteered as

ACAA, Annual Report of the American Colony Aid Association for the Year 1927-28.

33 ACAA, Annual Report of the American Colony Aid Association for the Year 1935-1936, 13.

34 ACAA, Annual Report of the American Colony Aid Association for the Year 1929-1930, 20 and ACAA, Annual Report of the American Colony Aid Association for the Year 1936-1937, 31.

35 ACAA, Annual Report of the American Colony Aid Association for the Year 1929-1930, 18.

36 ACAA, Annual Report of the American Colony Aid Association for the Year 1934-1935, 15. 
supervisors, and the Jerusalem Rotary Club took two boys from the playground on a picnic to the Dead Sea. ${ }^{37}$

A mixture of local and foreign capital funded the American Colony's child welfare institutions. The baby home was founded on initial donations from benefactors in the United States, including the wife of John H. Finley, the former head of the Red Cross Commission in Palestine in the years after the war. ${ }^{38}$ Most families could not afford to pay for their children's care in the home, but the ACAA reports noted that many mothers contributed by way of labor. Funds were donated by wives of colonial officials and the wealthy Palestinian community in Jerusalem. Donations of trees and hay were given in kind to the playground by the Department of Agriculture. ${ }^{39}$ Equipment for the playground was likewise donated by the Jerusalem YMCA and by local individuals. Money was also raised for all three sites through craft sales to tourists from the American Colony's handicrafts school.

Additionally, the ACAA had a well-developed financial network of private individuals and corporate donors, primarily in the United States. Their committee, which was headquartered in New York, was sponsored by politicians, academics, and businessmen including the First Lady of New York State, Eleanor Roosevelt. The ACAA sent annual appeals to this network for donations to carry out their work. In the early 1930s, for example, a new wing of the home was constructed thanks to a donation from friends of the American Colony in Indiana. ${ }^{40}$ In 1928 , a women's sewing society in New York donated infant clothing to the baby home. ${ }^{41}$ On one occasion, Empress Menen Asfaw of Ethiopia, who was already engaged in social welfare and child saving projects in Ethiopia, visited the baby home and donated to its upkeep. ${ }^{42}$

The ACAA's projects also benefitted from corporate philanthropy. Beginning in 1929, William Horlick Jr., son of a well-known family of malted milk purveyors and a subscribing member of the ACAA, made annual donations of malted milk to supplement breastfeeding for the patients of the child welfare station and the baby home. ${ }^{43}$ Though the Horlicks Company was founded in Chicago

ACAA, Annual Report of the American Colony Aid Association for the Year 1929-1930, 21; ACAA, Annual Report of the American Colony Aid Association for the Year 1932-1933, 25.

38 ACAA, Annual Report of the American Colony Aid Association for the Year 1927-1928.

39 ACAA, Annual Report of the American Colony Aid Association for the Year 1929-1930, 22.

40 ACAA, Annual Report of the American Colony Aid Association for the Year 1933-1934, 11.

41 ACAA, Annual Report of the American Colony Aid Association for the Year 1927-28.

42 ACAA, Annual Report of the American Colony Aid Association for the Year 1933-1934, 11.

43 ACAA, Annual Report of the American Colony Aid Association for the Year 1931-1932, 19 and ACAA, Annual Report of the American Colony Aid Association for the Year 1937-1938, 11. 
and headquartered in Racine, Wisconsin, by the 1920 it was a multinational corporation with an additional office in London. Corporate philanthropy was neither new nor exceptional in this period, but the involvement of the Horlicks Company in the ACAA's infant welfare programs raises important questions about the role of corporations in transnational social welfare projects. Analyses of colonial public health that focus solely on the apparatus of state bureaucracy tend to omit private capital from the story. In the postwar period, particularly in the era of market deregulation and global capitalism of the 1970s, multinational corporations would take an enlarged part in providing global humanitarian aid. ${ }^{44}$ The Horlicks Company's corporate philanthropy was not equivalent to the capitalist humanitarianism that would characterize later decades. However, its place in the schema of infant welfare provision in Jerusalem suggests that the story of multinational corporations in global social welfare provision has earlier roots to the postwelfare state and NGO era of the 1970s might lead us to believe.

\section{In the Aftermath of 1948: The ACAA between Arabization and Globalization}

Following the political rupture of the 1948-49 war, the devastation of the Nakba and the division of Jerusalem, the ACAA's work resumed amid a novel sociopolitical landscape. Although its social welfare activities mostly mirrored those undertaken during the Mandate years, the demographic circumstances of the population the ACAA served, as well as the local, national, and international institutional landscape in which it worked, had radically altered. Suddenly serving a mixed population of poor Jerusalem residents and newly displaced refugees, the ACAA formed connections with an emerging local Palestinian relief network. At the same time, the ACAA found itself within a new network of international aid organizations.

The ACAA formally reestablished itself in 1952, following several years of tumult in the wake of the 1948 war. Newly reincorporated under the Jordanian government, the ACAA resumed many of its previous activities albeit amidst a changed population. The reconstituted committee of the ACAA itself had

Tehila Sasson offers an analysis of this phenomenon for the postwar era in "Milking the Third World? Humanitarianism, Capitalism, and the Nestlé Boycott," American Historical Review 121, no. 4 (2016). Sasson's article examines the politics of the provision of artificial milk to infants in the Global South in the 1970s - in her case, in the boycott campaign to end bottle-feeding in the Third World. 
changed demographically, with many more Palestinian Arab members than in its prior iteration. ${ }^{45}$ The baby home, which had been used as an ophthalmic hospital by the Order of St. John's of Jerusalem in the intervening years, was renamed the Spafford Children's Hospital and reopened in 1953. The medical staff in charge of the hospital consisted of Dr. Mahmud Dajani and Mary Kahkedjian, a nurse who had previously worked with the ACAA before spending two years in training at the Boston Children's Hospital. The hospital's primary work was in treating endemic and epidemic diseases of Palestine malaria, eye disease (trachoma), typhoid, dysentery and rickets. ${ }^{46}$ While the hospital continued its work from the Mandate period, it also encountered a new patient population - child refugees. In the first year of the hospital's reopening, refugees accounted for over a quarter of the hospital's admissions; in 1955, two years later, they made up a full third of the patients. ${ }^{47}$

The infant welfare center also reopened in 1953, continuing its work of preventative care, medical treatment, and mothercraft instruction. In the first eight months after the reopening, 769 babies were registered at the center, of which 28 percent were refugees. ${ }^{48}$ Many of these children suffered from malnutrition, and the center provided donations of powdered and fresh milk as it had during the Mandate period. The ACAA also established an outpatient clinic to treat Jerusalem's adult population. The outpatient clinic was meant to cover the gaps left by the absence of hospital accommodation in Jerusalem. As a 1955 ACAA report highlighted, prior to the war and the partition of Palestine, Jerusalem hosted seven or eight private hospitals. ${ }^{49}$ Indeed, in 1918, one British medical missionary deemed Jerusalem "a city of hospitals." ${ }^{50}$ The division of Jerusalem, however, left almost all of those hospitals on the Israeli side of the city, thoroughly disrupting the system of public health for the Palestinian population. The only surviving hospital in East Jerusalem at the end of the war, the Augusta Victoria Hospital, was only able to accept accredited refugees in the early $1950{ }^{51}{ }^{51}$ Public health aid and social welfare governance was bifur-

45 All committee members excluding Vester and her daughter were Palestinian Arab men. American Colony Archive (ACA), American Colony Aid Association Minutes (1952), AC-03-57 (1952-65).

46 ACA, American Colony Aid Association Minutes (1953), AC-03-57 (1952-65).

47 ACA, American Colony Aid Association Annual Report for 1955, AC-03-57 (1952-65).

48 The report notes 215 of the newly registered babies were refugees. ACA, American Colony Aid Association Minutes (1953), AC-03-57 (1952-65).

49 ACA, American Colony Aid Association Annual Report for 1955, AC-03-57 (1952-65).

$50 \quad$ Ernest W. G. Masterman, "Jerusalem from a Point of View of Health and Disease," Lancet 191, no. 4930 (1918): 306.

$5^{1} \quad$ ACA, American Colony Aid Association Annual Report for 1955, AC-03-57 (1952-65). 
cated in the aftermath of the war; while refugees often represented the most disadvantaged of the population, there were new institutions created to serve their needs exclusively, and not those of the existing poor communities of the city. The ACAA struggled in these years to simultaneously accommodate the needs of this novel population and maintain a continual aid network for the nonrefugee Jerusalem poor.

The newly reestablished ACAA joined a network of East Jerusalem social welfare organizations. In the wake of the war, several new and preexisting organizations took on the work of caring for the devastated population. In the immediate environment of East Jerusalem, where the American Colony was located, there were three charitable institutions that specifically cared for poor, orphaned, and refugee children. Dar al-Awlad, a boys' hostel for homeless youth, had been founded in 1940, by a group of Palestinian Arab elites in Jerusalem and under the special patronage of Katy Antonius, wife of George Antonius. ${ }^{52}$ Following the war, Antonius reopened the home as an orphanage. Dar al-Tifl was an orphanage and school established in the wake of the Deir Yassin massacre of 1948, as a refuge for the orphans of the village. The orphanage's founder was Hind Husayni, a member of the powerful Jerusalemite family who had been active in social work, political organizing, and the Arab Women's Union in the 1930s and 1940s. ${ }^{53}$ Rawdat al-Zuhur was a home for destitute girls founded in 1952, by Elizabeth Nasir, the director of the social welfare department in Jerusalem. The ACAA worked closely with these charitable organizations by providing free medical examinations and treatments to their charges, creating a network of nongovernmental social welfare governance in the wake of cataclysmic political upheaval.

In the post-1948 environment, the ACAA was also integrated into emerging networks of international and transnational aid. In its prior incarnation, the ACAA relied on individual donations, corporate philanthropy, and a small amount of government support. While the ACAA continued to tap its wide network of individual backers in the United States, it also received funding from international public health, welfare, and development foundations. For example, the ACAA reopened its institutions in 1953, using a \$33,000 grant from the Ford Foundation. ${ }^{54}$ The United Nations Refugee Works Agency (UN RWA), which was newly established to govern the Palestinian refugee population, likewise assisted the ACAA. Starting in the 1970s, the ACAA also began partnerships with

\footnotetext{
$5^{2}$ Israel State Archives (ISA)/RG 2/P 342/18.

53 Chareen Stark, "The Legacy of Hind al-Husseini," Washington Report on Middle East Affairs: Voices of the Nakba (May-June 2008): 19-20.

54 ACA, American Colony Aid Association Minutes (1953), AC-03-57 (1952-65).
} 
international aid and development organizations such as Oxfam and USAID. ${ }^{55}$ The nature of the ACAA's multifocal and transnational financial network remained constant in the postwar period, but on a dramatically changed scale.

The trajectory of the ACAA's funding relationships in the post-1948 era represented a microcosm of the changing landscape of welfare aid and child welfare specifically. In the interwar period, when child welfare was just becoming a topic of international importance, ad-hoc networks of transnational and local charities and voluntary aid associations led the institutionalization of child welfare schemes. Those networks did not disappear in the postwar moment, but they were integrated into increasingly robust international development institutions. In the case of Palestine, specifically, they were also integrated into new mechanisms of international governance, in the form of the United Nations. At the same time, the governance of the daily lives of poor children in Jerusalem continued to be mediated through local organizations, institutions, and personnel. The mechanisms of international aid and development altered the institutional landscape in which child welfare projects occurred, but did not replace the intensely local character of those projects.

\section{Conclusion}

Since the 1920s, the ACCA and its institutional descendant, the Spafford Children's Center, have been parts of a local and transnational web of social welfare intervention aimed at helping Jerusalem's children. That web of nongovernmental organizations has provided health care, educational services, and welfare aid to the residents of Jerusalem, both in concert with and in the absence of the state. Far from acting simply as temporary relief organizations, these institutions and the services they provide became implicated in the permanent governance of Palestinian children and families. The history of institutions such as the ACAA illuminates the operation of governance in Jerusalem and its continuing dependence on voluntary organizations and nonstate actors. Studying such institutions also sheds light on subject populations such as children, the poor, and the socially marginalized, who have been typically erased in the historical record.

The ACAA and other similar institutions formed a network of daily governance in Jerusalem that was simultaneously locally embedded and transnationally connected. These institutions were essential in the proliferation of ideas about public health and child welfare that reached the global stage 
in the mid-twentieth century. Their day-to-day work and manners of operation, however, reveal that such ideas were filtered, transformed, and realized through local institutions, politics, and relationships. By highlighting the particularities of these local institutions, we can tell a history that is both specific to Jerusalem and connected to broader global stories. 


\title{
Epidemiology and the City: Communal vs. Intercommunal Health Policy-Making in Jerusalem from the Ottomans to the Mandate, 1908-1925
}

\author{
Philippe Bourmaud
}

The nineteenth century shaped an image of Jerusalem as an unhealthy city. Sanitary imagination, that is, the growing sense of disease as a hidden threat and the parallel picturing and popularization of what a healthy environment should be, encouraged the multiplication of community-based health institutions from the 1840 s onwards. ${ }^{1}$ Yet, these institutions fell short of forming a healthcare system, or of satisfying early twentieth-century public health activists promoting a needs-based approach to healthcare. ${ }^{2}$

Social and political change, not least the intensification of Jewish immigration, were the cause of these failures. By the first decade of the twentieth century, meeting the main medical needs of Jewish immigrants had become a major concern for the Zionist movement. The Young Turks were also concerned with the systematization of access to services, the lack of which had been made evident by the development of the empire's statistical apparatus. ${ }^{3}$ Just after World War I, connections between the various medical institutions in Jerusalem boosted public health research, nurturing hopes for the rationalization of a balkanized health sector, not through institutional integration, but through the identification of shared priorities. The number and scope of medical institutions in Jerusalem expanded rapidly, leading Jurji Zaydan, a medical student and the founder of the Egypt-based Al-Hilal newspaper, to note in

1 Yaron Perry and Efraim Lev, Modern Medicine in the Holy Land: Pioneering British Medical Services in Late Ottoman Palestine (London: I. B. Tauris, 2007); Norbert Schwake, Die Entwicklung des Krankenhauswesens der Stadt Jerusalem vom Ende des 18. bis zum Beginn des 20. Jahrhunderts, 2 vols. (Herzogenrath: Murken-Altrogge, 1983).

2 Marc-Olivier Desplaudes, "Une fiction d'institution: les 'besoins de santé de la population," in Comment se construisent les problèmes de santé publique, ed. Claude Gilbert and Emmanuel Henry (Paris: La Découverte, 2009).

3 Kemal H. Karpat, "The Ottoman Adoption of Statistics from the West in the 19th Century," in Studies on Ottoman Social and Political History: Selected Articles and Essays, ed. Kemal H. Karpat (Leiden: Brill, 2002), 132-45. 
1914 that Palestine offered the largest scope in sanitary services, and that the greatest concentration of health institutions in the Levant could be found in Jerusalem. ${ }^{4}$ And yet, the first years of the Mandate saw the organization of a dual healthcare system, split between a self-financed body of Zionist institutions on the one hand, and government and voluntary institutions under government supervision on the other.

Marcella Simoni and Sandy Sufian have shown that the Mandate, rather than fostering intercommunal cooperation, led the divergence of public health priorities between Jews and Arabs (Christians, in spite of the presence of many Christian medical missionary institutions aimed at catering to their health needs, and especially Muslims) to become major discrepancies in healthcare provision. ${ }^{5}$ This chapter questions the procedures and debates surrounding the setting of health policy priorities. It argues that the growth of late-Ottoman Jerusalem entailed a shift from communal to intercommunal definitions of health needs, initiating enquiries in the city and its surroundings. Establishing public health priorities required a capacity to process morbidity and mortality in a statistical fashion, which was a daunting task in late Ottoman Jerusalem. The Mandate developed an apparatus to deal with the task on the scale of the new territory of Palestine. A turning point, in 1923, was the debate about healthcare priorities between the Hadassah Medical Organization (HMO), the main Zionist medical organization in the early years of British occupation, ${ }^{6}$ its main funder, the American Jewish Joint Distribution Committee (AJDC), and British authorities. Rather than erasing community differences, health policy debates followed a late colonial pattern of decision-making where Westerners, endowed with money and expertise, had the upper hand, but had to propagandize the Arab population into adhering to the new public health priorities.

4 Jurji Zaydan, "Filastin" [Palestine], in Mu'allafat Jurji Zaydan al-kamilah [The complete works of Jurji Zaydan], 21 vols. (Beirut: Dar al-Jil, 1982), vol. 19, 542-43.

5 Marcella Simoni, A Healthy Nation: Zionist Health Policies in British Palestine (1930-1939) (Venice: Cafoscarina, 2010); Sandra M. Sufian, "Healing Jerusalem: Colonial Medicine and Arab Health from World War I to 1948," in Jerusalem Interrupted: Modernity and Colonial Transformation, 1917-present, ed. Lena Jayyusi (Northampton: Olive Branch Press, 2015).

6 Shifra Shvarts and Theodore M. Brown, "Kupat Holim, Dr. Isaac Max Rubinow, and the American Zionist Medical Unit's Experiment to Establish Health Care Services in Palestine, 1918-1923," Bulletin of the History of Medicine 72, no. 1 (1998). 


\section{Documenting Sanitary Change from the Ottoman to the Mandatory Period}

The material for a social history of Ottoman and Mandatory urban health policy making is in abundant, albeit uneven supply. This is partially due to a number of health-related series in the Ottoman Archives of the Prime Minister's Office (Başbakanlık Osmanlı Arşivi), which until very recently were unavailable. Still, data can be derived from other series: the HR.iD (Hariciye Nezâreti İdare, Ministry of Foreign Affairs fond) subseries sheds light on the foreign healthcare institutions in Jerusalem, ${ }^{7}$ offering an Ottoman counterpoint to the powers protecting those medical activities. ${ }^{8}$

The Jerusalem Municipal Archives, located in the municipal compound in West Jerusalem, present an array of documents. These documents deal not only with premunicipality local powers and municipal policy from the $1860 \mathrm{~s}$ onwards ${ }^{9}$ but also with charities and humanitarian foundations since the nineteenth century. ${ }^{10}$ The archives of the Department of Health of the British government of Palestine following the occupation of the country are split for the most part between the UK National Archives in London ${ }^{11}$ and the Israel State Archives in Jerusalem. ${ }^{12}$

7 Ottoman State Archives (BOA), HR.ì, gömlek 1550, dosya 11-64 (1875-1908); gömlek 1551, dosya 1 to 27 (1909-1917); gömlek 1793, dosya 16-31 (1912-14); gömlek 1794, dosya 1-6 (1908-10); gömlek 1803, dosya 63-68 (1912-13); gömlek 1812, dosya 22-28 (1911) and 41-50 (1902); gömlek 1813, dosya 1-6o (1904-17); gömlek 2022, dosya 81-84 and 93 (1904-6); gömlek 2038, dosya 24 (1908).

8 As regards French diplomatic archives, see Nantes Diplomatic Archives Centre (CADN), Jerusalem Consulate (hereafter Jerusalem), ser. A, files 103-108 (1850-1914).

9 See Yasemin Avc1, Vincent Lemire, and Falestin Naili, "Publishing Jerusalem's Ottoman Municipal Archives (1892-1917): A Turning Point for the City's Historiography," Jerusalem Quarterly, no. 60 (2014). On municipal healthcare institutions and the municipal hospital during the mandate, see Jerusalem Municipal Archives (JMA) 180 (1922-56).

$10 \quad$ JMA 284 (1895-1920s), 310 (1910-48), 392 (1910-49), 1649 (1879-1994), 2581 (1918-94), 2680 (1883-1914, 1978), $2682(1844-1896)$ and $2686(1890-1965)$.

11 These include the records of the nineteenth- and early twentieth-century British consulate in Jerusalem, established in 1841: The National Archives of the UK (TNA): Foreign Office (FO), 195 (1841-1914). The archives of the Mandatory Department of Health are dispersed through the subseries of the Colonial Office ( $\mathrm{CO}$ ) papers on Palestine: TNA: co 733 (1918-48).

12 Of interest for this chapter: Israel State Archives (ISA), files M/6/6561 (1922-23) and $\mathrm{M} / 20 / 6561$ (1922-23). 
Non-state actors were actively involved in the development of the healthcare system in Jerusalem. The Central Zionist Archives in Jerusalem host an array of documentation on various organizations for the colonization of Palestine, ${ }^{13}$ early Zionist parties such as the Lovers of Zion ${ }^{14}$ and on the Zionist Executive during the Mandate. ${ }^{15}$ Among research on precolonial medical endeavors, Stefan Wulf has written the history of the Mühlens sanitary mission to Jerusalem. His work is based on state archives in Berlin and institutional archives in Hamburg. ${ }^{16}$

Coming into prominence just before and after World War I, global American foundations took an interest in Jerusalem. The Rockefeller Archives Center in Tarrytown, New York, holds files documenting the close relationships between the International Health Board, funded by the Rockefeller Foundation, and the Zionist Executive in the antimalaria campaign in Palestine, ${ }^{17}$ as well as the foundation's connection with the AJDC, involved in the distribution of relief to Jews at the close of the Great War and the funding of the Hм0. ${ }^{18}$ These files shed light on the debates over health priorities and healthcare organization at the start of the Mandate.

\section{Nineteenth-Century Jerusalem: A Communal Approach to Health Hazards and Infectious Diseases}

\section{Healthcare in Jerusalem: Ottoman Reforms and Foreign Clientele}

The development of healthcare institutions over the nineteenth century was part of the larger movement to create modern institutions across the Ottoman Empire. It aimed at providing every province with public services

\footnotetext{
13 See Central Zionist Archives (CZA), J15: Palestine Jewish Colonization Association; J113: Hadassah Medical Organization (1918-77).

14 See CZA/A31: Personal papers of Dr. Hillel Jaffe (1864-1935).

15 Of particular interest are the record groups CZA/S28: Committee for the Care of Sufferers from Chronic Diseases (1924-27); L53: Health Council (1922-28).

16 See Stefan Wulf, Jerusalem - Aleppo - Konstantinopel: Der Hamburger Tropenmediziner Peter Mühlens im Osmanischen Reich am Vorabend und zu Beginn des Ersten Weltkriegs (Münster: LIT, 2005); Stefan Wulf, Das Hamburger Tropeninstitut 1919 bis 1945: Auswärtige Kulturpolitik und Kolonialrevisionismus nach Versailles (Berlin: Dietrich Reimer, 1994).

17 Rockefeller Archives Center, Tarrytown, NY (RAC), Rockefeller Foundation Records (RF), Photographs, FAo03, box 170, ser. 825 I (1924-25); Record Group (RG) 5, International Health Board (Інв)/D, FA115, ser. 2, box 61 (1918-25).

18 RAC, RF, Alfred E. Cohn Papers, Rockefeller University records, FA 802, box 18 (1921-51).
} 
such as hygiene control and municipal physicians. ${ }^{19}$ Until the 1840 s, institutional healthcare was available from specialized private practitioners involved in various trades and was organized on a denominational basis. The one hospital or bimaristan, based on a Muslim religious foundation or waqf, the bimaristan al-salahi, presumably established by Saladin in the late twelfth century, remained active until the early $1850 s .{ }^{20}$ Houses provided to lepers outside the city walls were said to be based on another Muslim waqf established in the sixteenth century. ${ }^{21}$ Outside the framework of waqf foundations, convents kept pharmacies, first and foremost for their own communities. In the early nineteenth century, the most important of these was the pharmacy of the Franciscan convent. ${ }^{22}$ However, over the second half of the nineteenth century, the bulk of Jerusalemite healthcare institutions were western-backed Jewish and Christian institutions. What purpose did these serve? They cannot be accounted for by the Foucauldian concept of discipline as in European hospitals, where the interiorization of such procedures as hospital rules was a way to render populations productive, ${ }^{23}$ nor by the understanding of Western medicine in Jerusalem as a "tool of empire,"24 working in sanitary enclaves alongside

19 Jens Hanssen, Fin de Siècle Beirut: The Making of an Ottoman Provincial Capital (Oxford: Oxford University Press, 2005), 115-37; Malek Sharif, Imperial Norms and Local Realities: The Ottoman Municipal Laws and the Municipality of Beirut (1860-1908) (Beirut: OrientInstitut; Würzburg: Ergon, 2014), 181-208.

20 Kamil al-Asali, Muqaddima fi tarikh al-tibb fi-l-Quds mundhu aqdam al-azminah hata sanat 1918 miladi [Introduction to the history of medicine in Jerusalem from ancient times until 1918] (Amman: Jordanian University, 1994), 165; Musa Sroor, Fondations pieuses en mouvement: De la transformation du statut de propriété des biens waqfs à Jérusalem (Aix-en-Provence: Institut de recherches et d'études sur le monde arabe et musulman (Iremam); Damascus, Beirut: Institut français du Proche-Orient (Ifpo), 2010), 177-78.

21 Henry Vandyke Carter, Reports on Leprosy (Second Series), comprising notices of the disease as it now exists in North Italy, the Greek Archipelago, Palestine and parts of the Bombay Presidency of India (London: Eyre and Spottiswoode, 1876), 14-15. The author goes on to quote British consul Moore that the waqf had been established by "a lady" and had remained active "[since] the time of Selim Sultan," referring to either the last years of Selim I's reign after the conquest of Jerusalem $(1517-20)$ or to the time of Selim II (156674), following the trend of evergetism in the Holy City during his father Süleyman's reign.

22 Schwake, Die Entwicklung, vol. 1, 91-92.

23 Michel Foucault, "L'incorporation de l'hôpital dans la technologie moderne," Hermès, La Revue 2, no. 2 (1988).

24 Roy MacLeod, "Preface," in Disease, Medicine, and Empire: Perspectives on Western Medicine and the Experience of European Expansion, ed. Roy MacLeod and Milton Lewis (London: Routledge, 1988). 
largely untouched surroundings ${ }^{25}$ or through sanitary control of colonial populations. In the long run, Jerusalem's hospitals and dispensaries were inspired by anticipations of colonial opportunities. Still, they were often founded and expanded at the request of local non-Muslim communities protected by European countries, whose rivalries afforded the former with leverage. ${ }^{26}$ Ottoman and foreign voluntary institutions were contrasting answers to popular demands.

Ottoman health policies focused on objective health needs in keeping with the agenda of Ottoman reforms, which called for territorial and communal equality of access to state services. The Jerusalem municipality enforced hygienic measures such as street cleaning and controlling slaughterhouses. Admission to the municipal hospital of Jerusalem, founded in 1891, was conditional on the payment of a flat-rate fee of one mecidiye, the late Ottoman currency. ${ }^{27}$ Recruitment was intercommunal: Greeks and Jews were hired as physicians, ${ }^{28}$ and Catholic women's orders, such as the Daughters of Charity, were used as nursing staff. ${ }^{29}$ The limits of this egalitarian spirit are embodied in the fact that healthcare was gendered. The Ottoman state tried to channel women into a formal training in midwifery and nursing, but with limited success, largely on account of the centralization of education in these professions in Istanbul. By contrast, it did not want them to go into the medical profession and ended up officially forbidding their practice as physicians. ${ }^{30}$

European institutions, on the other hand, were works of beneficence. They were inspired by a sanitary imagination and catered to a specific religious community rather than health needs. Earlier institutions, such as the pharmacy of the Franciscan convent, had partly been motivated by the needs of the Christian pilgrims who came to Jerusalem for the Easter celebrations. This function was increasingly incorporated into the missions of the Western-style hospitals as

25 David Arnold, Colonizing the Body: Epidemic Disease and State Medicine in Nineteenth Century India (Berkeley: University of California Press, 1993).

26 Philippe Bourmaud, "Les entrelacs du public et du privé dans le monde ottoman," in Espace et construction de soi, ed. Maria Uzcategui and Yves Moreau, special issue of Les Carnets du LARHRA 3, no. 2 (2014).

27 Sufian, "Healing Jerusalem," 116, 118.

28 Schwake, Die Entwicklung, vol. 2, 518; Tawfik B. Canaan, "Cerebro-Spinal Meningitis in Jerusalem," Al-Kulliyeh 2, no. 6 (1911).

29 Philippe Bourmaud, "Ya Doktor! Devenir médecin et exercer son art en "Terre sainte," une expérience du pluralisme médical dans l'Empire ottoman finissant (1871-1918)" (PhD diss., University of Provence, 2007), 714.

$30 \quad$ Ibid., 192. 
Christian pilgrims grew in number in the later part of the nineteenth century. In times of epidemics, these movements of pilgrims could be a subject of sanitary concern, yet not as much as the more numerous and scattered gathering of Muslim pilgrims to Mecca, who were accused of spreading cholera to Europe in 1865 , but whose route circumvented Jerusalem. ${ }^{31}$ Descriptions of Jerusalem in the nineteenth and early twentieth centuries dwelled on the city as a site of multiple sanitary hazards: garbage strewn on open fields, dark, narrow alleys, and the use of cisterns filled with stagnant waters accounted for morbidity in the city. ${ }^{32}$ The image was not pure imagination: poor sanitary conditions fueled the long-standing debate on modernizing the water supply of the city.33 Urban residents themselves were sensitive to the lack of hygiene, ${ }^{34}$ but it was the place Jerusalem held in the Western imagination that drew massive investments into healthcare in the city.

European hospitals and dispensaries were protected by a set of capitulations and treaties securing European institutions, Europeans subjects and certain non-Muslim Ottoman subjects against possible inequities under Islamic law. ${ }^{35}$ In practice, the capitulations barred Ottoman officials from inspecting the work of foreign institutions, an object of resentment for public health activists advocating needs-based health policies. ${ }^{36}$ Even after the abolition of the capitulations in 1914, and the British occupation, this state of affairs lingered:

The capitulations, in the days of the Turks, were the best of help for foreigners. They could do whatever they wanted in their castle and their

31 Sylvia Chiffoleau, Genèse de la santé publique internationale: De la peste d'Orient à l'O.M.S. (Beirut; Institut français du Proche-Orient; Rennes: Presses Universitaires de Rennes, 2012), 83-96.

32 Yehoshua Ben-Arieh, Jerusalem in the Nineteenth Century, vol. 1, The Old City (Jerusalem: Yad Ben-Zvi Institute, 1984), chap. 5 .

33 Vincent Lemire, La soif de Jérusalem: essai d'hydrohistoire, 1840-1948 (Paris: Publications de la Sorbonne, 2011).

34 See for instance, on World War I: Ihsan Turjman, 'Am al-jarad, Al-harb al-'uthma wa mahu al-madi al-uthmani fi Filastin [The year of the locust: the Great War and the fading of the Ottoman past in Palestine], ed. Salim Tamari (Beirut: Institute for Palestine Studies, 2008), 201.

35 John Edward Wansbrough et al., "Imtiyazat," in The Encyclopedia of Islam, ed. Hamilton Alexander Rosskeen Gibb (Leiden: Brill, 1986), 1178-225.

${ }_{3} 6$ Philippe Bourmaud, "Public Space and Private Spheres: The Foundation of St Luke's Hospital of Nablus by the CMS (1891-1901)," in New Faiths in Ancient Lands: Western Missions in the Middle East in the Nineteenth and Early Twentieth Century, ed. Heleen L. Murre-van den Berg (Leiden: Brill, 2006), 151-74. 
institutions, without interference or witness. There was no sanitary inspection of their hospitals, their asylums and their schools ... This was because when it came to charities, the owners thought that what they were giving was a divine favour, while they would not have borne the cost of bringing these institutions up to level. ${ }^{37}$

The capitulation system also made it harder to decipher public health priorities.

\section{Communal Patterns of Health Information and Public Health Priorities}

Public health priorities in Jerusalem evolved through the nineteenth and early twentieth centuries from a focus on epidemic diseases to a larger array of pathologies. Malaria and trachoma were given prominence, ${ }^{38}$ but studies started to show the prevalence of so-called infantile diseases (measles, German measles, mumps, etc.). ${ }^{39}$ Yet Ottoman health policy, under pressure from European states, ${ }^{40}$ still focused on the virulent epidemics liable to spread to Europe such as plague and cholera, and neglected other diseases, which in the long run killed many more. ${ }^{41}$

Redefining health policy was a difficult task owing to the lack of reliable data. Intracommunal data on epidemics had long been deemed more reliable than official figures. ${ }^{42}$ Moreover, foreign institutions under the capitulations shrouded their work in secrecy: Estelle Blyth, the daughter of the first Anglican bishop of Jerusalem, noted after the British occupation that in Ottoman times, "statistics of all kinds, whether Turkish or foreign, were jealously guarded by those in authority, and were exceedingly hard to get at." 43 Communal divisions hindered epidemiological analysis.

"Kitab maftuh ila da'irat al-sihhah" [Open letter to the Department of Health], Mir'at al-Sharq, 47, August 18, 1920, 1-2.

38 Edward W. G. Masterman, "Jerusalem from the Point of View of Health and Disease," Lancet 191, no. 4930 (1918); Anat Mooreville, "Oculists in the Orient: A History of Trachoma, Zionism and Global Health, 1882-1973" (PhD diss., University of California, Los Angeles, 2015).

39 Canaan, "Cerebro-Spinal Meningitis."

40 Chiffoleau, Genèse de la Santé publique internationale, 187-219.

41 Masterman, "Jerusalem from the Point of View," 305.

42 See, for instance, the Diplomatic Archive Center of the Ministry of Foreign and European Affairs, La Courneuve (MAE), Correspondance Consulaire et Commerciale (CCC), Jerusalem, RG 3, Laffon to the Foreign Minister, Jerusalem, December 12, 1865.

Estelle Blyth, When We Lived in Jerusalem (London: John Murray, 1927), 105. 


\section{Zionist Colonization Priorities}

As a colonization movement, Zionism had a vested interest in well-guided public health. Zionist rural colonies were located close to marshes where anopheles, the malaria vector, could breed easily and settlers soon became conscious of their particular vulnerability to the disease. ${ }^{44}$ Zionist expertise on malaria was therefore primarily rural, but given that most of Palestine's Jewish population was urban, malaria also influenced Zionist perceptions of urban planning. ${ }^{45}$ It was also among the workers' unions in the rural colonies that the first "sick funds" (Kupat Holim) were founded, which would later become the main financial resource of Zionist healthcare. ${ }^{46}$

In an intercommunal setting such as Jerusalem, Zionist physicians and their financial experts recognized the importance of moving away from the communal approach to healthcare, ${ }^{47}$ but they prioritized the issues that affected immigrants most, such as malaria. The restoration of the Ottoman constitution in 1908, vindicated the needs-based approach of Zionist physicians, but also moved away from the communal framework of health data.

\section{The New Ottoman Political Order: Publicizing “Objective” Public Health Problems}

\section{Common Good in the Age of Statistics}

The restoration of the constitution changed policy making in the Ottoman Empire, allowing public policy to be openly criticized. Official indifference was invoked to account for growing sanitary threats such as tuberculosis:

[Those] whom I blame are the venerable members of our municipality, who pass before those places everyday, and who are educated. They ... close their eyes to those public places that are falling apart and, much like poisoned marshes, ... mar their physical as well as mental health.

44 Sufian, "Healing Jerusalem," 103.

45 Derek J. Penslar, Zionism and Technocracy: The Engineering of Jewish Settlement in Palestine, 1870-1918 (Bloomington: Indiana University Press, 1991), 18; CADN, A, 137: Herthetély, "Notes sur Bersasba," October 20, 1900.

46 On the early growth of collective Zionist health organizations, see Shifra Shvarts, The Workers' Health Fund in Eretz Israel Kupat Holim, 1911-1937 (Rochester: University of Rochester Press, 2002).

47 Erica B. Simmons, Hadassah and the Zionist Project (Lanham: Rowman \& Littlefield, 2005), 55 . 
All that our funds for public gardens have produced is a dry and narrow minigarden, surrounded by dust; there would be no harm in being more generous and giving an ample and clear garden, planted with pines, away from the dust, ... where special areas would be reserved for various sports. ${ }^{48}$

A public-minded generation was coming of age among Jewish immigrants as well as educated Arabs. ${ }^{49}$ Dealing with public problems through the lens of statistics was a way to rationalize political decisions in the name of the common good. This view was shared by the new authorities: the restoration of the constitution brought to power the Young Turk movement, whose leaders and intellectuals were under the influences of Émile Durkheim and Frédéric Le Play, two French sociologists who were active proponents of social statistics. ${ }^{50}$ For all the national and religious rivalries in Jerusalem, this idea made its way into the city's medical milieu.

\section{Intercommunal Data Exchange and Connected Networks}

In the years leading up to the war, official, missionary and Zionist health professionals converged around the clinical and statistical study of the city's health needs. The main manifestation of that trend was the organization, by the German colonial milieu, of a sanitary mission to Jerusalem from 1912 to 1914. Its head, Professor Peter Mühlens, a specialist in tropical medicine and malaria at the Institute for Maritime and Tropical Diseases in Hamburg, had soon screened the children "in most of the Moham.[medan], Jewish and Christian schools." ${ }^{11}$ Between their arrival and October 1913, over eighteen thousand blood samples were tested for malaria..52 In 1913, Mühlens established the International Sanitary Administration of Jerusalem, which set out to map disease, not only in the city, but in Palestine at large. It united the Jewish Health Bureau, a bacteriological institute founded by American Zionist philanthropist

48 Elias Halabi, "Al-Sill fi-l-Quds wa asbab intisharihi fiha" [Tuberculosis in Jerusalem and the causes for its diffusion], Filastin 60 (August 16, 1911).

Simmons, Hadassah, 38-39; Philippe Bourmaud, “'A Son of the Country.' Dr Tawfiq Canaan, Modernist Physician and Palestinian Ethnographer," in Struggle and Survival in Palestine/Israel, ed. Mark LeVine and Gershon Shafir (Berkeley: University of California Press, 2012).

5o Uriel Heyd, Foundations of Turkish Nationalism: The Life and Teachings of Ziya Gökalp (Westport: Hyperion Press, 1979).

$5^{1}$ BOA, HR.ID 1515/7, report by Mühlens, Jerusalem, February 1, 1914.

52 BOA, HR.ì 1515/7, "Discours du Professeur Mühlens, Directeur de l'Institut international d'Hygiène à Jérusalem, le 23 octobre 1913." 
Nathan Straus, the Pasteur Institute of Jerusalem and its antirabies work ${ }^{53}$ and various German and local physicians fighting tuberculosis and promoting social medicine. ${ }^{54}$ Although members of the Mühlens mission considered racial differences to be a founding principle of public health, ${ }^{55}$ the recruitment of the Administration was intercommunal, as were the populations under its study.

This raises the question of the colonial dimension of Mühlens's work. The German mission was sent by the main German institution for colonial medicine, but unlike similar contemporary missions, it included physicians of other nationalities and indigenous specialists. This was partly due to the precedent of Zionist efforts to map public health. Yet the Mühlens mission benefited from growing connections within the medical milieu of Jerusalem. In 1910, an epidemic of cerebro-spinal meningitis, a disease whose ambiguous symptoms had long been misdiagnosed by the city's clinicians, brought together practitioners from various hospitals around the German physician of the Sha'are Tsedek Jewish hospital, Dr. Moritz Wallach, and Dr. Tawfik Canaan. ${ }^{56}$

More than by bacteriology, the identification of the epidemic was made possible by the networks at the intersection of which stood the authors of the study and in particular, in the words of Mühlens, "our indefatigable collaborator, Dr. Canaan." ${ }^{57}$ A German cross-denominational connection had linked Canaan and Wallach, as well as Dr. Grussendorf, head physician of the German Lutheran hospital of the Kaiserwerth deaconesses of Jerusalem. Canaan had temporarily replaced Wallach at Shaare Tsedek during 1910. This German connection later facilitated Canaan's inclusion in the work of the Mühlens mission. A second connection was educational and generational: it tied Canaan and his colleague and former fellow student at the Syrian Protestant College (SPC), Dr. Albert Abu-Chédid, a Jewish physician of Algerian origin working at the Ottoman municipal hospital of the city. ${ }^{58}$ Lastly, Canaan, as a Protestant and an English speaker, had ties with English Protestant missionaries, possibly through the local branch of the Young Men's Christian Association, many of whose members were former SPC students, ${ }^{59}$ and through the college's

53 "Nachrichten aus dem Hl. Lande," Das Heilige Land, no. 2 (April 1913).

54 Wulf, Jerusalem - Aleppo - Konstantinopel, 50-53, 69-70.

55 Ibid., $54-55$.

56 Canaan, "Cerebro-spinal meningitis."

57 BOA, HR.İ 1515/7, "Discours du Professeur Mühlens, Directeur de l'Institut international d'Hygiène à Jérusalem, le 23 octobre 1913."

$5^{8}$ Bourmaud, "A Son of the Country,'” 104-24.

59 "Athletic Notes. The Jerusalem Football Series," Al-Kulliyeh 5, no. 6 (1914): 195-98. 
Jerusalem alumni association. ${ }^{60}$ Jerusalem's situation as a medical hub in the Middle East by 1914 was boosted by the habitus of SPC alumni, who were encouraged to cultivate connections and use their expertise to promote social welfare.

In retrospect, the Mühlens mission, its colonial character notwithstanding, represented a road not taken: that of systematic exploration of sanitary needs, under European guidance, but in the spirit of international and intercommunal cooperation, with local and European actors working together on apparently equal terms.

\section{The British Mandate: Competing Efforts to Shape Health Priorities}

\section{Wartime Health Policies: A Military Imperative}

World War I put a stop to this convergence. The International Sanitary Administration, the Pasteur Institute of Jerusalem, ${ }^{61}$ and the Jewish Health Bureau ${ }^{62}$ continued working, as did German and Austrian health foundations. Yet within Jerusalem, a garrison town and the first medical center behind the Sinai front, all efforts converged towards protecting the health of the troops from cholera and typhus. ${ }^{63}$ On the other side of the frontline, British military medicine had similar goals. Vulnerability to malaria was greater, but the British medical infrastructure was steadier: it kept Allenby's expeditionary corps healthy when the Ottoman troops collapsed militarily and medically in September $1918 .{ }^{64}$

Relief and healthcare were delegated to charities and humanitarian organizations with financial connections abroad, such as the Ottoman Red Crescent Society until $1917,{ }^{65}$ and the HMO, which stepped in after the British occupation and, in 1918, set up an American Zionist Medical Unit (AZMU) for emergency medical relief. ${ }^{66}$ By 1920-21, the Department of Health (DOH) had

\footnotetext{
6o "Alumni Association: Jerusalem Branch," Al-Kulliyeh 2, no. 3 (1911): 107-8.

61 Wulf, Jerusalem - Aleppo - Konstantinopel, 100-110.

62 "Wartime Health Work in Jerusalem," New York Times, December 28, 1919.

63 Oya Dağlar, War, Epidemics, and Medicine in the Late Ottoman Empire (1912-1918) (Haarlem: Sota, 2008).

64 Eran Dolev, Allenby's Military Medicine: Life and Death in World War I Palestine (London: I. B. Tauris, 2007).

65 Abigail Jacobson, From Empire to Empire: Jerusalem between Ottoman and British Rule (Syracuse: Syracuse University Press, 2011), 35 .

66 Jeffrey Gurock, American Zionism: Mission and Politics; American Jewish History, vol. 8 (London: Routledge, 2014).
} 
been established within the British Government of Palestine, ${ }^{67}$ but the delegation of healthcare to voluntary organizations remained.

\section{Establishing the Mandate's Healthcare Services: Conflicted Priorities}

Health policy-making in the early years of British rule in Palestine was characterized by the uncertainties surrounding the implementation of the Mandate and the transition from local-level administration to the state-in-becoming of Palestine. Jerusalem was now a power center and less a cause for sanitary concern at the municipal echelon.

Arab health priorities were determined by the rejection of the Balfour Declaration and the fear of the demographic consequences of Jewish immigration. In his diary on February 1, 1919, Jerusalem-born nationalist and pedagogue Khalil al-Sakakini called for Ellis Island-type sanitary controls on the border and the right of the Arab population of Palestine to choose who could immigrate. ${ }^{68}$ Without ever mentioning Zionism, Canaan betrayed similar demographic anxieties. In a speech on graduation day at the American University of Beirut in June 1923, he advocated pronatality measures as a foundation of national strength. ${ }^{69}$ His implicit argument was that Arab demography should be upheld in the face of Jewish immigration. He lay the onus of the responsibility on Arab women, whose lack of education, a pervasive concern in educated Palestinian Arab society, ${ }^{70}$ he blamed for the high rate of infantile mortality he witnessed among peasants in his Jerusalem clinic.

By contrast, Zionist experts appeared interested in the executive control of health policy-making and enforcement. Beyond the AzMU's emergency medical relief, experts took a structural perspective on health, stressing the strategic importance of the sanitary screening of newcomers in an immigration society. In 1920, a group of German Jewish physicians published a memorandum on the Duties and Organization of the Health Service in Palestine, drawing up recommendations on Palestine's health policy from a Zionist perspective. The memorandum distinguished four fields of operation: immigration control and quarantine, infectious diseases, lung diseases (primarily tuberculosis),

\footnotetext{
67 Simoni, A Healthy Nation, 48.

68 Khalil al-Sakakini, Yawmiyyat Khalil al-Sakakini [The diaries of Khalil al-Sakakini], vol. 3 (Beirut: Institute of Palestine Studies, 2004), 67.

69 Tawfik B. Canaan, "Al-Sihhah asas al-hayah al-qawmiyyah" [Health as the basis of national life], Al-Kulliyeh 9, no. 9 (1923): 391-95.

70 Ela Greenberg, Preparing the Mothers of Tomorrow: Education and Islam in Mandate Palestine (Austin: University of Texas Press, 2010).
} 
and healthcare centers. It advised the wholesale delegation of state functions, immigration control in particular, to the Zionist movement. ${ }^{71}$

\section{Health Administration: By Whom and for Whom?}

In spite of Zionist aspirations to take an ample role in Palestine's health administration, the Mandate system imposed constraints that prevented the concentration of power within one of the two communities. How did Palestine's dual healthcare system develop, if not out of an unequal political position? The main answer is that it reflected financial inequality, with the Kupat Holim affording Zionist healthcare institutions with state-of-the-art services while the Arab community was dependent on an impoverished DOH and voluntary institutions. ${ }^{72}$

Yet the financial issue was inseparable from the political one: who were the actors and beneficiaries of health policies? The question ran at several levels. Within the Zionist movement, the AZMU and the Kupat Holim fought over their agenda, social medicine, and the demands of insured workers, respectively. ${ }^{73}$

The views of the director of the AZMU, Dr. Isaac Rubinow, were based on principles of intercommunal assistance, but the organization, staffed solely by Jews, also found itself in conflict with the DOH. By 1922-23, the DOH was forced to make drastic budget cuts, and the main financial backer of Rubinow's organization, now rebranded as the HMO, was considering a redistribution of its funds between the HMO and the DOH. The ensuing conflict was as much about money as it was about the respective missions of the various health actors in Palestine, and indeed, the respective roles of representatives of the Jewish and Arab communities and of immigrants versus indigenous personnel, within these organizations. ${ }^{74}$

The redefinition of the respective roles of the government of Palestine and the Zionist organizations implied consideration of the bicommunal logic of the Mandate, which was to begin in July 1923. Following the terms of the Balfour Declaration, the mandatory government was required to facilitate the establishment of the Jewish National Home and to avoid any discrimination between the Jewish and Arab communities. This began with recruitment. Rubinow complained that the DOH cheated on its obligations vis-à-vis both communities and discriminated against Jewish immigrants:

\footnotetext{
71 Theodor Zlocisti et al., Aufgaben und Organisation des Sanitätsdienstes in Palästina (Berlin: Jüdischer Verlag, 1920), 9-12.

72 Sufian, "Healing Jerusalem," 129; Simoni, $A$ Healthy Nation, 53-54.

73 Shvarts and Brown, "Kupat Holim," 28-46.

74 RAC, RF, FA802, 825, box 18: Rubinow to Seligsberg, Jerusalem, April 5, 1922.
} 
[Look] at the staff of the Public Health Department, for instance. Of some 45 or 5 o physicians, only 4 or 5 are Jews, most of them Arab Jews. The one or two European Jews who have succeeded in obtaining positions have done so as a result of pressure and protests. Public health and sanitation in Palestine is entrusted by the government ... to Syrian, Greek and Armenian physicians, to anybody except Jews. ${ }^{75}$

Yet another consequence of the Mandate system was that policy was under international scrutiny, which induced a drive to pursue easily demonstrable results. In Belgian Ruanda-Urundi, the mandatory power targeted yaws as a disease for which an effective cure was liable to be found at a limited cost. ${ }^{76} \mathrm{In}$ Palestine, the equivalent of yaws was malaria. Rubinow and Colonel Heron, the director of the $\mathrm{DOH}$, were quite sensitive to the international publicity given to their respective results, and accused each other of taking all the credit. ${ }^{77}$ Yet the AJDC was less sensitive to publicity than it was to the needs and development of Palestine's governmental institutions, and it consequently forced the HMO to scale down its operations.

\section{The First Health Week (1924): Manufacturing Consent}

There were various ways to publicize the success of mandatory health policies. One was to use telling indicators such as the infantile mortality rate, but this implied that these should be comparable across communities, or at least show a convergence between Jews and Arabs. Infantile mortality was a shared concern across the communities. It was a life-long preoccupation of Canaan, ${ }^{78}$ and a weapon for Rubinow to discredit Heron: the former wondered how the latter was able to boast the efficacy of his services, when the infantile mortality rates for the Arab population oscillated between 250 and 300 percent. ${ }^{79}$ The importance given to the infantile mortality rate reflected Arab and Jewish demographic anxieties, but the indicator was also considered the synthetic health indicator par excellence and the signifier of the Mandate's success. Speaking about African mandates in June 1925, William Rappard, a member of

\footnotetext{
75 Ibid.

76 Anne Cornet, Politiques de santé et contrôle social au Rwanda, 1920-1940 (Paris: Karthala, 2011).

77 RAC, RF, FA802, 825, box 18: Alfred E. Cohn, "Final report and contract, ca. 1922."

78 Bourmaud, “'A Son of the Country," 118-19.

79 RAC, RF, FA802, 825, box 18: Rubinow to Seligsberg, Jerusalem, April 5, 1922.
} 
the Permanent Mandates Commission, took vital statistics as the yardstick of the success of the mandates to improve the life of their population. ${ }^{80}$

Another way to show the success of health policies was to use attendance figures at awareness campaigns. The most popular event of this kind was the Health Week, organized for the first time in November 1924, under the guidance of the HMO and DOH, with the support of Jewish and Arab physicians and medias. According to various assessments, it attracted 6,000, ${ }^{81} 34,000,{ }^{82}$ and even up to 51,000 people in an official report, ${ }^{83}$ which is as good a proof as any of the importance given to demonstrating the event's popular success, and to a tendency to inflate figures to that end.

The Health Week, centered on a health exhibition at the Moscoviyyeh compound in Jerusalem, focused on health education, infantile mortality, and the dangers of malaria. Early on, Arab representatives had suggested active antimalaria propaganda among the Arab population to the mandatory government, ${ }^{84}$ especially as police enforcement of forcible antimalaria measures, such as throwing over water tanks, was becoming deeply unpopular. ${ }^{85}$ The Health Week, with posters of mosquitoes and displays on malaria prevention, attempted to manufacture Arab consent for prioritizing to antimalaria campaigns by displaying a less intrusive approach.

\section{Conclusion: Towards Differentialism}

Successful efforts to publicize health policies and antimalaria campaigns in particular, such as the Health Week, show that in the increasingly dual society of Jerusalem, an approach to health policy through health needs was not incompatible with a perception of different needs between the communities. Over time, this differentiation would allow a gap to grow between Jewish and Arab healthcare, but at the beginning of the 1920s, it seemed like the

8o Quoted in Philippe Bourmaud, "Les faux-semblants d'une politique internationale: la Société des Nations et la lutte contre l'alcoolisme dans les mandats (1919-1930)," in "Re-reading Mandate History through a Health Policy Lens," ed. Philippe Bourmaud, special issue, Canadian Bulletin of Medical History 30, no. 2 (2013).

81 Simmons, Hadassah, 70.

82 Sufian, "Healing Jerusalem," 142.

83 RAC, RF, FA115, 825, 2, box 61: Paul S. Carley, "Health Week in Palestine," 1924.

84 Library of the London School for Hygiene and Tropical Medicine, Government of Palestine, Proceedings of the first session of the Antimalarial Advisory Commission of the Department of Health, October 28, 1920.

85 See n. 37 . 
logical result of the coexistence of an indigenous and an immigrant population. Moreover, differences in healthcare provision and in health indicators created an opportunity for the inhabitants to make political demands, prolonging a Jerusalemite tradition of playing on communal differences to obtain funds. Yet with the budget cuts imposed on the DOH, this logic came to an end.

The communal character of sanitary data, inherited from the Ottoman period, was already obsolete by 1914, as epidemiological data circulated and started to be compared. Yet the mechanism of the Mandate, facilitating the development of one of the two national communities in Palestine, but prohibiting discrimination between Jews and Arabs, drew public attention to the gaps in the statistics. In the face of this, health policy makers had to organize intercommunal events to manufacture consent for their public health priorities and to give all Jerusalemites a sense of sharing the same city, both with its hazards and its growing, inclusive institutions.

This divergence was related to the uneven biological effects of certain diseases such as malaria on Jews and Arabs, but since awareness campaigns on the issue proved successful, divergences can largely be explained by financial and institutional differences. As the sanitary attention given to Jerusalem in the nineteenth century receded behind the city's new role as an administrative capital, the significance given to denominational differences in the city's social fabric from an epidemiological point of view declined. Immigration induced new urban sanitary scares, but with the development of the healthcare and health policies that immigration brought on, new forms of belonging - as an Arab or a Jew and as an urban dweller - also came into being. 


\title{
Being on a List: Class and Gender in the Registries of Jewish Life in Jerusalem, 1840-1900
}

\author{
Yali Hashash
}

This chapter explores the position of women and the poor within Jerusalem's Jewish communities ${ }^{1}$ by tracing the presence of these marginalized groups in registries created by contesting religious and administrative institutions in Jerusalem around the same time: the Sephardic Kolel and the English Mission Hospital (EMH). The Sephardic community of Jerusalem was reestablished in 1726, after decades of demographic decline. In 1841, the Ottoman Empire, in accordance with the centralistic tendencies of Ottoman reforms, appointed a haham bashi (an Ottoman government-appointed chief rabbi) as a senior official of the Jewish community and its representative to the regime. By the 1850s, the community numbered between six and eight thousand individuals. Of those, Ashkenazi Jews constituted about a third. The Ashkenazi population grew until they were able, in the 1860 s, to depart from the Sephardic Kolel to establish several small kolels of their own according to origin or specific religious practices. The Maghreb Jews similarly worked to establish their own kolel, and other ethnic groups such as Persian and Georgian Jews did the same. Nevertheless, the weakened Sephardic Kolel remained the largest and most stable kolel throughout the century, functioning as the sole representative of Jerusalem's Jews to the Ottoman authorities. ${ }^{2}$ Each kolel had its own traditional charitable associations and practices. Those were challenged from the 1840 s onwards, when modern philanthropic institutions were introduced.

Since the 1840s, different institutions have worked to establish modern philanthropic structures, mainly hospitals and schools, for Jewish communities in Jerusalem. These offered local, personal, and sectarian applications of modern state-like biopolitical power, and it was in this context that modern registries

1 For the use of the term "communities," see Yair Wallach, "Rethinking the Yishuv: LateOttoman Palestine's Jewish Communities Revisited," Journal of Modern Jewish Studies 16, no. 2 (2017).

2 Yehoshua Ben-Arieh, 'Ir bi-R'i Tekufah-Yerushalayim ba-Me'a ha-Tesha-'Esre, ha-Ir ha-'Atika [A city reflected in its times: Jerusalem in the nineteenth century: The Old City] (Jerusalem: Yad Ben-Zvi Institute, 1977), 303-36.

(C) YALI HASHASH, 2018 | DOI:10.1163/9789004375741_029

This is an open access chapter distributed under the terms of the prevailing CC-BY-NC-ND License at the time of publication. 
were introduced. The $\mathrm{EMH}$, established in 1844 , by the London Society for Promoting Christianity Amongst the Jews, also known as the London Jewish Society (LJS), was the first of such institutions. The EMH had a regulative aspect, given that it brought the Jewish body under the auspices of scientific scrutiny. At the same time, it offered life-sustaining services. Montefiore censuses mentioned in this chapter relate to the regulation of population, whereas the account book management reveals a growing awareness of the need to sustain the Jewish population under the kolel's responsibility.

\section{Historicizing Lists}

Lists and tables belong to a particular genre of writing, used to record inventories even before the invention of the alphabet. ${ }^{3}$ Though they may seem impersonal, lists often convey an intimate reality of the way individuals were classified and made into subjects, particularly in the nineteenth century. ${ }^{4}$ Michel Foucault's concept of biopolitics may be useful in studying practices of list-making or registration. Foucault's notion refers to a new technology of governing populations that gathered momentum in the eighteenth century, enabling the creation of modern nation-states. This new power is distinguished from earlier modes of governance. Biopolitics are not concerned with tools of pure punitive power or a power of deduction involving the taking of lives or property. Rather, the role of power in biopolitics is to sustain life, or better yet, to encourage it. Through modern medicine, road security, education, and the like, biopolitics has penetrated and regulated every aspect of the life of the citizen. Modern statistical lists, an important biopolitical practice, enable individuals to receive governmental services all the while registering them as potential objects of knowledge and, therefore, discipline and regulation. Lists follow a variety of rules of exclusion or inclusion. In History of Madness, ${ }^{5}$ Foucault explored the idea of social exclusion through the historicization of the concept of madness. Foucault was able to historicize and denaturalize the social exclusion of those who were deemed mad; showing that madness is not only a medical construct but also a legal, cultural, and political one. In the

3 Jack Goody, The Domestication of the Savage Mind (Cambridge: Cambridge University Press, 1977), 74-111.

4 Michel Foucault, The History of Sexuality, vol. 1, trans. Robert Hurley (New York: Vintage, 1990), 135-59.

5 Michel Foucault, History of Madness, ed. Jean Khalifa, trans. Jonathan Murphy and Jean Khalifa (London: Routledge, 2013). 
wake of Foucault, social critical theorists have used the idea of social exclusion to decipher the social constructions of societies and institutions and the rules by which they include or exclude certain individuals. Archival work in particular is important to this methodology as it allows scholars to unearth the ideology, philosophy, and politics behind these regimes of inclusion and exclusion. ${ }^{6}$

Jewish communities in Jerusalem were already familiar with state and communal registration practices of the countries from which they had immigrated. While some practices were considered beneficial - either to an individual or to the congregation - others were seen as harmful. The collective memory of the past homelands would have included modern population control mechanisms designed to allow the regulation of ethnically and religiously heterogeneous populations. The Jews of Jerusalem also would have been able to recall ways of evading or complying with those new demographical techniques. In eastern Europe in the nineteenth century, expedited state centralization worked to incorporate thousands of small Jewish corporative communities into the general polity. As part of that effort, states legislated compulsory metrical registries of births, deaths, and marriages. Multiethnic empires such Austro-Hungary or Russia sought administrative reforms that would break corporate organizations and create a more direct regulatory relationship between the individual citizen and the throne. Such reforms met with reluctance and noncooperation on the side of the Jews and other minorities of those empires. In 1804, for example, the Russian Empire demanded that Jews acquire surnames, a step that "signaled the beginning of a gradual transformation of Russian Jewry into a 'legible' people - from an inclusive corporate body to a component of the population that could be governed, categorized, and identified unambiguously through statistical publications and administrative reports." ${ }^{7}$

Like peasants and other minorities, Russian Jewish congregations were reluctant to practice metrical registrations out of fear of expulsion from cities, taxes, or conscription. Archivists of provincial towns and villages were happy to help local people erase files that could be used in their disfavor should the regime gain access to them. However, the incapacity of the regime to allocate professional manpower to the new administrative tasks allowed locals to slow

6 Michael A. Peters and Tina A. C. Besley, "Social Exclusion/Inclusion: Foucault's Analytics of Exclusion, the Political Ecology of Social Inclusion and the Legitimation of Inclusive Education," Open Review of Educational Research 1, no. 1 (2014).

7 Eugene M. Avrutin, "The Politics of Jewish Legibility: Documentation Practices and Reform during the Reign of Nicholas I," Jewish Social Studies 11, no. 2 (2005): 137. 
down the penetration of state biopolitical power into the intimate practices of daily life. ${ }^{8}$

The Ottoman Empire experienced similar processes: Sultan Mahmud II (1808-39) initiated a census to allow the creation of a new army after destroying the Janissary Corps in 1826 . The census was to allow an efficient conscription of male Muslims between the ages of 16 and 40, but its other purpose was to collect cizye taxes from Christians and Jews. Like in the Russian Empire, administrative mechanisms had not yet been developed. As a result, the sultan had to lean on the religious hierarchy to perform the actual registration, which was executed partially and poorly. Whether to evade conscription, taxes, or excess government control, the population at large cooperated little with the sultan's desire to enumerate his subjects. Females were not counted at all. ${ }^{9}$

By the last quarter of the nineteenth century, however, censuses were no longer being used solely as a means of deduction - taxes and conscription but were also utilized to sustain the population through public welfare, transportation, health, and other functions that had until that point been the responsibility of the communal organization of the sultan's subjects. As a result, a far more comprehensive and effective census system than the Empire had previously seen emerged during the last decades of its existence. The new census began between 1881 and 1893, and included females for the first time. Individuals were now required to carry identity cards with them when traveling or dealing with government departments, a prerequisite that elevated levels of population cooperation. ${ }^{10}$ It also meant being listed for taxes or conscription. Thus, the subjugation process - being recognized as eligible for citizenry benefits such as travel or a business license - entailed the elements of subjectification to the deductive power of the state.

This chapter considers two registries: one created by the Sephardic Kolel and another produced by the EMH. The account book of the Sephardic Kolel $\left(185^{-}-80\right)$ sheds new light on changing attitudes towards poverty and communal responsibility. The medical diaries of the Емн (1842-99) reveal that poor Jewish women were instrumental in using and shaping the new public spheres established by the mission to target the Jewish poor. Other sources such as the Montefiore censuses and their attached petitions are used to further elaborate

\footnotetext{
$8 \quad$ Ibid., 139 .

9 Stanford J. Shaw, "The Ottoman Census System and Population, 1831-1914," International Journal of Middle East Studies 9, no. 3 (1978).

10 Musa Şaşmaz, "The Ottoman Censuses and the Registration Systems in the Nineteenth and Early Twentieth Centuries," Osmanlı Tarihi Araştırma ve Uygulama Merkezi Dergisi OTAM 6 (1995).
} 
on the idea of lists and the ideological and administrative principles that determine their exclusion and inclusion regimes.

\section{When Registers become Archives}

The Department of Manuscripts and the Institute of Microfilmed Hebrew Manuscripts in the National Library of Israel (NLI) ${ }^{11}$ holds a large number of documents, the originals of which either belong to the NLI or to other collections and archives around the world. The NLI website states that the department "has undertaken to collect copies of all extant Hebrew manuscripts, whether privately owned or housed in public collections, from all over the world, by means of the Institute's seventy-six thousand reels of microfilm and thousands of scanned digital images." ${ }^{12}$ The NLI holds the original account book analyzed here as well as its microfilmed copy. Among its microfilmed reels are the Montefiore censuses and some attached petitions.

Jerusalem's archives hold a rich variety of account books belonging to merchants, institutions, and congregations. A joint research effort such as Open Jerusalem has the potential to create a detailed and versatile economic history of the city. As economic relations often crossed sectarian lines, this kind of effort can tell the city's social, political, and economic history in unprecedented detail. Account books are a source that requires time to analyze, as they usually need to be deciphered and interpreted using multiple expertise. Such analyses may benefit significantly from a team effort. Some of the chapters in this volume point to available economic sources: Stéphane Ancel mentions financial sources of the Ethiopian Church, some of which may be accounting ledgers, and Angelos Dalachanis and Agamemnon Tselikas report on income and expense registers of the Greek Orthodox Patriarchate of Jerusalem from the mid-nineteenth to mid-twentieth centuries. ${ }^{13}$

11 The NLI defines itself as the national library of the state of Israel and as the national library of the Jewish people. As such it aims to collect all material published in Israel or about Israel, as well as "the cultural treasures of Israel and of Jewish heritage." See http:// www.nli-education-uk.org.

12 http://web.nli.org.il/sites/NLI/English/collections/manuscripts/Pages/default.aspx.

13 See Stéphane Ancel's chapter, "The Ethiopian Orthodox Community in Jerusalem: New Archives and Perspectives on Daily Life and Social Networks, 1840-1940," and Angelos Dalachanis and Agamemnon Tselikas' chapter, "The Brotherhood, the City and the Land: Patriarchal Archives and Scales of Analysis of the Greek Orthodox Jerusalem in the Late Ottoman and Mandate periods," in this volume. 
The account book presented here makes a particularly good historical source for several reasons. First, changes discovered in an account book may reflect dramatic changes in community life. Historians of bookkeeping claim that throughout history, bookkeeping was an adaptive process that changed in accordance with conditions of time and place. Despite its adaptive tendencies, bookkeeping shows a certain dimension of stability because changes do not occur without significant reason. ${ }^{14}$ As such, we are able to use account books to examine change in the community. Second, the specific book discussed in this chapter was written in a manner that did not enable efficient external auditing. The ongoing reports were registered adjacently to their execution and do not rely on memory over time, which grants the book a high level of reliability. Third, reading and deciphering the $75^{\circ}$ pages of the account book is slow work. The nature of the work required to analyze such a source moderates potential bias in interpreting its findings.

In recent years, the Conrad Schick Library and Archive in Christ Church in Jerusalem have been cataloging and digitizing materials pertaining to the $\mathrm{LJS}^{.15}$ As librarians explained to me during my visits there in 2016, it is an ongoing process, and many documents, including maps, sketches, and letters, are yet to be revealed to researchers. Many items were transferred from the Oxford Bodleian Library, including the Medical Diaries of the EMH. Jerusalem's archives have rich materials about the philanthropic enterprises of the nineteenth and early twentieth centuries, and in particular medical philanthropies such as the French Catholic Hospital, built in 1851, and the Greek Hospital, built in $1871 .^{16}$

\section{The Sephardic Kolel Account Book: Between Inclusion and Exclusion}

New accounting history has developed as a branch of social and economic history since the 1970s, and was influenced by Foucault's analysis of power and bureaucratic knowledge. ${ }^{17}$ Research in that field has yielded some important

\footnotetext{
14 John R. Edwards, A History of Financial Accounting (London: Routledge, 1989), 14.

15 http://cmjisrae.w16.wh-2.com/CMJ-Ministries/Heritage-Centers/Conrad-Schick-Library.

16 For a survey of these institutions see Norbert Schwake, "Hospitals and European Colonial Policies in the 19th and Early 2oth Centuries," in Health and Disease in the Holy Land, ed. Manfred Waserman and Samuel S. Kottek (Lewiston: Edwin Mellen, 1996).

17 Christopher J. Napier, "Accounts of Change: 30 Years of Historical Accounting Research," Accounting, Organizations and Society 31, no. 4 (2006).
} 
insights, not least of which is the understanding that methods of accounting are never a transparent tool of adding and subtracting economic data, but a form relating content. Revealing the method of accounting allows us a glimpse into the ideological structure of the organization studied. This section relates to one specific financial source: the Sephardic Kolel account book (1851-80) containing the logs of the kolel incomes and expenses in those years as well as some financial contracts. It is stored at the Israel State Archives, and except for a few pages, it was first studied in my $\mathrm{PhD}$ dissertation. ${ }^{18}$ The $75^{\circ}$ manuscript pages include handwritten notes in Hebrew, combined with words in Aramaic, Turkish, Ladino, and Arabic, all in Hebrew characters.

The Sephardic Kolel account book is doubly paginated - one count is for pages and the other for columns, but occasionally there is a gap in page numbers and they do not correspond to column numbers. In addition to entries for incomes and expenses, the book contains three contracts signed throughout the years as well as several receipts for the cancellation of bonds. The income pages contain entries of income from emissaries, taxes, loans, and sale or lease of assets. The expense pages log items such as salaries, maintenance expenses, orphan fund expenses, accommodation of foreign dignitaries, charity, payment to scholars, payment of debts (principal and interest), taxes and bribes to officials. These items are not later summed, and there is no general account of annual income from tax or other sources, nor is there a general balance of annual expenses for salaries or debt repayment. Some of the donations by philanthropists such as Rothschild and Montefiore to particular groups in the community or for the purpose of establishing institutes were not recorded in the ledger at all. The account book therefore did not provide kolel management with a coherent picture of the community's overall financial status. An annual balance appears only once towards the end of the documentation. The lack of annual balances is an oddity that raises an important research question: if an annual accurate financial picture was not a purpose of the bookkeeping, then what was?

18 Pages from the first half of 1850 and from the month of Heshvan in 1854 are mentioned in Israel Bartal's "Berurim be-Shuley Tazkir Kolel ha-Sefaradim bi-Rushalayim Mi-Shenat Tartav" [Some queries regarding the 1885 memo of the Sephardic Kolel in Jerusalem], Zion 43 (1978). Yali Hashash, "Shinuy Gishot Klape 'Oni ba-Kehila ha-Sefaradit be-Yerushalayim, 1841-1880" [Changing attitudes toward poverty in the Sephardic community of Jerusalem, 1841-1880] (PhD diss., University of Haifa, 2011); Hashash, "Iske Halva'ot: Nihul Kaspe ha- Kehila ha-Sefaradit bi-Rushalayim ba-Me'ot ha-Shemone-'Esre ve-ha-Tesha'-Esre le-'Or Mismakhim Hadashim" [Loan business: the management of the Sephardic community's coffers in Jerusalem in the eighteenth and nineteenth centuries in the light of new documents], Zion 78, no. 4 (2013). 
In order to answer this question, we must first specify the method of bookkeeping kept in the ledger. It seems that the account book was maintained in the style of "income-expense" customary from Roman times and used around the world throughout history. This system includes several forms of documentation based on single entry, meaning one registry for each income or expense item, covering the flux of resources over time, without discriminating profit from income, or between various transaction types. This type of account has two primary goals: first, to enable the account manager to balance incomes and expenses, and second, to enable supervision of resource collection and allocation and of those entrusted with finances. In an organization such as the Sephardic community, donors may have wanted to know how their donations were allocated and whether the kolel managers were carrying out their duties honestly.

Alongside this single-entry system, a double-entry system evolved. Doubleentry bookkeeping is based on recording any quantitative activity in a system where at least one party is debited, and another credited. Recording a debit amount to one account and an equal credit amount to another account results in total debits being equal to total credits for all accounts in the general ledger. If the accounting entries are recorded without error, the aggregate balance of all accounts having positive balances will be equal to the aggregate balance of all accounts having negative balances. This method came into widespread use only in the mid-nineteenth century as a result of an increase in modern business initiatives and the separation between ownership and management of business. Changes in bookkeeping in the middle of the century expressed the change in its role. From a means of assessing the ability of a certain entity to repay or properly manage a deposit, bookkeeping became a source of information for making decisions regarding resource allocation and a basis for investment and profit.

Unlike double-entry bookkeeping, single-entry bookkeeping does not measure profit and does not evaluate performance, as incomes were generally regular, and expenses inevitable. Under these circumstances, an approach that was primarily supervisory was entirely sufficient. Therefore, smaller communities such as church congregations, monasteries, and other religious communities continued to use single-entry bookkeeping. ${ }^{19}$ Account management in

19 Edwards, A History of Financial Accounting, chaps. 4 and 5. In the 1860s, the Ottoman Empire began using double entry bookkeeping. The importance given to learning new methods of accounting as part of reform and social change is evident by the fact the Butrus al-Bustani (1819-93), one of the prominent Nahda scholars, published a guidebook 
the Jerusalem Sephardic community was therefore similar to the management of smaller religious communities, and its primary role was to balance incomes and expenses and prove to donors that the community's finance managers were not embezzling money.

The different entries in the account books from the eighteenth and nineteenth centuries show that the Sephardic community had economic ties with non-Jews in Jerusalem. ${ }^{20}$ Loans with high interest were taken from influential Armenians, Muslims, and Christians, just as they were taken from the elite members of the community. The kolel's coffer served as a high interest investment for a close circle of beneficiaries, among whom were non-Jewish local elite. This practice of loaning caused recurring financial crises. ${ }^{21}$ Indeed, the account book exposes the grave financial crisis faced by the kolel in 1853-54.

The book suggests that a general crisis lasted throughout the period the book was kept. The crisis was an evolving challenge, continually requiring varied solutions and diverse coping strategies. The solutions chosen were responses to constraints imposed by the external reality as well as responses to power structures within the community and tensions between differing sociopolitical concepts. These different strategies are reflected in the exclusion and inclusion regimes that governed the ideological and financial structure of the accounting operation. In particular, it uncovers changing attitudes regarding who was eligible to receive communal charity. The unlearned poor, who were almost entirely excluded from communal support until the mid185 os, were deemed eligible during the second half of the century.

\section{The Missionary Registers from the Conrad Schick Library and Archive: A Biopolitical Reading}

One of the items in the Conrad Schick archive are the medical diaries of the EMH by its directors during their tenure: Dr. Macgowan (1842-6o), Dr. Chaplin

on double-entry bookkeeping for merchants, stressing in its introduction that this knowledge had become crucial in order to comply with the new state law. Butrus al-Bustani, Kitab rawdat al-tajir fi mask al-dafatir [The trader's guide to bookkeeping] (Beirut, 1859). I thank Nicole Khiat for bringing this source to my attention.

20 Jacob Barnai, "The Jerusalem Jewish Community, Ottoman Authorities and Arab Population in the Second Half of the Eighteenth Century: A Chapter of Local History," Jewish Political Studies Review 6, no. 34 (1994).

21 Hashash, "Shinuy Gishot Klape" and "Iske Halva’ot." 


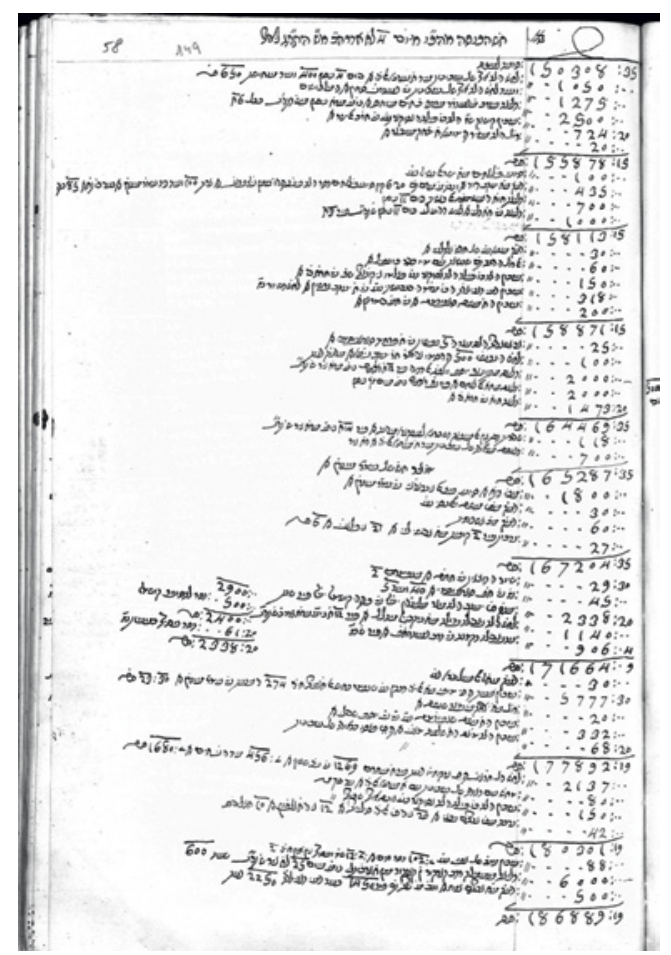

FIGURE 23.1

A page from the Sephardic Kolel account book, 1851-80, income, Adar 5613 (January-February 1853 ).

(1860-85) and Dr. Wheeler (1885-1909). The diaries' first entries are from early 1842, when the LJs Jerusalem clinic was first opened, and they follow the establishment of the EMH in 1844 by the LJS and the following seven decades.

The material in the medical diaries is of a double nature. Macgowan, who served as a physician in Jerusalem from 1842 to his death in 1860, wrote narrated reports on a regular basis. These were often published in the LJS journal, Jewish Intelligence, and were complemented by statistical data. His successors Chaplin and Wheeler, only wrote statistical reports, that is, tables that registered the number of admissions to the hospital and clinic visits according to gender, healing rates of hospital patients (but not clinic patients), and often the ethnicity of patrons. While many of these tables were published in Jewish Intelligence, the medical diaries offer an ordered sequence and details that were sometimes omitted in the journal. Other documents in the Conrad Schick archive, such as sermons, letters, and the entire volumes of Jewish Intelligence, offer a glimpse into varied aspects of evangelical discourse regarding the Jews. 
Researchers to date have largely depicted the medical establishments that sprung up in Jerusalem from the point of view of philanthropists, doctors, European interests or the local leadership. ${ }^{22}$ These studies brought to light the EMH's vast operation, the opposition it attracted and the competing Jewish initiatives it inspired. Most researchers agree on some basic facts based on contemporary evidence, namely: the hospital offered welfare as well as medical services; ${ }^{23}$ it accommodated the Jewish religious needs of its patients; ${ }^{24}$ there were hardly any proselyting efforts within the hospital compound; rabbinic institutions raised objections of one sort or other; ${ }^{25}$ the presence of the hospital gave rise to modern Jewish medical institutions; ${ }^{26}$ the medical mission was known for its high level of professional and personal service; and finally, despite objections and competition, and apparently due to its high level of professionalism and compassion, Jewish patients kept using its services. Researchers have used the published statistical data as sources of fact, though they were aware that the numbers were not necessarily accurate. Contemporary observers and current researchers often remain skeptical about the reliability of the numbers the EMH published.

22 Norbert Schwake, “Hospitals”; Marcel Chahrour, “A 'Civilizing Mission'? Austrian Medicine and the Reform of Medical Structures in the Ottoman Empire, 1838-1850," Studies in History and Philosophy of Science of Biological and Biomedical Sciences 38, no. 4 (2007); Shifra Swarts, "Meshihiyut ve-Politika be-Hakamat Mosdot ha-Refu'a ha-Yehudiyim ha-Rishonim bi-Rushalayim ba-Me'ah ha-19" [Messianisme and politics in the establishment of the first Jewish medical institutions in Jerusalem in the 19th century], in Refu'ah bi-Rushalayim le-Doroteha [Medicine in Jerusalem throughout the generations], ed. Efraim Lev et al. (Tel Aviv: Erets, 1999).

23 Yaron Perry, "Medical Treatment as a Missionary Instrument and Its Social Consequences: Aspects of the Work by the London Jews Society in Palestine up to 1914," in The Social Dimension of Christian Missions in the Middle East: Historical Studies of the 19th and 2oth Centuries, ed. Norbert Friedrich, Uwe Kaminsky, and Roland Löffler (Stuttgart: Franz Steiner, 2010), 149.

24 Margalit Shilo, Princess or Prisoner? Jewish Women in Jerusalem, 1840-1914, trans. David Louvish (Waltham: Brandeis University Press, 2005), 204.

25 Yaron Perry and Efraim Lev, Modern Medicine in the Holy Land (London: I. B. Tauris, 2007), 36-38; Ruth Kark and Shlomit Langboim, "Missions and Identity Formation among Indigenous Populations in Palestine:The Case of the Jewish Population," in Friedrich et al., The Social Dimension of Christian Missions, 112-15; Morgenstern, like Kark and Langboim, points to the measure of cooperation between the Perushim Jews and the Protestant mission. See Arye Morgenstern, Ha-Shiva li-Rushalayim [The return to Jerusalem] (Jerusalem: Shalem, 2007), 352-55.

Schwake, "Hospitals." 
Taking these findings of previous research as a basis, I take a more analytical approach to the statistical reports to discern patterns over the years. Even if numbers were inflated, recurring patterns might offer some insight into the demographics of the population that received medical care in the Емн. Furthermore, the availability of similar reports from other institutions allows us to widen our understanding of the different ways in which the Jewish population in Jerusalem accepted these institutions. My findings show that over the decades more women than men frequented the EMH (clinic and hospital), and that compared with the Rothschild Hospital, this trend seems to be characteristic. The Rothschild Hospital usually admitted more men than women. ${ }^{27}$

Statistical data from the EMH (see table 23.1) shows that more women than men were hospitalized despite the number of beds being equal in the men's and women's wards. Women continued to constitute the majority of hospitalized patients although their ratio was slowly decreasing, finally stabilizing around 55 percent. It further shows that in the outpatient clinic women consistently made up two-thirds of the patients, making the presence of women in the building, whether hospitalized or outpatients, central.

TABLE 23.1 Average clinic visits to the English Mission Hospital, 1862-80, by gender ${ }^{\mathrm{a}}$

\begin{tabular}{llllll}
\hline Year & Women & Men & Total & Women (\%) & Men (\%) \\
\hline $1862-65$ & 3,310 & 1,756 & 5,066 & 65 & 35 \\
$1866-70$ & 5,291 & 2,815 & 8,106 & 65 & 35 \\
$1871-75$ & 4,902 & 2,687 & 7,589 & 65 & 35 \\
$1876-80$ & 4,519 & 2,597 & 7,116 & 63 & 37 \\
\hline
\end{tabular}

a The medical journal does not provide distribution by gender for the clinic visits of 1861 . SOURCE: MEDICAL DIARIES OF THE ENGLISH MISSION HOSPITAL.

27 See Yali Hashash, "Gender, Religion and Secularism in the English Mission Hospital of Jerusalem, 1844-1880," Journal of Levantine Studies 7, no. 1 (2017). 
During the 186os, different quarterly reports of the Rothschild hospital were published in different Jewish newspapers. They appear to indicate that more men than women were admitted to the Rothschild Hospital. ${ }^{28}$ Table 23.2 shows that during the six consecutive years reported in the Jewish newspapers, an average of 46.75 percent of women were hospitalized, compared to an average of 53 percent during the same time in the Емн. The gap in actual numbers reported can be explained by the fact that the EMH had 24 beds and the Rothschild Hospital had only $18 .{ }^{29}$ It can thus be argued that the EMH was more of a feminine public space than its counterpart.

TABLE 23.2 Hospitalization at the Rothschild Hospital, 1870-76, by gender

\begin{tabular}{|c|c|c|c|c|c|c|}
\hline $\begin{array}{l}\text { Jewish } \\
\text { year }\end{array}$ & $\mathbf{A D}$ & Women & Men & Women (\%) & $\operatorname{Men}(\%)$ & Total \\
\hline $5^{6} 31$ & $\begin{array}{l}\text { September } 26,1870-\text { September } \\
16,1871\end{array}$ & 192 & 199 & $49 \cdot 1$ & $5^{0.9}$ & 391 \\
\hline $5^{6} 32$ & $\begin{array}{l}\text { September } 17,1871 \text {-October } 2 \text {, } \\
1872\end{array}$ & 207 & 243 & 46 & 54 & $45^{\circ}$ \\
\hline $5^{6} 33$ & $\begin{array}{l}\text { October } 3,1872-\text { September } 22 \text {, } \\
1873\end{array}$ & 216 & 244 & 47 & 53 & 460 \\
\hline $5^{6} 34$ & $\begin{array}{l}\text { September } 23,1873 \text {-September } \\
12,1874\end{array}$ & 161 & 198 & 44.9 & $55 \cdot 1$ & 359 \\
\hline 5635 & $\begin{array}{l}\text { September } 13,1874-\text { September } \\
20,1875\end{array}$ & 161 & 183 & 46.8 & 53.2 & 344 \\
\hline $5^{6} 3^{6}$ & $\begin{array}{l}\text { September } 21,1875^{-S e p t e m b e r} \\
19,1876\end{array}$ & 191 & 220 & 46.5 & $53 \cdot 5$ & 411 \\
\hline
\end{tabular}

SOURCES: FOR 5631, HAVATSELET, OCTOBER 27, 1871; 5632,JEWISH CHRONICLE, DECEMBER 5, 1873; 5633, HAVATSELET, NOVEMBER 28, 1873, 5634, HAVATSELET, DECEMBER 4, 1874; 5635, HAVATSELET, OCTOBER 29, 1875; 5636, HAVATSELET, DECEMBER 7, 1876.

28 For reports where more men than women are documented as hospitalized patients see:Jewish Chronicle, January 4, 1861; Ha-Melits, March 27, 1862; Ha-Magid, July 26, 1865; Ha-Magid, February 7, 1866; Ha-Magid, July 24, 1867; Ha-Magid, May 6, 1868; Ha-Magid, May 11, 1870. For quarterly reports that document more hospitalized women, see Ha-Levanon, July 9, 1863; Univers Israelite, October 1864; Ha-Magid, September 9, 1868.

Hashash, "Shinuy Gishot Klape," 189. 
These findings allow old evidence to be reexamined and interpreted in a new light. For example, we can now look for a connection between women's partiality to the Емн and attitudes towards women in the Jerusalem Evangelical mission. The special place Judaism had within the British colonial outlook informed the mission's attitude towards the Jews in Jerusalem. The narrative reports for the city as well as the different sermons and other documents found in the Conrad Schick archive, are a good resource for examining the specific interreligion relationship that was being formed in the city during the nineteenth century.

The EMH used modern mechanisms of population management in the sense that people who were treated as outpatients or inpatients were registered and classified. Men were more reluctant than women to be on these lists, supposedly because of the way it reflected on them as Jewish men. The EMH nevertheless remained extremely popular. Though its published numbers may be exaggerated, contemporary Jewish publicists systematically lamented the hospital's high attendance rates. Other Jerusalem medical institutions built for the Jews from the 1840 os on were also very popular. In looking to them for help and services, Jerusalem's poor encouraged the success of these institutions while availing themselves of different public networks.

The only exclusion mechanism that operated at the EMH was religious the institution only served Jews. The EMH's evangelical modernist ideology was reflected in the hospital's policies. The neglected Jewish women and the poor offered the medical missionaries a chance to exhibit what they believed to be some of their superior attributes - their modern perception of women and their compassionate attitude toward the poor. Recreationist ideas that circulated at the time reinforced the use of the EMH as a haven for new Jewish immigrants while the concept of the conversion of the Jews that would, in turn, allow for Christ's Second Coming stressed the importance of acquainting the Jews with Christian morality as exhibited in medical care. The EмH, like other medical institutions that followed, held "state-like" biopolitical power: it rewarded listed individuals with life-sustaining services. The statistics that made up the Емн registries were used for medical research ${ }^{30}$ and, at times, policy-making. Running the hospital contributed to the self-perception of British evangelicals as the benevolent, worthy alternatives to Muslim rule. Yet the subjectification of the patients - that is, turning them into subjects of care,

30 See for example the medical research of Dr. Thomas Chaplin in Efraim Lev and Yaron Perry, "Dr. Thomas Chaplin, Scientist and Scholar in Nineteenth-century Palestine," Palestine Exploration Quarterly 136, no. 2 (2004). 
putting them on lists of individuals entitled to receive the hospital's services was not accompanied by an immediate concrete act of subjugation.

\section{Being or Not Being on the List}

The state-like modern philanthropy that emerged in Jerusalem's Jewish community during the nineteenth century gave rise to new, more inclusive lists. These innovations directly challenged the principles of exclusion that categorized older lists. This is evident in the registry of female names. Jewish registration was traditionally connected with sacramental duties. Therefore, the birth of a boy was likely to be chronicled upon his circumcision and again at the time of his bar mitzvah ceremony. On the other hand, girls were typically registered for the first time upon marriage. Gila Hadar followed Sephardic female names and concluded that a woman's birth name was not only lacking from most registries, but often was not in use at all: "the personal name of a woman ... had little significance," notes Hadar. "The meaning and existence of a girl was only within the collective Jewish context in her role as woman, mother, and widow. After her marriage a woman ... was known as the wife of or the widow of someone."31

In the nineteenth century, the position of women in the Jewish communities of Jerusalem was determined by the community's conception of its calling: the city's rabbis saw the Jews of Erets Israel and particularly of Jerusalem as the center of the traditional rabbinic world and, therefore, as personifying the state of exile. ${ }^{32}$ The ensuing distinction between the worthy, scholarly poor, and the poor, who were considered a liability for the vocation of the

31 Gila Hadar, "Bienvenida 'Blessed be Her who Comes' and Azebuena 'Does Good Deeds': Name-giving Patterns for Girls and Women in the Judeo-Spanish Diaspora (Salonika, 1492-1943)," in Pleasant are their Names:Jewish Names in the Sephardi Diaspora, ed. Aaron Demsky (Bethesda: University Press of Maryland, 2010), 228.

32 Israel Bartal, Galut ba-'Arets [Exile in the homeland] (Jerusalem: Zionist Library, 1994), 16. As elsewhere in the Ottoman Empire, Sephardic rabbis in Jerusalem saw the exile situation as a metaphor for the general human condition of alienation and the existential sense of homelessness. In this view, exile is a voyage in which a man engages in penance so that he may eventually come home. The sufferings of the Jews in the Land of Israel serve in this worldview as a collective penance for the sins of past and present generations. See Matthias B. Lehmann, Ladino Rabbinic Literature and Ottoman Sephardic Culture (Bloomington: Indiana University Press, 2005), 174. 
community, ${ }^{33}$ informed attitudes toward women, who were excluded from Torah studies. This exclusion did not mean that women felt like outsiders to the community or to its values. They could, and indeed did, gain status insofar as they were able to tie their existence to the scholarly activity of men as wives, mothers, or volunteers in a synagogue or a yeshiva. And yet, pauper letters indicate that many contested their exclusion and worked to be part of the new lists. These letters, some of which can be found in the Central Archive of the Jewish People and the Institute of Microfilmed Hebrew Manuscripts in the National Library in Jerusalem, help to further understand the way that lists shaped people's lives. During the nineteenth century, thousands of pauper letters were sent from Jerusalem to European benefactors, begging for immediate relief from poverty. Most of the letters were written by women. ${ }^{34}$ These letters are often cited as evidence of the suffering endured by the Jewish community in Jerusalem. However, they have rarely been analyzed to reveal the reactions of the poor to the realities of their time.

Pauper letters were written either by individuals or by groups. In the Jerusalem archives, I found three documented collective letters: a collective letter to Montefiore from 1849, a collective letter to the British consul James Finn, from $1854,{ }^{35}$ and another letter to Finn from 1861. According to Finn, this petition was from the representatives of 650 families seeking land for farming. ${ }^{36}$

33 When the eminent Jewish historian Tsvi Gertz published a critical report on the Jewish communities of the four holy cities in Palestine, he focused on the distribution of alms as an expression of social evil. The communities' leadership, he claimed, saw the alms from the diaspora as a God-given right that was distributed to the haves while the have-nots received little, if any, money. Ha-Magid, January 15, 1873. This kind of criticism began to appear in Jewish newspapers in the late 1830s. Yehuda Elkalay argued for the restoration of Jews to Palestine and their productivization as a human-induced Ge'ulah. Further research is needed to establish whether there was actually a dialogue between evangelical restorationists and Elkalay.

34 For a review and discussion of pauper letters, see Shilo, Princess or Prisoner, 183-86. Shilo found most of these letters in the Bibliotheca Rosenthalia at the University of Amsterdam. Others are scattered among different archives, such as the Montefiore Archives at Oxford. For an annotated translation of this letter, see Yali Hashash, "A Petition for Aid: A Sephardi Collective in Jerusalem Appeals to the British Consul (1854)," in Sephardi Lives: A Documentary History, 1700-1950, ed. Julia Phillips Cohen and Sarah Abrevaya Stein (Stanford: Stanford University Press, 2014), 50-52.

36 Arnold Blumberg, A View from Jerusalem, 1849-1858: The Consular Diary of James and Elizabeth Anne Finn (Rutherford: Fairleigh Dickinson University Press, 1980); Ruth Kark, "Millenarism and Agriculture Settlement in the Holy Land in the Nineteenth Century," Journal of Historical Geography 9, no. 1 (1983); Vivian D. Lipman, "Britain and the Holy Land: 1830-1914," Jewish Quarterly 37, no. 4 (1990). 
Several elements are evident in the three letters and in other individual appeals I read. First, the independent collective appeals show a clear fear of community sanctions should kolel officials hear of the private initiative. Next, the letters criticize the leadership's lack of interest in its poor. Gender differences are evident: for example, men's appeals ask for much more substantial aid than women's. Awareness of contemporary ideas of citizenship is also evident from the letters, as is an awareness, on the part of the letter-writers, of the risk that paupers might reflect badly on their community when requesting help. These appeals protest the exclusion of their authors from the traditional, communal list and they create new channels of aid distribution and reception. ${ }^{37}$

Cooperation of the Jewish population in the five censuses conducted by Sir Moses Montefiore $(1839,1849,1855,1866,1875)$ was much better than in the Ottoman government census conducted in the 1880s. By the mid-1870s, the Ottoman government intended to use population registries and censuses as means of public development and not only as a way of recruiting soldiers and collecting taxes. The population at large, however, and the Jewish population in Jerusalem in particular, was still suspicious about revealing exact demographic information to the authorities. Before the census of the 1880 , the congregation heads that were in charge of reporting the number of households to the government had grossly underreported household numbers. Even the new census, conducted by professionals, only counted 7,100 Jews in Jerusalem. In comparison, the earlier Montefiore census of 1866 enumerated 6,650 Jews living in Jerusalem. The 1875 census counted more than ten thousand Jews. ${ }^{38}$ One can see the difference between lists that were considered judiciary and those that were considered to improve the well-being of Jerusalemites. Though not complete, the Montefiore lists seem to have been deemed beneficial, or less deductive, than the government's. Some of the disparity between the censuses may be related to the fact that some of the Jews living in Jerusalem preferred to hold European citizenship. But even then, one may argue that having foreign citizenship was another strategy used by Jews to not have to appear on the Ottoman lists.

37 Thus, for example, one of the letters reads, "May his compassion be upon me to write my name in his nook (pinkas)." Letter from a Sephardic widow to Sir Moses Montefiore, Jerusalem, 1849, Institute of Microfilmed Hebrew Manuscripts, INL: F.6193.

38 Hashash, "Shinuy Gishot Klape," adapted from Montefiore Census 1866, Institute of Microfilmed Hebrew Manuscripts, INL, F.6159. 


\section{Concluding Remarks: Inside Out?}

Two contesting religious and administrative institutions that practiced different inclusion and exclusion regimes created the lists and tables discussed in this chapter. In the 1850s, the lists of the account book of the Sephardic Kolel included a very short list of individuals, Jews and non-Jews, who interacted with the kolel's financial administration. This list exhibited what the kolel management saw as its religious and political obligations: as a minority it needed to pacify the strong non-Jewish families in Jerusalem, and as a studious congregation it needed to support its scholars. During the 1860 s, this attitude gradually shifted to include more of Jerusalem's Jewish poor in the lists of the kolel's beneficiaries. The English Mission Hospital in Jerusalem practiced an inclusive attitude towards Jews, excluding all others. Women in particular recognized the new venues through which they were able to negotiate their economic and medical situation. Pauper letters reveal the extent to which women and the poor were aware of the principles that guided the different lists that worked to enable or block a person's involvement in the urban life of nineteenth-century Jerusalem. The gap between the Ottoman and Montefiore censuses suggests different responses to governmental and charitable lists and registries. 


\title{
The Tramway Concession of Jerusalem, 1908-1914: Elite Citizenship, Urban Infrastructure, and the Abortive Modernization of a Late Ottoman City
}

\author{
Sotirios Dimitriadis
}

In January 1909, a group of Jerusalem businessmen and notables representing the Jerusalem Chamber of Commerce and the recently founded Banque commerciale de Palestine submitted a proposal for the construction of a tram system to the region's Ottoman authorities. The project contained plans to build an electrical tramway line that would link the historical walled core of the city to the residential neighborhoods that were beginning to emerge in the surrounding countryside. The petitioners' plans soon expanded to include provisions for the construction of a second tramway in the port city of Jaffa. The authorities were asked to draft a concession that would enable them to initiate work on these two lines. By providing transportation to the public of the two cities, the project aimed to expedite a process of urban expansion that had been gaining momentum since the end of the nineteenth century. The prospective investors, a cross-section of Jerusalem's local elites, were fully aware of how the introduction of modern infrastructure had benefitted other Ottoman cities; from the imperial capital in Istanbul to the nearby regional centers of Beirut, Damascus, and Aleppo. They seemed committed to endow their own city with a clear symbol of modern urban life. In the end, however, raising the necessary capital proved beyond the capabilities of the concessionaires, and the plans were eventually shelved by the outbreak of World War I.

Despite its eventual failure, this vignette from the history of late Ottoman Jerusalem could offer insight into the city's development during the period in question. The construction of urban infrastructure played a crucial role, both symbolically and materially, in the modernization of late Ottoman cities. This chapter will showcase the abortive project of the Jerusalem tramway and will place the city firmly within the framework of late Ottoman urban history. By examining the actors that mobilized in support of the project as well as highlighting the interplay between local elites and Ottoman administrators, I intend to study advancements in Jerusalem against the backdrop of developments that occurred during the period in other comparable Ottoman provincial capitals. My aim is to trace the elements, discourses, and practices

(C) SOTIRIOS DIMITRIADIS, 2018 | DOI:10.1163/9789004375741_030

This is an open access chapter distributed under the terms of the prevailing CC-BY-NC-ND License at the time of publication. 
that constituted the specific model of late Ottoman urban development. I do not intend to present an image of failed or uneven modernization, but rather to highlight the historical limits of that same model.

\section{Archives of Ottoman Citadinité}

Like other contributions to this volume, my chapter is structured around the critical application of the methodological aspirations of the field of Ottoman and Mediterranean urban history. With scholarship moving away from the macroeconomic inquiries of the center-periphery school, the study of the cities of the region has largely focused on the arrangements that sustained their diverse environments. Such arrangements included the connection between confessional communities and state institutions, relations among urban elites that transcended the sectarian divide, the steady flow and accommodation of rural migrants, and, in the late Ottoman period, the impact of the Tanzimat reforms and of the European presence. While I look at urban development in late Ottoman Jerusalem through the actions of the city's elites and the local authorities, my approach is informed by the debate around the analytical category of citadinité, a term that points to the significance of urban citizenship, formally and informally defined, in the evolution of eastern Mediterranean cities at the turn of the century. ${ }^{1}$ The concept pertains generally to the web of social practices that constitute citizenship in the Ottoman and Mediterranean contexts, and specifically to the emergence of a sense of urban identity among local notables and officials, structured around urban governance and the provision of services to the public. ${ }^{2}$

More recently, scholars have increasingly focused on the elements of ethnic rivalry, class exclusion, and political contestation, which were inherent to and defined the performance of Ottoman-Mediterranean citadinité. ${ }^{3}$ From that critical perspective, the unsuccessful attempt to construct a tram in Jerusalem

1 See, for example, Robert Ilbert's seminal monograph, Alexandrie 1860-1960: histoire d'une communauté citadine (Cairo: Institut français d'archéologie orientale, 1996), or Mohamed Naciri's earlier "Regards sur l'évolution de citadinité au Maroc," in Middle Eastern Cities in Comparative Perspective: Points de vue sur les villes du Maghreb et du Machrek, ed. Kenneth Brown et al. (London: Ithaca, 1986).

2 Isabelle Berry-Chikhaoui, "Les notions de citadinité et d'urbanité dans l'analyse des villes du monde arabe," Les Cahiers d'EMAM, no. 18 (2009).

3 Malte Fuhrmann, "Cosmopolitan Imperialists and Ottoman Port Cities: Conflicting Logics in the Urban Social Fabric," Cahiers de la Méditerranée, no. 67 (2003). 
on the eve of World War I is indicative of the constitution of the city's elites, the conduits through which they mobilized, and the strategies that they employed. The history of late Ottoman infrastructure demonstrates how elite solidarity and the sense of local citizenship were founded on a commitment to a process of urban transformation modelled after western Europe. Conversely, the eventual failure of the project not only highlights the inherent contradictions of late Ottoman urban elite politics - the rivalries, competing networks, and conflicting strategies that defined the performance of citadinité - but also reveals their relative weakness vis-à-vis external actors.

The plans for the construction of the tram in Jerusalem and Jaffa has left documentary traces spread throughout the Ottoman archives in Istanbul. This chapter is specifically based on the correspondence between the notables and businessmen associated with the Jerusalem Chamber of Commerce and the Banque commerciale de Palestine, on the one hand, and the provincial and central Ottoman authorities, on the other. These documents, along with two maps of the environs of Jerusalem and of Jaffa which sketch the proposed route of the tramlines (figs. 24.1 and 24.2), are preserved in the largely uncatalogued archives of the Ottoman Ministry of Commerce and Public Works (Ticāret ve Nāfía Nezāreti). ${ }^{4}$ I came across this material while working through the archive as part of a broader study of the history of late Ottoman infrastructure. This chapter will also serve as a small demonstration of the utility of this archive for late Ottoman urban history, and specifically for the history of late Ottoman Palestine and Jerusalem.

\section{Projects of Modern Infrastructure in the Ottoman Reform Era}

Proposals like the one concerning the tramlines of Jerusalem and Jaffa were typical for Ottoman cities at the turn of the twentieth century, when both the Ottoman authorities and local elite were preoccupied with the transformation of the cityscape in line with contemporary European standards. Technical modernization had been one of the priorities of Ottoman statesmen ever since the launch of the Tanzimat reforms in the late 183os. Mehmet Ali Pasha's Egypt demonstrated the beneficial effects of technological innovation not only on agricultural production and commerce, but also on the ability of the central state to facilitate its control over its territories. The Ottoman state elites were

4 For the history of the ministry and information on its archive, see Yusuf Sarmay et al., Başbakanlık Osmanlı Arşivi Rehberi [Guidebook to the Ottoman State Archives] (Istanbul: Başbakanlık Devlet Arşivleri Müdürlüğü, 2010), 240-42. 


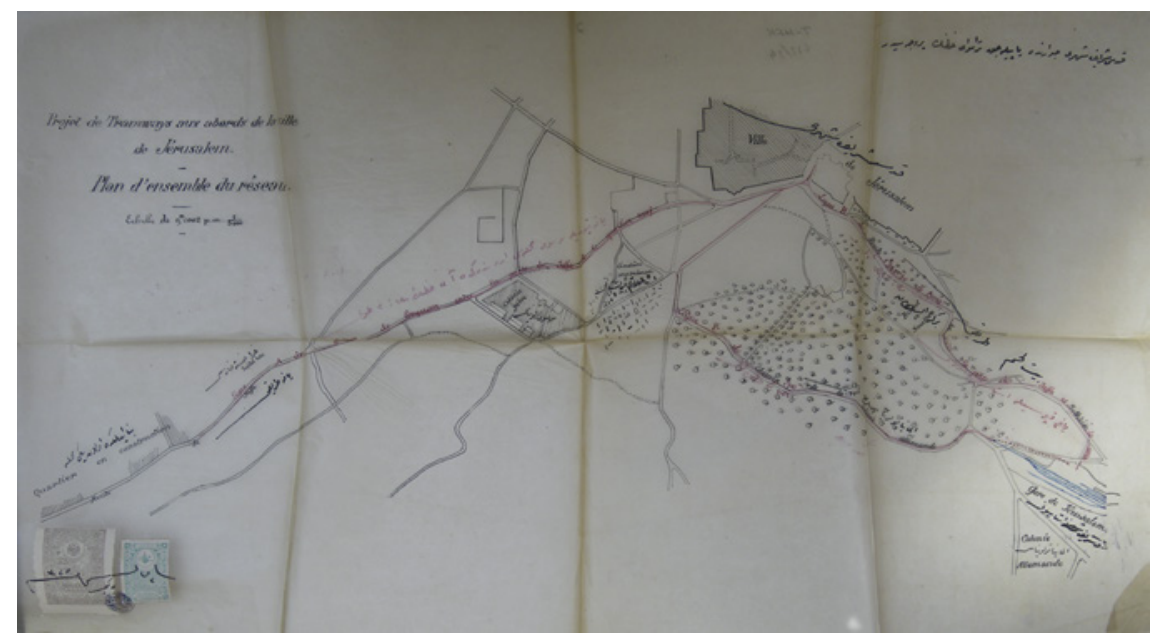

FIGURE 24.1 Tramway project for the suburbs of Jerusalem: outline of the network. OTTOMAN STATE ARCHIVES (BOA), T.HFN 693/34.

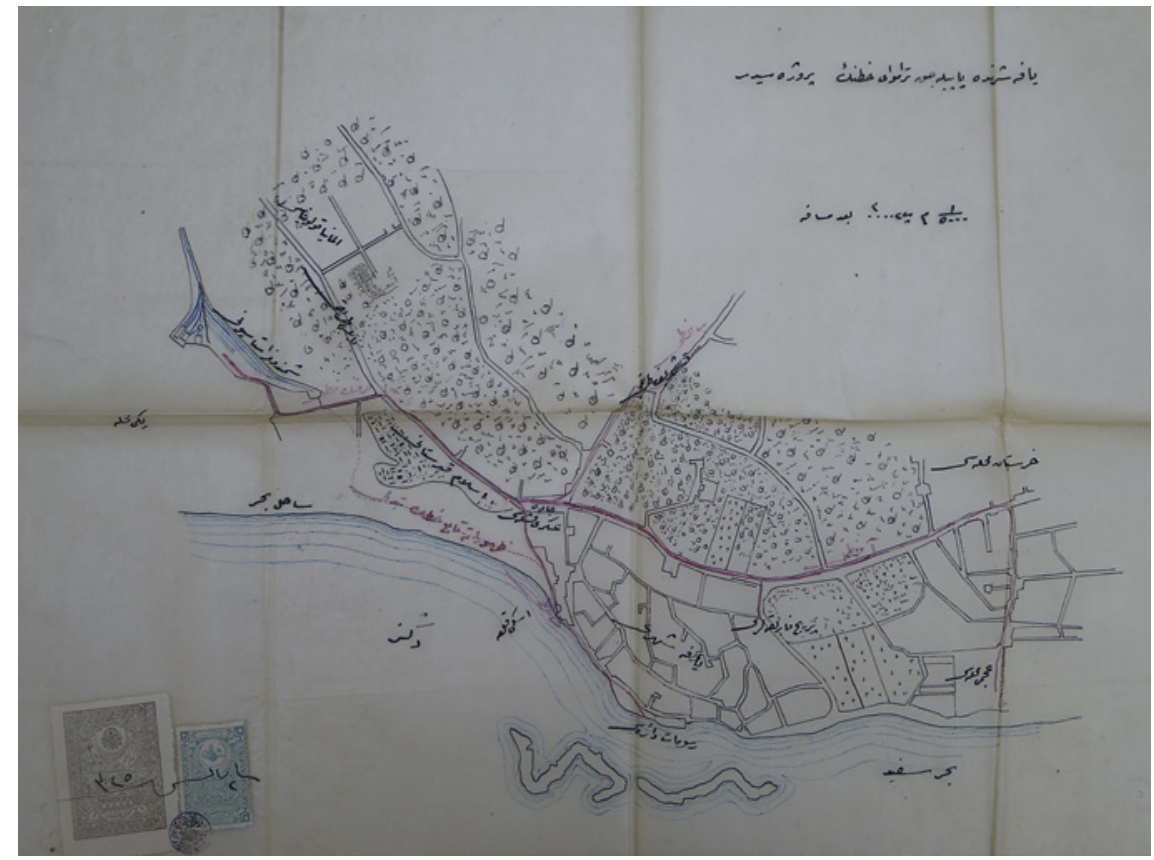

FIGURE 24.2 Plan of the tramline to be constructed in the city of Jaffa. OTTOMAN STATE ARCHIVES (BOA), T.HFN 693/34. 
therefore prepared to offer generous terms in order to attract foreign investments. European engineers courted members of the Ottoman administration and secured concessions to several grand public works projects. ${ }^{5}$ Soon, construction began on the first Ottoman railways in western Anatolia and the Balkans. ${ }^{6}$ In the end, however, expectations built around each of these projects proved overly optimistic. The Ottoman economy proved structurally unable to take full advantage of the potential of the new infrastructure networks. The costs of construction, exacerbated by the need to import almost all materials and most of the labor involved in the projects, far outweighed the modest economic benefits, contributing directly to the Ottoman default of 1875 . The restructuring of the empire's debt under international supervision, which followed the Ottoman defeat in the $1877-78$ war against Russia, allowed public investment in infrastructure to resume by the late 1880 s. $^{7}$

By that point, the Ottomans had taken measures to formalize the drafting process and awarding of concessions. Contracts were negotiated and closely contested between different branches of the imperial government and competing investors, who routinely secured the backing of their respective governments. ${ }^{8}$ For the European powers that were economically and diplomatically active in Ottoman Palestine and the Levant, the strategic value of their control over Ottoman transportation was seen as crucial for their imperial ambitions. Concessionaires attempting to rouse the interest of investors in their projects in the region routinely touted their potential for colonial expansion, as well as their beneficial impact on missionary activity and the traffic

5 For the history of the diffusion of modern technology and its unexpected consequences, see Daniel R. Headrick, The Tentacles of Progress: Technology Transfer in the Age of Imperialism, 1850-1940 (Oxford: Oxford University Press, 1988); also Timothy Mitchell, Rule of Experts: Egypt, Techno-politics, Modernity (Berkeley: University of California Press, 2002).

6 Donald Quataert, "Limited Revolution: The Impact of the Anatolian Railway on Turkish Transportation and the Provisioning of Istanbul, 1890-1908," in Workers, Peasants and Economic Change in the Ottoman Empire, 1730-1914 (Istanbul: Isis, 1993), 64-66; Basil C. Gounaris, Steam over Macedonia, 1870-1912: Socio-economic Change and the Railway Factor (Boulder: East European Monographs, 1993).

7 Edhem Eldem, "Ottoman Financial Integration with Europe: Foreign Loans, the Ottoman Bank and the Ottoman Public Debt," European Review 13, no. 3 (2005). For a comparative perspective from Egypt, see David S. Landes, Bankers and Pashas: International and Economic Imperialism in Egypt (London: Heinemann, 1958).

8 Faruk Tabak, "Imperial Rivalry and Port-Cities: A View from Above," Mediterranean Historical Review 24, no. 2 (2009). 
of visitors and pilgrims. ${ }^{9}$ Conversely, the Ottoman government, also aware of both the strategic and economic significance of modern infrastructure, used the process of awarding concessions as a means to balance out the influence of the competing European powers while minimizing the cost to the state treasury. The need for balance was perhaps greater than elsewhere in Ottoman Palestine. Over the course of the nineteenth century, the Ottoman rule in this region faced a series of challenges including foreign economic encroachment, Great Power rivalry, and an increase in the number of Christian and Jewish migrants.

\section{Jerusalem and Palestine in the Nineteenth Century}

In the early nineteenth century, Jerusalem was a small provincial town of about ten thousand inhabitants, its size constrained by its walls. Its urban economy and daily life were directly aligned to the peasant and nomadic societies of the surrounding region. However, by the eve of World War I, the city had emerged as an Ottoman provincial center; its population growing to around seventy thousand inhabitants..$^{10}$ The city had benefited greatly from the reorganization of the region's administration and its establishment as the seat of an independent district (mutașsarıflik) in $1872-74 .^{11}$ That development formally established the city as the administrative capital of a region increasingly integrated with the wider world. ${ }^{2}$ Accelerating trends that were already extant in

Anthony S. Travis, On Chariots with Horses of Fire and Iron: The Excursionists and the Narrow Gauge Railroad from Jaffa to Jerusalem (Jerusalem: Hebrew University Magnes Press, 2008), 107-11, highlights the use of religious imagery in the promotion of the JaffaJerusalem Railway among French investors.

10 Kemal H. Karpat, Ottoman Population, 1830-1914: Demographic and Social Characteristics (Madison: University of Wisconsin Press, 1985), 184-85, 222-23.

11 Alexander Schölch, Palestine in Transformation, 1856-1882: Studies in Social, Economic and Political Development, trans. William C. Young and Michael C. Gerrity (Washington, DC: Institute for Palestine Studies, 1993), 13-15; Butrus Abu-Manneh, "The Rise of the Sanjak of Jerusalem in the late 19th Century," in The Palestinians and the Middle East Conflict, ed. Gabriel Ben-Dor (Ramat Gan: Turtledove, 1978).

12 There is a vast literature on the history of late Ottoman Palestine, whose overview far exceeds the scope of this chapter. Besides Schölch, a selective list of monographs published in English could include Beshara Doumani, Rediscovering Palestine: Merchants and Peasants in Jabal Nablus, 1700-19oo (Berkeley: University of California Press, 1995); Yuval Ben-Bassat and Eyal Ginio, eds., Late Ottoman Palestine: The Period of Young Turk Rule (London: I. B. Tauris, 2011); and Abigail Jacobson, From Empire to Empire. Jerusalem Between Ottoman and British Rule (Syracuse: Syracuse University Press, 2011). 
the late eighteenth century, the policies of the Egyptian administration of the 1830s, and the Ottoman modernizers that replaced them after 1841 encouraged foreign commerce, expanded the cultivation of export crops, and opened the region to European interests. ${ }^{13}$

As foreign economic influence in the area led to increasing diplomatic influence, the European Powers sought to affirm their respective stakes on the Holy Land for reasons of political and ideological expediency. Jerusalem became one of the hubs of European presence in Ottoman Palestine; significant numbers of diplomats, merchants, missionaries, tourists, and pilgrims passed through the city. Resident Europeans cultivated contacts with the local Christian population, and many Ottoman subjects acquired foreign protection or citizenship. New settlements sprung up along the Jaffa Road, and Jerusalem gradually spilled into its rural environs, with new gates opening up on the old city gate walls and the moat being partially filled and covered over. ${ }^{14}$ The German Tempelgesellschaft established its canton in the Baka valley and from the 1870 on onwards, the city began to attract growing numbers of Jewish settlers..$^{15}$

From the perspective of Istanbul, European influence and migration to Palestine represented a threat to Ottoman rule in one of the empire's outlying but strategically and ideologically vital provinces. Under the rule of Sultan Abdülhamid II (1876-1909), the empire sought to counter the challenges it faced on all fronts with a variety of measures. These ranged from carefully balancing the competing interests of the European Powers to radically increasing the strength of provincial garrisons and the resources of provincial administrations. In the empire's Arab provinces, the sultan actively courted public opinion by emphasizing his caliphal title and invoking the religious allegiance that tied the local population with the imperial center. ${ }^{16}$ Within the framework of the Hamidian policies of "fine-tuning," investment in large-scale

13 For the early nineteenth century and the innovations introduced in Palestine under Egyptian rule, see Doumani, Rediscovering Palestine, 42-46, and Yasemin Avcı, Değişim sürecinde bir Osmanlı kenti: Kudüs (1890-1914) [An Ottoman city in the period of transformation: Jerusalem, 1890-1914] (Ankara: Phoenix, 2014), 52-57.

14 Ruth Kark and Michal Oren-Nordheim, Jerusalem and its Environs: Quarters, Neighborhoods, Villages, 1800-1948 (Detroit: Wayne State University Press), 34-35.

15 For the Tempelgesellschaft, see Mahmud Yazbak, "Templars as Proto-Zionists? The 'German Colony' in Late Ottoman Haifa,' Journal of Palestine Studies 28, no. 4 (1999). According to Avcl, Kudüs, 84, the number of Jewish inhabitants increased from two thousand to forty-five thousand from the early nineteenth century to 1914.

16 Selim Deringil, "Legitimacy Structures in the Ottoman State: The Reign of Abdülhamid II (1876-1909)," International Journal of Middle East Studies 23, no. 3 (1991); Ussama Makdissi, "Ottoman Orientalism," American Historical Review 107, no. 3 (2002). 
public projects - from the erection of public buildings to modern infrastructure networks - proved crucial. Though costly, the construction of roads, telegraph lines, and railways was essential for bringing provinces such as Palestine closer to Istanbul and maintaining order and control. Such projects had more than strategic value. The empire could also use them to provide its European rivals and the region's own local elites with evidence that it was capable of independently introducing the benefits of modern civilization to its territories. At the same time, state interventions in areas such as education and welfare broke the monopoly that missionaries largely enjoyed over such vital services. Though the Ottomans frequently lacked the necessary resources and expertise to carry out such projects, by involving European investors in what Soli Shahvar has termed "concession hunting," they could hope to balance out the interests among the different European powers, and ensure that the latter had a stake in the success of the empire's ongoing modernization project. ${ }^{17}$

Already in the 1850s and 186os, as the Ottoman Empire was granted access to the European bond markets, the imperial government was presented with proposals for the construction of railway lines and other public works projects in the Levant and Palestine. Most of these proposals focused on connecting the port cities on the Mediterranean coast to Damascus, Aleppo, and Jerusalem, as well as important agricultural areas such as the Hawran. These plans, which often contradicted each other and were always of a speculative character, largely failed to attract the attention of either Ottoman or European investors and were shelved during the 1870s. In 1888, with the Ottoman access to the European bond markets restored, the government issued a concession for the construction of a rail line connecting Jerusalem with Jaffa to Joseph Navon, a local Jewish notable and entrepreneur who had the support of George Franghia, the head engineer of the province. Almost immediately after receiving the concession, Navon sold it to French investors. The Société du Chemin de Fer Ottoman de Jaffa à Jérusalem raised the necessary capital of about 14 million francs, and construction on the line was completed in $1890 . .^{18}$ As a balancing act, the Ottomans gave the concession for the construction of a second regional line, which would connect Damascus to Haifa, to the British Syria Ottoman Railway Company in 189o. The company, however, failed to complete the project in the agreed timeframe and eventually filed for bankruptcy. When

17 Soli Shahvar, "Concession Hunting in the Age of Reform: British Companies and the Search for Government Guarantees; Telegraph Concessions through Ottoman Territories, 1855-1858," Middle Eastern Studies 38, no. 4 (2002).

18 Eduard Pech, Manuel des Sociétés anonymes fonctionnant en Turquie, $5^{\text {th }}$ ed. (Constantinople: Gerard Fréres, 1911), 56-58. 
construction began on the Hejaz Railway in 1900, the Ottoman government decided to construct a branch of the line to Haifa, which was completed in $1905 .{ }^{19}$ The financing of such ambitious technical projects directly from the state budget, assisted only by donations from Muslim communities within and outside the empire, signaled a more assertive policy of reaffirming Istanbul's writ over Palestine and the empire's Arab provinces. The railroad became a physical manifestation of the tenets of Ottoman imperialism in the region, and the stations of its different lines were adorned with a number of public buildings and monuments celebrating the civilizing mission of the sultan. ${ }^{20}$

\section{Urban Elites and the Construction of Urban Infrastructure}

The construction of railways remained a complex undertaking that most often depended on the influx of European capital, or at least relied on European technical expertise. At the same time, the late nineteenth and early twentieth century witnessed the construction of several smaller-scale public work projects across Ottoman Palestine. Some, such as new roads for the transportation of goods, people and troops, and irrigation canals to increase production in areas under cultivation, targeted rural areas. ${ }^{21}$ The Ottoman government was also interested in investing in the infrastructure of the region's rapidly growing towns and providing them with amenities that were becoming increasingly common in other cities in the empire. Beirut and Damascus were both equipped with electric lighting and a tram transportation system in $1907 .{ }^{22} \mathrm{To}$ facilitate commerce and ship traffic in Jaffa, plans for the construction of a new customs house and better port facilities were finally put in motion in $1908 .^{23}$ Because these projects were small in scale, they could be implemented using local resources; engineers from central and provincial administrations, and

19 Jacob Norris, Land of Progress: Palestine in the Age of Colonial Development, 1905-1948 (Oxford: Oxford University Press, 2013), 1-5, 47ff.

20 Michael Talbot, "The Exalted Column, the Hejaz Railway and Imperial Legitimation in Late Ottoman Haifa," Urban History 42, no. 2 (2015).

21 The archives of the Ministry of the Privy Purse (Hazine-i Hassa) contains vast amounts of information on efforts to improve cultivation in the region, and especially in estates that belonged to the sultan, such as 'Ayn al-sultan in Jericho. For examples, see Ottoman State Archives (вОА), нн.THR 27/2 and 325/13.

22 Jens Hanssen, Fin de Siècle Beirut: The Making of an Ottoman Provincial Capital (Oxford: Oxford University Press, 2005), 101-3; Stefan Weber, Damascus: Ottoman Modernity and Urban Transformation (1808-1918), vol. 1 (Aarhus: Aarhus University Press, 2009), 103-11.

23 BOA, T.HNF 693/34, Etude et construction des ports maritimes dans l'empire Ottoman. 
capital raised locally. Like in other comparable Ottoman cities, such projects held great appeal for Jerusalem's elites. The prospect of modernizing the urban fabric, coupled with the potential for financial gains, mobilized local notables. Building on their control over the agricultural economy and extensive kinship networks that expanded throughout and beyond Palestine, notable Jerusalemite families such as the al-Husaynis and the al-Khalidis established themselves as partners of the Ottoman state in the governance of the region. They maintained strong ties to the central administration, either directly or through institutions such as the Jerusalem municipality and the local chamber of commerce. As active participants in agricultural and commercial ventures, they also cultivated good relations with the European commercial and banking institutions active in the region.

By utilizing their contacts, such notable families could acquire concessions for public works projects in their name, then act as intermediaries between the state, European investors, and Jerusalem's general public. On the one hand, by taking control of Jerusalem's urban development, local notables could assert their position against the challenge represented by newly arrived European and Jewish migrant groups. On the other hand, the more the Ottoman state invested in public works in Jerusalem, the better the city's opportunities were for establishing itself as a major commercial and administrative center. In the late nineteenth century, local elites in Ottoman cities such as Beirut, Damascus, and Jerusalem were all lobbying their government to secure the construction of infrastructure in their cities. Consolidating their cities as the main transit stations and railheads in their respective regions was a potent way to secure the monopoly of commerce with their hinterlands at the expense of regional rivals. ${ }^{24}$

The political climate in the empire seemed to favor the initiatives of the notables. During the summer of 1908, the Young Turk Revolution had forced the sultan to reintroduce constitutional rule in the empire. ${ }^{25}$ In autumn 1908 , a group of local entrepreneurs associated with Süphi Pasha and the Jerusalem Chamber of Commerce established the Banque commerciale de Palestine as a means of coordinating investments in the economic development of the

\footnotetext{
24 For the competition between Haifa, Acre and Tripoli for the destination of the railroad, see Norris, Land of Progress, 3 off.

25 The Ottoman constitution of 1876 had been prorogued by Abdülhamid in 1878 . For recent historiographical approaches to the Young Turk Revolution and its impact on Ottoman Palestine, see Yuval Ben-Bassat and Eyal Ginio, "Introduction: The Case Study of Palestine during the Young Turk Era," in Late Ottoman Palestine: The Period of Young Turk Rule, ed. Yuval Ben-Bassat and Eyal Ginio (London: I. B. Tauris, 2011).
} 
region. ${ }^{26}$ The bank, whose shareholders included a cross-section of the city's commercial and land-owning elites, represented an attempt on the part of the local elites to play a more pronounced role in the region's economy, in line with the reassertion of national pride represented by the Young Turk movement in Istanbul. As such, it became involved in infrastructural projects and petitioned the government for a concession for the provision of Jerusalem with water through a modern system of pipes and pumps. The project stirred several debates between the central government, the businessmen associated with the Banque commerciale, and the municipality. The project eventually became mired in controversy when the municipality broke its contract with the Banque commerciale and awarded the concession to a German engineer, Carl Francke. ${ }^{27}$ A similar initiative to introduce street lighting in the city was blocked because of a dispute between the municipality and European consuls. The latter refused to acquiesce in the taxation of non-Ottoman residents to help finance the cost of the project. ${ }^{28}$

Within this framework, in January 1909, the provincial administration in Jerusalem was presented with a petition for a concession to construct an electrical tramline in Jerusalem with provisions to construct a similar line in Jaffa. The petition also called for the provision of electric lighting in the two cities. The Jaffa-Jerusalem Railway had attempted to secure a similar contract in 1907, but this plan had been shelved after the municipality proved unable to contribute to the cost of construction. ${ }^{29}$ The new petition was launched in the name of the Banque commerciale, specifically its founding members; al-Hajj Yusuf Wafa, who was the chamber of commerce president, Isma'il al-Husayni, Albert Antébi, and Selim Ayub. ${ }^{30}$ The petitioners submitted topographic plans for the two projects: the Jerusalem network (fig. 24.1) involved three lines that

26 Michelle U. Campos, Ottoman Brothers: Muslims, Christians, and Jews in Early TwentiethCentury Palestine (Stanford: Stanford University Press, 2011), 173-77.

27 Ibid., $177-78$. For a broader study of Jerusalem's chronic water shortages, and attempts to provide the city with water, see Vincent Lemire, La soif de Jerusalem: essai d'hydrohistoire (1800-1948) (Paris: Publications de la Sorbonne, 2010). For the dispute between the chamber of commerce and the municipality, set against the backdrop of the rivalry between the al-Husayini and the al-Khalidi families, see Schölch, Palestine in Transformation, 247-49.

28 Lemire and Avcl, "De la modernité administrative a la modernisation urbaine: Une réévaluation de la municipalité de Jérusalem, 1867-1917," in Municipalités méditerranéennes: les réformes urbaines ottomanes au miroir d'une histoire comparée (Moyen-Orient, Maghreb, Europe méridionale), ed. Nora Lafi (Berlin: Klaus Schwarz, 2005), 103-4.

29 Campos, Ottoman Brothers, 91.

$30 \quad$ BOA, T.HFN 693/34, 5 Mayıs 1325 [May 18, 1909]. 
would connect the walled city to the growing suburban settlements. All three lines terminated at Jaffa Gate, which had begun to evolve into the administrative center and the cultural heart of Jerusalem. ${ }^{31}$ Line A would move westward along the Jaffa Road, past the Muslim cemetery, and would terminate at the Ottoman hospital, covering a distance of 2,180 meters. ${ }^{32}$ Line B would connect the city to the Jaffa-Jerusalem Railway station, at Baq'a, passing to the north of Birkat al-Sultan and along the Bethlehem Road, for a total length of about 1,340 meters. Finally, Line $C$ would also terminate at the train station, this time from the south, after passing by the German colony. ${ }^{33}$ The plan for Jaffa (fig. 24.2) proposed the construction of a line between the city's rail station and the European quarter to the south of the city, with a smaller line branching off to the port and the customs house. ${ }^{34}$

The petitioners entered negotiations with the provincial government on the issues of the convention and the scope of the concession, which would be based on the recent concession for the construction and operation of the electric trams and lighting of Salonika and Beirut. ${ }^{35}$ According to the draft convention, the concession would have a duration of fifty years, after which point it would pass to the respective municipal authorities. The concessionaires pledged to establish a joint stock company, in accordance with Ottoman corporate law, to direct the construction and operation of the two projects. The company was obliged to begin construction within six months of the finalization of the contracts and the maps, and the projects had to be operation within five years of that date. The company would be exempt from dues on any equipment and material necessary for the construction imported into the region, as well as from property tax on its buildings. The Ottoman government reserved the right to any antiquities discovered during construction. Company personnel would have to be Ottoman subjects, and those coming into contact with the public had to be conversant in the local idiom (lisann-i mahaliye). Both sides agreed that the company would be paid 30 centimes for every kilowatt-hour

31 Avcl, Kudüs, 245ff.

32 Ibid., 236-37.

33 BOA, T.HFN 693/34, Projet de Tramways aux abords de la ville de Jerusalem - Plan d'ensemble du réseau. For the German colony of Jerusalem, see Yehoshua Ben-Arieh, Jerusalem in the 19th century: Emergence of the New City (Jerusalem: Yad Izhak Ben-Zvi; New York: St. Martin's Press, 1986), 127-32. BOA, T.HFN 693/34, Yafa şehrinde yapılacak tramvay hatının projesidir, 2 Mayıs 1325 [May 15, 1909]. 
of electricity consumed, and the prospective concessionaires deposited 1,000 Ottoman liras as guarantee. ${ }^{36}$

In May, the provincial council (meclis-i idāre) approved the draft convention and petitioned the Ministry of Commerce and Public Works in order to approve the petitions and launch the project. ${ }^{37}$ The resolution issued by the council vouched for the dependability of the concessionaires and their ability to cover the costs of construction, which were then estimated at 20,00o liras. ${ }^{38}$ The council also cited the necessity of endowing the two cities with a tram system, as the absence of modern means of transportation was detrimental to the conduct of commerce and to further urban expansion. ${ }^{39}$

Having secured the backing of the provincial authorities, al-Hajj Yusuf Wafa continued to pressure the municipal authorities for their endorsement and support for the project. In a memorandum to the provincial governor, the president of the chamber of commerce defended the clauses containing allowances on behalf of the company. He also requested the governor's mediation to convince the municipality to partially cover the cost of construction specifically paying for the paving of the streets the tramlines would pass through. According to him, the construction and operation of a system of modern transportation and electric lighting seemed straightforward in Ottoman port-cities such as Izmir, Salonika, and Beirut, or even Damascus, which had ample access to water. In Jerusalem, however, located far from the coast, where water was scarce, costs would be higher than anticipated. ${ }^{40}$ Without the support of the municipality, Wafa expressed doubts about the feasibility of the project and the ability of the concessionaires to fully finance it. To that end, he submitted a series of additions to the original convention which in his view would maximize the economic utility of the line, as well as its benefits to the inhabitants of Jerusalem and the local economy. He proposed that the convention include provisions for the extension of the tramline so that it would reach the Mount of Olives to the east and Bethlehem to the south within eight years. That branch of the network was to operate both a passenger and a freight

36 BOA, T.HFN 693/34, Küds-i Şerif ve Yafa Tramvaylar Muḳāvelenāmesi.

37 For the representative functions of the provincial council, see Campos, Ottoman Brothers, $166-68$.

38 The annual municipal budget was 12,000-14,00o liras just before the war. Avcı and Lemire, "De la modernité," 105.

39 BOA, T.HFN 693/34, 5 Mayis 1325 [May 18, 1909].

40 Besides pointing to the ongoing dispute about the water supply concession of Jerusalem, Yusuf Wafa was also probably suggesting that the electricity would be produced not by gas or oil, but in a steam plant. 
service, thus easily connecting the rural producers of the environs of Jerusalem with the city's markets and train station. ${ }^{41}$ The company would pledge to procure wagons wide enough for the needs of the passengers, divided into two classes, with separate spaces for female family members (haremlere mahșuss $).{ }^{42}$ Finally, the ticket price was set at 20 paras for first class and 10 paras for second class travelers, with police and military officers enjoying a 50 percent discount. ${ }^{43}$

\section{Conclusion: End of the Line?}

In the end, Wafa's concerns proved well-founded. The concessionaires were unable to secure the backing of the municipality or find other investors interested in the project, and withdrew their offer. In 1914, the Ottoman central government attempted to relaunch the project along the same terms, using the draft convention of 1909. The new plan proposed the issue of a single concession for all three stalled infrastructure projects of Jerusalem: the tram, the street lighting, and the modernized water system. A preliminary convention was signed between the Jerusalem municipality and Evripidis Mavrommatis, a Greek Ottoman from Istanbul, but the outbreak of World War I put the project on hold. ${ }^{44}$

This vignette from the history of late Ottoman Jerusalem illustrates the extent to which the provincial authorities and the elites wanted to transform their city. The inspiration for the modernization of the urban fabric did not necessarily come from the great capitals of Europe, but rather from the burgeoning urban centers of the Ottoman Empire, that is, cities such as Istanbul, Salonika, Izmir, and Beirut, which had seen a rapid transformation in the preceding decades. The developments that followed the revolution of 1908 gave certain notables and businessmen of Jerusalem the opportunity to attempt to put in motion their own vision for their city. Represented on the board of the newly founded Banque commerciale, and with the support of Süphi Pasha and the provincial government, they articulated their business plans

\footnotetext{
41 BOA, T.HFN 693/34, 23 Mart 1325 [April 5, 1909].

42 For the negotiation of physical contact and gender within the enclosed space of a tram wagon, see James Ryan, “'Unveiling' the Tramway: The Intimate Public Sphere in Late Ottoman and Republican Istanbul," Journal of Urban History (published online April 2016), accessed February 2, 2018, DOI:10.1177/oog6144216641070.

43 BOA, T.HFN 693/34, 23 Mart 1325 [April 5, 1909].

44 Avcı, "Jerusalem and Jaffa in the Late Ottoman Period: The Concession-Hunting Struggle for Public Works Projects," in Late Ottoman Palestine: The Period of Young Turk Rule, ed. Yuval Ben-Bassat and Eyal Ginio (London: I. B. Tauris, 2011), 91-92.
} 
in the discourse of technical modernization and urban development. They also stressed the need for Jerusalem and Jaffa to "catch up" with other cities of the region in terms of state investment and infrastructure. From this perspective, the introduction of tram transportation in the two cities (similar to the attempts to construct a modern water supply system and street lighting in Jerusalem) would facilitate further development and ensure that they acquired the technical artifacts of modern civilization that characterized Ottoman cities at the turn of the century.

The eventual failure of these endeavors, however, also reveals both the relative disadvantages of Jerusalem compared to the larger Ottoman cities as well as a general crisis of the political and economic model that had sustained the development of the empire's cities. Beyond Jerusalem's relative isolation, which made the costs of construction higher, the atypical presence of non-Ottomans in the city - be they European residents, Templar settlers or Jewish migrants and the protection these groups enjoyed from Ottoman interference thanks to the strong presence of the European diplomatic missions, meant that the local Ottoman institutions were relatively weak and enjoyed limited resources. At the same time, the initiatives of the Banque commerciale and the chamber of commerce were directly challenged by the Jerusalem municipality, which undermined the common front of local notables and the provincial administration with regard to Istanbul. Rather than a result of a family feud between the al-Husayni and al-Khalidi clans (that is, a subjective failing of the Ottoman elites of Jerusalem), the dispute between these institutions should be attributed to the novel political conditions in the period following the Young Turk Revolution. The reintroduction of constitutional rule brought along the concept of mass politics, turning local institutions from sites of manufacturing consent between the state and local notables to sites of contest between different political groupings. ${ }^{45}$ In these conditions, the elite arrangements that had spearheaded urban development could not be maintained. ${ }^{46}$ Large-scale investment in infrastructure would resume after the end of the war, but in the very different political and economic environment of the British Mandate.

45 This argument is more broadly expressed in Campos, "Making Citizens, Contesting Citizenship in Late Ottoman Palestine," in Late Ottoman Palestine: The Period of Young Turk Rule, ed. Yuval Ben-Bassat and Eyal Ginio (London: I. B. Tauris, 2011).

46 The collapse of cohesion among Ottoman elites as a result of new political challenges was not unique to Jerusalem, but can be observed in cities throughout the empire. For the example of Izmir, see Vangelis Kechriotis, "Protecting the City's Interest: The Greek Orthodox and the Conflict Between Municipal and Vilayet Authorities in İzmir (Smyrna) in the Second Constitutional Period," Mediterranean Historical Review 24, no. 2 (2009). 


\title{
Waqf Endowments in the Old City of Jerusalem: Changing Status and Archival Sources
}

\author{
Salim Tamari
}

The Old City of Jerusalem is unique in its predominance of endowed, or waqf, properties (public and family-based). At the end of the twentieth century, waqf properties in all categories totaled 1,781 units, or 54 percent of all properties in the Old City. ${ }^{1}$ In terms of area, these properties amounted to 348 dunams ( 1 dunam $=0.247$ acres), or about 66 percent of the total area of the Old City. One quarter of those were family endowments (waqf dhirrì), equivalent to 567 units or 84 dunams. The revenue of these endowments was assigned to both private and charitable purposes, which will be explained below. The task of finding accurate sources for interpreting the scope and character of these properties has been a major challenge for the historian. Court records and land registry archives have been plagued with problems of accessibility, shifting registration procedures, and proper bureaucratic organization of registered properties. An additional problem was the layers of leasing and subleasing of waqf properties, some of which were never registered. Since 1967 , another problem has emerged: the abuse of archaic legal categories of endowments by the State of Israel and its propensity to sequester waqf property on behalf of the state and settler groups. In this chapter I will examine how new archival sources can help to shed light on the extent and nature of these family and public endowments. These archival sources include municipal tax registries for Old City properties, aerial photography and on-site architectural surveys.

Several historical sources have examined the evolution and changing uses of these endowments, which will be cited in this review. Of immediate relevance to our study is a survey undertaken by the Arab Studies Society and the Welfare Association in the last two decades, from which the statistical material for this analysis is derived. ${ }^{2}$ Of the historical sources, two of the most cited

1 "The area under examination" in the original survey refers to the Muslim, Christian and Armenian quarters. The expanded Jewish quarter (after 1967) will feature in a separate volume of the survey, due to be published in 2018. In this essay I examine Jewish properties and endowments and compare them with the material for the three other neighborhoods.

2 See previous footnote.

(C) SALIM TAMARI, 2018 | DOI:10.1163/9789004375741_031

This is an open access chapter distributed under the terms of the prevailing CC-BY-NC-ND License at the time of publication. 
are Mujir al Din's classic study al-Uns al-jalil bi-tarikh al-Quds wa-l-Khalil ${ }^{3}$ and Muhammad Ghushah's more recent study of Islamic waqf and its history. ${ }^{4}$ The significance of these sources lies in their documentation of the changes in the size and status of these properties during the Ayyubid, Mamluk, and Ottoman periods. Most of the historical sources suffer from two major pitfalls: they do not examine the fate of waqf properties after the end of the Ottoman era (1917). They mainly address the conditions of Islamic family and public waqf, but not those of non-Islamic institutions and owners. This gap is especially problematic since Rum Orthodox and Armenian Church endowments alone control 131 dunums, or 25 percent of the area under study. A few historical works have addressed this lacuna in the late Ottoman period, including 'Abd al-Aziz Madani's Islamic Waqf in Jerusalem and its Environment ${ }^{5}$ and Ahmad Hamid Ibrahim al-Quda's The Christian Presence in Jerusalem in Ottoman Documents. ${ }^{6}$

This chapter addresses the status of waqf properties in Jerusalem during the second half of the twentieth century. It makes use of spatial field surveys and GIS technologies and draws on several available archival sources including aerial surveys and municipal tax records. The available data still contains a number of gaps and inconsistencies resulting from the historical shifts in regulations governing endowed properties and from multiple leases and subleases of these properties. We have pointed to the limits and pitfalls in our assessments of the size and nature of these loopholes, but hope that the new data utilized here may rectify earlier shortcomings. ${ }^{7}$

3 'Abd al-Rahman ibn Muhammad al-'Ulaymi, Al-Uns al-jalil bi-tarikh al-Quds wa-l-Khalil [The glorious history of Jerusalem and Hebron] (Najaf: al-Mațba'ah al-Ḥagdarīyah, 1968). For a contemporary analysis, see Donald P. Little, "Mujīr al-Dīn al-'Ulaymī's Vision of Jerusalem in the Ninth/Fifteenth Century," Journal of the American Oriental Society 115, no. 2 (1995).

4 Muhammad Hashim Musa Dawud Ghushah, Al-Awqāf al-Islamiyya fi-l-Quds al-sharif: dirasa tarikhiyya muwathaqa [Islamic waqf in Jerusalem: a historical documentation] (Istanbul: IRCICA, 2009).

5 Ziyad 'Abd al-Aziz Madani, al-Awqaf fi al-Quds wa-Jiwariha khilal al-qarn al-tasi' 'ashr al-miladi, 1215 H/180oAD-1336H/1918AD [History of awqāf in Jerusalem and its environs, 18001918] (Amman: al-Madan̄̄, 2004); see also Ziyad 'Abd al-'Aziz Madani, al-Awqaf al Masihiyyag fi-l Quds wa jiwaraha fil Qarnain al Thamin ashar, wal tasi' ashar al miladiyyin, 1700-1918 [Christian endowments in Jerusalem and its environs, 1700-1918] (n.p., 2010).

6 Ahmad Ḥamid Ibrahim Quḍa, Nasarả al-Quds: dirasa fi daw' al-wathảiq al-'uthmaniyya [The Christians of Jerusalem in light of Ottoman documents] (Beirut: Markaz Dirāsāt al-Waḥdah al-Arabīyah, 2007).

7 For a discussion of these limitations, see the monograph from which this essay is extracted: Munir Fakhr ed-Din and Salim Tamari, [Jerusalem properties and endowments in the 2oth century] (Beirut: Institute for Palestine Studies, forthcoming 2018, in Arabic). 


\section{Charitable and Family Waqf}

The primary distinction in endowed properties in Palestine is between those estates allocated for general charitable uses (waqf khayrī) and those confined for family use (waqf dhirrī) in perpetuity. Another distinction differentiates between what is known as "proper" waqf (waqf sahịh), pertaining to privatelyowned land, and "improper" waqf, pertaining to what was originally royal or sultanic land (amiriyya land) which had been allocated for the benefit of persons or charitable institutions but was retained in the control of the state or of the state treasury (beytülma $\bar{l})$. ${ }^{8}$ I will examine below the ramification of this distinction for Jerusalem's waqf properties when I discuss the extensive holdings of Hasseki Sultan endowments.

Insofar as the first distinction is concerned, there is an overlap between dhirri and charitable waqf, but only in one direction. Family waqf can acquire charitable functions in several cases, but most commonly when the revenue from a family property is allocated for the benefit of the needy from among kin members and outside the family. It may also be transferred entirely outside of family use and used for general welfare; this is the case when the lineage of the endowing family is terminated. ${ }^{9}$

The most common uses of both khayri and family waqf in Jerusalem are known as tảjir and tahkìr (short- and long-term leasing). The long-term leases are a source of continued conflict. Both cases confer leaseholds for a period not exceeding three years. It was assumed in the law that the mutawalli (supervisor) of the waqf would terminate the contract at the end of the three years in order to preserve the legal status of endowed property. Nevertheless, this principle was constantly violated in practice, especially in the case of hikr agreements. Hikr (literally "monopoly") is a long-term lease which allows the lease tenant, with the permission of the mutawalli, to build new constructions on the surface of endowed properties. It also allows the leasee (al-muhtakir) to sell, lease, or place under a new endowment the newly-constructed property without undermining or altering the status of the original endowed property. ${ }^{10}$ There are several negative consequences of hikr leases for the property holder. The most common of these consequences is the deterioration in the value of the rent over time due to inflation. Other consequences are the

Riyad Shahin and Ibrahim Ni'matallah, Al-Mulkiyyat wal Darảib fi al Ramlah fi Sijjilat al-Mahakim al-Shariiyya 1864-1914 [Land ownership and taxation in Ramla from Islamic court sijillāt, 1864-1914] (Gaza: Gaza Islamic University, 2005).

$9 \quad$ Ibid., 8 .

$10 \quad$ Ibid., 9-10. 
erosion of the legal owner's ability to maintain their rights during a regime change, and loss of the original ownership documentation. Shahin refers to the case of hikr properties belonging to the Radwan family in Ramla, similar to many cases in Jerusalem's Old City, in which the total annual waqf revenue amounted to merely ten piasters after decades of tenant occupancy. ${ }^{11}$

\section{Waqf in Historical Perspective}

The earliest documentation of waqf properties in Jerusalem date to the Ayyubid period, following the liberation of the city from Frankish rule. Sultan Saladin and subsequent governors began to consolidate the Islamic charitable institutions through the establishment of a network of schools, soup kitchens (takaya), and hospices to serve the city's population. Those investments were resumed after a long disruption, following the end of the Third Crusade, during Mameluke rule. The most important endowments then were those established by Sultan Dhaher Baybars (AD 1269), Emir Tankiz (1329), and the endowments of Prince Manjak (1355), and exist in extant archival sources of tax records and court sijillät. ${ }^{12}$ A more rigorous record of later endowments began in the Ottoman era during the sixteenth century. Those are documented in court sijillāt and in $\underline{H} \bar{a} k \hat{a} \bar{a} n \bar{\imath}$ records (known as Tapu tahrīr defterleri)..$^{13}$

Probate courts continued to register family waqf properties in Jerusalem after the sixteenth century, but a comprehensive survey of these estates is difficult due to the disorganized and dispersed character of these records. Major endowments belonging to the major potentates, including to the 'ayan of Jerusalem, such as the al-Khatib, Danaf, Ansari, Husayni, Khalidi, Budeiri, Imam, Quayder, Turjman, Nashashibi, and Quttaineh families, are well-documented. ${ }^{14}$ These wealthy family estates make up a substantial proportion of all family endowments in the city of Jerusalem.

\footnotetext{
11 Ibid., 11-12.

12 Muhammad Ghusha, "Al-Mulkiyyat al-Waqfiyya al-Maqqdisiyyah fil-Qarn Sadis-'ashr min khilal al-sijillat al "Uthmanioyyah" [Jerusalem waqf properties in the 16th century in Ottoman sijjils, dafters, manuscripts], in Awraq 'A'iliyya: Dirasat fi Tarikh Filastin al mu'asir [Family papers: studies in contemporary social history], ed. Muhammad Zakariyya et al., 2nd ed. (Ramallah: Institute for Palestine Studies, 2011), 241.

13 Ibid., 243-44. See also "List of Published Ottoman Tax Registers (Tahrir Defterleri)," Economic History of the Ottoman Empire website, n.d., accessed January 19, 2018, http:// ottoman.uconn.edu/bibliography/published-tahrirs/.

14 The list of these endowments and their size appear in table G-3, in Fakhr ed-Din and Tamari, Jerusalem Properties.
} 
Dhirrī endowments are not exclusive to Muslim families - Jewish and Christian family properties also possess them. The combined Christian public and private endowments constitute a very substantial proportion of all endowments in the city. Ziad al-Madani has estimated the number of Christian family waqf to constitute 48 percent of all dhirri waqf contracts for Jerusalem during the early twentieth century. Public endowments were bigger in size due to the nature of church and monastic estates in the city.

Abdul Karim Rafiq has examined the changing character of dhirri endowments in Palestine in his analysis of the Dabbas family waqf recorded in the Jaffa sharica court records on April 4, 1859. ${ }^{15}$ The endowment consists of urban real estate, agricultural landed property, and transferable assets in the cities of Jaffa, Ramla, Lydda, and Jerusalem. Rafiq argues that even though this endowment was registered by a Christian Orthodox family from Jaffa, the conditions of Islamic dhirri waqf apply. The conditions are the registration of endowed estates, the stipulation of the beneficiaries of its revenue, and the determination of its future disposition in the case of the death or demise of the original beneficiaries.

This endowment has all the main attributes of major family endowments. For example, it contains mansions, residential apartments, and orange groves (bayyarat) in the vicinity of Jaffa and Lydda as well as in Jerusalem. It also includes soap factories, vineyards, and courtyards (ahwāsh). The endowment also covers transferable assets such as olive oil jars and qantars (a measure of weight) of soap and rice. It also contains monetary assets such as gold and silver. The waqf contract lists the categories of beneficiaries from the dhirri endowment after deductions are made for the nazir of the waqf in the form of a salary for this position. The nazir in this case is the mutawalli of the endowment - normally chosen from among the mature male adult children of the waqif (endower), for rarely is the nazir a female or an outsider to the family. If the nazir fails to fulfill the conditions of his tenure, he may be removed from office. ${ }^{16}$ The usual beneficiaries of the waqf are the sons and daughters of the endower for several stated numbers of generations (usually three or four), after which it continues with the male line only. This changed condition is meant to block the transfer of the waqf revenue to the benefit of "outsiders" (aghrab, lit. "strangers"). A portion of the revenue is often allocated for the poor within the religious community of the donor. In this last case, family waqf and general (khayrī) waqf become identical.

\footnotetext{
15 Abdul Karim Rafiq, "The Dabbas Waqfiyyah at the Jaffa Court, 1 Ramadan 1275/April 4, 1859 and its Spatial, Economic and Social Attributes," Kronos 30 (2014): 77.

16 Rafiq, "The Dabbas," 78.
} 
Rafiq notes that endowed properties used to be leased for a period not exceeding three years, as stipulated by the dominant Hanafi legal school during the Ottoman period. Yet this stipulation was often violated, and increasingly so during the British Mandate period. ${ }^{17}$ An important difference between Islamic and Christian dhirri endowments is that Muslim contracts usually do not stipulate that the beneficiaries of the endowments must remain within the religious sect of the original endower, whereas this is common in Christian contracts. This difference is due to the rarity of religious conversion in Muslim cases. ${ }^{18}$

\section{Particularities of the Jerusalem Waqf}

Philanthropic waqf (khayrī) properties in Jerusalem are distinguished by their proportionally large size and numbers compared to similar endowments in the rest of the Middle East. Yitzhak Reiter, a leading authority on religious endowments, notes that the number of waqf properties in Jerusalem has surpassed on a per capita basis those of Istanbul, Cairo, Aleppo, and Bursa. ${ }^{19}$ Initially this was due to the religious importance of Jerusalem, through which many successive Sultans and princes in the Ayyubid, Mamluk, and Ottoman periods assigned local endowments for the service of pilgrims and the urban poor. In most cases they established waqf institutions to immortalize their or their wives' names. Celebrated examples of such cases are the Hasseki Sultan waqf, established by Princess Roxelana, and the Abu Madyan waqf in the Mughrabi Quarter, established by Abu Madyan al-Ghawth in AD 1320 to serve as residencies for pilgrims from the Maghreb in the vicinity of al-Buraq. These residencies later evolved into the Old City's Moroccan Quarter. ${ }^{20}$

During the Ottoman period, khayri waqf institutions proliferated in the form of schools, religious seminaries (zawāya), and Sufi soup kitchens (takaya). Muhammad Dawud Tamimi estimates that public waqf institutions belonging to Sufi groups constituted 46 percent of all endowed properties

17 According to sharica principles, endowed leases are normally contracted for one year in real estate, and for three years in agricultural properties. See Rafiq, "The Dabbas," 79.

18 Ibid., 81.

19 Yitzhak Reiter, Islamic Institutions in Jerusalem: Palestinian Muslim Organization under Jordanian and Israeli Rule (The Hague: Kluwer Law International, 1997), 26-27.

20 Ghusha, "Al-Mulkiyyat al-Waqfiyya" [Jerusalem waqf properties], 244. 
during the sixteenth century. ${ }^{21}$ According to Reiter, Jerusalem had the lion's share of all waqf properties in Palestine, noting that khayri waqf registered in sharica courts for Jerusalem amounted to 86 units, compared to 144 units registered in all other cities and villages, during the Ayyubid, Mamluk, and early Ottoman eras. ${ }^{22} \mathrm{He}$ notes the enhanced role of both khayri and private (family) waqf during the late Ottoman period, as well as during the British Mandate. Another surge in family waqf occurred during the period of Israeli occupation after $1967 .{ }^{23}$ During the British Mandate, the Higher Islamic Council purchased considerable landed properties and real estate in Palestine and converted them to public endowments in order to preempt the purchase of these lands by Zionist groups. These areas included several properties surrounding the Haram al-Sharif area and in the Mount of Olives (al-Tur), Baq'a and Talbieh neighborhoods. ${ }^{24}$

After a short hiatus during the Jordanian period, the process of endowment registration resumed its pace after the Israeli occupation of the city in 1967 . Ninety waqf properties were registered (one-third of which were charitable endowments) between 1967 and 1990 alone - compared with only 16 endowments registered during the Jordanian administration. More significant was the sudden rise in the number and size of family endowments during the same period. The total registered waqf properties in the Jerusalem and Jaffa courts (for Jerusalem registrations) amounted to 90 units between 1967 and 1993. Of those, 24 were khayri waqf and 66 were dhirrì waqf. In contrast, only 16 dhirri waqf contracts were recorded during the Jordanian from 1948 to $1967 .{ }^{25}$

The period after 1967 witnessed increased preoccupation with waqf properties as an instrument to enhance the sustenance and survival of Arab institutions in Jerusalem. Several institutional and state donors gave financial aid to Jerusalem institutions and required that their aid be conditioned on converting the assets of the receiving institutions into trust funds (mu'assasāt mawqüfa). ${ }^{26}$ This process was extended to a number of charity establishments that were originally established as public bodies or Ottoman societies

21 Muhammad Dảud al-Tamimi, Awqaf wa Amlak al Muslimin fi Filastin [Muslim waqf properties in Palestine] (Istanbul: Organization of Muslim Congress, 1984).

22 Reiter, Islamic Institutions, 26.

23 Ibid.

24 Ibid., 27.

25 Ibid., 29-34.

26 Michael Dumper, Islam and Israel: Muslim Religious Endowments and the Jewish State (Washington, DC: Institute for Palestine Studies, 1994), 183-230. 
according to civil law, and were then converted into waqf establishments registered in shari'a courts. Examples of these waqf institutions are the Arab Women's Union, headed by the Jerusalemite woman leader Zulaykha al-Shihabi and the Ibrahimiyyeh College. ${ }^{27}$ This meant that the disposition of their assets and properties were now governed by the sharia courts, which blocked their transfer to other private bodies in case of bankruptcy or self-dissolution.

There is no doubt that the conversion of private properties into the status of dhirrī waqf and of public institutions into khayri waqf institutions has protected these properties from fragmentation and - in many cases - from confiscation by the state. Dhirri waqf was an answer to the fragmentation of private property through inheritance. Similarly, the conversion of public institutions to khayri waqf has preempted the possibility of their sequestration or sale through privatization. Nevertheless, over the past five decades, the measures of protection taken have not always succeeded in preventing endowed land and properties from being subject to Israeli measures of control (see table 25.1). Israeli measures included:

a. The confiscation of waqf lands by declaring the territory in question as a security zone for military use.

b. Declaring the land or real estate as abandoned property (matrūka) if the mutawalli or caretaker of the property is an absentee, under Israeli law.

c. Declaring the endowed property to be state land (miri $\bar{l})$, and thus as "improper" waqf (waqf ghayr sahịh). These measures have often been applied to substantial agricultural land which were formerly registered as mīrī waqf. ${ }^{28}$

The Israeli government has also attempted, though not always successfully, to prevent the increase of endowed properties by legal and administrate measures such as:

27 Reiter, Islamic Institutions, 36-37.

28 Dumper, Islam and Israel, 157-59. Dumper notes that "while endowed estates established on private property (that is, "true or proper waqf") were not affected, nevertheless much of lands in the West Bank, including Jerusalem area waqf that were declared as miri land, and whose status were previously registered as waqf, were confiscated by military decisions. Those areas affected included lands administered by the Islamic Higher Committee, such as the al-waqf al-Khalili lands." Khalili waqf refers to public Islamic endowments in Palestine attributed to the patrimony of the prophet Ibrahim, also known as al Khalil (i.e. "the friend of God"). 
d. Undermining the legal status of decisions by the waqf administration and Jerusalem probate courts. First by coopting the waqf administration at the beginning of Israeli rule and then by challenging the domain of the Islamic Higher Committee, which came to administer these properties. The government also refused to acknowledge the decisions of the appeals court, and deported a number of judges and clerks of the Islamic Committee in the late 1960s and 1970s.

e. Attempting to transfer all decisions pertaining to waqf properties to the Islamic waqf administration in Israel and to the Jaffa shari'a court. Both of these institutions were more controllable by the Israeli state. These measures have been partially successful, since most family endowments are today subject to the appointments of their managers (mutawallis) by the Jaffa courts.

f. The Israeli state benefitted from the disputes between the Palestinian Authority and the Jordanian waqf administration in the West Bank and Jerusalem. The state was able to nullify many of the Palestinian Authority's decisions about waqf appointments and regarding revenues. ${ }^{29}$

The forgoing discussion about the preponderance of endowed properties in Jerusalem applies even more sharply to the situation in the Old City, which measures about one square kilometer. The sacred space of Old Jerusalem has been the main recipient of philanthropic endowments by governors, city notables, and religious institutions over the centuries. These endowments were aimed at giving legitimacy to dynastic rulers, new regimes in power, or for the benefit of followers of particular religious communities, sects, or Sufi orders. Endowments were often used to immortalize the name of the benefactor(s) and to secure a safe place for them in the afterlife. Christian orders have been particularly keen to provide endowments as sources for residential dwellings for their denominations. This explains to some extent the relatively large waqfiyya t belonging to certain churches in the Old City, which is examined in table $25 \cdot 1 .^{30}$

29 Dumper, Islam and Israel, 15.

30 It is important to highlight that the dependence on aerial photography in calculating the parameters and coordinates of these endowed properties can lead to a certain degree of error. For details on these discrepancies, see "Methodological Note" in the introduction to the original study, Fakhr ed-Din and Tamari, Jerusalem Properties. 
TABLE 25.1 Distribution of plots and percentage: total area and percentage, according to kind of property, 1967

\begin{tabular}{|c|c|c|c|c|c|c|}
\hline $\begin{array}{l}\text { Category } \\
\text { of property }\end{array}$ & $\begin{array}{l}\text { Number } \\
\text { of plots }\end{array}$ & $\begin{array}{l}\text { Percentage } \\
\text { of plots }\end{array}$ & $\begin{array}{l}\text { Total area } \\
\text { in dunums } \\
\text { (excl. } \\
\text { Haram } \\
\text { and Jewish } \\
\text { Quarter) }\end{array}$ & $\begin{array}{l}\text { Percentage } \\
\text { of area in } \\
\text { dunums } \\
\text { (excl. } \\
\text { Haram } \\
\text { and Jewish } \\
\text { Quarter) }\end{array}$ & $\begin{array}{l}\text { Total area } \\
\text { in dunums } \\
\text { including } \\
\text { Islamic } \\
\text { waqf, but } \\
\text { excluding } \\
\text { expanded } \\
\text { Jewish } \\
\text { Quarter }\end{array}$ & $\begin{array}{l}\text { Percentage } \\
\text { thereof }\end{array}$ \\
\hline State property & 11 & 0.3 & 21 & 4 & 21 & 3 \\
\hline $\begin{array}{l}\text { Jerusalem } \\
\text { municipality }\end{array}$ & 27 & 1.0 & 2 & 0.3 & 2 & 0.2 \\
\hline $\begin{array}{l}\text { (Jordanian) } \\
\text { Custodian } \\
\text { of Enemy }\end{array}$ & 69 & 2.0 & 10 & 2.0 & 10 & 1.5 \\
\hline Property & & & & & & \\
\hline Islamic waqf & 302 & 9.0 & 36 & 7.0 & 180 & 27 \\
\hline Family waqf & $5^{67}$ & 17 & 84 & 16 & 84 & 12.5 \\
\hline Church waqf & 912 & 28 & 228 & 43 & 228 & 34 \\
\hline $\begin{array}{l}\text { Private } \\
\text { property }\end{array}$ & 1,404 & 43 & 145 & 28 & 145 & 21 \\
\hline Total & 3,292 & 100 & $5^{26}$ & 100 & 670 & 100 \\
\hline
\end{tabular}

SOURCE: RECORDS OF LAND AND PROPERTY ASSESSMENT FOR MUNICIPAL TAXES (TAKHMINAT), 1966 (INSTITUTE FOR PALESTINE STUdiEs ARCHIVES, BEIRUT).

\section{Family Endowments and Private Property}

Private land and real estate properties constitute slightly over one quarter (28 percent) of the total area of taxed property in the area under study. ${ }^{31}$ As noted earlier, the proportion of private ownership of land in Jerusalem is considerably lower than that of other historical cities in Greater Syria and inside

31 The area excludes the enlarged Jewish Quarter, which will be analyzed below, and the Haram al-Sharif area. 
Palestine. Total endowed (waqfiyyāt) properties make up an astonishing 66 percent of all surface area of the Old City, certainly much higher than other comparable urban area in the entire Middle East. Family waqf occupies 16 percent of the area under study, amounting to more than half of the area designated as "private domain." As for type of usage, we note that half of all family waqf endowments are used for residencies (48 percent). ${ }^{32}$ These residencies are mainly leased properties to dwellers who are not members of the endowing family. As for other uses, we note that $5^{6}$ percent of the units are leased for commercial use, making up 11 percent of the area of family endowments. ${ }^{33}$

There is little difference observed in the use of private properties in comparison with family endowments. About half of all private properties (47 percent) in the Old City have been used for commercial reasons while slightly less than half (49 percent) are designated as private residencies. However, the areas concerned differ in this case. The area used for commercial reasons in private ownerships is 10 percent of the total area in this category, while residencies occupy 83 percent. This means that most commercial establishments are made up of small shops. ${ }^{34}$ Calculations based on the size of all properties in the Old City show that 95 percent of land in commercial use fall into units of less than 100 square meters, of which 37 percent are designated as private property, 13 percent as Islamic waqf, 18 percent as family waqf, and 30 percent as church waqf. ${ }^{35}$

The distinction between the so-called "proper waqf" and "improper waqf" (waqf sahị and waqf ghayr sahịh) has been the source of major debates in legal circles, mainly because of the consequences emanating from these designations. Proper waqf (also known as "true" waqf) refers to lands and properties that used to be privately owned and which were designated by the owners as endowed for public charity or for the communal use of the family. Improper waqf (sometimes referred to as "untrue" waqf) refers to mìrì or royal lands, which the sovereign or the state has designated for private or charitable uses. Those designations include the establishments of princely feudal estates (iqta iyyat amiriyya) during the Ottoman period and probably in earlier Islamic periods. These distinctions do not appear in the records of endowments for Jerusalem, and we assume, therefore, that improper waqf designations are the exception to the rule. ${ }^{36}$

32 Fakhr ed-Din and Tamari, Jerusalem Properties, table D-3.

33 Ibid.

34 Ibid.

35 Ibid., table D-4.

36 Hasseki Sultan is a possible exception, which is discussed in the following section. 
More recently, a legal debate has emerged about the nature of Hasseki Sultan endowments in Jerusalem and other cities in the region (Izmir, Ramla, Jaffa and Medina), which were established by Roxelana, the wife of Sultan Süleiman. These endowments include schools, public baths, and soup kitchens (takaya) in the Old City of Jerusalem and other establishments in its vicinity. In his analysis of Hasseki Sultan endowments, Iskandar Salameh notes:

Improper waqf lands in Palestine include the Jiftlik [agricultural] lands which were ceded originally from state lands (arädi amiriryya) by the Sultan as [feudal] awards to public servants and military commanders. Some rulers set aside some of these properties to themselves as Sultanic areas - such as the properties known as Khaseki Sultan, and the Jiftlik land which was registered in the name of Sultan Abdülhamid II. ${ }^{37}$

Salameh then concludes that

the claim that Hasseki Sultan is proper ("true") waqf is based on a mistaken assumption and is aimed at securing an equal exchange of value (hikr property) from the owners of these endowed properties, in a manner that will render them as tenants, and subsequently to impose the authority of the waqf administration on the properties so that they can claim the value of the hikr from previous years. ${ }^{38}$

This assessment of Hasseki Sultan (and other so-called improper endowments) seems to apply to commercial endowments in Bethlehem, where the ownership claims are in dispute, and not on Hasseki Sultan takaya and schools in the Old City of Jerusalem, where the commercial use of the endowments have disappeared from living memory.

37 Iskandar Salameh, "Khaski Sultan, Lamha Tarikhiyya" [Hasseki Sultan Waqf: a historical note], Law Practice. Adv. Iskandar Salameh, June 3, 2012, accessed January 19, 2018, http:// lawpractice-iskandar.blogspot.com/2012/o6/blog-post_03.html.

38 The Hasseki Sultan Waqf was established on Shawwal AH 964 (AD 1556). It states in its preamble: "What Princess Khaseki has endowed is registered as a proper and legal waqf, with clear and concise attribution" (Salameh, "Historical Note"). The expression "proper waqf" (waqf sahịh) in this document means that it was established by law, and not by decree. It differs, however, from the juridical terms of "proper waqf," which necessitates that the endowment cannot be Amiri (royal) estates, and that it cannot be established by order of the sovereign or ruler. 


\section{Public (khayrī) Endowments and the Custodian of Enemy Property}

Public (khayrī) endowments account for 264 dunums in the area under study, which is around 50 percent of the area examined above (see table 25.1). We should note that tax records do not include the Haram area, which amounts to an additional 144 dunums. If we add the Haram area to the Islamic public endowments, then the total khayri waqf would constitute more than a quarter of the examined area (27 percent). Without the Haram area, total Islamic charitable public waqf would amount to 7 percent from the land parcels in the Old City. Still Christian ecclesiastical waqf constitutes the majority of public endowments in Jerusalem's Old City. It amounts to 228 dunums or 43 percent of the total area under study (excluding the Haram area). In all the following statistical analysis these exclusions are assumed, except when the Haram area and the expanded Jewish Quarter are included in the data.

In terms of land use, there is considerable similarity between Christian and Islamic public awqāf - since the two main uses, commercial and residential, exhibit close patterns of usage. Commercial uses of endowed properties constitute 76 percent of Islamic waqf, and 62 percent of Christian waqf. In terms of residential uses, 10 percent of Islamic waqf and 30 percent of Christian waqf are residencies. In terms of area, the proportions are reversed (40 percent of Islamic waqf and 38 percent of Christian waqf are taken by residential units). These patterns clearly show that Christian churches invest a higher amount of their endowments in securing residencies in the Old City for their poor adherents.

The primacy of residential and commercial functions is followed by other uses such as religious worship facilities, public service facilities such as medical units and soup kitchens, and education. It is important to mention that the area and number of endowments allocated to education is very small in relative terms - only 11 percent of Islamic waqf and 4.7 percent of Christian waqf are allocated for education. One explanation for this seeming negligence is that many educational institutions in Jerusalem are registered outside the domain of public religious endowments. Another outstanding feature of Christian religious endowments is the absolute dominance of two churches in the size and number of their estates: the Rum Orthodox and the Armenians. ${ }^{39}$

Projections from this survey of waqf properties have excluded three main areas of considerable importance: the area around al-Haram al-Sharif, the blocks inside the Jewish Quarter which, since the occupation of Jerusalem in 1967, has been expanded in three directions, and the Mughrabi Quarter. The 
attributes of the Haram area are known in terms of size and its uses are known, but are not included in the calculations of this study. The expanded Jewish Quarter and the Mughrabi Quarter (which the Israeli government merged in 1967) make up blocks 29-38. These blocks house dispersed Jewish properties that came under the administration of the (Jordanian) Custodian of Enemy Property after the war of 1948. Until data about these blocks becomes more readily available, we must rely on the analysis provided by Adnan Abdul Raziq in a recent study. The data in table 25.2 is derived from this study, as well as from Arab Studies Society (ASs) data for the attributes of the ten blocks, 29 through 38 .

The data in this table examines properties in the post-1967 expanded Jewish Quarter, which includes annexed segments from the Armenian Quarter and the Christian Quarter. The breakdown of ownership of plots addresses the situation as it existed up to 1967 . This data reflects the preponderance of Islamic family waqf plots over all other properties, amounting to 40 percent of the total parcels - a ratio which exceeds its weight in other areas of the Old City. Another observation is the low percentage of parcels that belong to public

TABLE 25.2 Distribution of private and endowed properties in the expanded Jewish Quarter, 2013

\begin{tabular}{lrrrrrrr}
\hline Block No. & $\begin{array}{l}\text { Islamic } \\
\text { family } \\
\text { waqf }\end{array}$ & $\begin{array}{l}\text { Arab } \\
\text { private } \\
\text { property }\end{array}$ & $\begin{array}{l}\text { Jewish } \\
\text { property }\end{array}$ & $\begin{array}{l}\text { Islamic } \\
\text { waqf }\end{array}$ & $\begin{array}{l}\text { Christian } \\
\text { church } \\
\text { waqf }\end{array}$ & Other & Total \\
& 38 & 75 & 10 & - & 3 & 1 & 127 \\
$\mathbf{2 9}$ & 15 & 11 & 1 & - & 5 & 4 & 36 \\
30 & 18 & 7 & 34 & 9 & - & 1 & 69 \\
31 & 21 & 1 & 13 & - & - & - & 35 \\
32 & 41 & 22 & 27 & - & - & - & 90 \\
33 & 43 & 16 & 8 & - & - & - & 67 \\
34 & 7 & 4 & 6 & - & - & - & 17 \\
35 & 20 & 21 & 10 & - & - & - & 51 \\
36 & 18 & 44 & 3 & - & 1 & 1 & 66 \\
37 & 27 & 20 & 1 & - & - & - & 48 \\
38 & 248 & 221 & $\mathbf{1 1 3}$ & 9 & 9 & 6 & 606 \\
Total Parcels & & & & & & & \\
\hline
\end{tabular}

SOURCES: ADNAN 'ABDUL RAZIQ, HARAT AL-YAHUD FI AL-QUDS [THE JEWISH QUARTER IN JERUSAlEM] (NICOSIA: RIMAL PUBLICATIONS, 2013), 127 AND ASS/TAAWON "SURVEy of OLD CITY PROPERTIES" (UNPUBLISHED MANUSCRIPT, 2014). 
(that is, khayrī) Christian and Muslim waqf (amounting to 1.5 percent only for each). Unfortunately, we can only point here to the number of parcels in the ten blocks and not to its area, meaning that we must exercise caution in these projections. The only area that allows for accuracy in assessing the area in question is the Mughrabi Quarter, which is cited further.

As for Jewish properties, the data in table 25.3 indicates that 113 out of 606 parcels, or 19 percent of the total, belong to Jewish owners. The data available does not allow us to distinguish between private properties and Jewish waqf (endowed) properties. The data also reflects the high proportion of private Arab properties, amounting to 36 percent of the total (221 parcels), which is also one of the highest proportions of privately owned properties in the Old City on the whole. ${ }^{40}$ If we use the number of parcels to compare Arab-owned to Jewish-owned properties, we can arrive at a clearer picture for the ethnic breakdown of ownership, as can be seen in table $25 \cdot 3$.

TABLE 25.3 Ratio of Jewish and Arab properties in the expanded Jewish Quarter, 1968

\begin{tabular}{lcll}
\hline Block number & Number of parcels & $\begin{array}{l}\text { Percentage of Jewish } \\
\text { properties in block }\end{array}$ & $\begin{array}{l}\text { Percentage of Arab } \\
\text { properties in block }\end{array}$ \\
\hline 29 & 127 & $7 \cdot 9$ & 92.1 \\
30 & 36 & 2.8 & 97.2 \\
31 & 69 & $49 \cdot 3$ & 50.7 \\
32 & 35 & 37.1 & 63.9 \\
33 & 90 & 30 & 70 \\
34 & 67 & 11.9 & 88.1 \\
35 & 17 & 35 & $64 \cdot 7$ \\
36 & 51 & 19 & 80.4 \\
37 & 66 & 4.6 & 95.4 \\
38 & 48 & 2.1 & 97.9 \\
Total & 606 & $\mathbf{1 8 . 6}$ & $\mathbf{8 1 . 4}$ \\
& & & \\
\hline
\end{tabular}

SOURCES: ADNAN 'ABDUL RAZIQ, HARAT AL-YAHUD FI AL-QUDS [THE JEWISH QUARTER IN JERUSALEM] (Nicosia: Rimal PUblications, 2013) AND ASS/TAAWON, "SURVEy OF OLD CITY PROPERTIES" (UNPUBLISHED MANUSCRIPT, 2014).

40 Adnan 'Abdul Raziq, Harat al-Yahud fi al-Quds [The Jewish Quarter in Jerusalem] (Nicosia: Rimal, 2013), 49, 51. 
Table 25.3 indicates substantial Jewish properties in blocks no. 31 (49.3 percent of total properties in that block), no. 32 (37.1 percent), no. 33 (3o percent), no. 35 ( 35 percent), and no. 36 (19 percent), that is, in five blocks out of ten. As for blocks no. 29, 30, 34, 37, and 38, those properties are negligible.

The data that we have in this survey, as well as in 'Abdul Raziq's study of the Jewish Quarter, do not distinguish between Jewish waqf endowments and Jewish private property. It also assumes that Jewish property owners are non-Arab by definition. This might be a moot point today, but the reader should be reminded that a considerable number of Jewish families from the Old City, especially those that were most likely to have Jewish family endowments, such as the 'Elyashar, Toledano, and Navon families, did not always consider themselves as part of the Zionist settlement project in the Yishuv, and were often self-defined as native, Ottoman, or even Arab Jews. In his study of Jewish and Christian waqf properties in Palestine at the end of the Ottoman era, Ron Shaham notes that many Jews and Christians used to establish family waqf endowments, as well as convert their properties into public charities (waqf khayrī) in their communities, in order to protect them from state intrusion. Contrary to common perception, Shaham notes that well-known Jewish families chose to register their properties as waqf $d$ hirri (family endowments) in the Jerusalem and Jaffa shari'a courts. Those included the families of Youssef Nigo and Maymon Amipal. The Jewish religious establishment was divided on the issue of registering Jewish property in Islamic courts, but a majority supported this process, basing their support on the position that the "ruler's law is our law."41

Jewish properties in the ten blocks analyzed here $(10-38)$ amounted to 18.6 percent of the total. The overall size cannot be determined from the existing data, although an approximation can be reached if we assume that the averages are similar to those in Arab areas. ${ }^{42}$ The only area for which we have concrete data on the size of waqf properties in the expanded Jewish Quarter are the estates of the Mughrabi Quarter, which was annexed and

41 Ron Shaham, "Christian and Jewish 'Waqf' in Palestine during the late Ottoman Period," Bulletin of the School of Oriental and African Studies 54, no. 3 (1991). Data for Jewish properties in Jerusalem and Islamic courts can be found in the following entries: Mahkama Shar'iyya, Al Quds, vol. 27, fols. 173-74; Mahkama Shar'iyya, Al Quds, vol. 71, fol. 143; Mahkama Shariyya, Jaffa, vol. 47 , fol. 276.

42 There are noticeable variations in calculating the averages for Jewish properties between tables 25.2 and 25.3 above. However, these variations do not appear significant in calculating the total averages. See 'Abdul Raziq, Harat al-Yahud, 126-27. 
demolished in 1967-68 in order to expand the Western Wall/Buraq Wall Plaza. Since then, these estates have become part of the expanded Jewish Quarter. ${ }^{43}$

The survey undertaken of this area by the Ass indicates that the total number of properties in the Mughrabi Quarter was 127 units, of which 104 were registered as dhirri waqf. Islamic khayri waqf amounted to only 3 percent of the total, while Jewish properties amounted to 2 percent of the total, and the Mughrabi waqf amounted to 10 property units, or 8 percent of the total. The Abu Madyan family owned the single highest aggregate of properties in the area -73 property units, equivalent to 70 percent of all family endowments, followed by the Khalidi family (14 percent) and the Abu Sa'ud family (6 percent).$^{44}$

Table 25.4 attempts to situate the status of various waqf categories (family, public and religious) in the context of all property categories in the city, including private property, to gain a relational perspective. Here we have divided the table into two components, one side referring to data from the Ass survey (excluding blocks 29-38, that is, the post-1967 expanded Jewish Quarter), and the other side containing all blocks in the city, for purposes of comparison.

The significance of table 25.4, comparing the attributes of all categories of property, first without the expanded Jewish Quarter (blocks 29-38), and then with the expanded quarter, is that it shows very few variations in the percentage of parcels. One may conclude that the distribution of endowed properties contains a higher proportion of Jewish-owned properties (18 percent of the total) than any other area in the Old City, as would be expected. It also contains the highest proportion of family endowments (waqfiyyāt) than the average for the rest of the Old City ( 41 percent are Muslim endowments and 15 percent city endowments). The table shows the continued high significance of family waqf over all categories of ownership, the preponderance of church endowments, and the categorical plurality of private property plots in the Old City, despite the continued adoption of family and public waqf as a means of protecting property from state encroachment and confiscation.

43 The Arab Studies Society has provided data on the confiscated and destroyed properties in blocks nos. 33, 34, 35, and 38 in 1967-70. In those four blocks, the total confiscated properties amounted to 56.5 dunums, equivalent to 29 percent of the total area in this zone. See 'Abdul Raziq, Harat al-Yahud, 124.

Ass/WA, "Survey of Old City Properties" (unpublished manuscript, 2014). 
TABLE 25.4 All categories of property in Jerusalem's Old City, including waqf categories, mid-twentieth century

\begin{tabular}{|c|c|c|c|c|}
\hline \multirow[t]{2}{*}{ Category of property } & \multicolumn{2}{|c|}{$\begin{array}{l}\text { Number and percentage of } \\
\text { properties excluding blocs } 29^{-} 3^{8}\end{array}$} & \multicolumn{2}{|c|}{$\begin{array}{l}\text { All city properties, including data } \\
\text { for blocs } 29-38\end{array}$} \\
\hline & $\begin{array}{l}\text { Number of } \\
\text { parcels }\end{array}$ & $\begin{array}{l}\text { Percentage of } \\
\text { total }\end{array}$ & $\begin{array}{l}\text { Number of } \\
\text { parcels }\end{array}$ & $\begin{array}{l}\text { Percentage of } \\
\text { parcels }\end{array}$ \\
\hline State property & 11 & $<1$ & 13 & $<1$ \\
\hline $\begin{array}{l}\text { Jerusalem } \\
\text { municipality }\end{array}$ & 27 & 1 & 30 & $>1$ \\
\hline (Jordanian) & 69 & 2 & 70 & $>2$ \\
\hline $\begin{array}{l}\text { Custodian of } \\
\text { Enemy Property }\end{array}$ & & & & \\
\hline Islamic waqf & 302 & 9 & 311 & 8 \\
\hline Family waqf & $5^{67}$ & 17 & 815 & 21 \\
\hline Church waqf & 912 & 20 & 921 & $23 \cdot 5$ \\
\hline Private property & 1,404 & 42.5 & 1,731 & 44.5 \\
\hline
\end{tabular}

SOURCE: ASS/TAAWON, "SURVEY OF OLD CITY PROPERTIES" (UNPUBLISHED MANUSCRIPT, 2014); ADNAN 'ABDUL RAZIQ, HARAT AL-YAHUD FI AL-QUDS [THE JEWISH QUARTER IN JERUSALEM] (NICOSIA: RIMAL PUBLICATIONS, 2013).

\section{Conclusion}

This study examined the changing status of endowed properties (family and public) on the eve of Israeli occupation of the Old City of Jerusalem and its subsequent annexation in 1968. The main historical source for analyzing waqf properties in Jerusalem and other Arab cities have been hujjaj (deeds) of endowments recorded in the Islamic court records, and the Ottoman tax registry known as Tahrìr defterleri. The study referred to the utility of several new archival sources for assessing waqf properties: these include architectural field surveys of private homes and public establishments in the city, aerial photography recently made available from British, Ottoman, German, and Israeli sources, and municipal tax registers of Old City properties and leases. The last mentioned have been in existence for many decades, but was made accessible only recently. 
One main finding of this study is historical continuity in the use of public endowments as a means of providing medical, health, and schooling facilities for the poor. There has been a historical decline in the use of royal (or state) decrees in allocating waqf property as a form of patronage or, as in the case of Hasseki Sultan during the sixteenth century, for the provision of soup kitchens and other facilities for the poor. Those were endowed in the past in order to commemorate the name of the sultan, the royal family, or urban potentates. The state has assumed many of these functions in an increasingly secularized form. By contrast, family waqf deeds, which have been a historical instrument for preserving family property from fragmentation through inheritance, have continued to be used in Palestine, and in particular in the Old City of Jerusalem. Family (dhirri) waqf registration has been a crucial instrument in responding to political crisis in various periods of the twentieth century (World War I, Arab Revolt of 1936, 1948 War, and Israeli occupation and annexation of Jerusalem in 1967).

Another aim of this chapter was to assess the relative weight of endowed properties in relation to landed property in general. The Old City is unique in its preponderance of waqf establishments of all varieties: an astonishing one-fifth (21 percent) of all title deeds belong to family waqf, probably one of the highest in the Islamic and Arab regions. Another surprising finding is the high proportion of church property in the city that is registered as waqf (23 percent vs. 8 percent for Islamic public waqf), though this figure is somewhat exaggerated by the exclusion of the Haram area from the total area of waqf establishments. Although not technically an endowed property, the Haram provides many functions of charitable endowments under the same rubric: schools, libraries, Sufi zāwiyāt and soup kitchens. Finally, although private property deeds make up the majority of registered deeds in the Old City (1,771 parcels or 45 percent of all property deeds), they are nevertheless much lower than the ratio in any comparable city in the Middle East or North Africa. There is little doubt that the enhanced and enhancing role of family endowments has appreciated at the expense of private property.

The main problem with these extrapolations remains the calculation of property sizes (as opposed to the number of parcels and property units in each bloc). This remains unfeasible except in certain neighborhoods and segments of neighborhoods referred to in the body of the chapter (for example, the Mughrabi Quarter). What we have here is a concrete picture of the relative weight of the number of parcels in each property category, but great uncertainty about the area involved. We have assumed that the relative value of property units, on average, corresponds to its surface area, but this assumption needs to be examined more rigorously. This absence is due to limitations 
inherent in the Gis data calculated by the Ass/Taawon survey for this study as well as to our inability to achieve synchrony between the four archival sources utilized here to assess the overlapping categories of property: probate court records (hujjaj of endowments and property deeds), aerial photographic mapping, in situ architectural drawing of Old City buildings, and tax registration records.

Another shortcoming of this study is that it fails to assess the effects of changes brought about by the presence of settlers in the Old City, including land purchases and confiscation of private property, and changes brought about by Israeli government sequestrations of public property. We have discussed this issue briefly but the issue must be examined further. 


\title{
The Limitations of Citadinité in Late Ottoman Jerusalem
}

\author{
Louis Fishman
}

This chapter problematizes the notion that the political realities introduced following the 1908 Young Turk Revolution augmented a sustainable sense of harmony among the different communities in Ottoman Jerusalem. In fact, it will argue that the revolution perhaps even hindered the forging of an urban community or an idealistic type of citadinité. It does not aim to disprove that relations between communities existed within the urban arena of Jerusalem. However, it will question the extent of these relations and will set out to show how new barriers between the different communities were created as a result of political events in Istanbul and, in particular, in Palestine.

During the late Ottoman times, relations between neighbors from different religious and ethnic communities in Jerusalem can be defined as exhibiting a type of citadinité. Despite Ottoman structural divisions, which divided religious communities along sectarian lines, Muslims, Christians, and Jews interacted with one another in markets and public arenas. While it is not possible to define how widespread such interactions were, some of these communities also shared the same neighborhood. According to Michelle Campos, "deep ties [existed] between Old City Muslims, Christians, and Jewish families and neighbors across religious lines - sharing a courtyard, visiting each other on religious holidays, engaging in business partnerships ... Muslim girls learned Judeo-Spanish from their Sephardi Jewish neighbors; Christian and Jewish musicians performed at Muslim weddings and holidays."

Menachem Klein, in his recent book, goes to great lengths to document the relations between neighbors from the Jewish and Arab (Muslim and Christian) communities. According to Klein,

The unit of local identity, beyond the family and clan, was the neighborhood, or more correctly, the residential compound surrounding a common yard. While the Jews were in the majority in Jerusalem by the end

1 Michelle Campos, Ottoman Brothers: Muslims, Christians, and Jews in Early Twentieth-Century Palestine (Stanford: Stanford University Press, 2011), 18.

(C) LOUIS FISHMAN, 2018 | DOI:10.1163/9789004375741_032

This is an open access chapter distributed under the terms of the prevailing CC-BY-NC-ND License at the time of publication. 
of the nineteenth century, most of the housing was owned by Arabs. Jews lived among Arabs, and more Jews rented homes and apartments from Arabs than vice-versa. ${ }^{2}$

Furthermore, Salim Tamari, in his reading of the memoirs of Wasif Jawhariyyeh, ${ }^{3}$ paints a picture of close social ties in the daily lives of Jews and Arabs. His work serves to challenge the perception of Jerusalem as a city defined solely by bitter sectarian divisions. According to Tamari:

In [Jawhariyyeh's] rendition of daily life in the alleys of the Old City, we are struck by the weakness of this conception in two respects: one suggests that there was no clear delineation between neighborhood and religion; we see a substantial intermixing of religious groups in each quarter. The boundaries of habitat, furthermore, were the mahallat, the neighborhood network of social demarcations within which a substantial amount of communal solidarity is exhibited. Such cohesiveness was clearly articulated in periodic visitations and sharing of ceremonials, including weddings and funerals, but also active participation in religious festivities. These solidarities undermined the fixity of the confessional system from a premodern (perhaps even primordial) network of affinities. ${ }^{4}$

With the proliferation of public spaces in late nineteenth-century Jerusalem, new instances of citadinité transformed neighborhood relations. ${ }^{5}$ One of these spaces emerged in the new commercial center that lined Jaffa Road, connecting the Old City with the new neighborhoods situated outside the city's walls, which became home to the municipality in 1896. According to Abigail Jacobson, "this area was a mixed urban locale that served social, economic, and administrative functions for all of the city's inhabitants, as well as for its visitors. It was where people interacted and communicated." ${ }^{\text {Th }}$ This vibrant urban environment served both government and commercial needs, while drawing

2 Menachem Klein, Lives in Common: Arabs and Jews in Jerusalem, Jaffa, and Hebron (Oxford: Oxford University Press, 2014), 36.

3 Salim Tamari, “Jerusalem's Ottoman Modernity: The Times and Lives of Wasif Jawhariyyeh," in Jerusalem Quarterly, no. 9 (2000).

4 Tamari, "Jerusalem's Ottoman Modernity," 8.

5 Abigail Jacobson, From Empire to Empire: Jerusalem between Ottoman and British Rule (Syracuse: Syracuse University Press, 2011).

6 Ibid., 56 . 
the different ethnicities and religions together into a successful microexperiment of a modern city.

The above example reminds us that the activities of Ottoman institutions, such as recruitment to the Ottoman army, also led mixed groups to converge together in these very urban spaces. In September 1910, we see how Christians and Jews joined in a mutual day of celebration on the day they were drafted into the Ottoman army. The day started with an official ceremony held at Jerusalem's military headquarters. Army officials such as 'Abd al-Rahman, the Ottoman military attaché in Jerusalem, gave speeches. From there, the recruits were led to the train station by an Ottoman marching band, followed by families and friends from all the communities bidding them farewell at the train station, or remaining as onlookers. ${ }^{7}$ Such ceremonial events, which were prevalent in other Ottoman cities, ${ }^{8}$ allow us to capture a glimpse of a unique expression of citadinite that was inherently connected to the Ottoman period. This would disappear during the days of British rule. ${ }^{9}$ In fact, this picture is quite unique to the last years of the Ottoman Empire, since it was only after the revolution that conscription to the army became mandatory for Christians and Jews. Importantly, this did not only include the drafting of Sephardim, but that of Ashkenazim as well.

While there are numerous examples demonstrating forms of citadinité within the Hebrew press, it is important to highlight that "mixing of groups" did not only involve the mixing of Arabs with Sephardic Jews, but also with Ashkenazi Jews, including Zionists. ${ }^{10}$ These gatherings might seem surprising given that after the 1908 revolution, and leading up to World War I, Jews

Lemire looks at how the official opening of the hydraulic canals, in addition to other cases focusing on infrastructure, were also commemorated by "all the inhabitants of the city." See Vincent Lemire, Jerusalem 19oo: The Holy City in the Age of Possibilities (Chicago: University of Chicago Press, 2017), 4.

8 In her book, Sibel Zandi-Sayek describes how official ceremonies in Izmir drew crowds from its city's diverse communities together to take part in different communal events. See Sibel Zandi-Sayek, Ottoman Izmir: The Rise of a Cosmopolitan Port, 1840-1880 (Minneapolis: University of Minnesota Press, 2011), 154.

$9 \quad \mathrm{Ha}$-Or, September 21, 1910, 3; Ha-Herut, September 21, 1910, 3. In her record of the official farewell ceremony, Campos notes that the newspaper not only recognized the Jewish recruits by name, but also those who received a pardon by paying the bedel tax, in what she described as a form of humiliation. See Campos, Ottoman Brothers, 156.

10 For a unique look at relations between the influential Ashkenazi immigrant, Eliezer Ben-Yehuda, and the Palestinian Muslim notable and politician Ruhi al-Khalidi, see Jonathan Gribetz, Defining Neighbors: Religion, Race, and the Early Zionist-Arab Encounter (Princeton: Princeton University Press, 2014). 
and Arabs became more entrenched in conflict. ${ }^{11}$ An example of such a gathering was a ceremony held in the Jewish colony of Petah Tikvah to welcome the Ottoman governor, Muhdi Bey, who was on an official visit. Joining him in his entourage to the agricultural settlement was the kaimakam, Fahri Bey, the mayor of Jerusalem, Hussein Effendi Al-Husayni, and the well-known Jewish notable Albert Antébi. The Zionist representative, Arthur Ruppin, and other members of the Jewish Yishuv were also present. The newspaper Ha-Herut reported that the city was decorated with Ottoman flags and the governor was welcomed to the city by Jews and Arabs on horseback. ${ }^{2}$ The day included speeches given at the local synagogue; the Ottoman governor opted to give his speech in French, which was the dominant language among the Sephardic elite. For example, Antébi, despite being often described as the prototype Ottoman Jew, seems to have been more comfortable in French than in Ottoman Turkish. ${ }^{13}$

The fascinating portraits of citadinité within Jerusalem and in the other cities of Palestine, brought alive in works and sources, are congruent with other Ottoman cities during the late nineteenth and early twentieth centuries, where a mixing of the empire's different ethnic and religious communities began to transform the urban arena. These changes may have occurred as a direct result of the political changes within the empire during the nineteenth century, when the Ottoman state (Devlet-i 'Ośäaniye) transformed into a modern empire as the Ottoman administration strengthened Istanbul's central powers vis-à-vis the provinces. During the years of the Tanzimat (1839-76), notions of citizenship began to emerge along with a modern sense of patriotism for the vatan, the homeland, and the introduction of modern universities, newspapers, and tax reforms. These reforms also aimed to create a system of equality between all the empire's subjects, through measures such as abolishing the non-Muslim poll tax, the cizye. Nevertheless, the millet system, which allowed each community to govern its internal affairs, creating divisions between the

11 In my upcoming book, Claiming the Homeland:Jews and Arabs in Late Ottoman Palestine, 1908-1914 (tentative title), I lay out how the 1908 revolution stood as point of departure when both communities became entrenched in conflict and set out to make "claim" of their homeland. This played out both in Palestine and in Istanbul.

12 Ha-Herut, August 8, 1912.

13 Fishman, Claiming the Homeland; In one document, Antébi preferred to address the central government in Istanbul in French and not in Ottoman Turkish, unlike his Jerusalem Arab counterpart, Raghib al-Nashashibi, who in the same document addresses the government in Turkish. Ottoman State Archives (воA), DH.UмVM 1332.M.22; December, 21 1913 . 
different religious groups, remained intact in some form or another, despite radically changing in context following the 1908 revolution.

One of the direct outcomes of the Tanzimat era, that led to the promulgation of a constitution by Abdülhamid II, which was suspended until the Young Turks reinstated it in 1908, was the blurring of rigid divisions between the different ethnic and religious groups, allowing Ottoman urban citizens to cross the invisible borders that existed between the different communities. For example, during the last decades of the empire, we know that Muslims, Christians, and Jews began to study together in schools such as Galatasaray and Istanbul's renowned law school, the Hukūk Mektebi. Tramways in the major cities began to transport members of one community through the streets of the other. While Jerusalem's tramway was not established in the late Ottoman era (indeed it was only completed a few years ago), there was a plan during the last years of Ottoman rule to connect Jerusalem with the outlying areas, finally reaching Bethlehem, which would certainly have served all the communities in a similar fashion to those in Istanbul and other Ottoman cities. ${ }^{14} \mathrm{In}$ Jerusalem too, even though it was uncommon, Muslims also studied at Jewish schools, such as the two Jerusalem MPs in the postrevolutionary Ottoman parliament, Said al-Husseini and Ruhi al-Khalidi, who both studied for some time at Jerusalem's Alliance Israélite Universelle. ${ }^{15}$ While there seem to be fewer cases of Jews studying at Arab schools, a young immigrant from Russia, Moshe Sharet (né Moshe Shertok) studied briefly at an Arab school. This is probably where he picked up the fine Arabic skills we see in his letters written in the language, which were sent to his brother in Palestine while he served in the Ottoman army in Syria during World War I. ${ }^{16}$ Of course, the cases of Arabs attending Jewish institutions, and vice versa, serve as brilliant examples of citadinité. In schools and other institutions, the two groups interacted on a daily basis. However, the mixing of students and intellectuals does not seem to have produced a form of camaraderie which could have created strong bonds and joint political agendas.

14 For more information on this, see Yasemin Avcı, "Jerusalem and Jaffa in the Late Ottoman Period: The Concession-Hunting Struggle for Public Works Projects," in Late Ottoman Palestine: The Period of Young Turk Rule, ed. Yuval Ben-Bassat and Eyal Ginio (London: I. B. Tauris, 2011). See also Sotirios Dimitriadis' chapter on the Jerusalem tramway in the volume.

15 Rashid Khalidi, Palestinian Identity: The Construction of Modern National Consciousness (New York: Columbia University Press, 1997), 69, 77.

16 Moshe Sharet, Nitra'e ve-Ulay Lo: Mikhtavim me-ha-Tsava ha-'Otomani 1916-1918 [Shall we ever meet again? Letters of an Ottoman soldier 1916-1918], ed. Ya'akov Sharet (Tel Aviv: Ha-'Amuta le-Moshe Sharet, 1998), $15^{8}$. 
In the months and years following the 1908 revolution, the Ottoman nonMuslim populations entered politics as equals alongside their Muslim counterparts for the first time since the foundation of the empire. This was evident in the reopening of the Ottoman parliament in 1908. The parliament was characterized by its diversity of religious and ethnic groups: Turk and Arab Muslims were the largest groups, joined by a number of Greeks, Armenians, and Jews. In the years following the 1908 revolution, this new sense of equality was cultivated in the nation's capital of Istanbul, but was also evident throughout different urban arenas within the Ottoman lands (Memālik-i 'Oșmāniye).

Whether it be in Istanbul or Jerusalem, the Young Turks' revolutionary slogan, "Liberty, Equality, Fraternity and Justice," ushered in a new era of civic nationalism, where, regardless of ethnicity or religion, citizens embraced the notion of Osmanlulik, or Ottomanism, an inclusive type of nationalism embracing all peoples of the Ottoman state. Once again, I turn to Campos, who states that following the revolution, a new dynamic of "civic Ottomanism" was introduced. She describes this dynamic as "a grassroots imperial citizenship project that promoted a unified sociopolitical identity of an Ottoman people struggling over the new rights and obligations of political membership."17 Similar cases can be found also within Ottoman Anatolia, where multireligious and multiethnic groups supporting the new spirit of the revolution were formed. Such groups included the Society of Patriots (Vatanperverler Cemiyeti), which was made up of Muslims, Greeks, Armenians, and Catholics. ${ }^{18}$ In the multiethnic and religious city of Izmir, one of the Jewish MPs, Nisim Matsliah, prided himself on the fact that he received the vote of both Jews and Muslims. ${ }^{19}$

\section{Ottoman Jerusalem: A Mixed City among Its Many Forms of Divisions}

In her focus on Ottoman Jerusalem, Jacobson argues that Jerusalem needs to be treated as a "mixed city." She stresses the importance of "integrating Jews and Arabs into one historical analysis ... [which] recognizes and investigates the differences between and within these two groups and their experiences, and examines the forces and dynamics that influenced them and the

\footnotetext{
17 Campos, Ottoman Brothers, 3.

18 Ohannes Kilicdagi, "The Bourgeois Transformation and Ottomanism Among Anatolian Armenians after the 1908 Revolution" (MA diss., Boğaziçi University, 2005), 68.

19 Ha-Olam, March 3, 1909, 13-14.
} 
dilemmas they faced at this time of transition." ${ }^{20}$ During the late Ottoman era, Jerusalem was made up of numerous religious, ethnic, and linguistic groups, with the three main divisions, Jews, Christians, and Muslims, forming along the Ottoman division of religion as regulated by the millet system. ${ }^{21}$ Despite the widely-held notion that the Old City of Jerusalem is divided into four clearly demarcated quarters, Jewish, Muslim, Christian, and Armenian, "the quadripartite division of Jerusalem ... is a relatively late cartographic invention plastered on Jerusalem by European observers."22 Vincent Lemire, in his book Jerusalem 190o, points out that before 1837, "cartographers did not assign any ethnic-religious categories to any given part of the city," and the appearance of such maps coincided with the opening of the European consulates in the late $1830 \mathrm{~s}$. He reminds readers that the "quadripartite division only became set from the 1860 s on."23 The intermixing of the communities is also verified in the 1905 Ottoman census, where we find large groups of Muslims living in the Jewish Quarter, and vice versa. ${ }^{24}$ It is for this reason that Lemire argues that we need to focus on other divisions within Jerusalem's societies, such as "between the rich and poor, between secular and religious, between artisans and intellectuals." We should extend these categories to relevant distinctions between residents of Jerusalem's walled city and its new neighborhoods, which, by 1900, made up over half the population. ${ }^{25}$

In his review of multiple population censuses and statistics, Roberto Mazza provides a coherent breakdown of the city, calculating that in 1914, a total of eighty thousand people inhabited Jerusalem. At fifty thousand, Jews were the largest group, while "Christians and Muslims were more or less equally divided," placing them at about fifteen thousand for each community. ${ }^{26}$ However, Jews and Arabs were not homogenous. Though Muslims were largely Sunni Arabs, this division also included small populations of North African and Indian Muslims, and Turkish officials based in the city. In addition, the largest group of Sunni Arabs were divided in terms of loyalties towards their notables and religious leaders. ${ }^{27}$ Likewise, the majority of Christians in Jerusalem were also Arab. The largest community, which made up seven thousand of the

\footnotetext{
20 Jacobson, From Empire to Empire, 2.

21 Roberto Mazza, Jerusalem: From the Ottomans to the British (London: I. B. Tauris, 2009), 34 .

22 Lemire, Jerusalem 19oo, 17.

23 Ibid., 26.

24 Ibid., 27.

25 Ibid., 20.

26 Mazza, From the Ottomans to the British, 39.

27 Ibid., 40.
} 
fifteen thousand overall total, were Greek Orthodox (the church hierarchy also included ethnic Greeks), and the Catholic community was also made up of a majority of Arabs (even if not at the same level as the Greek Orthodox), and numbered 4,500. ${ }^{28}$ During the late nineteenth and early twentieth centuries, Muslim and Christians started to unite under the banner of Arab nationalism, and following the 1908 revolution, together with the other regions in Palestine, they began to imagine themselves as a modern political community. Collectively, they identified with what I call Palestinianism, which was not an ethnic or separatist nationalist identity, but rather a local identity that developed within the context of a larger Arab identity. ${ }^{29}$

Jerusalem's Jewish community was made up of numerous ethnic and linguistic groups and was arguably even more divided than the city's Arab populations (Muslim and Christians). First, the fifty thousand strong Jewish community was split along the Ashkenazi-Sephardic divide, with the Ashkenazim tracing their origins back to eastern Europe and the Sephardim tracing their roots back to Spain, whose expulsion of the Jews in 1492 sent many to Ottoman cities such as Salonika, Edirne, Istanbul and Izmir, and to those in the Ottoman Arab heartlands, such as Damascus, Beirut and Jerusalem. However, within each of these two main categories, there were numerous subgroups. In fact, the late nineteenth century, the Yishuv was made up of immigrants from different parts of Eastern Europe, the Ottoman Arab lands, the Balkans and North Africa. Some spoke Yiddish and Russian, while others spoke Ladino and Arabic. Furthermore, there were other groups that did not trace their roots back to Ashkenazim or Sephardim at all, such as the Persian-speaking Jews of Bukhara and the Arabic-speaking Jews of Iraq and Yemen, to name a few. In addition, there were the Jewish families who could trace their roots back for generations in Palestine. As we will see below, these different communities started to unite under a local form of Zionism, which for the first time started to break down the main barrier dividing Ashkenazi and Sephardic Jews.

\section{The Limits of citadinité in the Post-19o8 Period}

During the last decade, the scholars working on Ottoman Palestine have placed great emphasis on documenting relations between the Jewish and Arab communities, specifically within the urban sphere of Jerusalem. In addition to the works mentioned in the introduction, other studies within this field look at cases of intercommunal microrelations within Jerusalem, such as the relations

28 Ibid., 43 .

29 Fishman, Claiming the Homeland. 
between the Jewish Ishaq Shami and Arabs ${ }^{30}$ and that of the Sephardic Valero family. ${ }^{31}$ There also is a recent documentary on the era entitled 1913: Seeds of Conflict, ${ }^{32}$ which combines the opinions of these scholars and works to recreate the world of Jawhariyyeh. This documentary, which was based on the book Jerusalem 1913: The Origins of the Arab-Israeli Conflict, recreates a world where Muslims, Christians and Jews lived together and interacted in the neighborhoods of the Holy City. ${ }^{33}$

These narratives, which have focused closely on Jewish-Arab relations, have been central to deconstructing the dominant narrative of conflict that emerged during the subsequent British Mandate, the founding of the Israeli state and the Palestinian Nakba, and the years of Israeli occupation of the West Bank and the Gaza Strip. In other words, by demonstrating that relations between the different communities existed, these works show us a period when the two peoples were not set in conflict but rather interacted with each other as Ottoman citizens within multiple communities.

Parallel to the emergence of this new narrative, some scholars, including myself, have started to question the extent of these relations. For example, Edhem Eldem, who focuses on Ottoman Istanbul, argues against understanding the mixing between the different communities as something widespread in Ottoman cities. He holds that it certainly did not expand to the bulk of the population. Eldem writes, "indeed, the quaint and endearing image of Greeks, Armenians, Muslims and Jews sharing space, business and entertainment tends to mask the very real fact that the overwhelming majority of the population, across the board, was in fact held at bay from this protected and restrictive environment." ${ }^{34}$ Lemire emphasizes that his work, which focuses to a great extent on the dynamics of citadinité, is not aimed at "painting an idyllic portrait of a peaceful city blessed with a web of respect and mutual consideration between its inhabitants. Jerusalem around 1900 was, like all urban societies, a

30 Salim Tamari, "Ishaq al-Shami and the Predicament of the Arab Jew in Palestine," Jerusalem Quarterly, no. 21 (2004). Ruth Kark and Joseph B. Glass, "The Valero Family: Sephardi-Arab Relations in Ottoman and Mandatory Jerusalem," Jerusalem Quarterly, no. 21 (2004).

32 Ben Loeterman, 1913: Seeds of Conflict Trailer, April 8, 2015, accessed January 19, 2018, https://youtube/OlvTVvuI3oE.

33 Marcus Amy Dockser, Jerusalem 1913: The Origins of the Arab-Israeli Conflict (New York: Viking, 2007).

34 Edhem Eldem, "Istanbul as a Cosmopolitan City: Myths and Realities," in A Companion to Diaspora and Transnationalism, ed. Ato Quayson and Girish Daswani (Chichester: Wiley Blackwell, 2013. 
place crisscrossed by conflicts, competition and power relations." ${ }^{35}$ However, he asserts that "conflicts did not yet happen along the fracture lines between communities that we see nowadays." ${ }^{36}$ Certainly, his work on Jerusalem's municipality reveals that perhaps Jerusalem should be seen as a unique case because it was the second city in the Ottoman Empire that, due largely to a local initiative, established a municipality in the mid-186os and was characterized by its Muslim, Christian, and Jewish representation. ${ }^{37}$ Furthermore, Lemire's differentiating between Jerusalem's old and new cities and the dynamics of relations between Jews and Arabs within these two realms provides us with an important key to understanding how relations developed differently at various points in time and space.

Eldem's claim that mixing between the communities of Istanbul was limited could hold a kernel of truth when applied to Jerusalem. Perhaps the interchange of relations was reserved mostly for municipality leaders and other probable classes who "embodied this urbanness in full flower." ${ }^{38}$ In fact, for now, the sources used to portray neighborly relations between Jews and Arabs only seem to scratch the surface, making it difficult to substantiate the claims of a widespread multicultural sense of citadinité. For example, a good part of the scholarship on neighborly relations in late Ottoman Jerusalem is based on Jawhariyyeh's memoirs. Until now, however, no scholar has scrutinized these memoirs as a source for explaining relations between the two communities. That Jawhariyyeh recorded his thoughts and impressions decades after events occurred could undermine the accuracy of his descriptions of the late Ottoman period. Furthermore, we need to recognize that he was born in 1897, making him an eleven year old child when the revolution occurred. Thus, for example, his claim that following the revolution, Arabs welcomed the coup but Jews in the city mocked it seems based solely on hearsay. It would indeed be hard to imagine an eleven-year-old retaining such detailed information. It also contradicts most primary sources, which state that the Jewish community, like the Arab one, welcomed the revolution. ${ }^{39}$ One of the editors of Jawhariyyeh's memoirs, Issam Nassar, who is a contributing member of this volume, recognizes their limitations as a source. According to Nassar, this is a "memoir written - and rewritten - after the

\footnotetext{
35 Lemire, Jerusalem 1900, 5 .

36 Ibid.

37 Ibid., 104.

38 Ibid., 112.

39 Salim Tamari and Issam Nassar, The Storyteller of Jerusalem: The Life and Times of Wasif Jawhariyyeh, 1904-1948 (Northampton: Olive Branch Press, 2014), 70.
} 
fact." He explains that the memoirs appear to be based on "notes and diaries that he had written earlier." Jawhariyyeh's narrative is unquestionably valuable as we have little material from the period that addresses daily life in Jerusalem. However, caution is required when citing the memoirs as an overarching source, even if they do appear to be in keeping with other emerging narratives. Another case in which the Jawhariyyeh memoirs fall short of providing the full picture is in his description of Jerusalem's holy days as being celebrated by all three religions. His descriptions are often vague and unchanging over time. For example, he recalls that the Jewish celebration of Purim took place alongside a Greek Orthodox carnival that coincided with the last day of Lent. According to Jawhariyyeh, Jews and Muslims gathered together with Christians to observe the procession of people dressed in costume. However, in his description of the Jewish holiday of Purim, he states "the carnival tradition was also acted out by the Jewish community of Jerusalem at their homes and in their communes." He goes on: "We spent long evenings among them in their communes marveling at what we saw, particularly at the time of the Ottomans." ${ }^{40}$ From this passage, we can learn that indeed, festivities did offer opportunities for the different religious groups to come into contact with one another. However, we learn nothing at all about his interactions with Jewish celebrators (or viceversa, concerning the Greek Orthodox procession). ${ }^{41}$ Further, we learn from Jawhariyyeh that the Jewish celebration of Purim was being celebrated in Jewish neighborhoods (he appears to stress "their" homes and "their" neighborhoods). In other words, this could point to the fact that even if there were Jews living together with Arabs, the public celebration of the Jewish holiday took place in areas demarcated as Jewish neighborhoods.

In a section where he writes on neighborly relations, Jawhariyyeh uses the aforementioned Greek Orthodox carnival as a point of reference for celebrations that Christians and Muslims from the same neighborhood celebrated together, with no mention of Jewish participation. ${ }^{42}$ Also, it is clear from the passage that he is writing this in retrospect. Compared to later eras, this may have been more common in the Ottoman era, but it is hard to extract more

40 Tamari and Nassar, The Storyteller of Jerusalem, 58. In his recollection of going to the Dusturiyye school, Jawahariyyeh describes also a school where both Muslims and Christians studied together. Here, there is also no mention of Jews studying with Arabs, 74-76.

41 There are also reports of Arabs taking part in Jewish celebration of Lag B'Omer in Safad during the late Ottoman era. See Ha-Herut, June 15, 1913, 3. 
information about the extent of the interactions. Were the different groups simply onlookers at each other's festivities, or did they use the moments as opportunities for social exchange? Crucial to understanding relations in the late Ottoman era is to see how they transformed as the local populations the Jews and the Palestinians - were thrown into conflict by the growth of Zionism and an increasing a sense of Palestinianism, which was not only a reaction to the rise of Jewish nationalism but was also part of their desire to protect the Holy Land from European imperialism.

Jawhariyyeh's descriptions of the shared space during the holidays bear striking resemblance to events in Ottoman Izmir. In her work on the port city, Sibel Zandi-Sayek explores relations between its different communities. Concerning holidays, she writes,

Although each community celebrated its own holy days, many observances were made known to all because of their implications for the daily life of the entire city. Businesses and shops owned by Muslims, Jews and Christians were closed on Fridays, Saturdays and Sundays, respectively, which pressed other groups to make their provisions accordingly and left only four workdays for the entire city. ${ }^{43}$

She goes on to explain that holy days also included "public feasts [which] transformed the physical spaces of the city and created a temporary reconfiguration of public life. On these occasions, people refashioned select streets and other outdoor spaces to house or otherwise mark these events." 44 Like in Jerusalem, the late Ottoman period in Izmir also reminds us that "feasts and ceremonies animate the history of Ottoman urban communities, which are too often portrayed in neatly delineated religious, ethnic, and national categories." ${ }^{25}$ Lastly, missing from Jawhariyyeh's narrative is the fact that "religious feasts also produce more spontaneous transformations of the city's spaces. Holy days could be provocative; fueling latent prejudices, reifying the social boundaries between the neighborhoods, and rendering visible the power inequalities among them." ${ }^{46}$ This certainly held true in Jerusalem, where during the spring season of Passover and Easter, tensions between the different communities

\footnotetext{
43 Zandi-Sayek, Ottoman Izmir, 154.

44 Ibid., 156.

45 Ibid., 186.

46 Ibid., 156.
} 
increased, whereas the city depicted in Jawhariyyeh's descriptions seem to be devoid of conflict between the different communities. ${ }^{47}$

\section{The Linguistic Question of the Sephardim}

A complex dimension of Jerusalem citadinité is that local Sephardic communities had stronger ties with Palestinians than the Ashkenazi Jews did due to the fact the former spoke Arabic. Some even claimed they shared a "common identity" as Arabs. In his abovementioned book on Jews and Arabs, Menachem Klein states: "Before nationalism brutally separated the two words 'Arab' and 'Jew' and required the inhabitants of Palestine to count themselves as one or the other, there were people who thought of themselves as Arab Jews" and explains that "Arab-Jewish identity and local patriotism emerged alongside a sense of belonging to the Ottoman Empire." While we know for certain that there were a small group of Arabic-speaking Jewish intellectuals in Palestine during the late Ottoman period who defined themselves as such, this claim seems exaggerated when speaking of the Sephardic Jewish community in Palestine as a whole. ${ }^{48} \mathrm{~A}$ large part of the Sephardim in Jerusalem most likely did not see themselves as "Arabs," but possessed a Sephardic Jewish identity, which was inherently connected with the other Ottoman Jews within the empire. ${ }^{49}$ Klein then brings us back to the discussion of mixed neighborhoods, quoting from the memoir of Ya'akov Yehoshu'a, who writes that "the residential courtyards of the Jews and Muslims were common. We were like one family, we were all friends. Our mothers poured out their hearts to Muslim women and they poured out their hearts to our mothers. The Muslim women accustomed themselves to speaking the Ladino language. They frequently

47 During the late Ottoman era, there are documented cases of conflict not just between Jews and Muslims and Christians and Jews, but also between Christians and Muslims. That Jawhariyyeh does not document this leads in part to a nostalgic cosmopolitanism which could very well fail to reflect reality.

48 Jacobson, From Empire to Empire, 82-166.

49 Despite Klein's exhaustive work, his argument that Jerusalem's Sephardic Jewish population identified as "Arabs" seems hard to substantiate. Furthermore, Klein's use of memoirs also is problematic to an extent; for example, he quotes Palestinian writer Ghada Karmi to strengthen the argument that Sephardim did consider themselves "Arab Jews" in the late Ottoman Empire. According to Karmi, "We knew they (Ashkenazi) were different from 'our Jews,' I mean Arab Jews." However, Karmi herself was only born in 1939, and the quote, which projects an Arab identity on the Sephardim, is from a memoir she wrote in 2002. 
used that language's proverbs and idioms." This recollection is in keeping with Campos' quote about Muslim women learning Ladino. In other words, these are examples where Jewish residents' knowledge of Arabic was not a foregone conclusion. We observe that Arabs (Muslims and perhaps Christians) did learn Ladino. Perhaps we should reexamine the claim that "closer relations between Sephardi Jews and Muslims can be put down to the fact that they shared a common language. ${ }^{50}$ While it would be erroneous to dismiss these relations, future research needs to look beyond the (perhaps constructed) nostalgia and expand on socioeconomic conditions that explain the essence of Jewish-Arab neighborhood relationships. This certainly could portray a unique form of citadinité that transcends explanations of ties based on language or political developments, providing an important counterweight to a great deal of the current literature. Other cases emerging in the late Ottoman period of Palestinians learning Hebrew in order to communicate with the Jewish community offer insight into the relations between the two groups. ${ }^{51}$ Of course, a more focused research on Arabs studying and speaking Jewish languages would also expand our understanding of citadinité, showing how the voluntary acquisition of a language to communicate with others broke down boundaries and created new social relations.

In my own research, I have uncovered different accounts that cast doubt on how widespread the phenomenon was of Jews (Sephardic or Ashkenazi) knowing Arabic. In a report prepared during the years before World War I, the Zionist official Arthur Ruppin supplies a breakdown of languages within three Hebrew kindergarten classes. Out of 305 children, Ruppin claims that only 7.1 percent spoke Arabic as their mother tongue; not surprisingly, and in sync with Ottoman Jewry as a whole, the largest language spoken among the Sephardic children was Ladino (39.3 percent) and then Yiddish ( 38 percent). Following Arabic, other notable languages were Bucharic Persian, Georgian, Moroccan dialect, and Bulgarian. ${ }^{52}$ While some might contest Ruppin's work due to the fact that he was a representative of the Zionist Office, this survey seems it may

5o Kark and Glass, "The Valero Family," 30.

51 Ha-Herut, October 20, 1912, 3. In this article, we see documentation that some Arabs were learning Hebrew in the Jewish settlement of Zikhron Yaakov. In a memoir of a trip to Palestine, one American Jewish visitor, Benjamin Lee Gordon, to Ottoman Palestine, comments that on the train to Jerusalem, the Arab conductor communicated with him in Yiddish. He then goes on to also mention Arabs learning Hebrew because it was to their "advantage." See Benjamin Lee Gordon, New Judea: Jewish Life in Modern Palestine and Egypt (Philadelphia: Greenstone, 1919), 107.

$5^{2}$ Arthur Ruppin, The Jews of To-Day, trans. Margery Bentwich (New York: Henry Holt, 1913), 262. 
have been carried out in order to learn about the different communities and gain an understanding of how to instill a sense of Zionism. There would thus be no reason to play down the number of Jews speaking Arabic. In fact, given the circumstances, the opposite could have been true.

In 1910, the question of how much Arabic the Jews knew was the subject of a discussion in Jerusalem's Sephardic Hebrew newspaper Ha-Herut. In a letter addressed to the Ottoman Jewish community of the northern city of Safad, education supervisor and leading notable Salah al-Din Hajji Yusuf questioned why Jews were not learning Arabic and explained that "unfortunately, there is not one Ottoman Jew in Safad who knows how to read or write, a little or a lot." He then goes on to explain that due to this, the government was forced to give a government position allotted for a Jew to a Christian. He then asks:

Why is it that you are lazy? When will you finally treat the learning of Arabic as an equal? This is the language of the land, and as Ottomans you have the right to participate in legal matters and the rest of the government's administrative tasks. You can only benefit from these rights if you know the language of the state and only then can you work for your homeland, and to benefit from it as your supreme councils do as a result of your knowledge of other languages. I especially direct this call to my friend Mr. David Yusuf Efendi [editor of Ha-Herut] ... who knows the Hebrew language well, that he alert his brothers and his fellow people to the urgency of this and to the great pleasure they will reap by knowing Arabic and to point to the benefit the Ottoman Jews will obtain by doing so ... I know the love this respected editor has for his land (artso) and homeland (moledeto) and his will for the development of the state (medina). I hope that he will help me with this Holy Work for the good of our homeland. ${ }^{53}$

Salah al-Din Hajji Yusuf was correct in his assessment that the editor of Ha-Herut was interested in advancing the study of Arabic and Turkish among the Jewish community. However, what quickly becomes clear is that the Ottoman Jews of Safad were not the only group being discussed. Rather, the overall Sephardic Jewish community in Palestine, including Jerusalem, was part of the analysis. In response to Yusuf's letter, the editor elaborates that his paper led the campaign to teach Arabic and Turkish in schools, yeshivas, batey midrash, and even the Talmud Torah networks. According to the editor, some schools had already adopted a rigorous Arabic program and a teacher had been 
sent to Istanbul to complete a language exam, enabling him to teach Turkish upon his return. After expressing the extreme loyalty Jews have towards their Ottoman homeland, he reiterated that:

once we raise a generation of boys loyal to their homeland, we can hope that through their national feelings and their love of the Land, and through their knowledge of Turkish and Arabic - the languages of the state - we will receive high positions in the administration and the leadership of the army; we will participate in all branches of the government that (are currently) taken care of by those Muslims and Christians who know these languages.

The information provided here suggests that a great number of the Sephardim did not know either of the two languages well. This should not come as a surprise, however, since for many Ottoman Sephardim, French had long since become their language of choice. Further, Hebrew was quickly being adopted as the main language of communication among the Jews of Palestine. Many Sephardic Jews must have spoken a basic level of Arabic. Even so, they still lacked the Arabic reading and writing skills needed to serve the country and to integrate into the workforce within the larger Arab population in Palestine. While it is not possible to go into further detail, the issue of how many Jews actually knew how to read and write in Arabic arose in a Ha-Herut debate, in which the need to establish an Arabic newspaper to counter the anti-Zionist rhetoric in the local Arab press was suggested. One commentator stated that only a handful of Jewish intellectuals could read or write Arabic. ${ }^{54}$

In light of this, the above case of Muslim women speaking Ladino makes even more sense. If Jewish women did not have a strong grasp on the Arabic language, it could be that it was actually their Arab counterparts who were learning Ladino in order to communicate with them. Noteworthy also was that many Ashkenazi immigrants realized the importance of learning languages early on. Once in Palestine, they often learned Turkish (and some Arabic), understanding the central role it played in promoting their goal of an autonomous Jewish land under Ottoman control.

What was not questioned in Hajji Yusuf's plea to learn Arabic was the fact that the Jewish community in Palestine - regardless of ethnic or linguistic background - had already adopted Hebrew as their main language of study, and it was quickly becoming the lingua franca of the Jewish Yishuv. The proliferation of Hebrew in Palestine took hold before the 1908 revolution

Ha-Herut, July 4, 1912. 
and gained momentum after it, developing into a type of local Ottoman Zionism that was not only found in Palestine but was prevalent throughout other Ottoman cities. According to Julia Phillips Cohen, "Proponents of the movement judged their interest in the renaissance of Jewish culture and the Hebrew language to be in line both with the national aspirations of other Ottoman millets and with the promise of the new constitutional regime more generally." And "they were also careful to articulate a vision in which Palestine would become a national center and place of refuge for persecuted Jews without becoming a separate state."55 For example, the Sephardic Jewish Ottoman MP Nisim Matsliah, who was originally from Salonika but ran for elections in Izmir, noted that "I side with the right of Eretz-Israel as a spiritual national center; such a national center will play without a doubt an important role in our national lives, and due to the fact that our spiritual homeland will not be possible without settlements, we will support the settlement of Jews in Eretz-Israel as much as possible. ${ }^{n 6}$

For Ottoman Jews in Palestine, which included a majority of Sephardic Jews, together with a smaller minority of Ashkenazi Jews, the revolution connected their future with the survival of the Ottoman state, even so far as joining the ranks of its military as patriotic Zionists. For these young people, who were born and bred on a synthesis of local Zionist ideology and Ottoman patriotism, there was no contradiction between supporting the Ottoman state and settling the Land of Israel. However, this led to greater divisions in Palestine. For the actors of the revolution, the future was bound to Istanbul, but this notion was not shared by the overwhelming majority of Palestinians on the ground. The process of connecting directly to Istanbul was in keeping with changes occurring among Greeks and Armenians of the empire, where a national revival of a language and culture would be integrated with the new emerged civic Ottomanism, also in essence tying them closer to the capital through their representatives in the Ottoman parliament. These ethnic religious groups encouraged an Ottoman patriotic agenda in order to receive linguistic and national rights, leading to a certain level of separatism. Many Jews who adopted an antiZionist stance nevertheless supported Jewish migration to Palestine. This was the case of the influential Ottoman chief rabbi Hayim Nahum, who also lobbied on behalf of the Jewish Yishuv in Istanbul, which exhibited the centrality of Istanbul in the everyday lives of Jews in Palestine.

55 Julia Phillips Cohen, Becoming Ottomans: Sephardi Jews and Imperial Citizenship in the Modern Era (Oxford: Oxford University Press, 2014), 104.

$5^{6}$ Ha-Olam, March 3, 1909, 13-14. 


\section{Ottoman National Politics and Renegotiating the millet System}

On the political front, Bedross Der Matossian criticizes historical descriptions of a post-1908 utopian sense of equality between different ethnic groups within the empire, stating that "romanticizing the period and arguing that the different ethno-religious groups within the empire tried to see themselves as part of an Ottoman nation under the label 'civic nationalism' is rather misleading." He goes on to state that "constitutionalism failed to create a new understanding of Ottoman citizenship, grant equal rights to all citizens, bring under one roof in a legislative assembly, and finally resuscitate Ottomanism from the ashes of the Hamidian regime. ${ }^{57}$

Adding to this, I argue that the introduction of the new multireligious and multiethnic parliament introduced a period in which each community was "renegotiating the millet system," drawing new boundaries and reaching new understandings of what these changes really meant in practical terms. In short, even if the streets of Istanbul, Thessaloniki, or, for our purposes, Jerusalem, could be described as places of intercommunal relations exhibiting multiple forms of citadinité, the transformation from the millet into "national communities" led to a strengthening of divisions that begun to be broken down in the late nineteenth century. ${ }^{58}$ Furthermore, while it would be difficult to argue that a "civic Ottomanism" did not exist, the communities clearly remained divided, whether in the provinces or the urban areas, with each non-Muslim community separately voicing their grievances with respect to the Muslim political elite of Istanbul. In other words, even in the midst of this "civic Ottomanism" there remained a hierarchy whereby non-Muslim communities had to convince the secular Muslim political elite that their wishes were not detrimental to the empire. Simply put, the millet system transformed into a new system in

57 Bedross Der Matossian, Shattered Dreams of Reality: From Liberty to Violence in the Late Ottoman Empire (Stanford: Stanford University Press, 2014), 2-3. In another article, Eldem explains the extent of mixing between the different religious groups among the professional class of Istanbul. See Edhem Eldem, "(A Quest for) the Bourgeoisie of Istanbul: Identities, Roles and Conflicts," in Urban Governance Under the Ottomans: Between Cosmopolitanism and Conflict, ed. Urlike Freitag and Nora Lafi (London: Routledge, 2014).

58 A similar case of appropriating one's current understanding of intercommunal relations onto the past can be found in Mark R. Cohen's analysis of al-Andalus, who claims that portrayals of the Islamic Middle Age has been misrepresented and that the "interfaith utopia was to a certain extent a myth." See Mark R. Cohen, "The 'Golden Age' of JewishMuslim Relations: Myth and Reality," in A History of Jewish-Muslim Relations: From the Origins to the Present Day, ed. Abdelwahab Meddeb and Benjamin Stora, trans. Jean Marie Todd and Michael B. Smith (Princeton: Princeton University Press, 2013), 28. 
which each community would begin to negotiate their demands from the new Muslim bureaucratic metropolis.

This remained particularly true in the case of Palestine; however, in this case it was Jews and Muslims vying for support among Istanbul's new secular Muslim elite, with each group setting its claims in opposition to the other's. As opposed to the previous system, preferential status of Muslims was replaced with equality before the law, and they were placed on an equal status with the Jewish community: a development which undermined Muslim hegemony. As this occurred, Muslims strengthened their ties with the Christian community, a bond that had already begun to be forged in the late nineteenth century with the rise of Arab nationalism. Jewish immigration continued and included Sephardic Jews - not just Ashkenazim - and the rise of Zionism within Palestine's local Jewish communities; Palestine's Arab population began to jointly identify themselves as "Palestinians" Filasținiyuun, with terms such as al-Sha'b al-Filasțini (the Palestinian people) becoming more common. ${ }^{59}$ This included the adoption of the peasant cause by urban Arabs (notables and a new emerging intelligentsia) in Jaffa, Haifa, and Jerusalem, separating Palestine's urban community from its counterparts in cities such as Damascus and Beirut. In other words, while Palestine's urban elite had strong ties with Syria, their sense of Palestinianism set them apart from their brethren there. Being Palestinian did not contradict their sense of belonging to the Arab people of the empire, nor did it bring into question their loyalty to the Ottoman state.

Even if relations between Jews and Arabs existed in the local urban arena, they never developed in the countryside, where Jewish and Arab communities remained separated. Unlike the Arabs, who adopted the peasant cause and created a sense of Palestinianism, the Jewish community never made attempts to create alliances with Arab peasants. My research shows that often the opposite held true. The Ottoman period bears a striking resemblance to the years of the British Mandate, and in some ways to Israel's postmandate relations with its Palestinian minority; that is to say, the Jewish Yishuv during the late Ottoman period was a self-segregated community and had little interest in or interaction with the Palestinian majority. Similar to these later periods, much of the time the Jewish community viewed the Arab through a narrow lens that focused on violence and mistrust. In the newspaper Ha-Herut, many articles report on random acts of violence and theft committed by Arabs against Jews. In these 
articles, one can detect a clear sense that Arabs were seen as the "other," and Jews killed by Arabs are often described as "martyrs."60

It is in this context that I argue that neither the Palestinian nor the Jewish community was able to contrive a sense of a mutual homeland. If there was any "uniting" or "imagining as a community," it was a process happening to each group separately and not involving the other. The transformation of the Jewish population into a national community was not a uniquely Ashkenazi phenomenon, but was equally strong among the Sephardim. Despite good relations between Arabs and Jews within certain neighborhoods, and despite participation in joint government ceremonies, which can be interpreted as concrete example of citadinité, both communities were being coopted into new national groupings. Each group looked independently towards Istanbul as the metropolis and there was no shared, horizontal sense of equality and brotherhood.

6o One needs only to skim the paper to come across numerous stories of Arabs attacking Jews and Jews becoming the victim of Arab violence. This point is central in understanding that similar to Ashkenazi Jews (who have been documented as "looking down" on the Sephardim, see Lemire, Jerusalem 19oo, 145-46), the Sephardic population also held prejudices towards the greater Arab population. It also can be argued that Ottoman Turkish administrators also held similar prejudices towards the Arab peasant and rural populations. 
Angelos Dalachanis and Vincent Lemire - 978-90-04-37574-1 Downloaded from Brill.com04/26/2023 02:29:03PM via free access 


\section{Bibliography}

Abba Philippos. Know Jerusalem. Addis Ababa: Berhannena Selam Haile Selassie I Printing Press, 1972.

Abba Philippos. The Rights of the Abyssinian Orthodox Church in the Holy Places. Addis Ababa: Documentary Authorities, 1962.

'Abdul Raziq, Adnan. Harat al-Yahud fi al-Quds [The Jewish Quarter in Jerusalem]. Nicosia: Rimal, 2013.

Abdulfattah, Kamal, and Wolf-Dieter Hütteroth. Historical Geography of Palestine, Transjordan and Southern Syria in the Late 16th Century. Erlangen: Erlanger Geographische Arbeiten, 1977.

Abou-El-Haj, Rifa'at Ali. "Aspects of the Legitimation of Ottoman Rule as Reflected in the Preambles to Two Early Liva Kanunnameler." Turcica 21-23 (1991): 371-83.

Abou-El-Haj, Rifa'at Ali. Formation of the Modern State: The Ottoman Empire, Sixteenth to Eighteenth Centuries. Albany: State University of New York Press, 1991.

Abowd, Thomas Philip. Colonial Jerusalem: The Spatial Construction of Identity and Difference in a City of Myth, 1948-2012. Syracuse: Syracuse University Press, 2014.

Abowd, Thomas Philip. "The Moroccan Quarter: A History of the Present." Jerusalem Quarterly, no. 7 (2000): 6-16.

Abu al-Sa'ud, Abdallah. Al-Dars al-tamm fi al-tarikh al-'amm [A complete lesson in general history]. Cairo, 1872.

Abul-Hajj, Amal, and Archibald G. Walls. Arabic Inscriptions in Jerusalem: A Handlist and Maps. London: World of Islam Festival Trust, 1980.

Abu-Lughod, Janet L. Rabat, Urban Apartheid in Morocco. Princeton: Princeton University Press, 1980.

Abu-Manneh, Butrus. "The Husaynīs: The Rise of a Notable Family in 18th Century Palestine." In Palestine in the Late Ottoman Period: Political, Social, and Economic Transformation, edited by David Kushner, 93-108. Jerusalem: Yad Izhak Ben-Zvi, 1986.

Abu-Manneh, Butrus. "The Islamic Roots of the Gülhane Rescript." Die Welt Des Islams 34, no. 2 (1994): 173-203.

Abu-Manneh, Butrus. "The Rise of the Sanjak of Jerusalem in the Late 19th Century." In The Palestinians and the Middle East Conflict, edited by Gabriel Ben-Dor, 21-34. Ramat Gan; Turtledove, 1978.

Acun, Fatma, and Ramazan Acun. "Demand for Justice, and Response of the Sultan in the Early 16th Century." Études balkaniques 2 (2007): 125-48.

Adrianapolsetsi, Poghos. Zanazanut'iwn Hing Daruts' [The differences between five centuries]. Jerusalem: St. James Press, 1840. 
Afzal-Khan, Fawzia, and Kalpana Seshadri-Crooks, eds. The Pre-occupation of Postcolonial Studies. Durham: Duke University Press, 2000.

Aghavnuni, Mkrtich. “'Nakhnik' Voronts' Vorewé Mek Gortsē Tpagrvats é S. At'or 'oys Tparanin Mej” [Ancestors whose works have been published in the printing house of the see]." Sion, no. 11 (1933): 375 .

Ahıskalı, Recep. “'Divan-ı Hümayun Teşkilatı' [The governance of Imperial Chancery of State]. In Osmanlı, edited by Güler Eren, 6:24-33. Ankara: Yeni Türkiye Yayınları, 1999 .

Alami, Mohammad Ali. "The Waqfs of the Traditional Families of Jerusalem During the Ottoman Period," in Ottoman Jerusalem: The Living City, 1517-1917, edited by Sylvia Auld and Robert Hillenbrand, $145^{-5}$. London: Altajir World of Islam Trust, 2000.

Alderman, Goeffrey. "English Jews or Jews of the English Persuasion? Reflections on the Emancipation of Anglo-Jewry." In Paths of Emancipation: Jews, States, and Citizenship, edited by Pierre Birnbaum and Ira Katznelson, 128-56. Princeton: Princeton University Press, 1995.

Alexandridis, Ilarionas A. To typografeion tou Ierou Koinou tou Panagiou Tafou, itoi syntomos perigrafi tis istorias aftou apo tis idryseos tou mechri ton kath'imas chronon (1853-1911) [The printing house of the brotherhood of the Holy Sepulchre, that is, its short description and history from its establishment to the present day (1853-1911)]. Jerusalem, 1911.

Alkan, Mustafa. "Türk Tarihi Araştırmaları Açısından Vakıf Kayıtlar Arşivi” [Waqf records archive from the perspective of Turkish historical studies]. Vakıflar Dergisi 30 (2007): 1-34.

Alroey, Gur. An Unpromising Land: Jewish Migration to Palestine in the Early Twentieth Century. Stanford: Stanford University Press, 2014.

"Alumni Association. Jerusalem Branch." Al-Kulliyeh 2, no. 3 (1911): 107-8.

Alyot, Halim. Türkiye'de Zabıta [Police forces in Turkey]. Ankara: Kanaat Basımevi, 1947 .

Amit, Gish. “Salvage or Plunder? Israel's 'Collection' of Private Palestinian Libraries in West Jerusalem." Journal of Palestine Studies 40, no. 4 (2011): 6-23.

Anderson, Benedict. Imagined Communities: Reflections on the Origin and Spread of Nationalism. London: Verso, 1983.

Andézian, Sossie. "Formation des identités palestiniennes chrétiennes. Églises, espace et nation," Archives de sciences sociales des religions, no. 149 (2010): 189-210.

Antiochos, Spyridon. Ypomnima peri ton en Roumania monastiriakon ktimaton ton Agion Topon [Memorandum on the monastery properties of the Holy Places in Romania]. Athens: D. G. Efstratiou, 1901.

Anisimov, Oleg Viktorovich. Rossiia i Napoleon III: bor'ba za Sviatye Mesta Palestiny [Russia and Napoleon III: the struggle for the holy places of Palestine]. Moscow: Indrik, 2014. 
Anisimov, Oleg Viktorovich, ed. "Frantsuzskii konsul Edmond de Barrère i problema remonta rotondy Sviatogo Groba v Ierusalime, arkhivnye dokumenty. Publikatsia Olega Anisimova" [French consul Edmond de Barrère and the problem of the reconstruction of the Holy Sepulchre's dome: documents from archives published by Oleg Viktorovich Anisimov]. Ierusalimskij Pravoslavnyi Seminar 5 (2010): 199-216. Antébi, Elizabeth. L’homme du Sérail. Paris: Nil, 1996.

Arce, Agostino. Catalogus Descriptivus Illustratus Operumin Typographia Ierosolymorum Franciscali Impressorum, 1847-1880. Jerusalem: Typis franciscalibus, 1969.

Arce, Agostino. "Centenario de La Imprenta Franciscana de Jerusalén 1847-1947." Tierra Santa (November-December 1946), 34-41.

Archimandrite Innokentii (Prosvirnin), "Pam'iati Episkopa Porfiriia (Konstantina Alexandrovicha Uspenskogo) 1804-1885" [In memory of Bishop Porfirii (Konstantin Alexandrovich Uspenskii)]. Bogoslovskie Trudy 26 (1985): 315-25.

'Arif, al-, 'Arif. "The Closing Phase of Ottoman Rule in Jerusalem." In Studies on Palestine during the Ottoman Period, edited by Moshe Ma'oz, 334-40. Jerusalem: Magnes Press, 1975 .

'Arif, al-, 'Arif. al-Mufassal fi tarikh al-Quds [A detailed history of Jerusalem]. Jerusalem, 1961.

Arnold, David. Colonizing the Body: State Medicine and Epidemic Disease in NineteenthCentury India. Berkeley: University of California Press, 1993.

Arnon, Adar. "Mifkede ha-'Ukhlusiya bi-Rushalayim bi-Shalhe ha-Tekufa ha-'Otomanit" [Censuses of the population in Jerusalem at the end of the Ottoman period]. Cathedra, no. 6 (1977): 95-107.

Arnon, Adar. "Teguva le-He'arot M. Levin 'al Zihuy Shemot Rov'e Yerushalayim baTekufa ha-'Otomanit [Response to the comments of M. Levin on the identification of the names of Jerusalem Quarters in the Ottoman period]. Cathedra, no. 15 (1980): 197-98.

Arnon, Adar. "The Quarters of Jerusalem in the Ottoman Period." Middle Eastern Studies 28, no. 1 (1992): 1-65.

Asad al, Nasir al-Din. Muhammad Ruhi al-Khalidi: rảid al-bahth al-tarikhi al-hadith fi Filastin [Muhammad Ruhi al-Khalidi: pioneer of modern historical research in Palestine]. Cairo: Ma'had al-Buhuth wa-l-Dirasat al-Arabiyya, 1970.

Asali, Kamil Jamil. "Haratu'l-Maghariba fi al-Quds wa Ahammiyyatuha at-Tarihiyya" [Maghariba Quarter in Jerusalem and its importance in history]. In Al-Buhus ve al-Dirasat ve al-Makalat [Matters, studies and the articles]. Amman: Vezaretu'sSakafe, 2009.

Asali, Kamil Jamil. Mawsim al-Nabi Musa fî Filastin: Tarikh al-mawsim wa-l-maqam [The mawsim of Nabi Musa in Palestine: History of the mawsim and the sanctuary] (Amman: Matbảa al-Jami’a al-Urduniyya, 1990). 
Asali, Kamil Jamil. Muqaddima fi tarikh al-tibb fi-l-Quds mundhu aqdam al-azminah hata sanat 1918 miladi [Introduction to the history of medicine in Jerusalem from the ancient times until 1918]. Amman: Jordanian University, 1994.

Asali, Kamil Jamil, ed. Jerusalem in History. Buckhurst Hill: Scorpion, 1989.

Ashbee, Charles Robert. "Pro-Jerusalem." The American Magazine of Art 12, no. 3 (1921): 99-102.

Ashbee, Charles Robert, ed.Jerusalem, 1918-1920: Being the Records of the Pro-Jerusalem Council during the Period of the British Military Administration. London: John Murray, 1921.

Ashbee, Charles Robert, ed.Jerusalem, 1920-1922: Being the Records of the Pro-Jerusalem Council during the First Two Years of the Civil Administration. London: John Murray, 1924.

Astafieva, Elena. "Russie en Terre Sainte: Le cas de la Société impériale orthodoxe de Palestine (1882-1917)." Cristianesimo Nella Storia 1 (2003): 41-68.

Atalar, Münir. Osmanlı devletinde surre-i hümâyûn ve surre alayları [Surra-i Humayun and surra regiments in the Ottoman state]. Ankara: Diyanet İşleri Başkanlığı, 1991.

Atallah, Mahmoud. Fahras Makhtutat Al-Tuffaha [An index of manuscripts of the Tuffaha family]. Nablus, 1993.

"Athletic Notes. The Jerusalem Football Series." Al-Kulliyeh 5, no. 6 (1914): 195-98.

Avcı, Yasemin. Değişim sürecinde bir Osmanlı kenti: Kudüs (189o-1914) [An Ottoman city in the period of transformation: Jerusalem, 1890-1914]. Ankara: Phoenix, 2004.

Avcı, Yasemin. "Jerusalem and Jaffa in the Late Ottoman Period: The ConcessionHunting Struggle for Public Works Projects." In Late Ottoman Palestine: The Period of Young Turk Rule, edited by Yuval Ben-Bassat and Eyal Ginio, 81-102. London: I. B. Tauris, 2011.

Avcı, Yasemin, and Vincent Lemire. "De la modernité administrative à la modernisation urbaine: une réévaluation de la municipalité ottomane de Jérusalem (18671917)." In Municipalités méditerranéennes. Les réformes urbaines ottomanes au miroir d'une histoire comparée (Moyen-Orient, Maghreb, Europe Méridionale), edited by Nora Lafi, 73-138. Berlin: Klaus Schwarz, 2005.

Avcı, Yasemin, Vincent Lemire, and Falestin Naili. "Publishing Jerusalem's Ottoman Municipal Archives (1892-1917): A Turning Point for the City's Historiography." Jerusalem Quarterly, no. 60 (2015): 110-19.

Avrutin, Eugene M. "The Politics of Jewish Legibility: Documentation Practices and Reform during the Reign of Nicholas I." Jewish Social Studies 11, no. 2 (2005): 136-69. Ayalon, Ami. Reading Palestine: Printing and Literacy, 19oo-1948. Austin: University of Texas Press, 2004.

Ayalon, Ami, and Nabih Bashir. "Introduction: History of the Arabic Press in the Land of Israel/Palestine." National Library of Israel. Accessed November 19, 2017. http:// web.nli.org.il/sites/nlis/en/jrayed/Pages/History-of-the-Arabic-Press.aspx. 
Aytürk, İlker. "Revisiting the Language Factor in Zionism: The Hebrew Language Council from 1904 to 1914." Bulletin of the School of Oriental and African Studies 73, no. 1 (2010): $45^{-64}$.

Azaryahu, Maoz. "Naming the Streets of (Arab) Jerusalem during the British Period 1920-1948." Horizons in Geography, nos. 6o/61 (2004): 299-308.

Azoury, Negib. Le réveil de la nation arabe dans l'Asie turque. Paris: Librairie Plon, 1905.

Baer, Gabriel. "Jerusalem's Families of Notables and Waqf in the Early 19th Century," in Palestine in the Late Ottoman Period, edited by David Kushner, 109-23 (Leiden: Brill, 1986).

Baer, Gabriel. Studies in the Social History of Modern Egypt. Chicago: University of Chicago Press, 1969.

Bar, Doron, and Kobi Cohen-Hattab. "A New Kind of Pilgrimage: The Modern Tourist Pilgrim of Nineteenth-Century and Early Twentieth-Century Palestine." Middle Eastern Studies 39, no. 2 (2003): 131-48.

Barakat, Rana. “Urban Planning, Colonialism, and the Pro-Jerusalem Society." Jerusalem Quarterly, no. 65 (2016): 22-34.

Baram, Uzi. “Out of Time: Erasing Modernity in an Antique City." Archaeologies:Journal of the World Archaeological Congress 8, no. 3 (2012): 330-48.

Baratto, Claudio. "La tipografia francescana Di S. Salvatore." In La Custodia Di Terra Santa e l'Europa: I rapporti politici e l'attività culturale dei Francescani in Medio Oriente, edited by Michele Piccirillo, 207-11. Rome: Il Veltro, 1983.

Barbir, Karl K. Ottoman Rule in Damascus, 1708-1758. Princeton: Princeton University Press, 1980.

Barghuthi, Omar Bey Salih al-. "Local Self-Government-Past and Present." The Annals of the American Academy of Political and Social Science 164 (1932): 34-38.

Barkan, Ömer Lütfi. "Edirne ve Civarındaki Bazı İmaret Tesislerinin Yıllık Muhasebe Bilançoları" [Annual accountancy balances of some Imārah facilities in and around Edirne]. Türk Tarih Belgeleri Dergisi 1, no. 2 (1964): 235-377.

Barkey, Karen. Bandits and Bureaucrats: The Ottoman Route to State Centralization. Ithaca: Cornell University Press, 1994.

Barnai, Jacob. "The Jerusalem Jewish Community, Ottoman Authorities and Arab Population in the Second Half of the Eighteenth Century: A Chapter of Local History." Jewish Political Studies Review 6, no. 34 (1994): 7-45.

Barron, John Bernard. Palestine: Report and General Abstracts of the Census of 1922. Jerusalem: Greek Convent Press, 1923.

Bartal, Israel. "Berurim be-Shuley Tazkir Kolel Ha-Sefaradim Bi-Rushalayim Mi-Shenat Tartav" [Some queries regarding the 1885 memo of the Sephardic kolel in Jerusalem]. Zion 43 (1978): 97-118.

Bartal, Israel. Galut ba-'Arets [Exile in the homeland]. Jerusalem: Zionist Library, 1994. 
Bartal, Israel. "Mevaser U-Modi'a le-'Ish Yehudi: Ha-'Itonut ha-Yehudit ke-'Afik shel Hidush" [The Jewish press as a conduit of modernization]. Cathedra, no. 71 (1994): 156-64.

Barth, Fredrik. "Enduring and Emerging Issues in the Analysis of Ethnicity." In The Anthropology of Ethnicity: Beyond "Ethnic Groups and Boundaries," edited by Hans Vermeulen and Cora Govers. The Hague: Het Spinhuis, 1994.

Basili, Konstantin. Syriia i Palestina pod turetskim pravitel'stvom [Syria and Palestine under Turkish domination]. Odessa, 1862.

Batchen, Geoffrey. "Dreams of Ordinary Life: Cartes-de-Visite and the Bourgeois Imagination." In Photography: Theoretical Snapshots, edited by Jonathan J. Long, Andrea Noble, and Edward Welch, 80-97. London: Routledge, 2009.

Beeri, Eliezer. Reshit ha-Sikhsukh Yisrảel-Arav 1882-1911 [The beginning of the ArabIsraeli conflict, 1882-1911]. Tel Aviv: Sifriyat Poalim, 1985.

Behar, Cem. A Neighborhood in Ottoman Istanbul: Fruit Vendors and Civil Servants in the Kasap Illyas Mahalle. Albany: State University of New York Press, 2003.

Behar, Cem, and Alan Duben. Istanbul Households: Marriage, Family, and Fertility, 1880-1940. Cambridge: Cambridge University Press, 1991.

Bektaş, Yakup. “The Sultan's Messenger: Cultural Constructions of Ottoman Telegraphy, 1847-1880." Technology and Culture 41, no. 4 (2000): 669-96.

Ben-Arieh, Yehoshua. Ir bi-R' i Tekufah - Yerushalayim ba-Me' a ha-Tesha'-Esre, ha-Ir ha-'Atika [A city reflected in its times: Jerusalem in the nineteenth century: The Old City]. Jerusalem: Yad Ben-Zvi Institute, 1977.

Ben-Arieh, Yehoshua. Jerusalem in the 19th Century: Emergence of the New City. Jerusalem: Yad Izhak Ben-Zvi; New York: St. Martin's Press, 1986.

Ben-Arieh, Yehoshua. Jerusalem in the Nineteenth Century: The Old City. Jerusalem; New York: Yad Izhak Ben-Zvi; St. Martin's Press, 1984.

Ben-Bassat, Yuval. "Mass Petitions as a Way to Evaluate 'Public Opinion' in the Late Nineteenth-Century Ottoman Empire? The Case of Internal Strife among Gaza's Elite." Turkish Historical Review 4, no. 2 (2013): 135-52.

Ben-Bassat, Yuval. Petitioning the Sultan: Protests and Justice in Late Ottoman Palestine, 1865-1908. London: I. B. Tauris, 2013.

Ben-Bassat, Yuval, and Eyal Ginio. "Introduction: The Case Study of Palestine during the Young Turk Era." In Late Ottoman Palestine: The Period of Young Turk Rule, edited by Yuval Ben-Bassat and Eyal Ginio, 1-14. London: I. B. Tauris, 2011.

Ben-Bassat, Yuval, and Eyal Ginio. Late Ottoman Palestine: The Period of Young Turk Rule. London: I. B. Tauris, 2011.

Benvenisti, Meron. City of Stone:The Hidden History of Jerusalem. Translated by Maxime Kaufman Nunn. Berkeley: University of California Press, 1996.

Ben-Yehuda, Eliezer. Eliezer ben-Yehuda be-Vet ha-Asurim, Hanuka 654/1893: Igrot [Eliezer Ben-Yehuda in prison, Hannukah 654/1893]. Edited by Yehoshua Kaniel. Jerusalem: Yad Izhak Ben-Zvi, 1983. 
Ben-Yehuda, Eliezer. Ha-Halom ve-Shivro [The dream and its interpretation], http:// benyehuda.org/by/haidan_harishon.html.

Ben-Yehuda, Eliezer. Ha-Medina ha-Yehudit: Mảamarim Shonim 'al-Devar Ha-Tsa'at Mizrah Afrika [The Jewish state: assorted articles on the East Africa proposal]. Warsaw: Medina, 1905 .

Ben-Yehuda, Eliezer. Milon ha-Lashon ha-'vrit ha-Yeshana ve-ha-Hadasha [The dictionary of the Hebrew language, ancient and modern]. Edited by Moses Segal and Naphtali Tur-Sinai. 16 vols. Jerusalem: Hotsảat Makor, 1980.

Berdumiants, Petros. Meknut'iwn t'ght'oyn Poghosi ar Yep'esats'is [Interpretation of the Epistle of Paul the Apostle to the Ephesians]. Jerusalem: St. James Press, 1850.

Berg, Maxine, and Helen Clifford. "Selling Consumption in the Eighteenth Century: Advertising and the Trade Card in Britain and France." Cultural and Social History 4 , no. 2 (2007): 145-70.

Berry-Chikhaoui, Isabelle. "Les notions de citadinité et d'urbanité dans l'analyse des villes du Monde arabe." Les Cahiers d'EMAM, no. 18 (2009): 9-20.

Bertram, Sir Anton, and John W. A. Young. The Orthodox Patriarchate of Jerusalem: Report of the Commission Appointed by the Government of Palestine to Inquire and Report upon Certain Controversies between the Orthodox Patriarchate of Jerusalem and the Arab Orthodox Community. London: Oxford University Press, 1926.

Bertram, Sir Anton, and Harry Charles Luke. Report of the Commission Appointed by the Government of Palestine to Inquire into the Affairs of the Orthodox Patriarchate of Jerusalem. London: Oxford University Press, 1921.

Beška, Emanuel. "Anti-Zionist Attitudes and Activities of Rūḥī Al-Khālidī." In Arabic and Islamic Studies in Honour of Ján Pauliny, edited by Zuzana Gažáková and Jaroslav Drobný, 181-203. Bratislava: Univerzita Komenského v Bratislave, 2016.

Bezobrazov, Pavel V. Materialy dl'a biographii episkopa Porfiriia Uspenskogo [Materials on the biography of Bishop Porfirii Uspenskii]. Vol. 1, Official Papers; Vol. 2, Correspondence. St. Petersburg: Imperial Academy of Sciences, 1910.

Bialer, Uri. Cross on the Star of David: The Christian World in Israel's Foreign Policy, 19481967. Bloomington: Indiana University Press, 2005.

Bialer, Uri. "Horse Trading: Israel and the Greek Orthodox Ecclesiastical Property, 1948-1952." Journal of Israeli History 24, no. 2 (2005): 203-13.

Bickham, Troy. "Eating the Empire: Intersections of Food, Cookery and Imperialism in Eighteenth-Century Britain." Past \& Present, no. 198 (2008): 71-109.

Bierman, Irene A. Writing Signs: The Fatimid Public Text. Berkeley: University of California Press, 1998.

Bigon, Liora, ed. Place Names in Africa: Colonial Urban Legacies, Entangled Histories. Cham: Springer, 2016.

Bigon, Liora, ed. "Urban Planning, Colonial Doctrines and Street Naming in French Dakar and British Lagos, 1850-1930." Urban History 36, no. 3 (2009): 426-48. 
Blumberg, Arnold. A View from Jerusalem, 1849-1858: The Consular Diary of James and Elizabeth Anne Finn. Rutherford: Fairleigh Dickinson University Press, 1980.

Blumi, Isa. Rethinking the Late Ottoman Empire: A Comparative Social and Political History of Albania and Yemen, 1878-1918. Istanbul: Isis Press, 2003.

Blyth, Estelle. When We Lived in Jerusalem. London: John Murray, 1927.

Bosworth, Edmund. "The Land of Palestine in the Late Ottoman Period as Mirrored in Western Guide Books." Bulletin (British Society for Middle Eastern Studies) 13, no. 1 (1986): 36-44.

Bouquet, Olivier. “Is It Time to Stop Speaking about Ottoman Modernisation?” In Order and Compromise: Government Practices in Turkey from the Late Ottoman Empire to the Early 21st Century, edited by Marc Aymes, 45-67. Leiden: Brill, 2015.

Bourmaud, Philippe. "Les entrelacs du public et du privé dans le monde ottoman." In Espace et construction de soi, edited by Maria Uzcategui and Yves Moreau. Special issue, Les Carnets du LARHRA 3, no. 2 (2014): 123-38.

Bourmaud, Philippe. "Les faux-semblants d'une politique internationale: la Société Des Nations et la lutte contre l'alcoolisme dans les mandats (1919-1930)." In "Re-Reading Mandate History through a Health Policy Lens," ed. Philippe Bourmaud. Special issue, Canadian Bulletin of Medical History 30, no. 2 (2013): 69-9o.

Bourmaud, Philippe. "Public Space and Private Spheres. The Foundation of St Luke's Hospital of Nablus by the CMS (1891-1901)." In New Faiths in Ancient Lands: Western Missions in the Middle East in the Nineteenth and Early Twentieth Century, edited by Heleen Murre-van den Berg, 151-74. Leiden: Brill, 2006.

Bourmaud, Philippe. "'A Son of the Country.' Dr Tawfiq Canaan, Modernist Physician and Palestinian Ethnographer." In Struggle and Survival in Palestine/Israel, edited by Mark LeVine and Gershon Sharif, 104-24. Berkeley: University of California Press, 2012.

Bourmaud, Philippe. “Ya Doktor ! Devenir médecin et exercer son art en 'Terre sainte’: une expérience du pluralisme médical dans l'Empire ottoman finissant (1871-1918)." PhD diss., University of Provence, 2007.

Bowman, Glenn. "Sharing and Exclusion: The Case of Rachel's Tomb." Jerusalem Quarterly, no. 58 (2014): 30-49.

Bréhier, Louis. Le monde byzantin. Vol. 2, Les institutions de l'Empire byzantin. Paris: Editions Mimésis, 2015.

Brubaker, Rogers. "Ethnicity without Groups." Archives européennes de sociologie 43, no. 2 (2002): 163-89.

Buffon, Giuseppe. Les Franciscains en Terre Sainte (1869-1889): Religion et politique: une recherche institutionnelle. Paris: Cerf, Éditions franciscaines, 2005.

Burgoyne, Michael Hamilton. Mamluk Jerusalem: An Architectural Study. London: World of Islam Festival Trust for the British School of Archaeology in Jerusalem, 1987 . 
Büssow, Johann. Hamidian Palestine: Politics and Society in the District of Jerusalem, 1872-19o8. Leiden: Brill, 2011.

Bustani al-, Butrus. Dáirat Al-Ma'arif [The encyclopedia]. Vol. 8. Beirut: Librairie du Liban, 1956.

Bustani al-, Butrus. Kitab rawdat al-tajir fi mask al-dafatir [The trader's guide to bookkeeping]. Beirut, 1859 .

Bustani al-, Salim. Iftitahat Majalla al-Jinan Al-Bayrutiyya, 1870-1884 [Editorials of the Beirut journal al-Jinan, 1870-1884]. Edited by Y. Khuri. 2 vols. Beirut: Dar al-Hamrả, 1990.

Buzpınar, Şit Tufan. "Surre" [Sura]. In DiA (Türkiye Diyanet Vakfı İslam Ansiklopedisi) [Turkish Religious Foundation Encyclopedia of Islam]. Istanbul: TDV, 2009.

Cadiot, Jean-Michel. Les chrétiens d'Orient: vitalité, souffrances, avenir. Paris: Salvator, 2010.

Calame, Jon, and Esther Ruth Charlesworth. Divided Cities: Belfast, Beirut, Jerusalem, Mostar, and Nicosia. Philadelphia: University of Pennsylvania Press, 2009.

Camorani, Margherita. "Il Primo Secolo Della Tipografia Francescana Franciscan Printing Press Dal 1846 Al 1947." MA diss., Università Cattolica del Sacro Cuore di Milano, 2013.

Campos, Michelle U. "Making Citizens, Contesting Citizenship in Late Ottoman Palestine." In Late Ottoman Palestine: The Period of Young Turk Rule, edited by Yuval Ben-Bassat and Eyal Ginio, 18-33. London: I. B. Tauris, 2011.

Campos, Michelle U. "Mapping Urban Communities in Late Ottoman Jerusalem: A Digital Neighborhood Study" (forthcoming).

Campos, Michelle U.Ottoman Brothers: Muslims, Christians, andJews in Early TwentiethCentury Palestine. Stanford: Stanford University Press, 2011.

Canaan, Tawfiq. "Cerebro-Spinal Meningitis in Jerusalem." Al-Kulliyeh 2, no. 6 (1911): 206-15.

Canaan, Tawfiq. "The Child in Palestinian Arab Superstition." Journal of the Palestine Oriental Society 7, no. 4 (1927): 159-86.

Canaan, Tawfiq. "Al-Sihhah asas al-hayah al-qawmiyyah" [Health as the basis of national life]. Al-Kulliyeh 9, no. 9 (1923): 391-95.

Canbakal, Hülya. Society and Politics in an Ottoman Town: Ayntāb in the 17th Century. Leiden: Brill, 2007.

Candemir, Murat. "Bâb-ı Âli Evrâk Odası" [Record office of the Sublime Porte]. PhD diss., Istanbul University, 2002.

Caplan, Kimmy. "Trends and Characteristics in the Study of Orthodoxy in the Israeli Academy." Zion 74 (2009): 353-72.

Carmel, Alex. Die Siedlungen der württembergischen Templer in Palästina, 1868-1918. Stuttgart: Kohlhammer, 1973. 
Carter, Henry Vandyke. Reports on Leprosy (Second Series), Comprising Notices of the Disease as It Now Exists in North Italy, the Greek Archipelago, Palestine and Parts of the Bombay Presidency of India. London: Eyre and Spottiswoode, 1876.

Çelik, Zeynep. The Remaking of Istanbul: Portrait of an Ottoman City in the Nineteenth Century. Seattle: University of Washington Press, 1986.

Certeau, Michel de. The Writing of History. Translated by Tom Conley. New York: Columbia University Press, 1988.

Cerulli, Enrico. Etiopi in Palestina. 2 vols. Rome: Libreria dello Stato, 1943-47.

Chahrour, Marcel. “'A Civilizing Mission'? Austrian Medicine and the Reform of Medical Structures in the Ottoman Empire, 1838-1850." Studies in History and Philosophy of Biological and Biomedical Sciences 38, no. 4 (2007): 687-705.

Chamkerten, Astghik. Yerusaghém Ew Kuilpénkeanner [Jerusalem and the Gulbenkians]. Lisbon: Calouste Gulbenkian Foundation, 2007.

Chartier, Roger. Inscrire et effacer: culture écrite et littérature $\left(X I^{e}-X V I I I^{e}\right.$ siècle $)$. Paris: Gallimard, 2005.

Chevalier, Yves. "Quelques précurseurs chrétiens du sionisme." In Aspects du Sionisme: théorie, utopie, histoire. Actes de l'atelier international INALCO tenu au Collège de France, 21-31. Paris: INALCO, 1982.

Chiffoleau, Sylvia. Genèse de la santé publique internationale. De la peste d'Orient à l'OMS. Beirut: Institut français du Proche-Orient (Ifpo); Rennes: Presses universitaires de Rennes, 2012.

Çiftçi, Aynur. "Son Dönem İstanbul Karakolları. Anadolu Yakası ve Büyükdere Topçu Karakolu" [Police stations in late Ottoman Istanbul: the Asian Shore and Büyükdere police station]. MA diss., Yıldız Technical University, 1996.

Cleveland, William L. "The Municipal Council of Tunis, 1858-1870: A Study in Urban Institutional Change." International Journal of Middle East Studies 9, no. 1 (1978):33-61.

Cohen, Amnon. The Guilds of Ottoman Jerusalem. Leiden: Brill, 2001.

Cohen, Julia Phillips. Becoming Ottomans: SephardiJews and Imperial Citizenship in the Modern Era. Oxford: Oxford University Press, 2014.

Cohen, Julia Phillips, and Sarah Abrevaya Stein, eds. "A Debate on Zionism in the Ottoman Parliament (1911)." In Sephardi Lives: A Documentary History, 1700-1950, 222-24. Stanford: Stanford University Press, 2014.

Cohen, Mark R. “The 'Golden Age' of Jewish-Muslim Relations: Myth and Reality." In in A History of Jewish-Muslim Relations: From the Origins to the Present Day, edited by Abdelwahab Meddeb and Benjamin Stora, translated by Jane Marie Todd and Michael B. Smith, 28-38. Princeton: Princeton University Press, 2013.

Cohen Muller, Rina. "La presse hébraïque, un vecteur de l'entrée des Juifs dans la modernité." Yod. Revue des études hébraïques et juives, no. 17 (June 30, 2012): 13-23.

Cohen, William B. Français et Africains. Les Noirs dans le regard des Blancs, 1530-1880. Paris: Gallimard, 1981. 
Cohen, William B. Urban Government and the Rise of the French City: Five Municipalities in the Nineteenth Century. New York: St. Martin's Press, 1998.

Cohen-Hattab, Kobi, and Noam Shoval. Tourism, Religion, and Pilgrimage in Jerusalem. New York: Routledge, 2015.

Collin, Bernardin. Le problème juridique des lieux-saints. Cairo: Centre d'études orientales; Paris: Sirey, 1956.

Conboy, Seamus. “Changing Dublin Street Names, 1880's to 1940's.” Dublin Historical Record 64, no. 2 (2011): 205-25.

Coquery, Natacha. "Language of Success: Marketing and Distributing Semi-Luxury Goods in Eighteenth-Century Paris." Journal of Design History 17, no. 1 (March 1, 2004): 71-89.

Cornet, Anne. Politiques de santé et contrôle social au Rwanda: 1920-1940. Paris: Karthala, 2011.

Coşgel, Metin M. “Ottoman Tax Registers (Tahrir Defterleri).” Historical Methods 37, no. 2 (2004): 87-102.

Courtois, Sébastien de. Le nouveau défi des chrétiens d'Orient d'Istanbul à Bagdad. Paris: Lattès, 2009.

Crawford, Alan. C. R. Ashbee: Architect, Designer \& Romantic Socialist. 2nd ed. New Haven: Yale University Press, 2005.

Cust, Lionel George Archer. The Status Quo in the Holy Places. Jerusalem: Ariel Publishing, 1980. First published 1929.

Dağlar, Oya. War, Epidemics, and Medicine in the Late Ottoman Empire (1912-1918). Haarlem: Sota, 2008.

Dalachanis, Angelos. "Confessions et minorités." In Le Moyen-Orient fin XIX $X^{e}-X X^{e}$ siècle, edited by Leyla Dakhli, 73-98. Paris: Seuil, 2016.

Darling, Linda T. Revenue-Raising and Legitimacy: Tax Collection and Finance Administration in the Ottoman Empire, 1560-166o. Leiden: Brill, 1996.

Darrah, William C. Cartes de Visite in Nineteenth Century Photography. Gettysburg: W. C. Darrah, 1981.

Darwazih, Muhammad 'Izzat. Mudhakarrtwa-Tasjilat [Memories and remembrances]. 2 vols. Amman, 1984 .

Davie, May. "Manouk Avédissian, alias Béchar afandi al-mouhandis." In Médecins et ingénieurs Ottomanes à l'âge des nationalismes, edited by Méropi Anastassiadou, 221-42. Paris: Maisonneuve \& Larose, 2003.

Dekker, Rudolf. “Jacques Presser's Heritage: Egodocuments in the Study of History," Memoria y Civilización 5 (2002): 13-37.

Deleurmoz, Quentin. "Usages de Goffman au XIX ${ }^{\mathrm{e}}$ siècle: policiers en tenue, institutions et ordres sociaux à Paris." In "Sociologie et histoire: chantier permanent." Special issue, Carnets de bord en sciences humaines, no. 14 (2007): 33-42.

Der Matossian, Bedross. Shattered Dreams of Revolution: From Liberty to Violence in the Late Ottoman Empire. Stanford: Stanford University Press, 2014. 
Deringil, Selim. "Legitimacy Structures in the Ottoman State:The Reign of Abdülhamid II (1876-1909)." International Journal of Middle East Studies 23, no. 3 (1991): 345-59.

Deringil, Selim. The Well-Protected Domains: Ideology and the Legitimation of Power in the Ottoman Empire, 1876-19og. London: I. B. Tauris, 1998.

Derrida, Jacques, and Eric Prenowitz. "Archive Fever: A Freudian Impression." Diacritics 25, no. 2 (1995): 9-63.

Desplaudes, Marc-Olivier. "Une fiction d'institution: les besoins de santé de la population." In Comment se construisent les problèmes de santé publique, edited by Claude Gilbert and Emmanuel Henry, 252-72. Paris: La Découverte, 2009.

Diotallevi, Ferdinando. Diario di Terrasanta: 1918-1924. Edited by Daniela Fabrizio. Milan: Biblioteca Francescana, 2002.

Divine, Donna Robinson, and Philip Carl Salzman, eds. Postcolonial Theory and the Arab-Israel Conflict. London: Routledge, 2008.

Dmitrievskii, Alexei Afanas'evich. Ep. Porfirii Uspenskii kak iniciator iorganizator pervoi russkoi dukhovnoi missii v Ierusalime [Bishop Porfirii Uspenskii, the initiator and organizer of the First Russian Ecclesiastical Mission in Jerusalem]. St. Petersburg, 1906.

Dmitrievskii, Alexei Afanas'evich. Porfirii (Uspenskii). Po povodu stoletija so dnia ego rozhdenija [Porfirii (Uspenskii): on the occasion of the centenary of his birth]. St. Petersburg, 1906.

Dmitrievskii, Alexei Afanas'evich. "Uchrezhdenie i pervyi period deiatel'nosti Russkoi Dukhovnoi missii pod nachal'stvom Arkhimandrita Porfiriia (1842-1855)" [Foundation and first period of the activities of the Russian ecclesiastical mission under archimandrite Porfirii (1842-1855)], in Rossiia v Sviatoi Zemle. Documenty $i$ materialy, vol. II, edited by Nikolai N. Lisovoi (Moscow: Mezhdunarodnye otnosheniia, 2000).

Dolev, Eran. Allenby's Military Medicine: Life and Death in World War I Palestine. London: I. B. Tauris, 2007.

Doss, Madiha. "The Dragoman's Journey through Time and Space." Alif: Journal of Comparative Poetics, no. 26 (2006): 64-84.

Doumani, Beshara B. Family Life in the Ottoman Mediterranean: A Social History. Cambridge: Cambridge University Press, 2017.

Doumani, Beshara B. "Palestinian Islamic Court Records: A Source for Socioeconomic History." MESA Bulletin 19 (1985): 155-72.

Doumani, Beshara B. "Rediscovering Ottoman Palestine: Writing Palestinians into History." Journal of Palestine Studies 21, no. 2 (1992): $5^{-28}$.

Doumani, Beshara B. Rediscovering Palestine: Merchants and Peasants in Jabal Nablus, 1700-1900. Berkeley: University of California Press, 1995.

Dowty, Alan. “'A Question That Outweighs All Others': Yitzhak Epstein and Zionist Recognition of the Arab Issue." Israel Studies 6, no. 1 (2001): 34-54. 
Draskhanakerttsi, Hovhannes. Patmagrut'iwn Yovhannu Kat'oghikosi Amenayn Hayots [History of Catholicos Yovhann of All Armenians]. Jerusalem: St. James Press, 1843.

Duben, Alan. "Household Formation in Late Ottoman Istanbul." International Journal of Middle East Studies 22, no. 4 (1990): 419-35.

Dumont, Paul, and François Georgeon, eds. Villes ottomanes à la fin de l'Empire. Paris: L'Harmattan, 1992.

Dumper, Michael. Islam and Israel: Muslim Religious Endowments and the Jewish State. Washington, DC: Institute for Palestine Studies, 1994.

Dumper, Michael. The Politics of Jerusalem since 1967. New York: Columbia University Press, 1997.

Dumper, Michael. The Politics of Sacred Space: The Old City of Jerusalem in the Middle East Conflict. Boulder: Lynne Rienner, 2002.

Edwards, John R. A History of Financial Accounting. London: Routledge, 1989.

Efendi, Ömer Hilmi. Ithaf-Ül-Ahlaf Fi Ahkam-İl-Evkaf [Laws relating to foundations]. Ankara: Vakıflar Genel Müdürlüğü Yayınları, 1977.

Eisenman, Robert H. Islamic Law in Palestine and Israel: A History of the Survival of Tanzimat and Sharia in the British Mandate and the Jewish State. Leiden: Brill, 1978.

Eisler, Jacob. Der deutsche Beitrag zum Aufstieg Jaffas, 1850-1914: zur Geschichte Palästinas im 19. Jahrhundert. Wiesbaden: Harrassowitz, 1997.

Eldem, Edhem. "Istanbul as a Cosmopolitan City: Myths and Realities." In A Companion to Diaspora and Transnationalism, edited by Ato Quayson and Girish Daswani, 21230. Chichester: Wiley Blackwell, 2013.

Eldem, Edhem. "Ottoman Financial Integration with Europe: Foreign Loans, the Ottoman Bank and the Ottoman Public Debt." European Review 13, no. 3 (2005): 431-45.

Eldem, Edhem. "(A Quest for) the Bourgeoisie of Istanbul: Identities, Roles and Conflicts." In Urban Governance Under the Ottomans: Between Cosmopolitanism and Conflict, edited by Nora Lafi and Ulrike Freitag, 159-86. London: Routledge, 2014.

Elger, Ralf, and Yavuz Köse, eds. Many Ways of Speaking about the Self: Middle Eastern Ego-Documents in Arabic, Persian, and Turkish (14th-2oth Century). Wiesbaden: Harrassowitz, 2010.

Eliav, Mordechai, ed. Britain and the Holy Land, 1838-1914: Selected Documents from the British Consulate in Jerusalem. Jerusalem: Yad Izhak Ben-Zvi, 1997.

Emecen, Feridun. "Osmanlı Divanının Ana Defter Serileri: Ahkâm-ı Mîrî, Ahkâm-ı Kuyûd-ı Mühimme ve Ahkâm-ı Şikâyet [The principal series of registers of the Ottoman Imperial Council: Imperial decrees, decrees of the Ottoman Imperial Council, grievance decrees]. Türkiye Literatür Araştırmaları Dergisi 3, no. 5 (n.d.): 107-39. 
Emmett, Chad Fife. Beyond the Basilica: Christians and Muslims in Nazareth. Chicago: University of Chicago Press, 1995.

Emmett, Chad Fife. "The Christian and Muslim Communities and Quarters of the Arab City of Nazareth." PhD diss., University of Chicago, 1991.

Epstein, Yitshak. "She'ela Na'alama" [The hidden question] Ha-Shiloah 17 (December 1907): 193-206.

Erder, Yoram. "The Mourners of Zion: The Karaites in Jerusalem in the Tenth and Eleventh Centuries." In Karaite Judaism: A Guide to its History and Literary Sources, edited by Meira Polliack, 213-35. Leiden: Brill, 2003.

Erdoğan Yayla, Hilmi. "Accounting and the Art of Writing." Paper presented at the 19th Accounting, Business and Financial History Conference, Cardiff Business School Erasmus University, 2007, and the 31st annual congress of the European Accounting Association, Erasmus University, April 2008.

Ergin, Osman Nuri. Mecelle-i Umur-u Belediye [Book of municipal affairs]. Istanbul: Arşak Garoyan Matbaası, 1922.

Ergut, Ferdan. Modern Devlet ve Polis: Osmanlidan Cumhuriyet'e Toplumsal Denetimin Diyalektiği [The modern state and the police: the dialectics of social control from the Ottoman era to the republic]. Istanbul: Iletişim, 2004.

Erkmen, Alev. Geç Osmanlı Dünyası'nda Mimarlık ve Hafıza: Arşiv, Jübile, Âbide [Architecture and memory in the late Ottoman world: archive, jubilee, monument]. Istanbul: Bek, 2010.

Eroğlu Memiş, Şerife. "Osmanlı Taşra Toplumu ve Vakıf Kurumu: Kudüs, 1703-1831" [Ottoman provincial society and the waqf: Jerusalem, 1703-1831]. PhD diss., Hacettepe University, 2016.

Fahmy, Khaled. "The Police and the People in Nineteenth-Century Egypt." Die Welt Des Islams 39, no. 3 (1999): 340-77.

Fakhr ed-Din, Munir, and Salim Tamari. Jerusalem properties and endowments in the 2oth century. Beirut: Institute for Palestine Studies, forthcoming 2018, in Arabic.

Fanon, Frantz. A Dying Colonialism. Translated by Haakon Chevalier. New York: Grove Press, 1967.

Fanon, Frantz. The Wretched of the Earth. Translated by Richard Philcox. New York: Grove Press, 2005.

Faroqhi, Suraiya. "Political Activity among Ottoman Taxpayers and the Problem of Sultanic Legitimation (1570-1650)." Journal of the Economic and Social History of the Orient 35, no. 1 (1992): 1-39.

Farsakh, Leila. "Undermining Democracy in Palestine: The Politics of International Aid since Oslo." Journal of Palestine Studies 45, no. 4 (2016): 48-63.

Fattah, Hala, Jens Hanssen, Edouard Meténier, and Keith David Watenpaugh. "Opening the Doors: Intellectual Life and Academic Conditions in Post-War Baghdad." The 
Iraqi Observatory. July 15, 2003. Accessed January 1, 2018. https://www.h-net.org/ about/press/opening_doors/.

Ferziger, Adam S. The Emergence of the Community Kollel: A New Model for Addressing Assimilation. Beersheba: Rappaport Center for Assimilation Research and Strengthening Jewish Vitality, Bar Ilan University, 2006.

Finn, James, and Elizabeth Anne McCaul Finn. Stirring Times: Or, Records from Jerusalem Consular Chronicles of 1853 to 1856. 2 vols. London: C. K. Paul, 1878.

Fishman, Louis. "Understanding the 1911 Ottoman Parliament Debate on Zionism in Light of the Emergence of a 'Jewish Question.'” In Late Ottoman Palestine: The Period of Young Turk Rule, edited by Yuval Ben-Bassat and Eyal Ginio, 103-23. London: I. B. Tauris, 2011.

Fleischman, Ellen L. The Nation and its "New" Women: The Palestinian Women's Movement, 1920-1948. Berkeley: University of California Press, 2003.

Fleming, Juliet. Graffiti and the Writing Arts of Early Modern England. London: Reaktion, 2001.

Forster, Edward M. Howards End. New York: Penguin, 2000.

Foster, Zachary J. "Arab Historiography in Mandatory Palestine, 1920-1948." MA diss., Georgetown University, 2011.

Fotić, Aleksandar. "The Official Explanations for the Confiscation and Sale of Monasteries (Churches) and Their Estates at the Time of Selim II." Turcica 26 (1994): 33-54.

Foucault, Michel. History of Madness. Edited by Jean Khalfa and Jonathan Murphy. Translated by Jean Khalifa. London: Routledge, 2006.

Foucault, Michel. The History of Sexuality. Translated by Robert Hurley. 3 vols. New York: Vintage Books, 1988.

Foucault, Michel. "L'incorporation de l'hôpital dans la technologie moderne." Hermès, La Revue 2, no. 2 (1988): 30-40.

Fox, Gedảon. "Bibliyografiya, 'Itonim ve-Kitve 'Et Yehudiyim bi-Rushalayim, 1923-1854" [Jewish newspapers and periodicals in Jerusalem, 1923-1854." Cathedra, no. 6 (1977): 187-218.

Frary, Lucien J. "Russian Missions to the Orthodox East: Antonin Kapustin (1817-1894) and His World." Russian History 40, no. 1 (2013): 133-51.

Freitag, Ulrike, Malte Furhmann, Nora Lafi, and Florian Riedler, eds. The City in the Ottoman Empire: Migration and the Making of Urban Modernity. London: Routledge, 2011.

Friedland, Roger, and Richard Hecht. "The Nebi Musa Pilgrimage and the Origins of Palestinian Nationalism." In Pilgrims and Travelers to the Holy Land, edited by Bryan F. Le Beau and Menachem Mor, 89-118. Omaha: Creighton University Press, 1996. 
Frumkin, Gad. Derekh Shofet bi-Rushalayim [The way of a judge in Jerusalem]. Tel Aviv: Dvir, 1954.

Frutiger, Hans Hermann. Johannes Frutiger (1836-1899). Ein Schweizer Bankier in Jerusalem. Cologne: Böhlau, 2008.

Fuhrmann, Malte. "Cosmopolitan Imperialists and the Ottoman Port Cities: Conflicting Logics in the Urban Social Fabric." Cahiers de la Méditerranée, no. 67 (2003): 149-63.

Gerber, Haim. Ottoman Rule in Jerusalem, 1890-1914. Berlin: Klaus Schwarz, 1985.

Gerd, Lora A. "Porfirii Uspenskii: iz epistoliarnogo naslediia" [Bishop Porfirii Uspenskii: from his epistolograpy]. In Archivy Russkikh vizantinistov v Sankt-Peterburge [Archives of the Russian Byzantinologists in St. Petersburg], edited by Igor P. Medvedev. St. Petersburg: Dmitrii Bulanin, 1995, 8-21.

Gerd, Lora A. "Sekuliarizatsiia imenii vostochnykh monastyrei I tserkvei v Valakhii I Moldavii v nachale 1860-kh godov I Rossia" [Secularization of the properties of the eastern monasteries and churches in Walachia and Moldavia in the beginning of 186 os and Russia]. Vestnik pravoslavnogo Sviato-Tichonovskogo Gumanitarnogo universiteta 6 , no. 61 (2004): 7-34.

Gershon, Shafir. Land, Labor and the Origins of the Israeli-Palestinian Conflict, 1882-1914. Berkeley: University of California Press, 1996.

Ghushah, Muhammad Hashim Musa Dawud. Al-Awqāf al-Islamiyah fi-l-Quds al-sharif: dirasa tarikhiyya muwathaqa [Islamic awqāf in Jerusalem: a historical documentation]. Istanbul: IRCICA, 2009.

Ghushah, Muhammad Hashim Musa Dawud. "Al-Mulkiyyat al-Waqfiyya al-Maqqdisiyyah fil-Qarn Sadis-'ashr min khilal al-sijillat al 'Uthmanioyyah" [Jerusalem waqf properties in the 16th century in Ottoman sijillät, dafters, manuscripts]. In Awraq 'A'iliyya: Dirasat fi Tarikh Filastin al mu'asir [Family papers: studies in contemporary social history], edited by Muhammad Zakariyya, Ferraj Khalid, Salim Tamari and Issam Nassar. 2nd ed. Ramallah: Institute for Palestine Studies, 2011.

Gibson, Shimon, Yoni Shapira, and Rupert L. Chapman, eds. Tourists, Travellers and Hotels in Nineteenth-Century Jerusalem. Leeds: Maney Publishing, 2013.

Gilboa, Menucha. Leksikon ha-'Itonut ha-'Trit ba-Me'ot ha-Shemone-'Esre ve-ha-Tesha'Esre [Lexicon of Hebrew Press in the eighteenth and nineteenth centuries]. Jerusalem: Mosad Bialik, 1992).

Ginzburg, Carlo. History, Rhetoric, and Proof. Hanover: University Press of New England, 1999.

Ginzburg, Carlo. Myths, Emblems, Clues. Translated by John and Anne C. Tedeschi. London: Hutchinson Radius, 1990.

Giovannelli, Andrea. La Santa Sede e la Palestina: La Custodia di Terra Santa tra la fine dell'impero ottomano e la guerra dei sei giorni. Rome: Studium, 2000. 
Gitler, Inbal Ben-Asher. “'Marrying Modern Progress with Treasured Antiquity': Jerusalem City Plans during the British Mandate, 1917-1948." Traditional Dwellings and Settlements Review 15, no. 1 (2003): 39-58.

Glass, Joseph B. "Biography in Historical-Geography Research: Joseph Navon Bey. A Case Study." In The Land That Became Israel: Studies in Historical Geography, edited by Ruth Kark, 77-89. New Haven: Yale University Press; Jerusalem: Magnes Press, 1990.

Glass, Joseph B., and Ruth Kark, Sephardi Entrepreneurs in Jerusalem: The Valero Family, 180o-1948. Jerusalem: Magnes Press, 2007.

Glenk, Helmut. From Desert Sands to Golden Oranges: The History of the German Templer Settlement of Sarona in Palestine, 1871-1947. Victoria: Trafford, 2005.

Goff, Jacques Le. History and Memory. Translated by Steven Rendall and Elizabeth Claman. New York: Columbia University Press, 1992.

Goffman, Erving. Relations in Public: Microstudies of the Public Order. New York: Basic Books, 1971.

Goldhill, Simon. Jerusalem: City of Longing. Cambridge: Belknap Press of Harvard University Press, 2008.

Goody, Jack. The Domestication of the Savage Mind. Cambridge: Cambridge University Press, 1977.

Gordon, Benjamin Lee. New Judea: Jewish Life in Modern Palestine and Egypt. Philadelphia: Greenstone, 1919.

Gounaris, Basil C. Steam over Macedonia, 1870-1912: Socio-Economic Change and the Railway Factor. Boulder: East European Monographs, 1993.

Graf, Georg. Geschichte der christlichen arabischen Literatur. 5 vols. Vatican City: Biblioteca Apostolica Vaticana, 1959.

Grayevsky, Pinhas M. Ben Zvi. Sefer 'Avne Zikaron: 'Avne Kodesh bi-Rushalayim [Book of memorial stones: sacred stones in Jerusalem]. 15 vols. Jerusalem: Tzukerman, 1928.

Greenberg, Ela. Preparing the Mothers of Tomorrow: Education and Islam in Mandate Palestine. Austin: University of Texas Press, 2010.

Greenberg, Zalman. "The Turkish Municipal Hospital in Jerusalem and its Director Dr. Photios Efklides." In 38. Uluslararası Tıp Tarihi Kongresi Bildiri Kitabı. Proceedings of the 38 th International Congress on the History of Medicine. Actes Du38. International d'Histoire de La Médécine, edited by Nil Sarı, Ali Haydar Bayat, Yeşim Ülman, and Mary Işin, 1417-20. Ankara: Turk Tarih Kurumu, 2005.

Greganti, Fra Paolo. “Centenario Della Tipografia Francescana Di Gerusalemme (18471947)." La Terra Santa, 1947, 58-61.

Gribetz, Jonathan Marc. Defining Neighbors: Religion, Race, and the Early Zionist-Arab Encounter. Princeton: Princeton University Press, 2014. 
Gribetz, Jonathan Marc. "Reading Mendelssohn in Late Ottoman Palestine: An Islamic Theory of Jewish Secularism." In Secularism in Question:Jews and Judaism in Modern Times, edited by Ari Joskowicz and Ethan Katz, 48-64. Philadelphia: University of Pennsylvania Press, 2015.

Gultiaev, Roman, ed. Ierusalim v 1857 godu v fotografiakh iz kollektsii episkopa Porfiriia (Uspenskogo) [Jerusalem in 1857 based on photos from the collection of Bishop Porfirii (Uspenskii)]. Moscow: Indrik, 2007.

Güneş, Hasan H. "Kudüs'te Bir Mahalle: Sekiz Yüz Yıllık Meğāribe Mahallesi ve Serencamı" [A waqf neighborhood in Jerusalem: the Magarebeh neighborhood of eight hundred years and its adventure]. Vakıflar Dergisi 44 (2015): 9-35.

Habermas, Jürgen. The Structural Transformation of the Public Sphere: An Inquiry into a Category of Bourgeois Society. Translated by Thomas Burger and Frederick Lawrence. Cambridge: MIT Press, 1989.

Hadar, Gila. "Bienvenida 'Blessed Be Her Who Comes' and Azebuena 'Does Good Deeds': Name-Giving Patterns for Girls and Women in the Judeo-Spanish Diaspora (Salonika, 1492-1943)." In Pleasant Are Their Names: Jewish Names in the Sephardi Diaspora, edited by Aaron Demsky, 209-32. Bethesda: University Press of Maryland, 2010.

Haiduc-Dale, Noah. Arab Christians in British Mandate Palestine: Communalism and Nationalism, 1917-1948. Edinburgh: Edinburgh University Press, 2013.

Haiduc-Dale, Noah. "Rejecting Sectarianism: Palestinian Christians' Role in MuslimChristian Relations." Islam and Christian-Muslim Relations 26, no. 1 (2015): 75-88.

Haile, Getatchew. "Empress Tayitu and the Ethiopian Property in Jerusalem." Paideuma 35 (1989): 67-81.

Hajj al-, Badr. "Khalil Raad - Jerusalem Photographer." Jerusalem Quarterly, no. 11/12 (2001): 34-39.

Hajjar, Joseph N. L'Europe et les destinées du Proche-Orient. 3 vols. Damascus: Dar Tlass, 1988.

Halabi, Elias. "Al-Sill fi-l-Quds wa asbab intisharihi fiha" [Tuberculosis in Jerusalem and the causes for its diffusion]. Filastin, no. 6o (August 16, 1911): 2.

Halabi, Usama. Baladiya al-Quds al-'arabi [The municipality of Arab Jerusalem]. Jerusalem: Passia, 1993 .

Hale, Margaret E. "The Nineteenth-Century American Trade Card." Business History Review 74, no. 4 (2000): 683-88.

Halper, Jeff. "On the Way: The Transition of Jerusalem from a Ritual to Colonial City (1800-1917)." Urban Anthropology 13, no. 1 (1984):1-32.

Hamada, Muhammad 'Umar, Alam Filastin: min al-qarn al-awwal hatta l-khamis 'ashara hijri, min al-qarn al-sabi' hatta l-ishrin miladi [The notables of Palestine: from the first century until the fifteenth century AH, from the seventh century until the twentieth century AD ], vol. 4. Damascus: Dar al-Qutaiba, 2000. 
Hamadeh, Shirine. The City's Pleasures: Istanbul in the Eighteenth Century. Seattle: University of Washington Press, 2008.

Hanioğlu, M. Şükrü. Preparation for a Revolution: The Young Turks, 1902-19o8. Oxford: Oxford University Press, 2001.

Hanley, Will. "Papers for Going, Papers for Staying: Identification and Subject Formation in the Eastern Mediterranean." In A Global Middle East: Mobility, Materiality and Culture in the Modern Age, 1880-1940, edited by Avner Wishnitzer, Liat Kozma, and Cyrus Schayegh, 177-200. London: I. B. Tauris, 2014.

Hanssen, Jens. Fin de Siècle Beirut: The Making of an Ottoman Provincial Capital. Oxford: Oxford University Press, 2005.

Hanssen, Jens. "History, Heritage and Modernity: Cities in the Muslim World Between Destruction and Reconstruction." In The New Cambridge History of Islam, edited by Robert Hefner, 6:515-42. Cambridge: Cambridge University Press, 2010.

Hanssen, Jens. "The Origins of the Municipal Council in Beirut (1860-1908)." In Municipalités méditerranéennes: les réformes urbaines ottomanes au miroir d'une histoire comparée (Moyen-Orient, Maghreb, Europe méridionale), edited by Nora Lafi, 137-72. Berlin: Klaus Schwarz, 2005.

Hanssen, Jens. "Practices of Integration: Centre-Periphery Relations in the Ottoman Empire." In The Empire in the City: Arab Provincial Capitals in the Late Ottoman Empire, edited by Jens Hanssen, Thomas Philipp, and Stefan Weber, 49-74. Würzburg: Ergon, 2002.

Hanssen, Jens, Thomas Philipp, and Stefan Weber, eds. The Empire in the City: Arab Provincial Capitals in the Late Ottoman Empire. Wurzburg: Ergon, 2002.

Hashash, Yali. "Gender, Religion, and Secularism in the English Mission Hospital of Jerusalem, 1844-1880." Journal of Levantine Studies 7, no. 1 (2017):13-38.

Hashash, Yali. "Iske Halvảot: Nihul Kaspe ha- Kehila ha-Sefaradit bi-Rushalayim ba-Me'ot ha-Shemone-'Esre ve-ha-Tesha'-'Esre le-'Or Mismakhim Hadashim” [Loan business: the management of the Sephardic community's coffers in Jerusalem in the eighteenth and nineteenth centuries in light of new documents]. Zion 78, no. 4 (2013): 501-25.

Hashash, Yali. "A Petition for Aid: A Sephardi Collective in Jerusalem Appeals to the British Consul (1854)." In Sephardi Lives: A Documentary History, 1700-1950, edited by Julia Phillips Cohen and Sarah Abrevaya Stein, 50-52. Stanford: Stanford University Press, 2014.

Hashash, Yali. "Shinuy Gishot Klape 'Oni ba-Kehila ha-Sefaradit be-Yerushalayim, 1841-1880" [Changing attitudes toward poverty in the Sephardic community of Jerusalem, 1841-1880]. PhD diss., University of Haifa, 2011.

Hathaway, Jane. The Politics of Households in Ottoman Egypt: The Rise of the Qazdağlis. Cambridge: Cambridge University Press, 1997. 
Hathaway, Jane. "Rewriting Eighteenth-Century Ottoman History." Mediterranean Historical Review 19, no. 1 (2004): 29-53.

Haug, Mary-Elise. "The Life Cycle of Printed Ephemera: A Case Study of the Maxine Waldron and Thelma Mendsen Collections." Winterthur Portfolio 30, no. 1 (1995): $59-72$.

Hauken, Tor. Petition and Response: An Epigraphic Study of Petitions to Roman Emperors, 181-249. Bergen: Norwegian Institute at Athens, 1998.

Headrick, Daniel R. The Tentacles of Progress: Technology Transfer in the Age of Imperialism, 1850-1940. Oxford: Oxford University Press, 1988.

Hearn, Julie. "The 'NGO-Isation' of Kenyan Society: USAID \& the Restructuring of Health Care." Review of African Political Economy 25, no. 75 (1998): 89-100.

Heerma van Voss, Lex. "Introduction." International Review of Social History 46 (2001): 1-10.

Hernen, Elaine. "Names Are Everything: For Oscar Wilde, Posing as a Letter and Visiting Card." Vides: MLA Volume of Interdisciplinary Essays 1 (2013): 219-28. https://open.conted.ox.ac.uk/resources/documents/names-are-everything-oscar -wilde-posing-letter-and-visiting-card-elaine-hernen.

Herzog, Christoph. Osmanische Herrschaft Und Modernisierung Im Irak. Die Provinz Bagdad, 1817-1917. Bamberg: University of Bamberg Press, 2012.

Heyberger, Bernard. "Les nouveaux horizons méditerranéens des chrétiens du Bilād al-Šām (XVII e-XVIII ${ }^{\text {e }}$ Siècle).” Arabica 51, no. 4 (2004): 435-61.

Heyberger, Bernard. "Pratiques religieuses et lieux de culte partagés entre islam et christianisme (autour de la Méditerranée)." Archives de sciences sociales des religions, no. 149 (2010): 273-83.

Heyd, Uriel. Foundations of Turkish Nationalism: The Life and Teachings of Ziya Gökalp. Westport: Hyperion Press, 1979.

Heyd, Uriel. Ottoman Documents on Palestine, 1552-1615: A Study of The Firman According to the Mühimme Defteri. Oxford: Clarendon Press, 1960.

Heyd, Uriel. Studies in Old Ottoman Criminal Law. Edited by M. L. Ménage. Oxford: Clarendon Press, 1973.

Higginson, Stephen A. "A Short History of the Right to Petition Government for the Redress of Grievances." The Yale Law Journal 96, no. 1 (1986): 142-66.

Hilton, Matthew, James McKay, Nicholas Crowson, and Jean-François Mouhot. The Politics of Expertise: How NGOs Shaped Modern Britain. Oxford: Oxford University Press, 2013.

Hopwood, Derek. The Russian Presence in Syria and Palestine, 1843-1914: Church and Politics in the Near East. Oxford: Clarendon Press, 1969.

Hovhannisian, Astvatsatur. Zhamanakagrakan Patmut'iwn Surb Yerusaghémi [Chronological history of Holy Jerusalem]. Jerusalem: St. James Press, 1890. 
Hughes, David, Nathan Derejko, and Alaa Mahajna. Dispossession and Eviction in Jerusalem: The Cases and Stories of Sheikh Jarrah. Jerusalem: The Civic Coalition for Defending the Palestinians, 2009.

Hürmen, Fatma Rezan, ed. Bir Devlet Adamının Mehmet Tevfik Bey'in (Biren) II. Abdülhamid, Meşrutiyet ve Mütareke Devri Hatıraları [The Memoirs of a statesman: Mehmet Tevfik Bey (Biren) during the constitutional and armistice periods]. Istanbul: Arma Yayınları, 1993.

Hyman, Benjamin. "British Planners in Palestine, 1918-1936." PhD diss., London School of Economics and Political Science, University of London, 1994.

Iamilinets, Boris Fedorovich. Rossiia i Palestina. Otcherk politicheskikh i kul'turnoreligioznykh otnoshenii. XIX-nachalo XX v. [Russia and Palestine: essay on political, cultural and religious relations 19th-beginning of the 2oth centuries]. Moscow; St Petersburg: Institut Vostokovedenia RAN; Letnij Sad, 2003.

Ilbert, Robert. Alexandrie, 1830-1930: Histoire d'une communauté citadine. 2 vols. Cairo: Institut français d'archéologie orientale (IFAO), 1996.

İleri, Nurçin. "A Nocturnal History of Fin de Siècle Istanbul." PhD diss., Binghamton University, 2015.

Ilias, Athanasios. Ta metochia tou Panagiou Tafou kai tis Monis Sina stin Ellada [The monastery dependencies of the Holy Sepulchre and of Sinai Monastery in Greece]. Athens: Akritas, 2003.

Il'itch, Iakushev Mikhail. Antiokhijskii I Ierusalimskii Patriarkhat v politike Rossiiskoi imperii, 1830-natchalo $X X v$. [The patriarchates of Antioch and Jerusalem in the politics of the Russian Empire, 1830-early 2oth century]. Moscow: Indrik, 2013.

İnalcık, Halil. "Şikâyet Hakkı: 'Arz-ı Hâl ve 'Arz-ı Mahzar'lar" [Right to complain: petition and collective petition]. Osmanlı Araştırmaları 7-8 (1988): 33-54.

İnalcık, Halil. "The Nature of Traditional Society, Turkey." In Political Modernization in Japan and Turkey, edited by Robert Ward and Dankwart Rustow, 42-63. Princeton: Princeton University Press, 1964.

İpşirli, Mehmet. "Osmanlı Devleti'nde Kazāskerlik (XVII. Yüzyıla Kadar)” [The office of chief judge in the Ottoman state (up to the 17th century)]. Belleten 61, no. $23^{2}$ (1997): 597-699.

Ishaq, Adib. al-Kitabat al-siyyasiyya wa al-ijtimaiyya [Political and social writings]. Edited by N. 'Allush. Beirut: Dar al-Tali'a, 1978.

Ishkhanian, Rafael. Hay Girk'ē 1512-1920 [The Armenian book, 1512-1920]. Yerevan: Publishing House of AS ASSR, 1981.

Islamoğlu, Huri. "Politics of Administering Property: Law and Statistics in the Nineteenth-Century Ottoman Empire." In Constituting Modernity: Private Property in the East and West, edited by Huri Islamoğlu, 276-319. London: I. B. Tauris, 2004 . 
İpşirli, Mehmet. "Osmanlı Devleti'nde Kazāskerlik (XVII. Yüzyıla kadar)" [The office of chief judge in the Ottoman state (up to the 17th century)], Belleten 61, no. 232 (1997): 597-700.

İpşirli, Mehmet. “'Osmanlılarda Cuma Selamlığı (Halk-Hükümdar Münasebetleri Açısından Önemi)' [Ottoman Friday prayer (its significance with regard to peoplesovereign relationship)]. In Prof. Dr. Bekir Kütükoğlu’na Armağan [Tribute to Prof. Dr. Bekir Kütükoğlu], 459-71. Istanbul: Edebiyat Fakültesi Basımevi, 1991.

Jacobs, Joseph, Goodman Lipkind, Victor Rousseau Emanuel, Thomas Seltzer, Isidore Harris, and Israel Davis. "Montefiore." In Jewish Encyclopedia. Unedited version of 1906 edition. 2002-11. http://www.jewishencyclopedia.com/articles/10960-montefiore.

Jacobson, Abigail. From Empire to Empire:Jerusalem between Ottoman and British Rule. Syracuse: Syracuse University Press, 2011.

Jacobson, Abigail. "The Sephardi Community in Pre-World War I Jerusalem: Debates in the Hebrew Press." Jerusalem Quarterly, no. 14 (2001): 23-34.

Jad, Islah. "The NGO-Isation of Arab Women's Movements." IDs Bulletin 35, no. 4 (2004): 34-42.

Jarzmik, Oscar. “Theodore 'Teddy' Kollek, the Palestinians, and the Organizing Principles of Israeli Municipal Policy, 1967-1987." PhD diss., University of Toronto, 2016.

Jay, Robert. The Trade Card in Nineteenth Century America. Columbia: University of Missouri Press, 1987.

Joyce, Patrick. The Rule of Freedom: Liberalism and the Modern City. London: Verso, 2003.

Kalkan, İbrahim. "Torture, Law, and Politics in the Late Ottoman Empire, 1840-1918." PhD diss., New York University, 2015.

Kamel, Lorenzo. Imperial Perceptions of Palestine: British Influence and Power in Late Ottoman Times. London: I. B. Tauris, 2015.

Kaplan, Steven. "The Transnationalism of the Ethiopian Orthodox Tewahedo Church (EOTC) in the Holy Land." Journal of Levantine Studies 3, no. 1 (2013).

Karateke, Hakan T., and Maurus Reinkowski, eds. Legitimizing the Order: The Ottoman Rhetoric of State Power. Leiden: Brill, 2005.

Kark, Ruth. "Millenarism and Agricultural Settlement in the Holy Land in the Nineteenth Century." Journal of Historical Geography 9, no. 1 (1983): 47-62.

Kark, Ruth. "The Jerusalem Municipality at the End of Ottoman Rule." Asian and African Studies 14, no. 2 (1981): 117-41.

Kark, Ruth. "The Traditional Middle Eastern City: The Cases of Jerusalem and Jaffa During the Nineteenth Century." Zeitschrift Des Deutschen Palästina-Vereins 97, no. 1 (1981): 93-108.

Kark, Ruth, and Joseph B. Glass. "The Valero Family: Sephardi-Arab Relations in Ottoman and Mandatory Jerusalem." Jerusalem Quarterly, no. 21 (2004): 27-40. 
Kark, Ruth and Michal Oren-Nordheim.Jerusalem and its Environs: Quarters, Neighborhoods, Villages, 1800-1948. Jerusalem: Hebrew University Magnes Press; Detroit: Wayne State University Press, 2001.

Kark, Ruth, and Shimon Landman. "The Establishment of Muslim Neighborhoods in Jerusalem, Outside the Old City, During the Late Ottoman Period." Palestine Exploration Quarterly, no. 112 (1980): 113-35.

Kark, Ruth, and Shlomit Langboim. "Missions and Identity Formation among the People of Palestine: The Case of the Jewish Population." In The Social Dimension of Mission in the Middle East, edited by Norbert Friedrich, Uwe Kaminsky, and Roland Löffler, 101-20. Stuttgart: Franz Steiner, 2010.

Karpat, Kemal H. "The Ottoman Adoption of Statistics from the West in the 19th Century." In Studies on Ottoman Social and Political History: Selected Articles and Essays, edited by Kemal H. Karpat, 132-45. Leiden: Brill, 2002.

Karpat, Kemal H. Ottoman Population, 1830-1914: Demographic and Social Characteristics. Madison: University of Wisconsin Press, 1985.

Katz, Itamar, and Ruth Kark. "The Church and Landed Property: The Greek Orthodox Patriarchate of Jerusalem." Middle Eastern Studies 43, no. 3 (2007): 383-408.

Katz, Itamar, and Ruth Kark. "The Greek Orthodox Patriarchate of Jerusalem and its Congregation: Dissent over Real Estate." International Journal of Middle East Studies 37, no. 4 (2005): 509-34.

Katz, Kimberly. Jordanian Jerusalem: Holy Places and National Spaces. Gainesville: University Press of Florida, 2005.

Kayal, Hasan. Arabs and Young Turks: Ottomanism, Arabism, and Islamism in the Ottoman Empire, 1908-1918. Berkeley: University of California Press, 1997.

Kechriotis, Vangelis. "Protecting the City's Interest: The Greek Orthodox and the Conflict Between Municipal and Vilayet Authorities in İzmir (Smyrna) in the Second Constitutional Period." Mediterranean Historical Review 24, no. 2 (2009): 207-21.

Kedourie, Elie. "Religion and Politics." In The Chatham House Version and Other Middle Eastern Studies, edited by Elie Kedourie, 317-42. Chicago: Ivan R. Dee, 2004.

Kermeli, Eugenia. “Ebū's Su'Ūd's Definition of Church Vakfs: Theory and Practice in Ottoman Law." In Islamic Law: Theory and Practice, edited by Robert Cleave and Eugenia Kermeli, 141-56. London: I. B. Tauris, 1997.

Kermode, Jennifer. Enterprise and Individuals in Fifteenth-Century England. Stroud: Alan Sutton, 1991.

Kerrou, Mohamed, ed. Public et privé en Islam. Paris: Maisonneuve \& Larose; Tunis: Institut de recherche sur le Maghreb contemporain, 2002.

Kessler, Edward, ed. An English Jew: The Life and Writings of Claude Montefiore. London: Vallentine Mitchell, 1989. 
Khalaf, Amin, and Dotan Halevy. "Ke-Gerim ba-'Arets: Bet ha-Sefer ha-Haklải Mikveh Yisrảel ve-Talmidav ha-Aravim" [Foreigners in their country: the Mikveh-Israel Agricultural School and its Arab students, 1870-1939]. Zmanim 135 (2016): 82-99.

Khalidi, Rashid I. "Intellectual Life in Late Ottoman Jerusalem." In Ottoman Jerusalem:

The Living City, 1517-1917, edited by Sylvia Auld and Robert Hillenbrand, 221-28. London: Altajir World of Islam Trust, 2000.

Khalidi, Rashid I. The Iron Cage: The Story of the Palestinian Struggle for Statehood. Oxford: Oneworld Publications, 2007.

Khalidi, Rashid I. Palestinian Identity: The Construction of Modern National Consciousness. New York: Columbia University Press, 1997.

Khalidi, Rashid I. "A Research Agenda for Writing the History of Jerusalem." In Pilgrims, Lepers, and Stuffed Cabbage: Essays on Jerusalem's Cultural History, edited by Salim Tamari and Issam Nassar, 12-27. Jerusalem: Institute for Jerusalem Studies, 2005.

Khalidi, Walid. Before Their Diaspora: A Photographic History of the Palestinians, $1876-$ 1948. Washington, DC: Institute for Palestine Studies, 1984.

Khalidi, Walid. "Israel's 1967 Annexation of Arab Jerusalem: Walid Khalidi's Address to the UN General Assembly Special Emergency Session, 14 July 1967." Journal of Palestine Studies 42, no. 1 (2012): 71-82.

Khalidi, Walid. “'Kitab al-sayunizm aw al-mas'ala al-sahyūniyya Li-Muhammad Ruhi al-Khalidi al-mutawaffa sanat 1913' [The book “Zionism or the Zionist question” by Muhammad Ruhi Al-Khalidi who died in 1913]. In Dirasat Filastiniyya: Majmu'at Abhath Wadiat Takriman Li-l-Duktur Qastantin Zurayq [Palestinian studies: a collection of studies dedicated in honor of Dr. Constantin Zurayk], edited by Hisham Nashshabah. Beirut: Institute for Palestine Studies, 1988.

Kharatian, Albert. "Osmanyan Grak'nnut'yunē ew Arewmtahay Mamumlē" (1870-1890) [Ottoman censorship and the press of western Armenia in 1870-1890]. HistoricalPhilological Journal, no. 4 (1985): 103-116.

Khoury, Dina Rizk. State and Provincial Society in the Ottoman Empire: Mosul, 1540-1834. Cambridge; New York: Cambridge University Press, 1997.

Khuri-Makdisi, Ilham. The Eastern Mediterranean and the Making of Global Radicalism, 1860-1914. Berkeley: University of California Press, 2010.

Kilicdagi, Ohannes. "The Bourgeois Transformation and Ottomanism Among Anatolian Armenians after the 1908 Revolution." MA diss., Boğaziçi University, 2005.

Kimmerling, Baruch. "Be'ayot Konseptu'aliyot ba-Historyografya shel 'Erets 'Ahat u-Shne 'Amim" [Conceptual problems in the historiography of one land with two peoples]. In Eretz ahat u-shne 'amim [One land, two peoples], edited by Danny Ya'akobi, 11-22 Jerusalem: Magnes Press, 1999.

"Kitab maftuh ila da'irat al-sihhah" [Open Letter to the Department of Health]. Mir'at al-Sharq 47, no. 18 (August 18, 1920): 1-2. 
Kitromilidis, Paschalis M. "The Legacy of the French Revolution: Orthodoxy and Nationalism." In The Cambridge History of Christianity. Vol. 5, Eastern Christianity, edited by Michael Angold, 229-49. Cambridge: Cambridge University Press, 2006.

Klein, Menachem. Lives in Common: Arabs and Jews in Jerusalem, Jaffa and Hebron. Translated by Haim Watzman. London: Hurst, 2014.

Köprülü, Fuad. "Vakıf Müessesesinin Hukuki Mahiyeti ve Tarihi Tekamülü” [Legal status and evolution of the waqf institution]. Vakıflar Dergisi 2 (1942): 1-35.

Kopylova, Olga Nikolaevna, ed. Rossiia $i$ Khristianskii Vostok $v$ dokumentakh Gosudarstvennogo arkhiva Rossijskoj Federatsii, XIX-XX vv. Annotirovannyj ukazatel' del $i$ dokumentov [Russia and the Christian Orient: documents of the State archive of the Russian Federation, 19th-2oth centuries; annotated index of dossiers and documents]. Moscow: Indrik, 2015.

Kornilov, Alexandr Alexeevich. "Sozdanie i operativnye zadachi rossijskogo konsul'stva v Ierusalime, 1858-1859" [Creation and strategic goals of the Russian consulate in Jerusalem, 1858-1859]. Imperial Orthodox Palestinian Society. February 4. 2009. accessed January 12, 2018, http://www.ippo.ru/old/history/do/kons/2/index.html.

Krämer, Gudrun. A History of Palestine: From the Ottoman Conquest to the Founding of the State of Israel. Translated by Graham Harman and Gudrun Krämer. Princeton: Princeton University Press, 2008.

Krikorian, Haig Aram. Lives and Times of the Armenian Patriarchs of Jerusalem: Chronological Succession of Tenures. Sherman Oaks: H. A. Krikorian, 2009.

Krotoszynski, Ronald J. Reclaiming the Petition Clause: Seditious Libel, "Offensive" Protest, and the Right to Petition the Government for a Redress of Grievances. New Haven: Yale University Press, 2012.

Kroyanker, David. "Ha-Beniya ba-'Ir ha-'Atika" [Jerusalem architecture: the Old City] Adrikhalut Bi-Rushalayim 6. Jerusalem: Keter, 1993.

Kuehn, Thomas. Empire, Islam, and Politics of Difference: Ottoman Rule in Yemen, 18491919. Leiden: Brill, 2011.

Kupferschidt, Uri. "A Note on the Muslim Religious Hierarchy towards the End of the Ottoman Period." In Palestine in the Late Ottoman Period: Political, Social and Economic Transformation, edited by David Kushner, 123-29. Leiden: Brill, 1986.

Kushner, David. To Be Governor of Jerusalem: The City and District during the Time of Ali Ekrem Bey, 1906-1908. Istanbul: Isis Press, 2005.

Kütükoğlu, Mübahat S. Osmanlı belgelerinin dili: diplomatik [The language of Ottoman documents: diplomatic]. Istanbul: Kubbealtı Akademisi Kültür ve San'at Vakfi, 1994.

Lafi, Nora. "Mediterranean Connections: The Circulation of Municipal Knowledge and Practices during the Ottoman Reforms, c. 1830-1910." In Another Global City: Historical Explorations into the Transnational Municipal Moment, 1850-200o, edited by Pierre-Yves Saunier and Shane Ewen, 35-50. New York: Palgrave Macmillan, 2008. 
Lafi, Nora. "Petitions and Accommodating Urban Change in the Ottoman Empire." In Istanbul as Seen from a Distance: Centre and Provinces in the Ottoman Empire, edited by Elizabeth Özdalga, Sait M. Özervarli, and Tansu Feyral, 82-73. Istanbul: Swedish Research Institute in Istanbul, 2011.

Lafi, Nora. "Les pouvoirs urbains à Tunis à la fin de l'époque ottomane." In Municipalités méditerranéennes: les réformes urbaines ottomanes au mirroir d'une histoire comparée (Moyen-Orient, Maghreb, Europe méridionale), edited by Nora Lafi, 229-54. Berlin: Klaus Schwarz, 2005.

Lafi, Nora, ed. Municipalités méditerranéennes: les réformes urbaines ottomanes au miroir d'une histoire comparée (Moyen-Orient, Maghreb, Europe méridionale). Berlin: Klaus Schwarz, 2005.

Lambronatsi, Nerses. Khorhrdatsut'iwn Srbazan Pataragi [Thoughts during the liturgy]. Jerusalem: St. James Press, 1842.

Lamure, Bertrand. "Le premier pèlerinage populaire de pénitence en Terre Sainte: L'ultime croisade." Bulletin du Centre de recherche français à Jérusalem, no. 14 (2004): 9-34.

Landau, Jacob M. "The Educational Impact of Western Culture on Traditional Society in Nineteenth Century Palestine." In Studies on Palestine during the Ottoman Period, edited by Moshe Macoz, 499-506. Jerusalem: Magnes, 1975.

Landes, David S. Bankers and Pashas: International Finance and Economic Imperialism in Egypt. London: Heinemann, 1958.

Lang, Yosef. Daber 'Ivrit!: Haye Eli'ezer ben-Yehuda [Speak Hebrew! The life of Eliezer Ben-Yehuda]. Jerusalem: Yad Izhak Ben-Zvi, 2008.

Lang'at, Kiprono. "Deconstructing Neo-Colonialism and Liberalism: Kenya and the NGOs: A Discourse Analysis." International Education Journal 9, no. 2 (2008): 57-68.

Laroui, 'Abdallah. L'idéologie arabe contemporaine: essai critique. Paris: François Maspero, 1967.

Laskier, Michael M. "Aspects of the Activities of the Alliance Israélite Universelle in the Jewish Communities of the Middle East and North Africa: 1860-1918." Modern Judaism 3, no. 2 (1983): 147-71.

Laurens, Henry. La question de Palestine. Vol. 1, L'invention de la Terre Sainte (1799-1922). Paris: Fayard, 1999.

Laurent, Annie. Les chrétiens d'Orient vont-ils disparaître? Entre souffrance et espérance. Paris: Salvator, 2008.

Lazarus, Neil. The Postcolonial Unconscious. Cambridge: Cambridge University Press, 2011.

Lehmann, Matthias B. Ladino Rabbinic Literature and Ottoman Sephardic Culture. Bloomington: Indiana University Press, 2005.

Lemire, Vincent. Jerusalem 1900: The Holy City in the Age of Possibilities. Translated by Catherine Tihanyi and Lys Ann Weiss. Chicago: University of Chicago Press, 2017. 
Lemire, Vincent. Jérusalem 19oo: la ville sainte à l'âge des possibles. Paris: Armand Colin, 2013.

Lemire, Vincent. La soif de Jérusalem: essai d'hydrohistoire (1840-1948). Paris: Publications de la Sorbonne, 2010.

Lemire, Vincent. "Urbanités, Municipalités, Citadinités." In Le Moyen-Orient Fin $X I X^{e}-X X^{e}$ Siècle, edited by Leyla Dakhli, 115-34. Paris: Seuil, 2016.

Lemire, Vincent, ed. Jérusalem: histoire d'une ville-monde des origines à nos jours. Paris: Flammarion, 2016. Forthcoming in English translation by University of California Press.

Lemke, Wolf-Dieter. "Ottoman Photography: Recording and Contributing to Modernity." In The Empire in the City: Arab Provincial Capitals in the Late Ottoman Empire, edited by Jens Hansen, Thomas Philipp, and Stefan Weber, 237-49. Wurzburg: Ergon, 2002.

Lev, Efraim, and Yaron Perry. "Dr Thomas Chaplin, Scientist and Scholar in NineteenthCentury Palestine." Palestine Exploration Quarterly 136, no. 2 (2004): 151-62.

Levidis, Nikolaos. Ta en Roumania ellinika monastiriaka ktimata [The Greek monastery estates in Romania]. Athens: A. Konstantinidis, 1893.

Levin, Menachem. "Béayot Zihuyan shel Shekhunot Yerushalayim lefi Sheman ha-'Aravi-ha-'Otomani be-Sifre ha-Nufus" [Problems of identification of Jerusalem neighborhoods according to their Arabic-Ottoman names in the census books]. Cathedra, no. 15 (1980): 195-96.

Lévinas, Emmanuel. Ethics and Infinity: Conversations with Philippe Nemo. Edited by Philippe Nemo. Translated by Richard A. Cohen. 15th ed. Pittsburgh: Duquesne University Press, 2006.

Lévinas, Emmanuel. Totality and Infinity: An Essay on Exteriority. Translated by Alphonso Lingis. Pittsburgh: Duquesne University Press, 2016.

LeVine, Mark. Overthrowing Geography: Jaffa, Tel Aviv, and the Struggle for Palestine, 1880-1948. Berkeley: University of California Press, 2005.

Levonian, Garegin. Hay Girqē Ew Tpagrut'yan Arvestē [The Armenian book and the art of typography]. Yerevan: Haypethrat, 1946.

Levonian, Garegin. Hayoc Parberakan Mamulē [The Armenian press]. Alexandrapol: Abraham M. Malkhasian, 1895.

Levy, Lital. "The Nahḍa and the Haskala: A Comparative Reading of 'Revival' and 'Reform.”' Middle Eastern Literatures 16, no. 3 (2013): 300-316.

Lévy-Aksu, Noémi. "Institutional Cooperation and Substitution: The Ottoman Police and Justice System at the Turn of the 19th and 2oth Centuries." In Order and Compromise: Government Practices in Turkey from the Late Ottoman Empire to the Early 21st Century, edited by Marc Aymes, Benjamin Gourisse, and Elise Massicard, 146-68. Leiden: Brill, 2014. 
Lévy-Aksu, Noémi. Ordre et désordres dans l'Istanbul ottomane (1879-19o9). Paris: Karthala, 2013.

Limor, Yechieal. "Kronika shel Mavet Yadu'a be-Mahshava Merosh: 'Al Goralam Shel "Itonim Yomiyim be- Yisrảel" [Chronicle of a death foretold: on the fate of daily newspapers in Israel]. Keshr 25 (1999): 41-51.

Lipman, Vivian D. "Britain and the Holy Land: 1830-1914." Jewish Quarterly 37, no. 4 (1990): 35-40.

Lisovoi, Nikolai Nikolaevich, ed. Rossiia v Sviatoi Zemle: Documenty i materialy [Russia in the Holy Land: documents and materials]. 2 vols. Moscow: Mezhdunarodnye otnoshenia, 2000.

Lisovoi, Nikolai Nikolaevich. Rossiia $v$ Sviatoi Zemle: Documenty i materialy [Russia in the Holy Land. Documents and materials] 2 vols. (Moscow: Indrik, 2017).

Lisovoi, Nikolai Nikolaevich. Rossiia $v$ Sviatoi Zemle: Documenty i materialy [Russia in the Holy Land: documents and materials]. Vol. 3. Moscow: Indrik, 2015.

Little, Donald P. "Jerusalem under the Ayyubids and Mamlukes, 1187-1516 AD." In Jerusalem in History, edited by Kamil Jamil al-Asali, 177-99. Buckhurst Hill: Scorpion, 1989.

Little, Donald P. "Mujīr Al-Dīn Al-'Ulaymī's Vision of Jerusalem in the Ninth/Fifteenth Century." Journal of the American Oriental Society 115, no. 2 (1995): 237-47.

Lockman, Zachary. Comrades and Enemies: Arab and Jewish Workers in Palestine, 19061948. Berkeley: University of California Press, 1996.

Lockman, Zachary. "Railway Workers and Relational History: Arabs and Jews in BritishRuled Palestine." Comparative Studies in Society and History 35, no. 3 (1993): 601-27.

Loeterman, Ben. 1913: Seeds of Conflict Trailer. April 8, 2015. Accessed January 19, 2018, https://youtu.be/OlvTVvuI3oE.

Long, Burke O. Imagining the Holy Land: Maps, Models, and Fantasy Travels. Bloomington: Indiana University Press, 2003.

Lussault, Michel, and Pierre Signoles. La citadinité en questions. Tours: Urbama; University of Tours, 1996.

MacCarthy, Fiona. The Simple Life: C. R. Ashbee in the Cotswolds. Berkeley: University of California Press, 1981.

Mack, Merav, Angelos Dalachanis, and Vincent Lemire. "Matrimony and Baptism: Changing Landscapes in Greek (Rum) Orthodox Jerusalem (1900-1940)." British Journal of Middle Eastern Studies, published on line January 30, 2017. doi:10.1080/ 13530194.2016.1273093.

MacLeod, Roy. "Preface." In Disease, Medicine, and Empire: Perspectives on Western Medicine and the Experience of European Expansion, edited by Roy MacLeod and Milton Lewis, 1-18. London: Routledge, 1988.

Madani, Ziyad 'Abd al-'Azi. al-Awqaf al Masihiyyag fi-l Quds wa jiwaraha fil Qarnain al Thamin ashar, wal tasi' ashar al miladiyyin, 1700-1918 [Christian endowments in Jerusalem and its environs during the 18th and 19th centuries AD]. n.p., 2010. 
Madani, Ziyad 'Abd al-Azi. al-Awqaffi al-Quds wa-Jiwariha khilal al-qarn al-tasic 'ashr al-miladi, 1215 H/180o AD-1336 H/1918 AD [History of awqāf in Jeruslaem and its environs during the 19th century AD]. Amman: al-Madanī, 2004.

Madani, Ziyad 'Abd al-'Azi. Madinatal-Qudswa-juwarhafiawakhiral-'ahadal-'uthmani, 1246/1831-1336/1918 [The city of Jerusalem and its surroundings at the end of the Ottoman period, 1246/1831-1336/1918]. Amman, 2004.

Maiarelli, Andrea, ed. L'Archivio storico della Custodia di Terra Santa (ASCTS), 12301970. Milan: Terra Santa, 2012.

Mairs, Rachel. From Khartoum to Jerusalem: The Dragoman Solomon Negima and His Clients (1885-1933). London: Bloomsbury, 2016.

Majer, Hans Georg, ed. Das Osmanische "Registerbuch der Beschwerden"(Şikāyet Defteri) vom Jahre 1675. Vienna: Österreichische Akademie der Wissenschaften, 1984.

Makdisi, Ussama. The Culture of Sectarianism: Community, History, and Violence in Nineteenth-Century Ottoman Lebanon. Berkeley: University of California Press, 2000.

Makdisi, Ussama. “Ottoman Orientalism.” The American Historical Review 107, no. 3 (2002): 768-96.

Makdisi, Ussama. "Rethinking Ottoman Imperialism: Modernity, Violence and the Cultural Logic of Ottoman Reform." In The Empire in the City: Arab Provincial Capitals in the Late Ottoman Empire, edited by Jens Hansen, Thomas Philipp, and Stefan Weber, 29-48. Wurzburg: Ergon, 2002.

Mäkonnen Zäwde. Ityopya Enna Eyärusalem [Ethiopia and Jerusalem]. Addis Ababa, 1991; Ethiopian calendar: 1998-99].

Mandel, Neville J. The Arabs and Zionism before World War I. Berkeley: University of California Press, 1976.

Mann, Michael. "The Autonomous Power of the State: Its Origins, Mechanisms and Results." In States in History, edited by John A. Hall, 109-36. Oxford: Blackwell, 1989.

Manna, Adel. A'lam Filastin fi awakhir al-'ahd al-'uthmani: (1800-1918) [The notables of Palestine at the end of the Ottoman period (1800-1918)]. Beirut: Institute for Palestine Studies, 1995 .

Manna, Adel. "The Sijill as Source for the Study of Palestine During the Ottoman Period, with Special Reference to the French Invasion." In Palestine in the Late Ottoman Period: Political, Social and Economic Transformations, edited by David Kushner, 351-62. Leiden: Brill, 1986.

Mansur, As`ad. Tarikh al-Nasira min Aqdam Azmaniha Ila Ayamina al-Hadira [History of Nazareth from early times to our days]. Cairo, 1924.

Marcus, Amy Dockser.Jerusalem 1913: The Origins of the Arab-Israeli Conflict. New York: Viking, 2007.

Massad, Joseph. “Affiliating with Edward Said." In Edward Said: A Legacy of Emancipation and Representation, edited by Adel Iskandar and Hakem Rustom, 23-49. Berkeley: University of California Press, 2010. 
Massad, Joseph. "The 'Post-Colonial' Colony: Time, Space and Bodies in Palestine/ Israel." In The Preoccupation of Postcolonial Studies, edited by Fawzia Afzal-Khan and Kalpana Seshardi-Crooks, 311-45. Durham: Duke University Press, 2000.

Masterman, Edward W. G. "Jerusalem from the Point of View of Health and Disease." Lancet 191, no. 4930 (1918): 305-7.

Masters, Bruce Alan. The Origins of Western Economic Dominance in the Middle East: Mercantilism and the Islamic Economy in Aleppo, 160o-1750. New York: New York University Press, 1988.

Matalas, Paraskevas. "To Patriarcheio Ierosolymon kai i ellinorthodoxia" [The Patriarchate of Jerusalem and Greek Orthodoxy]. In Orthodoxia, ethnos kai ideologia [Orthodoxy, nation and ideology], edited by Scholi Moraiti, 113-21. Athens: Scholi Moraiti, 2007.

Mattar, Philip, ed. Encyclopedia of the Palestinians. New York: Facts on File, 2005.

Mazower, Mark. "Travellers and the Oriental City, c. 1840-1920." Transactions of the Royal Historical Society 12 (2002): 59-111.

Mazza, Roberto. Jerusalem from the Ottomans to the British. London: I. B. Tauris, 2009. Mazza, Roberto, Maria Chiara Rioli, and Stéphane Ancel. "The Italian Consulate in Jerusalem: The History of a Forgotten Diplomatic Mission (1846-1940)." Jerusalem Quarterly, no. 71 (2017): 94-105.

McCarthy, Justin. "Age, Family, and Migration in Nineteenth-Century Black Sea Provinces of the Ottoman Empire." International Journal of Middle East Studies 10, no. 3 (1979): 309-23.

McCarthy, Justin. Population History of the Middle East and the Balkans. Istanbul: Isis, 2002.

McCarthy, Justin. The Population of Palestine: Population History and Statistics of the Late Ottoman Period and the Mandate. New York: Columbia University Press, 1990.

McCarthy, Justin. Review of Jerusalem in the 19th Century: The Old City, by Yehoshua Ben-Arieh. The American Historical Review 91, no. 2 (1986): 440-41.

McTague, John J. “The British Military Administration in Palestine, 1917-1920." Journal of Palestine Studies 7, no. 3 (1978): 55-76.

Meaux, Lorraine de. La Russie et la tentation de l'Orient. Paris: Fayard, 2010.

Meinardus, Otto. Coptic Saints and Pilgrimages. Cairo: American University in Cairo Press, 2002.

Meinardus, Otto. “The Ethiopians in Jerusalem.” Zeitschrift Für Kirchengeschichte 76, nos. 1-2, 3-4 (1965): 112-47, 217-32.

Meinardus, Otto. Monks and Monasteries of the Egyptian Desert. Cairo: American University in Cairo Press, 1961.

Memorandum on the Monastic Character of Administration of the Greek Orthodox Church of Jerusalem. Jerusalem: Greek Convent Press, 1923. 
Mendes-Flohr, Paul R., and Jehuda Reinharz, eds. The Jew in the Modern World: A Documentary History. 2nd ed. Oxford: Oxford University Press, 1980.

Merz, Sibille. "'Missionaries of the New Era': Neoliberalism and NGOs in Palestine." Race \& Class 54, no. 1 (2012): 50-66.

Messick, Brinkley Morris. The Calligraphic State: Textual Domination and History in a Muslim Society. Berkeley: University of California, 1993.

Meyuhas Ginio, Alisa. Between Sepharad and Jerusalem: History, Identity and Memory of the Sephardim. Leiden: Brill, 2015.

Kopot', Jevguenii Mikhailovich. "Kvoprosu ob interpretatsii greko-arabskogo protivostoiania i vlianii Rossii v Antiokhiiskom patriarchate vo vtoroi polovine XIX V.: po materialam AVPRI" [An interpretation of the confrontation between Greeks and Arabs and the Russian influence in the patriarchate of Antioch in the second half of the 19th century: documents from the Archive of Foreign Policy of the Russian Empire (AVPRI)]. Vestnik Moskovskogo Universiteta 13, no. 3 (2011): 31-38.

Mitchell, Timothy. Colonising Egypt. Cambridge: Cambridge University Press, 1988.

Mitchell, Timothy. Rule of Experts: Egypt, Techno-Politics, Modernity. Berkeley: University of California Press, 2002.

Mombelli, Alessandro. La Custodia di Terra Santa. Jerusalem: Tipografia dei PP. Francescani, 1934.

Montefiore, Claude G. Liberal Judaism: An Essay. London: Macmillan, 1903.

Mooreville, Anat. "Oculists in the Orient: A History of Trachoma, Zionism and Global Health, 1882-1973." PhD diss., University of California, Los Angeles, 2015.

Morgenstern, Arye. Ha-Shivah li-Rushalayim [The return to Jerusalem]. Jerusalem: Shalem, 2007.

Moussa, Sarga. “Le sabir du drogman." Arabica 54, no. 4 (2007): 554-67.

Muhtadi, Abla. AlQuds, tarikh wa hadara [Jerusalem, history and civilization]. Amman: Dar Majdalawi lil nashr wảl tawzic, 2000.

Muñoz-Rojas, Olivia. Ashes and Granite: Destruction and Reconstruction in the Spanish Civil War and its Aftermath. Eastbourne: Sussex Academic Press, 2011.

Muradian, Anahit. "Yerusaghemi Hay Tpagir Grk'i Matenagitut'yunē (1833-1996) [Bibliography of Armenian books printed in Jerusalem (1833-1996)]. Edited by G. A. Suqiasian. Yerevan: Lusabats Press, 2011.

Murateants, Melikisedek. Patmut'iwn Hayastaneants' Ar'ak'elakan Surb Yekeghets'woy [History of the Holy Apostolic Armenian Church]. Jerusalem: St. James Press, 1872 .

Murre-van den Berg, Heleen. "The Study of Western Missions in the Middle East (18201920): An Annotated Bibliography." In The Social Dimension of Christian Missions in the Middle East, edited by Norbert Friedrich, Uwe Kaminsky, and Rolan Löffler, 35-53. Stuttgart: Franz Steiner, 2010. 
Musaee, Anwar H. M., Eeman Muhammad Abbas, Wan Kamal Mujan, and Roziah Sidik. "Waqf Land in the West Bank and Investment Current State of Affairs." Asian Social Science 10, no. 14 (2014): 23-39.

Muslih, Muhammad Y. The Origins of Palestinian Nationalism. New York: Columbia University Press, 1988.

Mutlu, Servet. "Late Ottoman Population and Its Ethnic Distribution." Turkish Journal of Population Studies 25 (2003): 3-38.

"Nachrichten aus dem Hl. Lande." Das Heilige Land, no. 2 (April 1913):120-21.

Naciri, Mohamed. "Regards sur l'évolution de citadinité au Maroc." In Middle Eastern Cities in Comparative Perspective: Points de vue sur les villes du Maghreb et du Machrek, edited by Kenneth Brown, Michelle Jolé, Peter Sluglett, and Sami Zubaida, 249-70. London: Ithaca, 1986.

Naïli, Falestin. "Chronique d'une mort annoncée? La municipalité ottomane de Jérusalem dans la tourmente de la Première Guerre mondiale." Revue des mondes musulmans et de la Méditerranée, no. 141 (2017): 171-90.

Naïli, Falestin. "La dé-municipalisation de la gouvernance urbaine et de l'espace politique post-ottoman: le cas de Jérusalem." Les carnets de l'Ifpo (blog). Accessed November 12, 2017. https://ifpo.hypotheses.org/7428.

Naïli, Falestin. "La mémoire et l'oubli à Artas: un élément de l'histoire rurale de la Palestine, 1848-1948." PhD diss., University of Provence; Aix-Marseille I, 2007.

Nanni, Giordano. The Colonisation of Time: Ritual, Routine and Resistance in the British Empire. Manchester: Manchester University Press, 2012.

Napier, Christopher J. "Accounts of Change: 30 Years of Historical Accounting Research." Accounting, Organizations and Society 31, no. 4 (2006): 445-507.

Naser, Hasan Ahmed Mu'tasem, "Jerusalem Municipality and Political Conflict: 19181942." International Journal of History and Philosophical Research 4, no. 1 (2016): 1-15. Nassar, Issam. Laqatat Mughayira: Al-Taswir Al-Mahalli Al-Mubakkir Fi Filastin, 18501948 [Alternative shots: early local photography in Palestine, 1850-1958]. London: Mu'assasat 'Abd al-Muhsin al-Qattan, 2005.

Newton, Melanie J. “'The Race Leapt at Sauteurs': Genocide, Narrative, and Indigenous Exile from the Caribbean Archipelago." Caribbean Quarterly 6o, no. 2 (2014): 5-28.

Nimr al-, Ihsan. Tarikh Jabal Nablus wa al-Balqa [History of Nablus and Balqa]. 4 vols. Nablus, n.d.

Norris, Jacob. Land of Progress: Palestine in the Age of Colonial Development, 1905-1948. Oxford: Oxford University Press, 2013.

Nshanian, Mesrop. Aknark mē Yerusaghémi S. Yakobeanc Tparanin vray [An essay on St. James Armenian printing house of Jerusalem]. Jerusalem: St. James Press, 1912.

Nshanian, Mesrop. “'Tparan Ar'ak'elakan At'or'oyn Srboc Yakobeanc Yerusaghémi, Harivrameay Yobeleanin art'iw 1833-1933' [Printing house of St. James Apostolic See, Jerusalem, on its centenary (1833-1933)]. Sion, no. 11 (1933): 357-59. 
Ogle, Vanessa. "Whose Time Is It? The Pluralization of Time and the Global Condition, 1870s-1940s." The American Historical Review 118, no. 5 (2013): 1376-402.

O'Mahony, Anthony. "Palestinian-Arab Orthodox Christians: Religion, Politics and Church-State Relations in Jerusalem, c. 1908-1925." Chronos: Revue d'Histoire de l'Université de Balamand, no. 3 (2000): 61-91.

Ormanian, Malachia. Haykakan Yerusaghém: Nkaragir At'or'oy Srbots Yakobeants' [Armenian Jerusalem: description of St. James Convent of Jerusalem]. Jerusalem: St. James Press, 1931.

Ormrod, William Mark, Gwilym Dodd, and Anthony Musson, eds. Medieval Petitions: Grace and Grievance. Rochester: York Medieval Press, 2009.

Ortayli, İlber. Tanzimattan Sonra Mahalli Idareler (1840-1878) [Local administrations after the Tanzimat]. Ankara: Sevinç Matbaası, 1974.

Ortayli, İlber. Studies on Ottoman Transformation. Istanbul: Isis, 1994.

Öztürk, Said. "Sosyo-Ekonomik Tarih Kaynağı Olarak Ahkam Defterleri” [Registers of decrees as sources of socioeconomic history]. In Pax-Ottomana: Studies in Memoriam Prof. Dr. Nejat Göyünç, edited by Kemal Çiçek. Ankara: Sota and Yeni Türkiye, 2001.

Özyer, Kani. "Vakıflar Genel Müdürlüğü Arşivi [Archive of the General Directorate of Foundations]. In Uluslar Arası Türk Arşivleri Sempozyumu, 19-17 Kasım 2005 [Turkish archive symposium, November 17-19, 2005], 1-11. Istanbul: BОA Publications, 2006.

Pagis, Yonatan. Mifkede ha-'Ukhlusin ha-'Otomaniyim be-'Erets Yisrảel 1875-1918 [Ottoman population censuses in the land of Israel, 1875-1918]. Jerusalem: Achva, 1997.

Palestine and Transjordan Administration Reports. Vol. 1, 1918-1924. Farnham Common: Archive Editions, 1995 .

Panzac, Daniel. La population de l'empire Ottoman: cinquante ans (1941-1990) de publications et de recherches. Aix-en-Provence: IREMAM, 1993.

Papadopoulos, Chrysostomos A. Istoria tis ekklisias ton Ierosolymon [History of the church of Jerusalem]. Thessaloniki: Pournaras, 2010. First published 1910 by Patriarchate of Alexandria Press.

Papastathis, Konstantinos. "Church Finances in the Colonial Age: The Orthodox Patriarchate of Jerusalem under British Control, 1921-25." Middle Eastern Studies 49, no. 5 (2013): 712-31.

Papastathis, Konstantinos. “To keno exousias sto Patriarcheio Ierosolymon, 1917-1918" [The power vacuum within the Orthodox patriarchate of Jerusalem, 1917-1918]. Historica $5^{1}$ (2009): 333-67.

Papastathis, Konstantinos. "To proskinimatiko zitima stin Palestini: Apo tin othomaniki kyriarchia stin vretaniki entoli, 1914-1931" [The question of the Holy Places of Palestine: from Ottoman rule to the British Mandate, 1914-1931]. PhD diss., Aristotle University of Thessaloniki, 2008. 
Papastathis, Konstantinos. "Religious Politics and Sacred Space: The Orthodox Strategy on the Status Quo Question, 1917-1922." Journal of Eastern Christian Studies 65, no. 1/2 (2013): 67-96.

Papastathis, Konstantinos. "Religious Politics in Mandate Palestine: The Christian Orthodox Community Controversy in the Thirties." British Journal of Middle Eastern Studies 43, no. 3 (2016): 259-84.

Papastathis, Konstantinos. "Secularizing the Sacred:The Orthodox Church of Jerusalem as a Representative of Greek Nationalism in the Holy Land." Modern Greek Studies Yearbook, nos. 30-31 (2016): 37-54.

Papastathis, Konstantinos, and Ruth Kark. "Colonialism and Religious Power Politics: The Question of New Regulations within the Orthodox Church of Jerusalem during the British Mandate." Middle Eastern Studies 50, no. 4 (2014): 589-605.

Papastathis, Konstantinos, and Ruth Kark. "Orthodox Communal Politics in Palestine after the Young Turk Revolution (1908-1910).” Jerusalem Quarterly, nos. 56-57 (2014 2013): 118-49.

Papastathis, Konstantinos, and Ruth Kark. “The 'Politicization' of the 'Religious': The British Administration and the Question of the New Regulations of the Orthodox Patriarchate of Jerusalem, 1938-1941." Middle Eastern Studies 50, no. 4 (2014): 589-605.

Papastathis, Konstantinos, and Ruth Kark. "The Politics of Church Land Administration: The Orthodox Patriarchate of Jerusalem in Late Ottoman and Mandatory Palestine, 1875-1948." Byzantine and Modern Greek Studies 40, no. 2 (2016): 264-82.

Pavlovitch, Mansurov Boris. Pravoslavnye poklonnikiv Palestine [Orthodox pilgrims in Palestine]. St. Petersburg, 1857.

Paz, Omri. "Crime, Criminals and the Ottoman State: Anatolia between the Late 1830 s and the Late 186os." PhD diss., University of Tel Aviv, 2010.

Pech, Eduard. Manuel des Sociétés anonymes fonctionnant en Turquie. $5^{\text {th }}$ ed. Constantinople: Gerard Frères, 1911.

Pedersen, Kirsten. The History of the Ethiopian Community in the Holy Land from the Time of Emperor Tewodros II till 1974. Jerusalem: Ecumenical Institute for Theological Research, 1983 .

Pedersen, Kirsten. “The Historiography of the Ethiopian Monastery in Jerusalem.” In Ethiopian Studies: Proceedings of the Sixth International Conference of Ethiopian Studies, edited by Gideon Goldenberg and Baruch Podosky, 419-26. Rotterdam: Balkema, 1986.

Peirce, Leslie. "Changing Perceptions of the Ottoman Empire: The Early Centuries." Mediterranean Historical Review 19, no. 1 (2004): 6-28.

Penslar, Derek Jonathan. Zionism and Technocracy: The Engineering ofJewish Settlement in Palestine, 1870-1918. Bloomington: Indiana University Press, 1991.

Perry, Yaron. "Medical Treatment as a Missionary Instrument and its Social Consequences: Aspects of the Work by the London Jews Society in Palestine up to 1914." 
In The Social Dimension of Christian Missions in the Middle East: Historical Studies of the 19th and 2oth Centuries, edited by Norbert Friedrich, Uwe Kaminsky, and Roland Löffler, 147-54. Stuttgart: Franz Steiner, 2010.

Perry, Yaron, and Efraim Lev, Modern Medicine in the Holy Land: Pioneering British Medical Services in Late Ottoman Palestine. London: I. B. Tauris, 2007.

Peters, Michael, and Tina Besley. "Social Exclusion/Inclusion: Foucault's Analytics of Exclusion, the Political Ecology of Social Inclusion and the Legitimation of Inclusive Education." Open Review of Educational Research 1, no. 1 (2014): 99-115.

Pieraccini, Paolo. Cattolici di Terra Santa. Florence: Pagnini, 2003.

Pieraccini, Paolo. Gerusalemme, Luoghi Santi e comunità religiose nella politica internazionale. Bologna: Dehoniane, 1997.

Pieraccini, Paolo. Il ristabilimento del Patriarcato latino di Gerusalemme e la Custodia di Terra Santa. La dialettica istituzionale al tempo del primo patriarca, mons. Giuseppe Valerga (1847-1872). Cairo: Franciscan Centre of Christian Oriental Studies; Jerusalem: Franciscan Printing Press, 2006.

Planhol, Xavier de. Les fondements géographiques de l'histoire de l'Islam. Paris: Flammarion, 1968.

Poovey, Mary. Making a Social Body: British Cultural Formation, 1830-1864. Chicago: University of Chicago Press, 1995.

Poujeau, Anna. "Renouveau monastique et historiographie chrétienne en Syrie." Archives de sciences sociales des religions, no. 151 (2010): 129-47.

Prousis, Theophilus C. "AVPR (Arkhiv Vneshnei Politiki Rossii) and the Orthodox East." Modern Greek Studies Yearbook, nos. 12-13 (1997-1996): 473-503.

Prousis, Theophilus C. "Archival Gleanings on Russian Trade and Consulates in the Near East." Balkanistica 17 (2004): 67-78.

Prousis, Theophilus C. "A Guide to AVPRI Materials on Russian Consuls and Commerce in the Near East." Modern Greek Studies Yearbook, nos. 16-17 (2001-200o): $513-36$.

Qalyubi al-, Tahir Adib. 'A'ilat wa shakhsiyyat min Yafa wa qadáiha [Families and Personalities from Jaffa and its District]. Beirut: al-Mu'assasa al-'Arabiyya, 2006.

Quataert, Donald. "Limited Revolution: The Impact of the Anatolian Railway on Turkish Transportation and the Provisioning of Istanbul, 1890-1908." In Workers, Peasants and Economic Change in the Ottoman Empire, 1730-1914, 63-80. Istanbul: Isis, 1993 .

Quataert, Donald. The Ottoman Empire, 1700-1922. Cambridge: Cambridge University Press, 2000.

Quda, Ahmad Hamid Ibrahim. Nasara al-Quds:Dirasa fi daw'al-wathảiq al- uthmanyya [The Christians of Jerusalem in light of Ottoman documents]. Beirut: Markaz Dirasat al-Wahdah al-Arabiyah, 2007.

Rafeq, Abdul-Karim. "Political Power and Social Networks: Popular Coexistence and State Oppression in Ottoman Syria." In Islamic Urbanism in Human History: Political 
Power and Social Networks, edited by Sato Tsugitaka, 22-37. London: Kegan Paul International, 1997.

Rapaport, Raquel. “The City of the Great Singer: C. R. Ashbee's Jerusalem.” Architectural History 50 (2007): 171-210.

Rapaport, Raquel. "Conflicting Visions. Architecture in Palestine during the British Mandate." PhD diss., University of Cardiff, 2005.

Raz, Guy. Tsalame ha-'Arets: me-Reshit Yemey ha-Tsilum ve-'ad ha-Yom [Photographers of the land: from early photography to this day]. Tel Aviv: ha-Kibuts ha-me'uhad, 2003 .

Razik, 'Adnan 'Abd al-, and Khalil Tofakji. Israeli Colonial Policies and Practices: De-Arabization of East Jerusalem. Jerusalem: Arab Studies Society, 2008.

Read, Donald. The Age of Urban Democracy: England, 1868-1914. 2nd ed. London: Longman, 1994.

Rafiq (al-Tamimi), Muhammad, and Muhammad Bahjat. Wilayat Bayrut [Province of Beirut]. 2 vols. Beirut: Dar Lahd Khatir, 1987.

Raymond, André. "The Ottoman Conquest and the Development of the Great Arab Towns." International Journal of Turkish Studies 1 (1979-80): 84-101.

Reimer, Michael J. "Urban Regulation and Planning Agencies in Mid-NineteenthCentury Alexandria and Istanbul." Turkish Studies Association Bulletin 19, no. 1 (1995): 1-26.

Reinkowski, Maurus. “The State's Security and the Subjects' Prosperity: Notions of Order in Ottoman Bureaucratic Correspondence (19th Century)." In Legitimizing the Order: The Ottoman Rhetoric of State Power, edited by Maurus Reinkowski and Hakan T. Karateke, 195-212. Leiden: Brill, 2005.

Reiter, Yitzhak. Islamic Institutions in Jerusalem: Palestinian Muslim Organization under Jordanian and Israeli Rule. The Hague: Kluwer Law International, 1997.

Rivlin, Eliezer. "Hazakot shel Hatserot u-Vatim bi-Rushalayim" [Subleases of courtyards and houses in Jerusalem]. In Festschrift Dr. Jakob Freiman Zum 70 Geburtstag. Berlin: Viktoria, 1937.

Roberts, Nicholas E. "Dividing Jerusalem: British Urban Planning in the Holy City." Journal of Palestine Studies 42, no. 4 (2013): 7-26.

Robertson, Roland. Globalization: Social Theory and Global Culture. London: Sage, 1992. Robson, Laura. Colonialism and Christianity in Mandate Palestine. Austin: University of Texas Press, 2011.

Robson, Laura. "Communalism and Nationalism in the Mandate: The Greek Orthodox Controversy and the National Movement." Journal of Palestine Studies 41, no. 1 (2011): $6-23$.

Rogan, Eugene L. "Instant Communication: The Impact of the Telegraph in Ottoman Syria." In The Syrian Land:Processes of Integration and Fragmentation, Bilad Al-Sham 
from the 18th to the 2oth Century, edited by Thomas Philipp and Birgit Schaebler, 113-28. Stuttgart: Franz Steiner, 1998.

Rogan, Eugene L. Frontiers of the State in the Late Ottoman Empire: Transjordan, 18501921. Cambridge: Cambridge University Press, 1999.

Rogan, Eugene L. Outside In: On the Margins of the Modern Middle East. London: I. B. Tauris, 2002.

Rogers, Mary Eliza. Domestic Life in Palestine. London: Kegan Paul International, 1989.

Rokem, Jonathan. "Politics and Conflict in a Contested City: Urban Planning in Jerusalem under Israeli Rule." Bulletin Du Centre de recherche français à Jérusalem, no. 23 (2012).

Rondot, Pierre. Les Chrétiens d'Orient. Paris: Peyronnet, 1955.

Rood, Judith Mendelsohn. Sacred Law in the Holy City: The Khedival Challenge to the Ottomans as Seen from Jerusalem, 1829-1841. Leiden: Brill, 2004.

Rosenthal, Herman, and Peter Wiernik. "Haskalah." In Jewish Encyclopedia. Unedited version of 1906 edition. 2002-11. http://www.jewishencyclopedia.com/ articles/7318-haskalah.

Rosenthal, Steven T. The Politics of Dependency: Urban Reform in Istanbul. Westport: Greenwood Press, 1980.

Rotbard, Sharon. White City, Black City: Architecture and War in Tel Aviv and Jaffa. Translated by Orit Gat. London: Pluto, 2015.

Rouaud, Alain. "La protection française des Abyssins de Jérusalem (1843-1898), Aperçu." Transversalités 85 (2003): 63-74.

Roussos, Sotirios. "Eastern Orthodox Perspectives on Church-State Relations and Religion and Politics in Modern Jerusalem." International Journal for the Study of the Christian Church 5, no. 2 (2005): 103-22.

Roussos, Sotirios. "Greece and the Arab Middle East:The Greek Orthodox Communities in Egypt, Palestine and Syria, 1919-1940." PhD diss., soAs, University of London, 1994.

Roussos, Sotirios. "The Greek Orthodox Patriarchate and Community in Jerusalem." In The Christian Heritage in the Holy Land, edited by Anthony O'Mahony, Goran Gunner, and Kevork Hintlian, 211-24. Jerusalem: Swedish Christian Center, 1995.

Roussos, Sotirios. "The Greek Orthodox Patriarchate and Community of Jerusalem: Church, State and Identity." In The Christian Communities in Jerusalem and the Holy Land: Studies in History, Religion and Politics, edited by Anthony O'Mahony, 38-56. Cardiff: University of Wales Press, 2003.

Rubenstein, Daniel. "The Jerusalem Municipality under the Ottomans, British, and Jordanians." In Jerusalem: Problems and Prospects, edited by Joel Kraemer, 88-94. New York: Praeger, 1980. 
Rubin, Noah Hysler. “Geography, Colonialism and Town Planning: Patrick Geddes' Plan for Mandatory Jerusalem." Cultural Geographies 18, no. 2 (2011): 231-48.

Ruppin, Arthur. The Jews of To-Day. Translated by Margery Bentwich. New York: Henry Holt, 1913.

Rustum, Asad. The Royal Archives of Egypt and the Origins of the Egyptian Expedition to Syria, 1831-1841. Beirut: American University of Beirut Press, 1936.

Ryan, James. “Unveiling' the Tramway: The Intimate Public Sphere in Late Ottoman and Republican Istanbul." Journal of Urban History. Published online April 11, 2016. Accessed February 2, 2018. doi:10.1177/oog6144216641070.

Sabri, Bahjat. "Liw' al-Quds Athna al-Hukm al-'Uthmani, 1840-1873' [The Jerusalem liwa during Ottoman rule, 1840-1873]. PhD diss., 'Ain Shams University, 1973.

Sadarove, Philip. "The Egyptian Press and Ottoman Press Law." In al-Dawla al'Uthmaniyya: Bidayat wa Nihayat [The Ottoman state: beginning and end], edited by Muhammad Arnout and H. Abu Shảar al-. Mafraq: Publications of Al-Bayt University, 2001.

Safi, Khaled. The Egyptian Rule in Palestine 1831-1840: A Critical Reassessment. Berlin: Mensch \& Buch, 2004.

Şahin, Eyüp. Türk Polisinden Seçkin Biyografiler [Selected biographies of the Turkish police]. Ankara: Emniyet Genel Müdürlüğü, 2012.

Said, Edward W. "Permission to Narrate." Journal of Palestine Studies 13, no. 3 (1984): $27-48$.

Sakakini al-, Khalil. "Nyu Yurk, Sultana, Al-Quds, 1907-1912 [New York, Sultana, Jerusalem, 1907-1912]. In Yawmiyyat Khalil al-Sakakini [The diaries of Khalil Sakakini], vol. 1, edited by Akram Musallam. Ramallah: Khalil Sakakini Cultural Centre; Institute for Jerusalem Studies, 2003.

Sakakini al-, Khalil. Yawmiyat Khalil Al-Sakakini [Diaries of Khalil Sakakini]. Edited by Akram Musallam, 8 vols. Ramallah: Khalil Sakakini Cultural Centre; Institute for Jerusalem Studies, 2003 .

Sakaoğlu, Necdet. "Arzuhalciler" [Petition-writer]. Dünden Bugüne İstanbul Ansiklopedisi [Encyclopedia of Istanbul from past to present]. Istanbul: Tarih Vakfi Yurt, 1993.

Salim al-, Farid. Palestine and the Decline of the Ottoman Empire: Modernisation and the Path to Palestine Statehood. London: I. B. Tauris, 2015.

Salzman, Philip Carl, and Donna Robinson Divine. Postcolonial Theory and the ArabIsrael Conflict. London: Routledge, 2008.

Salzmann, Ariel. “An Ancien Régime Revisited: 'Privatization' and Political Economy in the Eighteenth-Century Ottoman Empire." Politics \& Society 21, no. 4 (1993):393-423.

Salzmann, Ariel. "Citizens in Search for a State; the Limits of Political Participation in the Late Ottoman Empire." In Extending Citizenship, Reconfiguring States, edited by Michael Hanagan and Charles Tilly, 37-66. Lanham: Rowman \& Littlefield, 1999. 
Sanbar, Elias. Les Palestiniens: la photographie d'une terre et de son peuple de 1839 à nos jours. Paris: Hazan, 2004.

Sanbar, Elias, ed.Jérusalem et la Palestine: le fonds photographique de l'Ecole biblique de Jérusalem. Paris: Hazan, 2013.

Sanders, Jimy M. "Ethnic Boundaries and Identity in Plural Societies." Annual Review of Sociology 28 (2002): 327-57.

Saposnik, Arieh Bruce. Becoming Hebrew: The Creation of a Jewish National Culture in Ottoman Palestine. Oxford: Oxford University Press, 2008.

Sarınay, Yusuf et al., ed. Başbakanlık Osmanlı Arşivi Rehberi [Guidebook to the Ottoman State Archives]. Istanbul: Başbakanlık Devlet Arşivleri Genel Müdürlüğü, 2010.

Sassen, Saskia. "Cityness." In Urban Transformation, edited by Andreas Ruby and Ilka Ruby, 84-88. Berlin; Zürich: Ruby Press; Holcim Foundation for Sustainable Construction, 2008.

Şaşmaz, Musa. "The Ottoman Censuses and the Registration Systems in the Nineteenth and Early Twentieth Centuries." Osmanlı Tarihi Araştırma ve Uygulama Merkezi Dergisi (отAM) 6 (1995): 289-305.

Sasson, Tehila. "Milking the Third World? Humanitarianism, Capitalism, and the Moral Economy of the Nestlé Boycott." The American Historical Review 121, no. 4 (2016): 1196-224.

Saulson, Scott Bradley. "Eliezer Ben-Yehudah's Hamavo Hagadol: Introduction, Translation, Annotation." PhD diss., University of South Africa, 1985.

Sawalaniantz, Tigran. Patmut 'iwn Yerusaghémi [History of Jerusalem]. 2 vols. Jerusalem: St. James Press, 2000.

Sbaiti, Nadya, and Sara Scalenghe. "Conducting Research in Lebanon: An Overview of Historical Sources in Beirut (Part I)." Middle East Studies Association Bulletin 37, no. 1 (2003): 68-79.

Schmelz, Uziel O. "Ha-'Ukhlusiya ha-Kelalit be-'Erets Yisrảel: Godel ha-'Ukhlusiya haKelalit ba-'Arets 'Erev ha-Milhama” [The general population in the land of Israel: the size of the general population in the country on the eve of the war]. In Be-Matsor u-Vematsok: -'Erets Yisrảel be-Milhemet ha-'Olam ha-Rishona [The general population in the land of Israel: increase in the general population in the land on the eve of the war], edited by Mordechai Eliav, 17-29. Jerusalem: Yad Ben-Zvi Institute, 1991.

Schmelz, Uziel O. "Population Characteristics of Jerusalem and Hebron Regions According to Ottoman Census of 1905." In Ottoman Palestine, 1800-1914: Studies in Economic and Social History, edited by Gad Gilbar, 15-68. Leiden: Brill, 1990.

Schmelz, Uziel O. "The Population of Jerusalem's Urban Neighborhoods According to the Ottoman Census of 1905." Scripta Hierosolymitana 35 (1994): 93-113.

Schmelz, Uziel O. 'Ukhlusiyat -Yerushalayim: Temurot ba-'Et ha-Hadash [Modern Jerusalem's demographic evolution]. Jerusalem: Jerusalem Institute for Israel Studies, 1988. 
Schneer, Jonathan. The Balfour Declaration: The Origins of the Arab-Israeli Conflict. New York: Random House, 2010.

Schölch, Alexander. "The Demographic Development of Palestine, 1850-1882." International Journal of Middle East Studies 17, no. 4 (1985): 485-505.

Schölch, Alexander. "Jerusalem in the 19th Century (1831-1917)." In Jerusalem in History, edited by Kamal J. Asali, 228-49. Buckhurst Hill: Scorpion, 1989.

Schölch, Alexander. Palästina Im Umbruch, 1856-1882: Untersuchungen Zur Wirtschaftlichen Und Soziopolitischen Entwicklung. Stuttgart: Franz Steiner, 1986.

Schölch, Alexander. Palestine in Transformation, 1856-1882: Studies in Social, Economic, and Political Development. Translated by William C. Young and Michael C. Gerrity. Washington, DC: Institute for Palestine Studies, 1993.

Scholler, Heinrich. "The Ethiopian Community in Jerusalem from $185^{\circ}$ to the Conference of Dar-El-Sultan 1902, the Political Struggle for Independence." In Ethiopian Studies: Proceedings of the Sixth International Conference of Ethiopian Studies, edited by Gideon Goldenberg and Baruch Podolsky, 487-500. Rotterdam: Balkema, 1986.

Schulze, Winfried. Ego-Dokumente: Annäherung an den Menschen in der Geschichte. Berlin: Akademie, 1996.

Schwake, Norbert. Die Entwicklung des Krankenhauswesens der Stadt Jerusalem vom Ende des 18. bis zum Beginn des 20. Jahrhunderts. 2 vols. Herzogenrath: MurkenAltrogge, 1983 .

Schwake, Norbert. "Hospitals and European Colonial Policies in the 19th and Early 2oth Centuries." In Health and Disease in the Holy Land, edited by Manfred Waserman and Samuel S. Kottek, 232-62. Lewiston: Edwin Mellen, 1996.

Scott, David. Conscripts of Modernity: The Tragedy of Colonial Enlightenment. Durham: Duke University Press, 2004.

Scott, James C. Seeing Like a State: How Certain Schemes to Improve the Human Condition Have Failed. New Haven: Yale University Press, 1998.

Scrimgeour, Frederic John. Nazareth of Today. Edinburgh: William Green, 1913.

Segev, Tom. One Palestine, Complete: Jews and Arabs under the British Mandate. Translated by Haim Watzman. London: Little, Brown, 2001.

Shaham, Ron. "Christian and Jewish 'Waqf' in Palestine during the Late Ottoman Period." Bulletin of the School of Oriental and African Studies, University of London 54, no. 3 (1991): 460-72.

Shahin, Riyad, and Ibrahim Ni'matallah, Al-Mulkiyyat wal Darảib fi al Ramlah fi Sijjilat al-Mahakim al-Shariiyya 1864-1914 [Land ownership and taxation in Ramla (18641914) from Islamic court sijillāt]. Gaza: Gaza Islamic University, 2005.

Shahvar, Soli. "Concession Hunting in the Age of Reform: British Companies and the Search for Government Guarantees; Telegraph Concessions through Ottoman Territories, 1855-1858." Middle Eastern Studies 38, no. 4 (2002): 169-93. 
Shamir, Simon. "Egyptian Rule (1832-1840) and the Beginning of the Modern Period in the History of Palestine." In Egypt and Palestine: A Millennium of Association, 8681948, edited by Gabriel Baer and Ammon Cohen. Jerusalem: Ben-Zvi Institute for the Study of Jewish Communities in the East, 1984.

Shank, Barry. A Token of My Affection: Greeting Cards and American Business Culture. New York: Columbia University Press, 2004.

Shannaq, Mahmud Nahar. Baladiyyat al-Quds al-Sharif fi al-'ahd al-'uthmani: dirasat [The municipality of Jerusalem in the Ottoman period: studies]. Ramallah, 2010.

Sharet, Moshe. Nitrảe ve-Ulay Lo: Mikhtavim me-ha-Tsava ha-'Otomani 1916-1918 [Shall we ever meet again? Letters of an Ottoman soldier 1916-1918]. Edited by Ya'akov Sharet. Tel Aviv: Ha-'Amuta le-Moshe Sharet, 1998.

Sharif, Malek. Imperial Norms and Local Realities: The Ottoman Municipal Laws and the Municipality of Beirut (1860-1908). Beirut: Orient-Institut; Würzburg: Ergon, 2014. Shaw, Stanford J. History of the Ottoman Empire and Modern Turkey. Vol. 1. Empire of the Gazis: The Rise and Decline of the Ottoman Empire, 1280-1808. Cambridge: Cambridge University Press, 1976.

Shaw, Stanford J. "The Ottoman Census System and Population, 1831-1914." International Journal of Middle East Studies 9, no. 3 (1978):325-38.

Shaw, Stanford J. “The Population of Istanbul in the Nineteenth Century." International Journal of Middle East Studies 10, no. 2 (1979): 265-77.

Shaw, Stanford J., and Ezel Kural Shaw, History of the Ottoman Empire and Modern Turkey. Vol. 2, Reform, Revolution, and Republic: The Rise of Modern Turkey, 1808-1975. Cambridge: Cambridge University Press, 1977.

Sheehi, Stephen. "Portrait Paths: Studio Photography in Ottoman Palestine." Jerusalem Quarterly, no. 61 (2015): 23-41.

Shepherd, Naomi. Ploughing Sand: British Rule in Palestine, 1917-1948. London: John Murray, 1999.

Shilo, Margalit. Princess or Prisoner? Jewish Women in Jerusalem, 1840-1914. Translated by David Louvish. Waltham: Brandeis University Press, 2005.

Shohamy, Elana Goldberg, Eliezer Ben Rafael, and Monica Barni, eds. Linguistic Landscape in the City. Bristol: Multilingual Matters, 2010.

Shvarts, Shifra. The Workers' Health Fund in Eretz Israel: Kupat Holim, 1911-1937. Rochester: University of Rochester Press, 2002.

Shvarts, Shifra, and Theodore M. Brown. "Kupat Holim, Dr. Isaac Max Rubinow, and the American Zionist Medical Unit's Experiment to Establish Health Care Services in Palestine, 1918-1923." Bulletin of the History of Medicine 72, no. 1 (1998): 28-46.

Simmons, Erica B. Hadassah and the Zionist Project. Lanham: Rowman \& Littlefield, 2002.

Simoni, Marcella. A Healthy Nation: Zionist Health Policies in British Palestine, 1930-1939. Venice: Cafoscarina, 2010. 
Smirnova, Irina Iur'evna. Mitropolit Filaret i Pravoslavnyi Vostok: iz istorii mezhtzerkovnykh sviazei [Metropolitan Filaret and Orthodox Orient: a history of interchurch relations]. Moscow: Rosspen, 2014.

Sobranie mnenii I otzyvov Filareta, mitropolita Moscovskogo i Kolomenskogo, po delam Pravoslavnoi tserkvina Vostoke [A collection of the opinions and relations of Filaret, Metropolitan of Moscow and Kolomna, on the affairs of the Eastern Orthodox Church]. St. Petersburg: Synod Print, 1886.

Sodar de Vaulx, Marie. Les gloires de Terre Sainte: histoire de ses heros, de ses martyrs, de ses pèlerins. 2 vols. Paris: Bloud et Barral, 1899.

Sodar de Vaulx, Marie. Les splendeurs de la Terre Sainte: ses sanctuaires et leurs gardiens. Paris: Bloud et Barral, 1889.

Solomon-Godeau, Abigail. "A Photographer in Jerusalem, 1855: Auguste Salzmann and His Times." October, no. 18 (1981): 90-107.

Spyridon, S. N. "Annals of Palestine, 1821-1841." The Journal of the Palestine Oriental Society, no. 18 (1938): 63-132.

Sroor, Musa. Fondations pieuses en mouvement: de la transformation du statut de propriété des biens waqfs à Jérusalem, 1858-1917. Aix-en-Provence: Institut de recherches et d'études sur le monde arabe et musulman (IREMAM); Damascus, Beirut: Institut français du Proche-Orient, 2010.

Sroor, Musa. "Jerusalem's Islamic Archives: Sources for the Question of the Waqf in the Ottoman Period." Jerusalem Quarterly, nos. 22-23 (1999): 80-86.

St. Laurent, Beatrice, and Himmet Taskömür. "The Imperial Museum of Antiquities in Jerusalem, 1890-1930: An Alternative Narrative." Jerusalem Quarterly, no. 55 (2013): $6-45$.

Stabel, Peter. "Labour Time, Guild Time? Working Hours in the Cloth Industry of Medieval Flanders and Artois (13th-14th Centuries)." Tijdschrift Voor Sociale En Economische Geschiedenis 11, no. 4 (2014): 27-54.

Stamatopoulos, Dimitrios. Metarrythmisi kai ekkosmikeusi: Pros mia anasynthesi tis istorias tou Oikoumenikou Patriarheiou [Reforms and secularization: towards a reconstruction of the history of the Ecumenical Patriarchate]. Athens: Alexandria, 2003.

Stark, Chareen. "The Legacy of Hind al-Husseini." Washington Report on Middle East Affairs: Voices of the Nakba (May-June 2008): 19-20.

Stavrou, Theofanis George. "Russian Interest in the Levant 1843-1848: Porfirii Uspenskii and Establishment of the First Russian Ecclesiastical Mission in Jerusalem." Middle East Journal 17, no. 1/2 (1963): 91-103.

Stavrou, Theofanis George. Russian Interests in Palestine, 1882-1914: A Study of Religious and Educational Enterprise. Thessaloniki: Institute for Balkan Studies, 1963.

Stavrou, Theofanis George and Weisensel, Peter R. Russian Travelers to the Christian East from the Twelfth to the Twentieth Century. Columbus: Slavica, 1986. 
Stepanian, Hasmik. Hayatar'T'urk'eren Grakanut'yuny [Turkish literature in Armenianlettered Turkish]. Yerevan: Armenian National Academy of Sciences, 2001.

Stepanian, Hasmik. Hayatar' T'urk'erén Grk'eri ew Hayatar' T'urk'erén Parberakan Mamuli Matenagitut'iwn (1727-1968) [A bibliography of Armenian-lettered Turkish books and press (1727-1968)]. Istanbul: Türkuaz, 2005.

Stephan Powers, David. "Waqf." Encyclopaedia of Islam, 2002.

Storrs, Ronald. The Memoirs of Sir Ronald Storrs. New York: G. P. Putnam's Sons, 1937.

Sufian, Sandra M. "Healing Jerusalem: Colonial Medicine and Arab Health from World War I to 1948." In Modernity and Colonial Transformation, 1917-Present, edited by Lena Jayyusi, 115-36. Northampton: Olive Branch, 2015 .

Suleiman, Yasir, ed. Language and Society in the Middle East and North Africa: Studies in Variation and Identity. Richmond: Curzon, 1999.

Swarts, Shifra. "Meshihiyut ve-Politika be-Hakamat Mosdot ha-Refu'a ha-Yehudiyim ha-Rishonim bi-Rushalayim ba-Me'ah ha-19" [Messianism and politics in the establishment of the first Jewish medical institutions in Jerusalem in the 19th century]. In Refu'ah bi-Rushalayim le-Doroteha [Medicine in Jerusalem through the generations], edited by Efraim Lev et al., 129-45. Tel Aviv: Erets, 1999.

Syrku, Polikhronii Agapievich, ed. Opisanie bumag episkopa Porfiriia Uspenskogo pozhertvovannykh imvImperatorkuiu Academiiunaukpozaveshchaniiu [Description of the papers of Bishop Porfirii Uspenskii, left by him to the Imperial Academy of Sciences according to his testament]. St. Petersburg: Imperial Academy of Sciences, 1891 .

Tabak, Faruk. "Imperial Rivalry and Port-Cities: A View from Above." Mediterranean Historical Review 24, no. 2 (2009): 79-94.

Tadros Khalaf, Noha. Les mémoires de Issa al-'Issa: journaliste et intellectuel palestinien (1878-1950). Paris: Karthala, 2009.

Tafla, Bairu. A Chronicle of Emperor Yohannes IV (1872-1889). Wiesbaden: Harrassowitz, 1977.

Talbot, Michael. "The Exalted Column, the Hejaz Railway and Imperial Legitimation in Late Ottoman Haifa." Urban History 42, no. 2 (2015): 246-72.

Talbot, Michael. “Jews, Be Ottomans!' Zionism, Ottomanism, and Ottomanisation in the Hebrew-Language Press, 1890-1914." Die Welt des Islams 56, no. 3/4 (2016): $359-87$.

Tamari, Salim. "Confessionalism and Public Space in Ottoman and Colonial Jerusalem." In Cities and Sovereignty: Identity Politics in Urban Spaces, edited by Diane Davis and Nora Libertun de Duren, 59-82. Bloomington: Indiana University Press, 2011.

Tamari, Salim. "The Great War and the Erasure of Palestine's Ottoman Past." In Transformed Landscapes: Essays on Palestine and the Middle East in Honor of Walid Khalidi, edited by Leila Fawaz and Kamil Mansour, 105-36. Cairo: American University in Cairo Press, 2009. 
Tamari, Salim. The Great War and the Remaking of Palestine. Berkeley: University of California Press, 2017.

Tamari, Salim. "Ishaq al-Shami and the Predicament of the Arab Jew in Palestine." Jerusalem Quarterly, no. 21 (2004): 10-26.

Tamari, Salim. "Issa al Issa's Unorthodox Orthodoxy: Banned in Jerusalem, Permitted in Jaffa." Jerusalem Quarterly, no. 59 (2014): 16-36.

Tamari, Salim. "Jerusalem's Ottoman Modernity: The Times and Lives of Wasif Jawhariyyeh." Jerusalem Quarterly, no. 9 (2000): 5-27.

Tamari, Salim. "Khalil Sakakini's Ottoman Prison Diaries." Jerusalem Quarterly, no. 20 (2004): 7-23.

Tamari, Salim. Mountain Against the Sea: Essays on Palestinian Society and Culture. Berkeley: University of California Press, 2009.

Tamari, Salim. Year of the Locust: A Soldier's Diary and the Erasure of Palestine's Ottoman Past. Berkeley: University of California Press, 2011.

Tamari, Salim, and Issam Nassar. Al-Quds al-Intidabiyya fil al-Mudhakkirat al-Jawhariyyeh, 1918-1948 [British Mandate Jerusalem in the memoirs of Wasif Jawhariyyeh, 1918-1948]. Jerusalem: Institute for Jerusalem Studies, 2005.

Tamari, Salim, and Issam Nassar. Al-Quds al-'Uthmaniyya fi al-Mudhakkirat al-Jawhariyya: al-Kitab al-Awwal min Mudhakkirat al-Musiqi Wasif Jawhariyya, 1904-1917 [Ottoman Jerusalem in the Jawhariyyeh memoirs: the first book of the memoirs of the musician Wasif Jawhariyya, 1904-1917]. Vol. 1. Beirut: Institute for Palestine Studies, 2003.

Tamari, Salim, and Issam Nassar. The Storyteller of Jerusalem: The Life and Times of Wasif Jawhariyyeh, 1904-1948. Translated by Nada Elzeer. Northampton: Olive Branch, 2013.

Tamimi al, Muhammad Dảud. Awqaf wa Amlak al Muslimin fi Filastin [Muslim waqf properties in Palestine]. Istanbul: Organization of Muslim Congress, 1984.

Tarawina, Muhammad. Qada Yafa fi al-'ahd al-'uthmani: dirasa idariyya iqtisadiyya ijtima iyya, 1281-1333 h/1864-1914m [The district of Jaffa in the Ottoman period: administrative, economic and social studies, AH 1281-1333/M 1864-1914]. Amman: Jordan Ministry of Culture, 2000.

Ter Haar Romeny, Bas ter, ed. Religious Origins of Nations? The Christian Communities of the Middle East. Leiden: Brill, 2010.

Tibawi, Abdul Latif. The Islamic Pious Foundations in Jerusalem: Origins, History and Usurpation by Israel. London: Islamic Cultural Centre, 1978.

Titov Fedor Ivanovitch. Preosviatchennyj Kirill Naumov, episkop Melitopol'skii, byvchii nastoiatel' Russkoi Dukhovnoi Missii v Ierusalime [The most reverend Kirill Naumov, bishop of Melitopol, ex-chief of the Russian ecclesiastical mission in Jerusalem]. Kiev, 1902. 
Tobler, Titus. Nazareth in Palästina. Berlin: Reimer, 1868.

Torstrick, Rebecca L. Culture and Customs of Israel. Westport: Greenwood Press, 2004.

Travis, Anthony Selwyn. On Chariots with Horses of Fire and Iron: The Excursionists and the Narrow Gauge Railroad from Jaffa to Jerusalem. Jerusalem: Hebrew University Magnes Press, 2009.

Tripp, Charles. A History of Iraq. Cambridge: Cambridge University Press, 2007.

Tristram, Henry B. The Land of Israel: A Journal of Travels in Palestine. London: Society for Promoting Christian Knowledge, 1882.

Trouillot, Michel-Rolph. Silencing the Past: Power and the Production of History. Boston: Beacon, 1995 .

Tselikas, Agamemnon. Katagrafi tou archeiou tou Patriarcheiou Ierosolymon [Register of the Jerusalem Patriarchate archives]. Athens: Deltio tou Istorikou kai Paleografikou Archeiou tou Morfotikou Idrymatos tis Ethnikis Trapezas tis Ellados, 1992.

Tselikas, Agamemnon. "I typografia ton Ierosolymon: I typografiki kai ekdotiki drastiriotita tou ekei Orthodoxou Patriarcheiou" [Printing in Jerusalem: the printing and editorial activity of the Orthodox Patriarchate]. In "Epta Imeres," supplement, Kathimerini, April 7, 1996.

Tsimhoni, Daphne. "The Greek Orthodox Patriarchate of Jerusalem during the Formative Years of the British Mandate in Palestine." Asian and African Studies 12, no. 1 (1978): 77-121.

Tuğ, Başak. Politics of Honor in Ottoman Anatolia: Sexual Violence and Socio-Legal Surveillance in the Eighteenth Century. Leiden: Brill, 2017.

Tuğluca, Murat. Osmanlı Devlet-Toplum İlişkisinde Şikâyet Mekanizması ve İ̧̧leyiş Biçimi [The complaint mechanism and its functioning in the relationship between state and society in the Ottoman Empire]. Ankara: Türk Tarih Kurumu, 2016.

Türesay, Özgür. "L'Empire ottoman sous le prisme des études postcoloniales: À propos d'un tournant historiographique recent." Revue d'histoire moderne et contemporaine 6o, no. 2 (2013): 127-45.

Türesay, Özgür. "Le temps des almanachs ottomans: usage des calendriers et temps de l'histoire (1873-1914)." In Les Ottomans et le temps, edited by François Georgeon and Frédéric Hitzel, 129-57. Leiden: Brill, 2011.

Turjman, Ihsan. 'Am al-jarad, al-harb al-'uthma wa mahu al-madi al-'uthmani fi Filastin [The year of the locust: the Great War and the fading of the Ottoman past in Palestine]. Edited by Salim Tamari. Beirut: Institute for Palestine Studies, 2008.

'Ulaymi, Mujir Al-Din 'Abd al-Rahman ibn Muhammad al-. Al-uns al-jalil bi-Tarikh al-Quds wa-l-Khalil [The glorious history of Jerusalem and Hebron]. 2 vols. Najaf: al-Matba'ah al-Hagdariyah, 1968. 
Ursinus, Michael. Grievance Administration (Şikayet) in an Ottoman Province: The Kaymakam of Rumelia's "Record Book of Complaints" of 1781-1783. London: RoutledgeCurzon, 2005.

Uspenskii, Porfirii. Kniga bytiia moego. Dnevniki i avtobiograficheskie zapiski episkopa Porfiriia Uspenskogo [The book of my being: journals and autobiographical notes of Bishop Porphyrii Uspenskii] 8 vols. St. Petersburg: Imperial Academy of Sciences, 1894-1901.

Vakh, Kirill. “Osnovanie rossijskogo konsul'stva v Ierusalime v svete novykh arkhivnykh dokumentov" [Foundation of the Russian consulate in Jerusalem from the perspective of new documents]. Vostochnyj Arkhiv 31, no. 1 (2015): 29-32.

Van Leeuwen, Richard. Waqfs and Urban Structures: The Case of Ottoman Damascus. Leiden: Brill, 1999.

Vardapet, Vardan. Tesut'iwn Ant'aram Tsaghik Metsats'usts'éin [Commentary on the hymn for the Holy Virgin Unfading Flower]. Jerusalem: St. James Press, 1834.

Vatikiotis, Panayiotis J. "The Greek Orthodox Patriarchate of Jerusalem between Hellenism and Arabism." Middle Eastern Studies 30, no. 4 (1994): 916-29.

Veracini, Lorenzo. "The Other Shift: Settler Colonialism, Israel, and the Occupation." Journal of Palestine Studies 42, no. 2 (2013): 26-42.

Vercruysse-Bruneel, Dominique Joseph. La régénération du monde: opuscule dédié aux douze tribus d'Israël. Paris: Eugène Beyaert, 1860.

Vercruysse-Bruneel, Dominique Joseph. La résurrection dans le système de la régénération du monde, opuscule dédié aux douze tribus d'Israël. Bruxelles: Terneu, 1869.

Vester, Bertha Spafford. Our Jerusalem: An American Family in the Holy City, 1881-1949. Jerusalem: Ariel Publishing, $195^{0}$.

Volpe, Andrea L. "Cartes de Visite Portrait Photographs and the Culture of Class Formation." In The Middling Sorts: Explorations in the History of the American Middle Class, edited by Burton J. Bledstein and Robert D. Johnston, 157-69. London: Routledge, 2001.

Vovchenko, Denis. "Creating Arab Nationalism? Russia and Greece in Ottoman Syria and Palestine (1840-1909)." Middle Eastern Studies 49, no. 6 (2013): 901-18.

Wallach, Yair. "Readings in Conflict: Public Texts in Modern Jerusalem, 1858-1958." PhD diss., Birkbeck College, University of London, 2008.

Wallach, Yair. "Rethinking the Yishuv: Late-Ottoman Palestine's Jewish Communities Revisited." Journal of Modern Jewish Studies 16, no. 2 (2017): 275-94.

Wallach, Yair. "Shared Space in Pre-1948 Jerusalem? Integration, Segregation and Urban Space through the Eyes of Justice Gad Frumkin, Elect," working paper no. 21, Conflict in Cities and the Contested State, accessed January 15, 2018, http://www .conflictincities.org/PDFs/WorkingPaper21.pdf.

Wansbrough, John Edward et al. "Imtiyāzāt [Capitulations]." In The Encyclopedia of Islam, edited by Hamilton Alexander Rosskeen Gibb: Leiden: Brill, 1986. 
Wasserstein, Bernard. The British in Palestine: The Mandatory Government and ArabJewish Conflict, 1917-1929. 2nd ed. Oxford: Basil Blackwell, 1991.

Watenpaugh, Keith David. Bread from Stones: The Middle East and the Making of Modern Humanitarianism. Berkeley: University of California Press, 2015.

Weakley, Ernest. Report upon the Conditions and Prospects of British Trade in Syria. Cd. 5707 London: HMSO, 1911.

Weber, Max. The City. Glencoe: Free Press, 1958. First published 1922.

Weber, Stefan. "Laménagement urbain entre régulations ottomanes, intérêts privés et participation politique. La municipalité de Damas à la fin de l'époque Ottomane (1864-1918)." In Municipalités méditerranéennes: les réformes urbaines ottomanes au miroir d'une histoire comparée (Moyen-Orient, Maghreb, Europe méridionale), edited by Nora Lafi, 173-222. Berlin: Klaus Schwarz, 2005.

Weber, Stefan. Damascus: Ottoman Modernity and Urban Transformation, 1808-1918. 2 vols. Aarhus: Aarhus University Press, 2009.

Weill, Georges. "Élie-Aristide Astruc, rabbin, écrivain et publiciste (Bordeaux, 12 Décembre 1831-Bruxelles, 23 Février 1905)." Archives Juives 35, no. 1 (2002): 137-43. Wilson, Rachel Beckles. Orientalism and Musical Mission: Palestine and the West. Cambridge: Cambridge University Press, 2013.

Wishnitzer, Avner. Reading Clocks, Alla Turca: Time and Society in the Late Ottoman Empire. Chicago: University of Chicago Press, 2015.

Woodward Ernest L, and Rohan Butler. Documents on British Foreign Policy, 1919-1939. 1st ser., vol. 7. London: H MSO, 1958.

Wright, Gwendolyn. The Politics of Design in French Colonial Urbanism. Chicago: University of Chicago Press, 1991.

Wulf, Stefan. Das Hamburger Tropeninstitut, 1919 bis 1945: Auswärtige Kulturpolitik und Kolonialrevisionismus nach Versailles. Berlin: Dietrich Reimer, 1994.

Wulf, Stefan.Jerusalem-Aleppo-Konstantinopel: der Hamburger Tropenmediziner Peter Mühlens im Osmanischen Reich am Vorabend und zu Beginn des Ersten Weltkriegs. Münster: LIT, 2005.

“'Yaveluats, Handés Bacman Norakar'oyc Kuilpénkean Matenadaranin Ar'ak'elakan At'nr'oyn Srboc Yakobeanc" [Appendices, the opening ceremony of the newly built Gulbenkian Manuscripts' Archive of the Apostolic See of St. James]. Sion, no. 11 (1932): 355 .

Yaycıŏ̆lu, Ali. "Sened-i İttifak (1808): Osmanlı İmparatorluğu'nda Bir Ortaklık ve Entegrasyon Denemesi" [Charter of Alliance (1808): a partnership and integra-

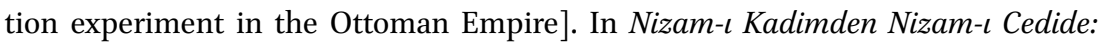
III. Selim ve Dönemi [Selim III and his era, from ancien régime to new order], edited by Kenan Seyfi, 667-709. Istanbul: ISAM, 2010.

Yazbak, Mahmoud. "Elections in Late Ottoman Palestine: Early Exercises in Political Representation." In Late Ottoman Palestine: The Period of Young Turk Rule, edited by Yuval Ben-Bassat and Eyal Ginio. London: I. B. Tauris, 2011. 
Yazbak, Mahmoud. "Europe, Cotton and the Emergence of Nazareth in 18th-Century Palestine." Oriente Moderno 93, no. 2 (January 1, 2013): 531-46.

Yazbak, Mahmoud. Haifa in the Late Ottoman Period, 1864-1914: A Muslim Town in Transition. Leiden: Brill, 1998.

Yazbak, Mahmoud. "The Municipality of a Muslim Town: Nablus, 1864-1914." Archiv Orientalni 67, no. 3 (1999): 339-6o.

Yazbak, Mahmoud. "Nablus, Nazareth and Haifa: Three Ottoman Towns in an Age of Transformation, 1840-1914." In Essays on Ottoman Civilization, Proceedings of the XIIth Congress of Ciepo, 395-410. Prague: Academy of Sciences of the Czech Republic, Oriental Institute, 1998.

Yazbak, Mahmoud. "Nabulsi Ulama in the Late Ottoman Period, 1864-1914." International Journal of Middle East Studies 29, no. 1 (1997): 71-91.

Yazbak, Mahmoud. “Templars as Proto-Zionists? The 'German Colony' in Late Ottoman Haifa." Journal of Palestine Studies 28, no. 4 (1999): 40-54.

Yediyıldız, Bahaeddin. "Müessese-Toplum Münasebetleri Çerçevesinde XVıII. Asır Türk Toplumu ve Vakıf Müessesesi" [On the framework of institution-society relations in the 18th century: Turkish society and waqf institutions]. Vakıflar Dergisi 15 (1982): 23-53.

Yeoh, Brenda S. A. "Street Names in Colonial Singapore." Geographical Review 82, no. 3 (1992): 313-22.

Yılmaz, İlkay. Serseri, Anarşist ve Fesadın Peşinde: Abdülhamid Dönemi Güvenlik Politikaları Ekseninde Mürur Tezkereleri, Pasaportlar ve Otel Kayıtları [In search of anarchist and mischief: internal passports, passports and hotel registers through the security policies during the Abdulhamid II era]. Istanbul: Tarih Vakfl, 2014.

Yosmaoğlu, İpek K. "Chasing the Printed Word: Press Censorship in the Ottoman Empire, 1876-1913." The Turkish Studies Association Journal 27, nos. 1-2 (2003):15-49. Yosmaoğlu, İpek K. "Counting Bodies, Shaping Souls: The 1903 Census and National Identity in Ottoman Macedonia." International Journal of Middle East Studies 38, no. 1 (2006): 55-77.

Young, George. Corps de droit ottoman; recueil des codes, lois, règlements, ordonnances et actes les plus importants du droit intérieur, et d'études sur le droit coutumier de l'Empire ottoman. Oxford: Clarendon, 1905.

Zander, Walter. "On the Settlement of Disputes About the Christian Holy Places." Israel Law Review 8, no. 3 (1973): 331-66.

Zandi-Sayek, Sibel. Ottoman Izmir: The Rise of a Cosmopolitan Port, 1840-1880. Minneapolis: University of Minnesota Press, 2012.

Zaydan, Jurji. "Filastin" [Palestine]. In Mu'allafat Jurji Zaydan al-kamilah [The complete works of Jurji Zaydan], 542-43. Beirut: Dar al-Jil, 1982.

Zena Ityopya bä-Hagär Qeddest Iyärusalem [Story of Ethiopia in Holy Jerusalem]. Correspondence Respecting Abyssinians at Jerusalem, 1850-1867. Addis Ababa, 1959. 
Ze'evi, Dror. An Ottoman Century: The District of Jerusalem in the 16oos. Albany: State University of New York Press, 1996.

Zilfi, Madeline C. The Politics of Piety: The Ottoman Ulema in the Postclassical Age (160o-180o). Minneapolis: Bibliotheca Islamica, 1988.

“Zionism." Universal Jewish Encyclopedia, n.d.

Zlocisti, Theodor et al. Aufgaben und Organisation des Sanitätsdienstes in Palästina. Berlin: Jüdischer Verlag, 1920. 


\section{Index of Persons}

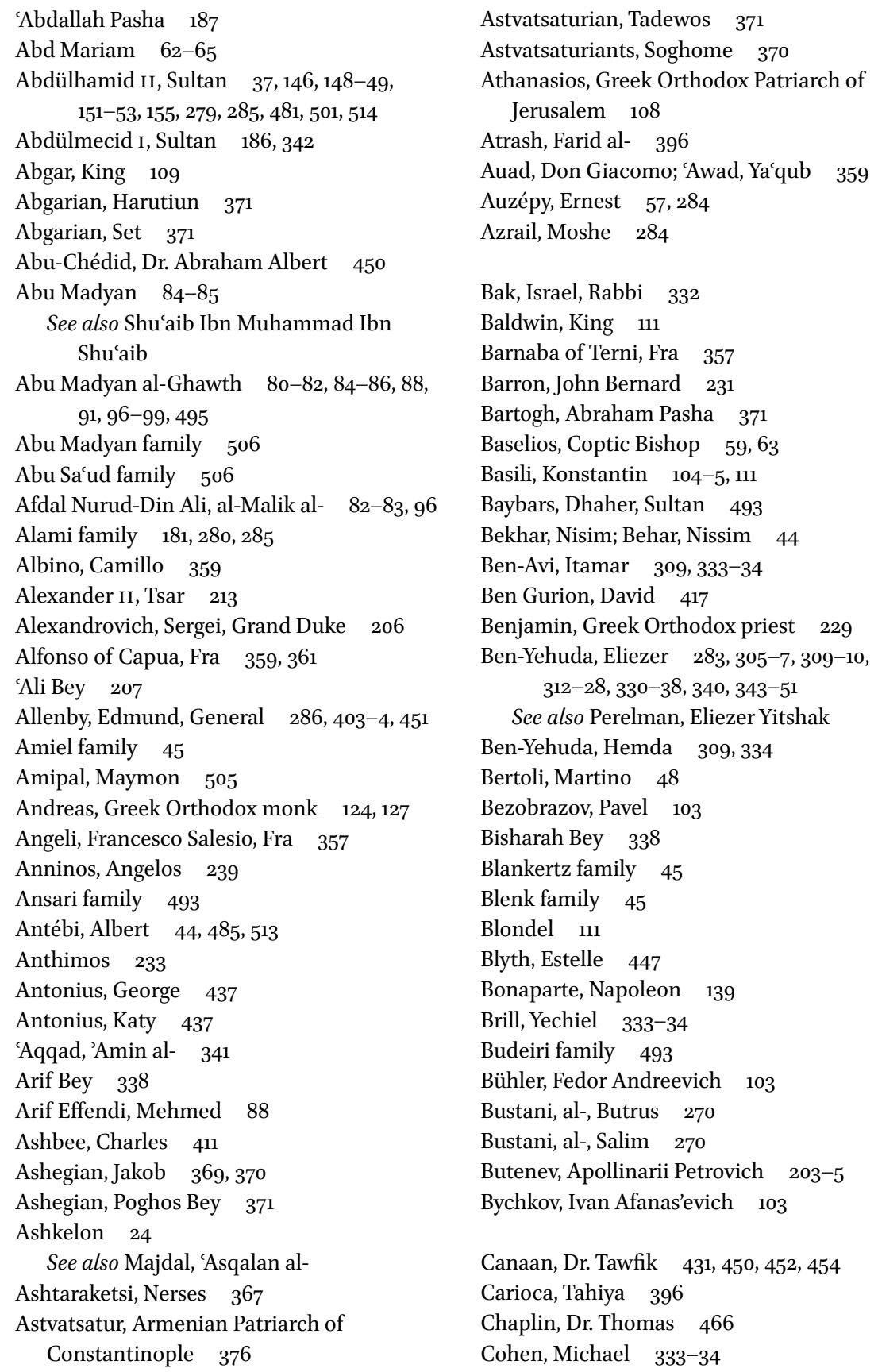


Cohen, Raphael Z. 39

Conder, Claude R. 347

Constantine, Emperor 329

Corbelli of Cortona, Guido, Fra $\quad 357-59$,

$$
\text { 362-64 }
$$

Crete, Petros 378

Curzon, George Lord $\quad$ 235, 239

Curdi, Stefano 361

Cyrus 329

Dabbas family 494

Dabdub, Gabriel 41

Dabdub, Ibrahim 41

Dajani, Dr. Mahmud 436

Dajani family 181

Damianos, Greek Orthodox Patriarch of Jerusalem 210, 229-31, 235-36, 395

Danaf family 493

David, King $\quad 88,285,328,413,415^{-16}$

Darwish ‘Ali Effendi Zada, Muhammad 197

Dawudi family 285

Dazdar, Ahmad Agha al- 193, 195

Din, 'Afdal al- 82

Din, Mujir al- 82

Dionysios, Greek Orthodox Metropolitan of Bethlehem 107

Diotallevi, Ferdinando, Custos of the Custody of the Holy Land 411

Dopieralo, Antonio 364

Dorgobuzhinov, Vladimir Ippolitovich 204-7, 221

Draskhanakertsi, Yovhann 377

Dumas, Tancrède R. 43

Durian, Yeghishe, Armenian Patriarch of Jerusalem 373-74, 378-80

Efklidis, Fotios; Photius Euclidès; Dr. Photios 38

Egzi'e, Fäqädä, Ethiopian Abbot 67

Elijah of Vilna 329

'Elyashar, Ya'akov, Rabbi Bashi $\quad 344,346$

Eppinger, Christian Friedrich 45

Eppinger, M.I. $\quad 208$

Fahreddin Muhammad ibn Fadlullah, Qadi 89

Fahri Bey $\quad 513$
Faik Bey 219

Filaret (Drozdov), Metropolitan of Moscow 105, 108, 112

Finley, John H. 434

Finn, James $\quad 54-58,228,472$

Francke, Carl $\quad 485$

Franghia, George $\quad 38,482$

Frötschner, Sebastian, Fra $35^{8}$

Frumkin, Gad 412

Frutiger, Johannes $\quad 67,70$

Frutiger, Martha 46

Fuad Pasha 218

Gabriel, Colonel 235

Gamil, Abdallah 359

Gastzinni, Isaac 333-34

Gherardi, Alexandre 43

Glazebrook, Dr. Otis Allan 427

Gobat, Samuel, Anglican Bishop in Jerusalem 110

Gorchakov, Alexander Mikhailovich $\quad 202-5$

Gottfried, King 111

Grayevsky, Pinhas Ben Tsvi 283, 290, 296-99, 301-4

Greganti, Paolo, Fra $35^{8}$

Grussendorf, Dr. Samuel $45^{\circ}$

Gulbenkian, Calouste 379

Gulbenkian, Sargis 379

Gulbenkian, Tiruhi 379

Gushakian, Torgom, Armenian Patriarch of Jerusalem $\quad 374$

Armenian Archbishop

379

Habib, Beshara 390

Haddad, Giulia 48

Hafiz Pasha 180

Hamdi Effendi, al-Haj Muhammad $\quad 189$

Hassan Bey 195

Hasseki Sultan $\quad 76,197,492,495,501,508$

Helena, Empress 329

Herod 329

Heron, Colonel 454

Hilmi Pasha, Grand Vizier $\quad 315^{-16}, 321$

Hoffmann family 45

Holliday, Clifford 421

Hovakimian, Sargis 374

Hovhannes, Armenian Patriarch of Jerusalem 368-69, 378 
Hovhannisian, Astvatsatur 371, 377

Husayni, Ahmad Rasim al- 310

Husayni, Hind 437

Husayni, Hussein Effendi al- $\quad 342,513$

Husayni, Isma'il al- 485

Hussieni, Ismail Bek al- 390

Husayni, Kamil al- 420

Husayni, Muhammad 'Ali al- $\quad$ 194, 197

Husayni, Muhammad Tahir Effendi al- 193

Husayni, Salim al- 36

Husayni, Sacid al- $283,305^{-7}, 310^{-13}, 315^{-19}$, $321,327,514$

Husayni, Zahir al- 194

Husayni, 'Umar al- 194

Husayni, al-, family $\quad 181-82,193,280,285$, $310,348,384,484,489,493$

Husayni al-, neighborhood 348

Husseini, Hussein Bey al- 393

Ibrahim Pasha $\quad 36,186-91,196,285,342$

Ierotheos, Greek Orthodox Patriarch of

Alexandria 112

Ignat'ev, Nikolai Pavlovich $\quad$ 207, 217, 220-21

Illarionov, Nikolai Nikoaevich $\quad 206,219$

Irnisberg, Mr. 345

Ishaq, Adib 270

'Issa, 'Issa al- 224

'Izzat Pasha, Muhammad 191

Jabotinsky, Vladimir 396

Jacob Effendi 370

Jacobian, Vahan 378

Jalal Effendi $\quad 287$

Jamal Pasha $390,393,427$

Jama'i, Nijim al-Din al- $\quad$ 196-97

Jarallah 197

Jarallah family 348

Jawhariyyeh, Afifeh 393

Jawhariyyeh, Fakhri 393

Jawharriyeh, Girgis $\quad 384,388$

Jawhariyyeh, Wasif $\quad 283,289,384-90$, $392-98,412,511,518-22$

Jawid Bey 342

Jazzar, Ahmad Pasha al- $\quad 187$

Jesus $\quad 25,329$

Kagan, Dr. Helena 432

Kahkedjian, Mary $\quad 436$
Kallistos, Greek Orthodox archimandrite 124

Kallistos, Greek Orthodox monk 127

Kamsarakan, Armenak Bey 379

Kapustin, Antonin, Russian archimandrite 54, 62-64, 102, 206, 209, 222

Karagüç 157

Karasevskii 104

Kartsov, Andrei Nikolaevich $\quad 206$

Karukeants, Kirakos 371

Kassar, Ali al- $\quad 396,398$

Katas, 'Isa D. 39 See also Gattas, Eissa D.

Kayat, As'ad 39

Khachikian, Hovhannes, Armenian senior priest 371

Khalebi, Ya'qub 209

Khalidi, Ahmad Sameh al- 390

Khalidi, Ibrahim Adham al- 37

Khalidi, Khalil Effendi al- 197

Khalidi, Mahmud Şevket al- 37

Khalidi, Muhammad 'Ali al- $\quad 189$

Khalidi, Muhammad Ruhi al- $\quad 283,305^{-7}$, $310,312-13,320-28,345,514$

Khalidi, Sheikh Khalil al- 390

Khalidi, Yassin al- $\quad 36,48-49,312$

Khalidi, Yusuf Ziya' al- 312

Khalidi family $181-82,280,285,312,484$, 489, 493, 506

Khan Ahad, Yaqub 197

Khapaian, Sahak 378

Khatib, al- family 493

Kiamil Bey $\quad 217-18$

Konstantin Nikolaevich, Grand Duke 105 , 114, 204

Kozhevnikov, Vassilii Fedorovich $\quad 206-7,217$, 219-20

Krivoshein, A. K. 205

Kuleserian, Babken, Bishop 381

Kurt, Mitri Habib $\quad 41$

Kyrillos II, Greek Orthodox Patriarch of

Jerusalem 105, 110-11, 113-15, 203, 205, 208-9, 220

Lambronatsi, Nerses 376

Lapidus, F. 48

Larson, Lars 393

Lavinio, Fra 356 
Lazaridis 113

Levitov, P. D. 205

Lipschitz, Ozer Dov 336

Lloyd George, David $\quad 236$

Lobanov-Rostovsky, A. B. 218

Loud, Edward F. 427

Luncz, Abraham Moses 333-34

Macgowan, Dr. Edward ４65-66

Mädhen, Wäldä, Ethiopian Monk 53

Maghribi, Ahmed al- 91, 97

Maghribi, al-Hajj Bashir Effendi

Maghribi, al-Hajj 'Umar al- 88

Maghribi, Hajj Necme bint Hajj Muhammad al- 88

Maghribi ibn Abdullah, al-Hajj Kasım al88, 91

Maghribi, Ismail ibn Hajj Muhammad al88

Maghribi, Sayyid Muhammad ibn Hajj Abdullah al- 88

Maghribi, Sayyide Cennet bint Hajj Muhammad al- 88

Maghribi, Sayyide Hatice bint Muhammad al88

Maghribi, Sheikh Abu Bakr Ibn Sheikh Ahmed al- 86

Maghribi, Sheikh Muhammad el- $\quad 81$

Maghribi, Sheikh Osman Ibn Sheikh Muhammad al- $\quad 81,86$

Mahmud II, Sultan $187,194,368,460$

Makonnen, Ras $\quad 68,70$

Manjak, Prince 493

Mansur, As`ad 253

Mansurov, Boris Pavlovich $104-5,114,204-5$, 207

Marabutti, N. S. $\quad$ 203-4, 222

Marum, Y'aqub 41

Massabni, Badia 396

Matsliah, Nisim $\quad 515,5^{26}$

Mauss, Charles 208

Mavrommatis, Evripidis 488

Mehmet Ali Pasha 139, 368, 477 See also Muhammad 'Ali

Meletios of Latakia, Greek Orthodox Patriarch of Antioch 122

Menen Asfaw, Empress of Ethiopia 434

Menilek II, Emperor of Ethiopia 56
Meo, Boulos 42

Mina, Pascal 286

Mirmiroglou, Vladimiros 124

Montefiore, Francis Abraham 322

Montefiore, Sir Claude $\quad 322,324,463,472$

Montefiore, Sir Moses 347, 473

Moore, Noel Temple 54

Mostras, G. 104

Muhammad, Prophet $\quad 82-83,97,194,329$

Muhammad 'Ali 194, 196

See also Mehmet Ali Pasha

Muhdi Bey 513

Mühlens, Peter $\quad 443,449,45^{0}-5^{1}$

Mukhin 205

Muhtadi, Ibrahim al- 197

Mujarrad, 'Umar al- $\quad 81,84-86,88,91,96,99$

Münzinger family 45

Muwaqat, Shakir al- 196-97

Myuhentisian, Hovhannes 368

Nahum, Hayim $\quad 5^{26}$

Napoleon III 205

Nashashibi, al-, family $\quad 285,348,493$

Nashashibi, Ragheb al- 390

Nasir, Elizabeth 437

Naumov, Kirill, Russian Ecclesiastical Mission

Bishop 105, 115, 202-3, 205, 206

Navon family 505

Navon, Joseph $\quad 39,341,482$

Nawfal, Niqula $\quad 271$

Nelidov, A. I. 219

Neofytos, Greek Orthodox monk 188

Nesselrode, Karl 106

Nicodemo, Ferdinando 42

Nicolas I, Emperor of Russia 104, 106

Nigo, Youssef 505

Nikiforos, Greek Orthodox Archimandrite 229

Ninos, Dimitrios 124, 127

Nolde, Boris 53

Nshanian, Mesrop $\quad 372-73,381$

Nubar, Poghos 378

Papazian, Stepan $\quad 378$

Perelman, Eliezer Yitshak 309

See also Ben-Yehuda, Eliezer

Peres, Haim 333-34

Petro, Nikola 284 
Pezechian, Amira Harutiun 368

Pines, Yechiel Michel 334

Pius IX, Pope $35^{2}$

Poghos, Armenian Patriarch of Jerusalem 368,379

Protasov, Nikolai 104

Qa'war, Tannus 255

Quayder family 493

Quttaineh family 493

Ra'ad, Khalil 392

Ra'uf Pasha $\quad 36,181,343,388,390-91$

Radwan family 493

Rahman, 'Abd al- 512

Rapaport, Raquel 410, 421

Rappard, William 454

Rashad Pasha 342

Rashid Bey $\quad 37,348$

Rashid Effendi, Husayn 195

Re'uven, Yehezkel 300

Rida Bey, 'Ali 342

Rikabi, 'Ali Rida al- 311

Robertson, Roland $\quad 425$

Rockenbauch family 45

Rogers, Mary 254

Roosevelt, Eleanor 434

Rothschild, Edmond James de, Baron 336-37

Roxelana, Princess $\quad 495,501$

Rubinow, Dr. Isaac $\quad 453-54$

Ruhi Bey Abdul Hadi 373

Runsio, Khawāja 197

Ruppin, Arthur 513, 523

Rustum Pasha 37

Sabella, Steven $\quad 359-60$

Saint Täklä Haymanot 66

Sakakini, Khalil $\quad 283,287-90,292-96,303-4$, $45^{2}$

Saladin $\quad 76,82,96,109,329,444,493$

Salah, 'Abdallah Bey al- $\quad 255$

Salah al-Din Hajji Yusuf $\quad 524-25$

Salah, Mantura 41

Salah, Mustafa Bey al- 255

Salim Effendi 340,345

Samuel, Herbert 230

Saruf, Fadlala 115
Sa'ud, 'Abdallah Abu al- $\quad 270$

Sacud, 'Uthman Effendi Abu al- 197

Sacud, al-Shaykh Muhammad Effendi, Abu al196-97

Sayyid Muhammad ibn İsmail 88

Schmidt, Nicolai 66

Sellase, Mahtsantä, Ethiopian Abbot 72

Seraphin, Pascal $\quad 70,72,74$

Serbinovich, K. 104, 110

Şevki Bey 157

Shakhashiri, M. O. 205

Shami, Ishaq 518

Sharet, Moshe 514

Shawa, Sami al- 397

Shaykh Jarrah $\quad 278,348$

Shaykh al-, Yusuf 338

Shihabi, Zulaykha al- 497

Shmoyil, Menahem 284

Shu'aib Ibn Muhammad Ibn Shu'aib $\quad 84-85$ See also Abu Madyan

Sienkiewicz, Joseph 220

Sodar de Vaulx, Marie 46

Sokolov, Konstantin Alexandrovich $\quad 206-7$, 218

Solomon, King 328

Spafford family $\quad 426$

Spafford Vester, Bertha $\quad 426-29$

St. Cricq Dartigaux, Mademoiselle de 46

Storrs, Ronald $\quad 235,403-4$

Straus, Nathan 450

Subhi Bey 323, 342

Sulayman Pasha 187

Suleiman I, Sultan 329,510 ,

Süphi Pasha $\quad 484,488$

Suradi, Muhammad al- 197

Sureyya Pasha 218

Sykes, Mark 403

Syrku, Polikhronii $\quad$ 103, 116

Tankiz, Emir 493

Tannous, Giuseppe Maria 364

Taytu Betul, Empress of Ethiopia $\quad 56,67$, 70-71, 74

Ter Petrosian, Daniel 367

Ter Petrosian, Davit $\quad 367$

Ter Petrosian, Zakaria, Armenian Patriarch of Jerusalem 367-69, 376

Tevfik Bey, Mehmed $\quad 57,284-85$ 
Thon, Dr. Jacob 231

Titov, Vladimir $\quad$ 104-5, 108-11

Tolstoi, A. P. $\quad 115$

Tristram, Henry B. 253

Turjman family 493

Tzormpatzoglou, Georgios 235

Umar, Caliph 329

'Umar, Dahir al- 187, 241

Uspenskii, Konstantin Alexandrovich, Russian archimandrite $100,102-17,202$

Valerga, Giuseppe, Latin Patriarch of Jerusalem 110, 113

Valero family 518

Valero, Hayim 'Aharon 39

Vanetsi, Teodoros, Armenian Patriarch of Jerusalem $\quad 367$

Vardapet Mnatsakanian, Kirakos $\quad 367$

Vardapet, Samuel 368

Vardapet, Vardan, Armenian archimandrite 375

Vasilevskii 221

Vehapetian, Harutiun $\quad 371^{-72}$

Vercruysse, François 45

Vester, Ferdinand 42
Voitsekhovich 104

Von Finkelstein, L. M. $\quad 46$

Wafa 197

Wafa, al-Hajj Yusuf $\quad 485,487-88$

Wallach, Dr. Moritz $\quad 450$

Weiss, Aaron $\quad 284$

Weißman of Baden, Giuseppe, Fra $\quad 359,361$

Wheeler, Dr. Percy Charles Edward d'Erf 466

Wilhelm II, Kaiser $\quad 285$

Yassin Effendi 342

Yeghiazar, Armenian Patriarch of Jerusalem 369

Yeghiazarian, Alikhan 368

Yellin, David 313

Yesayi, Armenian Patriarch of Jerusalem $369-71,376,380$

Yohannes IV, King 59, 63

Yorgo Boşo Efendi 283

Yusuf Efendi, David $\quad 524$

Yusufian, Petros 368

Yuzefovich, Trofim Pavlovich 207

Zäwditu, Empress of Ethiopia $\quad 56$

Zaydan, Jurji 440

Zuhur, Rawdat al-

437 


\section{Index of Places}

Abu Dis $\quad 188$

Aclun 166

Acre $186-87,190$

See also Saint Jean d'Acre

Acre (sanjak of) $\quad 187$

Addis Ababa $\quad 1,4,5^{2-53}$

Africa $54,56,5^{8}$

Akkerman 370

Akn 368

Aleppo 108, 190, 262, 269, 274, 278, 371, 475, 482

Alexandria $\quad 43,112,120,122,125,217,279,370$

Algeria 81, 275

Algiers $84,276,278$

Alliance Israélite Universelle school in Jerusalem 312

America 202, 341

American Colony $\quad 42,390,393,423,425^{-29}$, 432-34, 437

American Colony's Handicrafts School 434

American Colony Hotel 427

American School of Oriental Research 433

Amman 1, 188, 242-43, 274

Amud, Bab al- 408

See also Damascus Gate

Anatolia 479, 515

Anglican Missionary School $\quad 287$

Ankara 75, 77, 152

Anna Spafford Baby Home $\quad 423-24,428-32$, 434

Antioch 120, 122, 129

Aqsā, al-, mosque $\quad 41,76,82,83,94$

Arabian Peninsula 120

Archdiocese of Cyprus $\quad 125$

Armenian Patriarchate of Jerusalem $\quad 50,55$, $366,368,369$

Ashkelon 24

See also Majdal, 'Asqalan al-

Asia 341

Asia Minor 225

Athens 1, 101, 225-26, 235, 237-38, 419

Athos, Mount 105, 111, 125

Augusta Victoria Hospital 436

Austria 202, 359

Austro-Hungary 459
'Ayn Karim $\quad$ 84, 86-87, 96, 209-10

Azhar, al-, mosque 194

Baden 359

Baghdad 267, 271, 274

Baka, valley 481

Baq'a 486,496

Balkans 23, 114, 213, 479, 517

Balqa, al- $\quad 245^{-46,250}$

Beersheba 164

Beirut 2, 43, 104, 107, 111, 116, 146, 154, 166, 202, 205, 211, 214, 216-18, 241, 255, 266-72, 274, 277-79, 312, 339, 365, $45^{2}, 475,483-84,486-88,499,517$, 528

Beit Jala 113

Belfast 277

Belgium 46

Ben-Yehuda Street $\quad 234$

Ben-Zakay Sephardic Synagogue 300

Berlin 1, 277, 443

Bessarabia 128, 220, 228, 353

Bet Ya'akov Synagogue 345

Bethlehem 37, 46, 107, 110, 115, 193, 220, 231, $419,487,501,514$

Bethlehem Road 486

Bezalel School of Arts 417

Bialystok 301

Bilad al-Sham $\quad$ 139, 190, 242-43, 357

Birkat al-Sultan 486

Birkat al-Sultan Road 234

Bombay 301

Bonsh Bayi 420

Bordeaux 313, 320, 324

Boston Children's Hospital $\quad 436$

Britain 186, 202-3

Bukharan Quarter 302

Buraq, al- $90,396,495,506$

Bursa 495

Cairo 271, 279, 340, 357, 405, 495

Canada 42

Capua 359

Carmelite Monastery 46

Casa Nova $\quad 41,356-58$ 


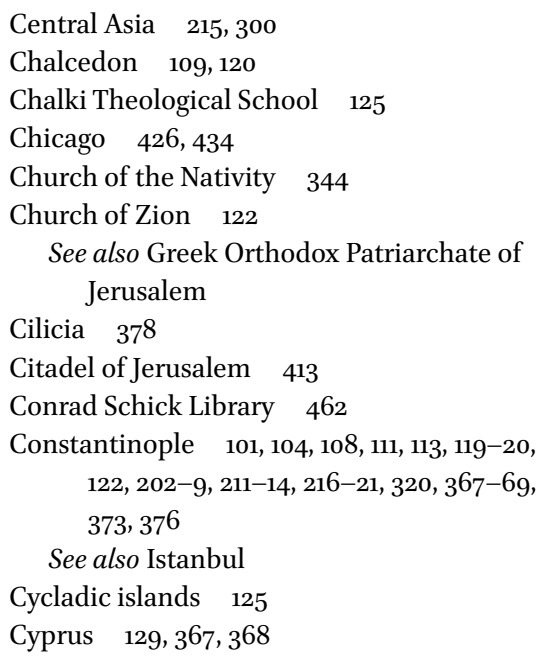

Däbrä Gännät, Ethiopian monastery of 67 Damascus 41, 82-83, 97, 108, 120, 166, 187, 190-91, 195, 219, 267-69, 271, 274, 278, $296,475,482-84,487,517,5^{28}$

Damascus Gate $\quad 41,97,408,412,423$ See also Amud, Bab al-

Damascus Hotel 41

Danube Principalities 111

Dar al-Awlad hostel 437

Dar al-Tifl orphanage and school 437

Dayr al-Qamar 269

Dayr al-Sultan $\quad 50-51,53,56,58-59,62,64$, 66-67

Dead Sea 41, 385, 392, 434

Deir Yassin 437

Dimashq al-Sham, eyālet $\quad$ 190-91

Dome of the Rock $76,83,94,98$

Dura 219

East Africa $\quad 317-18$

Eastern Europe $\quad 297,300,459,517$

Eastern Thrace 225

Ecumenical Patriarchate of Constantinople $108,119,121-22$

Edirne 517

Egypt $82,103,115,129,139,186,210,215,217$, $340,349,368,379,440,477$

Emmaus church 46

English Mission Hospital in Jerusalem (Е $344,457-58,460,462,465-70,474$
Erevan 1

Etchmiadzin 367

Ethiopia 53, 56, 63, 434

Ethiopian compound 50

Ethiopian Monastery Street 67

Europe $31,33,41,58,100,173,186,240,242$, 266-68, 290, 301, 341, 446-88

Fast Hotel $\quad 42,348$

See also Howard Hotel

Feil Hotel 40

Fez 82, 278, 301

France $42,65,100,112,163,202-3,205,225$, $267,273,313,323$

Franciscan Custody of the Holy Land 3 , $29-31,35,45,49,160,352,354-55$, $357-58,363-65,407,411$

Franciscan Custody Library 14, 29

Franciscan Printing Press (FPP) 29-30, $33-35,37-49,291,352-60,362,365$

French Catholic Hospital of Jerusalem 462

Frères des écoles chrétiennes, school 43

Fuga 232

Galata $\quad 154,268$

Galatasaray 158,514

Galilee $132,187,241$

Gaza $163-64,166,187,193,425,518$

German Lutheran hospital of the Kaiserwerth deaconesses of Jerusalem 450

Golgotha 368

Grand New Hotel 42

Greater Syria $\quad 186-87,190,499$

Greece 6, 116, 124-25, 214-15, 225, 227, 283, 378

Greek Hospital of Jerusalem 462

Greek Orthodox Patriarchate of Alexandria 120,125

Greek Orthodox Patriarchate of Antioch and all the East 120

Greek Orthodox Patriarchate of Jerusalem 5, 59, 108, 118-19, 123, 125, 134, 141, 202, 205, 223, 226-27, 230, 233, 236, 353, 461

See also Church of Zion

Grotto of the Nativity 220

Gulbenkian Library $\quad 55,374,379$ 
Habash, Haret al- $\quad 5^{0}$

Hadassah Medical Organization 441, 443, 453

Hadassah-Rothschild hospital in Jerusalem 432

Haifa $\quad 2,141,188,233,240-42,253-57$, $260-61,482-83,528$

Haiti 264-65

Hakhame Odessa school 337

Halab, eyālet 190

Hama 274

Hanafi legal school 495

Haram al-Sharif $76,82-83,85,89,98,496$, $502-3,508$

Haramayn (Mecca and Medina) $\quad$ 77, 94, 98

Harririeh Road 234

Hassanayn, Amin 396

Hasani, Abdussalam al- 88

Hasbayya $\quad 269$

Hawran 241, 482

Hebron $107,164,193,195,219,298,341$, 396-97

Herod's Gate 349,423

Hexarchy of the Holy Sepulchre in Istanbul 124

Holy Cross Monastery in Jerusalem $\quad 115$

Holy Sepulchre (Church of the) 41, 104, 106, 109, 111, 112, 126, 130, 181, 203, 205, 208, 395

Horn of Africa 57

Howard Hotel 41, 348

See also Fast Hotel

Hukūḳ Mektebi law school $\quad 514$

Hungary 357

Ha-Hurva, Ashkenazi Synagogue 300-301

Ibrahimiyyeh College 497

Imperial Orthodox Palestinian Society 206-8, 210, 216-17, 222

Imperial Society of Palestine 101-102

'Inbta 247

India 225,368

Indiana 434

Iraq 517

Israel 18, 20, 24, 101, 118, 139, 234, 264, 278, 309, 314, 320, 328, 334, 387, 416, 471, 490, $498,526,528$

Istanbul $1,5,21,23,52,54,59,77,87,94-95$, $101,108,121,124,133,147,151,154,156$,
158, 170-71, 176, 185-86, 189, 192-94, 198, 242, 244, 248, 268, 271-72, 279, 284, $312-13,353,385,445,475,477,481-83$, $485,488-89,495,510,513-15,517-19$

See also Constantinople

Izmir 130, 146, 487-488, 501, 515, 517, 521, $5^{26}$

Jaffa $36-38,44-45,104,163-64,176,193$, $202-4,216-17,219,221-22,230,261$, 277-78, 284, 298-99, 340-42, 350, 372, $475,477-78,481-83,485,489,494,496$, $498,501,505,528$

Jaffa Gate $39,41-43,287,293,299,349,356$, 392,486

Jaffa Road 44, 349, 481, 486, 511

Janzir 232

Jenin 245

Jerusalem, New City of $\quad 293,303,346,409$, $411,413-15,417-18,420$

Jerusalem, Old City of $83,101,134,200$, 210, 229, 293, 300, 303, 312, 346-52, 408-9, 411, 413-15, 417, 419-20, 423, $426,432-33,490,493,495,498,500-11$, 516

Jerusalem Rotary Club 434

Jerusalem, sanjak of $171,187,190-91,254$

Jewish Quarter 82, 499, 502-6

Jidda $\quad 269$

Jinjriah 420

Kasap İlyas neighborhood $\quad 23,156$

Katamon neighborhood 229

Kharberd 371

Kherson Theological Seminary 102

King David Street 234

King George Avenue $\quad 234$

Kolkata 371

Kostroma 102

Kostroma Theological Seminary $\quad 102$

Kütahya $\quad 189$

La Courneuve $\quad 52,54$

Latin Patriarchate of Jerusalem 352, 354, 364,407

Lebanon 108, 216, 332, 384

Lebanon, Mount $\quad 268$

Lecun 166

Leipzig $\quad 354$ 
Lod 193

London $1,5,163,236,291,322,324,370$, $403-5,416,435,442,45^{8}$

Lower Janzier Road 234

Luzhki 309

Lydda 494

Lyon $\quad 267$

Madrasa al-Afdaliyya $\quad 83-85$

Madrasa al-Dustūriyya $\quad 287$

Madrasa al-Fahriyya 89

Madrid 1

Maghariba, Bab al- $\quad 85,89$

Maghariba neighborhood $14,75,77,79$, $81-83,85,88,91,95,96$

See also Mughrabi Quarter

Maghariba, al-, Mosque $\quad 83,89,94$

Maghreb 82-84, 495

Mainz $\quad 35^{6}$

Majdal, 'Asqalan al- 24 See also Ashkelon

Maliki school of jurisprudence 84

Mamilla 234

Mamilla Road 349

Manchester 370

Marj Charbi 232

Marj Sarqui $23^{2}$

Mecca $77,82-83,89,98,446$

Medina $77,82,89,98,501$

Mekteb-i Mülkiye 313

Melbourne 129

Me’ah She`arim 340

Michigan 427

Middle East $\quad 39,100,122,131,211,215,225$, 264, 270, 272, 274, 277, 300, 354, 366, $375,383,451,495,500,508$

Mishkenot Sha'ananim 299, 340

Missionary Girls School 344

Moldavia 111, 217

Morocco 81, 275

Moscoviyyeh compound 455 See also Russian compound

Moscow 1, 105, 108, 114, 130, 212

Mosul 274

Mughrabi Quarter 495, 502-6, 508 See also Maghariba neighborhood Municipal Hospital of Jerusalem 349 Muslim cemetery of Jerusalem 486 Muslim Quarter 433
Nabi Musa 395

Nabi Samu'il 351

Nablus 2, 141, 166, 187-88, 190, 240-50, 252, 253-55, 257-61, 267, 269, 274, 279, 298, 312

Nantes $\quad 5^{2,54}$

Nazareth $107,141,240-42,252,254-57$, 260-61

Near East 104, 114

Neva, river 100

New York City 288, 434

New York State 434, 443

Newark 301

Nikiforia 230, 233-34

North Africa $\quad 276,300,508,517$

North America 340

Notre-Dame de Sion 43

Notre-Dame-de-France hospital 101

Odessa 102, 221

Olives, Mount of $\quad 1,109,209-10,229,419,487$, 496

Ophthalmic hospital by the Order of

St. John's of Jerusalem 436

Ottoman Empire $\quad 3,18,31,40,75,76,94-95$, 101, 111-12, 122, 134, 164, 168, 190, 209-10, 213, 236, 273, 287, 289, 291, 295, 303, 313, 316-18, 323, 327, 331, 343, 372-73, 387, $443,448,457,460,482,488,512-15,519$, 522

Ottoman hospital of Jerusalem 486

Ottoman lycée of Jerusalem 38

Palestine $\quad 2,6,18,21-25,37-8,40,42-43,45$, 70, 101-5, 107-8, 110-11, 114, 116-18, 121, 126-27, 132, 139-40, 163, 186-90, 192, 195, 201-3, 205, 209-11, 213-19, 224, 227-28, 234-35, 237-38, 240-2, 252, 253-54, 256-57, 260, 263-66, 272, 276-79, 284, 288-89, 290, 296-97, 299, 306, 308-310, 313-14, 316-27, 330-33, $335,343,345,350,365,373,384-88,390$, $392,396,403-4,418-19,424,426-27$, 429, 433-34, 436, 438, 441, 443, 448-49, $45^{2-54}, 456,475,477,479-84,492,494$, 496, 499-501, 505, 508, 510, 513-14, 517, $522,524-26,528$

Paris 42, 113, 208, 221, 271, 309, 313, 324, 370, 379 
Pasteur Institute of Jerusalem $\quad 45^{0-51}$

Patriarchal school at the Holy Cross

Monastery in Jerusalem 113

Pera 268

Petah Tikvah 513

Prussia $\quad 202-3$

Queen Melisende Road $\quad 417$

Racine, Wisconsin 435

Ramla 193, 493-94, 501

Rehavia 229, 234

Richard Cœur de Lion Street 417

Richelieu Lyceum in Odessa 102

Rome 1, 5, 43, 52, 108, 120, 354, 419

Rothschild Hospital of Jerusalem ～468-69

Ruanda-Urundi 454

Russia $100,105,107-8,112,114-15,202-5$, 210, 212, 220-21, 236, 337, 340, 459, 479, 514

Russian compound 101

See also Moscoviyyeh compound

Russian Ecclesiastical Mission in Jerusalem

(REM) 62-63, 102-3, 106, 115, 141, 202-3, 205-10, 215-16, 222

Russian Empire $\quad$ 101, 200, 212-13, 222, 309, 459-6o

Russian Imperial Academy 103

Russian Pilgrims' Hospital 209

Safed 166, 524

Saïda $\quad 63,166,187$

See also Sidon

Saida, eyālet $\quad 187,190$ See also Sidon, eyālet

Saint Jean d'Acre 219

See also Acre

Saint Julian Street 393

Saladin Road 417

Salonika $\quad 486,487-88,517,5^{26}$

See also Thessaloniki

Salt, al- 247

Sarona 45

Serbia 215

Serfidje $\quad 283$

See also Servia

Sham, al-, eyālet 190

Sharaf, Harat al-, neighborhood 82
Shacare Tsedek Jewish hospital $\quad 450$

Shwitra, neighborhood in Nablus 243, 261

Sidon 63, 187, 190-91, 193

See also Saïda

Sidon, eyālet $\quad 187,190-91$

See also Saida, eyālet

Siloam Monolith 209

Silsala, Bab al- $\quad 85,312$

Silwan $\quad 278$

Sinai, Monastery $\quad 111,115,220$

Sinai Peninsula 392, 451

Sofia 1

Spafford Children's Center $\quad 423,428,438$

Spafford Children's Hospital $\quad 436$

Spain 202, 517

St. Anne, seminary 43

St. Francis Street 417

St. Helena chapel $\quad 5^{0}$

St. James Armenian Printing House (SJAPH) $366-70,372-83$

St. James Church $\quad 119,134,369$

St. James Convent $\quad 366-67,371,378,382$

St. Lazarus Island 367

St. Nicolas Monastery 113

St. Paul Road 417

St. Petersburg $\quad 1,52,55,63,100,103$, 109-10, 202, 204-5, 207, 211-12, 214-17, 220-21

St. Sabbas Monastery $\quad 115$

St. Saviour's Convent $\quad 31,33,38,45,47$, 352-53, 357

St. Theodore Monastery 107

Sydney 129

Syria $40,102-3,105,108,132,255,274,311$, $314,514,5^{28}$

Syria, vilayet 254

Talas 370

Talbieh neighborhood $\quad 420,496$

Talbieh Road 234

Talpiyot 229-31

Tarablus, eyālet 190

See also Tripoli, eyālet

Tarrytown, New York State 443

Thessaloniki 146, 527

See also Salonika

Tophane 154, 158

Topkapı Palace $\quad 166$ 
"Torah and Work" School 338

Trieste 368,380

Tripoli 267, 271, 312

Tripoli, eyālet 190

See also Tarablus, eyālet

Tunis $\quad 267$

Tunisia 81

Tur, al- 496

Turkey $\quad 75,98,116,209,214-15,217,316,318$

Uganda 317

United States $31,33,42,46,202,266,427-28$, 434, 437

Vatican 54, 352, 354

Venice $366-67,382$
Via Dolorosa 41

Vienna $35^{8}, 369,380$

Wailing Wall 396, 433

Wallachia 111, 217, 227

Washington 1, 5

West Bank 423, 425, 498, 518

Western Europe 340,477

Western Wall $83,85,506$

Wisconsin 435

Yemen 517

Yıldız, imperial palace of $15^{2}$

YMCA 128,434

Zahleh $\quad 269$

Zion, Mount $\quad 285$ 